PNL-3608-1

UC-70

DOE/TIC-11432

\title{
West Valley Demonstration Project: Alternative Processes for Solidifying the High-Level Wastes
}

L. K. Holton, editor

October 1981

Prepared for the U.S. Department of Energy under Contract DE-AC06-76RLO 1830

Pacific Northwest Laboratory Operated for the U.S. Department of Energy by Battelle Memorial Institute 
NOTICE

This report was prepared as an account of work sponsored by the United States Government. Neither the United States nor the Department of Energy, nor any of their employees, nor any of their contractors, subcontractors, or their employees. makes any warranty, express or implied. or assumes any legal liability or responsibility for the accuracy, completeness or usefulness of any information, apparatus, product or process disclosed, or represents that its use would not infringe privately owned rights.

The views, opinions and conclusions contained in this report are those of the contractor and do not necessarily represent those of the United States Government or the United States Department of Energy.

\author{
PACIFIC NORTHWEST LABORATORY \\ operated by \\ BATTELLE \\ for the \\ UNITED STATES DEPARTMENT OF ENERGY \\ Uncier Contract DE-AC06-76RLO 1830
}

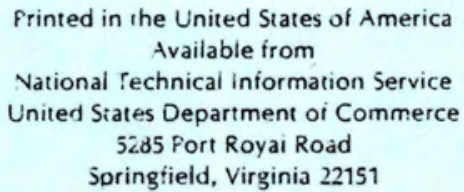

Price: Princed Copy $\$$

*; Microfiche $\$ 3.00$

NTIS

- Pages Selling Price

001-025 \$4.00

026-050 \$4.50

051-075 $\$ 5.25$

$076-100 \quad \$ 6.00$

101-125 \$6.50

126-150 \$7.25

$151-175 \quad \$ 8.00$

$176-200 \quad \$ 9.00$

201-225 $\$ 9.25$

226-250 \$9.50

251-275 \$10.75

$276-300 \quad \$ 11.00$ 
PNL $-3608-1$

UC -70

33679000561250

West Valley Demonstration Project

ALTERNATIVE PROCESSES FOR SOLIDIFYING THE HIGH-LEVEL WASTES

Editor: L. K. Holton

Principal Authors: L. K. Holton

D. E. Larson

W. L. Partain(a)

R. L. Treat

October 1981

Prepared for the U.S. Department of Energy under Contract OE-ACO6-76RLO 1830

Pacif ic Northwest Laboratory Richland, WA 99352

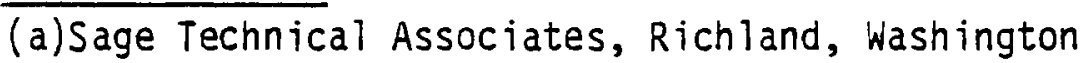




\section{FOREWORD}

In 1980, the U.S. Department of Energy (DOE) established the West Valley Solidification Project as the result of legislation passed by the U.S. Congress. The purpose of this project was to "carry out a high level nuclear waste management demonstration project at the western New York Nuclear Service Center in West Valley, New York." The DOE authorized the Pacific Northwest Laboratory (PNL), which is operated by Battelle Memorial Institute, to assess alternative processes for treatment and solidification of the WNYNSC high-level wastes. The Process Alternatives Study is the subject of this report.

Two pretreatment approaches and several waste form processes were selected for evaluation in this study. The two waste treatment approaches were the salt/sludge separation process and the combined waste process. Both terminal and interim waste form processes were studied. The terminal waste form processes considered were: borosilicate glass, low-alkali glass, marblesin-lead matrix, and crystalline ceramic. The interim waste form processes considered were: fused salt, silicate/salt, vinyl ester-styrene, and calcine.

The waste treatment/waste form processes were characterized, evaluated, and compared to determine the most practical solidification system for implementation at WNYNSC. This comparison was based on three elements: 1) the ability of the process to be ready for plant application in 1984,2$)$ the relative technical merits of the process, and 3) the relative cost of each process.

We wish to thank J. R. Carrell of PNL, who served as Project Manager, for his contributions in coordinating this project. We greatly appreciate the technical contributions of J. $L$. MCElroy of PNL, Burns and Roe Industrial Services Corporation, and Vitro Engineering Corporation. We would also like to thank the following technical reviewers:

O. F. Hill, O. E. Knowlton, L. T. Lakey, and O. H. Siemens, PNL;

C. Lunar and S. Vogler, Argonne National Laboratory;

H. E. Filter, Dow Chemical Company.

Substantial effort has been expended in coordinating, typing, and producing this report. We appreciate the contributions of the following people:

M. A. McKinney, Editor

S. E. Vickerman and M. A. Eierdam, Word Processors;

T. K. Swannack, Production Assistant. 
FOREWORD

FIGURES

TABLES

1.0 SUMMARY AND CONCLUSIONS

2.0 INTRODUCTION

2.1 PURPOSE OF THIS STUDY

2.2 STUDY APPROACH .

3.0 DESCRIPTION OF FACILITIES

3.1 MAIN PROCESSING BUILDING

3.1.1 Head-End Processing Cells . . . . . . . . . . . 3.3

3.1.2 Chenical Process and Extraction Cells . . . . . . . . 3.6

3.2 SELECTION OF PROCESSING CELLS FOR WASTE SOLIDIFICATION • • • . • • • 3.6

3.3 REFERENCE •

4.0 DESCRIPTION OF HIGH-LEVEL LIQUID WASTES . . . . . . . . . . . . . . 4.1

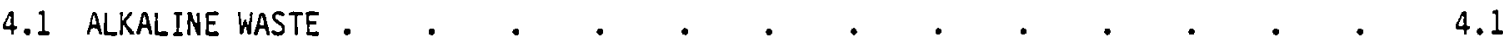

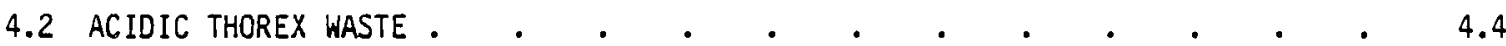

4.3 REFERENCES . . . . . . . . . . . . . . . . . . . . . . 4.8

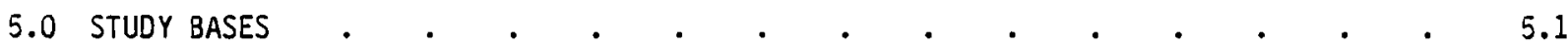

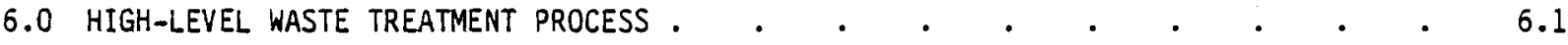

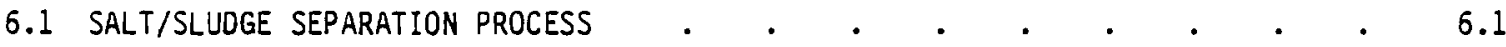

6.1.1 Process Flowsheet Salt/Sludge Separation Approach $\quad$. . . . 6.2

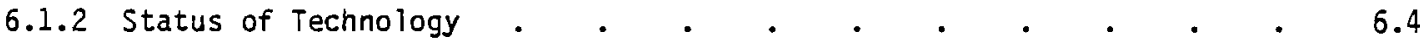

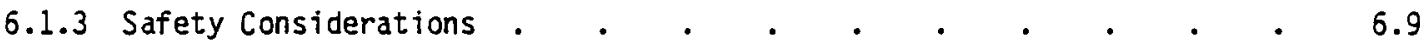

6.1.4 Facility Implementation . . . . . . . . . . . . . 6.10

6.2 COMBINED WASTE PROCESS APPROACH $\quad . \quad$. $\quad . \quad . \quad . \quad . \quad . \quad . \quad .6 .10$

6.2.1 Process Flowsheet Combined Waste Process . . . . . . . . 6.10

6.2.2 Status of Technology . . . . . . . . . . . . . . . . $\quad$. 6.13

6.2.3 Safety Considerations . . . . . . . . . . . . . . . . 6.13

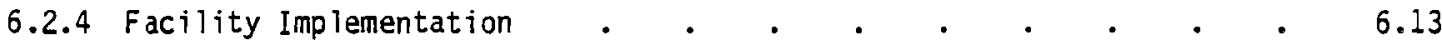

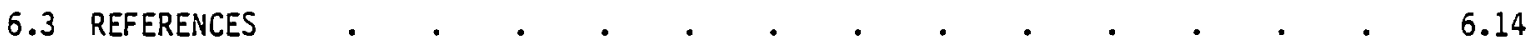




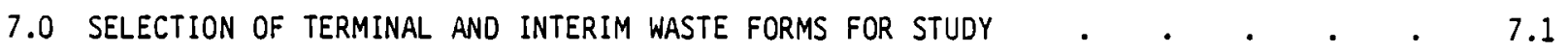

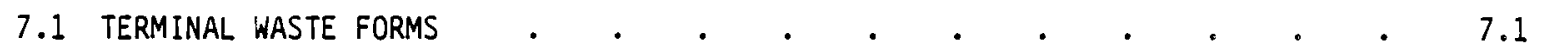

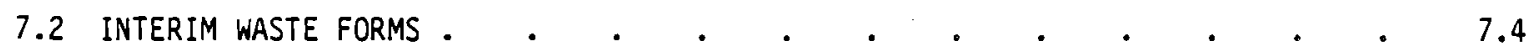

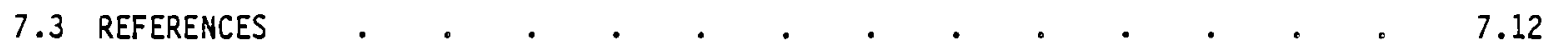

8.0 SOLIDIFICATION OF SALT/SLUDGE SEPARATED WASTE USING A TERMINAL WASTE FORM PROCESS 8.1

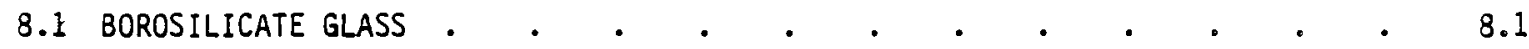

8.1.1 Waste Form Properties . . . . . . . . . . . . . . 8.1

8.1.2 Reference Process System Description and Material Balance . . . 8.6

8.1 .3 Status of Technology . . . . . . . . . . . . . . 8.11

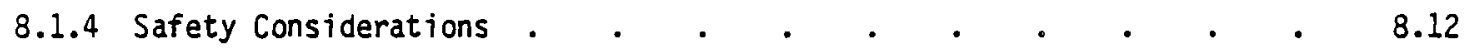

8.1.5 Facility Implementation . . . . . . . . . . . . 8.14

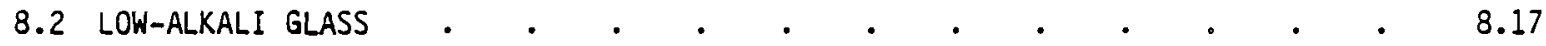

8.2.1 Waste Form Properties . . . . . . . . . . . 8.17

8.2.2 Process System Description and Material Balance . . . . . 8.18

8.2.3 Status of Technology . . . . . . . . . . . . . 8.24

8.2 .4 Safety Characteristics . . . . . . . . . . . . . 8.27

8.2.5 Facility Implementation . . . . . . . . . . . . 8.28

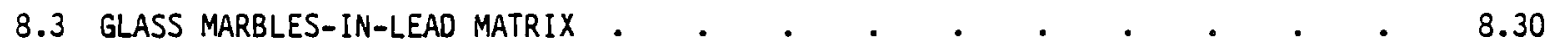

8.3.1 Waste form Properties . . . . . . . . . . . . 8.30

8.3.2 Process System Description and Material Balance . . . . . 8.30

8.3.3 Status of Technology . . . . . . . . . . . . . . 8.36

8.3.4 Safety Considerations . . . . . . . . . . . . 8.37

8.3.5 Facility Implementation . . . . . . . . . . . 8.38

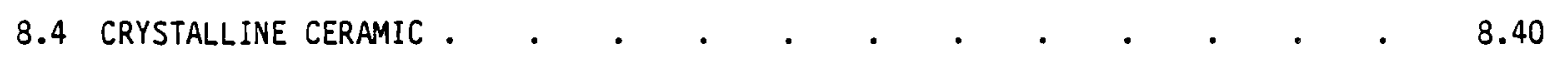

8.4.1 Waste Form Properties . . . . . . . . . . . 8.40

8.4.2 Process System Description and Material Balance . . . . . 8.41

8.4.3 Status of Technology . . . . . . . . . . . . . . 8.51

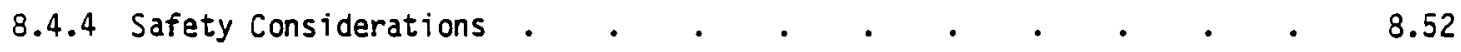

8.4.5 Facility Implementation $. \quad . \quad . \quad . \quad . \quad . \quad . \quad . \quad . \quad 8.52$

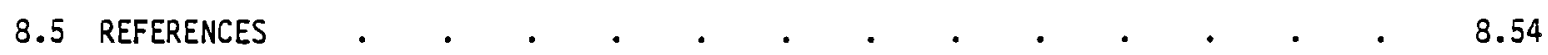

9.0 SOLIOIFICATION OF COMBINED ALKALINE PUREX AND ACIDIC THOREX WASTE $\quad \cdot \quad \cdot \quad \cdot \quad 9.1$

9.1 BOROSILICATE GLASS •

9.1.1 Waste Form Properties . . . . . . . . . . . . . 9.1 
9.1.2 Process System Description and Material Balance . . . . . . 9.1

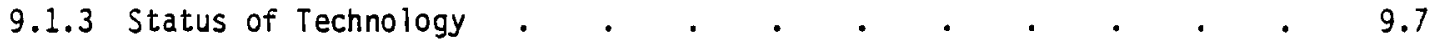

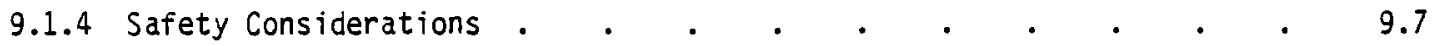

9.1.5 Facility Implementation . . . . . . . . . . . 9.8

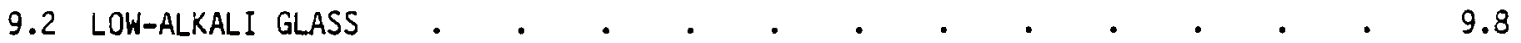

9.2.1 Waste Form Properties . . . . . . . . . . . 9.10

9.2.2 Process System Description and Material Balance . . . . . . 9.10

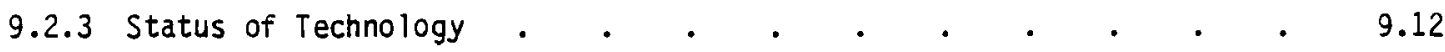

9.2 .4 Safety Considerations . . . . . . . . . . . . . 9.12

9.2.5 Facility Implementation $\quad . \quad$. . . . . . . . . . . 9.13

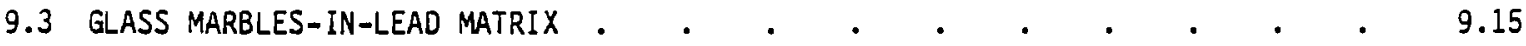

9.3.1 Waste Form Properties . . . . . . . . . . . 9.15

9.3.2 Process System Description and Material Balance . . . . . . 9.15

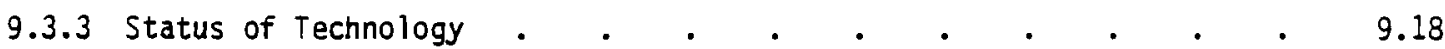

9.3.4 Safety Considerations . . . . . . . . . . . . . . . 9.18

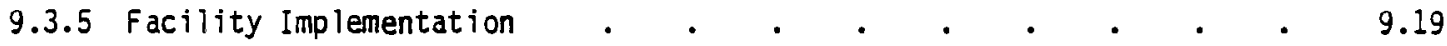

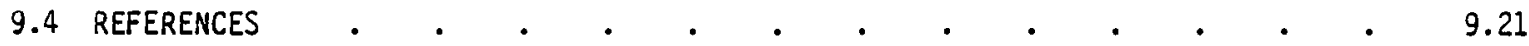

\begin{tabular}{l} 
10.0 SOLIDIFICATION OF COMBINED ALKALINE AND ACIDIC THOREX WASTE USING INTERIM \\
WASTE FORM PROCESSES.. \\
\hline
\end{tabular}

10.1 FUSED SALT $\quad$ •

10.1.1 Waste Form Properties . . . . . . . . . . . . 10.1

10.1.2 Process System Description and Material Balance $\quad . \quad$. $\quad . \quad$. 10.4

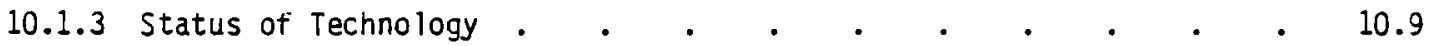

10.1.4 Safety Considerations . . . . . . . . . . . . 10.10

10.1.5 Facility Implementation . . . . . . . . . . . 10.12

10.2 SILICATE/SALT PROCESS . . . . . . . . . . . . . . . . . . 10.12

10.2.1 Waste Form Properties. . . . . . . . . . . 10.14

10.2.2 Process System Description and Material Balance . . . . 10.20

10.2.3 Status of Technology . . . . . . . . . . . 10.25

10.2.4 Safety Considerations . . . . . . . . . . . . 10.26

10.2.5 Facility Implementation . . . . . . . . . . 10.27

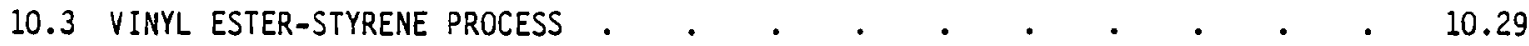


10.3.1 Waste Form Properties . . . . . . . . . . 10.26

10.3.2 Process System Description and Material Balance . . . . 10.31

10.3.3 Status of Technology . . . . . . . . . . . . 10.33

10.3.4 Safety Considerations . . . . . . . . . . 10.36

10.3.5 Facility Implementation . . . . . . . . . . 10.37

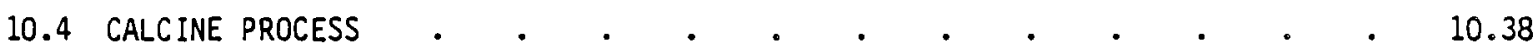

10.4.1 Waste Form Properties . . . . . . . . . . 10.39

10.4.2 Process System Description and Material Balance . . . . 10.43

10.4.3 Status of Technology . . . . . . . . . . . . 10.45

10.4.4 Safety Considerations . . . . . . . . . . . 10.48

10.4.5 Facility Implementation . . . . . . . . . . . . 10.49

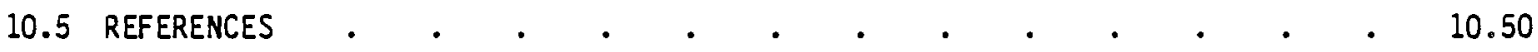

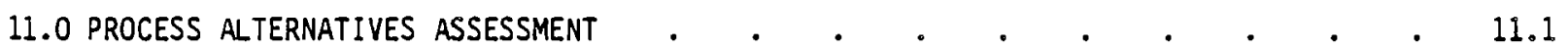

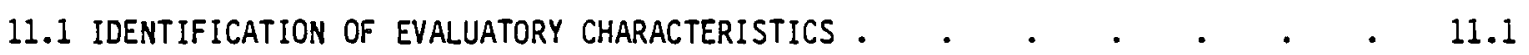

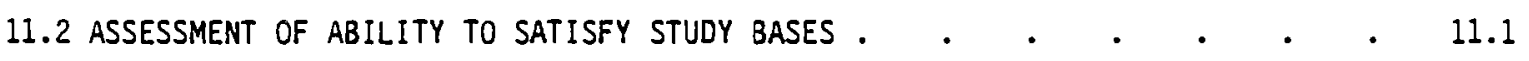

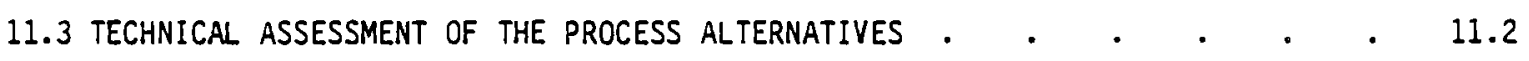

11.3.1 Processing Characteristics . . . . . • . . . 11.5

11.3.2 Waste Form Properties . . . . . . . . . . . . . 11.7

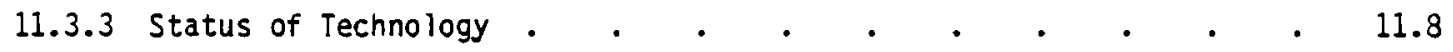

11.3.4 Safety Considerations . . . . . . . . . . . . . . . 11.8

11.3.5 Facility Implementation . . . . . . . . . . . . 11.9

11.3.6 Compatibility of the Interim Waste Form Processes with the Final
Waste Form ....
.

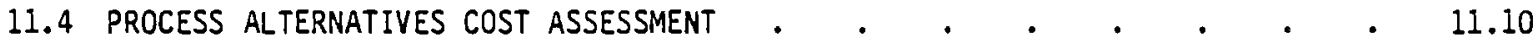

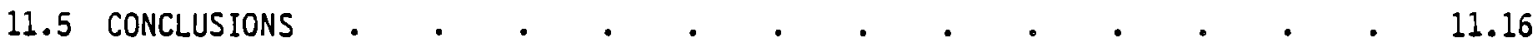

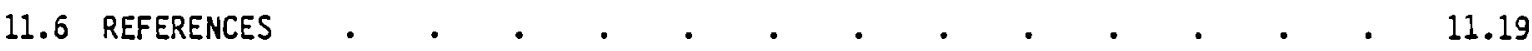

APPENDIX A - FLOWSHEET AND MATERIAL BALANCE; SOLIDIFICATION OF SALT/SLUDGE SEPARATED ALKALINE WASTE $\cdot \cdot \cdot \cdot \cdot \cdot \cdot \cdot \cdot \cdot \cdot \cdot \cdot \cdot \cdot \cdot \cdot \cdot \cdot \cdot \cdot$.

APPENDIX B - FLOWSHEET AND MATERIAL BALANCE; SOLIDIFICATION OF ACIDIC THOREX WASTE • B. B.1

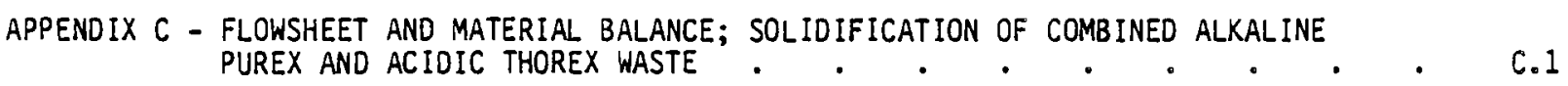

APPENDIX D - TECHNICAL RANKING CRITERIA FOR WASTE TREATMENT AND WASTE FORM PROCESSES • 0.1 


\section{FIGURES}

3.1 Major Features of Upper Portion of Main Process Building . . . . . . $\quad 3.2$

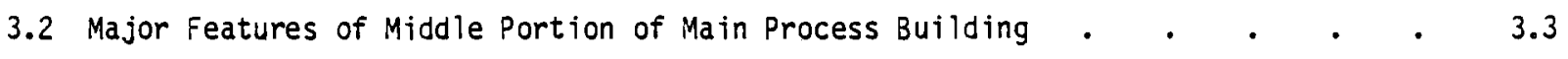

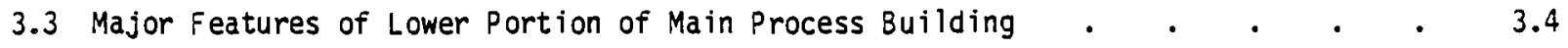

6.1 Simplified Process Flowsheet for the Salt/Sludge Separation Process . . . $\quad 6.3$

6.2 Simplified Process Flowsheet for Treatment and Solidification of Combined Alkaline Purex and Acidic Thorex Wastes . . . . . . . . . . 6.11

8.1 Comparison of Nuclear Waste Glass and Commercial Glass Viscosities . . $\quad 8.4$

8.2 Effect of Impact Velocity on Fraction of Respirable Particles Formed • • $\quad$ - 8.5

8.3 Typical Waste Glass Leach Rates .

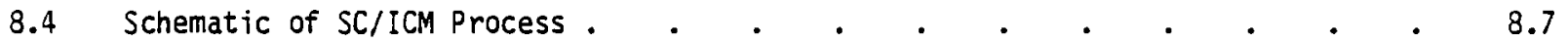

8.5 Simplified Flowsheet of Spray Calciner/In-Can Melter Process . . . . . 8.10

8.6 Conceptual Layout of Processing Equipment in the Chemical Processing Cell $\quad 8.14$

8.7 Conceptual Layout of Processing Equipment in the Scrap Removal Room . . . $\quad 8.15$

8.8 Silicon Release in Leach Rate Tests as a Function of Ambient Temperature . . 8.18

8.9 Schematic of the Low-Alkali Glass Process . . . . . . . . . . . . 8.18

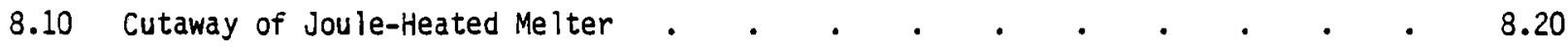

8.11 Facility Layout of the Low-Alkali Glass Process . . . . . . . . . 8.26

8.12 Marbles-in-Lead Process.$\quad$. $\quad$. $\quad$. . . . . . . . . . 8.29

8.13 Schematic of Glass Marbles-in-Lead Matrix Canister . . . . . . . . 8.30

8.14 Facility Layout of Marbles-in-Lead Process . . . . . . . . . . 8.35

8.15 Schematic of the Crystalline-Ceramic Process . . . . . . . . . . . 8.38

8.16 Facility Layout of the Crystalline Ceramic Process . . . . . . . . . $\quad$. 8.46

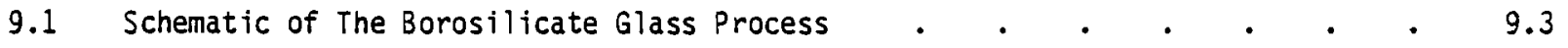

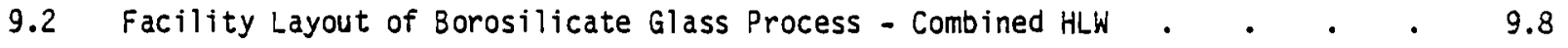

9.3 Facility Layout of Low-Alkali Glass Process - Combined HLLW . . . 9.13

9.4 Schematic of the Marbles-in-Lead Process - Solidification of Combined Wastes . 9.14

9.5 Conceptual Layout of the Equipment for the Marbles-In-Lead-Combined Alkaline Purex and Acidic Thorex Wastes ..$\quad \cdot \quad \cdot \quad \cdot \quad \cdot \quad \cdot \quad \cdot \quad \cdot \quad \cdot 9.18$

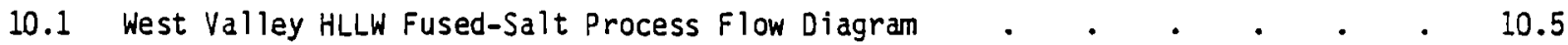

10.2 West Valley HLLW Fused Salt Removal from Canister Process Flow Diagram . . 10.5 
10.3 Conceptua1 Equipment Layout of the Fused Salt Process . . . . . . $\quad 10.11$

10.4 WNYNSC HLW Salt/Silicate Matrix Process Flow Diagram • • • • • • • . 10.19

10.5 Schematic Flowsheet for Silicate/Salt Removal Process . . . . . . 10.20

10.6 Conceptual Equipment Layout for Salt/Silicate Process . . . . . . 10.25

10.7 $\quad 137$ Cs Release in Distilled water From Portland Type II Cement, UF, and Vinyl Ester-Styrene Waste Form Containing BWR Chemical Regenerative waste as a Result of Leaching by the Modified IAEA Procedure . . . . . . . . 10.27

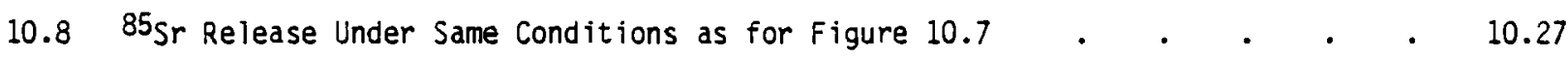

10.9 Percent Initial Weight Versus Time in Ambient Air for Dow Solidification Agent Specimens . . . . . . . . . . . . . . . 10.28

10.10 Thermogravimetric Weight Loss for Dow Solidification Agent Specimens $\quad$ • $\quad 10.29$

10.11 Leach Test Results for Rad BWR Waste at 1.65/1.0 Waste/Binder Ratio . . . 10.30

10.12 Conceptual Vinyl Ester-Styrene Process Flow Diagram . . . . . . . 10.32

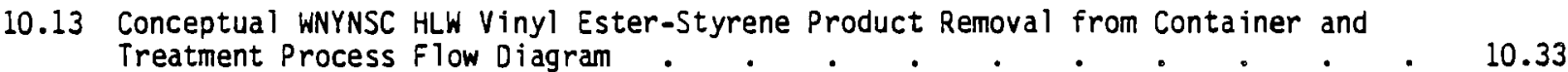

10.14 Conceptual Equipment Layout for Vinyl Ester-Styrene Process . . . . . 10.37

10.15 Acid-waste Particle Size Distribution . . . . . . . . . . . . 10.40

10.16 Defense Waste Calcine Particle Size Distribution $\quad . \quad$. $\quad . \quad$. . . $\quad$. 10.41

10.17 WNYNSC HLW Calcination Process Flow Diagram $\quad . \quad$. $\quad . \quad . \quad . \quad . \quad . \quad . \quad 10.43$

10.18 WNYNSC HLW Calcine Removal from Canister Process Flow Diagram . . . . $\quad 10.44$

10.19 Conceptual Equipment Layout for the Calcine Process . . . . . . 10.49 
1.1 Number of Canisters Produced By Each of the Waste Solidification Processes . . 1.3

2.1 Waste Treatment and Waste Form Processes Evaluated in Process Alternatives Study 2.2

3.1 Dimensions of Cells Used During Fuel Reprocessing at WNNSC . . . . • • . 3.4

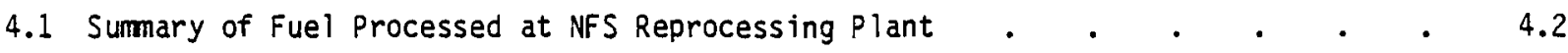

4.2 Estimated Composition of the Alkaline in Tank 802 . $\quad . \quad$. $\quad . \quad$. $\quad$. $\quad$. 4.3

4.3 Estimate of Radiochemical Inventory of the Alkaline Waste in Tank 802 . $\quad . \quad 4.4$

4.4 Chemical and Radiochemical Inventory of Tank 804 . $\quad . \quad$. . . . . . . 4.6

4.5 Estimated Situation of WNYNSC Wastes In 1987 . $\quad . \quad$. . . . . . . . 4.7

6.1 Estimated Chemical Composition of Salt/Sludge Separated Alkaline Waste Blend for

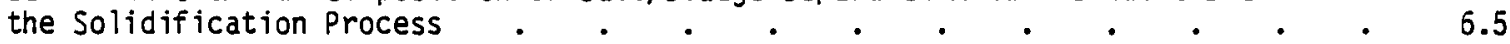

6.2 Estimated Salt Cake Composition for the Salt/Sludge Separation Process $\quad$. 6.6

6.3 Calculated Isotopic Composition of Low-Level Salt Cake from the Salt/Sludge Separation Process $\quad . \quad \cdot \quad \cdot \quad \cdot \quad \cdot \quad \cdot \quad \cdot \quad \cdot \quad \cdot \quad \cdot \quad 6.7$

6.4 Blended Waste Composition, Alkaline Purex and Acidic Thorex Waste $\quad$ • $\quad$ • 6.12

7.1 Relative Ranking of Waste Form Processes Based on Their Comparative Rating . $~ .7 .2$

7.2 Relative Ranking of Waste Forms and Processes Based on Their Comparative Rating . 7.3

7.3 Waste Form Rating by Alternative Waste Form Peer Review Panel . • • • . 7.3

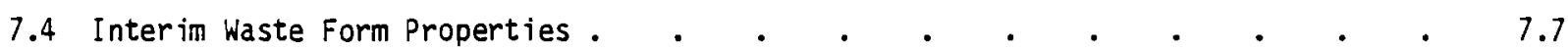

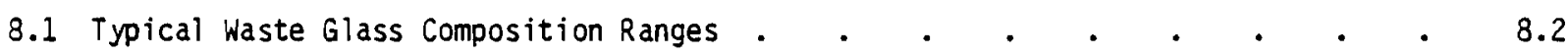

8.2 Chemical Composition of Glass-Formers Used to Solidify Simulated Salt/Sludge
Separated Alkaline Waste and Acidic Thorex Waste.$\quad \cdot \quad \cdot \quad \cdot \quad \cdot \quad \cdot \quad$. 8.3

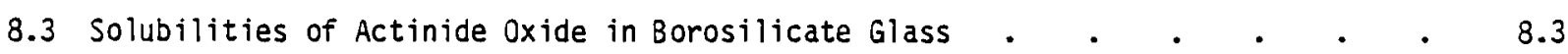

-4 Process Conditions and Material Balance Data for Solidifying the Alkaline Waste
Blend in A Borosilicate Glass (Salt Separation Process) $. \quad . \quad . \quad . \quad$.

8.5 Process Conditions and Material Balance Data for Solidifying the Acidic Thorex

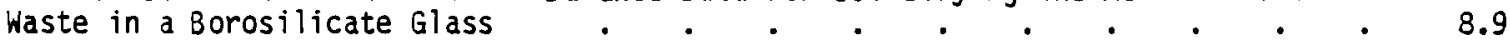

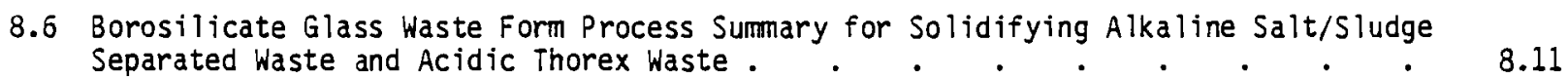

8.7 Composition Ranges for Low-Alkali Glasses Incorporating the Alkaline Waste . $\quad 8.17$

8.8 Process Conditions and Material Balance Data for Solidifying Alkaline Waste in

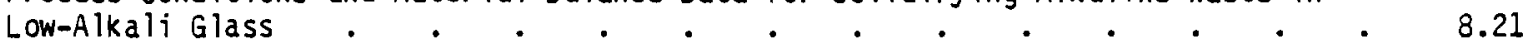

8.9 Process Flowsheet for Acidic Thorex Waste--Solidified in Low-Alkali Glass . . 8.21

8.10 Waste Form Product Sumary for Separated Alkaline Waste and Acidic Thorex Waste
Solidified Individually in Low-Alkali Glass..
. 
8.11 Corrosion Rates for Lead in Various Environments . . . . . . . . $\quad 8.31$

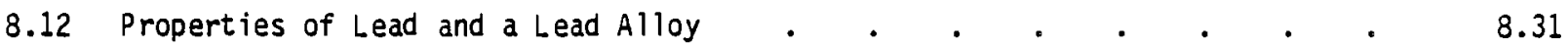

8.13 Process Conditions and Material Balance Data for Solidification of Alkaline

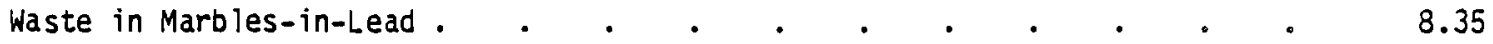

8.14 Process Conditions and Material Balance Data for Solidification of Acidic Thorex Waste Solidified in Marbles-in-Lead . . . . . . . . . . 8.36

8.15 Waste Form Product Surmary for Separated Alkaline Waste and Acidic Thorex Waste Solidified Individually in Marbles-in-Lead . . . . . . . 8.36

8.16 Performance Data on Crystalline-Ceramic waste Forms . . . . . . 8.41

8.17 Process Conditions and Material Balance Data for Solidification of Alkaline Waste in a Crystalline-Ceramic Waste Form . . . . . . . . 8.49

8.18 Process Conditions and Material Balance Data for Solidification of Acidic Thorex Waste in a Crystalline-Ceramic Waste Form $. \quad . \quad . \quad . \quad . \quad . \quad . \quad 8.50$

8.19 Waste Form Product Summary for Separated Alkaline Waste and Acidic Thorex Waste Solidified Individually in Crystalline Ceramic . . . . . . .

9.1 Composition of Borosilicate Glass Used for Solidified Combined Alkaline Purex and Acidic Thorex Wastes. . . . . . . . . . . . 9.2

9.2 Process Conditions and Material Balance Data for Solidifying Combined Alkaline Purex and Acidic Thorex Wastes in a Borosilicate Glass . . . . . . 9.4

9.3 Borosilicate Glass Waste-Form Product Sumary for Combined Alkaline Purex and Acidic Thorex Waste . . . . . . . . . . . . . 9.5

9.4 Composition of Low-Alkali Glass Used for Solidified Combined Alkaline Purex and Acidic Thorex Wastes . . . . . . . . . . . . . 9.10

9.5 Process Conditions and Material Balance Data for Solidifying Combined Alkaline Purex and Acidic Thorex Wastes in a Low-Alkali Glass . $. . . \quad . \quad$. 9.13

9.6 Low-Alkali Glass Waste Form Product Summary for Combined Alkaline Purex and Acidic

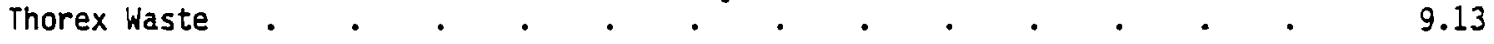

9.7 Process Conditions and Material Balance Data for Solidifying Combined Alkaline Purex and Acidic Thorex Wastes Solidified in Marbles-in-Lead.$\quad \cdot \quad \cdot \quad 9.17$

9.8 Marbles-in-Lead Waste Form Product Summary for Combined Alkaline Purex and Acidic Thorex Wastes.

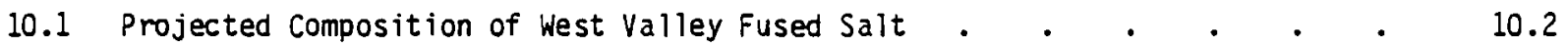

10.2 Process Conditions and Material Balance Data for Solidifying Combined Alkaline Purex and Acidic Thorex Waste in a Fused Salt $. \quad . \quad . \quad . \quad . \quad . \quad 10.8$

10.3 Fused-Salt Waste-Form Process Sumary, Solidification of Combined Alkaline Purex and

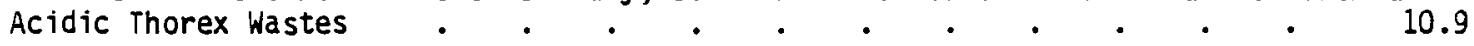

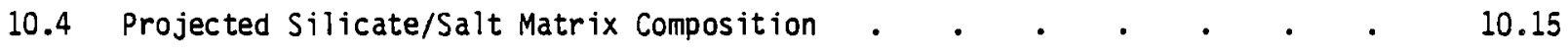

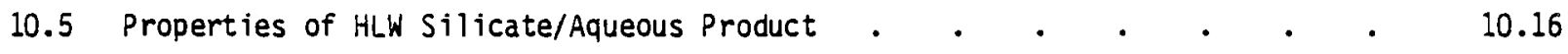

10.6 Properties of Aqueous-Silicate Products of NFS Wastes . . . . . . 10.17

10.7 Physical Properties of Clay-Rich Products . . . . . . . . . 10.18 
10.8 Typical Bulk Leach Rates of Clay-Rich Products Made from Actual Waste . .

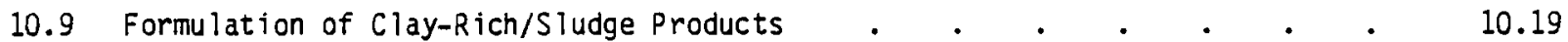

10.10 Bulk Leach Rates Based on ${ }^{137} \mathrm{Cs}, 90 \mathrm{Sr}$ and $239 \mathrm{Pu}$ for Clay-Rich Solidified

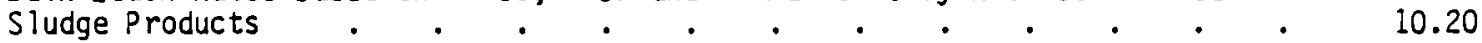

10.11 Process Conditions and Material Balance Data for Solidifying Combined Alkaline and Acidic Waste in a Salt/Silicate Waste Form . . . . . . 10.24

10.12 Silicate/Salt Waste Form Process Sumary: Solidification of Combined Alkaline Purex

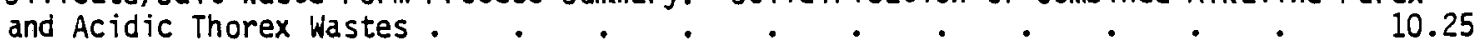

10.13 Solidification Verification Studies with Vinyl Ester-Styrene $\quad . \quad$. $\quad 10.30$

10.14 Compressive Strength of Vinyl Ester-Styrene Solidification Agent Specimens . $\quad 10.32$

10.15 Thermal Conductivity and Specific Heat of Vinyl Ester-Styrene $\quad$ - $\quad$ e 10.34

10.16 Process Conditions and Material Balance Data for Solidifying Combined Alkaline and Acidic Waste Vinyl Ester-Styrene Waste Form . . . . . . 10.40

10.17 Vinyl Ester-Styrene Waste Form Process Summary; Solidification of Combined Alkaline Purex and Acidic Thorex Wastes . . . . . . . . . 10.41

10.18 Projected Composition of Calcine from Blended Alkaline Purex and Acidic Thorex

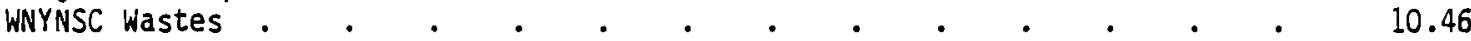

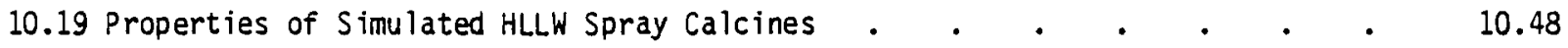

10.20 Process Conditions and Material Balance Data for Solidification of Combined Alkaline and Acidic Waste in a Waste Form . . . . . . . .

10.21 Calcine Waste Form Process Surmary Solidification of Combined Alkaline Purex and Acidic Thorex Wastes

10.22 Calcine as a Precursor for Glass and Composites . . . . . . . . 10.54

10.23 Status of Research and Development on Calcine. . . . . . . . 10.55

11.1 Waste Treatment and Waste Form Processes Being Evaluated . . . . 11.1

11.2 Weighting Factors for Ranking Categories . . . . . . . . 11.3

11.3 Sumary of Technical Comparison Ratings for Terminal Waste Form Processes . 11.4

11.4 Summary of Technical Comparison Ratings for Inter im Waste Form Processes . 11.4

11.5 Cost Surmary Salt Sludge Separation Process, Solidification in a Borosilicate Glass

11.6 Cost Summary, Combined Alkaline Purex and Acidic Thorex Waste Process, Solidification in a Borosilicate Glass. . . . . . . . . . . . . 11.13

11.7 Cost Surmary, Combined Alkaline Purex and Acidic Thorex Waste Process, Solidification as an Inter im Fused-Salt Waste Form Before Off-Site Terminal Solidification 11.14

11.8 Relative Handling and Disposal Cost for High-Level-Waste Canisters from Process Options 
. 


\subsection{SUMMARY AND CONCLUSIONS}

The 1980 U.S. Congress (Energy and Water Development Appropriations ACt) directed the Department of Energy (DOE) to prepare and implement a plan for removing the stored nuclear wastes from the Western New York Nuclear Service Center (WNYNSC) high-level-waste storage tanks and to determine the feasibility of solidifying the waste for safe storage. To accomplish this activity the DOE established the West Valley Solidification Project and requested that PNL do a preconceptual design study to evaluate converting the WNYNSC high-level wastes to a borosilicate glass waste form. In addition to this preconceptual design study, the DOE requested that PNL do an alternative-process evaluation study. The purpose of this alternative-process study was to assess two waste treatment approaches and several waste form processes for solidifying the alkaline Purex and acidic Thorex wastes stored at the WNYNSC.

The waste treatment approaches involve two different methods of treating the waste fractions (alkaline Purex supernate, alkaline Purex sludge, and acidic Thorex waste) before they are solidified by one of the alternative waste form processes. The first approach (the reference process approach) is called the salt/sludge separation process. In this approach the alkaline Purex and acidic Thorex wastes are solidified separately. The alkaline Purex waste fractions (supernate and sludge) are separated by centrifugation, settling and filtration processes. Radioactivity in the alkaline supernate is removed by ion-exchange processes, and the decontaminated supernate is concentrated by evaporation and formed into a low-level saltcake waste form. The radioactivity recovered from the supernate is combined with the alkaline sludge and process side streams and is solidified. The acidic Thorex waste is converted to a solidified waste form in a separate campaign that does not require any waste pretreatment. The second waste treatment approach is called the combined-waste process. This process involves blending the three waste fractions: alkaline supernate, alkaline sludge, and acidic Thorex waste. The resulting waste blend is then solidified.

The waste form processes considered for this study were selected based on the recommendations of several independent reviewers and an assessment of their relative technical merit. Both terminal and interim waste forms were investigated for use with the two waste treatment approaches. The terminal waste form is an ultimate waste form ready for final disposal. Borosilicate glass, low-alkali glass, glass marbles-in-lead matrix, and crystalline ceramic were the terminal waste forms considered in this study. The interim waste form is a temporary, solidified waste form that is suitable for transporting should the terminal waste form processing be done at another site. Inter im waste forms considered were: fused salt, silicate/ salt matrix, vinyl ester-styrene, and calcine. The interim waste forms were not considered for use in the salt/sludge separation waste treatment approach, and the crystalline ceramic waste form was not considered for use in the combined waste treatment approach.

Each of the waste treatment/waste form processes was characterized and assessed based upon their process attributes. Bases defined to provide guidelines for the study were developed from technical and schedular requirements of the West Valley Solidification Project. The major study bases are: 
- The waste solidification process will be sufficiently developed so that a waste form can be selected by 1984. Plant startup is assumed to be 1987 .

- The length of the high-level-waste solidification campaign is three years with an assumed plant efficiency factor of 0.60 .

- The high-level-waste treatment and waste form processes will be installed and operated within the main processing building at the WNYNSC.

The description of the waste treatment and waste form processes includes:

- waste form properties;

- process description, including definition of the process flowsheets and process material balances;

- status of technology;

- safety considerations;

- assessment of the feasibility of process and equipment implementation into the existing WNYNSC facilities.

Once defined, the process alternatives were judged on the following three technology characteristics:

1. the ability of the process to satisfy the study bases of the West Valley Solidification Project,

2. an assessment of the relative technical attributes for each process option,

3. the relative cost.

The number of canisters produced by each of the waste solidification processes is summarized in Table 1.1. These numbers are significant because of the expense involved in canister disposal. The combined-waste treatment approach produces five to seven times more canisters than the salt/sludge separation process because the potential low-level-waste salts have not been separated from the alkaline Purex waste in the salt/sludge separation process.

Al1 process approaches considered in this study were judged to satisfy the basic requirements set in the study bases with the exception of the crystalline-ceramic waste form process. The crystalline-ceramic process was considered to not be sufficiently developed such that a plant scale system could be operable at the WNYNSC by 1987. Also, the crystalline-ceramic process was judged to require additional process-building facilities to be implemented at the WNYNSC site.

A surmary of the technical ratings for the two waste treatment approaches and the various terminal waste form processes is surmarized in Section 11. In general there is only a slight technical advantage in the salt/sludge separation approach over the combined-waste process approach.

The salt/siudge separation process approach is characterized as being complex involving many batch operations (centrifugation, settling, filtration, and ion-exchange processes). These unit processes are necessary to separate the bulk of the nonradioactive chemical 
TABLE 1.1. Number of Canisters Produced by Each of the Waste Solidification Processes

\begin{tabular}{lc} 
Process & Number of Canisters $(a)$ \\
Salt/Sludge Separation Approach & \\
\hline Borosilicate Glass & \\
Low-Alkali Glass & 240 \\
Marbles-in-Lead & 377 \\
Crystalline Ceramic & 682 \\
Combined-Waste Approach & 121 \\
\hline Borosilicate Glass & \\
Low-Alkali Glass & \\
Marbles-in-Lead & 1500 \\
Fused-Salt & 2572 \\
Silicate/Salt Matrix & 3596 \\
Vinyl Ester & 944 \\
Calcine & 4691 \\
\end{tabular}

(a) $3.0 \mathrm{~m}$ in height by $0.61 \mathrm{~m}$ dia.

(b) $5120,55-$ gal barrels of decontaminated salt cake produced as low-level waste from salt/sludge separation approach.

constituents (supernate) from the radioactivity. This process approach minimizes the volume of high-level waste that requires handling and therefore the production rate of the high-level waste form product. Although the salt/sludge separation process is composed of many batch processes, these processes can be sequenced such that plant operations will run smoothly.

The approach of the combined-waste process is to solidify all radioactive and nonradioactive waste constituents present in the nuclear wastes. This approach involves simple processing. However, because of the three-year solidification campaign length and the high waste-form production rates required, multiple solidification systems are proposed to satisfy these process requirements, complicating the overall process. Also, because of the high canister-production rate, mechanical-transfer operations using the existing cranes at the facility are greatly complicated since the overhead crane is also needed for equipmentmaintenance tasks.

The state of development for the salt/sludge separation process, the combined-waste process and the various waste form processes ranges from well-characterized, remote, plant-scale, operational experience to conceptual processes having limited laboratory work done to support the concept. The majority of the process equipment for the salt/sludge separation process (centrifuges, ion-exchange columns) has been used on a plant scale at Hanford's B-Plant. The salt/sludge separation process is characterized as being more developed than the combined-waste processing approach; however development testing of the salt/sludge separation process will be required before plant implementation at the WNYNSC site.

The waste form processes vary in their state of development. Borosilicate glass has been produced with a radioactive pilot-scale process. The low-alkali glass and marbles-in-lead matrix have been produced on a laboratory scale, only conceptual process development has been completed. The technical ratings therefore are higher for the borosilicate glass, salt/sludge separation process. 
Implementing the various process alternatives into the existing WNYNSC facilities was considered an important rating criteria. Conceptual cell layouts were prepared to assess the feasibility of implementing these processes. All terminal waste form processes, except the salt/sludge separation approach with a crystalline ceramic waste form process, were judged able to be implemented within the existing facilities. The salt/sludge separation process, which requires fewer mechanical operations (canister handling), was judged to be easier to inplement within the WNYNSC facilities. The marbles-in-lead process will also be more difficult to implement because of service requirements and available cell space.

A summary of the technical ratings for the combined waste approach/interim waste form process alternatives is summarized in Section 11 . The interim waste form processes were compared with an additional rating category, i.e., interim waste form process compatibility with final waste form process. The interim waste form processes were not compared with the terminal waste form processes primarily because the purpose of interim waste is different.

The fused-salt and calcine interim waste form processes are preferred over the silicate/ salt matrix and vinyl ester-styrene processes when reviewing the overall technical ratings. The calcine process and the fused-salt processes are simple evaporation and waste-drying processes. Some nitrate decomposition is anticipated in these drying processes. The silicate/ salt matrix process involves blending of binding agents, such as clays, with the waste. This blend is formed into pellets and dried in a curing furnace before being placed in storage canisters. The vinyl ester-styrene process involves adding an organic binder, a promoter, and a catalyst to the waste blend to form pellets. The pellets are allowed to cure and then are placed in the storage canister. The additional complexity of producing the silicate/salt matrix and vinyl ester-styrene waste forms has resulted in a lower process-characteristic rating.

The waste form stability properties of the silicate/salt matrix and vinyl ester-styrene waste forms are superior to the fused-salt and calcine waste forms. However, the volume of silicate/salt and vinyl ester-styrene waste forms produced during solidification of the WNYNSC wastes is substantially higher than the fused-salt or calcine waste forms. Because of this the silicate/salt and vinyl ester-styrene processes receive only a slightly higher rating in terms of waste form characteristics.

The calcine process is considered ready far plant application at the WNYNSC. The other inter im waste form processes will require equipment-development work before they can be operated in a radiaactive production-scale facility. All processes however are anticipated to fit within the existing WNYNSC facilities.

The calcine process and fused-salt process produce waste forms that may easily be incorporated into waste treatment processes such as those proposed for application at the DOE sites. The silicate/salt matrix and vinyl ester-styrene waste forms will require some additional pretreatment before being converted to a terminal waste form. There is also the potential that these two waste form processes will increase the volume of the terminal waste form produced over the expected volume from processing the fused salt or calcine at the terminal waste form facility located at a DOE site. 
A preliminary cost estimate was prepared by Burns and Roe Industrial Services Corporation for three of the process alternatives. These est imates included costs associated with: 1) preparation of the existing facilities for waste processing, 2) construction of additional required facilities and equipment, 3) operating costs, 4) waste transportation and disposal costs, and 5) decontamination and demolition of all process related facilities including the high-level waste storage tanks. These costs assume that no process development will be required before the process can be implemented at the WNYNSC, and that the salt cake produced from the salt/sludge separation process can be disposed of inexpensively as a low-level waste. The total costs for the three options considered in the Burns and Roe study are summarized below. These costs are tentative and should not be considered as firm project cost estimates. These costs do, however, indicate the expected economic differences between the alternative process approaches.

\begin{tabular}{lc}
\multicolumn{1}{c}{ Process Approach } & $\begin{array}{c}\text { Estimated Cost } \\
1980 \text { dollars (millions) }\end{array}$ \\
$\begin{array}{l}\text { Salt/sludge Separation } \\
\text { Process, Borosilicate Glass } \\
\text { Waste Form }\end{array}$ & 326 \\
$\begin{array}{l}\text { Combined Waste Process, } \\
\text { Borosilicate Glass Waste Form }\end{array}$ & 491 \\
Combined Waste Process, \\
Fused-Salt Inter im Waste Form
\end{tabular}

The principal factor in the cost difference between the salt/sludge separation process and the combined-waste process when producing a borosilicate glass waste form is the reduced cost of packaging, transporting, and disposing of the smaller volume of high-level waste produced from the salt/sludge separation process. This cost difference dominates the overall wastemanagement project cost. The comparatively low cost of the fused-salt interim waste form approach is based primarily on the inexpensive incremental cost of converting the fused salt to a terminal waste form at a DOE site combined with the lower processing cost at the WNYNSC.

The waste form processes producing volumes of high-level waste greater than the borosilicate glass process will be more expensive based on waste form disposal cost. Therefore, when considering only the high-level-waste volumes, the cost of the process approaches should increase in the following order: borosilicate glass, low-alkali glass, and marbles-in-lead. The crystalline-ceramic process, al though producing the least number of canisters, is expected to be the most expensive process because of the additional facilities required. The same general trend in terms of cost is expected for the interim waste form processes. The process costs for the various interim waste form processes are expected to increase in the following order: fused salt, calcine, silicate/salt matrix, and vinyl ester-styrene.

The following conclusions were reached from this process alternatives study:

- The salt/sludge separation approach for waste treatment is preferred over the combined-waste process approach when producing a terminal waste form; however, it will require development testing before it is ready for plant application. If the 
combined-waste process is selected for conversion of the WNYNSC wastes to a terminal waste form, it is recommended that the process campaign length be increased from three years to make the overall process more reliable and easier to operate within existing WNYNSC facilities.

- The terminal waste form processes evaluated in this study are preferred in this order: borosilicate glass, low-alkali glass, marbles-in-lead matrix and crystalline ceramic.

- The interim waste form processing approach for solidification of the WNYNSC wastes is cost competitive with the salt/sludge separation process. If an interim waste form process is to be used for solidification of the WNYNSC waste, it is recommended that the process campaign length be increased. This will make the overall process approach more reliable and easier to operate within existing WNYNSC facilities.

- The interim waste form processes evaluated in this study were preferred in this order: fused salt, calcine, silicate/salt matrix and vinyl ester-styrene. 


\subsection{INTRODUCTION}

The purpose of the Atomic Energy Act of 1954 was to promote widespread participation in developing and using atomic energy for peaceful purposes. In 1954, the Atomic Energy Commission (AEC) began a program to encourage private participation in the reprocessing of irradiated nuclear fuel as part of its program to comercialize the entire nuclear fuel cycle.

In 1962, Davidson Chemical Co. established Nuclear Fuel Services, Inc. (NFS) to study the feasibility of constructing a nuclear fuel reprocessing facility. Contracts were later negotiated between NFS and the AEC and between NFS and the New York Atomic Research and Development Authority to build and operate a reprocessing plant at West Valley, New York, and to include a waste storage facility. However, as part of these agreements the State of New York was to take over perpetual care of the waste generated after the reprocessing activities were completed.

From 1966 to 1972, approximately $640 \mathrm{t}$ of nuclear fuel were processed at the WNYNSC. During operations $560,000 \mathrm{gal}$ of neutralized HLLW and 12,000 gal of acidic HLLW were generated. These wastes are currently stored at the WNYNSC in Tanks 804 and 802 , respectively. In 1972 , the $p l a n t$ was shut down to make several modifications. The AEC, however, decided that the extent of these modifications was enough to require a licensing review. By 1976, NFS had decided to terminate its fuel reprocessing business because of the cost associated with the modifications program and the uncertain regulatory requirements.

As indicated in Section 1.0, DOE established the West Valley Solidification Project and gave PNL the responsibility of doing a preconceptual design for removing the stored nuclear waste from its tanks at WNYNSC and solidifying it for safe storage. A reference preconceptual design for this waste treatment process is described in detail in PNL-3608-2. In addition, the DOE requested the PNL to evaluate alternative processes for treatment of the high-level wastes stored at WNYNSC.

\subsection{PURPOSE OF THIS STUDY}

The primary objective of this study is to evaluate two process approaches for waste treatment before solidification of the alkaline Purex and acidic Thorex HLLW stored at the WNYNSC. The two waste treatment approaches being considered are outlined in Table 2.1. The first process approach (the reference approach) involves the separation and radiochemical decontamination of the alkaline supernate. The alkaline sludge and activity recovered from the alkaline supernate are blended and solidified. The acidic Thorex waste is solidified in a separate processing campaign. The second waste treatment approach involves blending the entire contents of the alkaline Purex waste (alkaline sludge plus alkaline supernate) and the acidic Thorex waste. The resulting waste blend is then solidified.

A secondary objective of this study is to evaluate terminal waste form and inter im waste form solidification processes. The terminal waste form is a high integrity waste form suitable for ultimate disposal. The inter im waste form is a temporary, solidified waste form required for transportation should it be decided to further treat the waste at another site. 
TABLE 2.1. Waste Treatment and Waste Form Processes Evaluated in Process Alternatives Study

Waste Treatment Approach

Salt/sludge separation process

\author{
Waste Form Process \\ Borosilicate glass \\ Low-alkali glass \\ Marbles-in-lead matrix \\ Crystalline ceramic
}

\author{
Borosilicate glass \\ Low-alkali glass \\ Marbles-in-lead matrix \\ Fused-salt \\ Silicate/salt matrix \\ Vinyl ester-styrene \\ Calcine
}

\subsection{STUDY APPROACH}

Evaluation of the various waste treatment/waste form processes required identification, characterization, and assessment. Study bases are defined to provide guidelines for the study. These study bases were derived from the technical requirements and the schedular objectives of the overall West Valley Solidification Program.

The waste form processes studied were identified from a field of potential candidates. Recommendations of several independent technical review studies are used along with an assessment of technical merits to identify the waste form processes. These waste form processes, combined with the waste treatment approaches, are then characterized using the following study elements:

- waste form properties

- process flowsheet and material balance

- status of technology of waste form process and waste form

- safety considerations of process operations

- assessment of process and equipment implementation into existing WNYNSC facilities.

The waste treatment/waste form processes are characterized in sufficient detail to provide enough information for a technical process comparison. Extensive review of waste management literature combined with significant input from the West Valley Preconceptual Design (PNL-3608-2) was used to provide the necessary technical information. Data from the west Valley Preconceptual Design is drawn upon heavily when assessing implementation of the waste treatment/waste form process into the existing WNYNSC facilities.

The assessment of the waste treatment/waste form processes was based on three evaluatory elements. These are: 1) ability to satisfy the constraints defined in the study bases, 2) a relative technical evaluation of the waste treatment/waste form processes, and 3) a relative cost comparison of the various process approaches considered. 
The schedular constraints, technical merits, and relative economics of the waste treatment/waste form processes were combined to provide a complete assessment. Conclusions from the study have identified technically practical and economically favorable process approaches for solidification of the WNYNSC nuclear wastes. 
. 


\subsection{DESCRIPTION OF FACILITIES}

The WNYNSC occupies approximately 3,345 acres located in a rural area 30 miles southeast of Buffalo, New York. Less than 250 acres of the site have been developed for the reprocessing plant and associated facilities.

The existing facilities at the site include:

- a spent-fuel receiving and storage facility--This is a water bas in equipped with cranes and decontamination facilities.

- a reprocessing plant--This chemical-processing facility encompasses approximately $7.43 \times 10^{3} \mathrm{~m}^{2}(80,000$ square feet) of floor space. The plant is maintained in a shutdown condition.

- a low-level waste treatment facility--This facility is used to recover residual radioactive contamination from low-level process streams before release to the environment.

- a high-level waste storage facility--This facility consists of two, $2.84 \times 10^{6} \mathrm{~L}$ (750,000-gal) alkaline-waste storage tanks one tank contains approximately $2.12 \times$ $10^{6} \mathrm{~L}(560,000 \mathrm{gal})$ of high-level liquid waste, and the other serves as a spare, two, $\left.5.68 \times 10^{4} \mathrm{~L}(15,000-\mathrm{ga})\right)$ acidic-waste storage tanks one of which contains approximately $4.5 \times 10^{4} \mathrm{~L}(12,000 \mathrm{gal})$ of waste solution, and the other serves as a spare, and associated ventilation, surveillance and condensation systems. The tanks' design life is 50 years. Sampling to date indicates corrosion levels far below the design allowance.

- a NRC-licensed waste burial grounds--This burial ground occupies seven acres of the site. Approximately $3.94 \times 10^{3} \mathrm{~m}^{3}\left(139,000 \mathrm{ft}^{3}\right)$ of spent-fuel hardware and other solid waste are buried up to $15.2 \mathrm{~m}(50 \mathrm{ft})$ deep in these areas. Also located in this burial ground are a number of ruptured fuel assemblies encased in concrete. This facility was licensed by the AEC to accept waste generated from the reprocessing operations and is currently used to dispose of the small amounts of waste generated in the plant.

- New York State licensed burial grounds--This burial ground occupies 22 acres containing about $6.8 \times 10^{4} \mathrm{~m}^{3}\left(2.4 \mathrm{M} \mathrm{ft}^{3}\right)$ of contaminated wastes. Operation of these burial grounds ceased in 1975, primarily because of the overflow from some of the other trenches. Measures have been taken to correct this problem.

Other facilities at the site include administration buildings, craft shops, storage facilities, and process support-service facilities.

\subsection{MAIN PROCESSING BUILDING}

The main processing building at the WNYNSC was used for the reprocessing of spent nuclear fuel by the Purex extraction process. The plant was designed to recover uranium and plutonium 
from about $300 \mathrm{t}$ of spent fuel per year. Schematic elevation perspectives of the plant are shown in Figures 3.1, 3.2 and 3.3. Ten cells were used during fuel reprocessing operations at the WNYNSC. These cells are listed along with their physical dimensions in Table 3.1 .

The mechanical portion (head end) of the fuel reprocessing process consisted of separating the fittings and casings from the assemblies and then chopping the metal (ziracaloy or stainless steel) rods containing the fuel (fuel bundles) into short pieces ( 1.6 to $5 \mathrm{~cm}$ long) to expose the fuel. The spent fuel was leached from the hulls using nitric acid, leaving the fuel cladding behind. Next a solvent extraction process involving ten pulsed, countercurrent, extraction columns was used to recover the uranium and plutonium leached from the fuel elements.

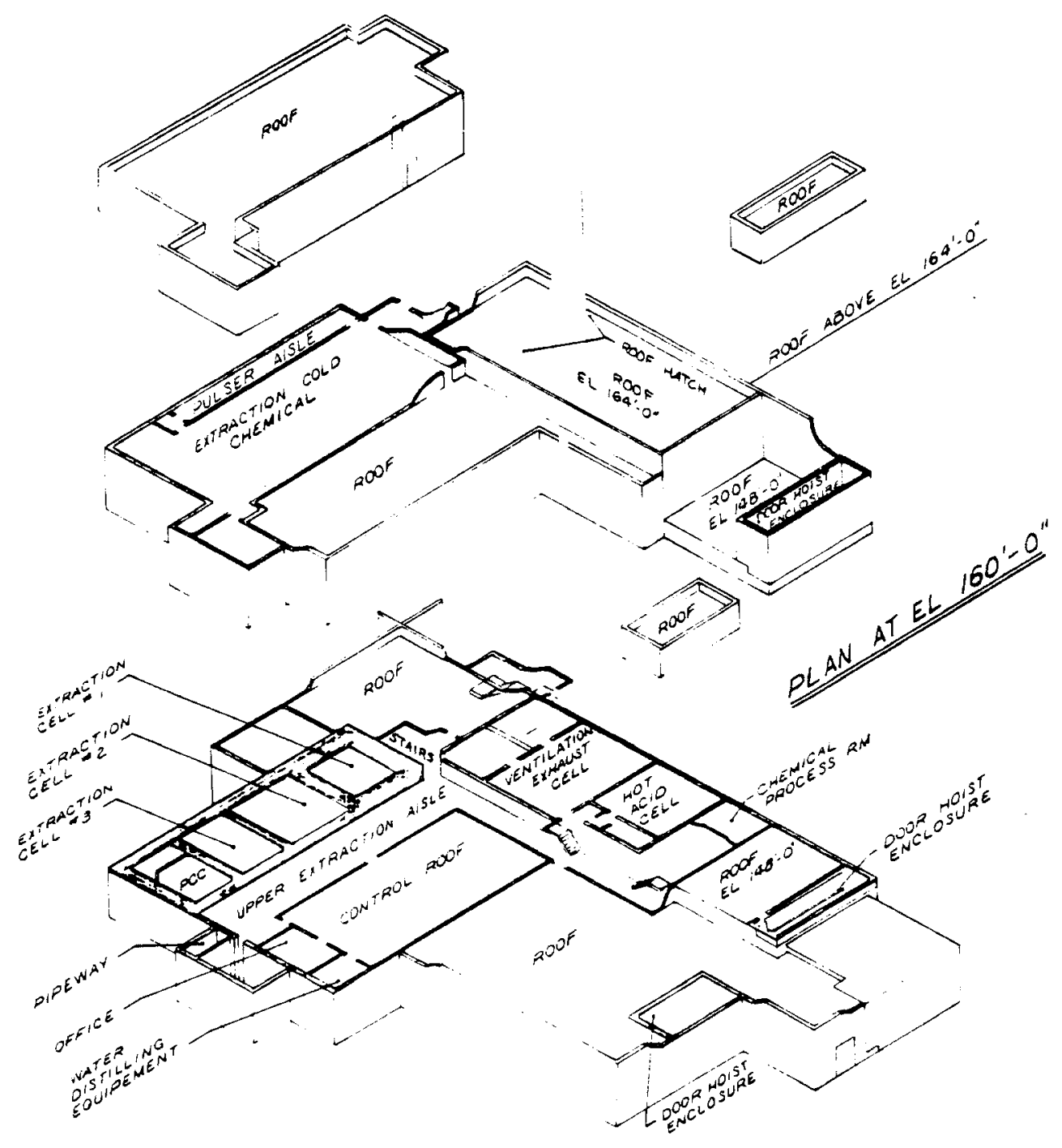

FIGURE 3.1. Major Features of Upper Portion of Main Process Building 


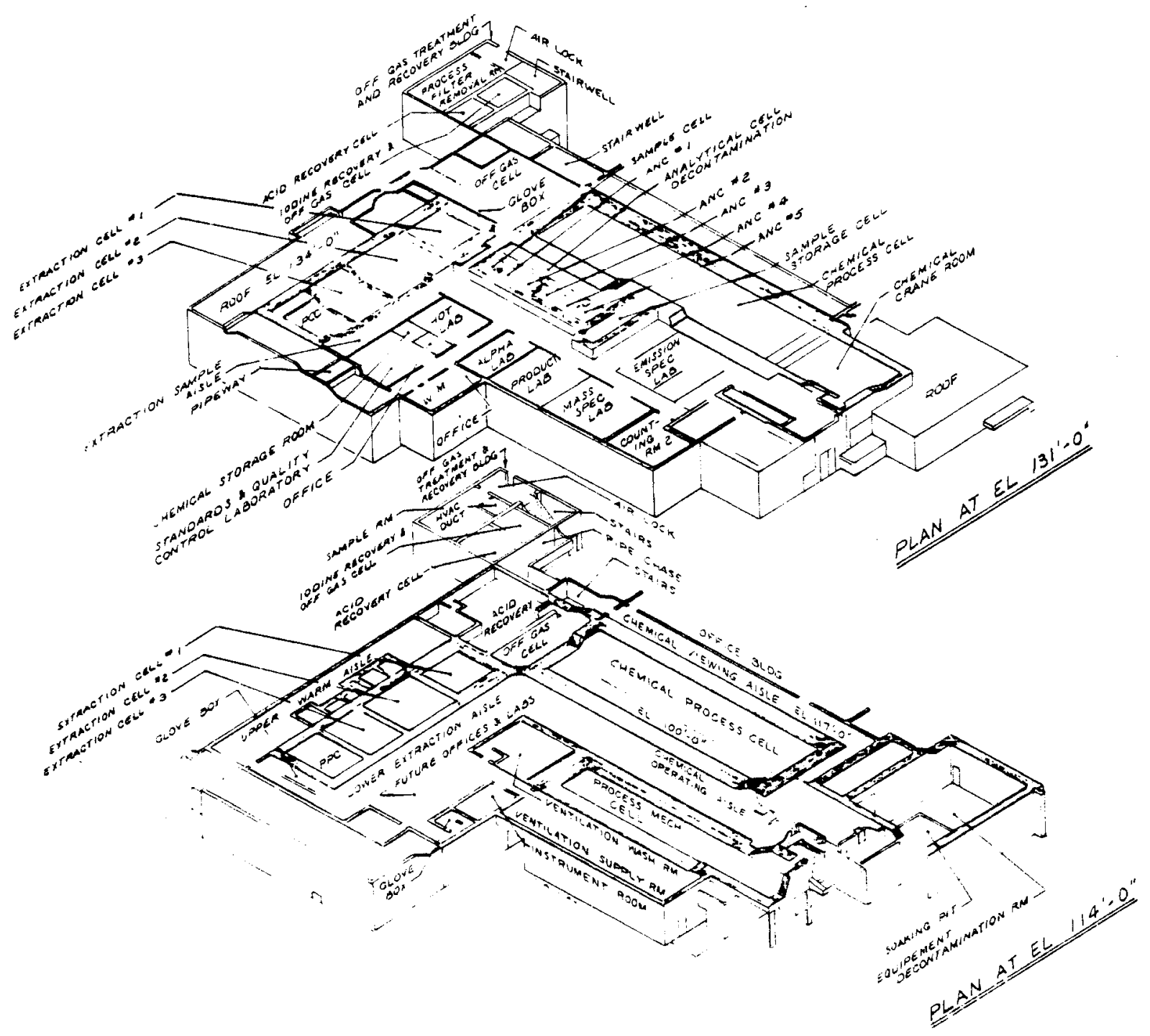

FIGURE 3.2. Major Features of Middle Portion of Main Process Building

The aqueous waste solutions from the solvent extraction process were partially evaporated to concentrate the wastes and remove most of the nitric acid, which was later recovered for reuse. The wastes were then neutralized and pumped to the waste tank farm for storage in an underground carbon steel tank. Waste that resulted from the reprocessing of a thoriumcontaining core was left in an acidic form and stored separately in a stainless steel tank.

\subsubsection{Head-End Processing Cells}

The equipment for trimming, chopping, and general handling of the fuel assemblies before the chemical dissolution of the fuel material was contained in several process cells: the process mechanical cell (PMC), the general purpose cell (GPC), and the scrap removal room (SRR). Maintenance, repair, and decontamination of the cranes and manipulators were conducted in a mechanical crane room (MCR), a manipulator repair room (MRR), and the GPC crane room. The 


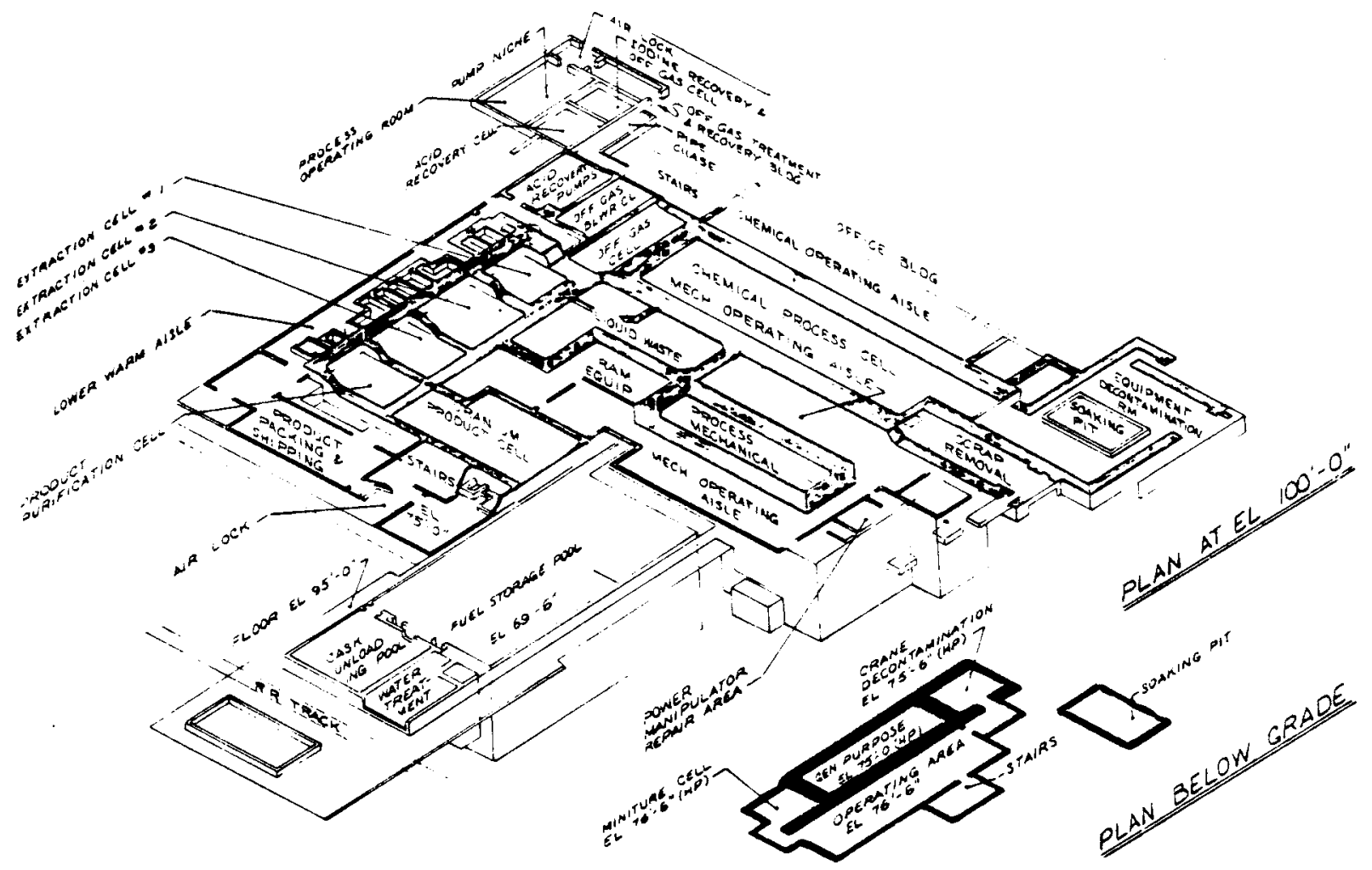

FIGURE 3.3. Major Features of Lower Portion of Main Process Building

TABLE 3.1. Dimensions of the Cells used During Fuel Reprocessing at WNYNSC(a)

\begin{tabular}{|c|c|c|c|c|c|}
\hline \multirow[b]{2}{*}{ Cell } & \multicolumn{4}{|c|}{ Dimensions, $\mathrm{m}$} & \multirow[b]{2}{*}{ Material (b) } \\
\hline & Width & Length & Height & $\begin{array}{c}\text { wall } \\
\text { Thickness }\end{array}$ & \\
\hline Processing mechanical cell & 3.7 & 15.8 & 7.6 & 1.7 & OC \\
\hline General purpose cell & 3.4 & 13.9 & 5.9 & 1.2 & HDC \\
\hline Scrap removal room & 3.0 & 11.6 & 4.0 & 1.0 & $O C$ \\
\hline Equipment decontamination room & 7.9 & 9.4 & 7.6 & 1.0 & OC \\
\hline Chemical processing cell & 6.7 & 28 & 13.1 & 1.8 & $O C$ \\
\hline Extraction cell 1 & 5.0 & 4.9 & 16.8 & 1.5 & OC \\
\hline Extraction cell 2 & 6.3 & 6.4 & 17.5 & 0.9 & OC \\
\hline Extraction cell 3 & 6.5 & 4.8 & 17.7 & 0.9 & OC \\
\hline Plutonium purification cell & 4.9 & 6.1 & 17.4 & 0.9 & OC \\
\hline Liquid-waste cell & 4.9 & 19.2 & 5.8 & 0.9 & $O C$ \\
\hline
\end{tabular}

(a) Adapted from Table V-2-3, NFS (1973).

(b) $O C=$ ordinary concrete; $H O C=$ high-density concrete. 
cranes and manipulators in the PMC and the GPC (and the chemical process cell discussed in the following section) were used for remote maintenance activities as well as process assistance. The cranes and manipulators are accessible in the crane room at one end of the process cell. The process cell is isolated from the crane room by a shielding door. A high-pressure spray in the crane room can be used for an initial remote decontamination of the cranes and manipulators before doing contact maintenance on them.

The PMC contained the hardware for trimming the fuel assemblies and chopping them into short sections in preparation for chemical dissolution. There is a chute leading into the GPC through which the chopped fuel pieces could be dropped into a waiting basket.

There were also cranes and manipulators in the PMC to handle the fuel during the sawing and shearing operations: two 1.8-t-capacity cranes, a power manipulator, and four pairs of master-slave manipulators. The two cranes were used to transport the fuel assembly to its various mechanical preparation work stations within the PMC; the manipulators were used for remote handling, maintenance, and inspections in the PMC. The two cranes and the power manipulator can travel the length of the cell on tracks and the width of the cell on trolleys mounted on the respective crane and manipulator bridges. The master-slave manipulators are mounted on the west wa11.

The walls of the PMC have six shielding windows for visual inspection of the equipment. A shielded transfer port is located in the east wall of the cell for transferring small equipment tools into the cell for remote maintenance of large items.

The MCR, used for the maintenance of the cranes and manipulators, is at the north end of the cell. It can be isolated from the cell by a $1-m$-thick concrete shielding door. An additional repair facility, the MRR, is beneath the MCR. It is connected to the MCR by a hatch that was used to lower the power manipulator tubes for maintenance.

The GPC was basically a collection and storage station for sheared fuel and scrap prior to dissolution and burial, respectively. The GPC is oriented east-west under the north end of the PMC and the chemical process cell (CPC), as shown in Figure 3.3. The GPC also contains a crane and manipulator used to handle the fuel baskets containing the chopped fuel pieces. As in the case of the cranes and the power manipulator located in the PMC, the 1.8-t-capacity crane and the power manipulator in the GPC are both bridge-mounted units that can trave] the length of the cell on tracks and the width of the cell on bridge-mounted trolleys. There are seven positions on a rack in the GPC where a loaded fuel basket may remain until it is transported to the CPC by cranes. Leached hulls, i.e., the fuel cladding that remained behind after chemical dissolution of the fuel material, could be returned to the GPC and packaged for waste burial. The GPC crane room (GCR), where decontamination and maintenance of equipment can be done, is at the west end of the GPC. This crane room is separated from the GPC by a shielding door.

The SRR, where leached hulls were transferred from the GPC to casks for delivery to the waste burial area, is above the GPC at the northeast corner of the CPC (discussed below). A cask trailer may be moved through the concrete shielding door to the outside to be loaded by a 
crane with drums of hulls from the GPC. There is also a decontamination spray to wash down the external portions of the cask trailer, as well as the internal surfaces of the SRR.

\subsubsection{Chemical Process and Extraction Cells}

The equipment items for dissolution of the fuel, separation and purification of the uranium and plutonium, cleanup of the used solvent, and concentration of the liquid wastes are housed in several process cells: the CPC, the three solvent extraction cells $(X C-1, X C-2$, and $X(-3)$, the product purification cell (PPC), and the liquid waste cell (LWC). Dimensions and other information concerning the cells are given in Table 3.1 .

The CPC contains two batch dissolvers, space for a third dissolver, a tank for feed adjustment and accountability, two waste evaporators, rework process vessels, and associated manipulators and plumbing. The CPC is serviced by two cranes, one with a 1.8-t hoist and a 1.8-t power manipulator, the other with a 14.5-t hoist. The chemical crane room (CCR), north of the CPC, was used to maintain the CPC cranes. The CPC vessels and piping were designed for remote maintenance and may be replaced via the equipment decontamination room (EDR).

At the south end of the CPC, and at right angles to it, is a row of four cells that contain solvent extraction, product purification, and product concentration equipment, as we 11 as columns and vessels for solvent cleanup. These are the three extraction cells $(X C-1, X C-2$, and $X C-3)$ and the PPC. Maintenance access to each of these four cells is through a plug in the cell roof. These cells and the equipment contained there in were designed to perform the following functions:

$\begin{array}{ll}\frac{C e l l}{X C-1} & \text { Partition cycle and high-level waste collection } \\ X C-2 & \text { 1st Pu cycle, 1st } U \text { cycle and No. } 1 \text { and No. } 2 \text { solvent-cleanup systems } \\ X C-3 & \text { 2nd } U \text { cycle and No. } 3 \text { solvent cleanup system } \\ \text { PPC } & \text { Pu purification by ion exchange, Pu concentration, and } U \text { concentration }\end{array}$

The LWC is adjacent to the extraction cells and contains process waste tanks in which waste liquids were stored before evaporation.

The acid recovery cell (ARC), at the southwest corner of the building, contains the system used to recover nitric acid from the waste evaporator overheads. The heart of the system is a sieve plate acid-fractionating column. Strong acid (12M) was recovered from the bottom of the column and the overhead weak acid $(0.0002 \mathrm{M})$ was withdrawn from the top of the column and stored at the lagoon.

A new off-gas cell has been added to the reprocessing plant. This cell is located on the southwest corner of the processing building. It contains equipment used for secondary dissolver off-gas treatment including iodine removal and filtration.

\subsection{SELECTION OF PROCESSING CELLS FOR WASTE SOLIDIFICATION}

Three cells have been selected for high-level-waste solidification processing for this study. These are the CPC, the SRR and, the EDR. The majority of the high-level-waste 
processing activities are to be performed in the CPC Cell. The SRR is used for solidification of decontaminated supernate resulting from the salt separation process. Decontamination and temporary storage of the high-level waste canisters will occur in the EDR.

These three processing areas were selected based on: 1) accessibility for equipment installation and maintenance, 2) compatibility of crane capacity with processing requirements, 3) shielding provided to the operators during processing operations (particularly in the case of the CPC ce11), 4) service features of these cells; i.e., windows, manipulators, cranes, process services for equipment, 5) ease of cell modification, if required, and 6) size requirements for containment of processing equipment. 


\subsection{REFERENCE}

Nuclear Fuel Services. 1973. Safety Analys is Report NFS Reprocessing Plant, West Valley, New York. Docket No. 50-201, Volume 1, Nuclear Fuel Services, Inc., Rockville, Maryland. 


\subsection{DESCRIPTION OF HIGH-LEVEL LIQUID WASTES}

The design of the NFS fuel-reprocessing plant was based upon the Purex technology developed at the government-operated fuel-reprocessing plants. During operations at the WNYNSC both uranium- and thorium-based fuels were reprocessed. Each fuel type produced a high-level nuclear waste that differed both in chemical composition and in quantity of waste produced.

The largest volume of nuclear waste $\left(2.15 \times 10^{6} \mathrm{~L}\right)$ was generated from the normal operation of the NFS plant to reprocess $624.5 \mathrm{t}$ equivalent of uranium fuel using the Purex process. Characteristics of the uranium fuel are sumarized in Table 4.1. Approximately $60 \%$ of this nuclear fuel came from the government-operated defense reactors and $40 \%$ by the commercial nuclear industry. The acidic column waste from fuel-reprocessing operations was neutralized by the addition of excess sodium hydroxide before being transferred to a carbon-steel storage tank (Tank 8D2). Waste neutralization resulted in precipitation of most metals and fission products in a sludge layer on the bottom of the tank. Alkali metal nitrates, sulphates and hydroxides formed a supernate layer above the sludge layer. This waste type is referred to as the alkaline waste in this report.

A second type of waste was generated from reprocessing $16 \mathrm{t}$ equivalent of thorium fuel at the Indian-Point Reactor. This fuel was reprocessed using modified technology for Thorex fuelreprocessing. The waste generated has a much smaller volume $\left(4.5 \times 10^{3} \mathrm{~L}\right)$ than the alkaline waste. The Thorex waste is stored in an acidic condition in a stainless steel storage tank. This waste is referred to as the acidic Thorex waste in this report.

\subsection{ALKALINE WASTE}

The greatest effort to solidify the waste at the WNYNSC will be with the alkaline waste primarily because of its large waste volume and its physical and chemical characteristics. There are reported differences in the total quantity of alkaline waste stored in Tank 802 . The most reliable estimate is given in the quarterly report from NFS to the State of New York (Duckworth 1978). This estimate placed the high-level waste volume at $2.1 \times 10^{6} \mathrm{~L}(561,000$ ga1). Other est imates given in NUREG-0043 (U.S. Nuclear Regulatory Commission 1976) and TID-29442 (DOE 1979) placed the waste volume at $2.3 \times 10^{6} \mathrm{~L}(600,000 \mathrm{gal})$. These differences are probably due to rounding off of previously reported data or waste evaporation.

The sludge volume is difficult to accurately measure primarily because of the limited number of access ports on the waste tank. Nuclear fuel Services has taken rough measurements of the sludge depth by dropping a weighted object on a calibrated string into the tank and noting the point at which the string became slack. From these estimates the sludge depth was determined to be 1.4 to $1.5 \mathrm{~m}$. This sludge depth would represent a sludge volume of $4.7 \mathrm{x}$ $10^{5} \mathrm{~L}(120,000$ gallons $)$. Other tests by NFS in which simulated waste solutions were prepared and allowed to settle for three to four months have confirmed the measured data.

The sludge is thought to be composed of two layers, the top layer being considerably less dense than the bottom layer. The denser layer of sludge is sloped downward away from the waste inlet point on the tank. This bottom layer is composed of sodium diuranate, fission-product 
TABLE 4.1. Surmary of Fuel Processed at NFS Reprocessing Plant(a)

\begin{tabular}{|c|c|c|c|c|c|c|}
\hline Lot No. & Reactor & $\begin{array}{c}\text { Commencement } \\
\text { Date } \\
\end{array}$ & MTU & $\begin{array}{c}\text { Total } \\
\text { Pluton ium, } \\
\mathrm{kg} \\
\end{array}$ & $\begin{array}{l}\text { Average } \\
\text { MWd/MTU }\end{array}$ & MWd \\
\hline 1 & NPR ${ }^{(b)}$ Def ined & $05 / 20 / 66$ & $\overline{28.8}$ & 2.3 & 75 & 2,160 \\
\hline 2 & NPR & $04 / 22 / 66$ & 19.7 & 1.7 & 75 & 1,478 \\
\hline 3 & NPR & $07 / 15 / 66$ & 46.7 & 50.9 & 1,287 & 60,100 \\
\hline 4 & Dresden-1 & $11 / 12 / 66$ & 50.0 & 191.0 & 8,500 & 426,200 \\
\hline 5 & Yankee Rowe & $06 / 07 / 67$ & 49.8 & 185.1 & 11,200 & 558,400 \\
\hline 6 & NPR & $09 / 02 / 67$ & 26.6 & 52.6 & 2,700 & 71,190 \\
\hline 7 & NPR & $12 / 02 / 67$ & 26.1 & 47.4 & 2,700 & 70,200 \\
\hline 8 & NPR & $01 / 06 / 68$ & 42.4 & 75.4 & 2,700 & 114,200 \\
\hline 9 & NPR & $05 / 05 / 68$ & 38.8 & 79.1 & 2,850 & 111,200 \\
\hline 10 & NPR & $06 / 29 / 68$ & 55.3 & 115.7 & 2,870 & 158,700 \\
\hline
\end{tabular}

11 Indian Point-1 11/15/68 Special case--16 MT uranium and thorium

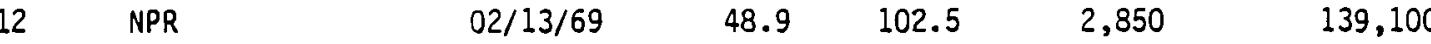

13 Yankee Rowe $\quad 05 / 14 / 69 \quad 19.6 \quad 176.0 \quad 20,500 \quad 400,000$

14 NPR $\quad 08 / 16 / 69 \quad 30.3 \quad \ldots \quad$ Unirradiated

15 Dresden-1 $10 / 01 / 69 \quad 21.5 \quad 104.6 \quad 10,900 \quad 235,000$

16 Indian Point-1 $11 / 23 / 69 \quad 15.6 \quad 107.6 \quad 15,794 \quad 247,966$

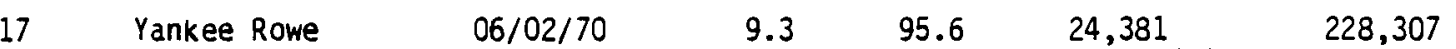

18 Pathfinder $\quad 08 / 14 / 70 \quad 9.6 \quad 7.1 \quad 2,231$ (a) $\quad 14,685$

19 Big Rock Point $\quad 11 / 26 / 70 \quad 18.4 \quad 72.8 \quad 9,212 \quad 171,361$

20 Indian Point-1 $\quad 01 / 11 / 71 \quad 7.6 \quad 68.1 \quad 23,455 \quad 177,502$

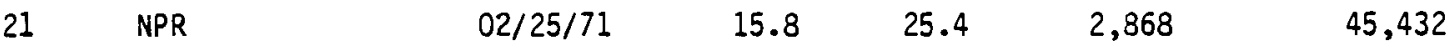

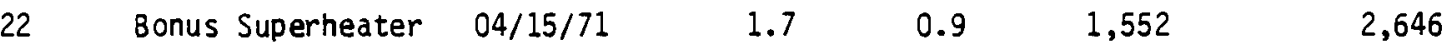

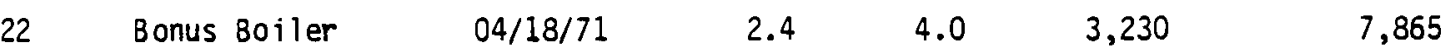

23 Humboldt Bay $\quad 05 / 02 / 71 \quad 20.8 \quad 87.2 \quad 10,466 \quad 219,631$

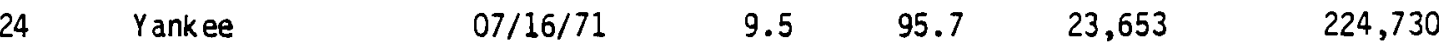

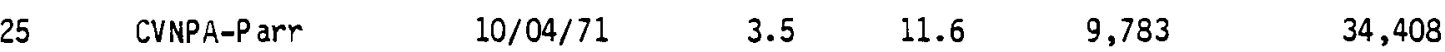

$\begin{array}{llllll}26 & \text { Big Rock Point } \quad 11 / 30 / 71 & 5.8 & 27.9 & 13,567 & 80,483\end{array}$

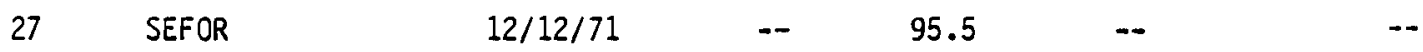

(a) NFS (1973)

(b) Only irradiated fuel averaged.

hydroxides and sulphates, and mangenese dioxides. The upper sludge layer is composed of hydrated ferric and aluminum hydroxides containing a high percentage of interstitial supernate.

Table 4.2 lists the chemical components of the alkaline waste sludge and supernate. The chemical inventory of the alkaline waste has been based on the NFS chemical accountability data, the NFS Waste Surveillance reports, and on the calculations based on total MWd burnup of fuel processed at NFS. 
TABLE 4.2. Estimated Composition of the Alkaline waste in Tank 802 (a)

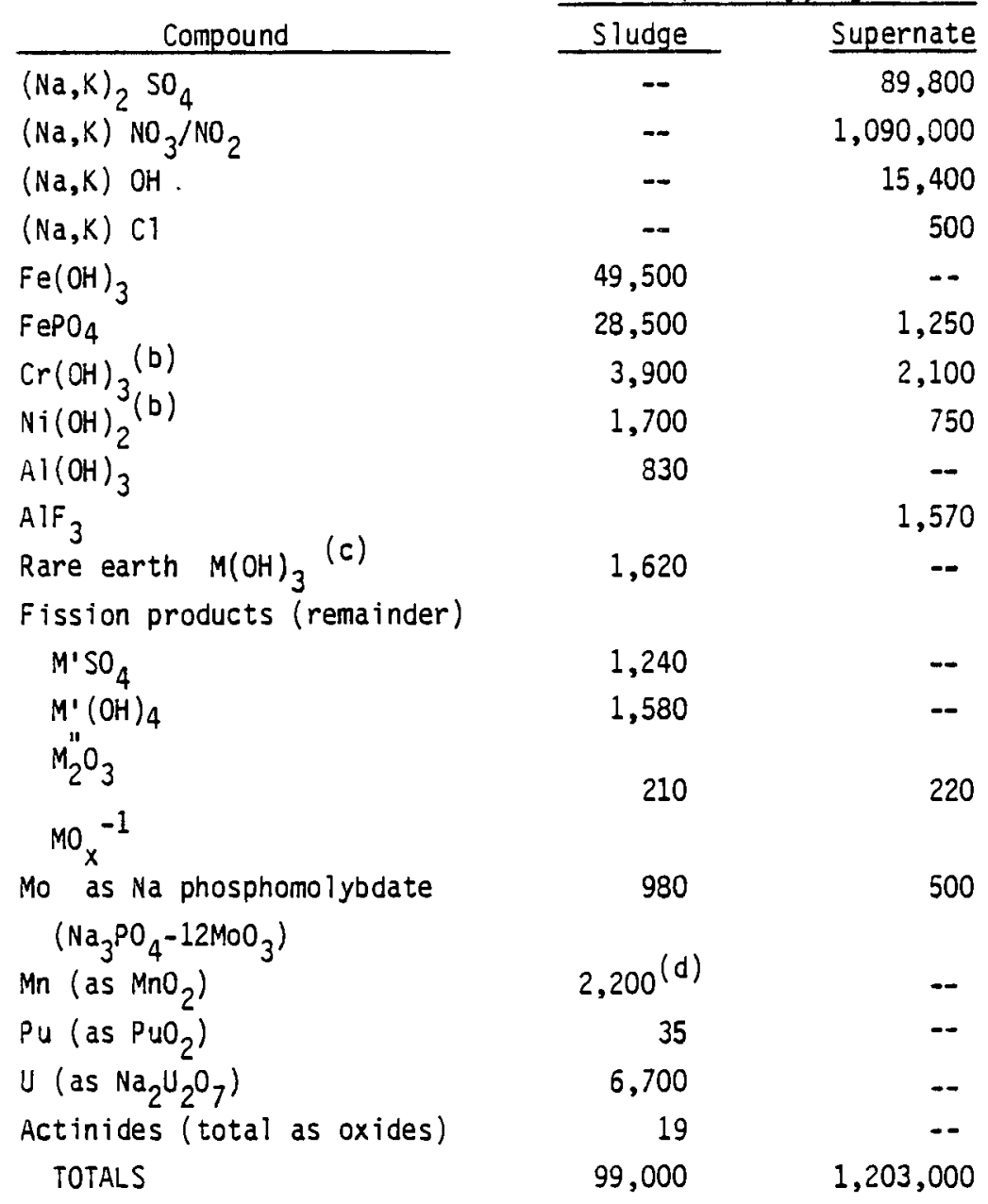

(a) Based on composite of information from Duckworth (1978), DOE (1978; Table 3.10), and on calculations based on total MWd burnup in fuel processed at NFS.

(b) Assuming ratio of chromium to nickel to be 19:9 (the ratio in which it occurs in 304 stainless stee 1 ).

(c) Average atomic weight $=143.9$.

(d) Estimated.

The radiochemical inventory of the alkaline waste is given in Table 4.3. Fairly complete data is available on the irradiation levels, discharge dates, and processing periods for the fuels used in the processing campaigns undertaken by NFS. This information combined with the ORIGEN tables was used to estimate the quantity of each major, radioactive fission product and actinide isotope at the time of reactor discharge for each reprocessing campaign. The nuclear waste radiochemical activity levels have been extrapolated to the year 1987, which is considered to be the time period when the waste will be solidified. 
TABLE 4.3. Estimate of Radiochemical Inventory of the Alkaline waste in Tank 802 (a)

\begin{tabular}{|c|c|c|c|}
\hline \multicolumn{2}{|c|}{ Fission Products } & \multicolumn{2}{|c|}{ Actinides } \\
\hline Radionuclide & Quantity, Ci & Radionuclide & Quantity, $\mathrm{Ci}$ \\
\hline $\mathrm{Se}-79$ & 50 & $\mathrm{~Np}-237$ & 23 \\
\hline $5 r-90$ & $6.7 \times 10^{6}$ & Np-239 & 220 \\
\hline$Y-90$ & $6.7 \times 10^{6}$ & Pu-238 & 1,500 \\
\hline $2 r-93$ & 250 & $P u-239$ & 1,800 \\
\hline$N b-93 m$ & 240 & Pu-240 & 970 \\
\hline TC-99 & 1900 & Pu-241 & 70,000 \\
\hline$R u-106$ & 110 & $P U-242$ & 1 \\
\hline$R h-106$ & 110 & $A m=241$ & 20,000 \\
\hline$P d-107$ & 6 & $A m-242$ & 180 \\
\hline Sb- 125 & 6,100 & $A m-242 m$ & 180 \\
\hline Te-125m & 6,100 & Am-243 & 220 \\
\hline$S n-126$ & 40 & $\mathrm{Cm}-242$ & 1 \\
\hline Sb-216m & 40 & $\mathrm{Cm}-244$ & 8800 \\
\hline$S b-126$ & 40 & $\mathrm{Cm}-245$ & 1 \\
\hline Cs -134 & 21,000 & $\mathrm{Cm}-246$ & 1 \\
\hline Cs-135 & 35 & TOTAL & $1.0 \times 10^{5}$ \\
\hline Cs-137 & $8.9 \times 10^{6}$ & & \\
\hline Ba-137m & $8.4 \times 10^{6}$ & & \\
\hline Ce-144 & 11 & & \\
\hline Pr-144 & 11 & & \\
\hline Pm-147 & 61,000 & & \\
\hline$S m-151$ & 200,000 & & \\
\hline$E u-152$ & 410 & & \\
\hline Eu-154 & 130,000 & & \\
\hline TOTAL & $3.1 \times 10^{\prime}$ & & \\
\hline
\end{tabular}

(a) Based on information from Charles Luner (ANL), estimated for year 1987.

\subsection{ACIDIC THOREX WASTE}

Acidic Thorex waste stored in Tank 804 was produced from a single campaign in which $16 \mathrm{t}$ of a thorium-enriched uranium fuel from the Consolidated Edison Indian point-1 reactor was reprocessed. The fuel had $1400 \mathrm{~d}$ of cooling at the time of processing. The initial composition of the waste was $93.5 \%$ thorium oxide and approximately $6.5 \%$ enriched (93\%) uranium oxide. The fuel was chopped and dissolved with concentrated nitric acid in the presence of approximately $0.04 \underline{M}$ to $0.05 \underline{M}$ fluoride and $0.1 \underline{M}$ boric acid. A small percentage of the fuel cladding may have been dissolved in each fuel batch.

Dissolver-solution separations were based on a modified Thorex process. The thorium remained with the fission products and other components of the high-level waste at separation. Uranium and plutonium isotopes were separated in the partition columns. Approximately 45,000 $\mathrm{L}$ 
(12,000 gal) of acidic high-level column waste were produced and then stored in Tank 804, a stainless steel storage tank. The waste is believed to be a single phase with no sludge or precipitates present.

A chemical inventory for the acidic Thorex waste is summarized in Table 4.4. This inventory was based on an analys is of an acidic Thorex waste sample done by Oak Ridge National Laboratory (ORNL). The results from this chemical analysis differ from chemical inventory records kept by NFS. This difference is particularly evident when reviewing the thorium inventory. The discrepancy is probably due to a nonrepresentative waste sample or precipitation of the thoria on the tank bottom. The radiochemical content of the waste, also summarized in Table 4.4, has been based on calculations made using ORIGEN data. This radiochemical estimate [Argonne National Laboratory (ANL)] is based on an extrapolation to the year 1987.

The alkaline and acidic Thorex waste volumes, weights of chemical components, radiochemical activity, and heat present in these wastes are given in Table 4.5 for the year 1987 . The data in these tables will be used to determine material and radiochemical balances for the processes being considered in this study. 
TABLE 4.4. Chemical and Radiochemical Inventory of Tank 8D4(a)

\begin{tabular}{|c|c|}
\hline Constituent & Quantity \\
\hline 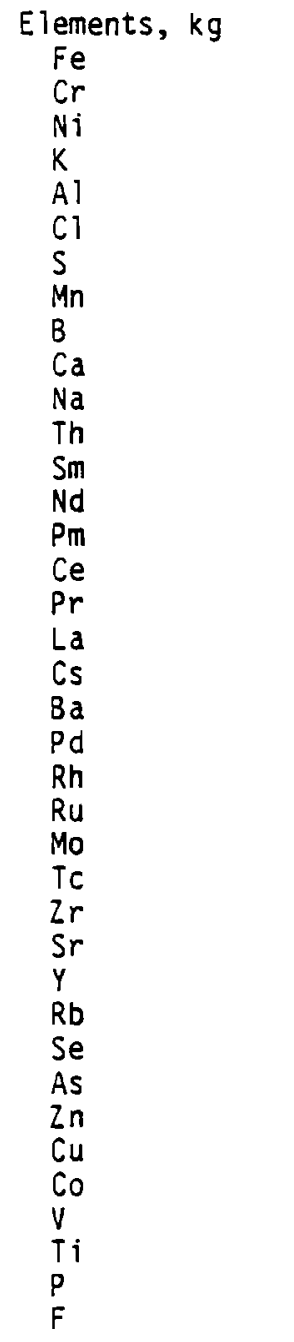 & $\begin{array}{c}2,200 \\
540 \\
320 \\
150 \\
460 \\
63 \\
32 \\
32 \\
18 \\
6.8 \\
310 \\
10,300 \\
9 \\
45 \\
1.4 \\
16 \\
8.1 \\
8.1 \\
32 \\
23 \\
4.5 \\
5.4 \\
16 \\
25 \\
8.1 \\
5.4 \\
8.1 \\
3.6 \\
3.6 \\
2.7 \\
0.5 \\
3.6 \\
2.7 \\
1.4 \\
0.9 \\
6.8 \\
9.9 \\
0.9\end{array}$ \\
\hline $\begin{array}{l}\text { Radionuc lide, Ci } \\
\text { Co-60 } \\
\text { Sr-90 } \\
\text { Y-90 } \\
\text { Cs }-134 \\
\text { Cs }-137 \\
\text { Ba-137m } \\
\text { Eu-154 } \\
\text { Total }\end{array}$ & $\begin{array}{r}1,500 \\
650,000 \\
650,000 \\
540 \\
690,000 \\
640,000 \\
\frac{4,200}{2.6 \times 10^{0}}\end{array}$ \\
\hline
\end{tabular}

(a) Based on information from DOE (1978; Table 3.12).

(b) Based on est imates extrapolated to 1987 by Charles Luner (ANL). 
TABLE 4.5. Estimated Situation of WNYNSC Wastes in 1987 (a)

\begin{tabular}{|c|c|c|c|c|c|c|}
\hline \multirow[b]{2}{*}{ Waste } & \multirow[b]{2}{*}{ Volume, L } & \multicolumn{2}{|c|}{ We ights, MT } & \multirow[b]{2}{*}{ Curies } & \multicolumn{2}{|c|}{ Heat } \\
\hline & & Solids (b) & Water & & Watts & BTU/h \\
\hline Tank 802 & & & & & & \\
\hline $\begin{array}{l}\text { Supernate } \\
\text { Sludge } \\
\text { TOTAL }\end{array}$ & $\begin{array}{l}2,100,000 \\
28,000(d) \\
2,128,000\end{array}$ & $\begin{array}{r}1,203 \\
99 \\
1,302\end{array}$ & $\begin{array}{l}1,537(c) \\
1, \overline{537}\end{array}$ & $\begin{array}{l}1.7 \times 10^{7} \\
1.4 \times 10^{7} \\
3.1 \times 10^{7}\end{array}$ & $\begin{array}{l}41,000 \\
50,000 \\
91,000\end{array}$ & $\begin{array}{l}140,000 \\
170,800 \\
310,800\end{array}$ \\
\hline Tank 8D4 & 45,600 & 40 & 42 & $2.4 \times 10^{6}$ & 6,690 & 22,800 \\
\hline TOTAL & $2,173,600$ & 1,342 & 1,579 & $3.4 \times 10^{7}$ & 97,690 & 333,600 \\
\hline
\end{tabular}

(a) Adapted from information from DOE (1978; Tables 3-10, 3-12) and from Char les Luner (ANL).

(b) In the chemical forms assumed in the tables. Complete calcination will reduce the total ca. 700 MT, chiefly due to the $\mathrm{NaNO}_{3}$ to $\mathrm{Na}_{2} \mathrm{O}$ conversion.

(c) Measured density of 1.3 taken for 802 . Density of 1.8 assumed for 804 .

(d) Dry weight, assumed density $=3.5$. About $6,700 \mathrm{~kg}$ of this are thought to be uranate and $84 \mathrm{~kg}$ (equivalent to $63,000 \mathrm{Ci}$ and $1,100 \mathrm{~W}$ ) to be transuranic oxides. 


\subsection{REFERENCES}

DOE. 1978. Western New York Nuclear Service Center Companion Report. TID-28905-2, DOE, Washington, D.C. (Prepared by Oak Ridge National Laboratory for DOE).

DOE. 1979. Report to the President by the Interagency Review Group on Nuclear Waste Management, TID-29442, National Technical Information Service, Springfield, Virginia.

Duckworth, J. P. 1978. Waste Surveillance Report 9-78-09. Nuclear Fuel Services, Inc., Rockville, Maryland. (Prepared for New York State ERDA)

Nuclear fuel Services. 1973. Safety Analysis Report NFS Reprocessing Plant, West Valley, New York, Docket No. 50-201, Volume 1, Nuclear Fuel Services, Inc., Rockville, Maryland.

Nuclear Regulatory Commission. 1976. Alternative Processes for Managing Existing Commercial High-Level Radioactive Wastes. NUREG-0043, U. S. Nuclear Regulatory Comission, Washington, D.C. (Prepared by PNL). 


\subsection{STUDY BASES}

The following bases were used for the process alternatives study. These bases were selected to be compatible with the West Valley Support Program Guidelines as outlined by $F$. R. Standerfer (DOE Richlland). Deviations from these defined study bases will be identified and justified.

1. All alkaline Purex waste stored in Tank 802 and acidic Thorex waste stored in Tank 804 will be solidified.

2. The chemical composition and properties of the alkaline Purex waste are summarized in Table 4.2, 4.3 and 4.5. The chemical composition and properties of the acidic Thorex waste are summarized in Table 4.4 and Table 4.5.

3. The high-level nuclear wastes will be solidified in a three-year campaign. The facility will be a FY-1983 construction project with final waste form selection in $F Y-1984$. The facility will begin operating in FY-1987 and complete the high-level waste solidification campaign in FY-1990.

4. The plant operating-efficiency factor for the waste solidification facility is 0.60. This factor includes processing the HLLW, and all transfer-line flushes, equipment washes and other liquid streams required to solidify the high-level waste.

5. The solidification process will be capable of processing solutions (principally oxalic acid) used for decontamination of the high-level waste storage tanks. Processing of the decontamination solutions will not occur within the three-year high-level waste solidification period.

6. Existing facilities at the WNYNSC will be used to the maximum extent possible. Significant building modifications required to implement the waste form processes will be identified along with construction of additional facilities.

7. The HLLW solidification facilities will be licensable.

8. Gaseous and liquid effluents produced from process operations will meet release limits set in NRC guidelines, EPA guidelines and National Air and Water Quality Standards.

9. The storage canister for high-level waste will have an overall dimension of $0.60 \mathrm{~m}$ $(2 \mathrm{ft})$ in dia by $3 \mathrm{~m}(10 \mathrm{ft})$ long. This canister will have a waste-product fill height of approximately $2.6 \mathrm{~m}(8.5 \mathrm{ft})$, representing a volume of $712 \mathrm{~L}$ for a canister having no fins.

10. Treatment, handling, and disposal of failed equipment, spent process materials, and secondary wastes are excluded from the current study and discussed only as required for evaluation of the high-level-waste solidification processes.

11. All waste solidification processes are engineered to be safe. Normal upsets and 
minor accidents in the process are engineered to not release radiochemical activity above background levels. Anomalies to the particular waste solidification process will be identified if a particular safety or environmental consideration is involved.

12. Several service facilities are required to support and interface with the solidification system. These facilities are: the Low-Level-Waste Treatment facility, the Low-Level-Waste Storage Facility, and the High-Level-Waste Storage Facility. These facilities will not be discussed in relation to the waste. solidification facility in this study. 


\subsection{HIGH-LEVEL WASTE TREATMENT PROCESSES}

During 1980 a panel of waste management experts, chaired by J. L. Crandall (Savannah River Laboratory), was convened by the DOE to evaluate potential waste treatment approaches and waste forms for solidifying the high-level wastes stored at the WNYNSC. This panel considered two waste treatment approaches appropriate for production of a waste form for the WNYNSC highlevel wastes. Both waste treatment approaches were considered to have sufficient technical merit to warrant further study. These two approaches differ in the waste methods used to condition the waste before solidification and in the quantity of waste form produced from waste solidification operations. The first waste treatment approach, designated as the reference. waste treatment approach, is termed the salt/sludge separation process. This process is discussed in Section 6.1. The second waste treatment approach, designated as the combined waste processing approach, is discussed in Section 6.2. The present study assesses these two waste treatment approaches.

\subsection{SALT/SLUDGE SEPARATION PROCESS}

Waste treatment for the reference process (salt/sludge separation process) will occur in two distinct campaigns. The first campaign involves conditioning and solidification of the acidic Thorex waste stored in Tank 8D4. This acidic waste may be solidified directly with only simple chemical adjustments. The alkaline waste stored in Tank $8 D 2$ is processed in a second waste solidification campaign. Solidification of the alkaline Purex waste requires complex waste conditioning and represents the major waste processing effort at the WNYNSC.

There are several reasons why separate processing of the alkaline Purex and acidic Thorex waste is desirable. The primary reason is that the facilities required to process both waste types are minimized. Solidifying the Thorex waste first provides a surge tank (Tank 804 ) for transferring alkaline waste from Tank 802 to the processing cell. A surge tank of intermediate size, such as Tank 804 serves as a buffer between the alkaline waste tank and the process receipt tank. More representative samples can be obtained in the smaller tank and proper chemdcal adjustments can be better assured.

Blending the Thorex waste and processed alkaline waste in the waste storage tanks should be avoided to minimize waste conditioning complications and equipment requirements. The salt/ sludge separation process requires physical separation steps including centrifugation, settling, and filtration. Blending the Thorex waste and the alkaline waste can result in the production of an alkaline sludge and an alkaline supernate that have physical and chemical characteristics that could make the waste separation steps difficult to achieve with high efficiency. $B$ lending these wastes would also increase the weight of sludge requiring physical separation by approximately $25 \mathrm{wt}$. For these reasons, the acidic Thorex and alkaline Purex wastes should be processed separately.

The disadvantage of not blending the Thorex and alkaline waste before waste solidification and after waste conditioning is the greater quantity of high-level-waste product produced. This greater quantity of waste form product is a result of the low thoria solubility in some waste forms considered. It is desirable to incorporate the thoria into the waste form matrix, 
thereby producing a high-integrity waste form product. Potentially there are 20 to 60 additional canisters of high-level-waste form resulting from separate solidification of the Thorex waste depending upon the waste form process.

\subsubsection{Process Flowsheet Salt/Sludge Separation Approach}

The design of the salt/sludge separation process is based primarily upon the requirements for treatment of the alkaline Purex waste. The overall objective of the salt/sludge separation process is to separate and decontaminate the bulk of the nonradioactive waste constituents from the radionuclides in the alkaline Purex waste. This processing approach is achieved by separating the alkaline sludge from the alkaline supernate. The supernate is then decontaminated by removal of radiochemical species ( $\mathrm{Sr}, \mathrm{Cs}, \mathrm{Pu}$; actinides) using ion-exchange processes. Radiochemical activity recovered from the supernate is combined with the separated sludge and solidified as a high-level-waste form. Decontaminated supernate is dewatered to form a solid low-level-waste salt product. This process approach minimizes the volume of high-level waste produced by converting the majority of the alkaline waste to a low-level-waste salt product.

A simplified process flowsheet for the salt/sludge separation process is shown in Figure 6.1. This flowsheet is divided into eight unit processes whose final purpose is to solidify the alkaline and acidic Thorex high-level-wastes, and low-level-waste sidestreams. The eight unit processes comprising the salt/sludge separation process are:

- sludge/supernate centrifugation and sludge washing

- gravity settling and sand filtration

- cesium ion exchange and cesium concentration

- strontium and actinide ion exchange

- recycle and secondary evaporation

- solidification-process effluent treatment

- decontaminated-supernate solidification

- waste solidification and canister-handling operations.

Specific details of this process flowsheet for alkaline waste conditioning and solidification can be found in Appendix $A$. The process flowsheet details for solidification of the acidic Thorex waste can be found in Appendix $B$.

Homogenized alkaline waste is transferred from the waste tanks to the centrifugationprocess module. Here the bulk of the alkaline sludge is separated from the alkaline supernate by centrifugation. The centrate from the centrifuge is transferred to the gravity-settling and sand-filtration process module. Sludge solids discharged from the centrifuge bowl are washed with water in three batchwise steps.

Each wash step includes a water wash of the centrifuge, agitation of the sludge/water mixture and separation of the homogenized slurry by centrifugation. The purpose of this sludge washing process is to remove soluble salts such as sodium nitrate and sodium sulphate from the alkaline sludge. The sludge washing process reduces the sodium in the sludge and thereby increases the waste loading achievable in the solidified high-level-waste form. This process also improves the quality of the waste forms by removing soluble salts such as sodium 


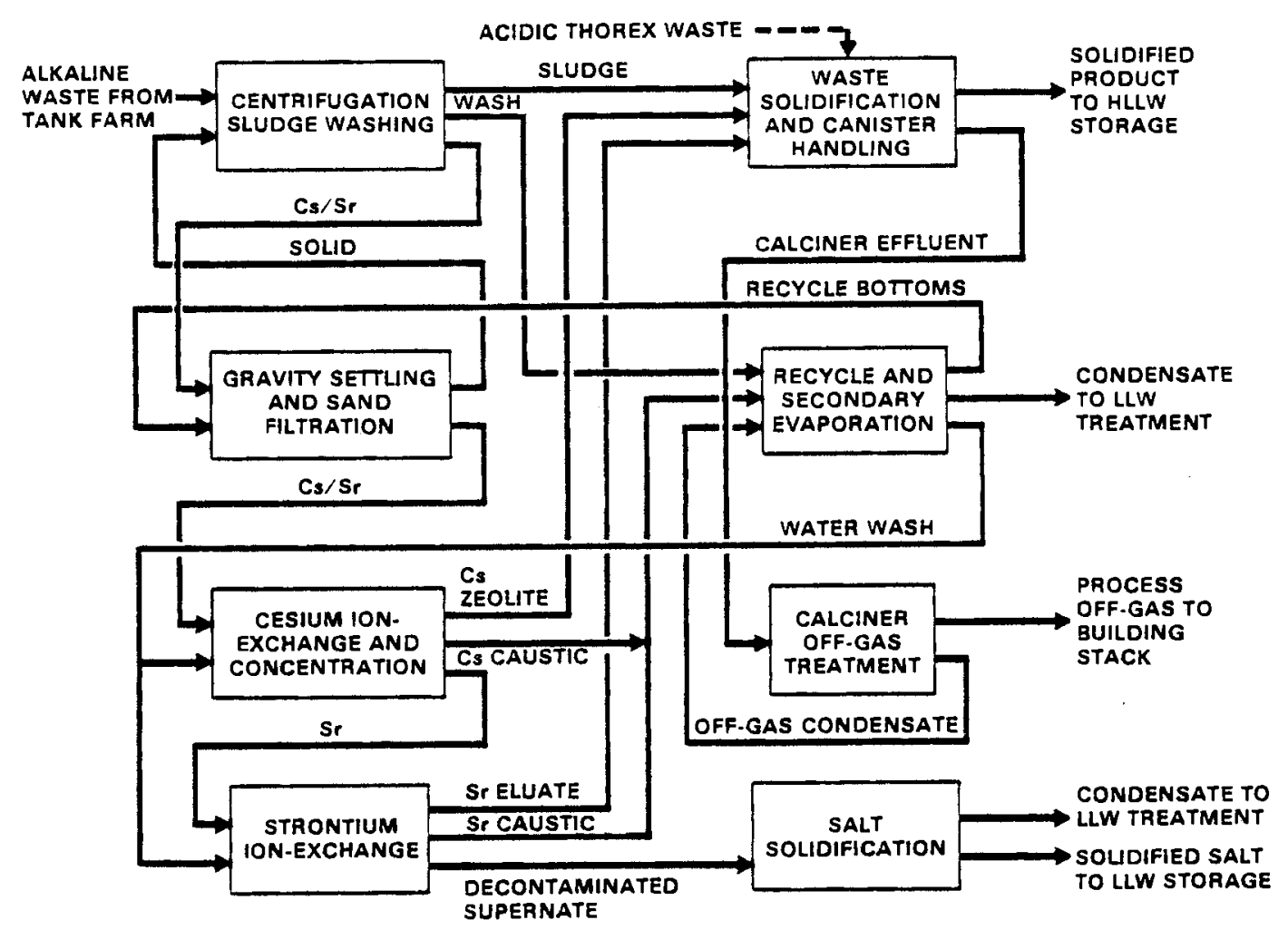

FIGURE 6.1. Simplified Process Flowsheet for the Salt/Sludge Separation Process

sulphate. Washed sludge is transferred to the feed makeup tank for the high-level-waste solidification process. Wash centrate is transferred to the recycle-evaporation process module.

Centrate from sludge/supernate separation is transferred to a gravity settler. Here the majority of the remaining solids in the supernate are allowed to settle. Solids collected in the gravity settler are recycled to the centrifuge feed tank. Supernate from the gravity settlers is passed through two sand filters which remove essentially all of the remaining suspended solids. Clarification of the supernate to less than 1 part-per-million is necessary to prevent passage of insoluble activity through ion-exchange columns and to prevent pluggage of the ion-exchange columns with solid material.

Filtrate from the sand filters is passed through two sets of ion-exchange columns. The first set uses a Duolite ${ }^{\circledR}$ ARC-359 ion-exchange resin. This ion-exchange column removes the cesium activity and nearly all of the actinide activity from the alkaline supernate. The second set of ion-exchange columns uses a Chelex-100 ${ }^{\circledR}$ ion-exchange resin. This ion-exchange column removes the strontium activity and the remaining actinide activity from the alkaline supernate. A backup ion-exchange column is also included to remove any residual actinide activity. The resin for this backup column has not been identified at this time.

(a) Duolite ARC-359, Registered Trademark, Diamond Shamrock, Inc. (a) Chelex-100, Registered Trademark, Bio-Rad Laboratories. 
Both the Duolite and Chelex ion-exchange columns are periodically eluted of activity and regenerated. The cesium eluate is passed to a cesium concentrator where the ammonia and carbon dioxide eluting agents are recovered. The cesium-concentrator bottoms are passed through a zeolite bed to strip the cesium from the evaporator bottoms. Effluent from the zeolite bed is recycled to the gravity settlers. The cesium-loaded zeolite is transferred to the feed-blend tank for the solidification process. Strontium eluate from eluting the strontium ion-exchange columns is transferred directly to the spray calciner feed tank.

The alkaline waste blend for the high-level-waste solidification process is composed of washed sludge, cesium-loaded zeolite, strontium eluate, and other solids such as spent-sand filter material. This high-level-waste blend is converted to a solid waste-form product using solidification processes that are discussed in Section 8 . The estimated chemical composition of this waste blend is sumarized in Table 6.1.

Process effluents from the waste solidification processes include air, water, $\mathrm{NO}_{\mathrm{x}}$, and volatile fission products. Radiochemical activity from the gaseous process effluents is removed by scrubbing, condensation, filtration and sorption. Process scrub liquids are recycled to the evaporation process, which consists of two evaporators operated in series. Bottoms from the first evaporator, the recycle evaporator, are recycled to the gravity settler; overheads are sent to the second evaporator. Bottoms from the second evaporator are combined with miscellaneous waste streams and provide feed to the recycle evaporator. Overheads from the second evaporator are condensed and sent to a Low-Level-Waste Treatment facility.

Decontaminated supernate from the ion-exchange columns is dewatered in a two-stage process. First, water from the supernate solution is removed in an evaporator. The bottoms from the evaporator are next fed to a wiped-film evaporator. Salt cake from the wiped-film evaporator is packaged in 55-gal steel drums. Condensate is further processed through the lowlevel-waste treatment facility. The estimated chemical composition of the salt-cake product is summarized in Table 6.2. The radiochemical, isotopic composition of the salt cake is summarized in Table 6.3. Process decontamination factors for soluble and insoluble forms of the major isotopes are presented. The solids-separation process provides a decontamination factor of $1.7 \times 10^{4}$ for insoluble species. All other decontamination factors are associated with ion-exchange processes. The dose rate at the surface of a 55-gal drum assumed to be used for sait cake packaging was estimated at $236 \mathrm{mR} / \mathrm{h}$ by the ISOSHLD computer code.

The eight unit processes in the salt/sludge separation flowsheet are all interdependent. Implementation of alternative high-level-waste solidification processes into the integrated salt/sludge separation flowsheet is achieved by simple substitution. Specific process streams between the waste solidification process and the waste treatment process must be compatible with each other however.

\subsubsection{Status of Technology}

The development of the integrated salt/sludge separation flowsheet began in 1972 at the Savannah River Laboratory (Jennings 1979). Prior to that time, the majority of the unit processes had been used on a production scale at Hanford. Presently, all unit processes that 
TABLE 6.1. Estimated Chemical Composition of Salt/Sludge Separated Alkaline Waste Blend for the Solidification Process

\begin{tabular}{|c|c|}
\hline Component & $\begin{array}{c}\text { Concentration, } \\
\mathrm{g} / \mathrm{L}\end{array}$ \\
\hline \multicolumn{2}{|l|}{ Solids } \\
\hline $\mathrm{Fe}(\mathrm{OH})_{3}$ & 33.9 \\
\hline $\mathrm{FePO}_{4}$ & 19.5 \\
\hline $\mathrm{Cr}(\mathrm{OH})_{3}$ & 2.6 \\
\hline $\mathrm{Ni}(\mathrm{OH})_{2}$ & 1.2 \\
\hline $\mathrm{Al}(\mathrm{OH})_{3}$ & 0.6 \\
\hline $\mathrm{RE}(\mathrm{OH})_{3}$ & 1.1 \\
\hline $\mathrm{FP}\left(\mathrm{SO}_{4}\right)$ & 0.9 \\
\hline $\mathrm{FP}(\mathrm{OH})_{4}$ & 1.1 \\
\hline $\mathrm{FP}_{2} \mathrm{O}_{3}$ & 0.1 \\
\hline $\mathrm{Na}_{3} \mathrm{PO}_{4} \mathrm{12MoO}_{3}$ & 0.7 \\
\hline $\mathrm{MnO}_{2}$ & 1.5 \\
\hline $\mathrm{PnO}_{2}$ & 0.02 \\
\hline $\mathrm{Na}_{2} \mathrm{U}_{2} \mathrm{O}_{7}$ & 4.6 \\
\hline Act. 0xide & 0.009 \\
\hline Other solids $(a)$ & 9.1 \\
\hline \multicolumn{2}{|l|}{ Salts } \\
\hline $\mathrm{NaNO}_{3} / \mathrm{NO}_{2}$ & 5.4 \\
\hline $\mathrm{Na}_{2} \mathrm{SO}_{4}$ & 0.04 \\
\hline $\mathrm{NaOH}$ & 0.008 \\
\hline $\mathrm{NaCl}$ & 0.0003 \\
\hline $\mathrm{FePO}_{4}$ & 0.006 \\
\hline $\mathrm{Cr}(\mathrm{OH})_{3}$ & 0.001 \\
\hline $\mathrm{Ni}(\mathrm{OH})_{2}$ & 0.0004 \\
\hline $\mathrm{AlF}_{3}$ & 0.0008 \\
\hline $\mathrm{Na}_{3} \mathrm{PO}_{4} \quad 1_{2} \mathrm{MOO}_{3}$ & 0.0003 \\
\hline
\end{tabular}

(a) $0.06 \mathrm{Ag}$ Mordenite; 3.24 Zeolite; 0.19 Silica Gel; 5.59 $\mathrm{SiO}_{2}$

compose the overall processing approach have been demonstrated in both a radioactive and nonradioactive environment either at Hanford, Savannah River Laboratory or the Pacific Northwest Laboratory.

The separation of sludge/supernate mixtures by centrifugation has been demonstrated in small-scale tests using nonradioactive simulated waste and actual radioactive neutral waste (Stone 1976). Large-scale tests have recently been completed using simulated sludge/supernate mixtures at the TNX facility located at the Savannah River Laboratory (Landon 1980). Technical 
TABLE 6.2. Estimated Salt-Cake Composition for the Salt/Sludge Separation Process

\begin{tabular}{lcc}
\multicolumn{1}{c}{ Component } & Weight Percent \\
\cline { 1 - 2 }$(\mathrm{Na}, \mathrm{K}) \mathrm{SO}_{4}(\mathrm{a})$ & & 5.30 \\
$(\mathrm{Na}, \mathrm{K}) \mathrm{NO}_{3} / \mathrm{NO}_{2}(\mathrm{a})$ & 64.97 \\
$(\mathrm{Na}, \mathrm{K}) \mathrm{OH}^{(\mathrm{a})}$ & 2.71 \\
$(\mathrm{Na}, \mathrm{K}) \mathrm{CL}(\mathrm{a})$ & 0.03 \\
$\mathrm{FePO}_{4}$ & 0.07 \\
$\mathrm{Cr}(\mathrm{OH})_{3}$ & 0.12 \\
$\mathrm{Ni}_{(\mathrm{OH}) 2}$ & 0.04 \\
$\mathrm{Na}_{2} \mathrm{CO}_{3}(\mathrm{~b})$ & 4.64 \\
$\mathrm{AlF}_{3}$ & 0.09 \\
$\mathrm{H}_{2} \mathrm{O}^{(\mathrm{C})}$ & $\underline{22.0}$ \\
& 99.97
\end{tabular}

\footnotetext{
(a) Sodium to potassium ratio, 99 to 1 .

(b) Formed during Cesium ion-exchange processes.

(c) Salt concentrated to 22 wt\% water
}

data developed from both these radioactive and nonradioactive tests can be used to estimate the expected performance in treating the WNYNSC alkaline waste.

The centrate from the sludge/supernate separation process is clarified by gravity-settling and sand-filtration processes. Technology for these unit processes was developed in the chemical industry. Adaption and demonstration of the gravity-settling and sand-filtration technology to clarification of simulated alkaline-supernate solutions has been completed on a plant scale (Landon 1980). Results of these tests have indicated for the Savannah River Plant waste that the required physical separations can be achieved.

The ion-exchange processes for removal of cesium, strontium and plutonium have been demonstrated with radioactive alkaline supernates from the Savannah River plant on a laboratory scale (Wiley and Wallace 1975; Wiley 1976). Sufficient decontamination factors for removal of cesium, plutonium and strontium were demonstrated in these tests to assure an adequately decontaminated supernate for Savannah River Plant waste (Baumgarten et al. 1979). Plant application of the cesium ion-exchange process has occurred in B-Plant at Hanford. Two campaigns were completed between March 1973 and February 1976 in which 3.3 million gallons of supernate were processed.

Other aspects of the ion-exchange process such as elutriant recovery, concentration of cesium carbonate solutions (Richardson 1969) and fixation of cesium on zeolite (Buckingham 1967, Buckingham 1970) have been developed and demonstrated at Hanford. 
TABLE 6.3. Calculated Isotopic Composition of Low-Level Salt Cake from the Salt/Sludge Separation Process

\begin{tabular}{|c|c|c|c|c|c|c|c|c|c|}
\hline & Isotope & Half-Life & $\begin{array}{c}\text { Percent } \\
\text { Insoluble (a) } \\
\end{array}$ & $\begin{array}{l}\text { Actiyity in } \\
1987(\mathrm{~b})(\mathrm{C} i)\end{array}$ & $\begin{array}{c}\text { Activity } \\
\text { in Sludge, } \\
\text { Ci } \\
\end{array}$ & $\begin{array}{c}\text { Activity in } \\
\text { Supernate, } \\
\text { Ci }\end{array}$ & $\begin{array}{r}\text { DF for (d) } \\
\text { Insoluble } \\
\text { Isotopes } \\
\end{array}$ & $\begin{array}{l}\text { DF for }(d) \\
\text { Soluble } \\
\text { Isotopes } \\
\end{array}$ & $\begin{array}{l}\text { Activity jn } \\
\text { Salt Cake, (b) } \\
\text { nCi/gram }\end{array}$ \\
\hline & $\mathrm{Se}-79$ & $6.5 \times 10^{4} y$ & 0 & 50 & 0 & 50 & 1 & 1 & 30.4 \\
\hline & $Z r-93$ & $1.5 \times 10^{6} y$ & 99.9 & 250 & 250 & 0.25 & $1.72 \times 10^{4}$ & 1 & 0.16 \\
\hline & $\mathrm{Nb}-93 \mathrm{~m}$ & $13.6 \mathrm{y}$ & 99.9 & 240 & 240 & 0.24 & $1.72 \times 10^{4}$ & 1 & 0.15 \\
\hline & Tc-99 & $2.13 \times 10^{5} y$ & 0 & 1900 & 0 & 1900 & 1 & 1 & 1156.4 \\
\hline & $R u-106$ & $368 \mathrm{~d}$ & 99 & 110 & 108.9 & 1.1 & $1.72 \times 10^{4}$ & 1 & 0.67 \\
\hline & $S b-125$ & $2.71 \mathrm{y}$ & 99 & 6100 & 6039 & 61 & $1.72 \times 10^{4}$ & 1 & 37.3 \\
\hline & Cs-134 & $2.06 \mathrm{y}$ & 0 & 21000 & 0 & 21000 & 1 & $10^{4}$ & 1.28 \\
\hline & Cs-137 & $30.2 y$ & 0 & $8.9 \times 10^{6}$ & 0 & $8.9 \times 10^{6}$ & 1 & $10^{4}$ & 542 \\
\hline & $P m-147$ & $2.62 y$ & 99.9 & 61000 & 60939 & 61 & $1.72 \times 10^{4}$ & 1 & 39.3 \\
\hline & Sm-151 & $93 y$ & 99.9 & 200,000 & $1.99 \times 10^{5}$ & 200 & $1.72 \times 10^{4}$ & 1 & 128.8 \\
\hline & Eu-152 & $13.4 y$ & 99.9 & 1410 & 409 & 0.40 & $1.72 \times 10^{4}$ & 1 & 0.24 \\
\hline & $N p-239$ & $2.35 \mathrm{~d}$ & 99.9 & 220 & 219.8 & 0.22 & $1.72 \times 10^{4}$ & 1 & 0.08 \\
\hline & $P u-238$ & $87.7 y$ & 99.9 & 1500 & 1500 & 1.5 & $1.72 \times 10^{4}$ & $3 \times 10^{3}$ & 0.053 \\
\hline & Pu-239 & $24,370 y$ & 99.9 & 1800 & 1800 & 1.8 & $1.72 \times 10^{4}$ & $3 \times 10^{3}$ & 0.063 \\
\hline & $P u-240$ & $6580 y$ & 99.9 & 970 & 969 & 0.97 & $1.72 \times 10^{4}$ & $3 \times 10^{3}$ & 0.034 \\
\hline & $P u-241$ & $13.2 y$ & 99.9 & 70,000 & 69930 & 70 & $1.72 \times 10^{4}$ & $3 \times 10^{3}$ & 2.49 \\
\hline & Ann-241 & $458 y$ & 99.9 & 20,000 & 19980 & 20 & $1.72 \times 10^{4}$ & $3 \times 10^{3}$ & 0.70 \\
\hline & $\mathrm{Cm}-244$ & $17.6 y$ & 99.9 & 8800 & 8791 & 8.8 & $1.72 \times 10^{4}$ & $3 \times 10^{3}$ & 0.31 \\
\hline & & & & & & & TOTAL ACTIV & I TY & $\begin{array}{l}2024.7 \mathrm{nCi} / \\
\text { gram salt cake }\end{array}$ \\
\hline
\end{tabular}

(a) Based on Table 3.7, TID-28905-2 (ORNL 1978)

(b) Total salt-cake weight $1.643 \times 10^{6} \mathrm{~kg}$

(c) Total actinide activity $3.65 \mathrm{nCi} / \mathrm{gram}$ salt cake

Total fission-product activity $2021 \mathrm{nCi} / \mathrm{gram}$ salt cake

(d) $\mathrm{DF}=$ decontamination factor 
Canister-handling operations have been demonstrated and baselined for a generic vitrification facility. Many of the canister processing and handing operations such as remote sealing and decontamination have already been developed and demonstrated (Larson 1980 ).

The removal of water from the decontaminated supernate is similar to evaporation of alkaline Purex wastes. Technology for a similar process has been developed and verified using simulated waste slurries (Goodlet 1968).

The process flowsheet and equipment definitions for the salt/sludge separation process were based on existing technology developed at government operated defense nuclear waste management facilities. Use of technical data developed at these defense sites defined the reference waste treatment process flowsheet and provided necessary data to complete the material balances.

There are significant physical and chemical differences between the WNYNSC high-level wastes and the high-level wastes stored at the government operated defense sites. The actinide and fission-product contents of the WNYNSC high-level wastes are ten to one hundred times higher than those of the defense wastes. There differences are due primarily to the higher burnup fuel reprocessed at the WNYNSC site and the nature and efficiency of the radionuclide recovery during fuel reprocessing operations. Because of these differences, the technical data developed at the defense waste-management sites may not be strictly applicable to management of the WNYNSC high-level wastes. Higher radiochemical-decontamination efficiencies will be required for the WNYNSC waste than for defense waste to produce an acceptable low-level salt cake.

A principal feature of the salt/sludge separation process is the physical and chemical separations of the radioactive waste constituents from the bulk of the nonradioactive waste constituents. The higher radiochemical levels of the WNYNSC waste challenges the technical capability of the present state of process development to achieve the required separation of radioactive constituents from the nonradioactive components. Most of the salt/sludge separation process should be verified experimentaliy using the actual waste.

The development efforts needed to support the existing sait/sludge separation flowsheet consist of these general areas:

1. physical separations processes, and

2. ion-exchange processes.

The reference preconceptual flowsheet includes the physical separation processes of centrifugation, gravity settling, and filtration. These three unit processes remove essentially all of the insoluble radiochemical activity from the supernate.

As a general rule in the chemical process industry these unit processes are experimentally evaluated using actual plant feedstock materials. Initial development work using simulated feed material provides a basis for process equipment selection. Final verification of the process-equipment performance using actual radioactive solutions is impractical on a plant scale. However, laboratory-scale tests can be conducted to predict equipment performance. 
Physical data such as viscosities, densities, etc. are necessary for plant design and can be obtained in plant scale nonradioactive tests. Simulated nonradioactive streams can also be used to determine operating performance of solid/supernate separations. The operating parameters that need to be determined for the salt/sludge separation process include:

- for the centrifuge

- estimates of cycle times

- loading rates

- basket volumes

- separation efficiencies

- identification of required remote design features

- for the gravity settlers

- settling rates for solids

- need and effectiveness of coagulating agents

- variables to achieve efficient separations, e.g., thermal cyciing, solid recycling

- for the sand filters

- efficiency of solids removal

- pressure drop

- loading characteristics

- ease of bed regeneration.

The ion-exchange process is sensitive to chemical variations in the feed systems. Factors such as the $\mathrm{Na} / \mathrm{Cs}$ ratio, salt concentration, $\mathrm{pH}$, presence of complexing agents, ion-exchange poisons, resin integrity, ion-exchange kinetics, elution kinetics and regeneration procedures need to be assessed using WNYNSC waste. Initial scoping studies for nonradioactive development can assess the entire ion-exchange process. Laboratory-scaie radioactive tests can verify process performance. The efficient ion-exchange removal of actinides (Am, Cm, Pu) from the supernate is particularly important for the sait/sludge separation flowsheet. The salt-cake product should be a low-levei waste which contains less than $10 \mathrm{nCi}$ of actinide activity per gram of salt-cake waste form.

\subsubsection{Safety Considerations}

Essentially all of the unit processes for the salt/sludge separation flowsheet have been used on a plant scale. As a result the potential safety problems are known and the system may be engineered to prevent these potential accidents. Three potential accidents that can be engineered against are:

1. The reaction of nitric acid with the Duolite ion-exchange resin, which promotes a strong exothermic chemical reaction and potentiai expiosion. This accident can potentially occur from the addition of nitric acid to the cesium ion-exchange column and then heating the ion-exchange column. This potential accident can be avoided by preventing nitric acid from contacting the Duolite resin. Nitric acid is required for elution of the Chelex 100 ion exchange. 
2. A criticality accident could hypothetically occur in the ion-exchange columns. The fissile material content of the alkaline waste may be high enough for a criticality accident, provided fissile material concentrates in the ion-exchange columns. Through geometry controls this hypothetical accident can be engineered against.

3. A high-pressure HLLW leak can develop. The sand-filter system and ion-exchange system operate at elevated pressures. Because of this there is a potential for a system leak, which would disperse high-level waste in the operating cell. Also because of these high pressures the service gallery connections must be disconnected during operations to prevent flow of radioactive material into the operating galleries. Equipment has been engineered in prior high-pressure remote applications to prevent these potential accidents, and the safety design features are we 11 known.

\subsubsection{Facility Implementation}

Implementation of the salt/sludge separation process into the CPC and SRR is discussed in Section 8.1.5.

\subsection{COMBINED WASTE PROCESS APPROACH}

The combined waste processing approach involves blending the entire volume of the acidic Thorex waste with the entire volume of the alkaline Purex waste. The resulting alkaline waste blend is chemically adjusted and solidified. A more detailed description of this process is provided in Appendix $C$.

\subsubsection{Process Flowsheet Combined Waste Process}

A simplified schematic of the combined waste processing approach is shown in figure 6.2. Alkaline Purex waste and acidic Thorex waste are blended together in Tank 802, the alkaline Purex waste storage tank. This blending process results in neutralization of the Thorex waste and possible precipitation of some metallic nitrates as hydroxides. Free hydroxide present in the alkaline waste is consumed by the hydronium ion and metallic nitrates in the Thorex waste in the assumed selective order of thorium, iron, and aluminum. The homogenized alkaline waste is periodically transferred from Tank 802 to Tank 804 and then to a waste receiving tank located inside the CPC. Water flushes following the waste transfers dilute the waste blend. The estimated composition of the alkaline waste blend is summarized in Table 6.4.

The blended alkaline waste is combined with recycle evaporator bottoms, additives such as glass-forming chemicals, and dilution water in the waste preparation tank for the solidification process. The resulting alkaline waste blend is solidified and packaged in high-levelwaste storage canisters. Lids are welded on the canisters, the welds are leak checked and the canisters decontaminated before the canisters are transferred to the high-level-waste storage facility.

Gaseous process effluents from solidification operations are decontaminated and released to the environment via the stack. Spent scrub-solution and process condensates are concentrated and recycled. Decontaminated condensates are released to the Low-Level-Waste Treatment system for further treatment before discharge to the environment. 


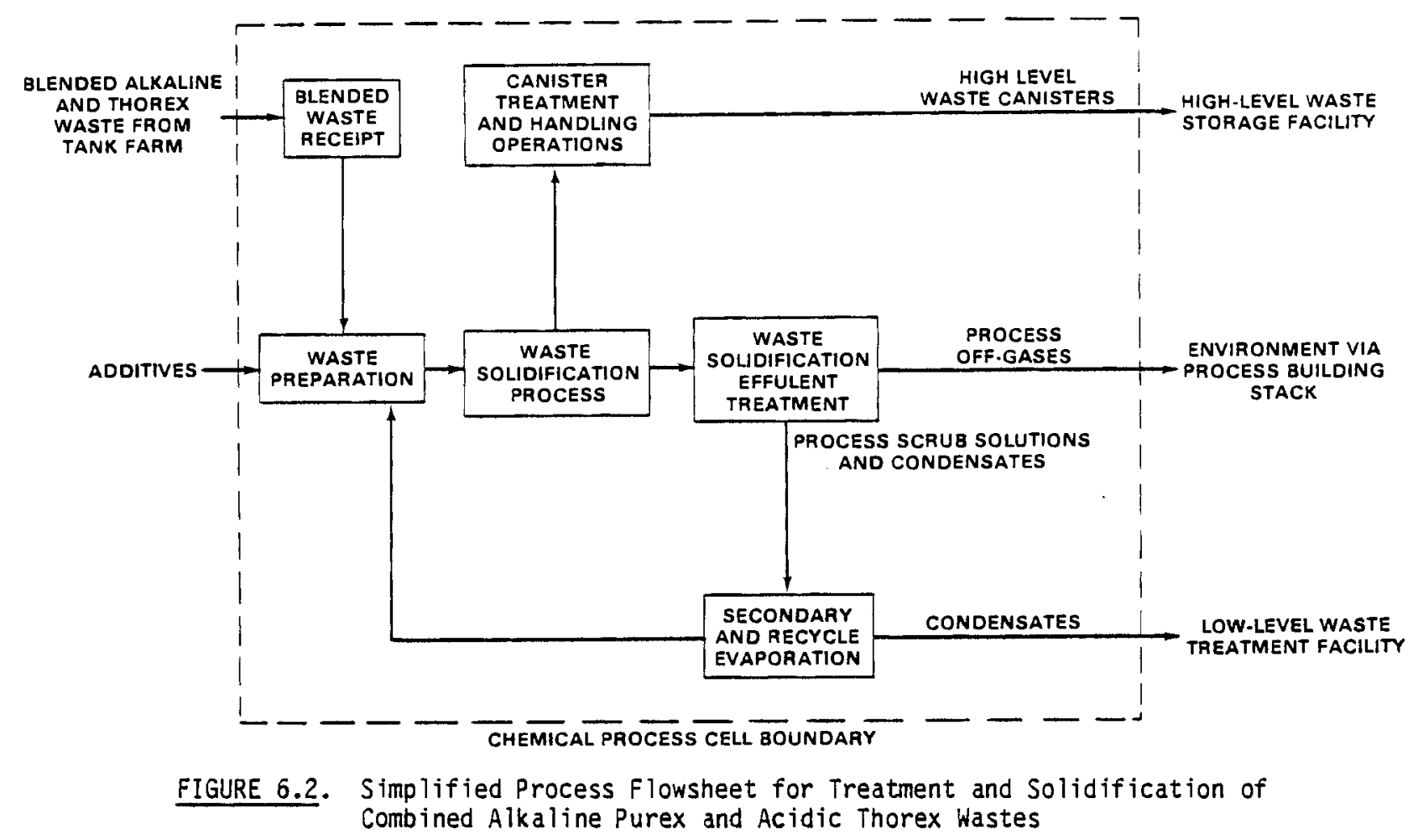

The waste solidification approach involves incorporation of all radioactive and nonradioactive components into the waste form product. This approach produces at least five times greater high-level waste-form product than if the bulk of the nonradioactive species was separated before waste solidification. Sodium is the limiting component in the waste blend loading. Only a 15 to $20 \mathrm{wt \%}$ loading of equivalent waste blend oxide can be incorporated into the waste form product and yield a satisfactory leach resistance.

Sulfate anion is another chemical species present in the waste blend which can potentially limit the waste loading. Information indicates that in borosilicate glasses the sulfate solubility will be limited to less than $1.0 \mathrm{wt} \%$ in the glass (Tooley 1974). In higher temperature glasses this solubility limit is expected to be greater. Based on the sulfate solubility limit of $1.0 \mathrm{wt} \%$, the waste oxide loading in a vitreous product would be approximately 11 wt\%. The accuracy of the sulfate-solubility data is questionable. Therefore, in the present study it will be assumed that the sulfate-solubility limit is 1 to $3 \mathrm{wt \%}$, and that the sodium establishes the waste-loading limit.

There are two basic approaches to accommodate the sulfate. The first approach is to lower the waste oxide loading. The second approach is to add a strong reducing agent to the waste form blend that will convert the sulfate to a volatile sulfur dioxide form, which will be removed in the solidification system off gases. The second approach has been demonstrated during in-can melting tests (Holton et al. 1980). During these tests the performance of siliconmetal powder and graphite powder were assessed as sulphate reducing agents. With silicon metal the amount of sulfate volatilized was approximately 90\%; with graphite the amount of sulfate volatilized was approximately $30 \mathrm{wt \%}$. Severe canister corrosion resulted in the test where 
TABLE 6.4. Blended Waste Composition for the Alkaline Purex and Acidic Thorex waste

\begin{tabular}{|c|c|}
\hline Component & $\begin{array}{c}\text { Concentration, } \\
\mathrm{g} / \mathrm{L}\end{array}$ \\
\hline$(\mathrm{Na}, \mathrm{K})_{2} \mathrm{SO}_{4}$ & 38.7 \\
\hline$(\mathrm{Na}, \mathrm{K}) \mathrm{NO}_{3} / \mathrm{NO}_{2}$ & 487.6 \\
\hline$(\mathrm{Na}, \mathrm{K}) \mathrm{CL}$ & 0.22 \\
\hline $\mathrm{Fe}(\mathrm{OH})_{3}{ }^{(\mathrm{C})}$ & 25.2 \\
\hline $\mathrm{FePO}_{4}$ & 12.9 \\
\hline $\mathrm{Cr}(\mathrm{OH})_{3}$ & 2.6 \\
\hline $\mathrm{Cr}\left(\mathrm{NO}_{3}\right)_{3}$ & 1.1 \\
\hline $\mathrm{Ni}(\mathrm{OH})_{2}$ & 1.1 \\
\hline $\mathrm{Ni}\left(\mathrm{NO}_{3}\right)_{2}$ & 0.43 \\
\hline $\mathrm{Al}(\mathrm{OH})_{3}(\mathrm{C})$ & 0.85 \\
\hline $\mathrm{Al}\left(\mathrm{NO}_{3}\right)_{3}$ & 0.41 \\
\hline $\mathrm{AlF}_{3}$ & 0.68 \\
\hline $\operatorname{RE}(\mathrm{OH})_{3}(\mathrm{a})$ & 0.70 \\
\hline $\mathrm{FPSO}_{4}(\mathrm{~b})$ & 0.54 \\
\hline $\mathrm{FP}(\mathrm{OH})_{4}{ }^{(b)}$ & 0.69 \\
\hline $\mathrm{FP}_{2} \mathrm{O}_{3}{ }^{(\mathrm{b})}$ & 0.19 \\
\hline $\mathrm{Na}_{3} \mathrm{PO}_{4} \quad 12 \mathrm{MoO}_{3}$ & 0.64 \\
\hline $\mathrm{MnO}_{2}$ & 0.96 \\
\hline $\mathrm{PuO}_{2}$ & 0.02 \\
\hline $\mathrm{Na}_{2} \mathrm{U}_{2} \mathrm{O}_{7}$ & 2.9 \\
\hline Act. Oxide & 0.009 \\
\hline $\mathrm{Th}(\mathrm{OH})_{4}{ }^{(\mathrm{C})}$ & 5.8 \\
\hline
\end{tabular}

(a) Rare earth e lements.

(b) Fission-product elements.

(c) Nitrates converted to hydroxides upon waste blending in this order: $\operatorname{Th}\left(\mathrm{NO}_{3}\right)_{3}$, $\mathrm{Fe}\left(\mathrm{NO}_{3}\right)_{3}, \mathrm{Al}\left(\mathrm{NO}_{3}\right)_{3}$.

(d) Volume of liquid waste plus rinse and process water, $2.3 \times 10^{6} \mathrm{~L}$.

silicon metal was added as a reducing agent. The second approach leads to high concentrations of sulfur dioxide in the off gas, which can be removed by standard flue-gas desulfurization techniques. The efficiency of flue-gas desulfurization processes is at best $90 \%$. With this efficiency the sulfur dioxide release limit of $80 \mathrm{\mu g} / \mathrm{m}^{3}$ sulfur dioxide/cubic meter of stack air, set by the National Air Quality Standards, cannot be met. These results assume; a threeyear solidification campaign, $50 \%$ volatilization of sulfate as sulfur dioxide, a stack gas flow of $100,000 \mathrm{ft}^{3} / \mathrm{min}$, and $90 \%$ removal of the sulfur dioxide. The flue-gas desulfurization process would also generate approximately 900, 55-gal drums of calcium sulfate/calcium carbonate 
sludge, which would be required to be handled as low-level waste. Based on this, the reference combined waste process approach assumes that the waste form will be engineered to accommodate the sulphate.

Many different waste solidification approaches can be implemented with the combined waste processing flowsheet. However, because of the high-sodium concentration of the waste, some waste form processes will require low waste loadings, making the volume of high-level waste form excessively high.

\section{2 .2 Status of Technology}

The combined waste processing approach for solidification of high-level wastes has not been seriously considered as a reference high-level-waste treatment approach. As a result there has been little or no development effort devoted toward this approach. Waste solidification studies, however, have evaluated the waste forms produced from the combined waste treatment flowsheet (Holton et al. 1980). These studies have shown that the waste characteristics (high concentrations of sodium, nitrate/nitrite, and sulphate) are not detrimental to producing a high-quality borosilicate-glass waste form. There are potential process related problems, some of which have been identified.

Sulfate may exhibit appreciable volatility during solidification operations. The decontamination and disposal of the recovered sulfate has not been developed in prior nuclear waste processes. The effect of sulphate on the overall system in terms of corrosion, deposition and removal efficiency of the gaseous effluents is unknown.

Nitrate and nitrite will be volatilized from the solidification operations at a rate of approximately $20 \mathrm{~kg} \mathrm{NO} / 100 \mathrm{~kg}$ of glass produced (assume borosilicate glass). This high $\mathrm{NO}_{\mathrm{x}}$ evolution rate will challenge the systems required to destroy the $\mathrm{NO}_{\mathrm{X}}$. It is assumed that $\mathrm{NO}_{\mathrm{X}}$ will not be recovered as nitric acid. Doing so would result in approximately $2.27 \times 10^{6} \mathrm{~L}$ $(600,000 \mathrm{gal})$ of $1.8 \mathrm{M} \mathrm{HNO}_{3}$, which would also require disposal.

\subsubsection{Safety Considerations}

The safety aspects of the combined waste processing system are essentially the same as those of the solidification systems that are discussed in Sections 9 and 10 .

\subsubsection{Facility Implementation}

The combined waste processing approach is simple, consisting primarily of the waste-form solidification process. The implementation of the combined waste processing approach into the WNYNSC facilities is therefore discussed in Sections 9 and 10. 


\subsection{REFERENCES}

Baumgarten, P. K., et al. 1979. "Development of an Ion-Exchange Process for Removing Cesium from High-Level Radioactive Liquid Wastes." Published in proceedings of the International Symposium on the Scientific Basis for Nuclear Waste Management, Boston, Mass achusetts.

Buckingham, J. S. 1970. Laboratory Evaluation of Zeolite Material for Removing Radioactive Cesium from Alkaline Waste Solutions. ARH-SA-49, Atlantic Richfield Hanford Co., RichTand, Washington (Available from Rockwe IT Hanford Company, Richland, Washington).

Buckingham, J. S. 1967. Waste Management Technical Manual. IS0-100-DEL, Isochem, Inc., Richland, Washington.

Department of Energy (DOE). 1978. Western New york Nuclear Service Center Companion Report. TID-18905-2, U.S. Department of Energy, Washington, D.C. (Prepared by ORNL).

Good let, C. B. 1968. Concentration of Radioactive Wastes. DP-1135, Savannah River Laboratory, Aiken, South Carolina.

Holton, L. K., et al. 1980. "Alternatives for Vitrification of Existing Commercial High-Level Waste by Spray Calcination/In-Can Melting." Papre presented at ANS Topical Meeting, Waste Management 1980, March 10-14, Tuscon, Arizona.

Jennings, A. S. 1979. "Plan for Solidification of Savannah River Plant High-Level Waste." Published in AIChE Symposium Series No. 191, Nuclear Engineering Questions: Power, Reprocessing, Waste Decontamination, Fusion, Volume 75 . American Institute of Chemical Engineers, New York, New York.

Landon, L. P. 1980. Technical Data Sumary for the Defense Waste Processing Facility. DPSTF77-13-3, Savannah River Laboratory, Aiken, South Carolina.

Larson, D. E. 1980. Spray Calciner/In-Can Melter High-Level Waste Solidification Technical Manual. PNL-3495, Pacific Northwest Laboratory, Richland, Washington.

Richardson, G. L. 1969. Evaporation of Cesium Ion Exchange Eluate Recovery of Ammonium Carbonate; Pll ot Plant Studies. BNWL-CC-2084, Pacific Northwest Laboratory, Richland, Washington.

Stone, J. A. 1976. Separation of SRP Waste Sludge and Supernate. OP-1441, Savannah River Laboratory, Aiken, South Carolina.

Tooley, F. V. 1974. The Handbook of Glass Manufacture, Vol. 1, p. 7, Books for Industry Inc., New York.

Wiley, J. R. 1976. Decontamination of Savannah River Plant Waste Supernate. DP-1436, Savannah River Laboratory, Aiken, South Carolina.

Wiley, J. R. and R. M. Wallace. 1975. Removal of Cesium from Savannah River Plant Waste Supernate. DP-1388, Savannah River Laboratory, Aiken, South Carolina. 


\subsection{SELECTION OF TERMINAL AND INTERIM WASTE FORMS FOR STUDY}

The considerations for selecting terminal and interim nuclear waste forms for solidifying of WNYNSC high-level liquid wastes are summarized in this section. Terminal waste forms, which are a final waste disposal form, were selected on the recommendations of several independent reviewers. The interim waste form serves as a temporary, solidified waste form required for transportation, should terminal waste solidification processing be done at another site. The interim waste forms were selected on recommendations from the NFS Waste Form Review Panel and on the ability of the interim waste form to satisfy basic technical criteria including: low radionuclide mobility, waste form stability, and compatibility with terminal waste form processing.

\subsection{TERMINAL WASTE FORMS}

Currently, the only requirement for a high-level nuclear waste form is that it be a stable solid (10 CFR 50, Appendix F, Nuclear Regulatory Commission 1978). The Nuclear Regulatory Cormission (NRC) has proposed regulations regarding the disposal of high-level solidified wastes. A draft regulation, 10 CFR 60, "Disposal of High-Level Radioactive Waste" (NRC 1980) has been issued by NRC for corment. This draft regulation indicates that the following properties may be important for solidified high-level waste forms:

- waste form homogenity

- heat load

- radiation level

- chemical durability

- physical durability

- fissile material content.

It is believed that borosilicate glass or other comparable terminal waste forms will be acceptable in a licensed repository.

Several recent studies (JAI 1980; Stone, Goforth and Smith 1979; DOE 1980) have rated waste forms and the associated processes. These studies were used as the bases for choosing waste form processes to be considered for WNYNSC. These studies are summarized in the following paragraphs.

Researchers at PNL who were involved in the DOE Alternative waste Forms Program prepared preconceptual designs of eleven different waste form processes (Treat et al. 1980). An independent contractor, E. R. Johnson Associates, Inc. (JAI), compared and ranked these processes (JAI 1980). The comparative rating was expressed quantitatively for all of the significant criteria relating to process engineering in a production facility. However, the rating does not include the merits of the waste form itself. The study rated the processes shown in Table 7.1 in descending order of feasibility with a normalized score of 100 representing the maximum possible rating. Processes that received the highest ranking were the in-can and the joule-heated glass-melter, which both produce a borosilicate glass. The lowest ranked processes were the crystalline-ceramic processes, which produces hot-pressed supercalcine and hotpressed SYNROC. 
TABLE 7.1. Relative Ranking of Waste Form Processes Based on Fheir Comparative Rating(a)

\begin{tabular}{|c|c|c|}
\hline Process & Comparative Rating (b) & Relative Rank \\
\hline In-can glass melting & 89 & 1 \\
\hline Joule-heated glass melting & 75 & 2 \\
\hline Glass ceramic & 70 & 3 \\
\hline Concrete & 65 & 4 \\
\hline Marbles-in-lead & 59 & 5 \\
\hline Titanate & 45 & 6 \\
\hline Cermet & 40 & 7 \\
\hline Supercalcine pellets-in-metal & 40 & 8 \\
\hline Carbon-coated pellets-in-metal & 36 & 9 \\
\hline Hot-isostatic-pressed supercalcine & 32 & 10 \\
\hline Hot-isostatic-pressed SYNROC & 24 & 11 \\
\hline
\end{tabular}

(a) From a study done by JAI for PNL (JAI 1980).

(b) Based on 100 as opt imum.

A study at SRL (Stone, Goforth, and Smith 1979) also ranked the principle waste forms and associated processes. The emphas is in this study was somewhat different in that it chose waste forms that appeared to be superior to borosilicate glass for further investigation. A numerical comparison was made on both the merits of the waste form and the feasibility of the engineering process. This study did not involve a separate preconceptual study of the engineering processes as was done in the PNL study, but rather used the existing literature or information supplied informally by proponents of various waste forms. The comparative standings based on the combined score of the waste form and the process are shown in Table 7.2. The rating was normalized to 100 , which represents an optimum waste form and process. When considering both waste form and process merits, the borosilicate glass process and the coated ceramic via sol Gel received the highest ranking.

Another study, which compared the various waste forms and associated processes, was conducted by an Alternative Waste Form Peer Review Panel (DOE 1980), chaired by Professor L. L. Hench of the University of Florida. This panel was composed of eight scientists and engineers representing independent, non-DOE laboratories from industries, government, and universities. Each panel member rated the waste forms and the results were then tabulated in three categories: 1) present scientific merits or least risk for use today, 2) research priority and 3) present or potential engineering practicality. Within each category, the waste forms fall into top, intermediate or bottom rank, according to the combined numerical ratings assigned by panel members (see Table 7.3). Overall, glass and multibarrier waste forms such as marbles-in-lead matrix or glass-in-a-glass matrix were given the highest ratings in terms of present scientific merit, engineering practicality, and research priority.

Additional input on the types of waste forms and processes appropriate for the WNYNSC wastes was reported by the Advisory Panel on NFS High-Level waste Forms chaired by J. R. Crandall (SRL). The Panel concluded that borosilicate glass, low-alkali glass, 
TABLE 7.2. Relatiye Ranking of Waste Forms and Processes Based on Their Comparative Rating(a)

\begin{tabular}{|c|c|c|c|c|}
\hline \multirow[b]{2}{*}{ Waste Form } & \multicolumn{3}{|c|}{ Comparative Rating (b) } & \multirow[b]{2}{*}{ Relative Rank $(c)$} \\
\hline & Waste Form & Process & Combined & \\
\hline Glass melting & 69 & 77 & 73 & 1 \\
\hline Coated ceramic via Sol Gel & 86 & 47 & 67 & 2 \\
\hline Coated ceramic & 91 & 37 & 64 & 3 \\
\hline Stuffed glass & 72 & 57 & 64 & 4 \\
\hline Glass marbles-in-metal matrix & 60 & 67 & 63 & 5 \\
\hline Supercalcine ceramic & 85 & 33 & 60 & 6 \\
\hline SYNROC ceramic & 87 & 30 & 59 & 7 \\
\hline Ceramic pellets-in-metal matrix & 71 & 40 & 56 & 8 \\
\hline FUE TAP concrete & 35 & 77 & 55 & 9 \\
\hline Hot-Pressed concrete & 52 & 50 & 51 & 10 \\
\hline Cermet (urea process) & 55 & 40 & 48 & 11 \\
\hline
\end{tabular}

(a) Stone, Goforth, and Smith 1980.

(b) Based on 100 as opt imum.

(c) Based on combined comparative rating.

TABLE 7.3. Waste Form Rating by Alternative Waste Form Peer Review Pane l(a)

\begin{tabular}{|c|c|c|c|}
\hline Waste Form & $\begin{array}{c}\text { Present } \\
\text { Scient ific } \\
\text { Merit } \\
\end{array}$ & $\begin{array}{l}\text { Research } \\
\text { Priority }\end{array}$ & $\begin{array}{l}\text { Engineering } \\
\text { Practicality } \\
\end{array}$ \\
\hline GI ass-commercial waste & TOP & INTER & TOP \\
\hline Glass-defense waste & TOP & INTER & TOP \\
\hline Multibarrier ( $g$ lass in $P D$ ) & TOP & воттом & TOP \\
\hline Multibarrier (glass in glass) & TOP & TOP & TOP \\
\hline Porous glass matrix & INTER & TOP & INTER \\
\hline SYNROC & INTER & TOP & INTER \\
\hline Tailored ceramics & INTER & TOP & INTER \\
\hline Titanates & INTER & INTER & INTER \\
\hline Multibarrier (ceramics in $\mathrm{Pb}$ ) & INTER & ВоTTOM & INTER \\
\hline Pelletized and stabilized calcine & BOTTOM & BOTTOM & TOP \\
\hline Clay ceramics & BOTTOM & ВOTTOM & INTER \\
\hline Cermet & BOTTOM & ВоTтOM & BOTTOM \\
\hline Concrete & BOTTOM & INTER & INTER \\
\hline Multibarrier (CVO coatings) & ВоTTOM & INTER & BOTTOM \\
\hline Multibarrier (coextruded) & воTTOM & INTER & BOTTOM \\
\hline
\end{tabular}

(a) DOE 1980. 
crystalline ceramics or coated particles might be appropriate waste forms for the salt/sludge separation waste processing option. The first three waste forms could be in either monolithic or matrix form but, presumably, the coated particles would be restricted to a metal-imatrix form. The Advisory Panel recognized borosilicate glass technology as available for near-term application, but felt that the other forms could be developed to the point of readiness two to three years after all development work could be completed on the borosilicate glass process.

For the unseparated, alkaline and acidic Thorex combined waste process approach, the Panel recommended low-alkali glass processed via a liquid-fed joule-heated melter. They recognized that several glass compositions and waste loading fractions might be appropriate for this option and noted that the off-gas system must be designed to handle large quantities of $\mathrm{NO}_{x}$ and, potentially, $\mathrm{SO}_{2}$.

The primary purpose of the present study is to provide the information required to make a selection between the three waste treatment approaches: 1) terminal waste form--salt/sludge separation process, 2) terminal waste form--combined waste process, and 3) interim waste form-combined waste process. Recognizing that the schedule for WNYNSC does not permit extensive development of new waste forms and associated process engineering, a limited number of waste forms were chosen for study. These waste form selections represent a consensus of the various studies referenced for waste processes having near-term engineering practicality.

For the salt/sludge separated flowsheet, the following waste form processes were selected: 1) Dorosilicate glass produced via the spray calciner/in-can melter process, 2) low-alkali glass produced via the liquid-fed joule-heated melter, 3) glass marbles in a lead alloy matrix, and 4) crystalline ceramic produced via a hot uniaxial pressing method. The acidic Thorex waste is solidified separately using these same processes and producing the same waste forms.

For the combined waste flowsheet, the glass processes appear capable of accepting the high soda-content waste but with a significantly reduced waste loading factor. There is some concern, however, that spray calcination could not occur without operating difficulties due to the low-melting temperature of the waste calcine. Therefore, for the combined waste process, the liquid-fed joule-heated melting process is assumed as the base case. In addition, the marblesin-lead waste form is also considered for the combined waste flowsheet al though the waste loading is low. A process for making a crystalline ceramic from the combined waste flowsheet is not presented since the high soda content of the waste would force the waste loading to be unacceptably low.

\subsection{INTERIM WASTE FORMS}

The interim waste form serves as a temporary, solidified high-level-waste form suitable for transportation. The interim waste form could be transported to another waste solidification facility for processing into a terminal waste form. This waste treatment approach may by required because the facilities at the WNYNSC may be judged to be inadequate and modifications may be too expensive for producing a terminal waste form. 
High-level nuclear waste can be incorporated into an interim waste form that would substantially reduce radionuclide mobility, allow handling and transportation conforming to existing regulations, allow for safe storage for an extended period of time, and be compatible with a terminal waste form process.

There could be significant cost and safety incentives for producing interim waste forms. Such an approach may:

- provide a substantially less mobile form than presently exists at an early date,

- allow additional time to make and implement a decision as to the best terminal waste form,

- minimize the number of final waste form solidification facilities.

Most interim waste form processes can also be used to solidify low-level and decontamination wastes for disposal. Thus, the need for separate waste solidification systems for both high-level and low-level wastes is avoided.

Interim waste forms should possess the following product and process characteristics:

- low radionuclide mobility by leachability, volatility, and particulate dispersion;

- resistant to radiation, thermal, and environmental degradation over the product lifet ime and during reasonable accidents (a suggested design life of the interim form is 50 years);

- compatible with processes to convert the interim waste form to the terminal waste form;

- capable of accommodating feed composition changes;

- produced by an inexpensive, simple and reliable process with minimum operating, maintenance and capital costs;

- have a minimal product volume to reduce safety hazards and costs

- have adequately developed technology for near-term implementation.

Converting the HLLW to an interim waste form would require removing the waste from the storage tanks, converting it to an interim form, and transporting it to the site where it will be converted with other HLLW to a final form for disposal. The reference approach for the inter im waste form processes assumes that the alkaline Purex and acidic Thorex waste would be homogeneously mixed to simplify processing. Studies considering interim waste forms for HLLW application are currently being done at ANL. In the WNYNSC Environmental Impact Statement being prepared at ANL, some consideration has been given by $S$. Vogler and V. Kolba (ANL) to appiying the interim waste form technology at WNYNSC.

The concept of the interim waste form, particularly for commercial high-level wastes, is relatively new. Prior waste management philosophy has generally been to convert the liquid nuclear waste slurry directly to a final form for disposal. Thus, there has been little technology developed toward solidifying high-level waste as an interim form except for calcine used at the Idaho National Engineering Laboratory (INEL) (ERDA 1977d), and salt cake used at Hanford 
(ERDA 1977a) and Savannah River (ERDA 1977b,c). The interim forms considered for use adapt technology from the high-level-waste solidification processes, radwaste solidification processes, and low-level-waste solidification processes (Holcomb and Goldberg 1976; ERDA 1976; National Academy of Sciences 1979; DOE 1979; Colombo and Neilson 1979). There has also been technology developed at Hanford (ERDA 1977a), Savannah River (ERDA 1977b,c) and the INEL (ERDA 1977d) for high-level-waste solidification in large underground storage tanks.

An assessment of the technical, safety, and environmental factors involved to implement an interim waste form process at WNYNSC was reviewed.

Interim waste forms selected for initial screening are shown in Table 7.4. The interim waste forms considered in the present study were then selected based on the degree to which they fulfill the requirements for an interim waste form. All of the forms shown have been tested to some extent with radioactive waste. The list provided in Table 7.4 is not exhaustive but is representative of waste form classes that can be considered as interim forms.

Recommendations from the NFS Waste Form Panel, chaired by J. L. Crandall (SRL), were also considered in selecting interim waste forms for study. The panel recomended that the following interim forms be considered: low-temperature fused-salt/sludge mixture; clay-additive form; polymer forms (i.e., Dow vinyl-ester styrene, Aropol WET@ 662-P water extended polyester. The $P$ anel also gave the following interim forms low ratings: asphalt, concrete, dry salt, raw calcine, and glass.

The criteria used by the NFS Waste Form $P$ anel to assess the interim waste forms were as follows: low dispersion in air in impact accidents, low solubility in water, low-processing temperature and simple processing methods, available technology, minimum additives and minimum volume, and easy reversability for terminal site operations. The $P$ anel tentatively gave lowtemperature fused-salt the highest rating of the recommended forms. Fused salt provides the lowest volume and can be easily converted to a terminal waste form. It also dissolves slowly enough to give time for recovery operations in the event of transportation accidents. The Panel assumed that the interim forms would be shipped promptly to an existing DOE high-levelwaste site. At the DOE sites, the WNYNSC waste would provide only a small addition to the existing stored waste and could be processed through the terminal waste form plants, which are already scheduled for construction at these sites.

The $P$ anel recommended that inter im waste forms be given equal emphasis with terminal waste forms for solidification of the WNYNSC wastes. The advantages of the interim waste forms listed by the Panel included:

- reduced waste processing at WNYNSC;

- reduced processing risks at WNYNSC (Although there is no doubt that waste processing can be done safely at WNYNSC, it presents more difficulty than at one of the large DOE sites such as Hanford, Idaho, or Savannah River. This difficulty is because of

(3) Ashland Chemical Co., Inc. 
IABLE 7.4. Interim Waste Form Properties

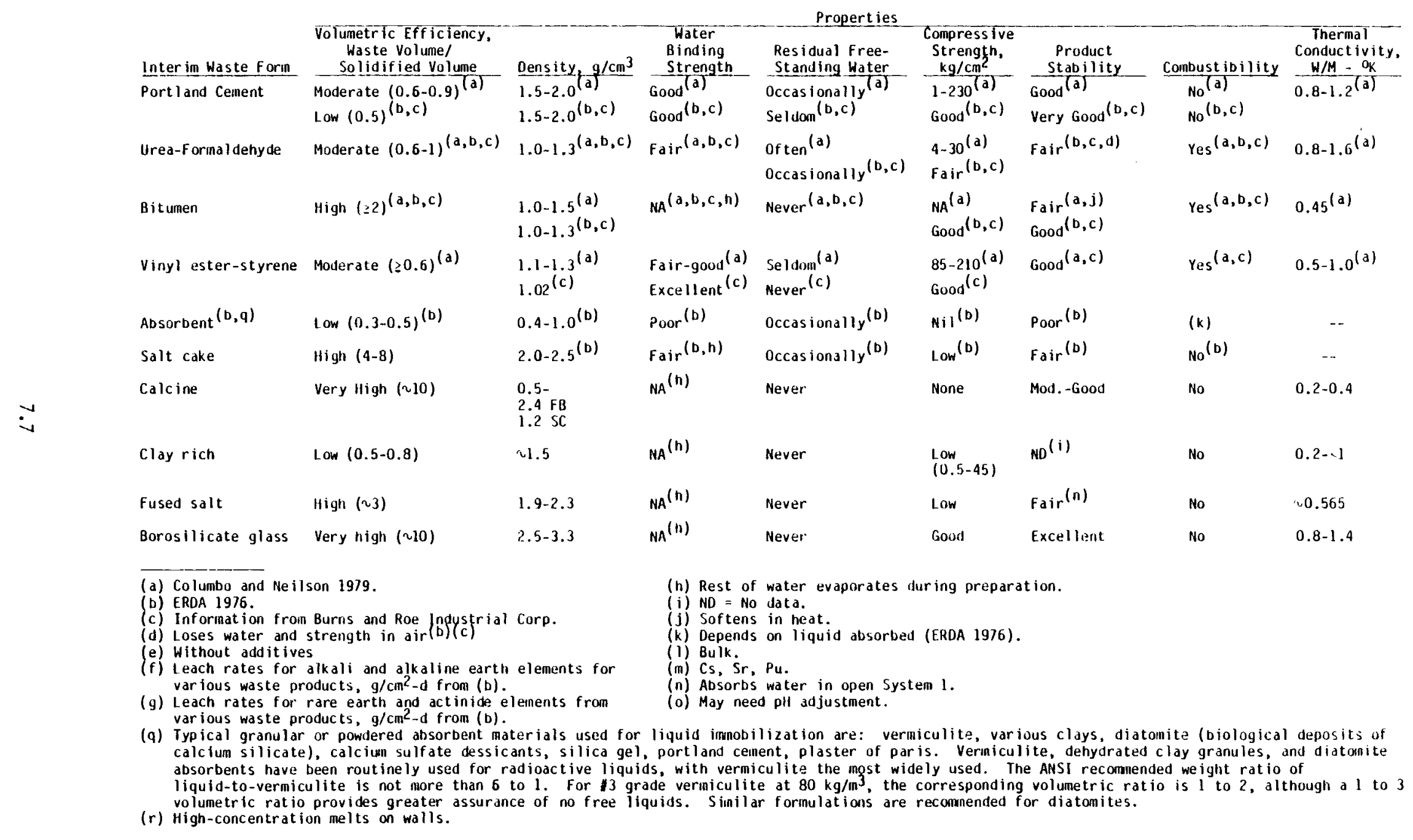


IABLE 7.4. (contd)

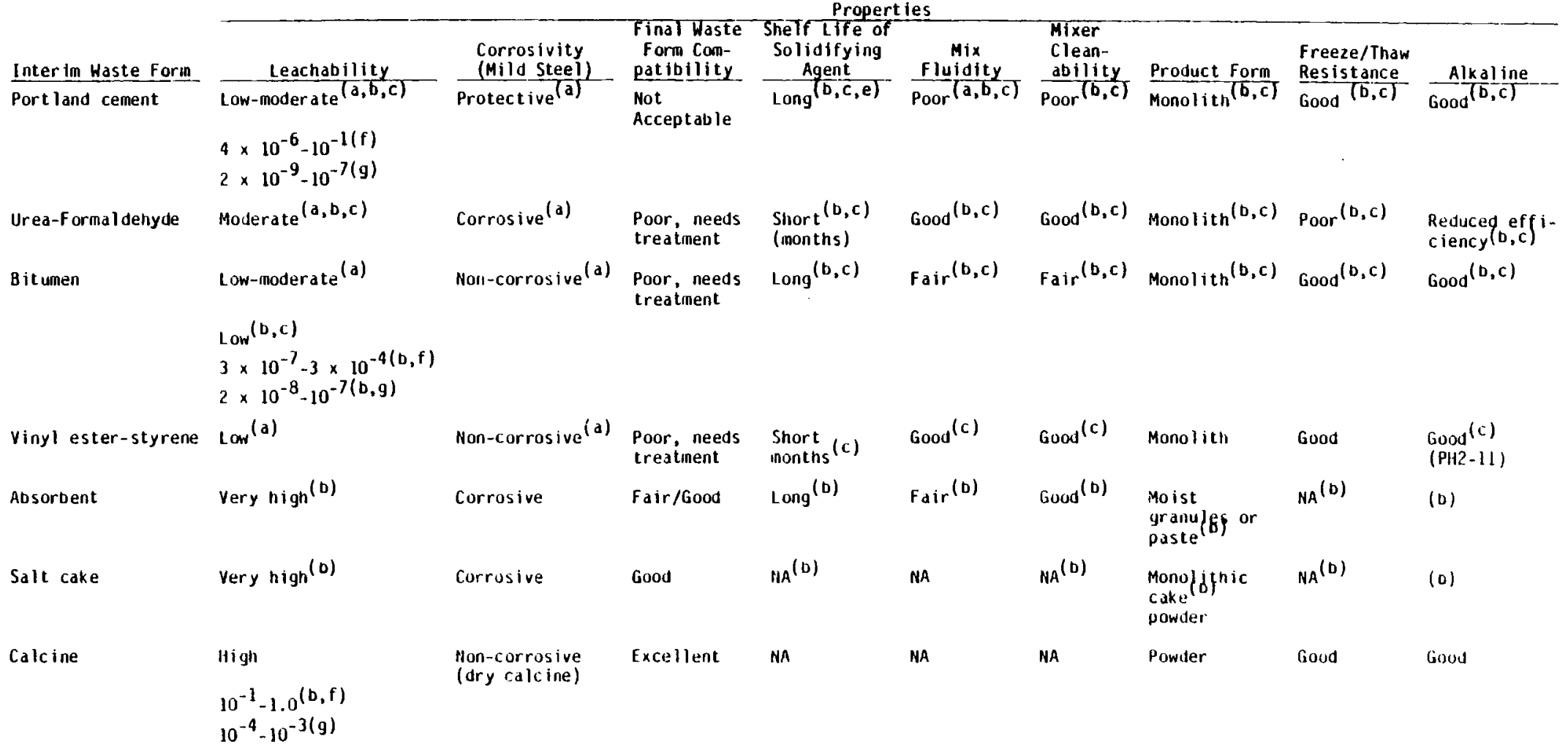


IABLE 7.4. (contd)

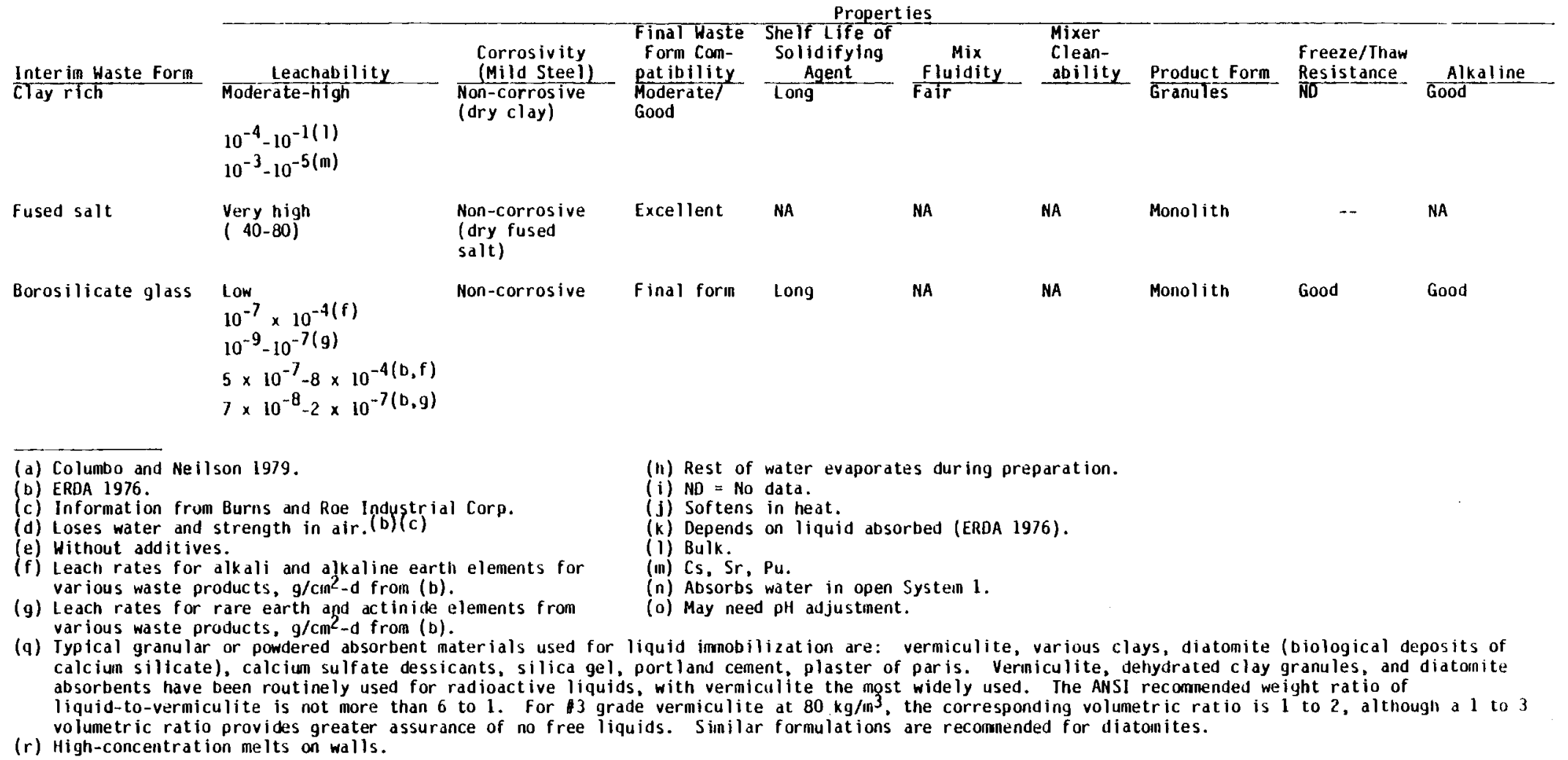




\section{TABLE 7.4. (contd)}

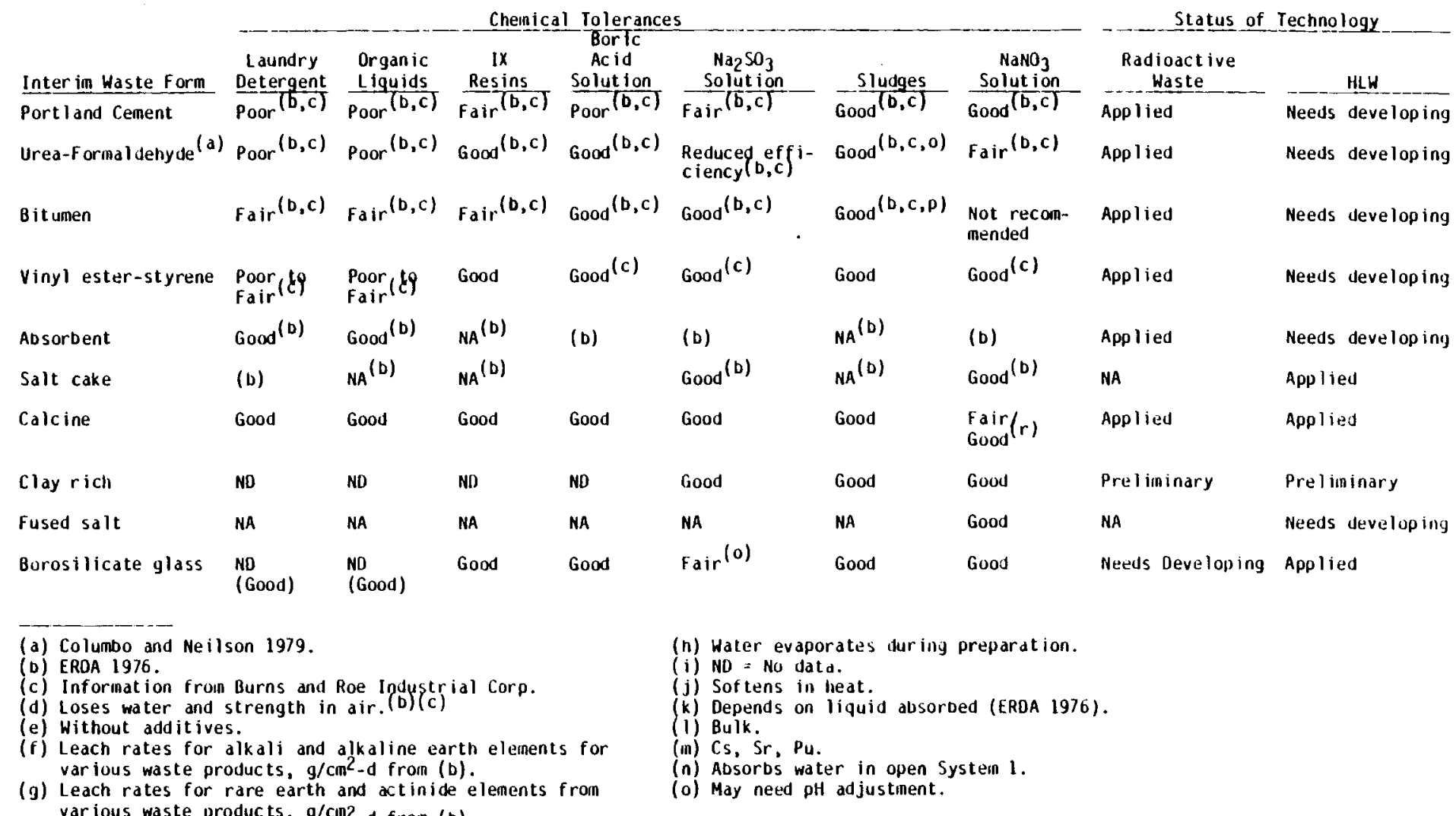

various waste products, $\mathrm{g} / \mathrm{cin} 2$ - $d$ from (b).

(q) Typical granular or powdered absorbent materials used for liquid imnobilization are: veriniculite, various clays, diatomite (biological deposits of calcium silicate). calcium sulfate dessicants, silica gel, portland cenent, plaster of paris. Veriniculite, dehydrated clay granules, and diatunite absorbents have been routinely used for radioactive liquids, with veriniculite the most widely used. The ANSI recomended weight ratio of liquid-to-verniculite is not more than 6 to 1 . For 13 grade vermiculite at $80 \mathrm{~kg} / \mathrm{m}^{3}$, the corresponding volumetric ratio is 1 to 2 , although a 1 to 3 volumetric ratio provides greater assurance of no free liquids. Sinilar formulations are recomended for diatonites.

(r) High-concentration melts on walls. 
the closer proximity to the public due to the small WNYNSC restricted area and

because of the limited backup personnel and facilities available at the WNYNSC

plant.);

- reduced processing costs at WNYNSC;

- earlier removal of the waste from WNYNSC;

- more time to select the optimum terminal disposal form;

The disadvantages of the inter im waste forms included:

- Two processing steps are needed, one at WNYNSC and one at the terminal processing plant with possible increase in risk.

- Potentially, two shipping steps are needed, one to the terminal processing plant and one to the repository with a possible increase in risk.

- Objections to receiving out-of-state waste may be expressed by a state having a terminal waste plant. (Their objections might be allayed by providing them with an assured schedule indicating when the state, which created the waste, plans to build their own terminal processing plant.)

Based on the recomendations of the NFS Waste Form Panel and a review of required characteristics of the interim waste form, the following forms were selected for further review: fused salt, silicate/salt matrix, vinyl ester-styrene, and calcine. The vinyl ester-styrene form was selected over other organic binder forms because it has the best composite properties for interim forms (see Table 7.4) and has been used industrially. Calcine was included because it is a well-developed reference case which is frequently considered for waste solidification. 


\subsection{REFERENCES}

Colombo, P. and R. N. Neilson, Jr. 1979. Properties of Radioactive Wastes and Waste Containers--First Topical Report. BNL-NUREG-50957, Brookhaven National Laboratory, Upton, New York. (Also, NUREG/CR-0619, U.S. Nuc lear Regulatory Comission, Washington, D.C.).

DOE. 1980. The Evaluation and Review of Alternative Waste Forms for Immobilization of HighLevel Radioactive Wastes, Report No. 2. DOE-TIC-11219, DOE, Washington, D.C. (Prepared by Alternative Waste Form Peer Review Panel).

Holcomb, W. F., and S. M. Goldberg. 1976. Available Methods of Solidification for Low-Level Radioactive Wastes in the United States. Technical Note ORP/TAB-96-4, U. S. Environmental Protection Agency, Washington, D. C.

JAI. 1980. Preliminary Evaluation of Alternative Waste Form Solidification Processes: Volume II Evaluation of Processes. JAI 80-160, E. R. Johnson Associates, Inc., Reston, Virginia.

National Academy of Sciences. 1979. Solidification of High-Level Radioactive Wastes. NUREG-CR-0895, National Academy of Sciences, Washington, D.C.

NRC. 1976. Alternative Processes for Managing Existing Cormercial High-Level Radioactive Wastes. NUREG-0043, U.S. Nuclear Regulatory Comm ission, Washington, O.C. (Prepared by PNL).

NRC. 10-CFR-50 (January 1, 1978). Appendix F. "Policy to the Citing of Fuel Reprocessing Plants and Related Waste Management Facilities."

NRC. 10-CFR-60 (1980). (A draft regulation).

Stone, J. A., S. T. Goforth and P. K. Smith. 1979. Preliminary Evaluation of Alternative Forms for Immobilization of Savannah River Plant High-Level Waste. DP-1545, E. I. Du Pont de Nemours \& Co., Savannah River Laboratory, Aiken, South Carolina.

Treat, R. L., et al. 1980. Preliminary Evaluation of Alternative Waste Form Solidification Processes, Volume I: Ident ification of the Processes. PNL-3244, Pacific Northwest Laboratory, Richland, Washington.

DOE. 1979. Technology for Cormercial Radioactive Waste Management. DOE/ET-0028, Volume 2 of 5, U.S. Department of Energy, Washington, D.C.

USERDA. 1977a. Alternatives for Long-Term Management of Defense High-Level Radioactive Waste--Hanford Reservation. ERDA 77-44, Volume 2 of 2, National Technical Information Service, Springfield, Virginia.

USERDA. 1977b. Summary--Aiternatives for Long-Term Management of Defense High-Level Radioactive Waste--Savannah River Plant. ERDA 77-42/2, Volume 2 of 2, National Technical Information Service, Springfield, Virginia.

USERDA. 1977c. Report--Alternatives for Long-Term Management of Defense High-Level Radioactive Waste--Savannah River Plant. ERDA 77-42/2, Volume 1 of 2 , National Technical Information Service, Springfield, Virginia.

USERDA. 1977d. Alternatives for Long-Term Management of Defense High-Level Radioactive Waste. Idaho Chemical Processing Plant. ERDA 77-43, National Technical Information Service, Springfield, Virginia.

USERDA. 1976. Alternatives for Managing Wastes from Reactors and Post-Fission Operations in the LWR Fuel Cycle. ERDA-76-43, Volume 2 of 5, National Technical Information Service, Springfield, Virginia. 


\subsection{SOLIDIFICATION OF SALT/SLUDGE SEPARATED WASTE USING A TERMINAL WASTE FORM PROCESS}

The terminal waste form process for solidification of the alkaline Purex waste includes salt/sludge separation as described in Section 6.1 with solidification of both the alkaline waste and the acidic Thorex waste described in this section. The reference process approach assumes that the acidic Thorex waste will be solidified in a separate campaign that precedes solidification of the alkaline Purex waste. Terminal waste form processes considered are: borosilicate glass, low-alkali glass, marbles-in-lead matrix, and crystalline ceramic.

\subsection{BOROSILICATE GLASS}

Borosilicate glass as a terminal host material for high-level nuclear waste has been under development for over twenty years. These glasses contain a selected mixture of glass formers, modifiers and the nuclear waste. Glass-forming additives are selected after considering the characteristics of the waste material and desired properties of the waste glass product. Glass formers generally compose 65 to $85 \mathrm{wt} \%$ of the final borosilicate glass. Borosilicate glass composition is governed by three factors:

- composition of the nuclear waste to be solidified

- vitrification process to be used

- physical and chemical properties desired of the final waste product.

An important requirement for the borosilicate glass process is that the glass viscosity he less than a specified value at the processing temperature. This permits satisfactory mixing and melting of the waste and glass formers and ensures that a high quality glass is produced. The spray calciner/in-can melter (SC/ICM) process was chosen as the reference process in this study for production of the borosilicate waste glass form because of its high state of development. The vitreous product is formed at $950^{\circ} \mathrm{C}$ to $1100^{\circ} \mathrm{C}$ in the $\mathrm{SC} / \mathrm{ICM}$ process. The viscosity of the glass melt at this temperature is engineered to be less than 200 poise to assure processability. Additional requirements of the glass include minimizing high-temperature volatility, minimizing corrosion, and promoting melt homogeneity.

\subsubsection{Waste Form Properties}

Glass is "...an inorganic product of fusion which has been cooled to a rigid condition without crystallizing," (American Society for Testing of Materials 1955). Scattered crystals are usually present $(\sim 5 \mathrm{vol \%})$ in most borosilicate waste glasses. Table 8.1 lists typical compositional ranges for glasses considered for high-level nuclear waste solidification.

Waste glasses are categorized according to the predominate glass-forming oxides used in the formulation. The predominate oxides in borosilicate glass are silica and boria. Boria $\left(\mathrm{B}_{2} \mathrm{O}_{3}\right)$ serves two purposes in borosilicate waste glass. First, it lowers the glass viscosity and, hence, the required processing temperature. Second, it increases the solubility of many waste constituents in the glass. For these reasons most borosilicate waste glasses (Table 8.1 ) contain 5 to 15 wt\% boria.

The amount of waste in the glass has a strong influence on the properties of the glass. Waste loading, generally expressed as wt\%, is the proportion of waste (in oxide form) in the 
TABLE 8.1. Typical Waste Glass Composition Ranges

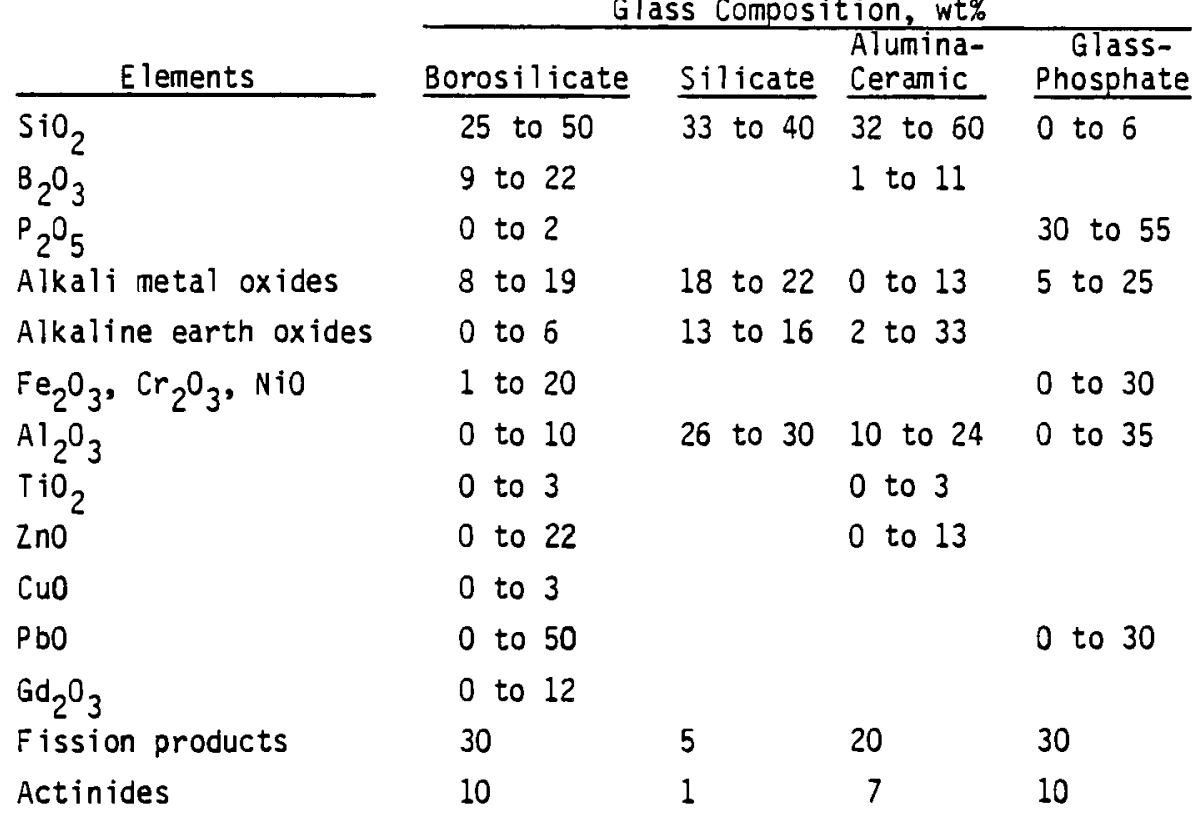

glass when measured and compared to the overall weight of the glass. Factors that limit the waste loading in a borosilicate glass include: 1) maximum solubility of waste components in the glass, 2) viscosity requirements of the molten glass, 3) glass leach resistance requirements, 4) maximum glass centerline temperatures during waste canister storage (due to the presence of heat-generating waste), and 5) maximum canister wall temperatures during waste storage (again, due to the presence of heat-generating waste). When all these factors are considered, the maximum waste loading of a borosilicate glass is in the range of 25 to $45 \mathrm{wt} \%$. However, to maintain processing flexibility the specific waste loading is kept in the range of 15 to 35 wt\%.

Table 8.2 lists the compositions of the glass formers for solidifying the nuclear waste from the salt/sludge separation process and the acidic Thorex waste into borosilicate glass. These waste compositions were developed in the laboratory and have been melted on a pilot-plant scale using the SC/ICM process (Holton, et al. 1980) however, cerium was used as a substitute for thorium in these tests. The waste loading of the Thorex waste is limited by the thoria solubility. The thoria is expected to behave like other actinide elements in the glass matrix. Solubilities of several actinide elements are sumarized in Table 8.3. A Thorex waste solubility of 15 wt\% was chosen in this study, based on an assumed thoria solubility of 10 wt\%. The alkaline waste loading in the borosilicate glass matrix is assumed to be 25 wt\%.

Borosilicate waste glasses are formulated to have a viscosity of 5 to 200 poise at the processing (melting) temperature, which is usually in the range of $950^{\circ} \mathrm{C}$ to $1100^{\circ} \mathrm{C}$. The viscosity of waste glasses is contrasted to that of commercial glasses in Figure 8.1. 
TABLE 8.2. Chemical Composition of Glass-Formers Used to Solidify Simulated Salt/Sludge Separated Alkaline Waste and Acidic Thorex Waste(a)

\begin{tabular}{|c|c|c|}
\hline \multirow[b]{2}{*}{$\begin{array}{l}\text { Glass-F ormer } \\
\text { Components }\end{array}$} & \multicolumn{2}{|c|}{ Quantity, wt\% } \\
\hline & Alkaline Waste & $\begin{array}{c}\text { Acidic Thorex } \\
\text { Waste }\end{array}$ \\
\hline $\mathrm{SiO}_{2}$ & 49.3 & 37.0 \\
\hline $\mathrm{B}_{2} \mathrm{O}_{3}$ & 16.4 & 17.0 \\
\hline $\mathrm{Li}_{2} \mathrm{O}$ & 2.74 & 2.9 \\
\hline $\mathrm{Na}_{2} \mathrm{O}$ & 15.1 & 16.0 \\
\hline $\mathrm{K}_{2} 0$ & 1.4 & 5.7 \\
\hline $\mathrm{CaO}$ & 2.74 & 10.0 \\
\hline $\mathrm{TiO}_{2}$ & 4.1 & 5.7 \\
\hline 2 no & -- & 5.7 \\
\hline $\mathrm{BaO}$ & 2.74 & -- \\
\hline MgO & 2.74 & - \\
\hline $\mathrm{ZrO}_{2}$ & 2.74 & - \\
\hline & 100 & 100 \\
\hline
\end{tabular}

(a) Holton 1980 .

TABLE 8.3. Solubilities of Actinide Oxides in Borosilicate Glass(a)

$\begin{array}{cc}\text { Actinide Oxide } & \text { Solubility, } \mathrm{wtq}_{2}(\mathrm{~b}) \\ \mathrm{UO}_{2} & 10.0 \\ \mathrm{PuO}_{2} & 4.5 \\ \mathrm{AmO}_{2} & 5.0 \\ \mathrm{CmO}_{2} & 0.09\end{array}$

(a) Walker and Riege (1979).

(b) Base glass composition in wt\%:

$\mathrm{SiO}_{2}=50.5 ; \mathrm{Na} O=27.5 ;$

$\mathrm{B}_{2} \mathrm{O}_{3}=13.6 ; \mathrm{TiO}_{2}=4.2 ;$

$\mathrm{CaO}=2.8 ; \mathrm{Al}_{2} \mathrm{O}_{3}=1.4$.

The density of a glass is a function of the chemical composition. Within limits, the density of a glass can be predicted from empiricaliy derived density factors for each chemical constituent. Waste glasses containing high loadings of fission products, which have higher atomic weights than most glass constituents, are more dense than those with low loadings of fission products. Certain special glass constituents such as lead or zinc also increase the glass density. Cormon nuclear waste glasses, depending upon waste loading, have a density in the range of 2.5 to $3.3 \mathrm{~g} / \mathrm{cm}^{3}$. In contrast, zinc-borosilicate glasses have a density of approximately $3.7 \mathrm{~g} / \mathrm{cm}^{3}$ or higher, and some lead-borosilicate glasses have a density of approximate iy $4.8 \mathrm{~g} / \mathrm{cm}^{3}$.

The fracture behavior of glass is known as friability. Fracturing increases the surface area available for leaching of radionuclides from the waste glass. Fracturing may also 


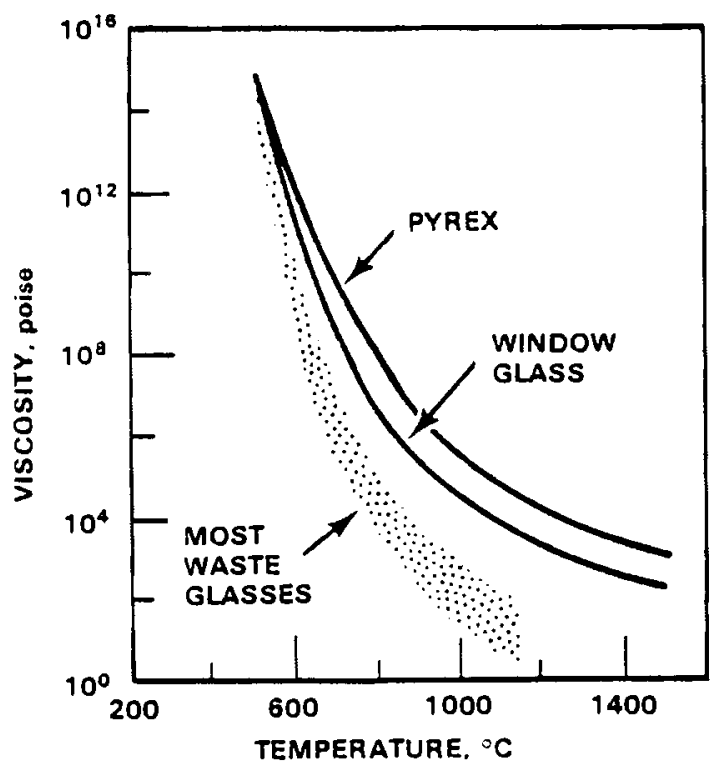

FIGURE 8.1. Comparison of Nuclear Waste Glass and Cormercial Glass Viscosities

produce small particles (<10 $\mathrm{m}$ in dia) that can become airborne and inhaled. Friability of borosilicate waste glass is usually measured by impact tests of various kinds; weights are either dropped on a glass specimen, or the glass specimen itself is dropped onto an unyielding surface.

Impact tests were conducted at PNL (Smith and Ross 1975) in which borosilicate glass cast into two different sized canisters was dropped onto an unyielding surface. The larger canisters, $16.76 \mathrm{~cm}$ in dia $\times 132 \mathrm{~cm}$ high, were dropped onto a concrete pad from heights of up to $61 \mathrm{~m}$ (maximum impact velocity $13.4 \mathrm{~m} / \mathrm{s}$ ). The smaller canisters, $5.1 \mathrm{~cm}$ in dia $\times 10.2 \mathrm{~cm} \mathrm{high,}$ were released into the path of a circular-moving 34-kg granite block mounted on a rotating arm. Impact velocities of up to $35.7 \mathrm{~m} / \mathrm{s}$ were achieved in this test. None of the large canisters were breached but some of the smaller canisters exhibited small cracks after impact above velocities of $23.2 \mathrm{~m} / \mathrm{s}$. Weight-loss measurements showed that no glass escaped through the canister cracks. After impact testing the canisters were opened and the particle size of the contained glass was measured. Figure 8.2 shows the amount of sub-10 um particles formed as a function of impact velocity. Both vitreous and devitrified (containing crystals formed within the glass) specimens of the same glass composition were included in these tests and no difference in friability was noted.

Resistance to leaching is a fundamental requirement for any nuclear waste form. The basic mechanisms for leaching are well known. Both intrinsic and extrinsic factors affect leaching. Intrinsic factors include: glass composition, thermal history of the waste form, radiation effects, and surface character. Extrinsic factors affecting leaching include temperature, pressure, composition, quantity, and flow rate of the leachant.

Figure 8.3 shows the typical range of leach rates obtained for borosilicate waste glasses when they were leached according to the International Atomic Energy Agency (IAEA) proposed 


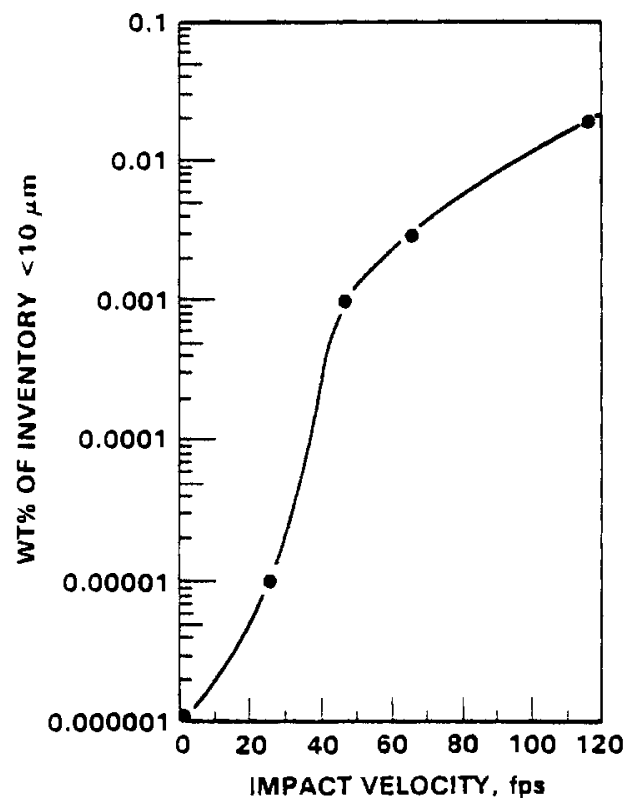

FIGURE 8.2. Effect of Impact Velocity on Fraction of Respirable Particles Formed

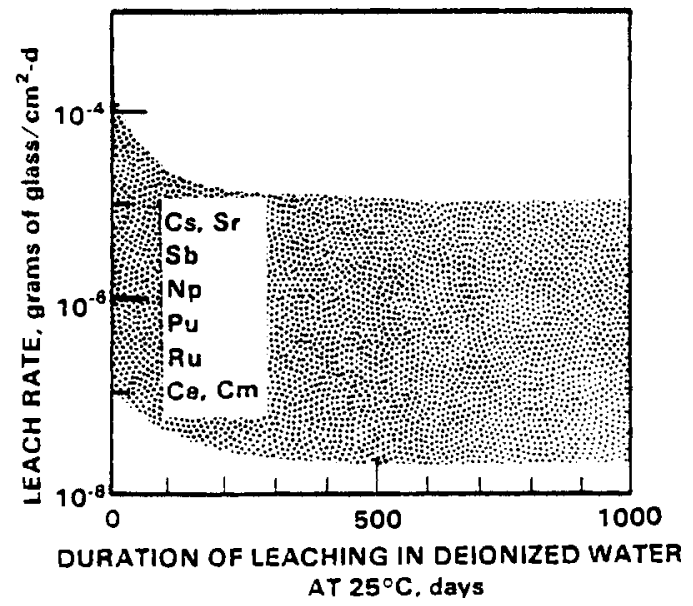

FIGURE 8.3. Typical waste Glass Leach Rates

standard leach test. Leach rate is dependent upon waste glass composition; however, most we11developed glasses have leach rates that are within the bounds shown in Figure 8.3. A thorough review of borosilicate glass leaching studies is found in Ross, et al. (1978), Ross and Mendel (1979).

Volatility of fission products such as $\mathrm{Rb}, \mathrm{Mo}, \mathrm{Ru}, \mathrm{Te}$, and $\mathrm{Cs}$ and of non-fission product elements such as $\mathrm{B}, \mathrm{Na}$, and $\mathrm{K}$ from borosilicate glass melts is directly dependent on glass viscosity and composition. In general higher viscosity glasses have a lower volatility. This is believed to occur because convection currents in the glass play an important role in replenishing the melt surface with volatile elements. High viscosity impedes convection and this impedes volatility. The heat of vaporization of all the volatile elements from the glasses is 
approximately the same; therefore, the vapor compositions above the melt are nearly independent of temperature. The volatility of glass-forming product elements is negligible at wastestorage temperatures. Volatility only becomes significant at temperatures above $700^{\circ} \mathrm{C}$, a temperature exceeded during glass melting. Cesium is the most volatile fission-product metal. Cesium losses of up to $24 \mathrm{wt} \%$ in four hours were measured when a borosilicate glass composition (cormercial glass $72-68$ ) was held at $1000^{\circ} \mathrm{C}$ in dry air (Gray 1980).

\subsubsection{Reference Process System Description and Material Balance}

The details of the borosilicate process flowsheet, process bases, assumptions, chemical and radiochemical material balances are presented in Appendix $A$ for the alkaline salt/sludge separation flowsheet and in Appendix $B$ for the acidic Thorex waste flowsheet.

Waste processing for the reference solidification approach will occur in two distinct phases. First, the Thorex waste will be transferred to the CPC located inside the main processing building and solidified in borosilicate glass using the SC/ICM process. The Thorex waste can be calcined directly without any adjustments. In the second phase, the empty Thorex storage tank (Tank 804) will serve as a surge tank for alkaline waste processing. Periodically, the alkaline Purex waste stored in Tank 802 will be homogenized as completely as possible and transferred in batches to Tank 804 . More frequently, the homogenized alkaline waste in Tank 804 will be transferred to the CPC. Processes for treatment of the alkaline radioactive waste before solidification (involving solid separations and ion-exchange operations) are done in the CPC.

Decontaminated supernate from alkaline waste processing is transferred from the CPC to the SRR. In the SRR, the decontaminated supernate is concentrated, solidified, and packaged as salt cake in 55-gal drums for storage and disposal. The salt-cake waste is a low-level waste that may be buried in a shallow burial site.

A simplified schematic of the SC/ICM process is shown in Figure 8.4. The system consists of: a HLLW feed system, a vitrification system that contains a spray calciner and an in-can melter, a canister-processing system that includes canister-lid welding, weld-leak testing, nondestructive canister examination and canister decontamination, and a calciner-effluent decontamination system.

The alkaline waste HLLW feed stream to the calciner is composed of liquid and solid wastes from the physical and chemical separations. Specifically, this HLLW feed stream includes: sand-filter solids, washed sludge slurry, zeolite loaded with cesium, acidic strontium eluate, and silica gel and silver mordenite from spent of $f$-gas sorber beds.

The HLLW feed is transferred to one of two spray calciner feed blend tanks and sampled. The sample analysis provides information needed to make chemical adjustments, if necessary, prior to waste solidification. High-level waste is pumped to the spray calciner using a submerged cantilver pump. The liquid nuclear waste is atomized with air into small droplets $(\sim 70 \mu \mathrm{m})$ by using a cormercially available spray nozzle. These droplets dry and are converted to calcine (primarily metallic oxides) as they fall through the heated spray calciner furnace. The nominal operating temperature of the spray calciner furnace is $700^{\circ} \mathrm{C}$ to $800^{\circ} \mathrm{C}$. The calcine 


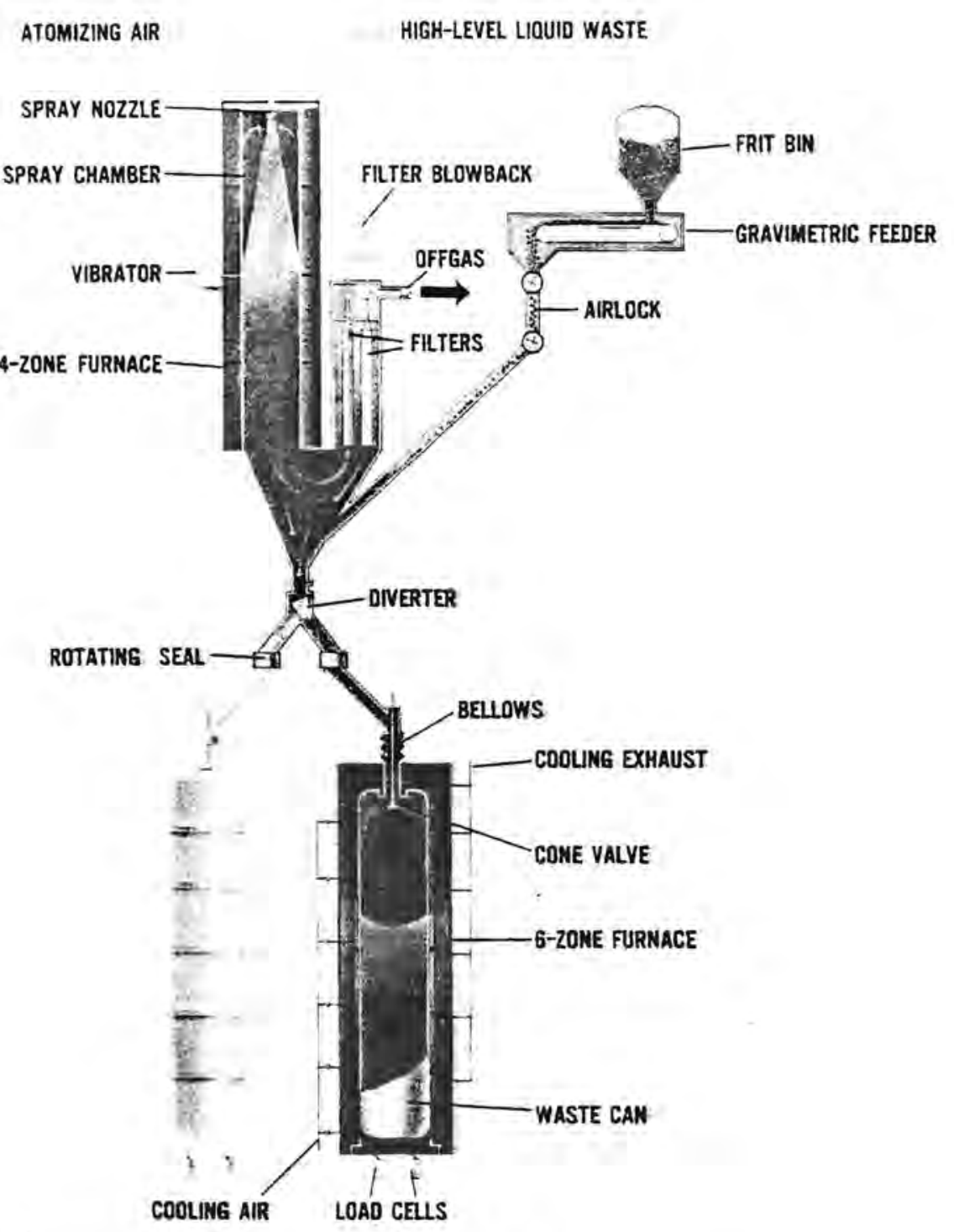

FIGURE 8.4. Schematic of SC/ICM Process

powder formed is mixed with the appropriate amount of glass frit added through a pipe at the base of the spray calciner. This mixture falls from the spray calciner into the product receiving canister. The calcine/glass-frit mixture is heated and melted to form a borosilicate glass. The nominal operating temperature of the in-can melter furnace is $1050^{\circ} \mathrm{C}$.

A connecting section couples the spray calciner with the two in-can meiters. A diverter valve located in this connecting section diverts the calcine/glass-frit mixture to the other canister once the first canister is ful1, thereby permitting continuous operation.

Off-gases from the SC/ICM process consist primarily of water vapor, $\mathrm{NO}_{x}$ from nitrate decomposition, and possibly volatile forms of sulfur, chloride, and fluoride. Volatile radionuclides include ruthenium and iodine with traces of cesium, rubidium, and tellurium. These chemical components are removed from the gaseous effluent stream by treatment processes. 
The process flowsheet details are given in Table 8.4 for solidifying the alkaline waste and in Table 8.5 for solidifying the acidic Thorex waste. The process stream numbers in these tables refer to the process lines shown in Figure 8.5. The waste-form production rates for the alkaline waste and Thorex waste solidification campaigns are significantly different. The alkaline waste is converted to a vitreous product at a rate of $24 \mathrm{~kg} / \mathrm{h}$ (Table 8.4 ), and the Thorex waste is converted to a vitreous product at a rate of $81.3 \mathrm{~kg} / \mathrm{h}$ (Table 8.5 ). This imbalance in production rates is due to the significant difference in waste loading between the two waste types. In actual operations the alkaline waste will be calcined at approximately three times the rate of the Thorex waste and produce glass at approximately one-third the rate of the Thorex waste.

The overall surmary of the two waste products is given in Table 8.6. Although the initial alkaline and Thorex waste volumes differ markedly, there is only a factor of three difference between the volumes of the high-level waste forms produced. The difference is primarily due to the large volume of alkaline waste converted to low-level-waste salt cake. The glass waste loadings assumed in this study are fairly conservative. Higher waste loadings may be accomodated with additional glass formulation study without compromising process flexibility and product durability.

\subsubsection{Status of Technology}

At present, the SC/ICM process is the most highly developed solidification process for producing borosilicate glass waste forms in the United States. This process is essentially ready for plant application; however, some specific development work on equipment and glass

TABLE 8.4. Process Conditions and Material Balance Data for Solidifying the Alkaline Waste Blend in a Borosilicate Glass (Salt Separation Process)

\begin{tabular}{|c|c|c|c|c|c|c|}
\hline \multirow{2}{*}{$\begin{array}{l}\text { Operation } \\
\text { Stream Number (a) }\end{array}$} & \multicolumn{6}{|c|}{ Operation Stream } \\
\hline & \multirow{2}{*}{$\begin{array}{l}\frac{1}{\text { Alka }} \\
\text { Feed } \\
\text { Slurry } \\
\end{array}$} & 2 & \multirow{2}{*}{$\begin{array}{l}\frac{3}{\text { Glass }} \\
\text { Forming } \\
\text { Frit } \\
\end{array}$} & \multirow{2}{*}{$\begin{array}{c}4 \\
\begin{array}{l}\text { In leakage } \\
\text { Air }\end{array} \\
\end{array}$} & \multirow{2}{*}{$\frac{5}{6}$} & 6 \\
\hline Parameter & & $\begin{array}{l}\text { Atomizing } \\
\text { Air }\end{array}$ & & & & $\begin{array}{l}\text { Calciner } \\
\text { Off Gas }\end{array}$ \\
\hline \multicolumn{7}{|l|}{$\mathrm{Flow}, \mathrm{kg} / \mathrm{h}$} \\
\hline Salt & 3.56 & & & & & \\
\hline Solid & 7.91 & & 16.7 & & 23.7 & \\
\hline $\mathrm{H}_{2} \mathrm{O}$ & 101.8 & & & & & 101.8 \\
\hline Air & & 49 & & 22 & & 71 \\
\hline $\mathrm{NO}_{\mathrm{x}}$ & & & & & & 2.34 \\
\hline Total & 112.27 & 49 & 16.7 & 22 & 23.7 & 175.14 \\
\hline Flow, L/h & 100.8 & & & & & \\
\hline Temperature, ${ }^{\circ} \mathrm{C}$ & 35 & 35 & 35 & 35 & 1050 & 300 \\
\hline Density, $\mathrm{g} / \mathrm{cm} 3$ & 1.1 & & 2.0 (bulk) & & $2.8\left(35^{\circ} \mathrm{C}\right)$ & \\
\hline Activity, Ci/L & 21.6 & & & & 260 & $2.17(\mathrm{Ci}$ \\
\hline
\end{tabular}

(a) Stream numbers refer to Figure 8.5 .

(b) Based on 597 days processing time. 
TABLE 8.5. Process Conditions and Material Balance Data for Solidifying the Acidic Thorex Waste in a Borosilicate Glass

\begin{tabular}{|c|c|c|}
\hline $\begin{array}{l}\text { Operation } \\
\text { Stream Number (a) } \\
\quad \text { Parameter } \\
\end{array}$ & \begin{tabular}{l}
\multicolumn{1}{c}{} \\
Acidic \\
Waste $(b)$ \\
Blend
\end{tabular} & $\begin{array}{l}2 \\
\text { Atomi } \\
A i\end{array}$ \\
\hline \multicolumn{3}{|l|}{ Flow, $\mathrm{kg} / \mathrm{h}$} \\
\hline Salt & 27.9 & \\
\hline Solid & & \\
\hline $\begin{array}{l}\mathrm{H}_{2} \mathrm{O} \\
\text { Air }\end{array}$ & 45.2 & 22 \\
\hline $\mathrm{NO}_{\mathrm{X}}$ & & \\
\hline Total & 73.1 & 22 \\
\hline Flow, L/h & 45 & \\
\hline Temperature, ${ }^{\circ} \mathrm{C}$ & 35 & 35 \\
\hline Density, $\mathrm{g} / \mathrm{cm}^{3}$ & 1.7 & \\
\hline Activity, Ci/L & 39.1 & \\
\hline
\end{tabular}

formulation may be required to implement the process at specific sites. The SC/ICM process involves chemical and mechanical operations that must be performed remotely on a routine basis. Some of these operations have not been performed on a remote production scale; however, the specific requirements of these operations are understood.

Development work on the SC/ICM process was started in the eariy 1960's on a laboratory scale at the Pacific Northwest Laboratory (PNL). This work led to the Waste Solidification Engineering Prototypes (WSEP) Program. During the WSEP Program, radioactive waste that was chemicaliy adjusted to represent power reactor waste was solidified using the SC/ICM process (Schneider 1969, Schneider and Kelley 1969, MCElroy et al. 1968, Bond et al. 1970, McElroy et al. 1972). Approximately $8600 \mathrm{~L}$ of HLLW having a radiochemical inventory of 25-M Ci were successfuliy solidified in 13 demonstration runs. During the WSEP, remote operation and maintenance of the SC/ICM system, the feed system, and the gaseous effluent system were demonstrated using an overhead crane and master-slave manipulators.

In further development of the SC/ICM process, PNL began the waste Fixation Program in 1972. As part of this program both pilot-scale and industrial-scale SC/ICM systems were developed in a nonradioactive environment. To date over $1300 \mathrm{~h}$ of operation with the nonradioactive pilot-scale spray calciner system and $1600 \mathrm{~h}$ of operation with the nonradioactive fullscale spray calciner have been logged in processing simulated HLLW. This development work resolved questions concerning wear and blockage of the atomizer nozzle, scale accumulation on the interior-wall, and the system's capacity. 


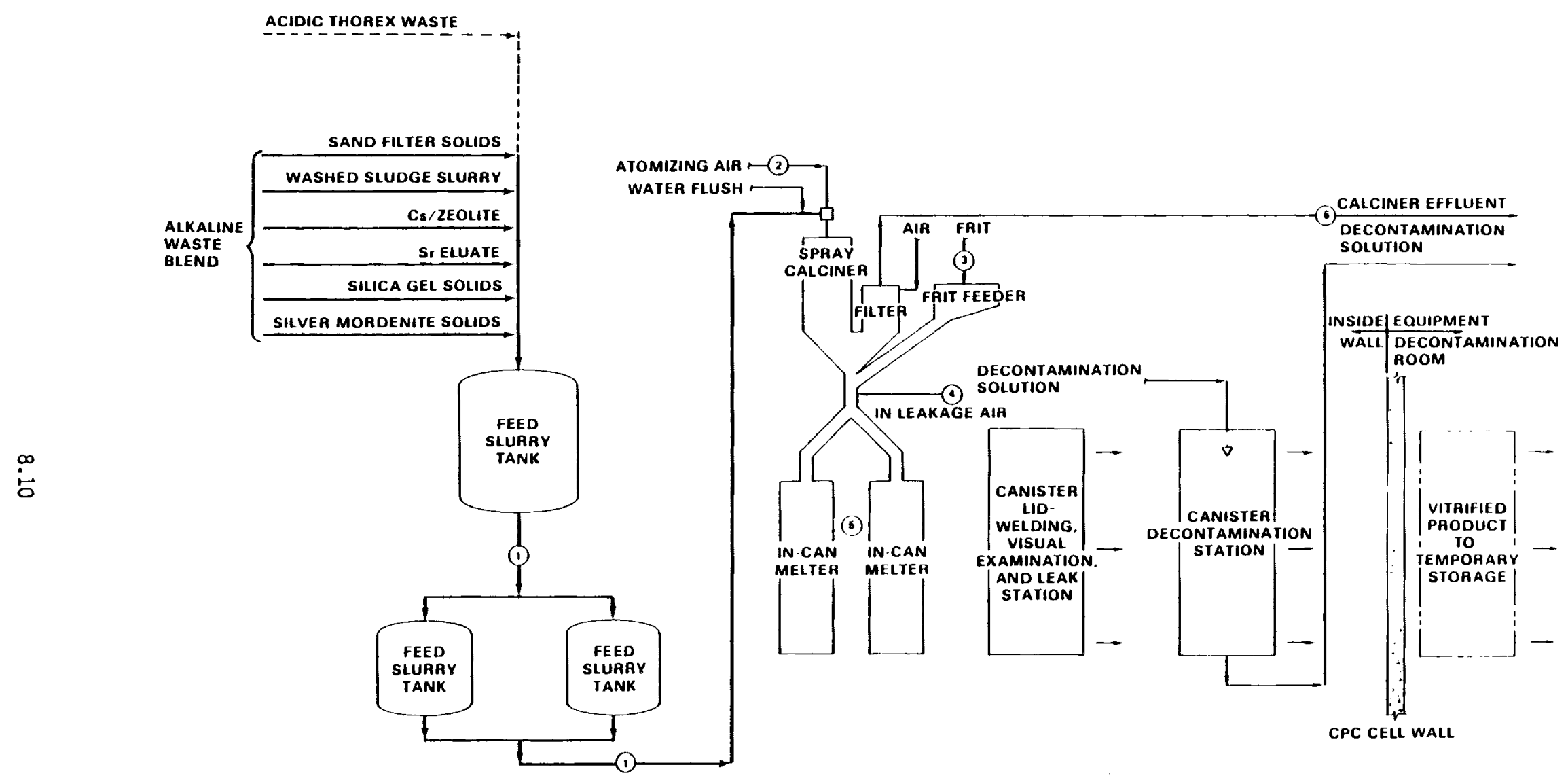

FIGURE 8.5. Simplified Flowsheet Schematic of Spray Calciner/In-Can Melter Process 
TABLE 8.6. Borosilicate Glass Waste Form Process Sumary for Solidifying Alkaline Salt/Sludge Separated Waste and Acidic Thorex Waste

\begin{tabular}{llll} 
Glass-production rate, $\mathrm{kg} / \mathrm{h}$ & $\begin{array}{c}\text { Separated } \\
\text { Alkaline Waste }\end{array}$ & & $\begin{array}{c}\text { Acidic } \\
\text { Thorex Waste }\end{array}$ \\
\cline { 2 - 2 } Number of HLW canisters & 24 & 81.3 \\
Activity per canister, $\mathrm{Ci}$ & 180 & 60 \\
Decay heat per canister, W & $1.7 \times 10^{5}$ & $4.0 \times 10^{4}$ \\
Low-level salt, number of 55-gal drums & 506 & 112 \\
High-level waste loading, wt\% & 5120 & Not applicable \\
Processing campaign length, d & 25 & 15 \\
& 597 & 60
\end{tabular}

The most recent radioactive demonstration of the SC/ICM system (Wheelwright et al. 1979) occurred during the Nuclear Waste Vitrification Project (NwVP) that was started during 1976 at PNL. The project demonstrated the solidification of actual high-level nuclear waste that was generated from the reprocessing of light-water reactor fuel using the SC/ICM process. The project was completed in March 1979 after two canisters of actual waste were prepared. Approximately $0.48-\mathrm{M} \mathrm{Ci}$ of activity were solidified during this demonstration.

Development of the in-can melting process has also continued. The in-can melter was used during the WSEP program and NWVP for vitrification of nUclear waste into a borosilicate glass form. The nonradioactive pilot-scale and full-scale in-can melters have been operated more than $900 \mathrm{~h}$ at glass-melting temperatures to produce simulated waste glasses.

Much work has been directed toward developing the waste-glass storage canister and the auxiliary systems required for handling canisters. Two basic designs have been developed and analyzed. A comprehensive study by Simonen and Slate (1979) has a detailed description of these analyses. The canister-processing equipment is essentially ready for plant application. Some radioactive development would be required before a remote facility is built.

Over 30 full-scale canisters have been filled using the in-can glass melting process. The diameter of these canisters ranged from $0.3 \mathrm{~m}$ (12 in.) to $0.52 \mathrm{~m}(28 \mathrm{in.})$. Development studies on canisters of simulated waste have included: the application of various cooling cycles and the evaluation of the effects on the glass, remote welding and weld inspection, placement of canisters in water storage for long-term corrosion evaluation, and establishment of a data base for canister design.

The following development efforts should be made before the SC/ICM process is applied to the WNYNSC facility:

- Study glass formulations containing simulated nonradioactive and actual radioactive wastes to assure the waste form products meet performance requirements.

- Determine effects of nonstandard formulation and process conditions on product quality.

- Evaluate potential equipment problems, such as excessive corrosion/erosion to equipment, and any potential operating difficulties associated with transferring materials. 


\subsubsection{Safety Considerations}

A preliminary safety assessment of the SC/ICM process was made by Holton et al. (1979). This study identified potential accidents associated with the spray calciner feed system, spray calciner, in-can melter, canister-handling operations, the calciner-effluent cleanup system, and the cell structure. Accidents were grouped according to: off-standard conditions, minor incidents, moderate accidents, design-basis hypothetical accidents, and hypothetical accidents. This study concluded that even in design-basis hypothetical accidents the radionuclide release to the environment from the solidification facility would not expose the public to an additional radiochemical dose greater than the nominal background dose of $100 \mathrm{mrem} / \mathrm{yr}$. Safety assessments for the SC/ICM process are also found in other studies (Barnes and Bendixsen 1977; Larson 1980; Southern Sciencies Applications 1978).

There are several hypothetical accidents that are characteristic of the SC/ICM system due to the nature of equipment operations. These hypothetical accidents are associated with release of $H L L W$ from the spray calciner feed system and release of calcine from the spray calciner system.

The feed system to the spray calciner will consist of a feed batch tank and a pump that both agitates the liquid-waste feed and transfers the feed siurry to the spray calciner under pressure through an air atomization nozzle. Two types of centrifugal pumps are recormended for the transfer of feed slurries from the feed batch tank to the spray calciner (Bechtel, Inc. 1977). These are the deep-well turbine-type canyon service pumps (Purex Technical Manual, HW-31000, General Electric Company 1955) and the cantilever-type centrifugal pump (Goodlet 1968). Both types of pumps are suitable for delivering radioactive waste slurries to the spray calciner in a high-radiation field $\left(10^{4} \mathrm{R} / \mathrm{hr}\right)$ and under required pressures near $50 \mathrm{psig}$. The high-pressure radioactive feed slurry is atomized by air in a commercially available spray nozzle.

A characteristic of the alkaline waste slurry is its highly abrasive solids content. Simulated slurries of this type have eroded through feed-transfer lines and severely damaged pump and impeller blades. Failure of feed-system components is inevitable despite specific engineered safety allowances; therefore, periodic replacement of high-velocity feed-transfer lines should be anticipated in normal plant operation. The worst conceived radionuclide-release accident is a feed-line rupture due to feed-line erosion. (It is assumed that the feed is atomized in a fine mist and behaves as fine particulates.) Such an event could grossiy contaminate the cell and its components. A large majority of the waste particles would be removed in the HEPA filtration system of the cell. The integrity of the air-filtration system for the cell is therefore an important part of the engineered system that assures adequate radionuclide containment.

The calciner system can become pressurized, and if so, will release calcine to the operating cell. The amount of calcine that is released depends on the degree of pressurization. Release of calcine due to the lack of system vacuum is usually caused by unexpected surges in the calciner feed rate or by opening the calciner system to the cell atmosphere. Other causes of system pressurization, such as combustion of accumulated organics, are very unlikely. 
Calcine will also be released during normal calciner-system maintenance and canisterhandling operations. Again, the air-filtration system of the cell serves as an important barrier in the control of radionuclide releases to the natural environment.

\subsubsection{Facility Implementation}

Implementation of the salt/sludge separation process into the existing fuel reprocessing cells at the WNYNSC is possible, provided that the existing facilities are upgraded and modified. This study assumes that the high-level-waste processing equipment, vitrification equipment, and effluent-treatment equipment will be installed in the CPC and the decontaminated salt-solidifying and salt-packaging equipment will be located in the SRR. Conceptual layouts of the process equipment based on the PNL/Vitro Preconceptual Design (Hill et al. 1981) in the $C P C$ and SRR are shown in Figures 8.5 and 8.7 , respectively.

The CPC is $6.7 \mathrm{~m} \times 28 \mathrm{~m} \times 13.1 \mathrm{~m} \mathrm{high}$ and has $1.8-\mathrm{m}$-thick concrete walls. The cell is serviced by a two-hook ( $1.8 \mathrm{t}$ and $14.5 \mathrm{t}$ capacity) remotely-operated crane and an electromechanical power manipulator. These remote operations are viewed through oil-filled shielding windows in the west and north walls of the cell. There is a door in the north wall for moving equipment (by remote control) in and out of the cell. The CPC presently contains two dissolvers, space for a third dissolver, a tank for feed adjustment and accountability, two waste evaporators, rework process vessels, and associated plumbing. The dissolvers are annular in design and installed around a solid plug of neutron-absorbing borated concrete.

In preparing to install the waste processing equipment, all of the existing equipment must be removed, including the borated concrete dissolver plugs. The cell must be decontaminated to a sufficiently low-radiation level to allow contact installation of the processing equipment.

The CPC will require modifications because at least three times as many pieces of equipment will be needed for the Waste Solidification Project as are currently installed. Consequently, many additional services to the cell will be required. Approximately 50 penetrations, ranging in sizes from $5.1 \mathrm{~cm}$ in dia to $35.6 \mathrm{~cm}$ in dia, will be required for these services. Most of the penetrations will be in the east wall of the CPC. Also, a process line(s) between the $C P C$ and the existing $H L W$ storage tanks will be required to transfer the stored HLLW to the waste treatment equipment. Because the streams that require sampling will contain solids, the existing samplers may not be satisfactory and may require modification.

The waste form canisters produced weight approximately $2970 \mathrm{~kg}$ (empty canister weight is approximately $976 \mathrm{~kg}$, glass weight $1993 \mathrm{~kg}$ ). Because of this canister weight it is recommended that the $1.8 \mathrm{t}$ hoist be replaced with a 4 or $5 t$ hoist. This would provide two cranes to transport canisters within the CPC and EDR.

Another alteration caused by placing the SC/ICM close to the west wall near the south end of the CPC will require two new shielded viewing windows at the $35.7 \mathrm{~m}$ elevation for operation and maintenance of the melter. Master-slave manipulators will be required at each of these windows and at one other window where closures will be welded on the filled-waste canisters. Some modifications to the floor and west wall of the chemical viewing aisle will also be required to accommodate the windows at the $35.7 \mathrm{~m}$ elevation and to remove the manipulators. 


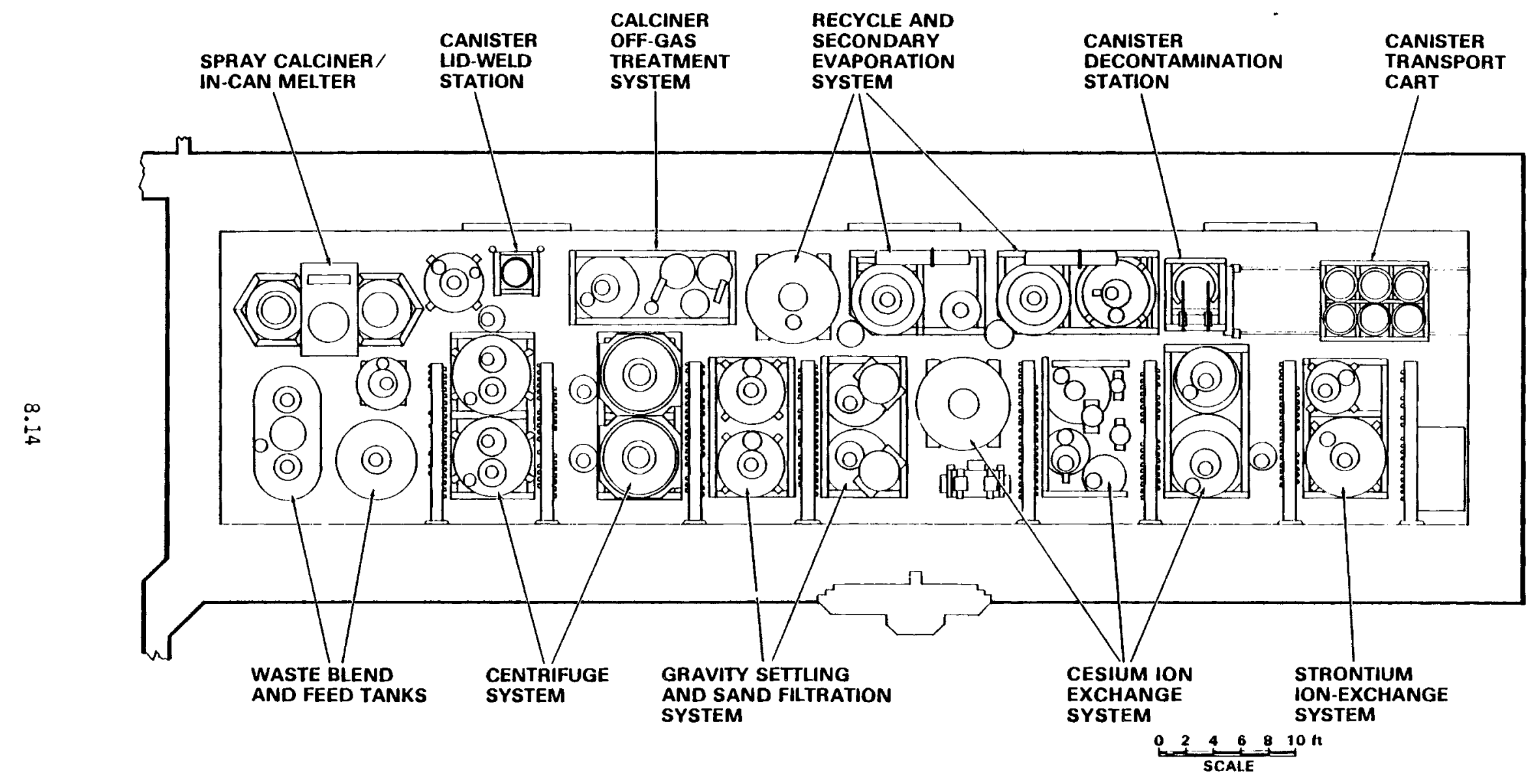

FIGURE 8.6. Conceptual Layout of Processing Equipment in the Chemical Processing Cell 


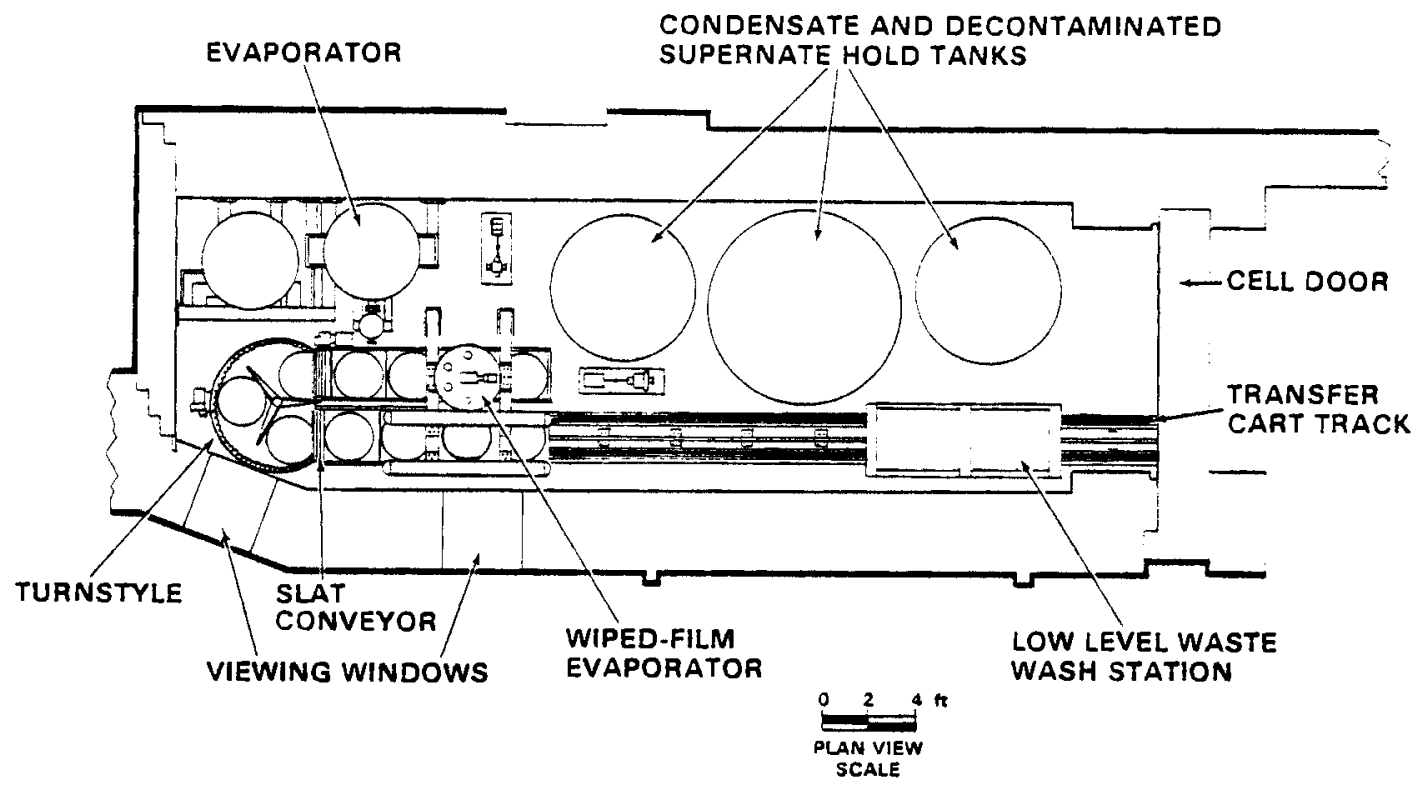

FIGURE 8.7. Conceptual Layout of Equipment in the Scrap Removal Room

Electrical leads will be required through the west wall of the CPC to service the SC/ICM. A shielded cubicle and a wall penetration, sloped at a $45^{\circ}$ angle, are required at the south end of the CPC to house the frit-addition airlock valves, the spray calciner filter-blowback valves, and the addition of the frit to the SC/ICM.

The equipment door in the north end of the CPC will be used for moving empty and full waste canisters into and out of the CPC. A new transfer cart will be required for moving the canisters. Two or three periscopes will be needed in the west wall of the CPC to view remote change-out and maintenance of the spray calciner feed nozzles, vibrators and filters.

The SRR is $3.0 \mathrm{~m} \times 11.6 \mathrm{~m} \times 4.0 \mathrm{~m}$ high and has $1.0 \mathrm{~m}$ thick concrete walls. The room is serviced by a 7-1/2 t remotely-operated crane. There is one shielded viewing window. The room has no installed processing equipment. The main function for the room was packaging and removal of fuel hardware and cladding following the chop-leach process.

In order to prepare the SRR for its new functions, several modifications will be required. First the SRR must be decontaminated to a sufficiently low radiation level to allow contact installation of the salt-concentrating and salt-packaging equipment. Since current plans call for contact and remote operation of this equipment, an additional viewing window and two sets of manipulator sleeves will be required. A minimum of four process lines will be required between the SRR and the CPC for transfer of process solutions and effiuents.

In addition to the CPC and the SRR, the Equipment Decontamination Room (EDR) will need to be modified to accormodate waste storage canisters. These changes will include adding canisterdecontamination equipment and a transport mechanism to transfer the high-level-waste canisters to the storage facility for high-level-waste canisters. 
Finally, numerous modifications to the essential building services (steam, process water, compressed air, electrical, etc.) will be required. Modifications will also be required in the process control room and in other service areas to accommodate the additional process equipment and process function changes that are made. Completion of installation and startup of the new Atmospheric Protection and Process off-Gas Systems will also be required.

\subsection{LOW-ALKALI GLASS}

Research is being done on low-alkali glasses at several laboratories. The objective is to provide a glass that is more durable than borosilicate glass. Chick and Buckwalter (1980) have recently characterized over 100 glasses to determine properites that improve leach resistance. In general, the leach resistance is improved by increasing silica, alumina, ferric oxide, and/or titania and reducing the glass alkali content. Correspondingly, leach resistance increases as the melting temperature (temperature at which the glass viscosity is 100 poise) increases. There are some exceptions to this rule where glasses with melting temperatures of $1050-1100^{\circ} \mathrm{C}$ have exhibited leach resistances comparable to glasses having a melting temperature of $1450^{\circ} \mathrm{C}$. More research and development on these compositions is warranted. For the purpose of this comparative study, assumptions of a low-alkali glass will imply glasses having melting temperatures of approximately $1450^{\circ} \mathrm{C}$.

\subsubsection{Waste Form Properties}

The low-alkali glass waste form properties are similar to those of the reference borosilicate glass. The low-alkali glass is produced in a joule-heated melter and poured into a steel canister where it solidifies into a vitreous monolith. The alkaline-waste-sludge loading in the low-alkali glass is restricted by the ferric oxide content to approximately $20 \%$ of the glass wight. A typical glass composition is given in Table 8.7. Thoria solubility limits the Thorex waste loading to $7.5 \mathrm{wt} \%$ ( $5 \mathrm{wt \%}$ thoria). A specific composition has not been developed for this waste type.

A comparison of low-alkali and borosilicate glass leach rates is shown in figure 8.8. In comparison with borosilicate glass, the leach resistance of low-alkali glass at $100^{\circ} \mathrm{C}$ is improved by approximately a factor of 10 . However, as the ambient temperature is raised the leach resistance of the low-alkali glass decreases more rapidly than the leach resistance of borosilicate glass. At $200^{\circ} \mathrm{C}$ the two glasses have approximately the same leach resistance. Heat content of the glass, glass geometry, and storage conditions will determine the temperature at which the leach behavior of the borosilicate and low-alkali glasses are similar.

Volatility losses from low-alkali glass at its melting temperature have been measured at approximately $170 \mathrm{~g} / \mathrm{m}^{2}-\mathrm{h}$. This is approximately a factor of 30 to 100 greater than for borosilicate glass (Chick and Buckwalter 1980) depending on the formulation and the actual temperature at which the melter is operated.

Other low-alkali glass physical properties such as impact resistance, radiation stability, thermal conductivity, thermal expansion, devitrification and phase separation behavior have not been characterized. It is assumed that these physical characteristics for the low-alkali glass will be similar to borosilicate glasses. 
TABLE 8.7. Composition Ranges for Low-ATkali Glasses Incorporating the Alkaline Waste

\begin{tabular}{lc}
\multicolumn{1}{c}{ Elements } & Glass Composition, wt\% \\
\hline $\mathrm{SiO}_{2}$ & 50 to 65 \\
$\mathrm{~B}_{2} \mathrm{O}_{3}$ & 12 \\
$\mathrm{P}_{2} \mathrm{O}_{5}$ & 2 \\
$\mathrm{Alkali}$ metal oxides & 10 \\
Alkaline earth oxides & 4 \\
$\mathrm{Fe}_{2} \mathrm{O}_{3}, \mathrm{Cr}_{2} \mathrm{O}_{3}, \mathrm{NiO}$ & 6 \\
$\mathrm{Al}_{2} \mathrm{O}_{3}$ & 1 to 10 \\
$\mathrm{TiO}_{2}$ & 0 to 3 \\
Fission products & 20 \\
Actinides & 10
\end{tabular}

\subsubsection{Process System Description and Material Balance}

The reference borosilicate glass waste form is produced in a SC/ICM process. The nominal processing temperature of the in-can melter is $1050^{\circ} \mathrm{C}$ if a stainless steel canister is used, or $1100^{\circ} \mathrm{C}$ if an Incone $1-600^{\circledR}$ canister is used. The low-alkali glass, however, has a nominal processing temperature of $1450^{\circ} \mathrm{C}$. This high processing temperature requires the use of a ceramic-lined melting cavity. A liquid-fed ceramic melter ( $L F C M$ ) is proposed for processing the low-alkali glass. A simplified schematic of the low-alkali glass process is shown in Figure 8.9. Generally this process is similar to the reference SC/ICM process. The major exceptions are that the glass-forming frit is added to the liquid feed before solidification and that the LFCM replaces the spray calciner and the two in-can melter furnaces.

Alkaline waste blend, consisting of washed-alkaline sludge/sand filter solids, cesiumloaded zeolite, strontium eluate, and off-gas sorber bed solids, is homogenized in the feed blend tank and sampled. Sample analysis provides information necessary to adjust the chemical composition of the alkaline slurry to form an optimum waste-glass composition. Glass-forming chemical adjustments are made to the alkaline slurry, the mixture blended, and the alkaline blend transferred to one of two LFCM feed tanks.

The adjusted alkaline slurry is fed to the LFCM at a controlled rate using an air-lift feed system. Alkaline waste slurry is dried and converted to vitreous product in the LFCM at a glass temperature of approximately $1450^{\circ} \mathrm{C}$. The glass that is formed is semi-continuously discharged into a mild steel waste canister. The glass cools and forms into a vitreous monolith with in the waste canister. Solidification of the acidic Thorex waste precedes solidification of the alkaline waste blend in a similar manner.

When the canister is filled, the melter is tipped back and the glass flow discontinued. The filled canister is decoupled from the melter. The canister is removed and transferred to the canister lid-weld station. A lid is welded on the canister, the lid weld-leak tested, and

(incone 1-600, registered trademark of the International Nickel Company, Inc. 


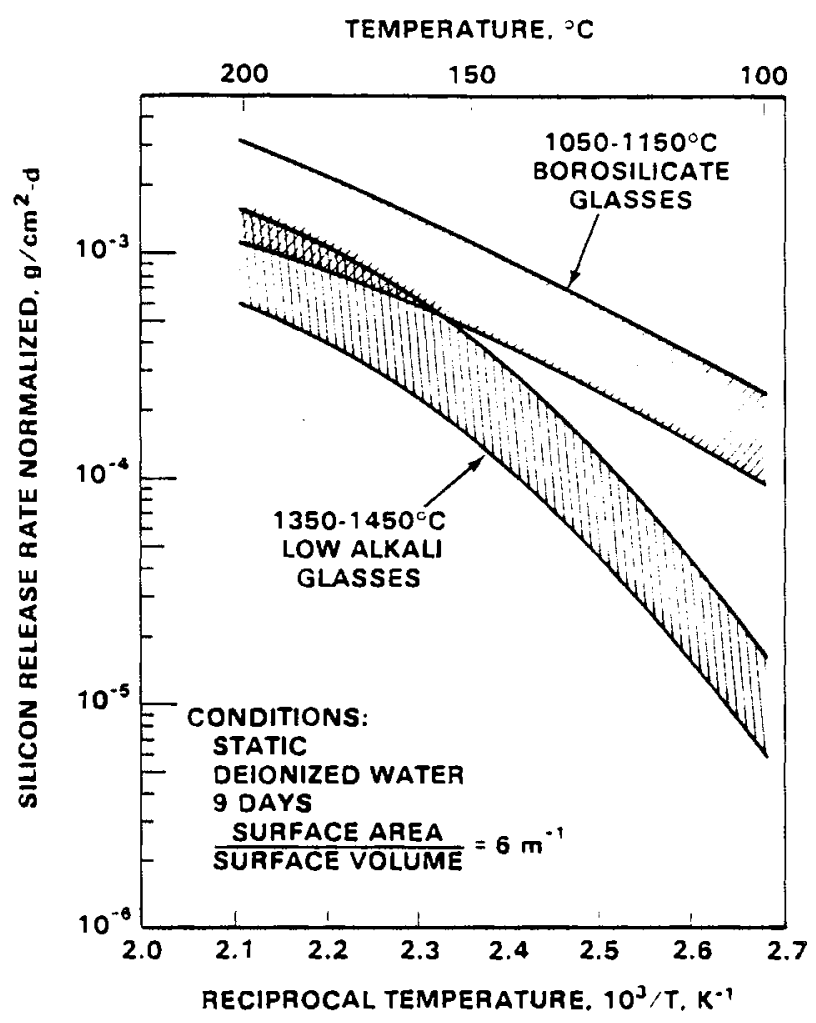

FIGURE 8.8. Silicon Release in Leach Rate Tests as a Function of Ambient Temperature

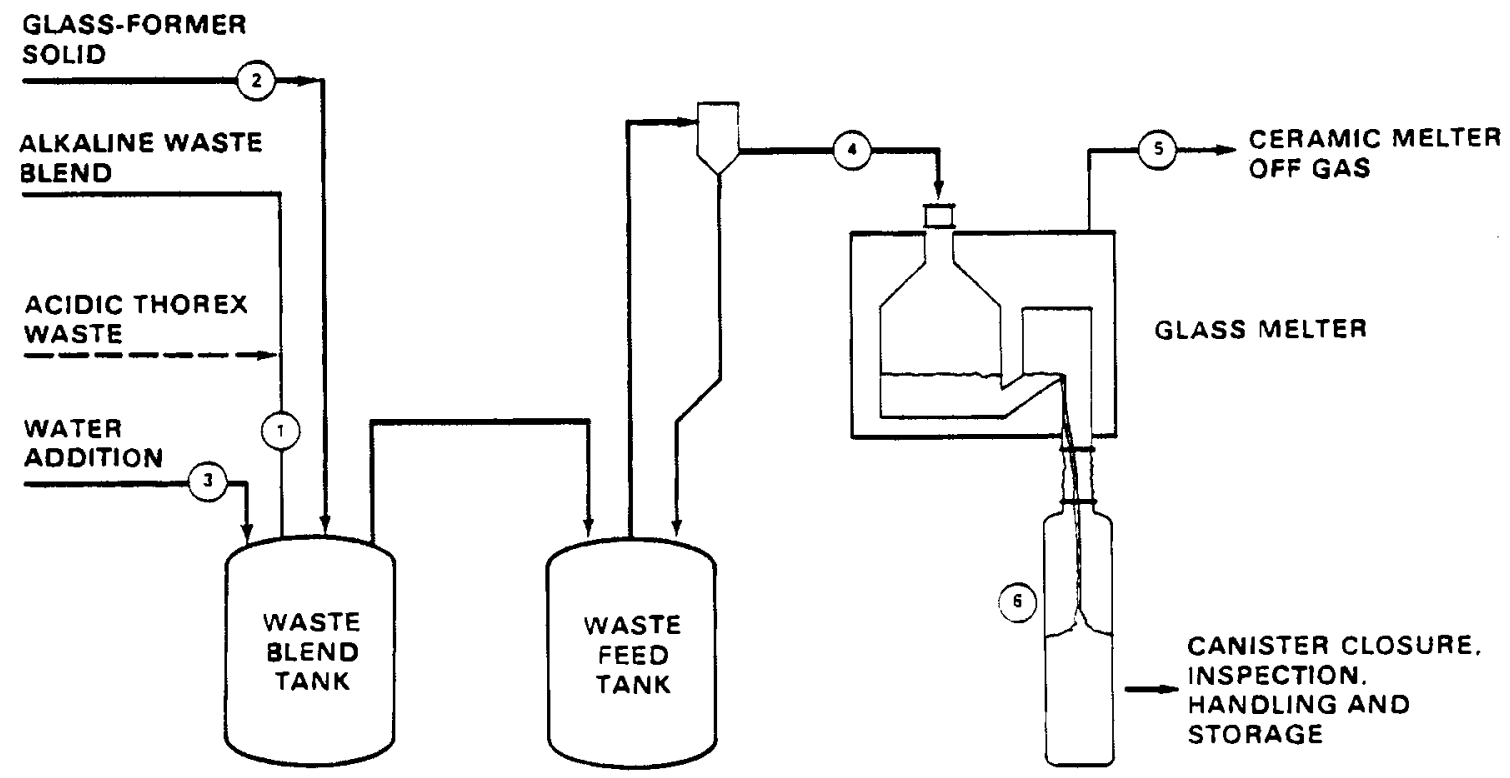

FIGURE 8.9. Schematic of the Low-Alkali Glass Process 
the canister visually inspected. The canister is then taken to the canister decontamination station and decontaminated before being transported into an interim storage facility.

The LFCM has a ceramic-lined cavity where glass is melted by the heat generated when electric current passes through molten glass (joule-heating). Figure 8.10 is a cutaway of a representative joule-heated melter. Electrodes are located on opposite sides of the melter cavity. The glass-forming chemicals can be introduced as a dry mix (as they would be if preprocessed with the spray calciner), as an alternate approach. In general higher quality glass will be produced if these two streams are well blended before solidification. In operating the LFCM, liquid slurry dries to a crust, or cold cap, on top of the molten glass surface. The cold cap is melted from below by the hot glass. The water in the feed slurry is quickly boiled off, although an aqueous pool may form if feed rates are too high. The carbonates, nitrates, and some of the sulfates decompose into oxides and gases. Volatile metallic elements that are driven off the hot glass tend to reflux in the cold cap, which reduces the total loss of these volatiles to the off-gas system. The normal glass inventory of a currently developed LFCM is approximately $400 \mathrm{~L}$ of molten glass.

Since the liquid slurry is melted in a large tank where some degree of mixing occurs before the glass is poured, the glass produced by this process tends to be more homogeneous than that produced in the SC/ICM process. During pouring the molten glass passes from the bottom of the melter tank under a weir and along a discharge chute to a pouring face. This path is heated by auxiliary heaters. Glass pouring is started by a mechanism that tilts the melter approximately $5^{\circ}$. The canister is attached to the melter shell via a flexible metal bellows that accomodates both thermal expansion and the tilting motion. The melter shell, bellows, and canister serve as an air-tight system to contain volatiles.

A high-temperature melter, suitable for producing the $1450^{\circ} \mathrm{C}$ low-alkali glass, requires refractory insulation in the walls of the tank area as well as in the roof. No metal, such as feed nozzles, can be exposed to the melting cavity without cooling. The joule-heating electrodes are made from either tin oxide or molybdenum. An iron-chromium-nickel alloy, such as Inconel $-690^{\circledR}$ can be used in the lower-temperature borosilicate glass melter.

The outside dimensions of the melter, with some allowance for connections, are $2 \mathrm{~m} x$ $3 \mathrm{~m} \times 2.5 \mathrm{~m}$ high. Because of the many cooling-water, c0oling-air, electrical and instrumentation connections, the space reserved for the melter in the CPC must be considerably larger than these dimensions. The total weight of the LFCM is estimated as $9000 \mathrm{~kg}$.

The LFCM has only one discharge chute leading to a single canister. The melter is tilted down for pouring and tilted back to stop the glass flow and then canister changeout takes place. This approach requires that canister changeout be accomplished in approximately one hour if continuous feeding to the LFCM is maintained.

The overhead crane will be used to move the canister to the various stations (glass pouring, lid welding and decontamination) in the CPC. Some type of turntable or trolley cart will

(incone 1-600, registered trademark of the International Nickel Company, Inc. 


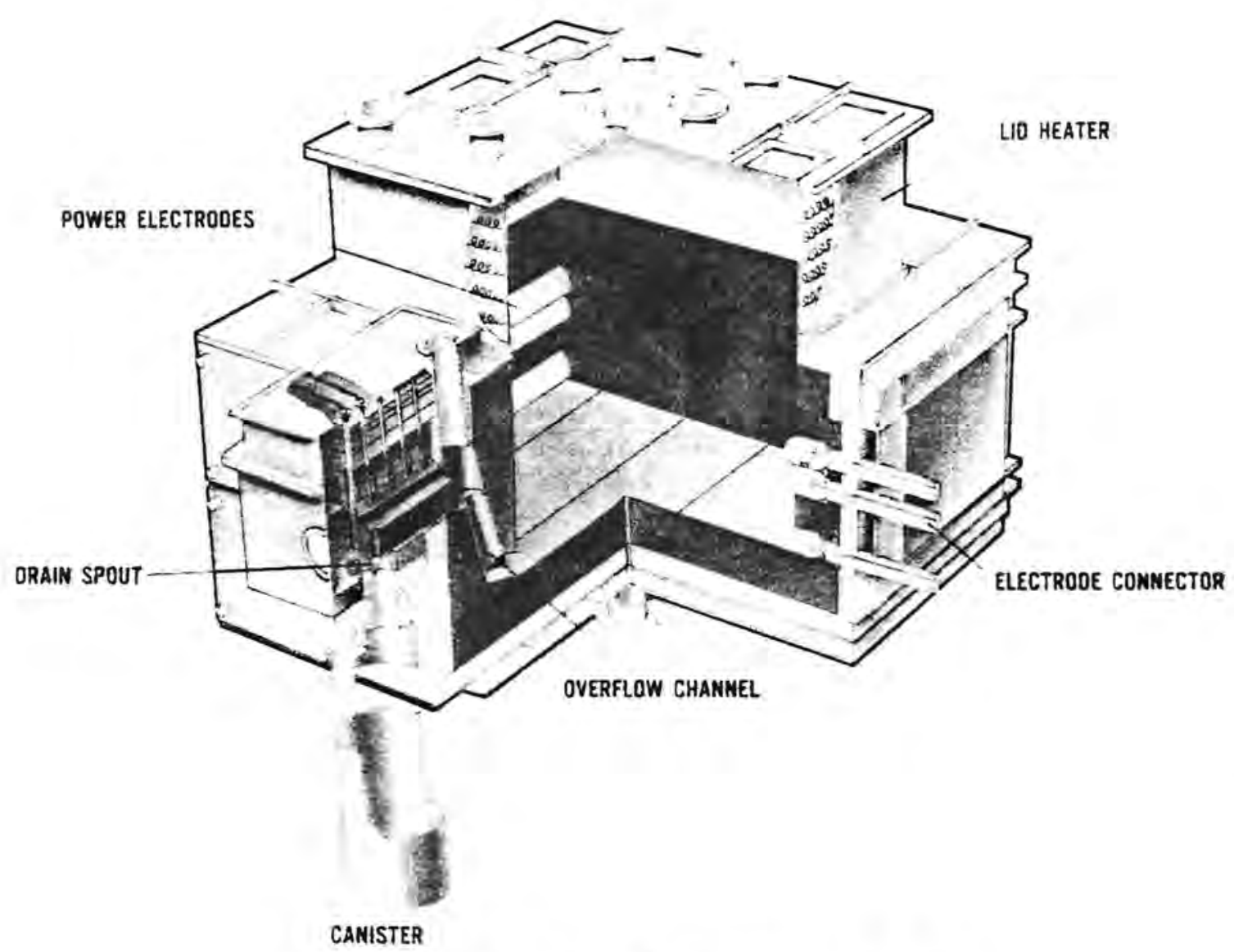

FIGURE 8.10. Cutaway of Electric-Heated Melter

be required to position the canister underneath the melter to receive glass. Lid-welding, leak-testing, canister decontamination, and canister-handling equipment is the same as that used in the reference process.

The material balance for the low-alkali glass containing the separated salt/sludge alkaline waste is presented in Table 8.8. The stream numbers shown on this table refer to Figure 8.9. The waste loading of the glass is limited to approximately 20 wt\% to minimize the formation of spinel crystals, which could settle in the LFCM. The material balance for the low-alkali glass containing the acidic Thorex waste is presented in Table 8.9. The waste loading is reduced to $7.5 \mathrm{wt} \%$ to minimize precipitation of thoria crystals in the LFCM. The fu11capacity operating days for the two solidification campaigns have been adjusted to allow a glass-production rate of $46.3 \mathrm{~kg} / \mathrm{h}$ for both campaigns, since this simplifies LFCM design and operation.

The waste form process sumary (Table 8.10) indicates that 250 canisters containing the alkaline waste and 127 canisters containing the acidic Thorex waste will be produced. In addition, 5120 barrels of decontaminated salt will be generated. Further development of low-alkali glass may allow higher waste loadings. Thus, the number of canisters produced would decrease proportionately. 
TABLE 8.8. Process Conditions and Material Balance Data for Solidifying Separated Alkaline Waste in Low-Alkali Glass

\begin{tabular}{|c|c|c|c|c|c|c|}
\hline $\begin{array}{l}\quad \text { Stream Number }(\mathrm{a}) \\
\text { Melter } \\
\quad \text { Parameters } \\
\end{array}$ & $\begin{array}{l}\frac{1}{\text { Alkaling }} \\
\text { Waste } \\
\text { (oxide) }\end{array}$ & $\begin{array}{l}\frac{2}{\text { Glass }} \\
\text { Former } \\
\text { Solids }\end{array}$ & $\begin{array}{c}\frac{3}{\text { Feed }} \\
\text { Dilution } \\
\text { Water } \\
\end{array}$ & 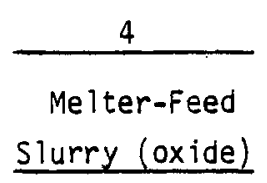 & Off Gas & Glass \\
\hline Flow, $\mathrm{kg} / \mathrm{h}$ & & & not required & & & \\
\hline Salt & 10.3 & & & 10.3 & & \\
\hline Solids & 0.73 & 36.9 & & 37.6 & & 46.3 \\
\hline $\begin{array}{l}\mathrm{H}_{2} \mathrm{O} \\
\text { Air }\end{array}$ & 134 & & & 134 & $\begin{array}{l}134 \\
20\end{array}$ & \\
\hline${ }^{\mathrm{NO}} \mathrm{x}$ & & & & & 3.1 & \\
\hline Total & 145.03 & 36.9 & & 181.9 & 157.1 & 46.3 \\
\hline Temperature, ${ }^{\circ} \mathrm{C}$ & 35 & & & $35^{\circ} \mathrm{C}$ & 300 & 1400 \\
\hline Density, $\mathrm{g} / \mathrm{cm}^{3}$ & $1.08(c)$ & 3 & & 1.22 & & 2.8 \\
\hline Flow, L/h & 134 & & & 134 & & $16.5\left(35^{\circ} \mathrm{C}\right)$ \\
\hline Activity, Ci/L & 21.6 & & & 21.6 & $14.5(\mathrm{Ci})$ & 175 \\
\hline Heat, w/L & 0.06 & & & 0.06 & & 0.51 \\
\hline
\end{tabular}

(a) Stream numbers refer to streams shown in Figure 8.9.

(b) Number of full-capacity operating days $=450$.

(c) Inleakage air.

TABLE 8.9. Process Flowsheet for Acidic Thorex Waste--Solidif ied in Low-Alkali Glass

\begin{tabular}{|c|c|c|c|c|c|c|}
\hline Stream Number (a) & $\begin{array}{c}\frac{1}{\text { Acidic }} \\
\text { Thorex } \\
\text { Waste (b) } \\
\end{array}$ & $\begin{array}{l}\frac{2}{\text { Glass- }} \\
\text { Former } \\
\text { Solids } \\
\end{array}$ & $\begin{array}{l}\frac{3}{\text { Feed- }} \\
\text { Dilution } \\
\text { Water } \\
\end{array}$ & $\begin{array}{l}\frac{4}{\text { Melter- }} \\
\text { Feed } \\
\text { Slurry }\end{array}$ & $\begin{array}{l}\frac{5}{\text { Melter }} \\
\text { Off Gas }\end{array}$ & Glass \\
\hline \multicolumn{7}{|l|}{ Flow, $\mathrm{kg} / \mathrm{h}$} \\
\hline Salt & 7.4 & & & 7.4 & & \\
\hline Solids & & 42.8 & & 42.8 & & 46.3 \\
\hline $\begin{array}{l}\mathrm{H}_{2} \mathrm{O} \\
\mathrm{Air}\end{array}$ & 12.0 & & $80.6^{(c)}$ & 92.6 & $\begin{array}{l}92.6 \\
20^{(d)}\end{array}$ & \\
\hline${ }^{\mathrm{NO}} \mathrm{x}$ & & & & & 2.9 & \\
\hline Tota $\hat{\imath}$ & $19.4^{(a)}$ & 42.8 & 80.6 & 142.8 & 115.5 & 46.3 \\
\hline Temperature, ${ }^{\circ} \mathrm{C}$ & 35 & & & 35 & & 1400 \\
\hline Density, $\mathrm{g} / \mathrm{cm}^{3}$ & 1.27 & 3.0 & & & 2.8 & $2.8\left(35^{\circ} \mathrm{C}\right)$ \\
\hline Flow, L/h & 12 & & & 92.6 & & 16.5 \\
\hline Activity, Ci/L & 37 & & & 5.2 & $2.4(\mathrm{Ci})$ & 26.7 \\
\hline Heat, $w / L$ & 0.14 & & & 0.1 & & 0.08 \\
\hline
\end{tabular}

(a) Stream numbers refer to streams in Figure 8.9.

(b) Number of full-capacity operating days $=227$.

(c) Water required to dilute feed to demonstrated feed concentration (500 g of solids/L).

(d) Inleakage air. 
TABLE 8.10. Waste Form Product Summary for Separated Alkaline Waste and Acidic Thorex Waste Solidified Individually in Low-Alkali Glass

\begin{tabular}{|c|c|c|}
\hline Process Characteristic & $\begin{array}{c}\text { Separated } \\
\text { Alkaline } \\
\text { Waste } \\
\end{array}$ & $\begin{array}{l}\text { Acidic } \\
\text { Thorex } \\
\text { Waste } \\
\end{array}$ \\
\hline Glass production rate, $\mathrm{kg} / \mathrm{h}$ & 46.3 & 46.3 \\
\hline Glass in canister, $\mathrm{kg}$ & 1993 & 1993 \\
\hline Number of canisters & 250 & 127 \\
\hline Activity per canister, $\mathrm{Ci}$ & $1.24 \times 10^{5}$ & $1.9 \times 10^{4}$ \\
\hline Decay heat per canister, $W$ & 360 & 53 \\
\hline Low-level salt, number of $55-g a l$ drums & 5120 & NA \\
\hline Process campaign length, $d$ & 450 & 227 \\
\hline
\end{tabular}

\subsubsection{Status of Technology}

The early research into glass forms for waste solidification concentrated on low-melting temperature glasses, for example, phosphate-based glasses. This research reflected the temperature limitations imposed by melting the glass former and waste in metal canisters or metallic melter cavities. As technology evolved, borosilicate glasses appeared to offer the best compromise of the waste form performance and the limitations of melter material.

Later, interest in adapting comercial glass technology to the needs of nuclear waste solidification resulted in developing ceramic-lined joule-heated melters that continuously melt borosilicate glasses. Since joule-heated melters are used in the commercial glass industry at temperatures in the range of $1200-1500^{\circ} \mathrm{C}$, some development work has been done to investigate glasses with higher melting points than the borosilicate glasses. Initial work on higher melting glasses was in pursuit of a glass-ceramic waste form. A glass-ceramic, as defined by Shookey (1960) in his patent of the process, is a myriad of fine-grained crystals, relatively uniform in size, randomiy oriented, and homogeneously dispersed in a glass matrix. The crystals comprise the major portion of the glass-matrix.

The development work on glass-ceramics is primarily related to the waste form (De, et al. 1976a, De et a1. 1976b; Oguino, Masuda and Tsunoda 1979). Barnes (1980) reported on operating experience with a high-temperature bench-scale joule-heated melter ( $27 \mathrm{~L}$ capacity) used to investigate both glass-ceramic compositions and high-temperature (approximately $1250^{\circ} \mathrm{C}$ ) borosilicate glass compositions. The experience with this melter, which employs tin-oxide electrodes is applicable to low-alkali glass technology.

An extensive study of the compositions, viscosity, volatility, and leach rates of lowalkali glass was made by Chick and Buckwalter (1980). They investigated over 100 glass compositions and compared the results from the most favorable compositions with established borosilicate glass compositions for comercial and defense wastes.

The LFCM technology is based both on commercial glass-making experience and seven years of melter experience at government laboratories working on waste solidification. Both solidsfed (calcine and glass frit) and liquid-fed melters have been investigated. They are based essentially on the same technology. Savannah River Laboratory is developing both solids-fed 
and liquid-fed melters directed toward the solidification of defense waste stored at SRL. willis (1980) surveyed the melters and reported on their operating experiences. All of the experience with larger melters has been with simulated radioactive wastes. However, Okeson, et al. (1980) reported on the operation of a Small LFCM using actual radioactive SRL waste. A large LFCM capable of producing up to $150 \mathrm{~kg} / \mathrm{h}$ glass is being designed at SRL to meet the needs of the defense waste solidification program.

Since 1973 joule-heated-melter research at PNL has been done with a variety of jouleheated melters (Buelt et al. 1979). Over $62,000 \mathrm{~kg}$ of glass has been produced in calcine-fed joule-heated melters. The full-scale melter (sized to solidify waste from a light-water reactor at a rate of $5 \mathrm{MTU} / \mathrm{d}$ ) has a tank capacity of approximately $250 \mathrm{~L}$. A description of this melter and its operating nistory was given by Dierks et al. (1980). In 1975, PNL researchers began experimenting with direct liquid feeding and found that a small amount of the glass formers should be mixed with the liquid feed before it was put into the melter (Chapman 1976; Buelt and Chapman 1978). A full-scale LFCM (again, sized for a commercial LWR fuel reprocessing plant of $5 \mathrm{MTU} / \mathrm{yr}$ ) with a tank capacity of approximately $400 \mathrm{~L}$ has processed approximately $10,000 \mathrm{~L}$ of simulated high-level waste, which is equivalent to approximately $3000 \mathrm{~kg}$ of glass. The experience in processing simulated defense waste in a LFCM at PNL was sumarized by Brouns, et al. (1980). The high-temperature bench-scale melter experience at PNL was reported by Barnes, Brouns, and Hanson (1980). Pacific Northwest Laboratory research has accumulated design information for refractories, electrode materials, feed injection, glass discharge, glass-foaming control, off-gas composition and power control for simulated, commercial and defense waste glass compositions.

The German and Belgian waste solidification programs have also investigated joule-heated ceramic melters. A LFCM is the reference system for the PAMELA plant to be built at the Eurochemic Site in Mol, Belgium. Weisenburger (1980) described both the reference LFCM for PAMELA and the development history of earlier melter prototypes. The reference LFCM is designed to produce waste glass at approximately 20 to $25 \mathrm{~kg} / \mathrm{h}$.

Other studies include those by Chapman (1980) and Kupfer and Palmer (1980). Chapman (1980) presented a good overview of melter design and control and discusses scale-up in melter size and the impact of decay heat. Kupfer and Palmer (1980) have investigated several defense waste glasses having melting temperatures of 1150 to $1250^{\circ} \mathrm{C}$. In addition, Palmer (1980) researched the interaction between melter electrode materials and various defense waste glass compositions. The glass temperatures in these tests ranged from 1200 to $1400^{\circ} \mathrm{C}$.

Development experience with the joule-heated melters has identified the following operational problem areas. Some of these can be completely solved by engineering development while others are unique to the process and will always be present to some extent.

1. The feed must be introduced through a cooled nozzle to prevent feed caking and feed plugging; however, the thermal stresses on the cooled nozzle have caused rupture of the nozzle cooling jacket. 
2. At high feed rates in the LFCM, a liquid pool can partially cover the cold-cap crust. Occasionally the cold-cap crust will crack and very rapid boil off of the accumulated liquid causes a large steam and gas surge in the off-gas system.

3. Several mechanisms can produce a foam-up in the tank of glass that can back up into the lid area and off-gas pipe and force out foam and unmelted crust fragments with the glass stream.

4. It is very difficult to determine the glass inventory, cold cap status, and foam status in the melter because visual observation through ports is hampered by the high temperatures and corrosion caused by the process.

5. Both foaming and ruthenium volatility are minimized if a reducing agent is included with the glass composition. However, reducing agents must be closely controlled or metals will precipitate onto the floor of the melter and possibly short out the electrodes. High-temperature ceramic compounds such as iron spinel may also precipitate as a sludge in the melter. A reducing atmosphere is not permitted if the electrodes are tin oxide, and conversely, an oxidizing atmosphere is not permitted if molybdenum electrodes are used.

6. The overall volatility loss of the $1450^{\circ} \mathrm{C}$ glass was measured at 30 to 100 times the loss of borosilicate glass at $1050^{\circ} \mathrm{C}$ without a cold cap. The volatility loss of each element has not been measured to determine if excessive volatility of a particular glass former or radionuclide will cause a problem. The cold-cap crust is expected to trap most of the metallic volatiles in a refluxing mode. However, whenever feeding must be interrupted, the cold cap will melt, and the hot glass will be exposed to the air atmosphere above the melt, allowing the volatiles to escape to the off-gas system. Operating experience has shown that the metallic volatiles do not totally pass into the off-gas system but instead partially condense in the cooler crevices of the melter insulation. These volatiles can also migrate into and condense inside the installation ports of the auxiliary heaters, leading to contamination of the cell during heater maintenance. Off-gas piping leading from the melter has been plugged with condensed volatiles and entrained dust.

7. Operating experience with nonradioactive development LFCM's has also revealed problems during the pouring operation. Sludge accumulations or large flow perturbations, such as those caused by melter-tilting operations or off-gas pressure fluctuations, can cause off-center pour streams that hit the sides of the discharge face or the sides of the bellows connecting the canister. This can result in glass flow blockages that can cause auxiliary heaters to short out, cause great difficulty in closing the valve in the bellows in the canister connecting section, and cause difficulties in disengaging the canister. View ports to monitor this situation can probably be included both in the melter tank region and the discharge region, but some method of easily cleaning the condensed volatile species from the windows must be developed.

More experience with a LFCM producing simulated HLLW low-alkali glass is required. This experience can be expected to more sharply define the extent to which the above operational problem areas can be accormodated in the design. 
The technology for design and operation of a LFCM for low-alkali glass is available. Insufficient data has been collected to accurately predict the melter life-expectancy. Actual operation of a prototype melter using simulated glass compositions optimized for the NFS wastes will be required before final design of the actual production melter is made. Preventing the radionuclides from volatilizing is forseen as the principal operating problem.

\subsubsection{Safety Considerations}

In this study, the definition of safety includes both public safety and occupational safety. Improved safety is closely related to operational ease, and therefore, many of the safety characteristics are also process characteristics.

The LFCM has been described in the previous section. The primary safety requirement of the LFCM process is to maintain the integrity of the melter enclosure above and below the glass level. Leakage above the glass level, coincidental with a loss of melter vacuum, would result in the release off-gas to the cell atmosphere. Periodic surges in steam rates from the LFCM are a normal mode of operation, and the off-gas system is designed to respond to these surges. However, such operating characteristics place an additional demand on the control system and increase the potential for a melter-cavity pressurization, resulting in off-gas being released to the cell atmosphere. Two hypothetical accident scenarios, a criticality in the glass and a steam explosion caused by water and molten glass interaction were discussed by Buelt and $P$ artain (1980). Although these events are considered hypothetical, they are part of the safety comparison. The introduction of organic materials in the melter feed stream may lead to either rapid burning of the organic materials or volatilization followed by recapture in the off-gas scrubber systems. Under steady-state melter operation, the temperature of the type of the cold cap and the air space above the cold cap is expected to be $300^{\circ} \mathrm{C} \pm 100^{\circ} \mathrm{C}$. Depending on the organic material present, volatilization may be the more likely event. Overall, in comparison to the reference SC/ICM process, the LFCM introduces two new safety concerns (those of the hypothetical accidents). However, the LFCM reduces the overall mechanical complexity by eliminating the spray calciner and by requiring a simpler canister connecting section.

The off-gas system for the LFCM is the same as for the reference process (Appendix A). The LFCM process is not equipped with a dry particulate-decontamination device comparable to the spray calciner filters. As a result, a greater amount of radioactive contaminates will require removal in the LFCM off-gas treatment system. However, both systems can be designed to be equally effective in removing radioactivity. The off-gas system for the LFCM must accommodate a larger range of flow-rate changes as a result of stream surges, but otherwise is considered to have the same safety concerns as the off-gas system for the reference process.

The canister-handling operations for low-alkali glass are very similar to those of the reference process, and the same safety characteristics apply. The canister connecting and disconnecting operation for the LFCM will probably result in less routine cell contamination than will the equivalent operation for the SC/ICM process. This is because the SC/ICM process leaves an unconsolidated residue of calcine at the interface of the connecting section and the canister. This residue may become airborne when the canister is changed. However, the LFCM process may require greater maintenance activity, which may release contamination. The cell 
air-filter requirements should be about the same for both processes. The LFCM will be more difficult to decontaminate at the end of its service and witl be buried with a greater inventory of radionuclides than will the equipment from the SC/ICM process.

\subsubsection{Facility Implementation}

A conceptual layout of the equipment for the low-alkali glass process is shown in Figure 8.11. This is essentially the same layout as proposed for the reference process with the exception that the LFCM takes the place of the SC/ICM. Although not indicated in this layout, it may be necessary to rearrange the equipment modules in order to locate the off-gas module (G) closer to the LFCM.

The feed system for the low-alkali glass process will use the same tanks as proposed for the reference SC/ICM process. However, increased agitation sufficient to ma inta in a homogeneous mixture of the feed and powdered glass frit will be required. The feed slurry will be more abrasive as a result of incorporating the glass-forming frit in the liquid feed. Consequently, interior tank surfaces, agitators, and recirculation loop piping will erode more rapidly.

\subsection{GLASS MARBLES-IN-LEAD MATRIX}

Glass marbles encapsulated in a lead-alloy matrix has been proposed as an alternate waste form that has several advantages over a glass matrix. Metal-matrix encapsulation of nuclear waste can serve: 1) to increase thermal conductivity of the waste form and lower internal
A. CENTRIFUGE SYSTEM
B. GRAVITY SETTLING AND FILTRATION SYSTEM
C. CESIUM ION-EXCHANGE SYSTEM
D. STRONTIUM ION-EXCHANGE SYSTEM
E1. HLIW FEED STORAGE
E2. LFCM
E3. CANISTER-CONNECTION SYSTEM
E4. CANISTER LID-WELDING STATION

E5. CANISTER-DECONTAMINATION STATION

E6. CANISTER-TRANSPORT CART

F. RECYCLE AND SECONDARY EVAPORATION

SYSTEM

G. OFF.GAS TREATMENT SYSTEM

H. DECONTAMINATED SUPERNATE SOLIDIFICATION AND PACKAGING

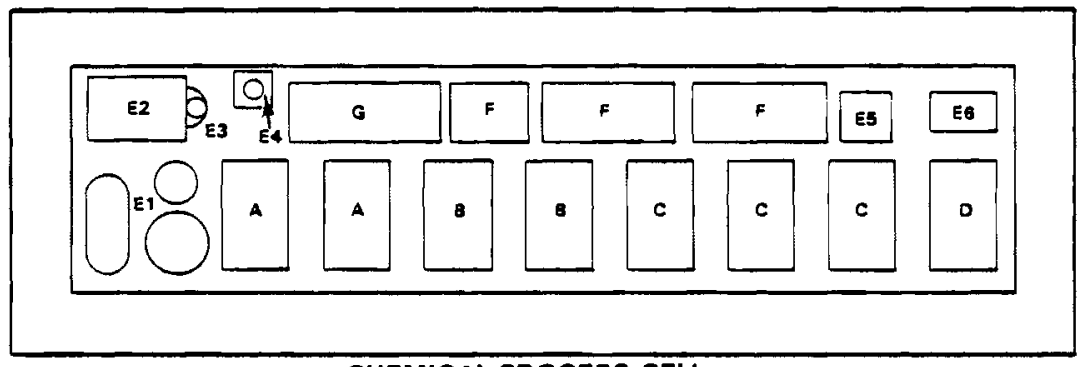

CHEMICAL PROCESS CELL

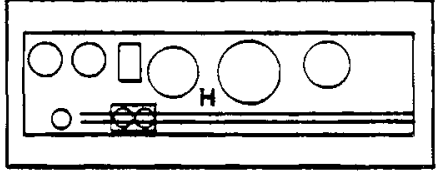

SCRAP REMOVAL CELL

FIGURE 8.11. Facility Layout of the Low-Alkali Glass Process 
temperatures, and 2) to increase the degree of containment by increasing the leach resistance and impact resistance. A ceramic-lined joule-heated melter is used to form glass marbles. A marble-forming machine, a marble transport and storage system, a metal-melting furnace, and other equipment must be added to the process. The resulting canisters are approximately twice as heavy and have about one-half the amount of glass as canisters containing glass monoliths. Other advantages of the marbles-in-lead waste form include the ability to sample the glass product periodically for quality assurance.

\subsubsection{Waste Form Properties}

The marbles-in-lead matrix waste form is composed of borosilicate glass marbles that are typically $1 \mathrm{~cm}$ in diameter and are encapsulated in a lead alloy matrix. The metal alloy is composed of $95 \%$ lead-5\% tin. In general these waste form glass marbles will have a thermal conductivity 9 to 13 times greater than a borosilicate glass (Lokken 1981). The thermal conductivity of glass marbles-in-lead-tin matrix varies from 9.1 to $9.0 \mathrm{~W} / \mathrm{m}^{\circ} \mathrm{K}$ from 40 to $275^{\circ} \mathrm{C}$, and the thermal conductivity of borosilicate glass varies from 0.71 to $0.93 \mathrm{~W} / \mathrm{m}^{\circ} \mathrm{K}$ from 40 to $300^{\circ} \mathrm{C}$. The borosilicate glass marbles have the same glass composition as in the reference process for the alkaline HLLW, but have a lower Thorex waste loading in the Thorex waste glass. The filled marbles-in-lead canister consists of a central annulus containing the marbles and an outer annulus of metal approximately $2.5 \mathrm{~cm}$ thick.

Performance specifications for the borosilicate glass marbles are the same as those given for the reference borosilicate glass monolith. No significant glass/lead interaction is predicted. The performance of lead in various environments is presented in Table 8.11. Properties of lead and lead/tin alloys are given in Table 8.12.

\subsubsection{Process System Description and Material Balance}

A schematic of the marbles-in-lead process is shown in Figure 8.12. A LFCM is used to vitrify the waste. The additional equipment systems required for the marbles-in-lead process are a marble-making machine, a product sorter and scrap recycle system, a canister-fill station and a lead-melting furnace.

The LFCM has been described in the preceding section on low-alkali glass. Design and operational requirements will be significantly reduced because of the lower melting temperature of the borosilicate glass. The required melting rate of $36 \mathrm{~kg} / \mathrm{h}$ has been demonstrated with simulated waste at PNL. Inconel 690 electrodes that have a good life expectancy in a variety of glass compositions can be used. Glass pouring will have to be closely controlled to prevent

TABLE 8.11. Corrosion Rates for Lead in Various Environments

\begin{tabular}{lc}
\multicolumn{1}{c}{ Environment } & Corrosion Rate, m/y \\
Sea water & 12.7 \\
Soil & 0.1 to 3.8 \\
Marine atmosphere & 0.6 \\
Rural atmosphere & 0.5 \\
Industrial atmosphere & 0.4
\end{tabular}


TABLE 8.12. Properties of Lead and a Lead Alloy

\begin{tabular}{|c|c|c|}
\hline Properties & Lead & $95 \%$ Lead $-5 \%$ T in \\
\hline Density, $\mathrm{g} / \mathrm{cm}^{3}$ & $\overline{11.34}$ & 11.0 \\
\hline Melting temperature, ${ }^{\circ} \mathrm{C}$ & 327 & 312 \\
\hline $\begin{array}{l}\text { Thermal conduct ivity, } \\
\mathrm{W} / \mathrm{m}-\mathrm{O} \mathrm{K}\end{array}$ & 34.7 & 35.6 \\
\hline $\begin{array}{l}\text { Therma 1 expansion } \\
\times 10^{-6} / 0^{\circ} \mathrm{C}\end{array}$ & 29.3 & 28.7 \\
\hline $\begin{array}{l}\text { Annea led tensile } \\
\text { strength, ksi }(a)\end{array}$ & 2 & 3.4 \\
\hline Elongation, $\not(a)$ & 40 & 50 \\
\hline Cost, $\$ / 1 b$ & 26 & 49 \\
\hline Relative cost/volume, & 2.8 & 4.0 \\
\hline
\end{tabular}

(a) As cast condition

excessive scrap formation at the marble machine. The melter size, space requirements, and weight are the same as those estimated for the LFCM used to produce low-alkali glass.

The off-gas system for an LFCM used to make glass marbles must have a somewhat higher capacity and permit faster response control than that required in making glass-monolith forms. The increased requirements are necessary to prevent steam surges in the melter from pressurizing the system. Pressure fluctuations in the LFCM will produce undesirable surges in the glass flow to the marble machine, which affects overall process performance. To achieve good control of the off-gas system pressure and to reduce condensation of volatiles from the melter, the scrubbing ejector and condenser must be mounted very close to the melter.

The marble-making machine is based on a design conceived by researchers at the corning Glass Company (U.S. Patent No. 3254979,1966$)$ ). The machine consists of a metal belt of individual aluminum cup-molds that shear the viscous glass stream into gobs and vibrate the glass gobs into a spherical shapes as they cool. For a given glass pouring rate, the length of the belt is dictacted by the type of cooling used and the limitations of the cooling rate imposed by the glass composition. The marble-making machine includes a vented dust enclosure, mechanical drives for the belt, pneumatic vibrators for the cup molds, a scrap sorter, and a scrapcrusher mill. The scrap resulting from very small or very large glass pour rates must be collected, crushed, and transported back to the LFCM for recycling.

The marble-making machine may require more maintenance than many of the other equipment systems because of vibration inherent in the design and the high mechanical complexity. High maintenance should be expected and ease of decontamination should be included in the marble machine design. Preheating and cooling of the molds is carried out with steam. Service connections include: compressed air, steam, water, temperature sensors, and belt speed control. Effluents include off gas, steam condensate, and glass fragments. 


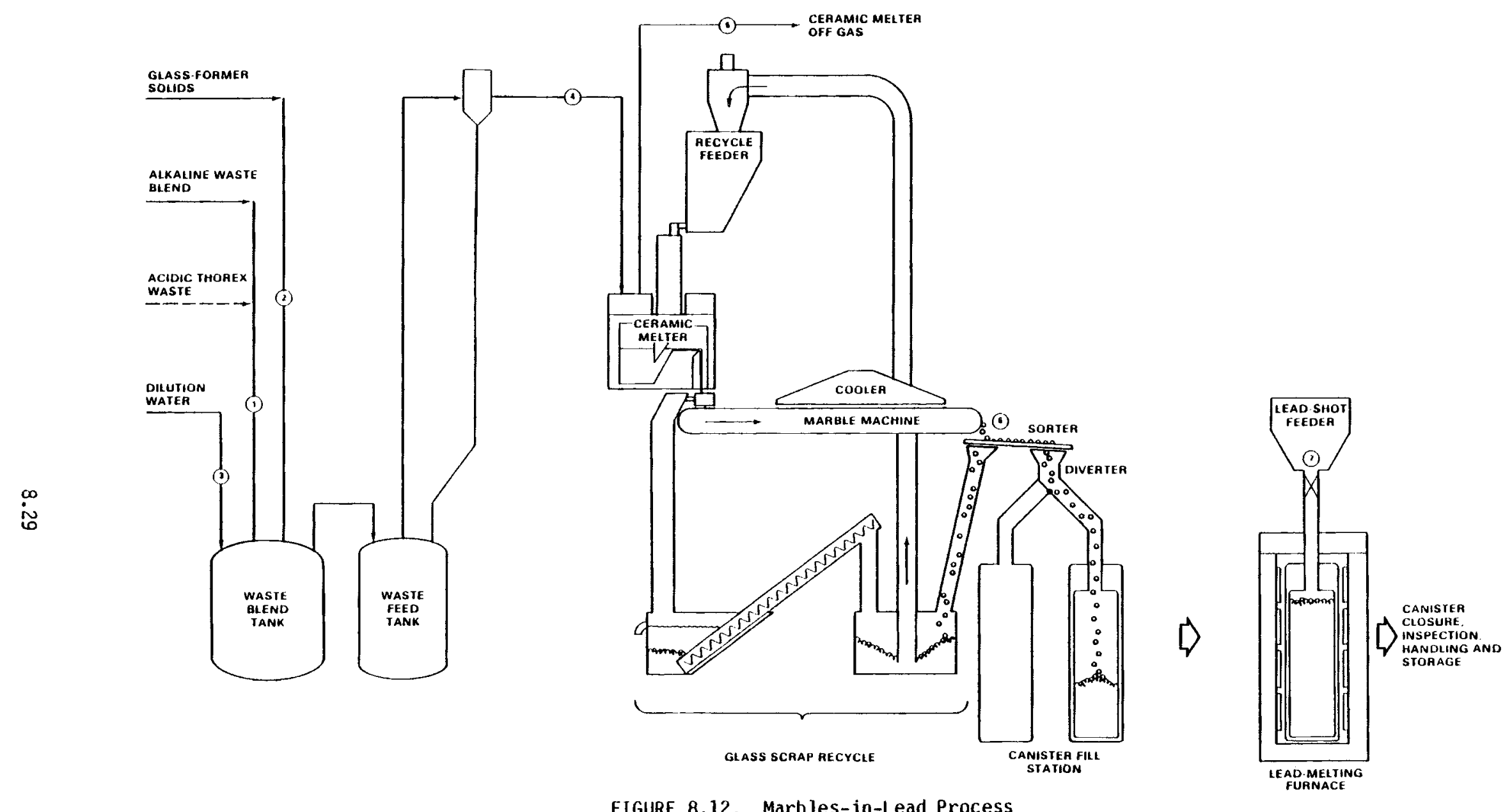

FIGURE 8.12. Marbles-in-Lead Process 
The marbles from the machine are sorted on a vibrating plate to reject shards and broken marbles. The acceptable marbles fall into a hopper that directs the marbles via a deflection nozzle to one of two canisters-loading stations. The canisters are then moved by crane to the metal fill station. The canister changeout requirements for the marbles-in-lead process should be less demanding of equipment and operator interaction than for the equivalent operation in the SC/ICM process or for the LFCM process where glass is poured directly into a canister. The less demanding interaction is because of the lower contamination potential in this step of the marble process.

The canisters for the marbles-in-lead process have the same external dimensions as the reference canisters. Instead of interior fins, a wire-mesh basket is positioned in the canister, leaving approximately a $2.5 \mathrm{~cm}$ annulus between the basket and the canister. This provides a lead barrier around the matrix waste form. The basket must be designed and anchored to withstand the $2300 \mathrm{~kg}$ buoyancy force of the marbles floating in the molten lead. A springloaded lid covering the basket keeps the marbles in the basket (Figure 8.13).

The lead-melting furnace is induction-heated. The canister filled with marbles is heated while the lead shot is introduced to the canister through a delivery pipe that penetrates the cell from a lead-shot staging area. At approximately $400^{\circ} \mathrm{C}$ the lead shot melts and fills the interstices between the marbles. After the canister is filled with molten lead, it must be cooled from the bottom up in a controlled manner to prevent shrinkage voids from forming.

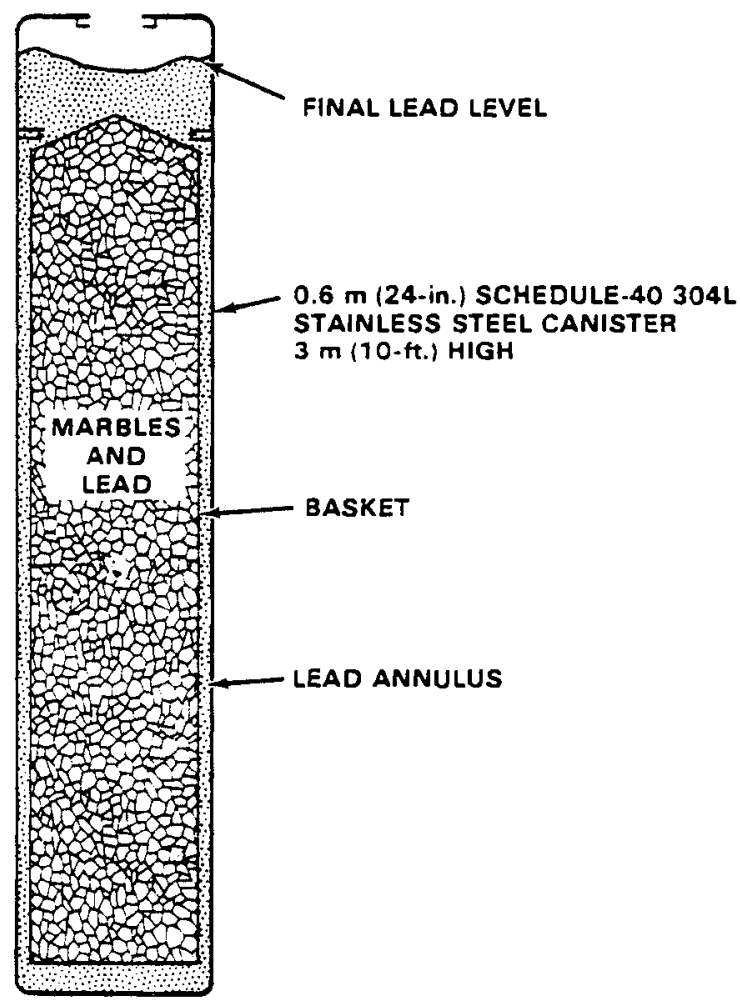

FIGURE 8.13. Schematic of Glass Marbles-in-Lead Matrix Canister 
The service requirements for the lead-melting furnace include $30 \mathrm{~kW}$ of radio frequency power, temperature sensors, on off-gas collection port, weight indication, and a cooling system (water, steam or air). The space requirements for this system are envisioned to be $2 \mathrm{~m} \times 3 \mathrm{~m}$ floor space and $4 \mathrm{~m}$ in height. Weight of the equipment is estimated to be $1000 \mathrm{~kg}$. Overhead clearance must be sufficient to allow canister transport by crane. The remaining canister operations, including lid welding, leak checking, and decontamination are done with the same equipment as specified in the reference process.

Since marbles are produced with a LFCM, the solidification campaign length of the separated alkaline Purex and the acidic Thorex waste have been adjusted to $392 d$ and $265 d$, respectively, to achieve a uniform $36 \mathrm{~kg} / \mathrm{h}$ glass-production rate. The same glass waste loading (25 wt\%) for the separated alkaline waste is used as in the reference process. However, the Thorex waste loading has been reduced from $15 \mathrm{wt} \%$ to $7.5 \mathrm{wt} \%$ ( $5 \mathrm{wt} \%$ thoria) because the 1 imited thoria solubility might cause a buildup of thoria sludge in a joule-heated melter. The process material balances for the separated alkaline waste solidification campaign and the Thorex solidification campaign are presented in Tables 8.13 and 8.14 , respectively. The waste form process sumary is presented in Table 8.15. Each canister will contain $833 \mathrm{~kg}$ of glass and $5720 \mathrm{~kg}$ of lead. A total of 682 canisters will be produced. In addition, there will be 5120 barrels of decontaminated supernate from the salt/sludge separation process campaign.

TABLE 8.13. Process Conditions Material Balance Data for Solidification of Alkaline Waste in a Marbles-in-Lead

\begin{tabular}{|c|c|c|c|c|c|c|c|}
\hline Stream Number (a) & 1 & & & & 5 & 6 & 7 \\
\hline Description & $\begin{array}{c}\text { Alkaliffe) } \\
\text { Waste }\end{array}$ & $\begin{array}{l}\text { Gormer } \\
\text { Former } \\
\text { Solids } \\
\end{array}$ & $\begin{array}{l}\text { reed } \\
\text { Oifution } \\
\text { Water }\end{array}$ & $\begin{array}{c}\text { Meed } \\
\text { Feed } \\
\text { STurry } \\
\end{array}$ & $\begin{array}{l}\text { Melter } \\
\text { Off Gas }\end{array}$ & Glass & $\begin{array}{l}\text { Lead } \\
\text { Shot }\end{array}$ \\
\hline Flow, $\mathrm{kg} / \mathrm{h}$ & & & not required & & & & \\
\hline Salt & 11.9 & & & 11.9 & & & \\
\hline Solids & 0.84 & 25.2 & & 26 & & 36 & 247 \\
\hline $\begin{array}{l}\mathrm{H}_{2} \mathrm{O} \\
\mathrm{Air}\end{array}$ & 155 & & & 155 & $\begin{array}{l}155 \\
20(c)\end{array}$ & & \\
\hline $\mathrm{NO}_{\mathrm{x}}$ & & & & & 16.6 & & \\
\hline Total & 167.7 & 25.2 & & 192.9 & 191.6 & 36 & 247 \\
\hline Flow, L/h & 155 & & & 155 & & 12.8 & \\
\hline Temperature, ${ }^{\circ} \mathrm{C}$ & 35 & & & 35 & 300 & 1100 & 35 \\
\hline Density, $\mathrm{g} / \mathrm{cm}^{3}$ & 1.08 & 2.0 & & 1.24 & & $2.8\left(35^{\circ} \mathrm{C}\right)$ & 11 \\
\hline Activity, Ci/L & 21.6 & & & 21.6 & $16.7(\mathrm{Ci})$ & 260 & \\
\hline Heat, W/L & 0.08 & & & 0.08 & & 0.75 & \\
\hline
\end{tabular}

(a) Stream numbers refer to Figure 8.12.

(b) Based on 393 full-capacity operating days.

(c) Inleakage air. 
TABLE 8.14. Process Conditions and Material Balance Data for Solidification of Acidic Thorex Waste in Marbles-in-Lead

\begin{tabular}{|c|c|c|c|c|c|c|c|}
\hline $\begin{array}{l}\text { Stream Number }(a) \\
\text { Parameters }\end{array}$ & $\begin{array}{l}\frac{1}{\text { Acidic }} \\
\text { Thorex } \\
\text { Waste } \\
\end{array}$ & $\begin{array}{l}\frac{2}{\text { GTass- }} \\
\text { Former } \\
\text { Solids } \\
\end{array}$ & $\frac{3}{\begin{array}{l}\text { Dilution } \\
\text { Water }\end{array}}$ & $\begin{array}{l}4 \\
\text { Melter } \\
\text { Feed } \\
\text { slurry } \\
\end{array}$ & $\begin{array}{l}\frac{5}{\text { Melter }} \\
\text { Off Gas }\end{array}$ & Glass & $\begin{array}{l}7 \\
\text { Lead } \\
\text { Shot }\end{array}$ \\
\hline \multicolumn{8}{|l|}{$\mathrm{Flow}, \mathrm{kg} / \mathrm{h}$} \\
\hline Salt & 6.3 & & & 6.3 & & & \\
\hline Solids & & 33.4 & & 33.4 & & 36 & 247 \\
\hline $\begin{array}{l}\mathrm{H}_{2} \mathrm{O} \\
\mathrm{Air}\end{array}$ & 10.2 & & $61.8^{(c)}$ & 72 & ${ }_{20}^{72}(d)$ & & \\
\hline $\mathrm{NO}_{x}$ & & & & & 2.5 & & \\
\hline Totaî & 16.5 & 33.4 & 61.8 & 111.7 & 94.5 & 36 & 247 \\
\hline Flow, L/h & 10.2 & & & 72 & & 12.8 & \\
\hline Temperature, ${ }^{\circ} \mathrm{C}$ & 35 & & 35 & 35 & 300 & 1100 & 35 \\
\hline Density, $\mathrm{g} / \mathrm{cm}^{3}$ & 1.27 & 3.0 & & 1.6 & & $2.8\left(35^{\circ} \mathrm{C}\right)$ & 11 \\
\hline Activity, Ci/L & 37 & & & 5.6 & & 30 & \\
\hline Heat, W/L & 0.14 & & & 0.01 & & 0.05 & \\
\hline
\end{tabular}

(a) Stream numbers refer to Figure 8.12.

(b) Based on 264 full-capacity operating days

(c) Water required to dilute feed to demonstrated feed concentration (500 q of solids/L).

(d) In leakage air.

TABLE 8.15. Waste Form Product Sumary for Separated Alkaline Waste and Acidic Thorex Waste Solidified Individually in Marbles-in-Lead

\begin{tabular}{|c|c|c|}
\hline Process Characteristic & $\begin{array}{c}\text { Separated } \\
\text { Alkaline } \\
\text { Waste } \\
\end{array}$ & $\begin{array}{c}\text { Acidic } \\
\text { Thorex } \\
H L W \\
\end{array}$ \\
\hline Glass production rate, $\mathrm{kg} / \mathrm{h}$ & 36 & 36 \\
\hline Glass in canister, $\mathrm{kg}$ & 833 & 833 \\
\hline Lead in canister, $\mathrm{kg}$ & 5,720 & 5,720 \\
\hline Number of canisters & 407 & 275 \\
\hline Activity per canister, $\mathrm{Ci}$ & $7.6 \times 10^{4}$ & $8.7 \times 10^{3}$ \\
\hline Decay heat per canister, $W$ & 221 & 24 \\
\hline Low-level salt, number of 55 -gal drums & 5,120 & NA \\
\hline Processing campaign length, $d$ & 392 & 265 \\
\hline
\end{tabular}

\subsubsection{Status of Technology}

The status of technology of the LFCM and associated feed system has been discussed in the preceding low-alkali-glass section. Required development work on the LFCM used for borosilicate glass production will be essentially the same as that reported in the low-alkali glass section. Uncertainties expressed about the use of a LFCM to produce a low-alkali glass with a higher melting temperature do not apply to the borosilicate glass formulation used for glass marbles. 
A marble machine at PNL using water spray cooling has produced marbles at a rate of approximately $60 \mathrm{~kg} / \mathrm{h}$ (Platt and Powell 1980). The marble machine has not been designed with remote operation and maintenance features, but no special problems in this regard are envisioned. However, extended operation under expected conditions should be conducted to gather data on reliability. The marble machine is judged to require the highest maintenance level in the marbles-in-lead process. An alternative to the vibrating cup molds on a belt is a glass stream device that allows puddles of glass to harden into buttons on a rotary cooling disc. With further development work this approach may prove more adaptable to remote operation.

Development experience with the glass marbles-in-lead matrix process has identified the following operational areas. Some of these problems can be solved with engineering development, while others are inherent to the process.

1. Startup and shutdown techniques need to be tested and operational modes developed to optimize speed and rate of pour and to eliminate large globs of slag, small and imperfect glass spheres and glass stringing.

2. A closed loop system for the marble-machine track and molds needs to be developed before pouring radioactive materials. The use of water sprays directed into the hot molds is one method of reducing the inlet mold temperature; however, this method will spread radioactive contamination.

3. Commercial marble-making machines require continual operator surveillance and adjustments. Techniques, procedures, and systems need to be developed so that the marblemaking operation can be monitored, adjusted and kept in continued operation by remote maintenance.

4. A negative-pressure pneumatic system for recycling glass scrap to the melter needs development. Development work is needed to a) explore the operating regimes and control ranges of the transport system, b) optimize design of solids feeder systems to improve solids inertia and acceleration, and c) determine provisions to eliminate operating problems such as jarming.

5. The lead-shot melting furnace is commercially available but will require some modification. The actual canister coupler, lead-shot delivery nozzle, and off-gas Tine will require some development. A prototype system should be demonstrated with sufficient throughput to insure that all design problems have been foreseen.

The marbles-in-lead process requires more canister-movement steps than the glass-monolith processes. Conceptually, canisters will be moved from station-to-station by the $14.5 t$ overhead crane. At each station a turntable may be required to rotate the canister underneath the overhead equipment to permit accurate alignment. These transport stations should be designed and a mock-up made before final design.

\subsubsection{Safety Considerations}

Many of the safety concerns in operating the LFCM process are discussed in the low-alkali glass section. In general, these same safety considerations also exist for the marbles-in-lead process. Additional safety considerations need to be given the glass marble-making equipment and canister-transporting equipment. 
The marble-making machine and associated equipment introduce significantly greater mechanical complexity to the process. This in itself is detrimental to safety because of higher maintenance requirements. Some small glass shards and dust will be generated during the marble forming operation. However, the total contamination released to the cell may be less than that for the reference process (SC/ICM).

The safety concerns of the lead-fill operation center around the stored energy in the molten lead. The specific concern is whether any type of water cooling is permissible during canister cool-down since a steam explosion can occur under some conditions of water contact with molten metal. For this reason it is suggested that forced air cooling be used.

Canister-handling hazards are increased in the marbles-in-lead process because of the increased weight (145\% above reference) of the canister and the increased total number of canisters required because of the reduced glass loading in each. There is little danger in a breach in the marble-in-metal waste form, but handling accidents may damage other process equipment containing waste in a more dispersible form.

The safety parameters describing interim storage of the filled canisters include: handling requirements, decay-heat loading, gas-pressure buildup in the canister, and durability of the waste form. Overall, the glass marbles-in-lead process has better safety parameters than the reference process, with the exception of the need to handle more and heavier can isters.

Release of radioactivity to the environment in operating the marbles-in-lead process is expected to be slightly greater than for the reference process. The marbles-in-lead process will yield more contaminated process equipment for eventual disposal and also some lead effluent to the atmosphere. The long-term (greater than $500 \mathrm{yr}$ ) release of lead to the environment is felt to pose a greater risk than that of the radionuclide release from the glass waste.

\subsubsection{Facility Implementation}

The marbles-in-lead process in the CPC will use approximately the same feed system as specified for the reference process. The LFCM will occupy approximately the same floor space as the SC/ICM, but the height will be less. The marble machine, scrap recovery system, marble sorter, marble-fill station and lead-fill station will all require additional floor space. The lid-welding station and the canister-decontamination stations occupy the same space as identified in the reference process.

A conceptual placement of the additional equipment is indicated in Figure 8.14. The canister filling must be carried out in the CPC because it is the only cell having the required height and a high-capacity crane. This conceptual layout indicates that approximately three modules of the salt/sludge-separation process equipment must be transferred to another cell with in the facility. Tentatively, the cesium ion-exchange system, which occupies three modules in the reference design, is relocated in the PMC. 

A. CENTRIFUGE SYSTEM
B. AGGLOMERATION AND SETTLING SYSTEM
C. CESIUM ION-EXCHANGE SYSTEM
D. STRONTIUM ION-EXCHANGE SYSTEM
E1. HLLW FEED SYSTEM
E2. LFCM
E3. MARBLE MACHINE
E4. SCRAP RECOVERY AND RECYCLE SYSTEM
E5. PNEUMATIC TRANSPORT SYSTEM

E6. MAR 8LE.FILL STATION

E7. LEAD-FILL STATION

E8. LID-WELD STATION

9. CANISTER-DECONTAMINATION STATION

E10. CANISTER TRANSPORT CART

F. RECYCLE AND SECONDARY EVAPORATION SYSTEM

G. OFF.GAS TREATMENT SYSTEM

H. SALT SOLIDIFICATION AND PACKAGING

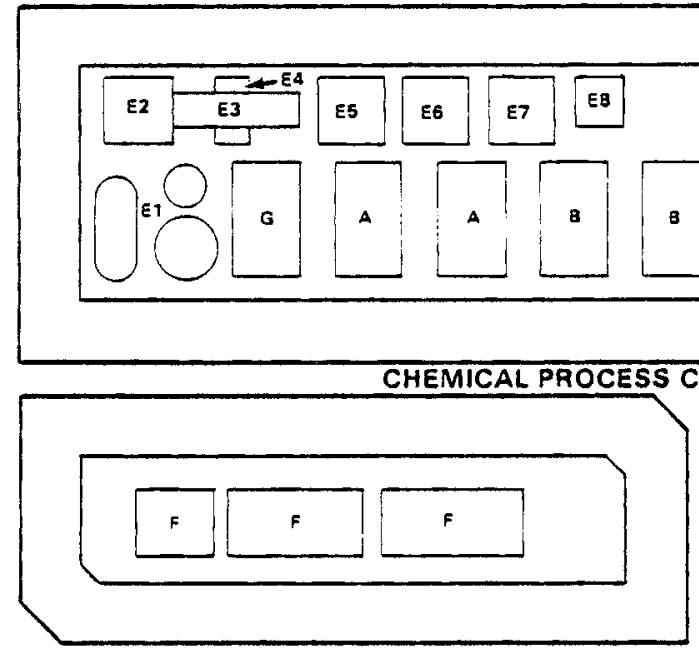

PROCESS MECHANICAL CELL
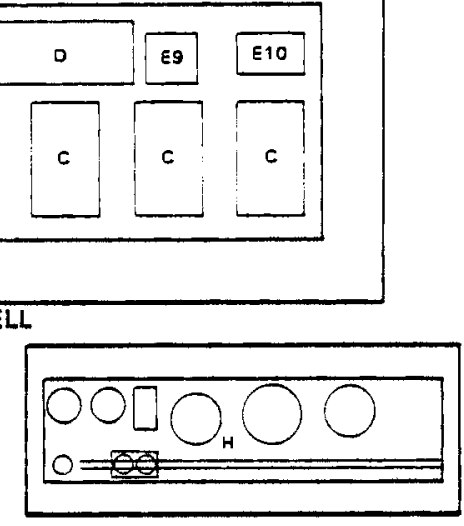

SCRAP REMOVAL CELL

FIGURE 8.14. Facility Layout of Marbles-in-Lead Process

The reference process essentially uses three major cells in the facility; the CPC, the SRR, and the EDR. Altering the PMC to accommodate extra equipment will be more difficult than the use of the above three rooms because of access restrictions. The three rooms designated for the reference process all contain large access doors while the PMC is accessible only through a hatch into the crane room. Moving complete modules into the cell through this access is difficult. It will be necessary to individually move tanks, piping, and ion-exchange columns into the PMC and then assemble these systems in-place. This will be costly both in terms of man-hours and man-rems. Use of the PMC will require decontamination before and after use, along with potential replacement of the existing cranes. Additional shielded piping runs between the PMC and the CPC will be required, along with upgrading or replacement of an off-gas and ventilation system for the PMC.

Finally all processes require a cask-loading facility when the canisters are transferred to an off-site repository. Currently the cask is envisioned as accepting seven reference canisters. The lead matrix may tend to offset the shielding built into the cask. However, in general, a cask loaded with glass monoliths may weigh 50 tons while the cask containing marbles-in-lead may weigh 80 tons. The cask-handling facility must be capable of handling the larger loads.

\subsection{CRYSTALLINE CERAMIC}

Crystalline ceramics appear to have several advantages when compared to the reference process; however, this waste form is only in the conceptual stage of development. Furthermore, 
there are some distinct disadvantages when considering crystalline ceramics for use at WNYNSC. Some of the advantages and disadvantages are highlighted in the next two paragraphs.

Crystalline ceramics are generally considered more thermodynamically stable than glass. Several investigators have proposed incorporating the HLLW into crystalline ceramics. By virtue of the additives to the HLLW, an assemblage of host crystalline forms can be prepared that will accept most of the diverse radionuclides present in HLLW. Generally a higher waste loading can be obtained with crystalline ceramics than with glass waste forms. The leach resistance of the crystalline ceramics is reportediy superior to that of borosilicate glass.

On the other hand, the process for blending HLLW with the additives and for making the crystalline mineral forms at high-temperature and pressure is more complex than the glassproduction process. The process described below is based on concepts developed on the laboratory scale. The process incorporates one uniaxial hot press. As a result, the operating campaign is extended to nine years. It would require a significantly larger facility and additional and more complex equipment to complete a three-year solidification campaign.

\subsubsection{Waste Form Properties}

The waste form for the separated salt/sludge alkaline waste is made by hot-pressing a group of crystals into a cylinder $0.5 \mathrm{~m}$ in dia by $0.3 \mathrm{~m}$ long. This crystalline cylinder has a density of approximately $4 \mathrm{~g} / \mathrm{cm}^{3}$ and weighs $235 \mathrm{~kg}$. Nine of these crystalline cylinders are loaded into a stainiess steel canister.

The principal mineral forms in the crystalline-cylinder waste form that incorporates the alkaline waste may include perovskite, zirconolite, nepheline, magnetoplumbite, and some monazite. The alakline waste is incorporated into these and other minerals with an average loading of $50 \mathrm{wt \%}$ on an oxide basis. The ceramic waste form proposed for this study is a generic representation of several specific approaches; therefore, a specific proportion for the individual mineral species is not given. However, for the acidic Thorex waste, the mineral assemblage will incorporate the waste with a 70 wt\% loading consisting primarily of monazite, but with some zirconolite, perovskite, and hollandite.

General performance data on crystaliine materials, including supercalcine pellets, SYNROC, and tailored ceramics, is compiled in Table 8.16. The ceramic waste form proposed in this study is considered to have similar performance specifications.

\subsubsection{Process System Description and Material Balance}

The process for producing a crystaliine ceramic uses essentially the same equipment as the reference solidification process described in Appendix $A$. The solidification process requires spray calcining the HLLW as well as many powder and solids-handling steps before the final hotpressing into a cylindrical waste form.

Preliminary equipment capacity and space limitations dictated that the crystalline-ceramic process be conducted in a nine-year solidification campaign. Due to the nine-year campaign, the salt/sludge separation process need only operate at approximately a third of the production rate required for the reference waste form. The lower processing rate can be expected to result in some process simplification and a scale-down of equipment capacities for this part of the process. 
TABLE 8.16. Performance Data on Crystalline-Ceramic Waste Forms

\begin{tabular}{|c|c|c|c|c|}
\hline Waste Forms & $\begin{array}{c}\text { Leach Resistance } \\
\mathrm{g} / \mathrm{Cm}^{2}-d\end{array}$ & Impact Resistance & Fire Resistance & $\begin{array}{l}\text { Radiation } \\
\text { Stability } \\
\end{array}$ \\
\hline Supercalcine & $\begin{array}{l}\text { Na } 25 \\
\text { Si } 7 \\
\text { Sr } 0.3 \\
\text { Cs } 0.7(c)\end{array}$ & $\begin{array}{l}4.4 \text { wt\% of fragments } \\
\text { are less than } 37 \mathrm{~m} \\
\text { diameter }(\mathrm{a}) \\
4155 \text { psi diametral } \\
\text { compressjve } \\
\text { strength }(\mathrm{c}) \text {. }\end{array}$ & $\begin{array}{l}\text { Volatility is approx- } \\
\text { imately } 3 \text { to } 30 \text { times } \\
\text { less than } 72-68 \\
\text { glass }(a) \text {. }\end{array}$ & $\begin{array}{l}\text { Some degradatio } \\
\text { of crystal } \\
\text { phases }(a) \text {. }\end{array}$ \\
\hline SYNROC & $\begin{array}{l}10^{-1} \text { of } \\
\text { borosj licate } \\
\text { glass }(\mathrm{b}) \\
1 \text { to } 10^{-3} \mathrm{~g}(\mathrm{~m}) \\
\text { glass } / \mathrm{m}^{2}-\mathrm{d}(\mathrm{e})\end{array}$ & $\begin{array}{l}\text { Quantitative data not } \\
\text { reported; fractures } \\
\text { with very low yield } \\
\text { of small particulates. }\end{array}$ & $\begin{array}{l}\text { Matrix material is } \\
\text { resistant to high } \\
\text { temperatures. }\end{array}$ & $\begin{array}{l}\text { Less than } 2 \text { vol } \\
\text { increase. }\end{array}$ \\
\hline $\begin{array}{l}\text { Tailored } \\
\text { Ceramics }\end{array}$ & $\begin{array}{l}\text { (Leach rates } \\
\text { Compared to } \\
76-68 \text { glass) }(4) \\
\mathrm{Na} 10^{-1} \\
\text { Cs } 10^{-1} \\
\text { Sr } 10^{-2} \\
\text { Ru } 10^{-1} \text { to } 10^{-3} \\
\mathrm{Fe} 10^{-1} \text { to } 10^{-3}\end{array}$ & $\begin{array}{l}\text { Quantitative data not } \\
\text { reported; fractures } \\
\text { with very low yield } \\
\text { of small particulates. }\end{array}$ & $\begin{array}{l}\text { Matrix material is } \\
\text { resistant to high } \\
\text { temperature. }\end{array}$ & Not available \\
\hline
\end{tabular}

\footnotetext{
(a) Rusin, Gray and Wald (1979).

(b) Schulz et al. (1980).

(c) Wald et al. (1980).

(d) Harker et al. (1980).

(e) Coles and 8 azan (1980).
}

A conceptual process for forming a small monolith of crystalline-ceramic waste form material is shown in Figure 8.15. The alkaline waste blend resulting from salt/sludge separation is spray calcined. Additives required to form the desired mineral assemblage are fed into the bottom of the calciner, much in the same way frit is added in the SC/ICM process. An alternate approach is to add crystal-forming additives to the HLLW feed to the spray calciner. This will increase the capacity requirements for the calciner, however. The output of the spray calciner falls into a stirred vertical calciner/roaster where final decomposition of any salts takes place as well as providing the initial mixing of HLW calcine and mineral-forming additives. A screw-fed cooler receives the powder from the vertical calciner and delivers it to a closed pneumatic-transport system through an airlock valve.

The pneumatic-transport system uses a cyclone dust separator and sintered metal filter candles to de-entrain the HLLW powder. The powder is fed through an airlock in the bottom of the cyclone separator to a ball mill where the calcine powder and the additives are ground and mixed. It is unknown if this approach will result in adequate particle grinding and mixing to enable the desired crystalline materials to form during uniaxial hot-pressing. Adding crystalforming additives to the HLLW feed for spray calcination may enhance crystal forming, however. The powder is pneumatically vacuumed from the ball mill through a size classifier by the process off-gas system. The powder that is sufficiently fine to pass the classifier is de-entrained by another high-efficiency dust separator. The small residual dust still entrained in the off- 


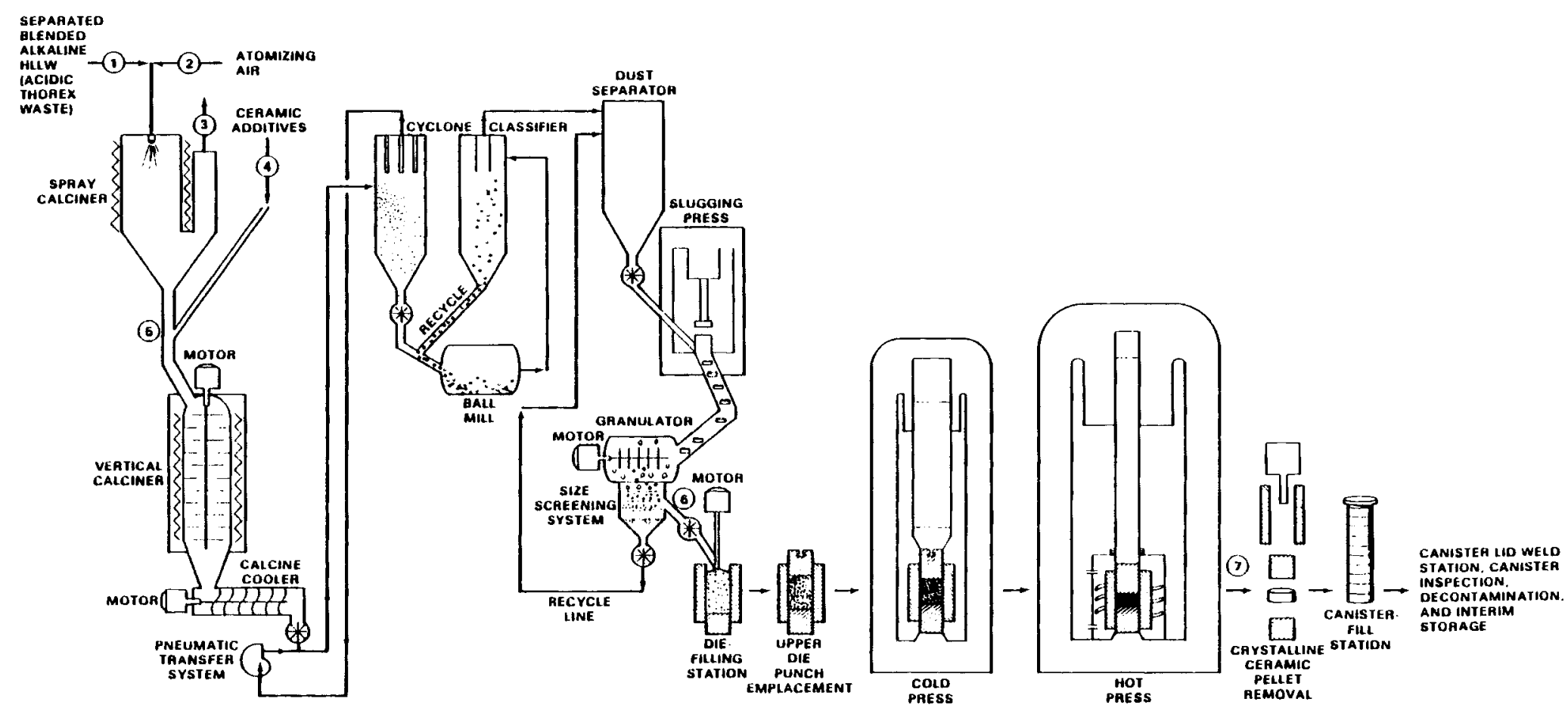

FIGURE 8.15. Schenatic of the Crystalline-Ceramic Process 
gas is scrubbed out in the off-gas treatment system and recycled as spray calciner feed. The main powder stream is fed through an airlock into a slugging press that makes pellets from the powder. These pellets fall into a granulator where the pellets are broken up and sized. Small fines are recycled as feed to the slugging press. Properly sized granules are loaded into a graphite die. The granules in the graphite die undergo a preliminary compaction in a cold press. Following that, the graphite die is loaded into the hot-uniaxial press where final compaction at a temperature of $1300^{\circ} \mathrm{C}$ forms the mineral assemblage. The graphite die is loaded into a ram press that pushes out the die punches and the waste form small monolith. Nine of these billets $(0.5 \mathrm{~m} 0.0$. by $0.3 \mathrm{~m}$ in length) are loaded into a canister that is then sealed, leak tested, decontaminated and moved to onsite interim storage.

Each of the major pieces of equipment and processes are discussed in more detail below. of interest for comparative purposes is the process complexity, control sensitivity, maintenance requirements, safety of operation, status of technology, service requirements, and space requirements for each major piece of equipment.

Spray Calciner feed System. The spray calciner feed system must have the capacity to hold a batch of alkaline waste with fixed proportions of silver mordenite, silica gel, zeolite and filter sand from the waste separation process. The crystalline ceramic is not as tolerant of changes in the composition of the HLLW blend as is glass, and hence, radioactive side streams must be carefully blended with the HLLW to ensure adequate quality in the final hot-pressed waste form. The flowsheet system is designed for treatment of alkaline sludge over approximately an eight year period. It is proposed that a large surge tank be used to contain the periodic batches of spent silver mordenite, sand, and zeolite. If these materials are changed out annually, a 40,000 L tank would be required to hold this material and the residual heel from the previous batch. The solid materials may require wet grinding/milling before loading into this tank to ensure suspension. Two smaller surge tanks, of perhaps $2000 \mathrm{~L}$ capacity each, would be required to hold $C S$ and $S r$ eluates and spent silica gel. These two tanks are required to provide time for sampling and chemical adjustment. The feed to the spray calciner would consist of proportionate feeds from one of the alkaline separated sludge tanks, one of the eluate/silica gel tanks, and the 40,000 L tank. This may best be accomplished by feeding the different streams at the proper rates to a single feed tank used to supply the spray calciner. This tank would continuously receive feed and discharge feed.

Spray Calciner. The spray calciner is capable of operating at an average rate of $53 \mathrm{~L} / \mathrm{h}$. This suggests a calciner with a barrel diameter of about $60 \mathrm{~cm}$. Off gases pass through sintered metal filters and are decontaminated in a scrubber system. The scrubber slurry is evaporated and recycled. The calcine temperature at the calciner discharge port is about $350^{\circ} \mathrm{C}$. Air is used to atomize the liquid feed to the calciner and to blow-back filters, and vibrators are used to dislodge calcine from the calciner walls.

Ceramic-Forming Additives. Various ceramic forming additives, including $\mathrm{SiO}_{2}, \mathrm{CaO}$, $\mathrm{Al}_{2} \mathrm{O}_{3}, \mathrm{ZrO}_{2}, \mathrm{TiO}_{2}$, and $\mathrm{NiO}$ are added in the oxide form at a rate proportionate to the oxide feed rate of the high-level waste to the spray calciner. For some crystalline formulations powdered nickel, iron or titanium is also added. These materials are added from outside the cell through a double air lock. These materials could be heated to relieve some of the heating 
load from the vertical caiciner. Ceramic-forming additives and the sidestream species, such as zeolite, sand, etc., comprise about $50 \%$ of the weight of the final waste form on an oxide basis for the separated salt/sludge alkaline waste. Additives (including phosphorous oxide added as phosphoric acid) comprise $30 \%$ of the final waste form for Thorex wastes.

Vertical Calciner. The vertical calciner raises the temperature of the waste/additives mixture from about $350^{\circ} \mathrm{C}$ to about $900^{\circ} \mathrm{C}$. The heated section of the calciner is about $0.18 \mathrm{~m}$. The design is similar to that employed in the vertical-sintering kiln concept developed by Exxon at INEL. A motor is employed to ensure movement of the calcine through the calciner. The calcine falls into a calcine cooler.

Calcine cooler. A small cooler is used to reduce the temperature of the calcine from $900^{\circ} \mathrm{C}$ to about $50^{\circ} \mathrm{C}$. Calcine is moved to the water-jacketed cooler via a motor-powered auger. A rotary airlock is positioned between the cooler and a pneumatic transfer system to isolate air flows between the calcining system and the transfer system. The cooler is about $15 \mathrm{~cm}$ in diameter and $120 \mathrm{~cm}$ in length.

Pneumatic Transfer System. A pneumatic transfer system is used to elevate calcine about $8 \mathrm{~m}$ to a cyclone.

Cyclone. A cyclone and filter assembly is used to separate air and calcine from the pneumatic transfer system. The filters, located above the cyclone, can be blown back with air. A rotary air lock is located beneath the cyclone to provide air-flow isolation.

Ball Mill. Powder is continuously fed to the ball mill. Alumina or zirconia balls are used since they are compatible with the product. Steel balls can also be used if iron powder can be tolerated in the product. The ball mill is operated under a vacuum, which permits the continuous withdrawal of finely ground powder.

Classifier. Powders drawn from the ball mill are continuously classified. Coarse powders are returned to the ball mill for further grinding.

Dust Separator. Fine powders are separated from the ball-mill discharge using a highefficiency dust separator. Air discharged from the dust separator is scrubbed in the spray calciner off-gas cleanup system. A rotary airlock is used to provide air-flow isolation.

Slugging Press. A hydraulic press produces pellets at a rate of $6.3 \mathrm{~kg} / \mathrm{h}$. Assuming that pellets $1 \mathrm{~cm}$ thick and $7.6 \mathrm{~cm}$ in dia are made with a density of $2.59 \mathrm{~g} / \mathrm{cm}^{3}$, approximately 1 pellet is produced each minute. The press is totally enclosed and fitted for remote vacuum cleaning, with dust discharged to the spray calciner off-gas scrubber system. Other than the pressing mechanism, at least one other moving part is required to eject the pellets. The hydraulic system is contained outside the cell. Provisions for replacing degraded hydraulic fluid are included. Pressing occurs at about 20,000 psi.

Granulator. Slugged pellets fall into a granulator where they are ground into particles less than $2 \mathrm{~mm}$ in dia. A motor is required to power the granulator.

Screening System. Particles from the granulator fall by gravity into a screening system where three fractions are produced. The "overs" fraction consists of particles $2 \mathrm{~mm}$ in dia and 
over. Normally there is no "overs" fraction, but when "overs" are produced, they are recycled manually. The "fines" fraction is recycled to the slugging press. The "accepts" fraction is fed, via a star feeder, to a die and punch assembly.

Die-filling System. A graphite die, $1.2 \mathrm{~m}$ long and $0.5 \mathrm{~m} \mathrm{ID,} \mathrm{with} \mathrm{a} \mathrm{bottom} \mathrm{punch} \mathrm{is} \mathrm{fil-}$ led to a height of $0.9 \mathrm{~m}$ with granulated material. A rotating paddle situated $15 \mathrm{~cm}$ below the top of the die spreads the material evenly in the die and senses when the die is full. When full, the die and punch assembly is lowered and transferred to another station where an upper punch is emplaced. Total fill cycle is $37 \mathrm{~h}$, assuming a $1.33 \mathrm{~g} / \mathrm{cm}^{3}$ material bulk density. Some surge capacity exists in the filling system.

Upper Punch Emplacement. An upper graphite punch is emplaced on the filled assembly. The completed assembly is transferred to a cold-pressing operation. cycle time is one hour.

Cold-Pressing. The filled assembly is pressed with a large hydraulic cold press. Pressing pressure is about $10,000 \mathrm{psi}$. The material is pressed to a density of $2.5 \mathrm{~g} / \mathrm{cm}^{3}$. As with the slugging press, the hydraulic feed system is located outside the cell. After pressing, the assembly is transferred to a hot-pressing operation. Cold-pressing cycle time is one hour

Hot-Pressing. The assembly is hot pressed using induction heating with the die as the susceptor. Pressing temperature and pressure is $1300^{\circ} \mathrm{C}$ and $15,000 \mathrm{psi}$, respectively. The graphite die and punches must be protected against oxidation, and hence, expendable graphite wool and argon-gas purges are used. The final material density is $4.0 \mathrm{~g} / \mathrm{cm}^{3}$. Total cycle time is 37 hours.

Die/Punch/Pellet Separation. This separation requires another hydraulic press. The coldpress may be adaptable to perform the cold-pressing as well as the pellet-separation operations. The assembly is placed horizontally on a table where a hydraulic ram ejects both the punches and the pellet. The pellet is transferred to the canister-loading station. The punches are dipped in a graphite slurry to build up worn surfaces and set aside to dry. When dry, the lower punch is reinserted hydraulically and the assembly moved to the die-filling station. The work cycle time is 3 hours.

Canister filling. Nine pellets, each weighing $235 \mathrm{~kg}$ are loaded into a $51 \mathrm{~cm}$ in dia canister using a hydraulic ram to load all the pellets at once. Frequency of this operation is once every two weeks.

The process material balance is based on a nine year campaign for solidifying both the alkaline Purex waste and the acidic Thorex waste. The process flowsheet for solidification of the alkaline Purex waste is given in Table 8.17 . The ceramic production rate of $6.3 \mathrm{~kg} / \mathrm{h}$ is governed by the decision to install only one, uniaxial hot press in the new facility. Production rates may be increased with more hot presses and by increasing the capacity of the other operations if such action does not exceed a reasonable crane utilization rate.

The process flowsheet for solidification of the acidic Thorex waste is given in Table 8.18 . The same production rate is specified for this campaign since the uniaxial hot press is the limiting piece of equipment. 
TABLE 8.17. Process Conditions and Material Balance Data for Solidification of Alkaline Waste in a Crystalline-Ceramic Waste Form

\begin{tabular}{|c|c|c|c|c|}
\hline Stream Number ${ }^{(d)}$ & 1 & 2 & 3 & 4 \\
\hline Parameters & $\begin{array}{l}\text { Alkaline } \\
\text { Waste }\end{array}$ & $\begin{array}{l}\text { Atomizing } \\
\text { Air } \\
\end{array}$ & $\begin{array}{l}\text { Spray } \\
\text { Calciner } \\
\text { Off Gas }\end{array}$ & $\begin{array}{l}\text { Ceramic } \\
\text { Add it ive } \\
\end{array}$ \\
\hline $\mathrm{Flow} \mathrm{kg} / \mathrm{h}$ & & & & \\
\hline Salt & 2.6 & & & \\
\hline Solids & 0.2 & & & 2.52 \\
\hline $\mathrm{H}_{2} \mathrm{O}$ & 33.4 & & 33.4 & \\
\hline Air & & 16 & 16 & \\
\hline${ }^{N 0}{ }_{x}$ & & & 0.77 & \\
\hline Total & 36.3 & 16 & 50.2 & \\
\hline Flow, L/h & 33.4 & & & \\
\hline Temperature, ${ }^{\circ} \mathrm{C}$ & 35 & 30 & 300 & \\
\hline Density, $\mathrm{g} / \mathrm{cm}^{3}$ & 1.09 & & & \\
\hline Activity, $\mathrm{Ci} / \mathrm{L}$ & 21.6 & & $(0.7 \mathrm{C} i)$ & \\
\hline Heat, W/L & 0.14 & & & \\
\hline $\begin{array}{l}\text { (a) Based on } 1816 \\
\text { (b) Bulk powder d } \\
\text { (c) Bulk density } \\
\text { (d) Stream number }\end{array}$ & $\begin{array}{l}\text { full-capacit } \\
\text { ensity, total } \\
\text { of granules. } \\
\text { s refer to } F i\end{array}$ & $\begin{array}{l}\text { operating } \\
\text { density is } \\
\text { ures } 8.15 \text {. }\end{array}$ & $\begin{array}{l}\text { days. } \\
\text { approxima }\end{array}$ & y $4 \mathrm{~g} / \mathrm{cm}^{3}$. \\
\hline
\end{tabular}

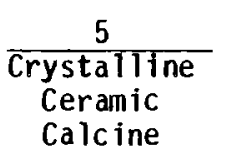

Feeds tock

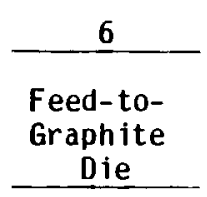

\begin{tabular}{c}
$\frac{7}{\text { Small Monoliths }} \begin{array}{c}\text { of Crystalline } \\
\text { Ceramic }\end{array}$ \\
\hline
\end{tabular}

6.3

6.3

6.3

$(275 \mathrm{~kg})$

400

$1.2^{(b)}$

35

$(113 \mathrm{Ci} / \mathrm{kg})$

$(0.033 \mathrm{~W} / \mathrm{kg})$
6.3

$(275 \mathrm{~kg})$
$(37.3 \mathrm{~h} / \mathrm{monolith})$

1300

$1.33^{(\mathrm{c})} 4$

$(113 \mathrm{Ci} / \mathrm{kg}) \quad(26,555 \mathrm{Ci})$

$(0.33 \mathrm{~W} / \mathrm{kg}) \quad(91 \mathrm{~W})$

b) Bulk powder density, total density is approximately $4 \mathrm{~g} / \mathrm{cm}^{3}$.

(d) Stream numbers refer to Figures 8.15. 
TABLE 8.18. Process Conditions and Material Balance Data for Solidification of Acidic Thorex Waste in a Crystalline-Ceranic Waste Form

\begin{tabular}{|c|c|c|c|c|c|c|c|}
\hline \multirow[t]{2}{*}{ Stream Number } & 1 & 2 & 3 & 4 & \multirow{2}{*}{$\begin{array}{l}\frac{5}{\text { Crystalitine- }} \\
\text { Ceramic } \\
\text { Calcine } \\
\text { Feedstock } \\
\end{array}$} & \multirow{2}{*}{$\begin{array}{c}6 \\
\begin{array}{c}\text { Feed to } \\
\text { Graphite } \\
\text { Die }\end{array} \\
\end{array}$} & \multirow{2}{*}{$\begin{array}{l}7 \\
\begin{array}{c}\text { Small Monoliths } \\
\text { of Crystalline } \\
\text { Ceramic }\end{array} \\
\end{array}$} \\
\hline & $\begin{array}{l}\text { Acidic } \\
\text { Thorex } \\
\text { Waste }\end{array}$ & $\begin{array}{l}\text { Atomizing } \\
\text { Air } \\
\end{array}$ & $\begin{array}{l}\text { Spray } \\
\text { Calciner } \\
\text { Off Gas }\end{array}$ & $\begin{array}{c}\text { Ceramic } \\
\text { Additives }\end{array}$ & & & \\
\hline \multicolumn{8}{|l|}{ Flow, $\mathrm{kg} / \mathrm{h}$} \\
\hline Salt & 10.0 & & & & & & \\
\hline Solids & & & & 1.89 & 6.3 & 6.3 & $(275 \mathrm{~kg})$ \\
\hline $\mathrm{H}_{2} \mathrm{O}$ & 16.2 & & 16.2 & & & & \\
\hline Air & & 7.8 & 7.8 & & & & \\
\hline${ }^{N 0}{ }_{x}$ & & & 3.9 & & & & \\
\hline Total & 26.2 & 7.8 & 27.9 & & 6.3 & 6.3 & $(275 \mathrm{~kg})$ \\
\hline Flow, L/h & 16.2 & & & & & & (37.3 h/monolith) \\
\hline Temperature, ${ }^{\circ} \mathrm{C}$ & 35 & & & & 400 & 35 & 1300 \\
\hline Density, $\mathrm{g} / \mathrm{cm}^{3}$ & 1.27 & & & & $1.2^{(b)}$ & $1.33^{(c)}$ & 4 \\
\hline Activity, $\mathrm{Ci} / \mathrm{L}$ & 37 & & $(0.6 \mathrm{Ci})$ & & $(105 \mathrm{Ci} / \mathrm{kg})$ & $(105 \mathrm{Ci} / \mathrm{kg})$ & $(24,100 \mathrm{Ci})$ \\
\hline Heat, W/L & 0.14 & & & & $(0.27 \mathrm{~W} / \mathrm{kg})$ & $(0.27 \mathrm{~W} / \mathrm{kg})$ & $(62 W)$ \\
\hline
\end{tabular}

\footnotetext{
(a) Based on 167 full-capacity operating days.

(b) Bulk powder density, total density is approximately $4 \mathrm{~g} / \mathrm{cm}^{3}$.

(c) Bulk density of granules.

(d) Stream numbers refer to Figure 8.15 .
} 
As shown in the waste form process summary presented in Table 8.19, a total of 121 canisters are produced by solidifying both separated salt/sludge alkaline waste and the acidic Thorex waste. In addition 5120 barrels of decontaminated supernate are produced during the solidification of the separated salt/sludge alkaline waste. The canister diameter for the crystalline ceramic is $0.52 \mathrm{~m}$ versus the $0.61 \mathrm{~m}$ in dia used for glass waste forms. The height is the same, however.

\subsubsection{Status of Technology}

There have been four principal approaches to incorporation of HLLW in a polycrystalline form. Supercalcine (McCarthy 1977) incorporated the radionuclides into specific crystalline phases or contained the radionuclides in a solid solution within the host crystalline lattice. The host crystalline structures include: pollucite, apatite, monozile, scheelite, sodalite, fluorite, tetragonal-zirconia, and spinel (Rusin et al. 1978). McCarthy (1979) proposed specific supercalcine formulations compatible with the Savannah River Plant sludges. The supercalcine development evolved into tailored ceramic research. The status of technology is currently a better understanding of the mineralogy and waste element distribution (Harker, et al. 1980; Roy, et al. 1980) and the preliminary process design (Treat, et al. 1980). The titanate process design by Sandia Laboratory (Dosch 1980) uses an ion-exchange process for capturing the radionuclides on a sodium or calcium titanate bed. The loaded bed can be calcined and then hot pressed to achieve a titanate mineral ceramic consisting of: rutile, zirconolite, perorskite, metallic solid solutions, and a hollandite-type structure (Dosch, Hlara and Headley 1980). The SYNROC concept (Ringwood et al. 1979) is a tailored ceramic based on titanate mineral analogs to naturally occurring minerals. Current efforts in the SYNROC field include tailoring the ceramics to defense waste and better characterization and process development (Ringwood, Reese, and Tewhey 1980; Newkirk, et al. 1980). A processing approach to SYNROC, and one that is applicable to tailored ceramics in general, is the SOL-GEL process being developed at ORNL for application to nuclear waste solidification (Angelini et al. 1980).

The process layout presented in this section is based on a generalized tailored ceramic. The steps in mixing waste and additives and the steps in precompaction and final hot-pressing

TABLE 8.19. Waste Form Product Sumary for Separated Alkaline Waste and Acidic Thorex Waste Solidified Individually in Crystalline Ceramic

\begin{tabular}{|c|c|c|}
\hline & Separated & Acidic \\
\hline Process Characteristics & Alkaline Waste & Thorex Waste \\
\hline Crystalline ceramic production rate, $\mathrm{kg} / \mathrm{h}$ & 6.3 & 6.3 \\
\hline Crystalline ceramic in canister, $\mathrm{kg}$ & 2,475 & 2,475 \\
\hline Waste loading, wt\% & 50 & 70 \\
\hline Number of canisters & 111 & 10 \\
\hline Activity per canister, $\mathrm{Ci}$ & $2.8 \times 10^{5}$ & $2.4 \times 10^{6}$ \\
\hline Decay heat per canister, $W$ & 820 & 670 \\
\hline Low-level salt, number of $55-g a 1$ drums & 5,120 & NA \\
\hline Processing campaign length, $d$ & 1,816 & 167 \\
\hline
\end{tabular}


needed in the laboratory for consistently preparing a high-density ceramic form have been translated into a mechanical process flowsheet. Essentially all process steps will require development and verification on the plant scale.

\subsubsection{Safety Considerations}

The quantity of radioactive material held in any one piece of equipment in the crystallineceramic process is very low. For example, there is no tank of waste glass as there is in a melter. However, this advantage is offset by the highly dispersable, powdery state of the waste form through the majority of the process stages. The process treatment of the calcine powder is continuous and is enclosed within piping and process vessels up to the point where the granules are loaded into a graphite die for hot pressing. The granules are much less dispersible than the powder. The pneumatic powder-transport systems have the inherent ability to disperse the powder to the cell should a breach of the piping occur. However, there is no significant source of stored dispersive energy in the system that could breach the cell containment. There are many motor-driven stages in the process, however, and some calcine leakage can be expected around the seals despite negative atmospheres. Also the complexity of the equipment will make decontamination difficult. The high maintenance expected from rotating equipment that handles the solids will increase personnel exposure and contribute to contamination release to the cell. The maintenance and operating requirements of this process will require design of a new facility to house this equipment. The new facility will have superior remote maintenance and decontamination support, such as a greater number of power manipulators, TV cameras, and remote-maintenance repair cells. The facility will also be designed so that only the piston, anvil and yoke of the presses are located in the cell. The hydraulic and control equipment is located in a shielded facility above or below the radioactive process cell.

Overall this process should have not experienced any explosive or high-pressure incidents that might damage the cell or the off-gas system. However, the complexity of the powderhandling equipment is expected to lead to a long-term buildup of contamination in the cell. Extra reliability will need to be built into the process and the cell off-gas systems to prevent radionuclide release from the facility.

\subsubsection{Facility Implementation}

The CPC will be used for HLLW storage and the separation processes for the alkaline waste. The blended alkaline waste will be pumped through a multi-barrier pipe to the adjacent new facility that houses the crystalline ceramic process equipment. A conceptual layout of the processing cell in the new facility is shown in Figure 8.16 .

A new facility is required because the CPC is almost completely filled with the salt/sludge separation equipment. It is not practical to install and maintain the process equipment in the PMC or GPC because of the very limited access to these cells. In addition, the hydraulic presses are too massive to be installed in these cells. The need to isolate the hydraulics and controls of the hydraulic presses from the process cell and the need for a high degree of visibility and manipulation to operate hydraulic presses require that a new facility be designed to fulfill these requirements. 
1. HLLW FEED

2. SPRAY CALCINER

3. CERAMIC ADDITIVES

4. VERTICAL CALCINER
5. CALCINER COOLER

9. CLASSIFIER

6. PNEUMATIC TRANSFER 10. DUST SEPARATOR

7. CYCLONE SEPARATOR 11. SLUGGING PRESS 8. BALL MILL 12. GRANULATOR

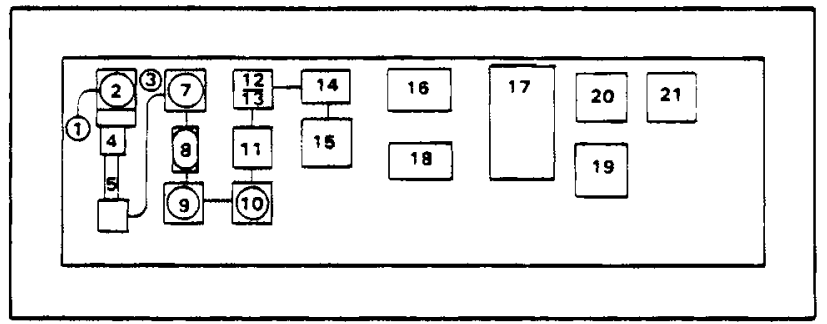

13. SCREENING SYSTEM

14. DIE-FILLING STATION

15. UPPER PUNCH PLACEMENT

16. COLD PRESSING

17. HOT PRESSING

18. DIE/PUNCH/PELLET SEPARATION

19. CANISTER FILLING

20. LID-WELD STATION

21. CANISTER DECONTAMINATION

NEW CRYSTALLINE CERAMIC PROCESS FACILITY

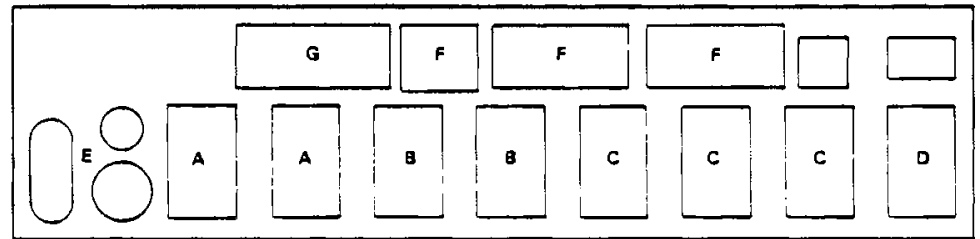

CHEMICAL PROCESS CELL

A. CENTRIFUge SYSTEM

8. AGGLOMERATION AND SETTLING

C. CESIUM ION-EXCHANGE

D. STRONTIUM ION-EXCHANGE

E. HLLW FEED TANKS

F. RECYCLE AND SECONDARY EVAPORATION

G. OFF.GAS TREATMENT SYSTEM

H. SALT SOLJDIFICATION AND PACKAGING

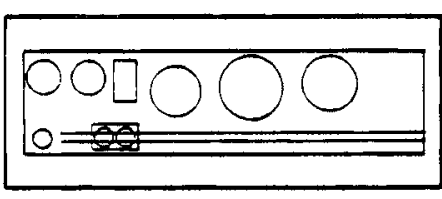

SCRAP REMOVAL CELL

FIGURE 8.16. Facility Layout of the Crystalline Ceramic Process 


\subsection{REFERENCES}

American Society for Testing Materials (ASTM). 1955. "ASTM Standards on Glass and Glass Products." Prepared by ASTM Comittee C14, American Society for Testing Materials.

Angelini, R., et ai. 1980. "Sol-Gel Technology Applied to Crystalline Ceramics." Paper Presented at the November 16-21 Annual Meeting of the Materials Research Society, Boston, Mass achusetts.

Barnes, S. M. 1980. High Temperature Vitrification of Hanford Residual-Liquid Waste in a Continuous Melter. PNL-3343, Pacific Northwest Laboratory, Richland, Washington.

Barnes, S. M., R. A. Brouns, and M. S. Hanson. 1980. "Processing of High-Temperature Simulated Waste Glass in a Continuous Ceramic Melter." Scientific Bas is for Nuclear Waste Management 2, 0. 864 , Plenum Press, New York, New York.

Barnes, R. G., and R. B. Bendixsen. 1977. Waste Solidification Accident Information. NEDG-21601, General Electric Company, San Jose, California.

Bechte1, Inc. 1977. Calciner Feed System for the Spray Calcination In-Can Melting Process. Technical Report \#2, Bechtel Inc., San Francisco, California.

Bond, W. R., et al. 1970. Waste Solidification Program, Volume 6, Spray Solidification Performance During First Radioactive Tests in Waste Solidification Engineering Prototypes. BNWL-1391, Pac ific Northwest Laboratory, Richland, Washington.

Brouns, R. A., et al. 1980. Immobilization of High-Level Defense Wastes in a Slurry-Fed Electric Glass Melter. PNL-3372, Pacific Northwest Laboratory, Richland, Washington.

Bue 1t, J. L., et al. 1979. "A Review of Continuous Ceramic-Lined Melters and Associated Experience at PNL." Ceramics in Nuclear Waste Management, CONF-790420, National Technical Information Service, Springfield, Virginia.

Buelt, J. L., and W. L. Partain. 1980. Safety Assessment of the Liquid-Fed Ceramic Melter Process. PNL-3493, Pac if ic Northwest Laboratory, Richland, Washington.

Bue 1t, J. L., and C. C. Chapman. 1978. Liquid-Fed Ceramic Melter: A General Description Report. PNL-2735, Pacific Northwest Laboratory, Richland, Washington.

Chapman, C. C. 1980. "Nuclear Waste Glass Melter Design Including the Power and Control Systems." Conference Record of the IEEE Industry App lications Society, 80 CH1575/000-0031, Cincinnati Section of the Industry Applications Society, Cincinnati, Ohio.

Chapman, C. C. 1976. Experience with a Joule-Heated Ceramic Melter While Convective Simulated High-Level Waste to Glass. BNWL-207I, Pacific Northwest Laboratory, Richland, Washington.

Chick, L. A., and C. Q. Buckwalter. 1980. Low Leach Rate Glasses for Immobilization of Nuclear Wastes. PNL-3522, Pac if ic Northwest Laboratory, Richland, Washington.

Coles, D. G., and F. Bazan. 1980. "Continuous-Flow Leaching Studies of Crushed and Cored SYNROC." Journal of Nuclear Technology, Workshod on Comparative Leaching-Behavior of Radioactive Wastes Forms, Argonne National Laboratory, Argonne, Illino is.

De, A. K., et al. 1976a. "Development of Glass Ceramics for the Incorporation of Fission Products." Ceramic Bulletin 55 (5).

De, A. K., et al. 1976b. "Fixation of Fission Products in Glass Ceramics." IAEA-SM-270/11, Paper Presented at International Symposium on the Management of Radioactive Wastes from the Nuclear Fuel Cycle, March 22-26, 1976, International Atomic Energy Agency, Vienna, Austria. 
Dierks, R. D., et al. 1980. Investigation of Corrosion Experienced in a Spray Calciner/ Ceramic Melter System. PNL-3406, Pac ific Northwest Laboratory, Richland, Nashington.

Dosch, R. G. 1980. "Final Report on the Applications of Titanates, Niobates, and Tantalates to Neutralized Defense Waste Decontamination Material Properties, Physical Forms, and Regeneration Techniques." SAND-80-1212, Sandia National Laboratories, Albuquerque, New Mexico.

Dosch, R. G., P. F. Hlara, and T. J. Headley. 1980. "Titanate Waste Farms for High Level Waste - An Evaluation of Materials and Processes." Paper Presented at the November 16-21 Annual Meeting of the Materials Research Society, Boston, Massachusetts.

General Electric Company. 1955. Purex Technical Manual. HW-31000, General Electric Company, Richland, Washington.

Goodlet, C. B. 1968. Concentration of Radioactive Wastes. DP-1135, Savannah River Laboratory, Aiken, South Carolina.

Gray, W. J. 1980. "Volatility of Some Potential High-Level Radioactive Waste Forms," pp. 147-169, Harwood Academic Publishers, Radioactive Waste Management, Vol. 1.

Harker, A. B., et al. 1980. "Tailored Ceramic Nuclear Waste Forms" Paper oresented at the Symposium for Scientific Basis for Nuclear Waste Management Sponsored by the Materials Research Society at the Annual Meeting, November 16-21, Boston, Massachusetts.

Holton, L. K., et al. 1979. "Safety Analysis of a Spray Calciner/In-Can Melter System for Vitrification of High-Level Radioactive Waste." PNL-SA-7819, Pacific Northwest Laboratory, Richland, Washington. (Also presented at American Chemical Society Meeting, September 9-14, 1979, Washington, D.C.)

Hill, O. F., et al. 1981 West Valley Demonstration Project: Preconceptual Design Study for Solidifying High-Level Waste. DOE/TIC-11433 (PNL-3608-2), Pac ific Northwest Laboratory, Richland, Washington.

Knapp, Warren, . Addison, and Elmer Smith, "Methods for Forming Balls from Thermoplastic Materials," U.S. Patent 3254979, June 7, 1966.

Kupfer, M. J., and R. S. Palmer. 1980. Physical and Chemical Characterization of Borosilicate Glasses Containing Hanford High-Level Waste. RHO-SA-189, Rockwell Hanford Operations, Richland, Washington.

Larson, D. E. 1980. Soray Calciner/In-Can Melter High-Level Waste Solidification Technical Manua 1. PNL-3495, Pacific Northwest Laboratory, Richland, Washington.

Lokken, R. 0. 1981. Thermal Conductivity of Multibarrier Waste Form Components. PNL-3090, $P$ ac ific Northwest Laboratory, Richland, Washington.

McCarthy, G. D. 1977. "High-Level Waste Ceramics: Materials Consideration, Process Simulation and Product Characteristics." Nuclear Technology 39:92-105.

McCarthy, G. D. 1979. "Crystalline Ceramics from Defense High-Level Wastes." Letter to the Editor, Nuclear Technology 44, 451.

MCElroy, J. L., et al. 1972. "Waste Solidification Program Summary Report," Vol. II of Evaluation of WSEP High-Level Waste Solidification Processes. BNWL-1667, Pac ific Northwest Laboratory, Richland, Washington.

MCElroy, J. L., et al. 1968. Pot Solidification Performance During the First Radioactive Tests in WSEP, Volume 4, Waste Solidification Program. BNWL-814,-Pacific Northwest Laboratory, Richland, Washington.

Newkirk, H., et al. 1980. "Ceramic Processing, Phase Equilibria and Leaching Characteristics of SYNROC D Formulations for U.S. Defense Wastes." Paper Presented at the November 16-21 Annual Meeting of the Materials Research Society, Boston, Massachusetts. 
Oguino, N., S. Masuda, and N. Tsunoda. 1979. "Solidification of HLLW by Glass-Ceramic Process." Paper Presented at International Symposium of Ceramics in Nuclear Waste Management, Cincinnati, Ohio, April 30 - May 2, 1979. Co-Sponsored by the American Cancer Society and the U.S. Department of Energy, U.S. Department of Energy, Washington, D.C.

Okeson, J. K., et al. 1980. A Small Scale Demonstration of High-Level Radioactive Waste Processing and Solidification Using Actual SRP Waste. DP-MS-80-2, Savannah River Laboratory, Aiken, South Carolina.

Palmer, R. A. 1980. Interaction Between Candidate Melter Electrode Materials and Defense Waste Glass Melts. RHO-SA-173, Rockwell Hanford Operations, Richland, Washington.

Platt, A. M., and J. Powe 11. 1980. Nuclear Waste Technology Quarterly Progress Report. PNL-3000-6, Pac ific Northwest Laboratory, Richland, Washington.

Ringwood, A. E., et al. 1979. "Immobilization of High-Level Nuclear Reactor Wastes in SYNROC," Nature 278:217-223.

Ringwood, A. E., K. D. Reese, and J. Tewhey. 1980. "Immobilization of High Level Nuclear Reactor Wastes in SYNROC: Current Status." Paper Presented at the November 16-21 Annual Meeting of the Materials Research Society, Boston, Massachusetts.

Roy, R., et al. 1980. "Matrix Encapsulated Waste Forms: Theory and Application to Idealized Systems, Hydrated Radio- and Encapsulant Phases, and SRP/INEL Wastes." Paper Presented at the November 16-21 Annual Meeting of the Materials Research Society, Boston, Massachusetts.

Ross, W. A., et a1. 1978. Annual Report on Characterization of High-Level Waste Glasses. PNL-2625, Pacific Northwest Laboratory, Richland, Washington.

Ross, W. A., and J. E. Mende1. 1979. Annual Report on the Development and Characterization of Solidified Forms for High-Level Wastes; 1978. PNL-3060, Pacific Northwest Laboratory, Richland, Washington.

Ross, W. A., et al. 1980. Annual Report on the Characterization of High-Level Waste Glasses. PNL-2625, Pacific Northwest Laboratory, Richland, Washington.

Rusin, J. M., et al. 1978. Multibarrier Waste Forms Part I: Development. PNL-2668-1, Pacific Northwest Laboratory, Richland, Washington.

Rusin, J. M., W. J. Gray, and J. W. Wald. 1979. Multibarrier Waste Forms Part II: Characterization and Evaluation. PNL-2668-2, Pacific Northwest Laboratory, Rich and, Washington.

Schneider, K. J. 1969. Waste Solidification Program, Vol. 1. Process Technology - Pot, Spray and Phosphate Glass Solidification Processes. BNWL-1073, Pacific Northwest Laboratory, Richland, Washington.

Schneider, K. J., and V.P. Kelley. 1969. Waste Solidification Program, Volume II, Design Features of the Waste Solidification Engineering Prototypes. BNWL-968, Pacific Northwest Laboratory, Richland, Washington.

Schuiz, W. W., et al. 1980. Preliminary Evaluation of Alternative Forms for Immobilization of Hanford High-Level Defense Wastes. RHO-ST-32, Rockwell Hanford Operations, Richland, Washington.

Shookey, S. D. 1960. Process for the Production of Glass-Ceramics. U.S. Patent 2,920,971, U.S. Patent office, washington, D.C.

Simmons, J. H., et al. 1979. "Fixation of Radioactive Waste in High-Silica Glasses." Nature 278, pp. 729-731.

Simonen, F. A., and S. C. Slate. 1979. Stress Analysis of High-Level Waste Canisters-Methods, Applications and Design Data. PNL-3036, Pacific Northwest Laboratory, Richiand, Washington. 
Smith, T. H., and W. A. Ross. 1975. Impact Testing of Vitreous Simulated High-Level Waste in Canisters. BNWL-1903, Pacific Northwest Laboratory, Richland, Washington.

Southern Sciences Applications, Inc. 1978. Safety Analysis of High-Level Waste Solidification Processes. SSA-112, Southern Sciences, Inc., Dunedin, Florida.

Treat, R. L., et al. 1980. Preliminary Evaluation of Alternative Waste Form Solidification Processes, Volume I: Ident ification of Processes. PNL-3244, Pacific Northwest Laboratory, Richland, Washington.

Wald, J. W., et al. 1980. Comparative Waste Forms Study. PNL-3516, Pac if ic Northwest Laboratory, Richl and, Washington.

Walker, C. T., and U. Riege. 1979. "Compatibility of Actinides with HLW Borosilicate Glass: Solubility and Phase Formation." Published in Proceedings, Ceramics in Nuclear Waste Management, CONF-790420 American Ceramic Society and U. S. Department of Energy, Washington, D.C.

Weisenburger, S. 1980. "Nuclear Waste Vitrification in a Ceramic-Lined Electric Glass Melter," Conference Record of the IEEE Industry Applications Society. 80CH1575/000-0043, Cincinnati SEction of the Industry Applications Society, Cincinatti, Ohio.

Wheelwright, E. J., et al. 1979. Technical Sumary Nuclear Waste Vitrification Project. PNL3038, Pacific Northwest Laboratory, Richland, Washington.

Willis, T. A. 1980. Startup and Operation of a Plant-Scale Continuous Melter for Vitrification of Savannah River Plant Simulated Waste. DP-MS-80-48, Savannah River Laboratory, Aiken, South Carolina. 


\subsection{SOLIDIFICATION OF COMBINED ALKALINE PUREX AND ACIDIC THOREX WASTE}

Three waste form processes for incorporating a combined mixture of the alkaline Purex and acidic Thorex high-level waste into a terminal, waste form are discussed in this section. These three waste form processes are: a borosilicate glass process, a low-alkali glass process, and a borosilicate glass marbles-in-lead matrix process. These processes are similar to those discussed in Section 8.0. Only differences between these processes and the corresponding processes discussed in Section 8.0 will be discussed.

The crystalline-ceramic waste form considered for the alkaline salt/sludge separation process is not considered for the combined waste process approach. Allowable sodium concentrations in crystalline-ceramic materials are very low ( $2 \mathrm{wt} \%)$. The high-sodium content of the combined waste blend (alkaline Purex plus acidic Thorex) would require that a large number of canisters of crystalline-ceramic waste form be produced, making this process approach impractical.

\subsection{BOROSILICATE GLASS}

The combined alkaline waste blend, formed from adding the acidic Thorex waste to the alkaline purex waste, can be solidified in a borosilicate glass matrix. The high-sodium content of combined waste will limit its waste loading to approximately 18 wt\%. Incorporating the entire alkaline waste volume (alkaline sludge plus alkaline supernate) into borosilicate glass will result in the production of five to six times more glass than if the sodium had been separated from the waste before solidification. This situation requires that the solidification process (composed of three liquid-fed joule-heated melters) have a higher capacity to meet the requirements of a three-year HLLW solidification campaign.

\subsubsection{Waste Form Properties}

The composition of the combined alkaline waste, anticipated glass-forming additives and the resulting borosilicate glass are summarized in Table 9.1. The waste loading in the glass matrix is $18 \mathrm{wt} \%$.

The fission-product content of the glass is only $11 \mathrm{ci} / \mathrm{kg}$, approximately one-eighth the activity of the borosilicate glass for the separated salt/sludge alkaline waste. The physical and mechanical properties of this waste form, such as leach resistance, thermal stability, radiation resistance, and friability are considered the same as the borosilicate glass for the reference borosilicate glass process (Section 8.1). Nonradioactive laboratory-scale and nonradioactive pilot-scale process development have shown that the leach resistance of the borosilicate glass waste forms from the combined waste process and the salt/sludge separation process are essentially equal (Holton, et al. 1980).

\subsubsection{Process System Description and Material Balance}

The combined alkaline Purex and acidic Thorex waste composition includes high concentrations of sodium, nitrate, nitrite, and sulphate. The melting-point temperatures of the waste is controlled by the sodium concentration. It is estimated that the melting point of the alkaline waste blend is $320^{\circ} \mathrm{C}$. This low melting temperature means that the waste blend cannot 
TABLE 9.1. Composition of Borosilicate Glass Used for Solidified Combined Alkaline Purex and Acidic Thorex Wastes

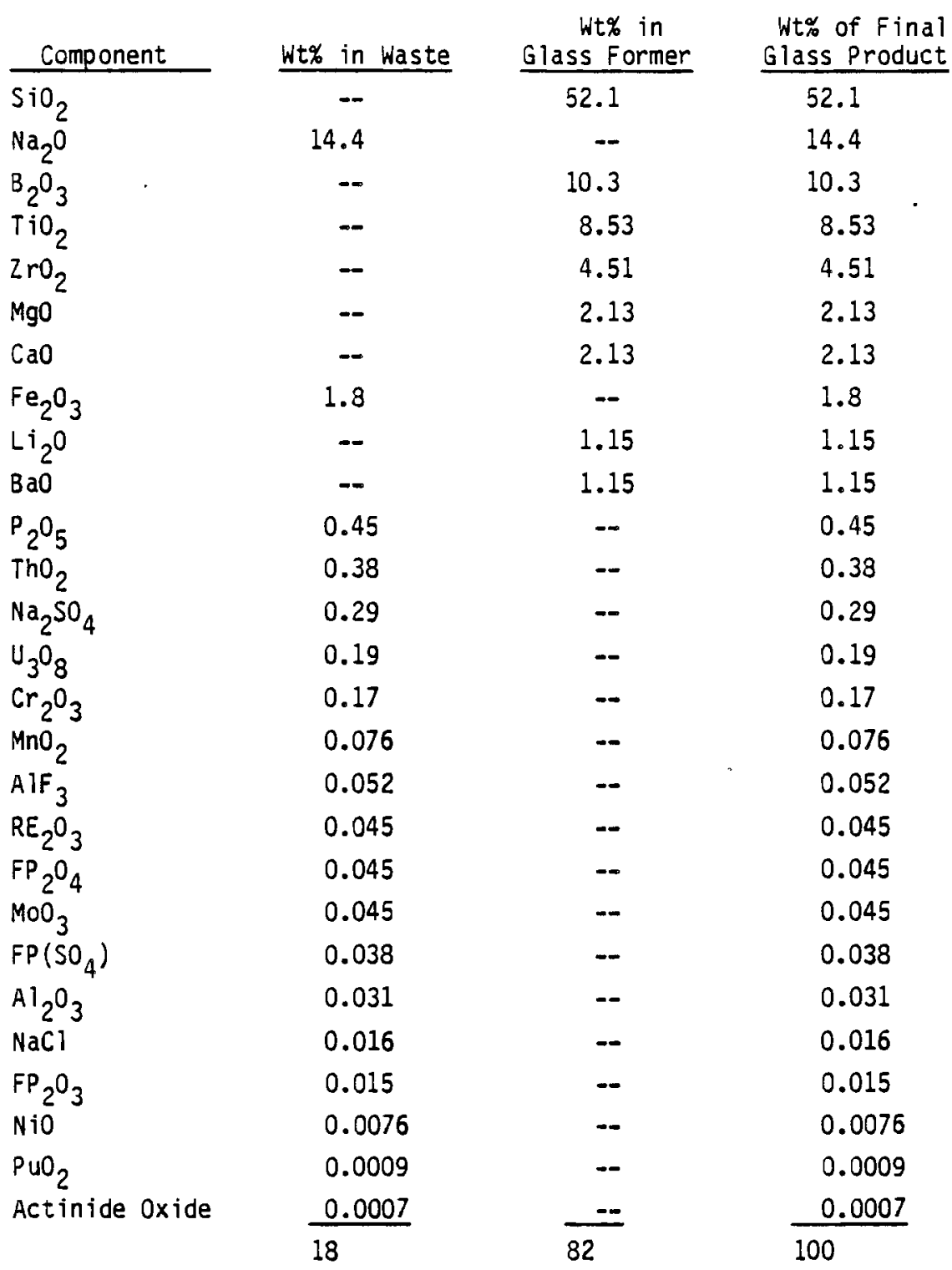

be easily solidified with a spray calciner/in-can melter process without caking problems in the calciner and canister containing section. Because of this, the LFCM was chosen as the solidification process for producing the borosilicate glass waste form.

A simplified schematic of the borosilicate glass process is shown in figure 9.1. Details of the process flowsheet and process material balance are presented in Appendix $C$. The $b$ lended alkaline Purex and acidic Thorex wastes are transferred from the tank farm to a feed tank located inside the CPC. The alkaline waste blend is combined with process recycle streams, sampled, diluted, and the glass-forming chemicals are added. The resulting waste blend is transferred to one of three LFCM feed systems, fed to the LFCM via an airlift, and converted to 


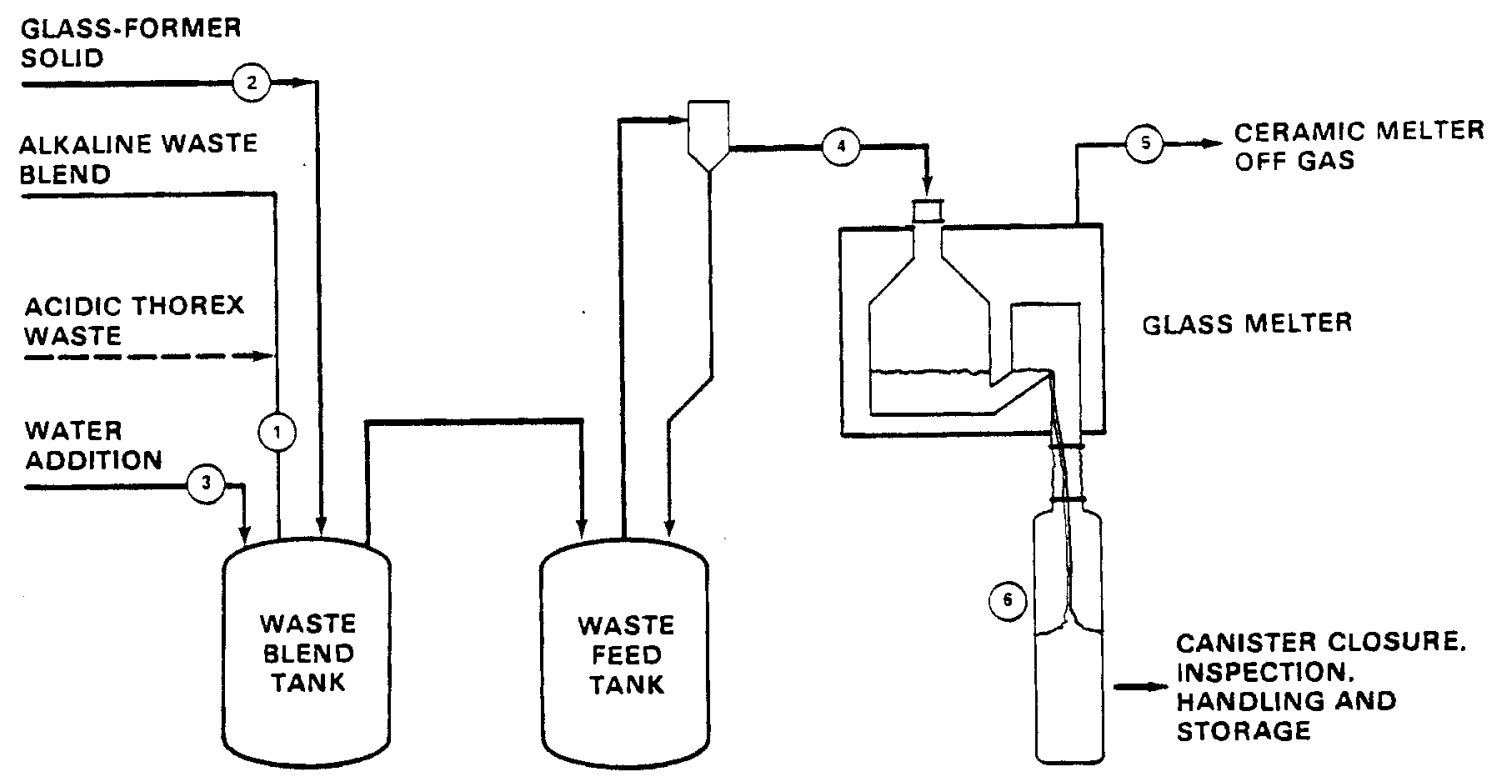

FIGURE 9.1. Schematic of the Borosilicate Glass Process

a vitreous form that is poured into steel canisters. The canisters are processed in the same manner as in the reference process.

The process material balance is presented in Table 9.2 and the waste form summary is presented in Table 9.3. This waste process option produces 1500 borosilicate glass canisters as compared to the 240 canisters produced when solidifying the alkaline waste and Thorex waste in the separated salt/sludge treatment approach.

The three-year solidification campaign with a $60 \%$ equipment efficiency will require a glass-production rate of $190 \mathrm{~kg} / \mathrm{h}$. Three LFCM's operating in parallel are proposed to meet this production rate. Glass-forming chemicals in the oxide form are used in lieu of glass frit to avoid introducing more sodium into the process, since glass frit must contain some soda. Each melter will fill a canister in $31.4 \mathrm{~h}$. Therefore, canisters must be processed through the post-fill stages on an average of one every $10.5 \mathrm{~h}$.

off gas consisting primarily of water, $\mathrm{NO}_{x}$ and $\mathrm{SO}_{2}$, is released from the melter and processed through a multistage off-gas system designed to remove radionuclides and $\mathrm{SO}_{2}$ and to reduce the $\mathrm{NO}_{\mathrm{x}}$ to $\mathrm{N}_{2}$. The present material balance assumes that all the sulfur is incorporated into the glass without any adverse effects.

Water is added to the alkaline feed-slurry mixture to dilute the solids loading based on conversion to oxides to $500 \mathrm{~g}$ of oxide/ $\mathrm{L}$. This equivalent solids loading has been demonstrated in development air-lift feed systems using simulated alkaline waste.

An alternative to diluting the mixture of HLLW and glass-former solids is to modify a solid feeder, for example a screw type, so that the HLLW can be added to the glass-former solids in the proper ratio to form a wet mixture that can be fed into the LFCM. The advantage 
TABLE 9.2. Process Conditions and Material Balance Data for Solidifying Combined Alkaline Purex and Acidic Thorex Wastes in a Borosilicate Glass

\begin{tabular}{|c|c|c|c|c|c|c|}
\hline Stream Number(b) & $\begin{array}{l}\frac{1}{\text { Blended }} \\
\text { Alkaljne } \\
\text { Waste } \\
\end{array}$ & $\begin{array}{c}2 \\
\text { Glass } \\
\text { Former } \\
\text { Solids }\end{array}$ & $\begin{array}{l}\frac{3}{\text { Feed }} \\
\text { Dilution } \\
\text { Water }\end{array}$ & $\begin{array}{c}\frac{3}{\text { Melter }} \\
\text { Feed } \\
\text { Slurry }(c)\end{array}$ & $\begin{array}{l}4 \\
\text { Melter } \\
\text { Off gas }\end{array}$ & Glass \\
\hline \multicolumn{7}{|l|}{ Flow, $\mathrm{kg} / \mathrm{h}$} \\
\hline Salt & 78.5 & & & 78.5 & & \\
\hline Solids & 6.27 & 154 & & 160.3 & & 190 \\
\hline $\begin{array}{l}\mathrm{H}_{2} \mathrm{O} \\
\text { Air }\end{array}$ & 175 & & $205^{(d)}$ & 380 & $\begin{array}{l}380 \\
60\end{array}$ & \\
\hline $\begin{array}{r}\mathrm{NO}_{x} \\
\text { Total }\end{array}$ & $259.8^{(\mathrm{a})}$ & 154 & 205 & 464.8 & $\begin{array}{l}34.3 \\
474.3\end{array}$ & 190 \\
\hline Flow, L/h & 175 & & 205 & 380 & & 68 \\
\hline Temperature, ${ }^{\circ} \mathrm{C}$ & 35 & & 30 & 35 & 300 & 900 \\
\hline Density, $\mathrm{g} / \mathrm{cm}^{3}$ & 1.56 & 3.0 (bulk) & & 1.6 & & $2.8\left(35^{\circ} \mathrm{C}\right)$ \\
\hline Activity, Ci/L & 12.4 & & & 5.9 & & 177 \\
\hline Heat, $W / L$ & 0.04 & & & 0.018 & & 0.50 \\
\hline
\end{tabular}

(a) Based on 657 full-capacity operating days.

(b) Stream numbers refer to Figure 9.1.

(c) Total for 3 LFCMs.

(d) Water required to dilute feed to demonstrated feed concentrations (500 g of solids $/ L)$, includes recycle evaporator bottoms.

TABLE 9.3. Borosilicate Glass Waste-Form Product Sumary for Combined Alkaline Purex and Acidic Thorex Waste

\begin{tabular}{lll}
\multicolumn{1}{c}{ Parameters } & & Combined Wastes \\
\hline Glass production rate, $\mathrm{kg} / \mathrm{h}$ & & 190 \\
Glass in canister, $\mathrm{kg}$ & & 1993 \\
Number of canisters & $2.3 \times 10^{4}$ \\
Activity per canister, Ci & 65 \\
Decay heat per canister, W & 657 \\
Processing campaign length, d &
\end{tabular}

of this approach would be to reduce the evaporation requirements, and therefore the power and size, and the number of LFCMs required. However, this approach to feeding has not been developed for the remote operation and maintenance required for HLLW processing.

The agitators and pumps in the feed system will require high maintenance because of the errosive nature of the feed. The control, instrumentation, and service requirements of the feed systems for all waste treatment options are similar and are not described in detail here. Space must be provided for the three feed system modules $(1.8 \mathrm{~m} \times 3.66 \mathrm{~m}$ floor area). A detailed description of an LFCM has been presented in Section 8.2.2 for the low-alkali glass process. The operational details will not be repeated in this section. 
The three LFCMs each have a liquid feed-rate capacity of $152 \mathrm{~L} / \mathrm{h}$ and a glass-production rate of $55 \mathrm{~kg} / \mathrm{h}$. The glass production rate is approximately $50 \%$ higher than PNL has demonstrated on a sustained basis without boosting techniques in the LFCM. It is believed that increased capacity can be accomplished by increasing the size of a melter. The melter size will be limited, however, by available cell space and by the capacity of the crane.

The LFCM for borosilicate glass with an $1100^{\circ} \mathrm{C}$ melting point can employ Incone 1690 electrodes. Incone 1690 is more rugged than molyddenum or tin-oxide electrodes required by the high-temperature low-alkali glass process. The insulating requirements for the $1100^{\circ} \mathrm{C}$ borosilicate glass LFCM, especially in the lid area, are also less demanding than in the low-alkali LFCM.

Two of the major control and operational problems of an LFCM are glass foam generated in the melter and steam surges in the off-gas system. These surges are caused by a rapid boil-off of an accumulated liquid pool that is suddenly exposed to molten glass. There is also a concern that heavy metals or crystals will accumulate on the bottom of the melter tank as a sludge and cause problems such as plugging the glass drain and shorting between electrodes.

Control of the LFCM is made difficult by the limited sensing capability in the melter. Electrical resistance of the glass is easily measured. Monitoring total melter weight (from which glass weight can be inferred) may be achieved with sophisticated design. It may also be possible to maintain a platinum thermowell in the glass tank to indicate glass temperature directly and to provide some indication of glass level. Control of the process is accomplished by short-term adjustments in feed rate and by power and long-term adjustments in feed composition.

Maintenance of the LFCMs typically involves clearing feed-line blockages, replacing thermocouples, replacing auxiliary heater elements, clearing glass blockages in the discharge trough and in the pouring channel, and adjusting the canister connection mechanism. Failure of melter refractories due to erosion and corrosion or the need to replace a main electrode probably requires the replacement of the entire melter. An LFCM cannot be decontaminated sufficiently to allow contact maintenance.

The combined services required by the three LFCMs include $350 \mathrm{~kW}$ of power, cooling water, steam for cooling, and 100 standard cubic feet per minute of compressed air for cooling. The melters occupy a horizontal space of $2.5 \mathrm{~m} \times 3.0 \mathrm{~m}$ and are $3.0 \mathrm{~m}$ high. Additional clearance must be allowed for maintenance and service jumpers. The melter must be mounted above the cell floor to allow placement of the waste canister beneath. The total empty weight of each melter is estimated to be $12,000 \mathrm{~kg}$.

The off-gas system for a LFCM must be capable of responding rapidly to large fluctuations in off-gas flow rate, primarily steam surges. For fast response and operational flexibility each LFCM may need to have its own scrubber ejector and main condenser located close to the melter. Further analys is will be required to determine if the off-gas system redundancy should be carried further, through a system of filters, $\mathrm{NO}_{\mathrm{x}}$ destructors, and blowers. $\mathrm{AlsO} \mathrm{a} \mathrm{SO}_{2}$ scrubber may be required. 
The canister design has been described in the reference process section, 8.1. The canisters for LFCM processes do not require internal fins. The importance of developing an effective design for the canister connection device was also discussed in Section 8.2. A canister is changed out every $31.4 \mathrm{~h}$ on each melter. The changeout must be completed in less than an hour if the liquid feed rate is to remain continuous. Since three melters are in operation, a canister changeout must be accomplished on an average of every $10.5 \mathrm{~h}$. Production rates must be monitored and adjusted so that two canisters do not become filled at the same time. The canister changeouts require the use of one of the overhead cranes. The potential exists for conflict with other canister post-fill operations requiring the use of the crane. This conflict must be avoided by proper scheduling. In general, the higher production rate of the combined waste canisters (one every $10.4 \mathrm{~h}$ as compared to one every $66 \mathrm{~h}$ in the reference process) will require that the post-fill operations be more automated and reliable.

After canister changeout, a lid is welded on the canister at one of the two lid-welding stations, and the canister is also checked for leaks. It then undergoes rough decontamination at a single decontamination station. Then it is loaded on the transport cart and moved in batches of six canisters to the EDR. No auxiliary cooling of the canister is necessary since the decay-heat loading is relatively low. Final decontamination and loading into the onsite cask will take place in the EDR. Due to the average production time of $10.4 \mathrm{~h}$ per canister, it may not be possible to process canisters in the EDR at this rate without significant modifications. The number of times that the heavy shielding door separating the CPC and the EDR must be opened is proportional to the number of canisters produced. Therefore, whether the present door can sustain the required operating duty must be determined.

\subsubsection{Status of Technology}

The development history of the liquid-fed joule-heated melters (LFCMS) has been given in Section 8.2. The solidification of the combined alakline wastes as borosilicate glass within a three-year period at $60 \%$ plant availability requires a glass-production rate $190 \mathrm{~kg} / \mathrm{h}$. It is possible that a single LFCM with a surface area of approximately $5 \mathrm{~m}^{2}$ could achieve this production rate. The commercial glass industry uses electric melters much larger than this. Researchers at the Savannah River Laboratory are preparing a conceptual design of a LFCM having a $2.6 \mathrm{~m}^{2}$ surface area. However, to determine the required number of melters PNL Used a conservative scale-up factor of approximately $50 \%$ above demonstrated LFCM production rates. Perhaps more importantly the weight of each of these LFCMs, which has been estimated at $12 t$ approaches the crane capacity $(14.5 \mathrm{t})$ of the CPC. If there is a malfunction in one of the melters, having two others creates operational flexibility because the campaign length can be extended with the remaining melters.

In general, the technology required for a LFCM has been demonstrated. However, more work at making the design suitable for remote operation, inspection, and maintenance is required. The glass discharge and canister connection system in particular require additional development. 


\subsubsection{Safety Considerations}

The major parameters for judging the safety and environmental acceptability of this combined waste treatment option includes the waste dispersive driving forces in the process, the chemical toxicity of reagents, and secondary wastes generated from the process.

The dispersive forces present in this process include those in pressurized HLLW in the feed transfer and recirculation piping and in the stored thermal energy in the melter's glass inventory. Steam surges exceeding the off-gas system capacity may pressurize the melter and cause the release of HLLW to the cell atmosphere. There is a theoretical, but extremely low, probability that a water-glass or water-molten salt thermal reaction could cause a steam explosion with sufficient energy to rupture the melter and possibly breach the CPC containment. The potential for this accident also exists in the reference SC/ICM process, but with a lower probability and consequences. Radiation exposure is expected to be similar to that gained in the SC/ICM process since maintenance requirements are similar. The total number of process vessels in the combined waste treatment option will be less than those in the separated alkaline waste solidification option, but this will be offset somewhat by the increased size of the equipment. The 5120 barrels of decontaminated salt in the separated waste treatment option are not present as a secondary waste in this waste treatment option.

The chemical toxicity of this process is roughly comparable to that of the SC/ICM process. The major difference is that a very large quantity of $\mathrm{NO}_{x}$ and $\mathrm{SO}_{2}$ will be produced that must be reduced to $\mathrm{N}_{2}$ and trapped as $\mathrm{SO}_{4}{ }_{4}$ or $\mathrm{S}^{=}$by the off-gas system. To reduce $\mathrm{NO}_{x}$, large quantities of $\mathrm{NH}_{3}$ will be required, and the potential for $\mathrm{NH}_{4} \mathrm{NO}_{3}$ formation becomes a safety and operating consideration. The $\mathrm{NH}_{4} \mathrm{NO}_{3}$ if formed will crystallize and deposition in off-gas piping and on filters. The secondary wastes generated by this process include the $\mathrm{N}_{2}, \mathrm{NO}_{x}, \mathrm{SO}_{2}$ gases emitted to the atmosphere and the $S^{=}$or $\mathrm{SO}_{4}=$ trapped for chemical disposal.

\subsubsection{Facility Implementation}

A conceptual layout of the combined borosilicate glass process in the CPC is presented in Figure 9.2. Sufficient room in the cell exists for all process equipment. The SRR is not required for salt evaporation, which frees it for equipment maintenance or decontamination if necessary.

Three additional shielded windows, two periscopes, three boom-mounted cameras, five wallmounted manipulators and two overhead manipulators are required to carry out the solidification campaign. Most of the redundant manipulators and viewing devices are required because of the additional LFCMs and associated primary off-gas systems and the high canister production rate. Having one very large LFCM or extending the operating campaign may be an alternative that could facilitate implementation of this process.

The EDR will require extensive modifications to permit the high throughput of canisters. The interim on-site storage must be capable of holding approximately 1500 canisters. 

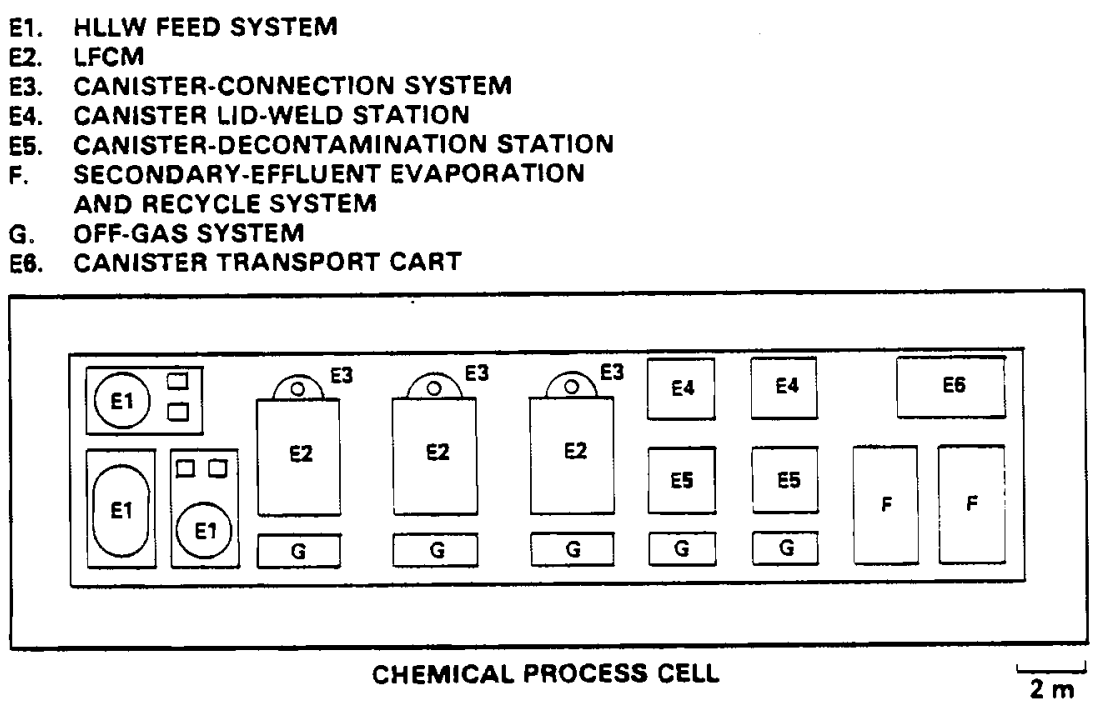

FIGURE 9.2. Facility Layout of Borosilicate Glass Process - Combined HLW

\subsection{LOW-ALKALI GLASS}

The challenge in formulating a low-alkali glass that will accormodate the combined alkaline Purex and acidic Thorex wastes is the $80 \%$ sodium oxide $\left(\mathrm{Na}_{2} \mathrm{O}\right)$ and the $10 \%$ sulfate in the waste oxides. The waste loading in the glass is restricted by both of these components. A low-alkali glass can be formulated if the waste loading is reduced to $12.6 \mathrm{wt} \%$ to limit the sodium oxide loading to 10 wt\% in the glass. In addition, only approximately I wt\% sulfate can be absorbed in the glass matrix. Sodium oxide is assumed as the limiting HLLW component in the low-alkali glass.

Much of the process description for the combined low-alkali glass process is similar to that for low-alkali glass incorporating separated salt/sludge from the alkaline waste. Only major parameters and process differences are described in this section.

\subsubsection{Waste Form Properties}

The low-alkali glass requires approximately a $1450^{\circ} \mathrm{C}$ melting temperature. The waste can be incorporated into the HLLW as $12.6 \mathrm{wt \%}$ of the total glass composition. An anticipated lowalkali glass composition is given in Table 9.4. This exact composition has not been tested, however, it is a close parallel to the glass 79-339 reported by Chick and Buckwalter (1980).

The leach performance of this low-alkaline glass is also presumed to be the same as the 79-339 glass. Properties of the low-alkali glass waste form are discussed in section 8.2.

The principal difference between the low-alkali glasses for the separated alkaline Purex waste and unseparated alkaline waste is the factor of 10 lower activity of the latter as a result of waste dilution.

\subsubsection{Process System Description and Material Balance}

A joule-heated ceramic melter with high-temperature electrodes is required to produce the low-alkali glass. The process incorporates direct liquid feeding to the melter, as does the 
TABLE 9.4. Composition of LOW-Alkali Glass Used for Solidified Combined Alkaline Purex and Acidic Thorex Wastes

\begin{tabular}{|c|c|c|c|}
\hline Components & Wt\% in Waste & $\begin{array}{c}\text { Wt\% in } \\
\text { Glass Formers } \\
\end{array}$ & Total \\
\hline $\mathrm{SiO}_{2}$ & -- & 62.8 & 62.8 \\
\hline $\mathrm{Na}_{2} \mathrm{O}$ & 10.0 & -- & 10.0 \\
\hline $\mathrm{B}_{2} \mathrm{O}_{3}$ & -- & 9.9 & 9.9 \\
\hline $\mathrm{Fe}_{2} \mathrm{O}_{3}$ & 1.26 & 5.0 & 6.26 \\
\hline $\mathrm{Al}_{2} \mathrm{O}_{3}$ & 0.06 & 3.8 & 3.86 \\
\hline $\mathrm{MnO}_{2}$ & 0.05 & 3.0 & 3.05 \\
\hline $\mathrm{NiO}$ & 0.005 & 1.7 & 1.7 \\
\hline $\mathrm{CaO}$ & -- & 1.2 & 1.2 \\
\hline $\mathrm{P}_{2} \mathrm{O}_{5}$ & 0.315 & $\cdots$ & 0.315 \\
\hline $\mathrm{ThO}_{2}$ & 0.265 & -- & 0.265 \\
\hline $\mathrm{Na}_{2} \mathrm{SO}_{4}$ & 0.202 & $\cdots$ & 0.202 \\
\hline $\mathrm{U}_{3} \mathrm{O}_{8}$ & 0.132 & -- & 0.132 \\
\hline $\mathrm{Cr}_{2} \mathrm{O}_{3}$ & 0.117 & $\cdots$ & 0.117 \\
\hline $\mathrm{RE}_{2} \mathrm{O}_{3}$ & 0.032 & -- & 0.032 \\
\hline $\mathrm{MoO}_{3}$ & 0.032 & -- & 0.032 \\
\hline $\mathrm{Cs}_{2} \mathrm{O}$ & 0.03 & -- & 0.03 \\
\hline sro & 0.03 & --- & 0.03 \\
\hline $\mathrm{FP}\left(\mathrm{SO}_{4}\right)$ & 0.027 & $\cdots$ & 0.027 \\
\hline $\mathrm{NaCl}$ & 0.011 & -- & 0.011 \\
\hline $\mathrm{PuO}_{2}$ & 0.0005 & - & 0.0005 \\
\hline \multirow[t]{2}{*}{ Actinide Oxide } & 0.0005 & - & 0.0005 \\
\hline & 12.6 & 87.4 & 100 \\
\hline
\end{tabular}

borosilicate glass, combined waste process described in Section 9.1. The melter capacity must be increased by $50 \%$ as a result of the lower waste loading necessary to produce low-alkali glass. Dry chemicals must be transferred into the cell and blended with the $H L L W$ at the rate of $325 \mathrm{~kg} / \mathrm{h}$.

The vitrification of the combined alkaline Purex and acidic Thorex wastes eliminates the centrifuges, ion-exchange columns, and salt evaporation and packaging equipment required for the separated salt/sludge treatment option. Offsetting this process simplification is the need to operate several melters to vitrify the larger quantity of $H L L W$ and the post-vitrification handling, storage and transportation of approximately ten times as many HLLW canisters as produced by the reference SC/ICM process.

Three LFCMs, each having a design capacity for producing glass at $108 \mathrm{~kg} / \mathrm{h}$ (217 L/h liquid feed rate), are required. The melter design requirements needed for the $1450^{\circ} \mathrm{C}$ melting temperature of low-alkali glass have been described in detail in Section 8.2. The principal difference is the greater design production rate of the LFCM's required for the combined waste treatment option. Each LFCM will have twice the capacity of the single LFCM described in Section 8.2. 
The parameters of a LFCM operating at $1450^{\circ} \mathrm{C}$ have been discussed in Section 8.2. The combined waste treatment option introduces significant $\mathrm{SO}_{4}$. The $\mathrm{SO}_{4}$ has a low solubility in the glass and tends to form a water-soluble molten salt that floats on the surface of the glass if present in excess of the glass solubility limit. It may be desirable to reduce part of the $\mathrm{SO}_{4}$ to $\mathrm{SO}_{2}$, a gaseous effluent. Significant quantities of a reducing agent such as carbon may be required to accomplish this reduction but too much reduction will result in the precipitation of metals in the glass tank. The $\mathrm{NO}_{x}$ generated from the waste will consume much of the reducing agent, so care must be taken in controlling the amount of reducing agent to be added. The techniques and instrumentation for controlling the glass-oxidation state are not well-developed. Molybdenum is the only known choice for electrode material if reducing conditions can be maintained. The high temperatures rule out Inconel 690 for electrode material and tin oxide cannot tolerate reducing conditions.

Each meiter will contain approximately $900 \mathrm{~L}$ of glass. The outer dimensions of the melter with allowance for connections is $2.5 \mathrm{~m} \times 3.5 \mathrm{~m}$ horizontal and $3.0 \mathrm{~m}$ in height. Additional space must be allowed for remote connection of services. The total weight of each melter system is est imated to be $14 \mathrm{t}$, which approaches the capacity of the largest crane in the CPC.

Each meiter will fill a canister in 18 hours. Therefore a canister is produced every $6 \mathrm{~h}$. The two cranes in the CPC can transport the canisters. Canister changeout must be completed in less than an hour, however, to maintain continuous feeding to the LFCM. With three LFCMs operating in parallel, the canister changeout times must be closely co-ordinated so that crane operations do not conflict. Although a detailed schedule for operating the crane has not been prepared, no process restrictions are foreseen. Such a schedule may indicate a reduction in process capacity if one of the cranes is taken out of service. Furthermore, some type of trolley or turntable system will be required to position the canister under each of the LFCMs. Another trolley system will also be used to move empty and filled canisters into and out of the cell.

The off-gas system for a LFCM must be capable of responding rapidly to large fluctuations in off-gas flow rate, primarily steam surges. For fast response and operational flexibility, each LFCM may need its own scrubber ejector and main condenser located close to the melter.

The canisters must be closed at a remote lid-welding station, checked for helium leaks, and decontaminated in the CPC before being moved to the EDL where final decontamination and cask-loading is done. A maximum of six hours is available for processing at each operating station. If allowance is made for variations in LFCM production rates such that a canister changeout may be required within three hours following the prior changeout, the available time at a post-fill operating station would be only three hours. Therefore, two lid-welding/ leak-detection stations, as in the reference borosilicate glass process, are required and two decontamination stations are required.

A trolley carrying six canisters transports filled and empty canisters between the CPC and the EDR. This operation occurs every $36 \mathrm{~h}$. A detailed layout of the operations in the EDR including final decontamination, cask loading, and transport to on-site interim storage, has not been made, however, it would be prudent to assume that at least two on-site casks are required. 
The process material balance of the combined waste treatment option for the low-alkali glass is summarized in Table 9.5. The glass-production rate required for a three-year solidification campaign, operating at $60 \%$ efficiency, is $325 \mathrm{~kg} / \mathrm{h}$. Table 9.6 states the waste form summary. The number of low-alkali-glass canisters produced is approximately 2572.

\subsubsection{Status of Technology}

The development history of the liquid-fed joule-heated melters (LFCMs) has been given in Section 8.2 .3 and 9.1 .

Limited development work has been done with high temperature nuclear waste glass compositions and melters. Most of the waste-glass melter experience has been with the $1100^{\circ} \mathrm{C}$ jouleheated melters. The low-alkali glass process will therefore require more development than will the borosilicate glass process.

\subsubsection{Safety Considerations}

The majority of the safety concerns for the low-alkali glass process were discussed in Section 8.2. The only additional safety concern is that of handling and transporting the large number of canisters with in the process cell and between the process cell and the high-level waste storage facility. Canister handing and transportation operations will be carried out at approximately 10 times the rate as in the reference borosilicate glass process. Therefore,

TABLE 9.5. Conditions and Material Balance Data for Solidifying Combined Alkaline Purex and Acidic Thorex Wastes in Low-Alkali Glass

\begin{tabular}{|c|c|c|c|c|c|c|}
\hline Stream Number(d) & $\begin{array}{l}\frac{1}{\text { Blended }} \\
\text { Alkaline } \\
\text { Waste } \\
\end{array}$ & $\begin{array}{l}\frac{2}{\text { Glass }} \\
\text { Former } \\
\text { Solids } \\
\end{array}$ & $\begin{array}{l}\frac{3}{\text { Feed }} \\
\text { Dilution } \\
\text { Water } \\
\end{array}$ & $\begin{array}{l}\frac{4}{\text { Metter }} \\
\text { Feed (a) } \\
\text { Slurry } \\
\end{array}$ & $\begin{array}{c}5 \\
\begin{array}{l}\text { Melter } \\
\text { off Gas }\end{array}\end{array}$ & $\begin{array}{l}6 \\
\text { Glass } \\
\text { Production } \\
\text { Rate (c) } \\
\end{array}$ \\
\hline \multicolumn{7}{|l|}{ Flow, $\mathrm{kg} / \mathrm{h}$} \\
\hline Salt & 78.5 & & & 78.5 & & \\
\hline Solids & 6.27 & 284 & & 290.3 & & 325 \\
\hline $\mathrm{H}_{2} \mathrm{O}$ & 175 & & $475^{(b)}$ & 650 & 650 & \\
\hline Air & & & & & 60 & \\
\hline $\mathrm{NO}_{x}$ & & & & & 34.3 & \\
\hline Total & 259.8 & 284 & 475 & 1019 & 744.3 & 325 \\
\hline Flow, L/h & 175 & & & 650 & & 116 \\
\hline Temperature, ${ }^{\circ} \mathrm{C}$ & 35 & & & 35 & 300 & 1200 \\
\hline Density, $\mathrm{g} / \mathrm{cm}^{3}$ & 1.56 & 3 & & 1.56 & & $2.8\left(35^{\circ} \mathrm{C}\right)$ \\
\hline Activity, Ci/L & 12.4 & & & 3.33 & $10.9(\mathrm{Ci})$ & 18.6 \\
\hline Heat, $W / L$ & 0.04 & & & 0.01 & & 0.06 \\
\hline
\end{tabular}

(a) Based on 657 full-capacity operating days.

(b) Water required to dilute feed to demonstrated feed concentrations (500 g of solids/L), includes recycle evaporator bottoms.

(c) Total for 3 LFCMs.

(d) Stream numbers refer to streams in Figure 9.1. 
TABLE 9.6. Low-Alkali Glass Waste Form Product Sumary for Combined Alkaline Purex and Acidic Thorex Waste

\begin{tabular}{ll}
\multicolumn{1}{c}{ Parameters } & Combined Wastes \\
\cline { 1 - 2 } Glass production rate, $\mathrm{kg} / \mathrm{h}$ & 325 \\
Glass in canister, $\mathrm{kg}$ & 1993 \\
Number of canisters & 2572 \\
Activity per canister, $\mathrm{Ci}$ & $1.3 \times 10^{4}$ \\
Decay heat per canister, $\mathrm{W}$ & 38 \\
Processing campaign length, d & 657
\end{tabular}

there is a greater risk of in-cell equipment damage causing radionuclide release as the result of accidents during canister movement. Additional movement of materials from the CPC to the SRR will result in spreading more radioactive contamination to the SRR.

\subsubsection{Facility Implementation}

All of the equipment for the low-alkali glass process can be located in the CPC. The general limitation imposed by the present facility is the lack of sufficient viewing windows and manipulators required to operate the three LFCMs, two lid-welding/leak-detection stations, and two decontamination stations. These limitations can generally be overcome by the addition of extra viewing windows, master-slave manipulators, power manipulators and TV cameras. A conceptual layout of the CPC is shown in Figure 9.3 .

The EDR will be required to do final decontamination and cask-loading operations for approximately 10 times the number of canisters processed in the separated alkaline waste treatment option. Six fresh canisters and six filled canisters must be processed through the EDR every $36 \mathrm{~h}$. The filled canisters must undergo final decontamination and then be loaded into a cask for transfer to interim high-level waste storage. In addition, the EDR will serve as the staging area for many activities, including in-cell maintenance, process equipment decontamination, and process equipment maintenance. Glass-forming solids will be fed into the cell through a new delivery pipe and airlock system at the south end of the CPC. The present EDR facility will require modification to permit these activities. A more detajled time and motion study may demonstrate the need to expand the facility to handle part of the work load now designated for the EDR.

\subsection{GLASS MARBLES-IN-LEAD MATRIX}

Glass marbles in a lead-alloy matrix has been proposed as an alternative waste form. The advantages of this waste form are: 1) the ability to do quality surveillance on the marble waste form, 2) the shipping and storage protection provided by the lead matrix, and 3 ) the geologic isolation enhancement provided by the lead. The disadvantages are: 1) more and heavier canisters (marbles-in-lead canisters contain approximately two and a half times the weight of the glass-filled canister, but contain less than half the quantity of glass); 2) the environmental hazards of lead, which may exceed, in the long-term, the hazards of the radionuclides; and 3 ) the additional process equipment required to produce the marbles, sort and load them into, canisters, and carry out the encapsulation in lead. 

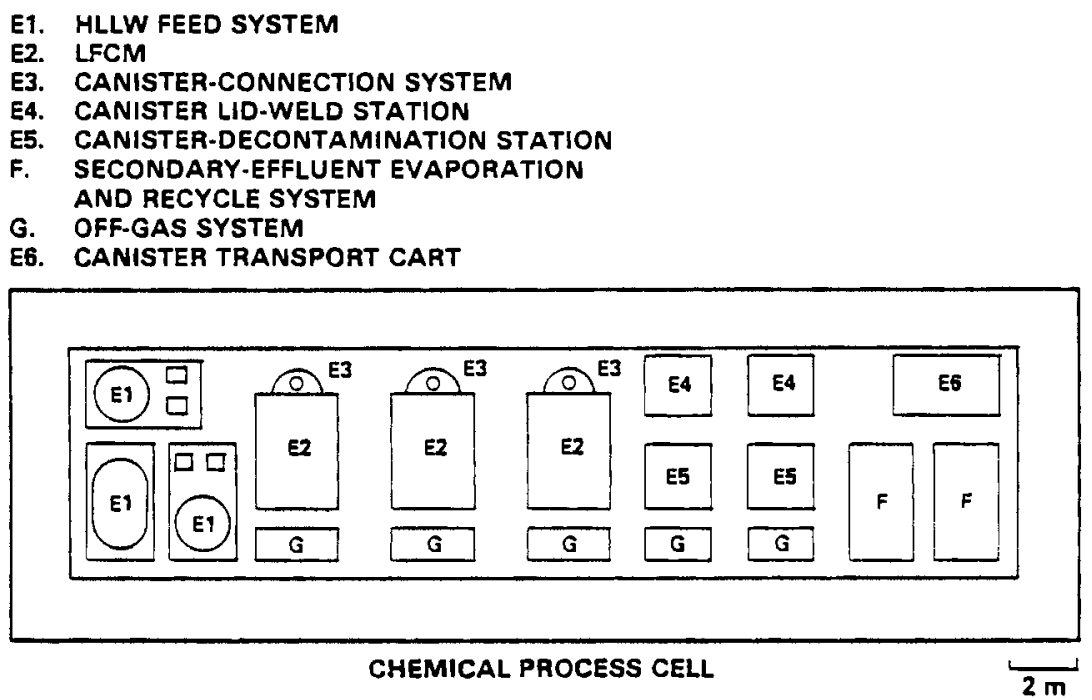

FIGURE 9.3. Facility Layout of Low-Alkali Glass Process - Combined HLLW

The borosilicate glass process is described in Section 9.1. Reference to this section is made where necessary to avoid repetition.

\subsubsection{Waste Form Properties}

The marbles-in-lead matrix consists of borosilicate glass marbles encapsulated in a lead alloy in a $0.7 \mathrm{~m}(2 \mathrm{ft})$ in dia by $3.4-\mathrm{m}(10-\mathrm{ft})$ high canister. The canister is modified to include a wire basket as described in section 8.3. The metal is lead (or 95\% lead tin-5\% alloy). The filled canister consists of a concentric basket containing the marbles ( $1 \mathrm{~cm}$ in dia), which are encapsulated in lead and a $2.5 \mathrm{~cm}$ thick annulus of lead surrounding the basket. The physical characteristics of the marbles-in-lead waste form are sumnarized in Section 8.3.

\subsubsection{Process System Description and Material Balance}

A simplified schematic of the process for the marbles-in-lead matrix is shown in Figure 9.4. This is the same process described in Section 8.3 except that three parallel LFCM/ marble machines will be required to meet the required production rates.

The material balance for the marbles-in-lead process is surmarized in Table 9.7. The waste loading in the glass marbles is $18 \mathrm{wt \%}$, however, encapsulating the marbles in lead reduces the waste form loading to $7.5 \mathrm{wt} \%$. The number of glass canisters produced is 3596 . A waste form summary is shown is Table 9.8.

Feed and production rates are given assuming that three LFCM's are employed. All of the solidification is carried out within a three-year campaign assuming a $60 \%$ operating factor (657 full production days). A canister is filled with marbles and lead, sealed, tested, and decontaminated every $3.7 \mathrm{~h}$. 


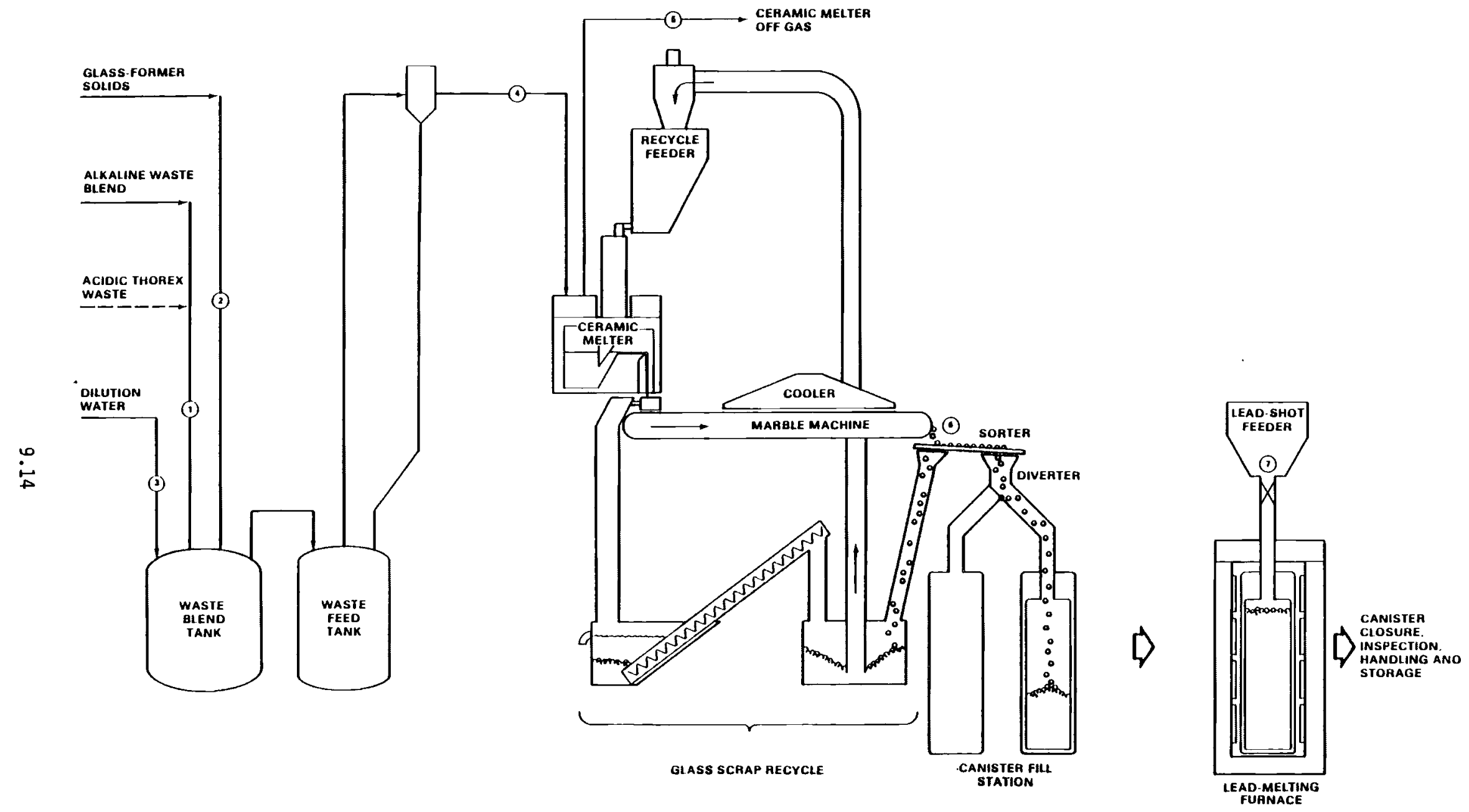

FIGURE 9.4. Schematic of the Marbles-in-Lead Process - Solidification of Combined Wastes 
TABLE 9.7. Process Conditions and Material Balance Data for Solidifying Combined Alkaline Purex and Acidic Thorex Wastes Solidified in Marbles-in-Lead

\begin{tabular}{|c|c|c|c|c|c|c|c|}
\hline Stream Number (e) & $\begin{array}{l}\frac{1}{\text { Blended }} \\
\text { Alkaline } \\
\text { Waste } \\
\text { from Tanks } \\
\end{array}$ & $\begin{array}{l}\frac{2}{\text { Glass }} \\
\text { Former } \\
\text { Solids } \\
\end{array}$ & $\frac{3}{\begin{array}{c}\text { Feed } \\
\text { Dilut jon } \\
\text { Water }(b)\end{array}}$ & $\begin{array}{c}4 \\
\begin{array}{c}\text { Melter } \\
\text { Feed } \\
\text { Slurry (d) }\end{array}\end{array}$ & $\begin{array}{l}\text { Melter } \\
\text { off Gas } \\
\end{array}$ & $\begin{array}{c}\text { Glass } \\
\text { Production } \\
\end{array}$ & $\begin{array}{l}\text { Lead } \\
\text { Shot } \\
\end{array}$ \\
\hline \multicolumn{8}{|l|}{ Flow, $\mathrm{kg} / \mathrm{h}$} \\
\hline Salt & 78.5 & & & 78.5 & & & \\
\hline Solids & 6.27 & 154 & & 160.3 & & 190 & $1300^{(c)}$ \\
\hline $\mathrm{H}_{2} \mathrm{O}$ & 175 & & 205 & 380 & 380 & & \\
\hline Air & & & & & 60 & & \\
\hline${ }^{N O}{ }_{x}$ & . & & & & 34.3 & & \\
\hline Total & 259.8 & 154 & 205 & 464.8 & 474.3 & 190 & 1300 \\
\hline Flow, L/h & 175 & & 205 & 380 & & 68 & \\
\hline Temperature, ${ }^{\circ} \mathrm{C}$ & 35 & & 30 & 35 & 300 & 900 & \\
\hline Density, $\mathrm{g} / \mathrm{cm}^{3}$ & 1.56 & $3($ bulk) & & 1.6 & & $2.8\left(35^{\circ} \mathrm{C}\right)$ & 11 (bulk) \\
\hline Activity, Ci/L & 12.4 & & & 5.9 & & 177 & \\
\hline Heat, $W / L$ & 0.04 & & & 0.018 & & 0.50 & \\
\hline
\end{tabular}

(a) Based on 657 full-capacity operating days.

(b) Water required to dilute feed to demonstrated feed concentration (500 g of solids/L).

(c) Average rate. Peak rates may be 5 times average.

(d) Total for 3 LFCMs.

(e) Stream numbers refer to streams shown in Figure 9.4 .

TABLE 9.8. Marbles-in-Lead Waste Form Product Summary for Combined Alkaline Purex and Acidic Thorex Wastes

\begin{tabular}{ll}
\multicolumn{1}{c}{ Parameters } & Combined Wastes \\
\cline { 1 - 2 } Glass production rate, $\mathrm{kg} / \mathrm{h}$ & 190 \\
Glass in canister, $\mathrm{kg}$ & 833 \\
Lead in canister, $\mathrm{kg}$ & 5720 \\
Number of canisters & 3596 \\
Activity per canister, Ci & $9.5 \times 10^{3}$ \\
Decay heat per canister, W & 27 \\
Processing campaign length, d & 657
\end{tabular}

The equipment design is very similar to that described in Section 8.3. A marble-forming machine is located beneath each of the three LFCMS. The marble-production rate required for the combined waste option is $76 \mathrm{~kg} / \mathrm{h} /$ machine as compared to $36 \mathrm{~kg} / \mathrm{h}$ for the separated waste option. Approximately $60 \mathrm{~kg} / \mathrm{h}$ has been demonstrated with a prototypical marble machine at PNL (Platt and Powe 11 1980). This production rate may require a longer marble machine to achieve sufficient cooling before the marble is discharged from the cup mold. The size of the marble machines for the combined wastes option is estimated to be $1 \mathrm{~m}$ in width by $6 \mathrm{~m}$ in length by $3 \mathrm{~m}$ in height. These space requirements include the sorting hopper at the end of the marble 
machine, the dust-control hoods, and the scrap-recovery hopper. The scrap crushing and recycle is done in a separate crushing $\mathrm{mill}$ that occupies a space of approximately $1.5 \mathrm{~m} \times 2 \mathrm{~m}$. The estimated weight of the system is $1500 \mathrm{~kg}$.

There are two positions underneath each marble-machine sorter where the empty canisters are loaded with the marbles. A diverter nozzle in the sorter equipment switches the filling operation to an unfilled canister while a filled canister is being replaced. The space requirement for each of the fill stations is included in the marble-machine space requirements. A canister will take $11 \mathrm{~h}$ to fill. But with three parallel processes a canister changeout will be required every four hours.

There will be four lead-fill stations. This will allow $16 \mathrm{~h}$ to preheat the canister and the marbles, fill the canister with lead shot, melt the lead shot, top off with lead, and cool the canister from the bottom upwards. The description of the lead-filling operation is given in Section 8.3. The space requirements for lead-fill stations are $2 \mathrm{~m} \times 2 \mathrm{~m}$ and $4 \mathrm{~m}$ in height. The lead shot are loaded into delivery hoppers and are piped into the cell by gravity flow. An average of $518 \mathrm{~kg} / \mathrm{h}$ of lead short will be processed through each of four lead-handling stations.

Two lid-welding and helium leak-detection stations for the canisters are required. This will allow eight hours per canister for the lid-welding and lead detection operations. One station could conceivably handle the canister processing requirements in $3.7 \mathrm{~h}$, but two stations will prevent this station from becoming a processing bottleneck. The lid-welding/ leak-detection stations are the same as those described in Section 8.1.2. The space requirements are $2 \mathrm{~m}$ by $2 \mathrm{~m}$ and a height of $8 \mathrm{~m}$ for each station.

The filled canisters are transferred in batches of six at a time on a trolley car from the CPC to the EDR. The trolley must be unloaded and the unfilled canisters moved back into the CPC. This operation is carried out every $22 \mathrm{~h}$. In the CPC each canister must undergo final decontamination and loading into the site cask for transporting to onsite interim storage. Detailed scheduling of crane movement for decontamination and cask-ioading has not been determined, but processing canisters at this high rate may be difficult to carry out in the present facility.

\subsubsection{Status of Technology}

The status of technology for borosilicate glass production in an LFCM is given in Sections 8.2 and 9.1.3. The status of marbles-in-lead technology is described in section 8.3.3. This process technology can be implemented at the WNYNSC by 1987 , but it is uncertain whether the existing WNYNSC facility can be adapted to handle the canister-production rate required by this waste treatment option.

\subsubsection{Safety Considerations}

Many of the safety concerns of the marbles-in-lead process are associated with the complexity of the process and the high number of canisters that must be handled. There is a greater safety concern in the combined waste process approach as opposed to the salt/sludge separation approach because of the high waste-form production rate. 
The marble-machine operation requires a scrap-handling step. The glass marble is a relatively nondispersable form, however, a small quantity of glass dust and shards may be expected as well as a release of volatiles from the pouring-glass stream during operations. The marblemachine enclosure hood will tend to control these sources of cell contamination. Buildup of volatile deposits on the marble-machine enclosure hood may be a source of contaminants during maintenance of this system. A large, glass spill arising from malfunction of the marble machine would be contained within the scrap hopper, but would be more of a nuisance than a contamination source. Because the marble machine is considered a high maintenance device, occupational exposure is considered to be increased as a result of the additional equipment (three marble machines). The scrap-glass crusher is considered to be part of the marblemachine system for the purpose of this safety discussion.

Filling the canisters with marbles may also generate some dust, but with an air sweep over the canister neck, this source of cell contamination should be small. The waste form is nondispersable at this point and there is very little dispersive energy. Occupational exposure from maintenance of this equipment is expected to be low.

The lead-filling operation involves significant thermal energy. There is no mechanism for converting the thermal energy to mechanical energy unless water is used to cool the canister. A lead spill into water could lead to a steam explosion. A steam explosion increases the chance that a missile could breach the cell boundary (shielded windows or in-cell HEPA filters). For this reason forced air-cooling of the canisters is recommended. The lead-fill stations are not foreseen as requiring high maintenance and consequently should not significantly increase occupational exposure.

Transporting the large number of very heavy canisters within the cell is seen as an increased hazard to all process equipment. The feed system and melters contain the waste in a dispersable form. Crane maintenance will increase because of the heavy use of the $14.5 t$ crane imposed by this processing option. The increased crane maintenance will likely cause an increase in occupational exposure. The risk of physical injury from transporting so many heavy canisters in casks may be greater than the risk of radiation contanination or exposure.

\subsubsection{Facility Implementation}

A conceptual layout of the process equipment in the CPC for the marbles-in-lead waste form for combined alkaline Purex and acidic Thorex wastes is shown in Figure 9.5. All of the equipment required to implement this process will fit into the CPC. Equipment is more congested than desired, however. It is questionnable if the EDR can handle the canister throughput required for this waste treatment option within a three-year solidification campaign. Shifting the bulk of the off-gas equipment to an adjacent cell can ease this congestion. 
E1. HLLW FEED SYSTEM

E2. LFCM

E3. MARBLE-FORMING MACHINE

E4. CANISTER LID-WELD STATION

E5. CANISTER DECONTAMINATION (LOCATED IN EDR)

E6. CANISTER TRANSPORT CART
F. SECONDARY EFFLUENT EVAPORATION AND RECYCLE SYSTEM

G. OFF-GAS SYSTEM

M. LEAD FILL AND MELT FURNACES

R. GLASS-SCRAP RECOVERY AND RECYCLE SYSTEM

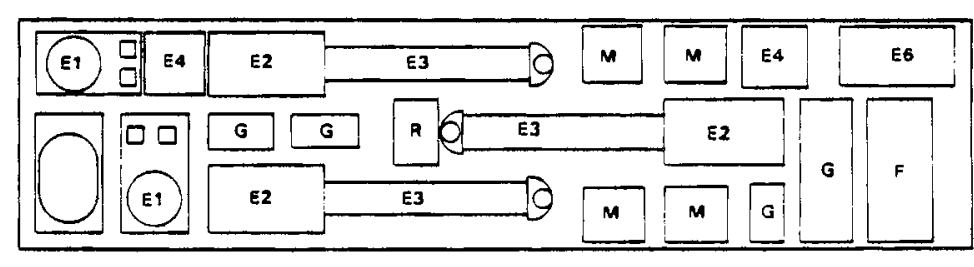

CHEMICAL PROCESS CELL

$2 m$

FIGURE 9.5. Conceptual Layout of the Equipment for the Marbles-In-Lead Process-Combined Alkaline Purex and Acidic Thorex Wastes 


\subsection{REFERENCES}

Chick, L. A. and C. Q. Buckwalter. 1980. Low Leach Rate Glasses for Immobilization of Nuclear Wastes. BNWL-2071. Pacifir Northwest Laboratory, Richland, Washington.

Holton, L. K., et al. 1980. "Alternatives for Vitrification of Existing Commercial High-Level Waste by Spray Calcination/In-Can Melting." Presented at ANS Topical Meeting, Waste Management 1980, March 10-14, Tuscon, Arizona.

Platt, A. M., and J. Powe 11. 1980. Nuclear Waste Management Quarterly Progress Report. PNL-3000-6, Pacif ic Northwest Laboratory, Richland, Washington. 


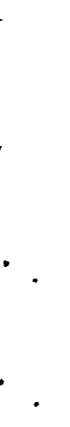


10.0 SOLIDIFICATION OF COMBINED ALKALINE AND ACIDIC THOREX WASTE USING INTERIM

WASTE FORIN PROCESSES

The four interim waste processes (fused salt process, silicate/salt matrix process, vinyl ester-styrene process, and calcine process) are described in this section. The reference waste processing approach assumes that the acidic Thorex waste will be blended into the alkaline Purex waste in the alkaline waste storage tank. This approach minimizes the process equipment requirements and simplifies the waste-transfer operations.

\subsection{FUSED SALT}

The fused-salt waste form is essentially composed of a fused mass of all the solids in both waste tanks. This waste form is produced by evaporating water from the blended contents of alkaline Purex and acidic Thorex wastes and then melting the wet slurry (salt cake) to form a fused-salt monolith upon cooling. The fused-salt product is less dispersible than the original, liquid waste product and should be compatible with final waste form processes. The properties of fused salt do not approach the anticipated requirements for a final nuclear waste torm however.

\subsubsection{Waste Form Properties}

Fused salt is an anhydrous material that is amorphous in structure and contains precipitated sludges and chemicals dispersed throughout the structure. There has not been significant development directed toward converting HLLW, particularly the WNYNSC waste, to a fused-salt form. Specific physical, chemical and radiological characteristics of the fused-salt waste form are not known. These properties may be inferred, however, from studies done by $S$. Vogler (ANL) with chemicals or radioactive wastes that are considered to have characteristics similar to the fused-salt form. There have been a number of other fused-salt studies on wastes including: Hanford (Kirkman and Godfrey 1969) and Savannah River Plant high-level wastes, Atomics International Molten Salt waste Treatment Process (McKenzie et al. 1975), and investigations on reprocessing spent nuclear fuels using molten salts (Long 1967, Chiotti 1969). Physical properties can also be inferred from properties of molten salts used for heat transfer.

The projected chemical composition of the fused-salt waste form is given in Table 10.1 . This fused-salt composition assumes that the acidic Thorex waste constituents are neutralized by free hydroxide ions in the alkaline waste. The product composition also assumes that the fused-salt melter operates at a temperature low enough that metal nitrates do not decompose.

Approximately 83 wt\% of the chemical components of the alkaline Purex and acidic Thorex waste blend are $(\mathrm{Na}, \mathrm{K}) \mathrm{NO}_{2} / \mathrm{NO}_{3}$. Other significant chemical components are $(\mathrm{Na}, \mathrm{K})_{2} \mathrm{SO}_{4}$, $\mathrm{Fe}(\mathrm{OH})_{3}, \mathrm{FePO}_{4}$, and $\mathrm{Th}\left(\mathrm{NO}_{3}\right)_{4}$. These chemicals comprise $97 \mathrm{wt} \%$ of the chemicals in the waste blend, excluding water. Sodium is the predominant cation (sodium to potassium ratio approximately 99 to 1 ) and nitrate is anticipated to be the dominant anion in the waste blend. Nitrite ion was produced by radiolytic nitrate decomposition. As a first approximation, fused salt is assumed to have physical and chemical properties similar to crystalline sodium nitrate. 
TABLE 10.1. Projected Composition of West Valley Fused Salt

\begin{tabular}{|c|c|}
\hline Component & We ight, $\mathrm{kg}$ \\
\hline $\mathrm{Na}_{2} \mathrm{SO}_{4}$ & 89,000 \\
\hline $\mathrm{Na} \mathrm{NO}{ }_{3} / \mathrm{NO}_{2}$ & $1,121,525$ \\
\hline $\mathrm{NaCl}$ & 500 \\
\hline $\mathrm{Fe}(\mathrm{OH})_{3}$ & 57,910 \\
\hline $\mathrm{FePO}_{4}$ & 29,750 \\
\hline $\mathrm{Cr}(\mathrm{OH})_{3}$ & 6,000 \\
\hline $\mathrm{Cr}\left(\mathrm{NO}_{3}\right)_{3}$ & 2,470 \\
\hline $\mathrm{Ni}(\mathrm{OH})_{2}$ & 2,450 \\
\hline $\mathrm{Ni}\left(\mathrm{NO}_{3}\right)_{2}$ & 990 \\
\hline $\mathrm{Al}(\mathrm{OH})_{3}$ & 1,950 \\
\hline $\mathrm{Al}\left(\mathrm{NO}_{3}\right)_{3}$ & 948 \\
\hline $\mathrm{AlF}_{3}$ & 1,570 \\
\hline $\mathrm{RE}(\mathrm{OH})_{3}(\mathrm{a})$ & 1,620 \\
\hline $\mathrm{FP}\left(\mathrm{SO}_{4}\right)^{(\mathrm{b})}$ & 1,240 \\
\hline $\mathrm{FP}(\mathrm{OH})_{4}^{4} \quad(\mathrm{~b})$ & 1,580 \\
\hline $\mathrm{FP}_{2} \mathrm{O}_{3}$ (b) & 430 \\
\hline $\mathrm{Na}_{3} \mathrm{PO}_{4} \quad 12 \mathrm{MoO}_{3}$ & 1,480 \\
\hline $\mathrm{MnO}_{2}$ & 2,200 \\
\hline $\mathrm{PuO}_{2}$ & 35 \\
\hline $\mathrm{Na}_{2} \mathrm{U}_{2} \mathrm{O}_{7}$ & 6,700 \\
\hline Act. $0 x i d e(c)$ & 20 \\
\hline $\mathrm{Th}(\mathrm{OH})_{4}$ & 13,310 \\
\hline TOTAL & $1.344 \times 10^{6}$ \\
\hline
\end{tabular}

(a) Rare earth hydroxides.

(b) Fission product sulphates, hydroxides, and oxides.

(c) Actinide oxides.

Sodium nitrite, potassium nitrate, and potassium nitrite, the other major species, also have physical and cnemical properties similar to those of sodium nitrate. The physical properties of sodium nitrate are summarized below:

\begin{tabular}{|c|c|}
\hline Chemical formula: & $\mathrm{NaNO}_{3}$ \\
\hline Molecular weight: & 85 \\
\hline Specific gravity: & 2.25 \\
\hline Melting point: & $307^{\circ} \mathrm{C}$ \\
\hline Decomposition temperature: & $3800_{C}$ \\
\hline $\begin{aligned} \text { Solubility, } & 25^{\circ} \mathrm{C} \text { water: } \\
& 100^{\circ} \mathrm{C} \text { water: }\end{aligned}$ & $\begin{array}{l}921 \mathrm{~g} / \mathrm{L} \\
1800 \mathrm{~g} / \mathrm{L}\end{array}$ \\
\hline Thermal conductivity: & $0.00565 \mathrm{~W} / \mathrm{cm}^{0} \mathrm{~K}$ \\
\hline
\end{tabular}


The density of solid $\mathrm{NaNO}_{3}$ is $2.25 \mathrm{~g} / \mathrm{cm}^{3}$ as determined by $\mathrm{x}$-ray measurements. At its melting point $\left(309^{\circ} \mathrm{C}\right.$ ) the density of fused $\mathrm{NaNO}_{3}$ is calculated to be $1.92 \mathrm{~g} / \mathrm{cm}^{3}$ (Bloom et al. 1953). Therefore caution has to be taken when melting fused $\mathrm{NaNO}_{3}$ because of the volume increase in going from solid to liquid.

Sodium nitrate decomposes at $520^{\circ} \mathrm{C}$ according to the following equation:

$$
2 \mathrm{NaNO}_{3} \rightarrow 2 \mathrm{NaNO}_{2}+\mathrm{O}_{2}
$$

Also, the sodium nitrite can decompose at $320^{\circ} \mathrm{C}$ (Weast 1973). It is reported that nitrates may explode when shocked, exposed to heat or flame, or by spontaneous chemical reaction (Sax 1979). However, more recent information (Breon et al. 1980) indicates that Hitec (a) and Draw (b) salts were stable at $550^{\circ} \mathrm{C}$ for more than $140 \mathrm{~h}$, even during exposure to about $10^{9} \mathrm{R}$ of garma radiation. Other studies at Hanford (Beitel 1976) indicated that waste salt cake alone could not be ignited even at temperatures up to $440^{\circ} \mathrm{C}$ and that reaction would occur only in the presence of reducing material. Nitrate-based salts are strong oxidizers and, in the presence of reducing materials, can detonate. In the absence of reducing agents, reaction rates are very slow. Extensive industrial use, especialiy with heat-transfer salts, has shown that molten salts can be handled safely under ordinary conditions.

Fused salts are soluble in water. Preliminary solubility experiments in still water at ambient temperature indicate that fused $\mathrm{NaNO}_{3}$ dissolves rapidly at a rate of approximately $0.05 \mathrm{~g} / \mathrm{min}-\mathrm{cm}^{2}$ (or a penetration rate of $0.02 \mathrm{~cm} / \mathrm{min}$ ).

The radiation stability of sodium nitrate is not as clear. Data (Johnson and Forten 1961; Hennig, Lees, and Matheson 1953) indicate that sodium nitrate has a $G$ value of approximately 0.2 molecule (for each $100 \mathrm{eV}$ of energy absorbed 0.2 molecule of oxygen is formed). With 3.3 $\times 10^{4} \mathrm{Ci}$ per canister, conservative calculations indicate that approximately 0.4 mole of oxygen is formed per day $(8.3 \mathrm{~L} / \mathrm{d})$. When formed, the oxygen remains trapped in the fused-salt lattice, and release of this oxygen usually requires elevated temperatures. However, the data indicate that the $G$ value falls off with larger amounts of energy absorbed (Hennig, Lees, and Matheson 1953). There are also indications that heating results in some back reaction of nitrite ion with oxygen to form nitrate ion, which can reduce the oxygen yield. No measurements have been taken over an extended time period. oxygen and hydrogen buildup can potentially pressurize the storage canister and cause release of radioactive contaminates. Some measurements will be necessary to confirm these calculations and to demonstrate that storage of the fused-salt high-level interim waste form canisters can be done safely.

Several experiments have been performed with the simulated WNYNSC fused-salt mixtures. As described by $S$. Vogler (ANL), simulated WNYNSC waste solution was prepared by dissolving the following salts in $50 \mathrm{~mL}$ of distilled water:

(a) Hitec 430 (E. I. du Pont De Nemours \& CO.), $53 \mathrm{wt \%} \mathrm{KNO}, 40 \mathrm{wt} \% \mathrm{NaOH}, 7 \mathrm{wt} \% \mathrm{NaNO}_{3}$. (b) Draw Temp 430 (E. F. Houghton \& $\mathrm{CO}$.), 50 wt\% $\mathrm{KNO}_{3}, 50 \mathrm{wt} \% \mathrm{NaNO}_{3}$. 


$$
\begin{aligned}
63.4 \mathrm{~g} \mathrm{NaNO}_{3} & (64 \mathrm{wt} \%) \\
27.2 \mathrm{~g} \mathrm{NaNO}_{2} & \left(27.4 \mathrm{wt}_{\%}\right) \\
7.5 \mathrm{~g} \mathrm{Na}_{2} \mathrm{SO}_{4} & (7.6 \mathrm{wt} \%) \\
1.0 \mathrm{~g} \mathrm{KOH} & (1.0 \mathrm{wt} \%)
\end{aligned}
$$

The water was then removed from the solution by evaporation, and three types of fused salt were prepared. One solution was heated to $220^{\circ} \mathrm{C}$ after the removal of the water and then was allowed to solidify. The second solution was prepared in the same manner except that $10 \mathrm{wt} \% \mathrm{Fe}_{2} \mathrm{O}_{3}$ was added before the salt was allowed to solidify. The third solution was similar to the first except that this solution was heated to $350^{\circ} \mathrm{C}$ before being allowed to solidify.

The rate of dissolution of fused salt in static water at room temperature was determined to be $0.03 \mathrm{~g} / \mathrm{cm}^{2}-\mathrm{min}$. Using the density of sodium nitrate $\left(2.25 \mathrm{~g} / \mathrm{cm}^{3}\right)$, a penetration rate of $0.013 \mathrm{~cm} / \mathrm{min}$ is derived.

Samples were impacted with up to $375 \mathrm{~J}$ (or $37.8 \mathrm{~J} / \mathrm{cm}^{3}$ ) of available energy, and approximately half the available energy was absorbed. The sample fractured in two sequences. First, the sample was broken into large particles absorbing approximately $10 \%$ of the available energy, then the remaining energy was absorbed during crushing. The three impacted samples yielded the following quantities of fines less than $10 \mathrm{um}$ in dia.

$\begin{array}{lll}\frac{\text { Sample Preparation Method }}{\text { Salt prepared by heating to } 220^{\circ} \mathrm{C}} & & \text { wt\% Fines } \\ \text { Salt prepared by heating to } 350^{\circ} \mathrm{C} & 0.0013 \\ \text { Salt prepared by heating to } 220^{\circ} \mathrm{C} & \\ +10 \text { wt\% } \mathrm{Fe}_{2} \mathrm{O}_{3} & 0.009\end{array}$

A reference canister containing $700 \mathrm{~L}$ of salt with an assumed total weight of $2.2 \mathrm{x}$ $10^{6} \mathrm{~g}$ and involved in an impact accident at $35.8 \mathrm{~m} / \mathrm{sec}(80 \mathrm{mph}$ ) would be subjected to an energy input of $\sim 2 \mathrm{~J} / \mathrm{cm}^{3}$. Since the respirable fractions and new surface areas are approximately proportional to the amount of energy absorbed (above the threshold), experimental results represent conservative estimates of impact consequences.

\subsubsection{Process System Description and Material Balance}

A schematic diagram of the fused-salt process is shown in Figure 10.1. Schematic concepts for removing the fused salt from the canister for processing into a final form for disposal are shown in Figure 10.2 .

B lended alkaline Purex and acidic Thorex waste are transferred from the tank farm to a feed-hold and blending tank located inside the CPC. In the feed-blending tank the waste blend is cnemically adjusted, if required, and sampled for a material balance. The blended waste is transferred at ambient temperature to the feed tank for the wiped-f $i$ lm evaporator. The blended waste is then siurried at a controlled rate to the wiped-film evaporator, where it is concentrated to a paste containing approximately $50 \mathrm{wt \%}$ water. This paste drops into a container located inside a melting furnace (in-can melter). The high water content of the waste blend minimizes potential evaporator wear and pluggage problems and maintains good heat-transfer efficiency. In the melter the canister contents are heated to about $380^{\circ} \mathrm{C}$ to $\mathrm{drive}$ off the 


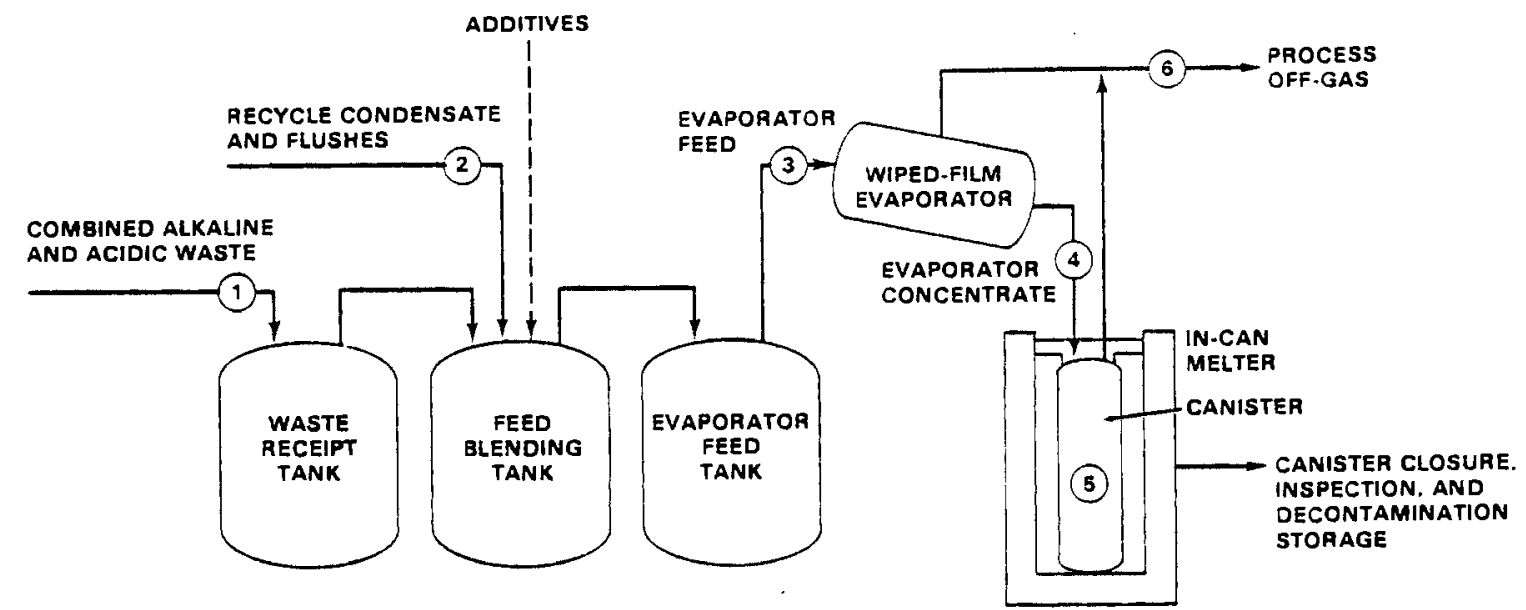

FIGURE 10.1. West Valley HLLW Fused-Salt Process Flow Diagram

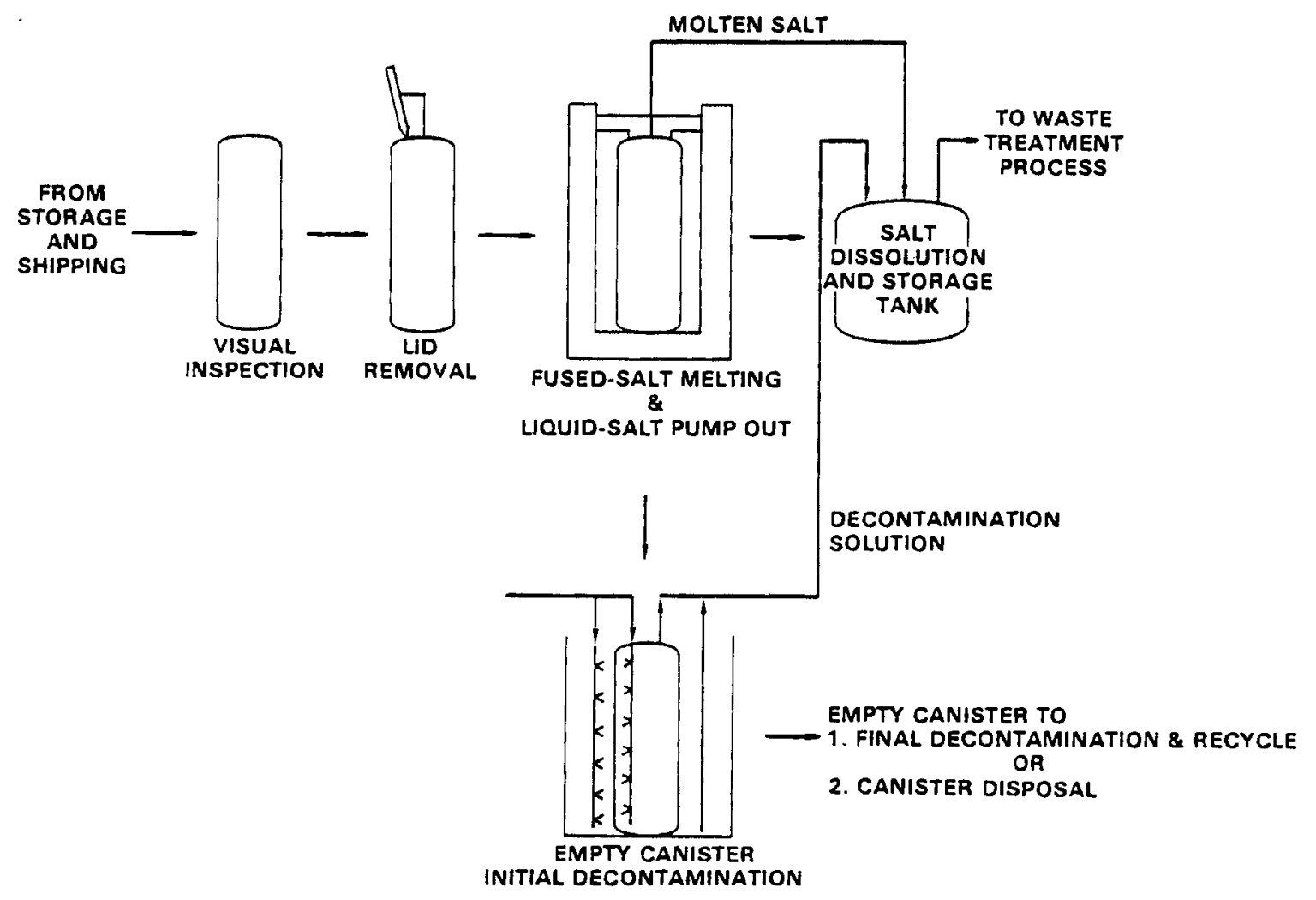

FIGURE 10.2. West Valley HLLW Fused-Salt Removal from Canister Process Flow Diagram

remaining water and to melt the waste into a monolithic cake. No water from hydration of the salts is assumed to be in the final salt-cake product. The melter can be zone heated and cooled to minimize the settling of high density particles on the bottom of the canister. On completion of canister filling, the fill spout is flushed with water to remove salt buildups. Then the fill spout is removed from the canister. After the flush water has evaporated the 
canister is removed from the melter and a lid is placed on the canister. The lid is then seal welded, and the canister weld is examined. A vent may be required on the canister to release gasses produced from radiolytic decay of nitrate/nitrite. Finally the canister is visually inspected for integrity and is decontaminated before being placed in interim storage for eventual shipment to the final processing site.

The fused-salt waste form will be converted to a terminal waste form at another wastesolidification facility. The fused-salt canister is shipped to the final processing site, removed from the shipping cask, inspected, and decontaminated, if necessary. Then the seal weld is mechanically removed from the lid. The opened canister is placed into an in-can melter furnace, and the canister heated to melt the salt cake. The contents are pumped (pump installed into canister after the contents are melted) or removed via steam-jet and transferred to a receiver tank that contains water or acidic solvent. The empty canister is decontaminated internally with an installed spray bar. The decontanination solution is added to the saltsolution receiver tank. Dissolved salt-cake slurry can then be combined with on-site waste for processing or processed separately to produce a terminal waste form product. It is expected that this slurry will be compatible with defense-site waste-processing schemes to produce a terminal waste form. The canister may then be further decontaminated, if necessary, for reuse or disposal.

The wiped-film evaporator and in-can melter are similar to equipment that have been adapted to fully remote canyon operation. No manipulator operations are required or associated with these process operations. However, since the wiped-film evaporator has mechanical rotating parts, it may require more maintenance than other pieces of process equipment, with the possible exception of pumps. Thus, the evaporator and evaporator/melter connecting section should be designed so that they are readily accessible for flushing and removal. The in-can melter process developed at PNL was selected for the fused-salt melter because of its simplicity and advanced state of development for solidifying high-level waste.

The only unique process control feature of the melter system is the use of a gammaemission detection system in the cell wall to determine the fused-salt level in the canister. This detection system can be supplemented by weighing, material balances, and temperature detection gas-bubble-pressure differential measurements, if desired. This process control technology has been demonstrated at PNL.

The off-gas system of the reference vitrification process (Appendix $A$ ) was used as a basis for designing the fused-salt off-gas system. The size of equipment could be somewhat reduced since there is a smaller quantity of air flow in the process off gas. The No destructor may not be needed if the melter temperature is maintained below $400^{\circ} \mathrm{C}$. Additional assessment needs to be done to determine if the iodine and ruthenium sorption processes are required.

Other unit processes needed to support the fused-salt process are: the recycle and secondary evaporation process, the secondary off-gas treatment, and the canister-handling and processing equipment. These unit processes are similar to those required for the reference borosilicate glass waste-form process (Appendix A). 
The material balance for the fused-salt process is given in Table 10.2. The stream identification numbers on the material balance refer to the process flow diagram (Figure 10.1). The overall summary of the fused-salt waste form process is given in Table 10.3.

The decay-heat rate of the fused-salt canisters is $\sim 103 \mathrm{~W}$. This heat load would result in a centerline canister temperature of 60 to $70^{\circ} \mathrm{C}$, and a surface temperature of $52^{\circ} \mathrm{C}$ at an ambient air temperature of $50^{\circ} \mathrm{C}$. The dose rate at the canister surface based on a simplified model is estimated to be $280 \mathrm{R} / \mathrm{h}$.

The reference fused-salt process assumes that the fused-salt melter furnace operates at $380^{\circ} \mathrm{C}$, primarily to minimize $\mathrm{NaNO}_{3}$ decomposition. The waste canister does not have internal heat-transfer fins. Preliminary estimates indicate that from 5 to 10 melters may be

TABLE 10.2. Process Conditions and Material Balance Data for Solidifying Combined Alkaline Purex and Acidic Thorex waste in a Fused Salt

\begin{tabular}{|c|c|c|c|c|c|c|}
\hline Stream Number $(c)$ & $\begin{array}{l}\frac{1}{\text { Alkaline }} \\
\text { Waste } \\
\text { Blend } \\
\end{array}$ & $\begin{array}{c}\frac{2}{\text { Recycle }} \\
\text { and } \\
\text { Flushes } \\
\end{array}$ & $\frac{3}{\begin{array}{c}\text { Evaporator } \\
\text { Feed (d) }\end{array}}$ & $\begin{array}{l}4 \\
\text { Evaporator } \\
\text { Concentrate }\end{array}$ & $\frac{5}{\begin{array}{c}\text { Fused-Salt } \\
\text { Product }(a)\end{array}}$ & $\begin{array}{c}6 \\
\text { Process } \\
\text { Off Gas }\end{array}$ \\
\hline \multicolumn{7}{|l|}{ Flow, $\mathrm{kg} / \mathrm{hr}$} \\
\hline Salt & 78.5 & -- & 78.5 & 78.5 & 78.5 & 0.016 \\
\hline Solids & 6.3 & $\cdots$ & 6.3 & 6.3 & 6.3 & 0.001 \\
\hline $\mathrm{H}_{2} \mathrm{O}$ & 150 & 25 & 175 & 85 & & 175 \\
\hline $\mathrm{NO}_{\mathrm{X}}$ & -- & -- & -- & -- & -- & $0-35^{(b)}$ \\
\hline Total & 234.8 & 25 & 259.8 & 170 & 106 & 175 \\
\hline Temperature, ${ }^{\circ} \mathrm{C}$ & Ambient & Ambient & Ambient & $\sim 130$ & Ambient-380 & 130 \\
\hline Density, $\mathrm{g} / \mathrm{cm}^{3}$ & 1.57 & 1.0 & 1.48 & $\sim 1.7$ & 2.0 & --- \\
\hline Flow, L/h & 150 & 25 & 175 & 85 & 53 & $\cdots$ \\
\hline Activity, Ci/L & 14.4 & Negligible & 12.3 & 25.4 & 40.7 & $(2.1 \mathrm{Ci})$ \\
\hline Heat, $W / L$ & 0.041 & 0 & 0.037 & 0.073 & 0.118 & \\
\hline
\end{tabular}

(a) Only water of hydration left estimated at $20 \mathrm{wt} \%$.

(b) Depending on mode of melter operation, $\mathrm{NO}_{x}$ could be from 0 up to $35 \mathrm{~kg} / \mathrm{hr}$.

(c) Stream numbers refer to streams in $F$ igure 10.1 .

(d) Total for six evaporators.

TABLE 10.3. Fused-Salt Waste-Form Process Summary, Solidification of Combined Alkaline Purex and Acidic Thorex Wastes

\begin{tabular}{lll}
\multicolumn{1}{c}{ Process Characteristics } & & Fused-Salt Wast \\
\cline { 1 - 2 } Fused-salt-production rate, $\mathrm{kg} / \mathrm{h}$ & & 106 \\
Number of fused-salt canisters & & 944 \\
Activity per canister, $\mathrm{Ci}$ & $3.6 \times 10^{4}$ \\
Decay heat per canister, watt & & 103 \\
Specific gravity salt cake & & 2.0 \\
Dose rate at canister surface, $\mathrm{R} / \mathrm{h}$ & & 300 \\
Processing campaign length, days & & 657
\end{tabular}


needed to achieve the required production rates to satisfy a three-year processing campaign length. Improving the process heat-transfer rate by either raising the process operating temperature or using heat-transfer fins within the canister can reduce the number of fused-salt melters. Increasing the operating temperature will result in nitrate/nitrite decomposition requiring more gaseous effluent treatment. Adding heat-transfer fins will increase the number of fused-salt canisters produced by approximately 10\%, or an additional 100 canisters. Additional process development is needed to accurately determine the cost-effective operating parameters and equipment requirements of the process.

\subsubsection{Status of Technology}

Technology related to producing fused salt as a high-level radioactive waste form has been studied to a limited extent, however, the technology has not been demonstrated.

In-tank solidification, using external evaporators to remove the water, has been used at Hanford to solidify aged high-level wastes from which most of the heat-emitting isotopes have been removed (Kirkman and Godfrey 1969, Petrie et al. 1975). The solidified salt cakes are stored in large, underground, mild steel tanks (up to $3800 \mathrm{~m}^{3}$ ) filled to a height of 5 to $7 \mathrm{~m}$ with salt cake, depending on the heat load. Approximately $140,000 \mathrm{~m}^{3}$ of salt cake will be accumulated by the completion of the program in the early 1980's (Schultz et al. 1975). A typical composition range of this salt cake is 70 to $96 \mathrm{wt \%} \mathrm{NaNO}, 2$ to $10 \mathrm{wt \%} \mathrm{NaNO}, 0$ to 5 wt\% $\mathrm{NaOH}, \mathrm{O}$ to $5 \mathrm{wt} \% \mathrm{NaAlO}_{2}$, and 2 to $10 \mathrm{wt} \% \mathrm{Na}_{2} \mathrm{CO}_{3}$. The salt cake also contains small amounts of saturated terminal liquor, estimated to be 5 to $10 \mathrm{wt \%}$.

Recent pilot-scale studies (Fox 1975) have shown that synthetic terminal liquor, a highly alkaline sodium-nitrate/nitrite solution, can be evaporated to as little as 25 wt\% water at feed rates up to $60 \mathrm{~L} / \mathrm{h}$ in a wiped-film evaporator with $0.46 \mathrm{~m}^{2}$ of heat-transfer surface. Although the low-water-content products were fluid when discharged, they solidified at room temperature with no visible free water. A similar performance has been demonstrated at the SRL with synthetic Savannah. River Plant and Hanford alkaline salt wastes (Goodlett 1975). Feed rates for the SRL unit $\left(0.92 \mathrm{~m}^{2}\right.$ heat-transfer surface) were about $70 \mathrm{~L} / \mathrm{h}$. There has been significant wiped-film and other evaporator development and application for radioactive waste concentration (Dierks and Bonner 1975; Godbee 1973; Goodlett 1979; Goodlett 1978a; Goodlett 1976; Goodlett 1978b).

The in-can melter (Blair 1979; Larson and Bonner 1976; Wheelwright et al. 1979) and jouleheated melter (Buelt and Chapman 1979; Buelt and Chapman 1978) processes for high-level-waste vitrification have been demonstrated at PNL. This technology is similar to that needed for molten-salt production. Molten-salt technology in support of ANL's pyrometallurgical processes for EBR-II fuel reprocessing, Hanford's Salt Cycle Process, and ORNL's molten-salt reactor is well developed (Long 1967; Chiotti 1969). The melt-casting technique for preparing radioactive cesium chloride capsules has been in use for about a year by Atlantic Richfield Hanford Company (Braden et al. 1971).

of more immediate application to waste disposal, Atomics International has prepared and cast 1000 - to $1500-\mathrm{kg}$ blocks of ash-containing salt as part of their molten salt combustion process development (McKenzie et al. 1975). The blocks, containing about 50 wt\% $\mathrm{Na}_{2} \mathrm{CO}_{3}$, 
10 wt\% $\mathrm{Na}_{2} \mathrm{SO}_{4}, 20 \% \mathrm{NaCl}$, and $20 \%$ ash, are cast directly into a stainless steel cart, cooled to solidify (freezing point about $720^{\circ} \mathrm{C}$ ), and dumped out. Several months of nonradioactive operation have been demonstrated without evidence of corrosion to the cart. Smalier drums of salt can be cast by a similar technique if desirable.

The only significant industrial use of liquid salts, such as sodium nitrate mixed with other salts, is as a heat-transfer medium in the fluid state. However, there has been a substantial amount of waste form processing development that applies to fused-salt waste processing. Therefore, it can be regarded as a form and process for which much technology has been basically developed. These related programs include conversion of high-level waste to saltcake, glass, and calcine forms. A recent program has been undertaken at ANL to further develop fused salt as a waste form and to apply the associated process to the West valley waste.

The suitability of fused-salt monoliths as an interim waste form and long-term storage media needs to be determined with regard to waste-form properties and behavior. Application of salt-matrix techniques for solidification of specific salts or salt solutions requires laboratory and pilot-plant development. Future investigations could include optimum salt compositions, materials of construction, casting techniques, etc.

\subsubsection{Safety Considerations}

The fused-salt process is a simple process that has low potential for consequential accidents and damage to the environment.

The fused-salt process, as described here, has not been developed as an integrated process for high-level radioactive waste solidification. However, general technology for radioactive waste concentration by evaporation in wiped film and other evaporators has been developed and demonstrated over the last 20 to 30 years. High-level-waste solidification by in-can melting has been under development and demonstration at PNL for about 15 years. General technology for handling and processing molten salts has been under development for many years for heattransfer media, molten-salt reactor fuel and fuel reprocessing, and low-level-waste treatment. Thus, although the fused-salt process has not been specifically developed for high-level waste, the technology can be regarded as well advanced and demonstrated. But for specific application to West Valley waste, an integrated equipment demonstration is recommended. The literature reviewed did not indicate any particular hazard potential beyond those normally encountered in radiochemical processing.

For radionuclide processing facilities, there are no unique hazards associated with the fused-salt process. The waste is always at least doubly contained before contact with operating personnel and triply contained before access to the general public. The process operates at up to $400^{\circ} \mathrm{C}$ to $550^{\circ} \mathrm{C}$ at nearly atmospheric pressure and produces a monolithic product of low, mechanical strength. The effluents generated are not particularly hazardous when compared with higher temperature processes since there is little chemical decomposition, radionuclide volatilization. or dilution air. Process effluents are minimal (waste condensate and possibly melter cooling air). The effluents and potential accident production sources are 
minimal and process systems, backup process systems, and multiple containment could easily cope with postulated incidents. The number of equipment pieces are few and their complexity is minimal.

Normal process dispersive forces include pressurized transfer of feeds and process temperatures up to 400 to $550^{\circ} \mathrm{C}$. This dispersion potential is typicaliy encountered in remote, radiochemical, facility operations and is not felt to be of significant hazard potential.

The most significant hazard potential would be an explosion or pressurization in the in-can melter. (The evaporator is operated at a sufficientiy low temperature that an explosion is highly unlikely.) The melter explosion could be postulated by organic contaminants in the feed being vaporized and exploding. The chance of this happening is highly remote due to the melter environment being mostly water vapor and the nitrates in the melter being fairly stable. However, if the explosion did occur, it would be contained by the waste container, the melter, and then the cell, in addition to other building containment systems. Another accident of some probability would be a rotating part on the wiped film evaporator coming off of the assembly. In this case, the part would be contained in the evaporator shell. One other accident could be the loss of melter-temperature control causing a product container breach and radionuclide volatility. This accident is highly unlikely since there would be a number of safety systems included to prevent this occurrence, but even if it did happen the consequences would be limited to loss of salt product to the floor and perhaps a small loss of volatile radionuclide.

Accidents with severe consequences that could be postulated for this system are highiy unlikely. The system is simple and appears to be safe. The product is a monolith, and even if the container is breached while the product is molten or solid, there is low potential for radionuclide dispersal. The safety of long-term (50 yr) storage of the canisters needs to be assessed with regard to gas generation from radiolysis of water or nitrate/nitrate. Venting of the canisters is possible; however, the environmental consequences need to be assessed.

The only process-related environmental impact is the release of effluents and discarding some wastes for controlled disposal. Routine effluent and waste releases are minimal and have no significant impact on the environment or population. Effluent releases are limited to process condensate that is treated for removal of hazardous materials before release. There are no significant hazardous chemicals used or generated in the process; no radionuclides are volatilized with the possible excention of indine and ruthenium; and no dilution or vehicle gases and materials are used in the process. There is a very limited amount of particulate entrainment in the process off-gas; however, the process off-gas system is designed to remove these particulates with a high degree of efficiency.

\subsubsection{Facility Implementation}

A conceptual layout of this process in the CPC is presented in Figure 10.3. The equipment layout is based on a conservative case where six fused-sait modules are needed to meet the capacity of $175 \mathrm{~L} / \mathrm{h}$ of blended feed. All of the modules can be placed in the CPC with other equipment modules needed to perform the waste solidification (Figure 10.3). The fused-salt process module consists of a melter, wiped-film evaporator, evaporator feed tank, venturi 
A. HLLW RECEIVING TANKS

B. WASTE FEED BLENDING TANKS

C. FUSED-SALT PROGRESS MODULE

1. IN-CAN MELTER

2. WIPED-FILM EVAPORATOR

3. CANISTER TRANSFER CART

4. EVAPORATOR FEED TANK

5. CONDENSATE RECEIVER TANK,

VENTURI SCRUBBER, HEAT EXCHANGER, DEMISTER
E4. CANISTER LID-WELD STATION

E5. CANISTER DECONTAMINATION

E6. CANISTER TRANSPORT CART

F. RECYCLE AND SECONDARY EVAPORATION

G. OFF-GAS TREATMENT SYSTEM

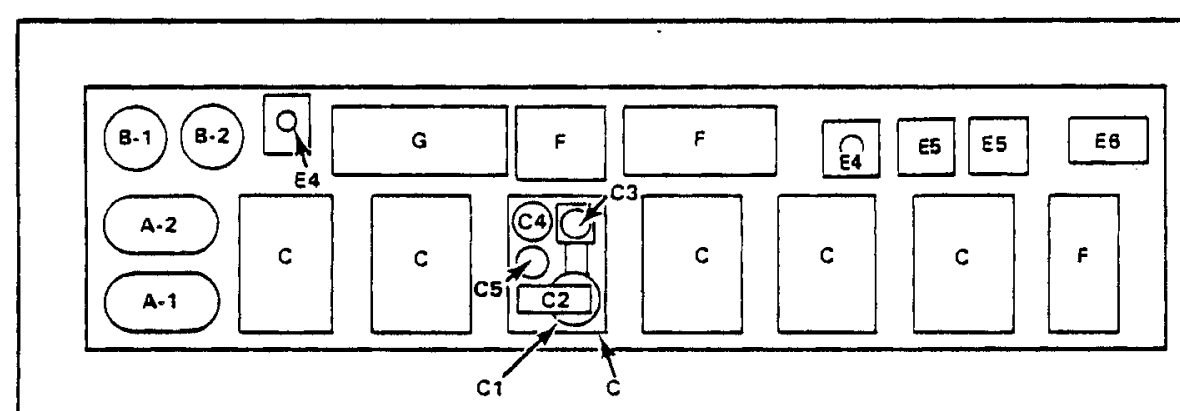

$2 \mathrm{~m}$

FIGURE 10.3. Conceptual Equipment Layout of the Fused-Salt Process

scrubber, heat exchanger, demister and a condensate receiver unit for initial off-gas treatment. Process development and optimization may show that only two or three fused-salt modules of higher capacitr will be needed to achieve the desired capacity.

Maintenance on the fused-salt and feed modules will be done using a crane with two mounted television cameras. Routine operations will be done from the gallery and control room with the crane or remote controls.

\subsection{SILICATE/SALT PROCESS}

A large number of waste form variations are included in the generic silicate/salt matrix product. The reference silicate/salt form consists of blended alkaline nuclear waste included within an aluminosilicate clay matrix. The mineral matrix serves multiple purposes including: acting as a binding medium, physically entrapping waste chemicals in the clav/crystalline matrix structure, and sorption of waste radionuclide ions on the clay. The reference process is the "clay-rich" aqueous-silicate process (Barney and Brownell 1977) that has been developed at the Atlantic Richfield Hanford Company on a laboratory scale with radioactive and nonradioactive waste materials (Barney 1974; Barney 1975; Delegard and Barney 1975; Barney 1976).

The silicate/salt matrix is produced by concentrating the waste, mixing the waste with an aluminosilicate clay, and after chemical adjustment with caustic, forming the waste into pellets for curing at an elevated temperature. The production process is relatively complicated when compared to the fused-salt process, primarily due to the increased number of processing steps and associated equipment involved. It is advantageous to form the silicate/salt matrix into pellets instead of a monolith to enable waste removal from the storage container required 
for incorporation of the product into glass or other acceptable terminal waste forms. The silicate/salt matrix is anticipated to be compatible with glass and certain ceramic waste form compositions. The silicate/salt waste form product is very adaptable to waste composition changes. The process is moderately expensive, safe, and produces little effect on the environment during waste processing.

\subsubsection{Waste Form Properties}

The reference silicate/salt matrix in this study is a mixture of alkaline waste blend and aluminosilicate clay that is formed into pellets and cured. The waste salts are included in the loose matrix structure. Selected cations and anions are sorbed on mineral exchangers and trapped in a crystalline structure (cancrinite), which is formed in the curing process. Clay is used as a pellet-binding medium.

In this process powdered aluminosilicate clays such as kaolin or bentonite are mixed and allowed to react with aqueous solutions or slurries of caustic waste at temperatures in the range of 30 to $100^{\circ} \mathrm{C}$. The reaction produces a salt-filled sodium aluminosilicate with radioactive isotopes trapped in an aluminosilicate framework. For wastes that contain nitrate ion, the mineral product has the framework of cancrinite. The anticipated composition of the silicate/salt matrix based on At lantic Richfield Hanford Company (ARHCO) studies is shown in Table 10.4 .

In the reference clay-rich process an aluminosilicate mineral is mixed with the blended WNYNSC waste that has been chemically adjusted to greater than $2 \mathrm{M} \mathrm{NaOH}$. One gram of calcined bentonite clay is blended with one liter of waste slurry to produce a final product with a volume of about $1.5 \mathrm{~L}$. The mixed product has a consistency similar to that of paste. On curing, cancrinite crystals, about $0.5 \mathrm{\mu m}$ in dia, form in the matrix, which traps cesium and other radionuclides. The formation of cancrinite crystals requires about 2 moles of $\mathrm{NaOH}, 0.5$ mole of $\mathrm{NaNO}_{3}$ and 0.7 mole of water per mole of kaolinite or bentonite as shown in the chemical reactions below:

$$
\begin{aligned}
& \mathrm{Al}_{2} \mathrm{Si}_{2} \mathrm{O}_{7} \cdot 2 \mathrm{H}_{2} \mathrm{O}+2 \mathrm{NaOH}+0.52 \mathrm{NaNO}_{3}+0.68 \mathrm{H}_{2} \mathrm{O}- \\
& 2\left(\mathrm{NaAlSiO}_{4}\right) 0.52 \mathrm{NaNO}_{3} 0.68 \mathrm{H}_{2} \mathrm{O}+3 \mathrm{H}_{2} \mathrm{O}- \\
& \mathrm{Al}_{2} \mathrm{Si}_{4} \mathrm{O}_{11} \cdot \mathrm{H}_{2} \mathrm{O}+2 \mathrm{NaOH}+0.52 \mathrm{NaNO}_{3}+0.68 \mathrm{H}_{2} \mathrm{O}- \\
& \text { (montmorillonite) } \\
& 2\left(\mathrm{NaAlSiO}_{4}\right) 0.52 \mathrm{NaNO}_{3} 0.68 \mathrm{H}_{2} \mathrm{O}+2 \mathrm{H}_{4} \mathrm{SiO}_{4} \\
& \text { (cancrinite) }
\end{aligned}
$$

Other salts in addition to $\mathrm{NaNO}_{3}$ can be trapped in the structure. The reaction rate to produce the cancrinite mineral is highly temperature sensitive in the range of $50^{\circ} \mathrm{C}$ to $100^{\circ} \mathrm{C}$. The reaction at $100^{\circ} \mathrm{C}$ is essentially complete within $1.3 \mathrm{~h}$. Complete curing and drying of the product to a solid product will be governed by drying conditions (temperature) and the characteristics of the product (geometry, mass, porosity, water content). 
TABLE 10.4. Projected Silicate/Salt Matrix Composition

\begin{tabular}{|c|c|}
\hline Component & We ight, $\mathrm{kg}$ \\
\hline $\mathrm{Na}_{2} \mathrm{SO}_{4}$ & 89,000 \\
\hline $\mathrm{NaNO}_{3} / \mathrm{NO}_{2}$ & $1,121,525$ \\
\hline $\mathrm{NaCl}$ & 500 \\
\hline $\mathrm{Fe}(\mathrm{OH})_{3}$ & 57,910 \\
\hline $\mathrm{FePO}_{4}$ & 29,750 \\
\hline $\mathrm{Cr}(\mathrm{OH})_{3}$ & 6,000 \\
\hline $\mathrm{Cr}\left(\mathrm{NO}_{3}\right.$ & 2,470 \\
\hline $\mathrm{Ni}(\mathrm{OH})_{2}$ & 2,450 \\
\hline $\mathrm{Ni}\left(\mathrm{NO}_{3}\right)_{2}$ & 990 \\
\hline $\mathrm{Al}(\mathrm{OH})_{3}$ & 1,950 \\
\hline $\mathrm{Al}\left(\mathrm{NO}_{3}\right)_{3}$ & 948 \\
\hline $\mathrm{AlF}_{3}$ & 1,570 \\
\hline $\mathrm{RE}(\mathrm{OH})_{3}$ (a) & 1,620 \\
\hline $\mathrm{FP}\left(\mathrm{SO}_{4}\right)^{(\mathrm{b})}$ & 1,240 \\
\hline $\mathrm{FP}(\mathrm{OH})_{4}^{4} \quad(\mathrm{~b})$ & 1,580 \\
\hline $\mathrm{FP}_{2} \mathrm{O}_{3}^{(b)}$ & 430 \\
\hline $\mathrm{Na}_{3} \mathrm{PO}_{4} \quad \mathrm{I}_{2} \mathrm{MOO}_{3}$ & 1,480 \\
\hline $\mathrm{MnO}_{2}$ & 2,200 \\
\hline $\mathrm{PuO}_{2}$ & 35 \\
\hline $\mathrm{Na}_{2} \cup_{2} \mathrm{O}_{7}$ & 6,700 \\
\hline Act. Oxide $(c)$ & 20 \\
\hline $\mathrm{Th}(\mathrm{OH})_{4}$ & 13,310 \\
\hline $\mathrm{NaOH}$ & $1.0 \times 10^{5}$ \\
\hline Bentonite (or Kaolin) & $2.2 \times 10^{6}$ \\
\hline Waste Water & $1.6 \times 10^{6}$ \\
\hline Waste Product Weight & $5.2 \times 10^{6} \mathrm{~kg}$ \\
\hline \multicolumn{2}{|c|}{$\begin{array}{l}\text { (a) Rare-earth hydroxides. } \\
\text { (b) Fission product hydroxides, } \\
\text { suiphates and oxides. } \\
\text { (c) Actinide oxides. }\end{array}$} \\
\hline
\end{tabular}

In addition to the "clay-rich" process described here, two variations of this process have also been developed to a limited extent. These two processes are the lean-clay process and the clay-calcination process. These process variations require more process steps and equipment. These variations result in a waste form product with improved properties, such as leachability and hardness, over the clay-rich product; however, these improvements were not deemed to be sufficient in this study to warrant this waste form as a reference case.

There is the potential of significantly improving the clay-rich product leachability by adding radionuclide-specific sorption materials, such as zeolites (clinoptilolite and Linde AW-500) which are structurally similar to the clays in the process. These zeolites have been 
shown to be very effective in sorbing radioactive cesium and strontium in neutralized highlevel-waste solutions (Buckingham 1967). The clay-rich process is similar to the process for making ion-exchange materials (pellets) for industrial ion-exchange use. However, this modification of the clay-rich process has not been experimentally explored.

Some anticipated physical properties of the silicate/salt matrix are summarized in Table 10.5. These properties are expected to be typical of the clay-rich aqueous-silicate process studied at ARHCO.

The properties for the WNYNSC alkaline-waste silicate/salt product could vary significantly from those indicated in Table 10.5. This is due primarily to the low sodium-hydroxide content of the waste. The formation of cancrinite and other product properties such as hardness are dependent on product reactions involving sodium hydroxide. Therefore the product is anticipated to be improved by the addition of sodium hydroxide. Except for the low, sodium hydroxide level, the chemical composition of the blended alkaline WNYNSC waste has roughiy the same general chemical composition as the Hanford wastes studied.

At lantic Richfield Hanford Company studies evaluated several flowsheets for solidifying NFS supernatant solutions using aqueous-silicate reactions. Results have been reported in ARHCO quarterly progress reports (Campbell and Kupfer 1974). Highlights of the findings are summarized here:

- A synthetic NFS waste will form satisfactory aqueous-silicate products, but only after additional caustic is added to the waste. Cancrinite will form only when the additional caustic is introduced.

- Waste volume increases for products in this clay-rich process range from 70 to $85 \%$.

TABLE 10.5. Properties of HLW Silicate/Aqueous Product

\begin{tabular}{|c|c|c|c|}
\hline Flowsheet Alternative & $\begin{array}{l}\text { Leach Rate, } \\
\mathrm{g} / \mathrm{cm}^{2} \text {-day }\end{array}$ & $\begin{array}{c}\text { Volume } \\
\text { Increase, } \%\end{array}$ & $\begin{array}{c}\text { Hardness } \\
\mathrm{kg} / \mathrm{cm}^{2}\end{array}$ \\
\hline \multicolumn{4}{|l|}{ Cancrinite plus excess clay $(b)$} \\
\hline Kaolin & $0.6-10^{-2}$ & 26 & $10->45$ \\
\hline Calcined kaolin & $0.3-10^{-2}$ & 20 & $>45$ \\
\hline Bentonite & $10^{-2}-10^{-4}$ & 32 & $3-10$ \\
\hline Calcined bentonite & $10^{-2}-10^{-3}$ & 26 & $>45$ \\
\hline \multicolumn{4}{|l|}{ Washed cancrinite plus binder } \\
\hline Calcined kaolin & $10^{-2}-10^{-4}$ & 60 & $>45$ \\
\hline Calcined bentonite & $10^{-3}-10^{-4}$ & 25 & $>45$ \\
\hline \multicolumn{4}{|c|}{ Nepheline from fired clay product } \\
\hline Kaoline & $10^{-3}-10^{-4}$ & 25 & $>45$ \\
\hline Bentonite & $10^{-4}-10^{-5}$ & 30 & $>45$ \\
\hline
\end{tabular}

(a) A hardness index measured by a soil penetrometer.

(b) Synthesized at a clay/waste ratio of $1.0 \mathrm{~g} / \mathrm{mL}$. 
- Several synthetic NFS aqueous-silicate products were subjected to $200^{\circ} \mathrm{C}$ to $500^{\circ} \mathrm{C}$ temperatures for three weeks to investigate their thermal stabilities. All samples showed loss of water due to heating. Samples containing excess sodium nitrate showed some thermal decomposition of the sodium nitrate at $500^{\circ} \mathrm{C}$.

- Using a gamma-irradiation facility, a dose of $8 \times 10^{9}$ rads (about twice the expected ${ }^{137}$ Cs radiation estimated for an NFS aqueous-silicate product) was administered to several NFS aqueous-silicate product samples. For those samples containing excess sodium nitrate, significant radiolys is of the excess sodium nitrate occurred. The cancrinite suffered no alteration or transformation in testing of both the heated and the irradiated samples.

Properties of various clay-waste mixtures having varied concentrations of caustic are listed in Table 10.6. These data show that a significant increase must be made in caustic concentration over that of NFS supernate $(0.17 \mathrm{M} N \mathrm{NOH})$ to achieve a relatively hard product (20 $\mathrm{kg} / \mathrm{cm}^{2}$ hardness).

Leach rates for the products depend strongly on the processing mode used. Solid products prepared from actual Hanford terminal waste solution had extended bulk leach rates of about $10^{-2}$ to $10^{-3} \mathrm{~g} / \mathrm{cm}^{2}-d$ for the clay-rich process, 1 to $4 \times 10^{-4}$ for the lean-clay process (using a portland cement binder), and 2 to $6 \times 10^{-4}$ for the clay-calcination process, based on ${ }^{137} \mathrm{Cs}$ in the leachate.

Forty-nine commercially available clays were reacted by the clay-rich process to compare product quality and to aid in eliminating clays that yielded soft products, high-product volumes, or products with low-liquid sorptive capacity. Calcined and uncalcined kaolin and bentonite were considered as potential reagents for the process. To the extent of the market survey, no source currently supplies calcined bentonite although kaoline is routinely calcined at many plants. Therefore, limited studies were done using laboratory calcined bentonite.

TABLE 10.6. Properties of Aqueous-Silicate Products of NFS Wastes

\begin{tabular}{|c|c|c|c|c|c|c|}
\hline $\begin{array}{l}\text { Clay/waste } \\
\text { Ratio, g/mL }\end{array}$ & $\mathrm{NaOH}$ & $\begin{array}{l}\text { Concentration } \\
\text { Waste, } M \\
\end{array}$ & $\begin{array}{c}\text { Volume Increase } \\
\text { of Waste } \\
\text { from } \mathrm{NaOH}, \% \\
\end{array}$ & $\begin{array}{l}\text { Total Volume } \\
\text { Increase } \\
\text { of Waste on } \\
\text { Reaction, } \% \\
\end{array}$ & $\begin{array}{l}\text { Liquid Not } \\
\text { Sorbed, \% } \\
\end{array}$ & $\begin{array}{c}\text { Hardness } \\
\mathrm{kg} / \mathrm{cm}^{2}\end{array}$ \\
\hline 0.75 & & 0.18 & - & 50 & 0 & 0 \\
\hline 1.0 & & 0.18 & -- & 60 & 0 & 0 \\
\hline 0.65 & & 1.90 & 15 & 75 & 10 & 0 \\
\hline 0.87 & & 1.90 & 15 & 50 & 0 & 0.8 \\
\hline 0.65 & & 4.50 & 15 & 70 & 5 & 32 \\
\hline 0.87 & & 4.50 & 15 & 75 & 5 & 45 \\
\hline 0.60 & & 6.54 & 25 & 70 & 0 & 32 \\
\hline 0.80 & & 6.54 & 25 & 85 & 0 & 18 \\
\hline
\end{tabular}

(a) Hardness, as measured by a penetrometer, is a measure of the force necessary to indent the sample $6 \mathrm{~mm}$ dia probe. 
The product quality survey showed that generally each of the four types of clays behave as a group. With few exceptions then, all calcined $k$ aolin products have roughly the same properites. Uncalcined kaolin products are also similar among themselves as are the products of calcined and uncalcined bentonite (Table 10.7).

The clay/waste solution ratio is stoichiometrically high in clay in the clay-rich process. As the clay/waste ratio increases product volume and hardness increase. The minimum amounts of clay necessary to form solid products from standard waste solutions have been defined (Barney 1974). At a $1.0 \mathrm{~g} / \mathrm{mL} \mathrm{clay} /$ waste ratio, product volumes are roughly $45 \%$ higher than initial waste volumes for the calcined and uncalcined kaoline products and the calcined bentonite products. For uncalcined bentonite, the product volume increase is approximately 55\%. For a given clay/waste ratio, product hardness decreases according to the series: calcined kaolin>calcined bentonite>kaol in bentonite. In all cases, product hardness may be vastly improved by driving off excess water by curing at $100^{\circ} \mathrm{C}$.

TABLE 10.7. Physical Properties of Clay-Rich Products(a)

\begin{tabular}{|c|c|c|c|}
\hline Name of Clay, Source & Type of Clay & $\begin{array}{l}\text { Hardness } \\
\mathrm{kg} / \mathrm{cm} 2(\mathrm{~b})\end{array}$ & $\begin{array}{l}\text { Volume Product/ } \\
\text { Volume Feed }\end{array}$ \\
\hline $\begin{array}{l}\text { BL-42, Baroid Division, } \\
\text { National Lead Company }\end{array}$ & Bentonite & 3.2 & 1.57 \\
\hline $\begin{array}{l}\text { MC-101, Georgia Kaolin } \\
\text { Company }\end{array}$ & Bentonite & 3.3 & 1.53 \\
\hline $\begin{array}{l}\text { Wyo-Bond, Federa } 1 \\
\text { Benton ite Company }\end{array}$ & Bentonite & 3.5 & 1.50 \\
\hline Calcined $B L-42$ & Calcined bentonite & 18 & 1.43 \\
\hline Calcined MC-101 & Calcined bentonite & 9.5 & 1.50 \\
\hline Calcined Wyo-Bond & Calcined bentonite & 19 & 1.50 \\
\hline $\begin{array}{l}\text { KCS, Georgia Kaolin } \\
\text { Company }\end{array}$ & Kaolin & 28 & 1.47 \\
\hline $\begin{array}{l}\text { Catalpo, Freeport } \\
\text { Kaolin Company }\end{array}$ & Kaolin & 28 & 1.40 \\
\hline $\begin{array}{l}\text { PAB, J. R. Simplot } \\
\text { Company }\end{array}$ & Kaolin & 22 & 1.48 \\
\hline Calcined PAB, & Calcined kaolin & 45 & 1.47 \\
\hline $\begin{array}{l}\text { Satintone } 1 \text {, } \\
\text { Engelhard Industries }\end{array}$ & Calcined $k$ aolin & 45 & 1.40 \\
\hline $\begin{array}{l}\text { Glomax PVR, Georgia } \\
\text { Kaol in Company }\end{array}$ & Calcined kaolin & 45 & 1.40 \\
\hline
\end{tabular}

(a) Products made by reaction of synthetic waste \#1 at $1.0 \mathrm{~g} / \mathrm{m} 1$ clay/waste ratio at $60^{\circ} \mathrm{C}$ for 5 days.

(b) Hardness figure indicates pressure necessary for a cylindrical probe to penetrate $0.635 \mathrm{~cm}$ into product sample. 
Leaching experiments performed on cylindrical samples (10-40 g each) show that uncalcined $k$ aolin and bentonite products swell when soaked in water. In contrast, products from calcined clays remain structurally intact while leaching. In spite of cracking, uncalcined bentonite products give vastly superior leach rates over products from other clays (see Table 10.8).

A study (Delegard and Barney, 1975) was done to determine the effectiveness of the clayrich process to solidify ${ }^{106} \mathrm{Ru}$. Calcined and uncalcined kaolin and Indian Hill clay were used as reactants. None of these three is effective in fixing the ruthenium from a caustic-fortified waste liquor. A simple water wash of these products results in a loss of 299\% of the ruthenium from the solids. It appears that ruthenium (as $\mathrm{RuO}_{4}{ }^{2-}$ ) is not entrapped in the crystalline framework of cancrinite. However, because of the short half-life (1 yr) of ${ }^{106} \mathrm{Ru}$, this is not considered a serious problem for long-term storage.

The clay-rich process was applied to Purex sludge fortified with caustic. Reaction of Purex sludge with clay, but without additional caustic, resulted in crumbly products, Various ratios of Indian $\mathrm{Hill} \mathrm{Clay,} \mathrm{Purex} \mathrm{sludge,} \mathrm{and} 50 \% \mathrm{NaOH}$ solution (Table 10.9) were reacted as pellets and then were leached. Table 10.10 gives the bulk leach rates of the products based on the cesium, strontium and plutonium nuclides leached. The leach rates based on ${ }^{137} \mathrm{Cs}$ are similar to leach rates obtained for Indian $\mathrm{Hill} /$ waste solution products. The leach rates based on strontium and plutonium increase slightly with increasing clay/sludge ratios. The reason for this unexpected trend has not yet been determined. As in other clay-rich products, increasing the clay/waste ratio results in increased underwater mechanical stability. TABLE 10.8. Typical Bulk Leach Rates of Clay-Rich Products Made
from Actual waste $(a)$

\begin{tabular}{|c|c|c|}
\hline Clay & $\frac{\text { Bulk Leach }}{1 \text { day }}$ & 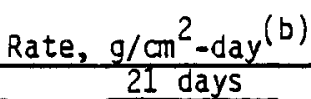 \\
\hline Kaolin & $5 \times 10^{-1}$ & $3 \times 10^{-2}$ \\
\hline Calcined Kaolin & $3 \times 10^{-1}$ & $1 \times 10^{-2}$ \\
\hline Bentonite & $1 \times 10^{-3}$ & $3 \times 10^{-4}$ \\
\hline Calcined Bentonite & $2 \times 10^{-2}$ & $1 \times 10^{-3}$ \\
\hline Indian $\mathrm{Hill}$ & $2.6 \times 10^{-3}$ & $6.7 \times 10^{-4}$ \\
\hline
\end{tabular}

(a) Products made at $1.0 \mathrm{~g} / \mathrm{ml} \mathrm{clay} /$ waste ratio with Hanford waste tank $241-8 X-110$ waste solution.

(b) Bulk leach rate $=\frac{(\text { fraction Cs leached })(\text { sample weight })}{\text { (geometric surface area)(time) }}$

TABLE 10.9. Formulation of Clay-Rich/Sludge Products

$\begin{array}{cccc}\text { Product } & \begin{array}{c}\text { Clay } \\ \text { Weight, g }\end{array} & \begin{array}{c}\text { Sludge } \\ \text { Weight, g }\end{array} & \begin{array}{c}50 \% \mathrm{NaOH} \\ \text { Volume, ml }\end{array} \\ \text { B } & 4 & 1 & 4 \\ \text { C } & 4 & 3 & 3 \\ & 4 & 6 & 2\end{array}$


TABLE 10.10. Bulk Leach Rates Based on $137 \mathrm{Cs}, 90 \mathrm{Sr}$ and $239 \mathrm{pu}$ for Clay-Rich Solidified Sludge Products

\begin{tabular}{|c|c|c|}
\hline $\begin{array}{l}\text { Product/ } \\
\text { Element }\end{array}$ & $\frac{\text { Bu lk Leach }}{1 \text { day }}$ & $\frac{\text { Rate, } \mathrm{g} / \mathrm{cm}^{2}-\text { day }}{23 \text { days }}$ \\
\hline $\mathrm{A} / \mathrm{Cs}$ & $1.4 \times 10^{-3}$ & $1.6 \times 10^{-5}$ \\
\hline $\mathrm{B} / \mathrm{Cs}$ & $1.4 \times 10^{-3}$ & $2.9 \times 10^{-5}$ \\
\hline $\mathrm{C} / \mathrm{Cs}$ & $3.5 \times 10^{-4}$ & $1.5 \times 10^{-5}$ \\
\hline $\mathrm{A} / \mathrm{Sr}$ & $1.7 \times 10^{-4}$ & $7.5 \times 10^{-6}$ \\
\hline$B / S r$ & $1.3 \times 10^{-4}$ & $5.7 \times 10^{-6}$ \\
\hline $\mathrm{C} / \mathrm{Sr}$ & $7.0 \times 10^{-5}$ & $4.6 \times 10^{-6}$ \\
\hline $\mathrm{A} / \mathrm{Pu}$ & $9.4 \times 10^{-4}$ & $7.6 \times 10^{-5}$ \\
\hline $\mathrm{B} / \mathrm{Pu}$ & $5.0 \times 10^{-4}$ & $3.5 \times 10^{-5}$ \\
\hline $\mathrm{C} / \mathrm{Pu}$ & $8.0 \times 10^{-4}$ & $1.7 \times 10^{-5}$ \\
\hline
\end{tabular}

\subsubsection{Process System Description and Material Balance}

The clay-rich aqueous-silicate process solidifies a blended mixture of alkaline Purex and acidic Thorex wastes that have been concentrated and chemically adjusted with caustic. This alkaline waste blend is mixed with calcined bentonite clay and extruded into pellets that are cured and dried at an elevated temperature.

A process flow diagram for the clay-rich aqueous-silicate process is shown in figure 10.4. Blended alkaline waste is pumped in batches to respective receiver tanks in the processing facility. The waste is concentrated in batches in the process evaporator to the maximum practical waste concentration since the final product volume is proportional to the feed volume. The concentrated feed is chemically adjusted with 19M (50 wt\%) sodium hydroxide to provide a waste with greater than or equal to $2 \mathrm{M}$ sodium hydroxide. Other chemical adjustments may be necessary. The feed is then transferred in batches to the mixer feed tank where it is continuously fed at a controlled rate to a mechanical mixer. The feed tank provides a constant flow of waste to the mixers where the waste is mixed with calcined bentonite. The resulting clay mixture is continuously extruded into pellets that are hardened and then dried in hot-air drying ovens to less than 1 wt\% moisture content. The dried pellets are transferred to a hopper using a conveyor and elevator system. Empty canisters are filled from the hopper, and a lid is welded on. The weld is tested for leaks and the surface of the canister is decontaminated.

The reaction between the calcined bentonite and the alkaline waste blend occurs at temperatures as low as $30^{\circ} \mathrm{C}$. However, the reaction rate has a large temperature coefficient. The reaction half-times for the bentonite reaction are 1,9 , and 60 hours for reaction temperatures of $100^{\circ} \mathrm{C}, 75^{\circ} \mathrm{C}$ and $50^{\circ} \mathrm{C}$, respectively. The zeolytic water associated with the cancrinite product can be removed in a temperature range of $100^{\circ} \mathrm{C}$ to $300^{\circ} \mathrm{C}$. At approximately $700^{\circ} \mathrm{C}$ the trapped sodium nitrates and nitrites begin to decompose, forming $\mathrm{Na}_{2} \mathrm{O}$ and $\mathrm{NO}_{\mathrm{X}}$. At even higher temperatures, $900^{\circ} \mathrm{C}$ to $1200^{\circ} \mathrm{C}$, the cancrinite product melts. The reference design is based on operation of the reaction chamber at $250^{\circ} \mathrm{C}$ to achieve a rapid reaction rate. 


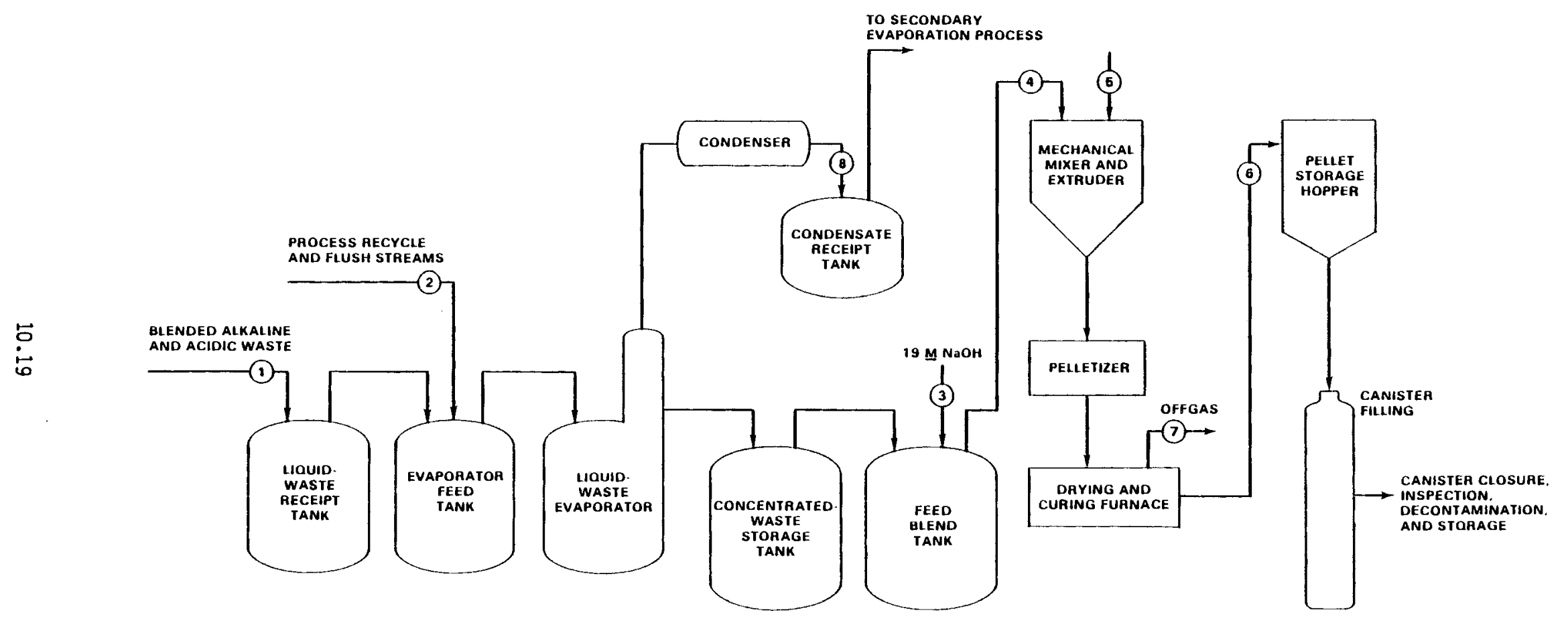

FIGURE 10.4. WNYNSC HLW Salt/Silicate Matrix Process Flow Diagran 
The volumes of clay and waste solution are nearly additive, with the amount of clay necessary to form an acceptable product determining the volume increase of the process. A minimum of $0.75 \mathrm{~g}$ of bentonite per milliliter of dissolved salts is necessary to fix all of the radioactive salts in the cancrinite structure. This results in a requirement of excess bentonite in the mixture to drive the reaction to completion. Since the packed density of bentonite is $2.6 \mathrm{~g} / \mathrm{ml}$, each gram of clay added results in a volume increase of $0.38 \mathrm{ml}$. The volumetric contribution of the salt-cake wastes depends on the bulk density, composition, and water content of the dissolved salt solution.

A schematic flowsheet of the silicate/salt removal process is shown in figure 10.5. The storage canister is transported from the interim storage facility to a final waste-processing site. The canister is removed from the shipping cask, inspected, and decontaminated if necessary. Then the canister seal weld is mechanically removed from the lid. The canister contents are vacuum transferred to a receptacle where they can be dissolved or fed directly into the final waste-solidification process. Adding the pellets directiy into the final waste solidification process could result in a high, final, waste form volume due to the presence of large quantities of sodium, which must be diluted.

Idaho National Engineering Laboratory has studied the characteristics of silicate/salt matrix in storage as well as methods for its removal from containers. Removal of the pellets will be complicated if the product consolidates into a rigid structure during storage. In this case mechanical (auger) and/or chemical (dissolution) methods will be needed to assist in the removal of the product from the canister. The silicate/salt waste form product is compatible with the anticipated defense waste solidification processes for incorporation into a terminal waste form such as borosilicate glass. The empty canister may then be decontaminated for reuse or disposal, if appropriate.

The process material balance for the silicate/salt waste form process is surmarized in Table 10.11. The stream identification numbers on the material balance table refer to the process flow sheet schematic (Figure 10.5).

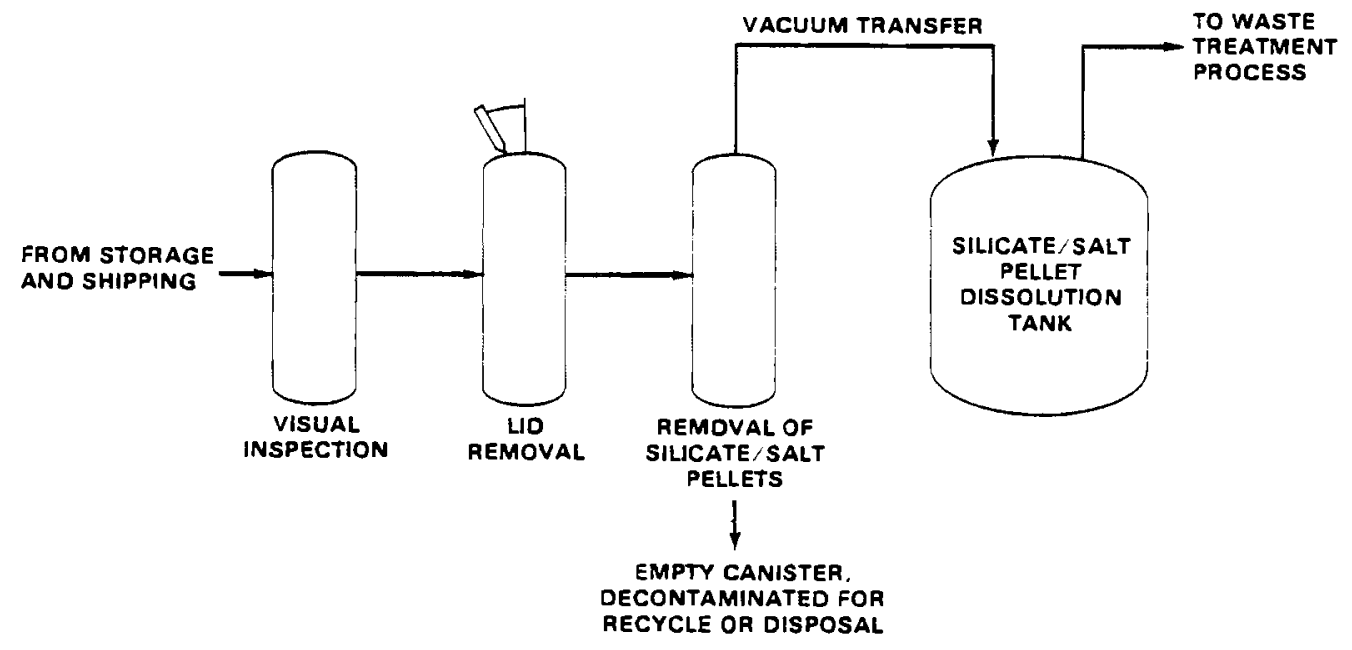

FIGURE 10.5. Schematic Flowsheet for Silicate/Salt Removal Process 
TABLE 10.11. Process Conditions and Material Balance Data for Solidifying Combined Alkaline and Acidic Waste

in a Silicate/Salt Waste Form

\begin{tabular}{|c|c|c|c|c|c|c|c|c|}
\hline Stream Number (b) & 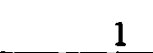 & 2 & 3 & 4 & 5 & 6 & 7 & 8 \\
\hline Parameters & $\begin{array}{l}\text { Alkaline } \\
\text { Waste } \\
\text { Blend }\end{array}$ & $\begin{array}{c}\text { Recycle } \\
\text { and } \\
\text { Flushes }\end{array}$ & $\begin{array}{l}\text { Caustic } \\
\text { Adjustment }\end{array}$ & $\begin{array}{l}\text { Mixer } \\
\text { Feed }\end{array}$ & $\begin{array}{c}\text { Clay } \\
\text { Addition }\end{array}$ & $\begin{array}{l}\text { Silicate/Salt } \\
\text { Matrix Product }\end{array}$ & $\begin{array}{c}\text { Drying/Curing } \\
\text { off Gas }\end{array}$ & $\begin{array}{c}\text { Evaporator } \\
\text { off Gas }\end{array}$ \\
\hline \multicolumn{9}{|l|}{ Flow, $\mathrm{kg} / \mathrm{hr}$} \\
\hline Salt & 78.5 & $\cdots$ & - & 78.5 & & 78.5 & & 0.0008 \\
\hline Solids & 6.3 & -- & - & 6.3 & & 6.3 & & \\
\hline $\mathrm{H}_{2} \mathrm{O}$ & 150 & 25 & 13.3 & 113.3 & & 1 (Free) & 112.3 & 75 \\
\hline Air & -- & -- & -- & -- & & -- & As needed & \\
\hline $\mathrm{NaOH}(100 \%)$ & -- & - & 13.3 & 13.3 & & 13.3 & & \\
\hline Bentonite Clay & - & -- & -- & -- & 155 & 155 & & \\
\hline $\begin{array}{l}\text { Silicate/Salt } \\
\text { Matrix }\end{array}$ & -- & -- & - & -- & - & 254.1 & & \\
\hline Total & 234.8 & 25 & 26.6 & 211.4 & 155 & 254.1 & 112.3 & 75 \\
\hline Temperature, ${ }^{0} \mathrm{C}$ & Amb. & Amb. & Amb. & Amb. & Amb. & Amb. & $185^{\circ} \mathrm{C}$ & $100^{\circ} \mathrm{C}$ \\
\hline Density, $\mathrm{g} / \mathrm{cm}^{3}$ & 1.57 & 1.0 & 1.53 & 1.8 & 2.6 & $1.2^{(a)}$ & & \\
\hline Flow, L/h & 150 & 25 & 17.4 & 113 & 59.6 & 212 & & \\
\hline Activity, Ci/L & 14.4 & Negl. & 0 & 19.1 & 0 & 10.2 & $(0.002 \mathrm{Ci})$ & $(0.002 \mathrm{Ci})$ \\
\hline Heat, W/L & 0.041 & 0 & 0 & 0.054 & 0 & 0.03 & 0 & 0 \\
\hline
\end{tabular}

(a) Bulk density of pellets in canister approximately 1.2 .

(b) Stream numbers refer to streams shown in Figure 10.4. 
The overall waste form process sumary for the silicate/salt process is given in Table 10.12. The production rate for the canisters is approximately one every three hours based on a three-year operating campaign with plant efficiency of $60 \%$. Surface and centerline temperatures of the waste product canisters are anticipated to be slightly above the ambient temperature. A dose rate of approximately $60 \mathrm{R} / \mathrm{hr}$ is estimated at the canister surface.

With process optimization the initial waste feed volume may be further reduced from that assumed and perhaps an approach for producing a denser product can be developed. It is projected that these improvements could reduce the number of canisters by roughly $30 \%$.

\subsubsection{Status of Technology}

This silicate/salt matrix process approach appears to be technically feasible based on laboratory tests using a simulated NFS waste composition. Solid NFS sludge wastes might be solidified in a similar manner, as evidenced by preliminary laboratory testing with actual Hanford sludges. However, application of this technology to chemically dissolved sludge wastes (possibly involving dilute oxalic acid) has not yet been tested or seriously considered.

Development of the clay-rich version of the aqueous-silicate process has progressed to the stage of preliminary pilot-plant testing and conceptual, engineering design activity. Most development work has been on a laboratory scale with radioactive and nonradioactive wastes to establish the feasibility of the process. The characteristics of products formed with Hanford alkaline-salt waste solutions and synthetic WNYNSC wastes have been determined. pilot-plant studies demonstrated mixing clay with waste-terminal liquor at processing rates up to about $5 \mathrm{~kg}$ of product per hour. Approximately one to three years of additional engineering development work will be required to prepare the process for practical design. This time requirement will be governed by the need to develop or adapt mixing and conveying equipment for remote operation and maintenance. Cold tests of pilot-plant equipment have shown that use of a continuous horizontal mixer for blending clay and residual liquor at rates up to $150 \mathrm{~L} / \mathrm{min}$ is operationally feasible.

Several areas of research and development need to be completed before an aqueous-silicate process (clay-rich version) can be used to manage WNYNSC waste:

- corrosion experiments (dry and undried clay products contained in mild steel and stainless steel canisters);

- kinetics and heat-release dynamics of curing large-product monoliths;

- radiolysis of sorbed $\mathrm{H}_{2} \mathrm{O}$ and nitrate;

- heat transfer and vapor diffusion related to product drying;

- general extension of process to handle salt-slurry wastes;

- reduction of low-temperature product dispersibility;

- further characterization of chemical and radionuclide content in supernate and sludge;

- general process development;

- investigation of process applicability to solidification of chemically dissolved sludge (e.g., using oxalic acid). 
TABLE 10.12. Silicate/Salt Waste Form Process Summary; Solidification of Combined Alkaline Purex and Acidic Thorex Wastes

\begin{tabular}{ll}
\multicolumn{1}{c}{ Process Characteristics } & Silicate/Salt Waste \\
\hline Silicate/sait production rate, $\mathrm{kg} / \mathrm{hr}$ & 254.1 \\
Number of silicate salt canisters & 4691 \\
Activity per canister, $\mathrm{Ci}$ & $7.2 \times 10^{3}$ \\
Decay heat per canister, $\mathrm{W}$ & 21 \\
Bulk density of waste form & 1.2 \\
Dose rate at canister surface, $\mathrm{R} / \mathrm{hr}$ & 60 \\
Processing campaign length, $d$ & 657
\end{tabular}

The uncertainties associated with retrievability, storage life, and radiolys is of $\mathrm{H}_{2} \mathrm{O}$ or $\mathrm{NO}_{3}$ represent major shortcomings inherent in an aqueous-silicate clay-rich product. The general product advantages and disadvantages are indicated below:

\section{Advantages}

- Produces a reasonably leach-resistant solid product, which can be stored in easily retrieved and transported canisters.

\section{Disadvantages}

- The product could contain significant quantities of absorbed water (up to $35 \mathrm{wt \%}$ ) and thus would not be thermally stable under all conceivable storage vault temperatures.

- The product would contain significant quantities of absorbed nitrate salts in addition to water. Thus, radiolytic instability may require that the tanks be vented to prevent potential overpressurization.

- Canister materials would have to withstand the internal corrosion (as yet undefined) associated with a humid environment.

- The addition of alumina and silica (as clay) to the NFS waste would complicate, if not preclude, possible future reprocessing operations such as actinide removal or volume reduction.

- The increased interim and final product volumes are significant because of increased handling, storage, and cost.

\subsubsection{Safety Considerations}

The silicate/salt matrix process and its engineering have not advanced to the state where they are well characterized and can be fully assessed for plant production, safety, and environmental effects. However, a review of process development and engineering to date does not indicate that there would be any product or process areas that would present a significant safety hazard.

For radionuclide processing facilities there are no unique hazards associated with the silicate/salt matrix process. The waste is always at least doubly contained before contact with operating personnel and triply contained before access to the general public. The mild 
conditions under which the process operates imply a low accident potential. The process temperature does not exceed $250^{\circ} \mathrm{C}$; the operations are conducted at atmospheric pressure; and no process materials are used, except for the HLLW, that present any hazard. At the low processoperating temperatures, no volatile hazardous chemicals or radionuclides are generated with the possible exception of some iodine and ruthenium. Of course, aqueous vapor, driven from the product entrains some hazardous materials. However, the effluent treatment system is specifically designed to remove these hazardous materials before effluent release.

The silicate/salt matrix process does present some increased potential for minor accidents over simple processes, such as the fused-salt process, due to the increased number of process steps and complex equipment.

At the operating process conditions and even practical off-standard process conditions, it is difficult to conceive of conditions that would cause accidents of major potential consequences, such as explosions or gross loss of radionuclide containment. There is always potential for equipment failure and leaks. Probably one of the more serious accidents would be caused by dropping a canister or equipment and breaching the integrity of in-cell equipment containing radionuclides. This accident is common to all processes considered in this study, but it is more likely to occur in this process due to the high volume of canisters handled. In the event of this accident all material would be contained within the Class I safety structure.

The silicate/salt waste form and process have a low potential for damaging the environment. The potential for pressurizing canisters due to radiolys is of water and $\mathrm{NO}_{3}^{-}$in the water form should be investigated, however. The only normal effluent from the process is the aqueous condensate that has been treated for hazardous-materials removal. Also, there may be some air used in product curing that has also been treated for hazardous-materials removal.

\subsubsection{Facility Implementation}

The silicate/salt matrix process is relatively complicated when compared to the fused-salt process. This additional complexity is the result of the increased number of process steps and product handling operations. Much of the equipment required for the salt/sludge separation flowsheet can be used for the silicate/salt matrix process. Unit processes that are adaptable include: the high-level-waste receipt, recycle and secondary evaporation system, the off-gas treatment system, and the canister handling and processing systems. Additional canisterhandling equipment will be necessary to accormodate the canister-production rate of one canister every three hours. New systems would have to be located within the CPC and would include: clay feeding, mechanical product mixer, pelletizer, hardening/drying oven(s), interim particulate lag storage, product conveyors, loading system, and feed concentration. Much of the process complexity is caused by the need to produce a pelletized product to enable the waste to be removed from the storage container for incorporation into the final waste form.

A conceptual layout and equipment sizes were developed based on cormunications with Norman Engineering Company. This layout of the silicate/salt matrix equipment in the CPC is shown in Figure 10.6. This layout will require use of much of the CPC space allocation for waste-feed 

A. HLLW RECEIVING TANKS
B. WASTE FEED BLENDING TANKS
C. HLLW EVAPORATOR SYSTEM
D. SALT/SILICATE MATRIX PROCESS SYSTEM

E4. CANISTER LID-WELD STATION

\section{E5. CANISTER DECONTAMINATION \\ E6. CANISTER TRANSPORT CART \\ F. RECYCLE AND SECONDARY EVAPORATION \\ G. OFF.GAS TREATMENT SYSTEM}

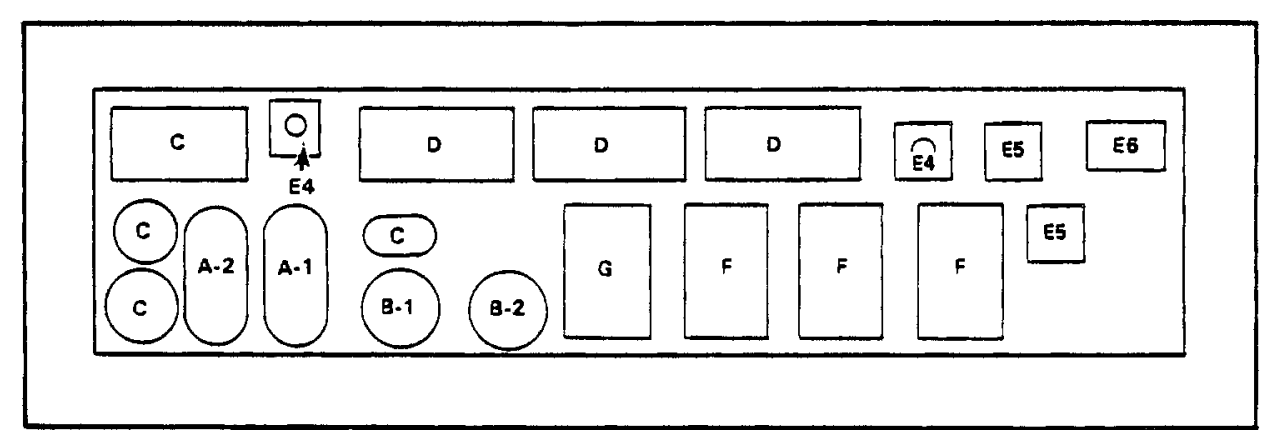

CHEMICAL PROCESS CELL

\section{$\overline{2 m}$}

FIGURE 10.6. Conceptual Equipment Layout for Salt/Silicate Matrix Process

conditioning (as in the salt/sludge separation flowsheet). Also, a feed-concentration system would be needed to adjust the feed volume to a minimum consistent with processing. Since the final product volume is proportional to the initial feed volume, this initial volume would need to be minimized. The very high production rate of filled canisters may overburden the crane in the CPC and the operations in the EDR. A time and motion study should be conducted to establish realistic equipment and facility needs.

\subsection{VINYL ESTER-STYRENE PROCESS}

The organic-binder waste form selected as the reference product uses vinyl ester-styrene as the binder. This product was selected over other organic-binder products because it appears to have the best aggregate properties needed for an interim waste form. Vinyl ester-sytrene is an organic material that hardens to an essentially unyielding form and traps water and other waste materials in a matrix structure. The product is made by mixing the waste with a liquid binder, a catalyst, and a promoter that hardens to form the solid matrix. For the WNYNSC application the waste would be converted into pellets or other small shapes to aid in their removal from the container and to facilitate rendering to a chemical form compatible with the terminal waste form processes being considered. The product represents a substantial improvenent in product properties related to safety, such as leachability and dispersion potential in air. However, there are questions regarding its stability during long-term radiation exposure and fire. The process for producing vinyl ester-styrene monoliths is simple, but the requirements for producing pellets and later for converting pellets to a form compatible with a terminal waste form process, could involve complex processing for which there has been little development. The vinyl esterstyrene product and process (Filter and Roberson 1977; Filter 1978a; Filter 1978b; Filter 1976) has been well developed by Dow Chemical Co. and has been applied to Radwaste solidification. No previous study has been done that applies to high-level-waste solidification. 


\subsubsection{Waste Form Properties}

A vinyl ester-styrene thermosetting resin was developed by the Dow Chemical Co. for use in a proprietary solidification process (Dow 1978) for Radwastes. The resin is mixed directly with wet solid wastes and then polymerized at room temperature after adding a promoter and a catalyst. The polymerization reaction is exothermic and, hence, raises the waste-form temperature. Polymerization is mostly complete after 30 to $60 \mathrm{~min}$. In the Dow system, the waste and resin are usually mixed in the solidification container before starting the polymerization. Wastes are entrapped in the polymer matrix. No chemical reaction between the waste and solidification agent takes place. Studies on the Dow polymer system have been done at Brookhaven National Laboratory (BNL) (Colombo and Neilson 1979) using various simulated wastes. Specimens were prepared at BNL using Dow's proprietary procedure. Solidified products were obtained with all wastes tested (see Table 10.13). No free-standing water was noted in any of the waste forms produced. Since the polymerization reaction is exothermic, solidification in a closed container may produce small quantities of free-standing water resulting from condensation on cold container surfaces. They vinyl ester-styrene forms a homogeneous product but requires vigorous mixing of this highly viscous material.

Modified IAEA and equilibrium leach tests were conducted on vinyl ester-styrene waste samples containing various simulated wastes. The data on leaching of ${ }^{137} \mathrm{Cs}$ and ${ }^{85} \mathrm{Sr}$ from vinyl ester-styrene (waste/binder $=1.9$ by $w t$ ) waste forms are plotted in Figures 10.7 and 10.8. The activity-release rate of ${ }^{137} \mathrm{Cs}$ and ${ }^{85} \mathrm{Sr}$ was largest for urea formaldehyde and smallest for vinyl ester-styrene waste forms. The release rate from vinyl ester-styrene did not vary greatly with the radionuclide considered.

The compressive strengths of waste forms prepared by the solidification of various simulated wastes with vinyl ester-styrene were measured by the American Society for Testing Materials method C39-72, "Test for the Compression Strength of Cylindrical Concrete Specimens." Compressive-strength measurements on vinyl ester-styrene waste forms were 1 imited to formulations with water/binder ratios of $1.0,1.5$, and 2.0 by volume (corresponding to weight ratios of 1.0, 1.5 and 1.9). Chemical interactions with the waste are not considered. The data in Table 10.14 are average results on three specimens of each formulation. After compressive

TABLE 10.13. Solidification Verification Studies With Vinyl Ester-Styrene (Dow Nuclear Binder 101)

\begin{tabular}{|c|c|c|}
\hline Waste Type & $\begin{array}{l}\text { Waste/Binder } \\
\text { Volume Ratio } \\
\end{array}$ & $\begin{array}{l}\text { Gel Time, } \\
\min \end{array}$ \\
\hline Bead Resin Waste (Slurry) & 2.0 & 8 \\
\hline BWR Chemical Regenerative Waste & 1.65 & 3 \\
\hline $\begin{array}{l}\text { Boric Acid Waste(a) } \\
\text { Boric Acid Waste }\left(8 \text { wt\% } \mathrm{H}_{3} \mathrm{BO}_{3}\right)\end{array}$ & $\begin{array}{l}1.5 \\
1.5\end{array}$ & $\begin{array}{l}4 \\
3\end{array}$ \\
\hline $\begin{array}{l}\text { Diatomaceous Earth waste } \\
\text { ( } 40 \text { wt\% in Water) }\end{array}$ & 1.5 & 4 \\
\hline
\end{tabular}

(a) Required waste pretreatment to produce an acceptable solid. 


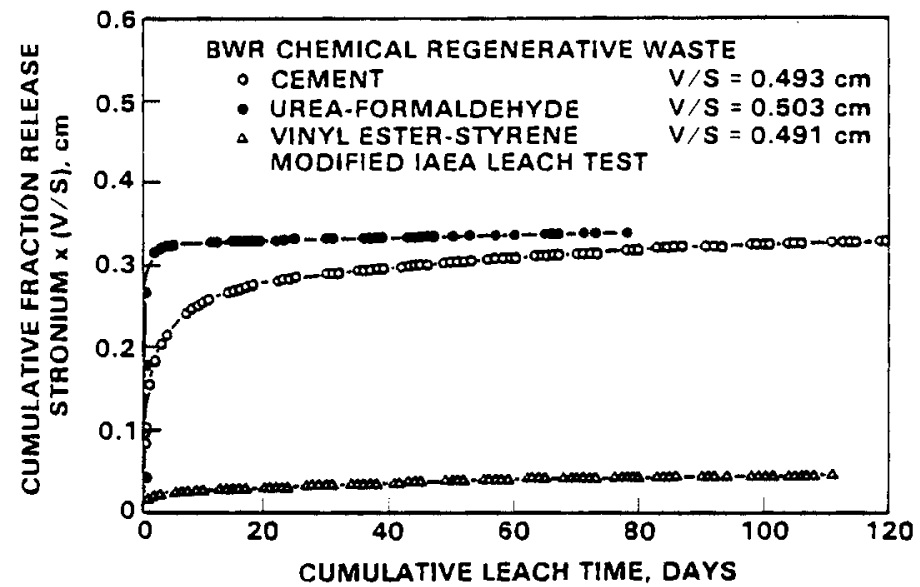

FIGURE 10.7. ${ }^{137} \mathrm{Cs}$ Release in Distilled Water From Portland Type II Cement, UF, and Vinyl Ester-Styrene Waste Form Containing BWR Chemical Regenerative Waste as a Result of Leaching by the Modified IAEA Procedure.

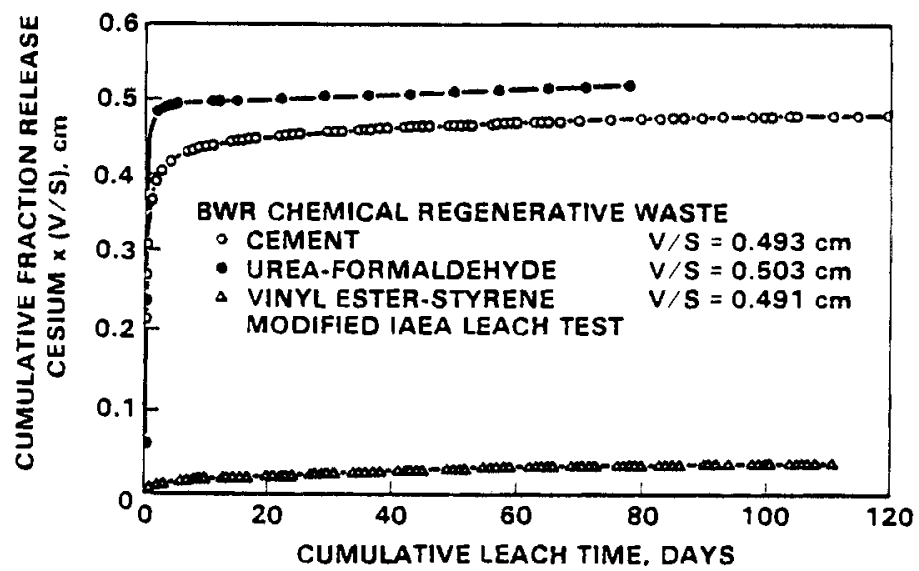

FIGURE 10.8. ${ }^{85} \mathrm{Sr}$ Release Under Same Conditions as for Figure 10.7

TABLE 10.14. Compressive Strength of Vinyl Ester-Styrene Solidification Agent Specimens

\begin{tabular}{ccccc}
$\begin{array}{c}\text { Water/Binder } \\
\text { Weight Ratio }\end{array}$ & $\begin{array}{c}\text { Sample } \\
\text { Dia, in. }\end{array}$ & $\begin{array}{c}\text { Sample } \\
\text { Length, in. }\end{array}$ & $\begin{array}{c}\text { Compressive } \\
\text { Strength, 1b/in.2 }\end{array}$ \\
\cline { 2 - 4 } 1.0 & 1.81 & & 3.13 & 2920 \\
1.5 & 1.81 & 3.09 & 2140 \\
1.9 & 1.81 & 3.07 & 1280
\end{tabular}

failure, small quantities of water were observed as droplets on the fracture fragments, apparently squeezed out of the test specimens. The specimens all failed in brittle fracture.

Vinyl ester-styrene specimens in the form of cylindrical disks were produced with water/ VE-S ratios of $1.0,1.5$, and 2.0 by volume. Figure 10.9 shows the change in weight of these specimens as a function of time with exposure to ambient air at $72^{\circ} \mathrm{F}$ and $57 \%$ relative humidity. 


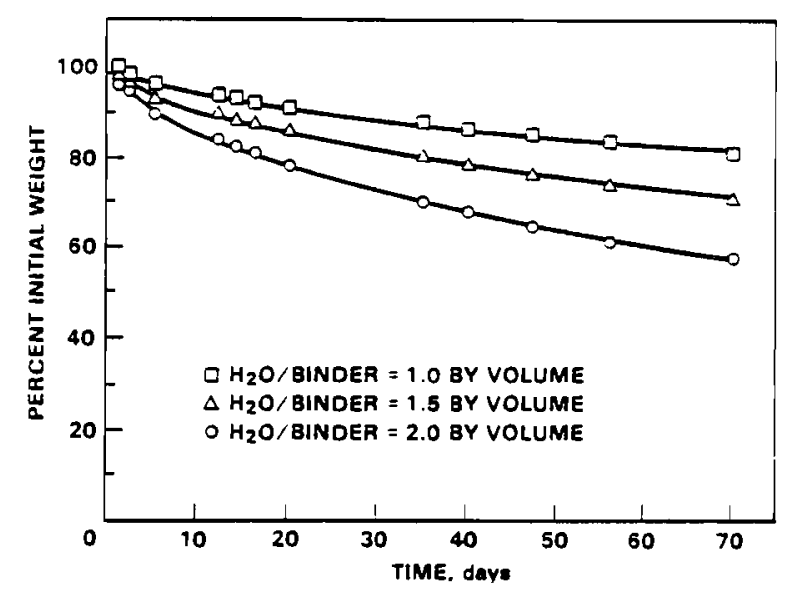

FIGURE 10.9. Percent Initial Weight Versus Time in Ambient Air for Dow Solidification Agent Specimens

Weight loss was most rapid during the first days of testing and was greater for the higher water/binder ratios. At 70 days, the percent weight losses were $17.5 \%, 28.0 \%$ and $41.6 \%$ for water/binder volume ratios of $1.0,1.5$ and 2.0 , respectively. The weight loss was due to loss of water by evaporation and was not complete in 70 days, as indicated by the continuing, al though decreasing, loss of weight with time. If the specific gravity of the vinyl esterstyrene is assumed to be 1.0 , the weight loss at $70 \mathrm{~d}$ corresponds to the removal of $35.6,47.7$, and 62.1 wt\% of the contained water at water/binder volume ratios of $1.0,1.5$, and 2.0, respectively. The percent of contained water removed per unit of time is greater for higher water/ binder ratios. Specimens kept in airtight containers showed no weight loss in $70 \mathrm{~d}$.

A thermogravimetric analysis was also done on vinyl ester-styrene specimens with water/ binder volume ratios of $1.0,1.5$, and 2.0 , over a temperature range of $25^{\circ} \mathrm{C}$ to $600^{\circ} \mathrm{C}$, with a scanning rate of $10^{\circ} \mathrm{C} / \mathrm{min}$ and in a nitrogen atmosphere. The curves in figure 10.10 , showing the average results at each water/binder ratio, indicate two temperature regions in which most of the weight loss takes place. The losses at $50^{\circ}$ to $200^{\circ} \mathrm{C}$ are due to water evaporation. Polymer decomposition begins at $350^{\circ} \mathrm{C}$ and is essentially complete at $500^{\circ} \mathrm{C}$.

The thermal conductivity of vinyl ester-styrene waste forms was determined at $45^{\circ} \mathrm{C}$ with a unidirectional heat-flow thermal-conductance analyzer. The test results are shown in Table 10.15. Specimens lost water during testing, which lowered the thermal conductivity. In actual waste forms, the thermal conductivity depends on the type of waste that is solidified and on the waste-to-binder ratio.

The specific heats of vinyl ester-styrene waste forms at $25^{\circ} \mathrm{C}$ were determined with a differential-scanning calorimeter. The ranges of values are listed in table 10.15. In actual practice the specific heat will be a function of the waste/binder ratio and the type of waste solidified. 


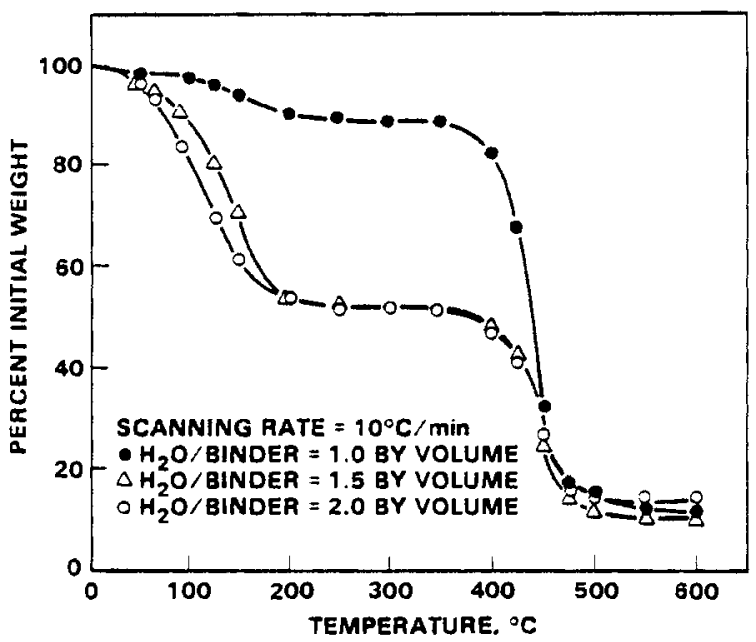

FIGURE 10.10. Thermogravimetric Weight Loss for Dow Solidification Agent Specimens

TABLE 10.15. Thermal Conductivity and Specific Heat of Vinyl Ester-Styrene

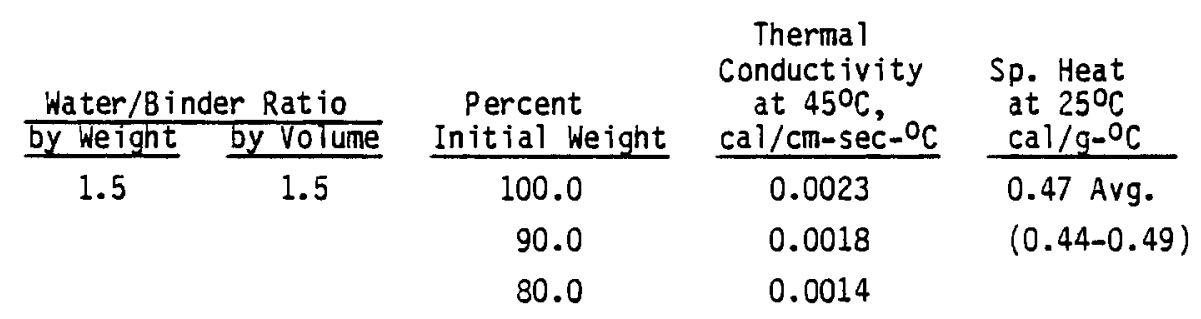

Most of the vinyl ester-styrene product data and characterization has been done by Dow Chemical Company (Filter and Roberson 1977; Filter 1978a; Filter 1978b; Filter 1976). This data development is specifically oriented toward characterizing solidified Radwaste for process licensing.

Nonradioactive vinyl ester-styrene waste samples were subjected to heat-exposure tests. Samples of solidified simulated waste did not melt, sublime or ignite when exposed at $538^{\circ} \mathrm{C}$ $\left(1000^{\circ} \mathrm{F}\right)$ for $10 \mathrm{~min}$ in an electric-muffle furnace. Additional sample examination showed that when completely removed from their containers, they lost 27 to $29 \%$ of their weight during the test.

To determine if any radioactive isotopes would be lost under the heat-exposure test conditions, the test was repeated using a simulated Pressurized Water Reactor (PWR) waste containing $0.5 \mathrm{Ci}$ of ${ }^{137} \mathrm{Cs}$. The solidified specimens used simulated PWR evaporator-bottom waste at a 1.8/1.0, waste/binder ratio. The tests were run in the same electric-muffle furnace used for the nonradioactive tests. Specimens were held at $538^{\circ} \mathrm{C}\left(1000^{\circ} \mathrm{F}\right)$ for 10 min both in cans with and without lids and in no container. There was sample weight loss of 10 to $31 \%$ based on specific test conditions, but no cesium loss from the samples was detected.

The samples from the heat test that were not in a container were completely immersed in deionized water. The data show that approximately $5 \%$ of the ${ }^{137}$ Cs leached out of the specimens in 90 days. More than half the $5 \%$ of the ${ }^{137}$ Cs leached out of the heated specimens during the 
first day, while leaching from the control specimens occurred at a more uniform rate. Since the surface of the samples was charred slightly in the heat test, some surface effect of leaching could be expected. However, no detrimental effects on the long-term leaching were caused by heating the specimens for 10 min at $538^{\circ} \mathrm{C}\left(1000^{\circ} \mathrm{F}\right)$.

Samples of vinyl ester-styrene were also tested to evaluate its combustibility. The test was done using the $16.5 \mathrm{~cm}(6.5 \mathrm{in.})$ in diameter and $19.1 \mathrm{~cm}(7.5 \mathrm{in.})$ in length samples. The samples were $\mathrm{placed}$ in the bottom of a fire pit formed by a half section of a 55-gal drum cut lengthwise. One gallon of No. 2 fuel oil was placed in the fire pit and ignited. The fuel oil burned with a vigorous flame for 6 to $7 \mathrm{~min}$ of the approximate $10 \mathrm{~min}$ burning time. After the flame burned out, the samples were removed from the fire pit, observed, cooled in air, and weighed. Samples of solidified nonradioactive simulated Boiling Water Reactor, Mixed Bed Resin (MBR) and decontamination solvent wastes were tested both in the gallon containers and with the containers removed. A solidified, nonradioactive, simulated PWR waste was also tested in a container with no top. None of the tested samples supported combustion after the fuel oil fire burned out. Testing the samples with the container removed was the most severe case. The surface of the samples charred but the specimens did not burn, even when the fuel oil was increased to $2 \mathrm{gal}$, which increased the burning time to 20 min. Half sections of the samples show that the interior of the specimens was not affected by the heat from the flame. The simulated MBR sample also showed the homogenous distribution of the ion-exchange resin beads in the solid matrix.

Long-term water leach tests measure the ability of the solidified product to prevent release of the radioactive species to the environment, particularly to ground water. Initial long-term leaching tests were made with nonradioactive species. Leach-test results with the radioactive wastes compared favorably with the nonradioactive simulated wastes. The ${ }^{137} \mathrm{Cs}$ leached at a slightly higher rate than the ${ }^{60}$ Co from all solidified specimens except the solidified MBR waste. The results of the leach test on solidified Boiling water Reactor waste at $1.65 / 1.0$, waste/binder volume ratio are shown in Figure 10.11 .

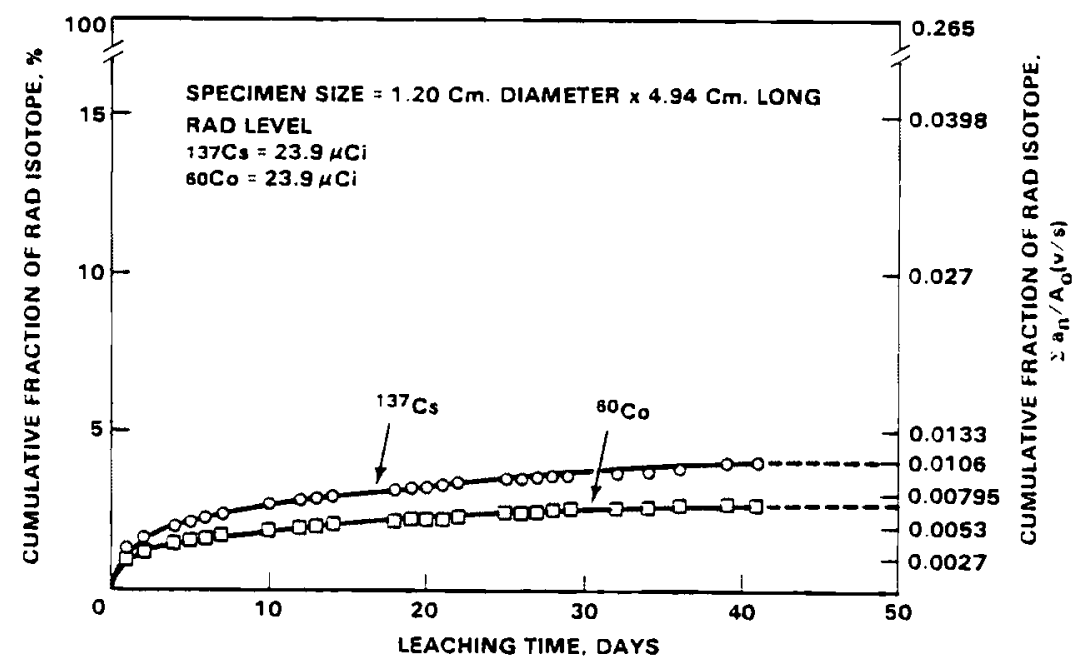

FIGURE 10.11. Leach Test Results for Rad BWR Waste at $1.65 / 1.0$ Waste/Binder Ratio 
Other data show that the leach rate from the MBR waste is about two orders of magnitude lower than that of the PWR waste. The difference cannot be attributed to tracer level, as the level of the MBR waste is about twice that of the PWR waste. Since a chemical reaction occurs in the ion-exchange process, it is reasonable to expect the radioactive species to be chemically bound to the MBR waste and did not leach as rapidly in deionized water.

\subsubsection{Process System Description and Material Balance}

The Dow solidification system for Radwastes has been under development for 10 years and has been under demonstration and application for about the last 5 years. However, the application to HLLW is new. The areas of new technology required to implement this process included: 1) the solidification of HLLW in vinyl ester-styrene, 2) the production of small shapes such as pellets that can be removed from the storage container, and 3) the treatment of the product particles so that the waste is compatible with the final solidification process. These areas will require a significant engineering and development effort, which is beyond the scope of this study.

Simplified process flow diagrams for the vinyl ester-styrene process are shown in Figures 10.12 and 10.13. Blended alkaline Purex and acidic Thorex waste from the tank farm is transferred to a receiving tank located inside the process building. Depending on the feed concentration, evaporation may be necessary since the final product volume is related to the initial feed volume. The waste blend is transferred to a blending tank in the proportion to be used in the process. The waste blend is adjusted with nitric acid until the final pH is 2.5 to 11. Any other desired or proprietary chemical adjustments are made at this time.

The waste blend is then added to the binder solution and mixed. A catalyst is added, followed by a promoter. The material is then placed in small molds and allowed to cure before being placed in a container. The curing process is an exothermic reaction that generally requires less than one hour to complete. The reaction is mild and is easily controlled. The reaction temperature and the hardness of the product after curing are used as the processcontrol techniques to assure satisfactory process completion. The waste pellets are removed from their molds and added to a storage canister. After the storage container is filled, the container may be capped-seal welded, the weld examined, and the container decontaminated, if necessary, for storage.

Confirmatory process testing will be required to optimize process parameters and chemical additions. Each volume of waste will require about 0.5 volume of binder. The catalyst and promoter volume are small. Conditions are designed such that a processing temperature of $100^{\circ} \mathrm{C}$ is not exceeded. Testing would determine the feasibility of casting the product in small shapes and would indicate if a mold releasing agent is needed.

The vinyl ester-styrene canisters are shipped to the final processing site for incorporation of the product into the final waste form. The canister is removed from the shipping cask, inspected, and then decontaminated if necessary. The seal weld is mechanically removed from the lid. Then the contents may be removed by vacuuming, pouring, or dissolution. The canister may then be decontaminated and recycled or disposed of. Figure 10.13 is a schematic of the vinyl ester-styrene removal process from the temporary storage canisters. 


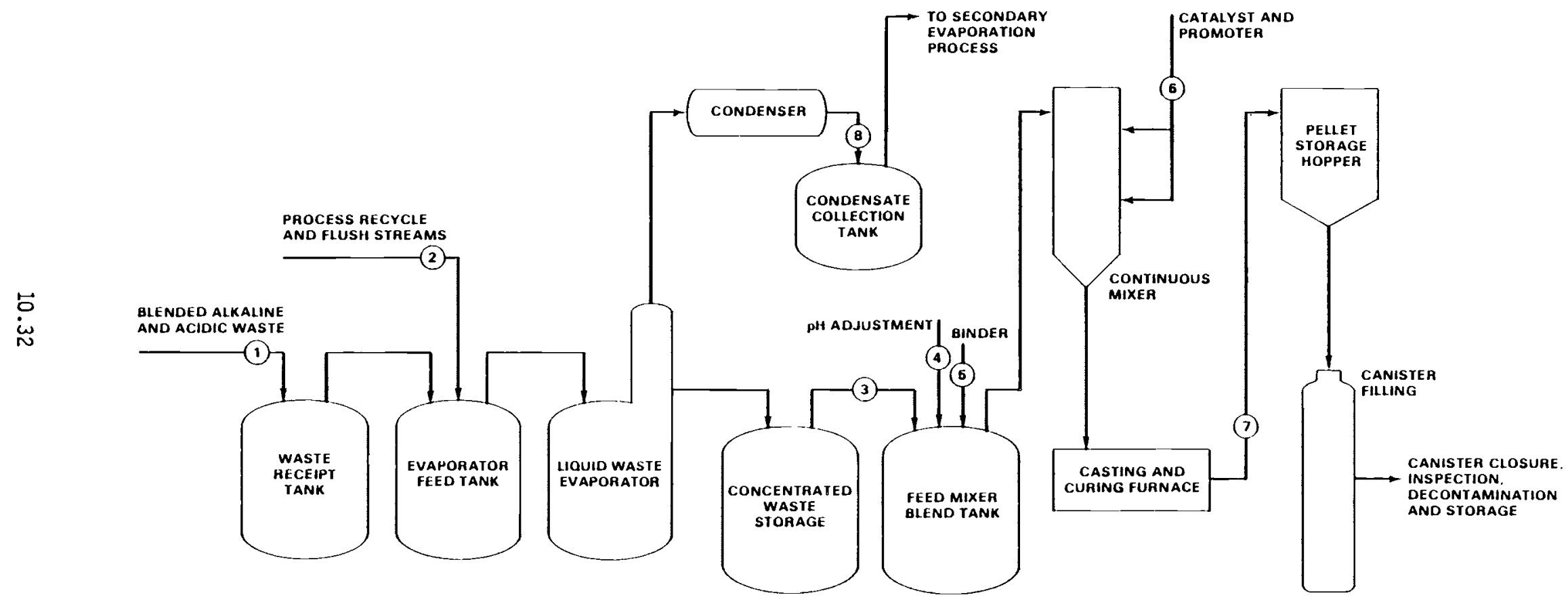

FIGURE 10.12. Conceptual Vinyl Ester-Styrene Process Flow Diagram 


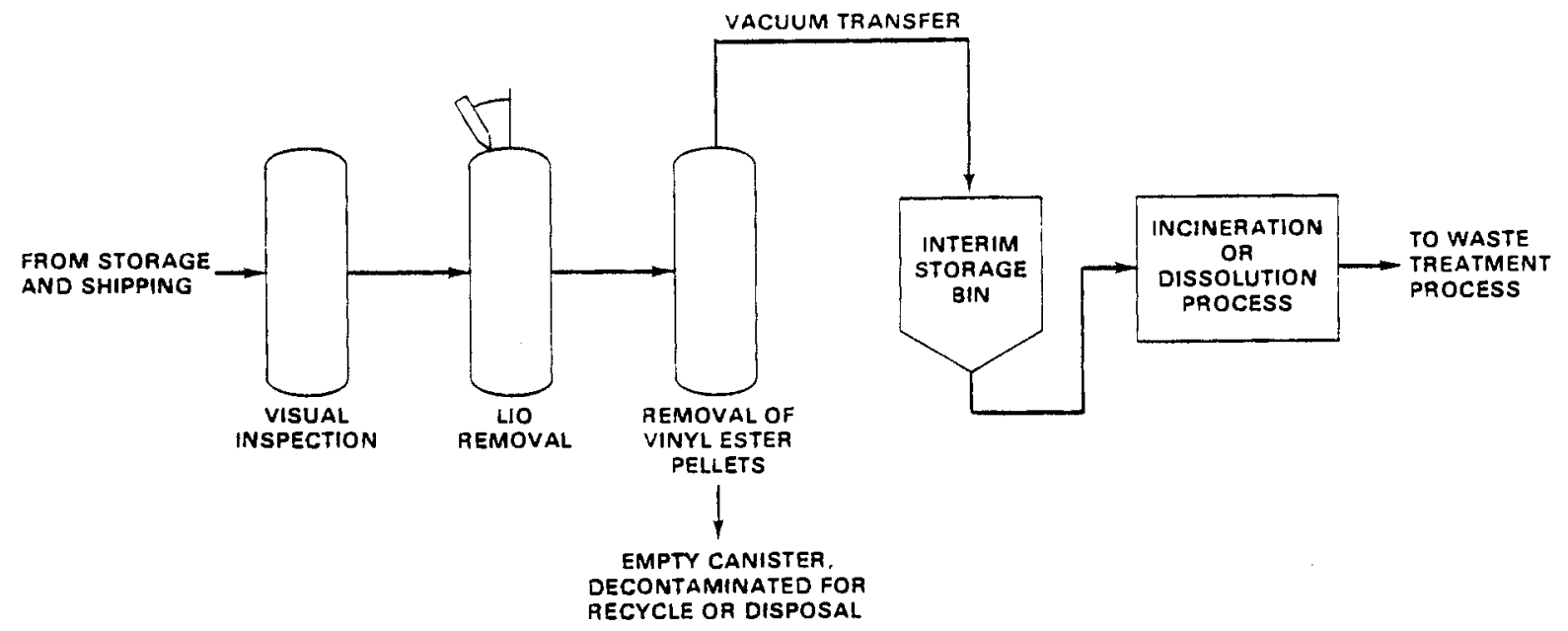

FIGURE 10.13. Conceptual WNYNSC HLW Vinyl Ester-Styrene Product Removal from Container and Treatment Process Flow Diagram

The treatment of the product to produce a form that would be compatible with the final waste form process would likely involve incineration or dissolution. In any event, the technology must be developed and is likely to be relatively complicated and expensive.

The process material balance for the vinyl ester-styrene process is given in Table 10.16 . Stream identification numbers on the material balance table refer to the process flow diagram in $F$ igure 10.12 .

The overall process summary for the vinyl ester-styrene process is given in Table 10.17 . The production rate for the canisters is approximately one every three hours, based on a threeyear solidification campaign with a plant-operating efficiency of 0.60 . The surface and centerline temperatures of the canisters are only slightly above ambient. The dose rate at the canister surface would be approximately $60 \mathrm{R} / \mathrm{hr}$.

The material balance for the reference case is very preliminary due to the absence of specific development related to the particular waste and the absence of available data on the proprietary Dow process. There is the possibility that the final product volume can be somewhat reduced by process optimization and by further concentration of the process feed. However, the number of canisters produced are anticipated to be substantially more than that for the fused salt or calcine interim waste forms.

\subsubsection{Status of Technology}

The Dow vinyl ester-styrene process (directed towards solidification of radwastes from commercial PWR and BWR power reactors) has been under laboratory development for 10 years. The vinyl ester-styrene process has been approved for licensing by the NRC and a number of states for use at commercial reactors. Studies are being done by BNL to further characterize product properties.

Dow possesses certain proprietary information, both patented and unpatented, relating to the vinyl ester-styrene process. Using this technology requires a license agreement with Dow. At present, there are five utilities that are licensed by Dow to use the process. These are: 
TABLE 10.16. Process Conditions and Material Balance Data for Solidifying Combined Alkaline and ACid Waste in a Vinyl Ester-Styrene Waste Form

\begin{tabular}{|c|c|c|c|c|c|c|c|c|}
\hline Stream Number $(\mathrm{a})$ & 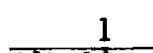 & 2 & 3 & 4 & 5 & 6 & 7 & 8 \\
\hline Description & $\begin{array}{l}\text { Alkaline } \\
\text { Waste } \\
\text { Blend } \\
\end{array}$ & $\begin{array}{l}\text { Recycle } \\
\text { and } \\
\text { Flushes }\end{array}$ & $\begin{array}{l}\text { Mixer } \\
\text { Feed }\end{array}$ & $\begin{array}{c}\mathrm{pH} \\
\text { Admustment } \\
\end{array}$ & Binder & $\begin{array}{c}\text { Catalyst } \\
\text { and Promoter }\end{array}$ & VES Product & $\begin{array}{l}\text { Evaporator } \\
\text { Condensate }\end{array}$ \\
\hline \multicolumn{9}{|l|}{ Flow, $\mathrm{kg} / \mathrm{hr}$} \\
\hline Salt & 78.5 & & 78.5 & & & & 78.5 & \\
\hline Solids & 6.3 & & 6.3 & & & & 6.3 & \\
\hline $\mathrm{H}_{2} \mathrm{O}$ & 150 & 25 & 100 & & & & 100 & 175 \\
\hline $\mathrm{HNO}_{3}(12.2 \mathrm{M})$ & & & & As required & & & As req. & \\
\hline Binder & & & & & $\begin{array}{l}V \text { inyl-ester } \\
\text { resin }\end{array}$ & & $(\sim 70 L)$ & \\
\hline Catalyst & & & & & & $\begin{array}{l}40 \% \text { soln of } \\
\text { Benzoyl Peroxide }\end{array}$ & Small amount & \\
\hline Promoter & & & & & & $\begin{array}{l}\text { Tertiary amine, } \\
H, N \text { dimethyl } \\
\text { to luidine }\end{array}$ & Small amount & \\
\hline \multicolumn{9}{|l|}{ VES Product } \\
\hline Total & 234.8 & 25 & 184.8 & As required & -- & -- & $\sim 255$ & 175 \\
\hline Temperature, ${ }^{\mathrm{O}} \mathrm{C}$ & Ambient & Amb tent & Ambient & Ambient & Ambient & Ambient & Amb. & 100 \\
\hline Density, $\mathrm{g} / \mathrm{cm}^{3}$ & 1.57 & 1.0 & 1.8 & 1.35 & -- & -- & $1.2^{(b)}$ & \\
\hline Flow, L/h & 150 & 25 & 100 & $\begin{array}{l}\text { To be } \\
\text { determined }\end{array}$ & 70 & Small volume & 210 & 75 \\
\hline Activity, $\mathrm{Ci} / \mathrm{L}$ & 14.4 & Negl. & 21.6 & 0 & 0 & 0 & 10.3 & $2.7 \times 10^{-6}$ \\
\hline Heat, W/L & 0.041 & 0 & 0.062 & 0 & 0 & 0 & 0.03 & 0 \\
\hline
\end{tabular}

(a) Stream numbers refer to streams shown in Figure 10.12.

(b) Bulk density of vinyl ester-styrene product $\simeq 1.2$. 
TABLE 10.17. Vinyl Ester-Styrene waste Form Process Summary; Solidification of Combined Alkaline Purex and Acidic Thorex Wastes

\begin{tabular}{lll}
\multicolumn{1}{c}{ Process Characteristics } & & $\begin{array}{c}\text { Vinyl } \\
\text { Ester-Styrene Waste }\end{array}$ \\
\cline { 1 - 2 } Vinyl ester-styrene production rate, $\mathrm{kg} / \mathrm{h}$ & & 250 \\
Number of vinyl-ester canisters & 4708 \\
Activity per canister, Ci & $7.2 \times 10^{3}$ \\
Decay heat per canister, $W$ & 21 \\
Bulk density of waste form & 1.2 \\
Dose rate at canister surface, R/h & 60 \\
Processing campaign length, $d$ & 657
\end{tabular}

1. Commonwealth Edison - Dresden I and Quad Cities,

2. Metropolitan Edison - Three Mile Island,

3. Portland General Electric - Trojan,

4. Niagara Mohawk - Nine Mile Point,

5. Duke Power - McGuire and Catawba.

Dow has also licensed five equipment manufacturers (UNC Nuclear Industries, Atcor Washington Inc., Hittman Nuclear and Development Corp., Stock Equipment Company, and Teledyne Energy Systems, Inc.) and six architect/engineer firms (Catalytic, Gilbert and Associates, Bechtel Power Corp., Teledyne Readco, Aerojet Energy Conversion Company and NUS Corp.) to design, install, or modify new or existing waste-solidification equipment to use the Dow Process. Dow has also licensed three companies (Chem Nuclear Systems Inc., Epicor, and Hittman Nuclear and Development) to provide mobile solidification services to those utilities who choose not to install their own permanent system.

Only one of the utilities listed above has their Dow process system in operation at the present time. Three more are in the final stages of installation and do expect to have their systems on stream during 1981. The process itself, however, has been demonstrated successfully at Three Mile Island (through Chem Nuclear Systems, Inc.) where approximately 100, 55-gal drums of auxiliary building waste have been solidified. The Dow process has been successfully demonstrated with prototypical equipment at six different utilities using actual power-plant radioactive waste. The waste was solidified in 55-gal drums and in 50- $\mathrm{ft}^{3} 1$ iners.

There has been no development or specific studies directed toward the use of the Dow process for high-level-waste solidification. However, some of the low-level-waste development studies apply. For application to WNYNSC waste, specific product formulation and characterization are needed. The major areas requiring development and/or resolution would be: product formulation and properties, radiation stability for extended periods, flamability, rendering methods to make the waste form compatible with the final solidification process, waste form sizing to make the organic product amenable to placing and removing from the temporary storage package (handling), and long-term storage characteristics. 


\subsubsection{Safety Considerations}

The vinyl ester-styrene process is a simple process that has been complicated by a unique application. The process has an acceptably low potential for consequential accidents and damage to the environment. The process has been licensed by NRC for use in Radwaste solidification, and the product has been accepted by all state authorities where commercial, radionuclide burial grounds exist.

The application of the Dow process for solidification of the WNYNSC wastes is unique in several respects: 1) it solidifies HLLW, 2) it requires a pelletized product that can be easily removed from its storage container, and 3 ) the pelletized product must be compatible with the final waste form solidification process. These features of the application have not been developed or reviewed for safety implications. It is not expected that these features would result in any unacceptable safety hazards. However, there are questions about the product stability for extended times and about the processes used to produce a pelletized product and then change the product to a form compatible with the vitrification process. These processes are likely to substantially complicate the Dow process, and it has not been determined if there would be an accompanying increase in safety hazard potential.

Based on application of this process to Radwaste systems, potential accidents have been identified and evaluated by the Dow Company (Dow 1978). The most significant hazards are related to the flammability of the binder and the exothermic reaction between the promoter and the catalyst should they be inadvertently mixed. These safety-related studies have shown that the risks and hazard potential are acceptable. Engineering can provide additional safety margins and minimize accident consequences, if necessary.

Standard safety precautions are required for handling of chemicals. Tests were done to determine if there are any negative effects due to chemical reactivity during inadvertent mixing of chemicals. Chemicals were mixed in the laboratory to simulate either operator or equipment error. These tests indicated that if the catalyst and promoter are mixed, heat will be generated due to the inherent exotherm of the system. However, no violent reaction will result. As a secondary precaution, the chemical-storage stations can be separated and each chemical can be sequenced for addition from a separate location.

The binder is a flammable liquid and does require a fire protection system that is compatible with that particular chemical. Explosion-proof intrinsically-safe electrical equipment and circuitry for instruments and controls are also required.

Other features of the Dow System that contribute to safety are:

1. The waste and solidification materials do not chemically react.

2. No chemicals are added during solidification that would contribute to the evolution of gaseous radioactive products.

3. The system is entirely liquid phase for ease of operation and maintenance before solidification.

Equipment installation will result in the batch and metering tanks being located outside of the solidification area, as is typical of the present design of nuclear power plants. The 
most credible accident that could occur would be a leak in one of the lines used to transfer waste from the metering tank into the mixing area. This would result in the contents of one drum being spilled into the process area. Contamination may result and require a shut down of the equipment for repair and clean-up. It is believed that most of this material can be removed remotely. Ventilation can be sized to provide the necessary air movement and filtration for the Dow System. Therefore, no safety problems are anticipated with respect to release of radioactivity to the environment.

The Dow process would have negligible impact on the environment since there are no process effluents. The only effluents that may be related to the process would be process condensate from feed concentration. There may also be a small quantity of organic vapor emitted from the organic binder.

\subsubsection{Facility Implementation}

Facility and equipment requirements for solidifying the WNYNSC wastes require a unique application of the Dow process. Standard preconcentration equipment is needed to minimize the final process volume. But the balance of equipment requirements must be developed or engineered for this application. Only limited equipment developed used for Radwaste solidification systems are applicable for this unique process due to the need to make small shapes, such as pellets or balls, that can be easily removed from a product container and be changed to a form compatible with the final waste form process. Without additional process development and facility engineering the space equipment requirements will be speculative. Therefore it is not known if the process equipment can be implemented within the CPC. A postulated layout is shown in Figure 10.14 for the CPC. This layout is similar to the silicate/salt matrix process'.

The principle equipment systems would consist of feed preconcentration, feed makeup, waste blending, casting/curing, and pacxaging. The waste blending and the casting/curing equipment

A. HLLW RECEIVING TANKS

B. WASTE FEED BLENDING TANKS

C. HLLW EVAPORATOR SYSTEM

D. VINYL ESTER-STYRENE PROCESS SYSTEM

E4. CANISTER LID-WELD STATION
E5. CANISTER DECONTAMINATION

E6. CANISTER TRANSPORT CART

F. RECYCLE AND SECONDARY EVAPORATION

G. OFF-GAS TREATMENT SYSTEM

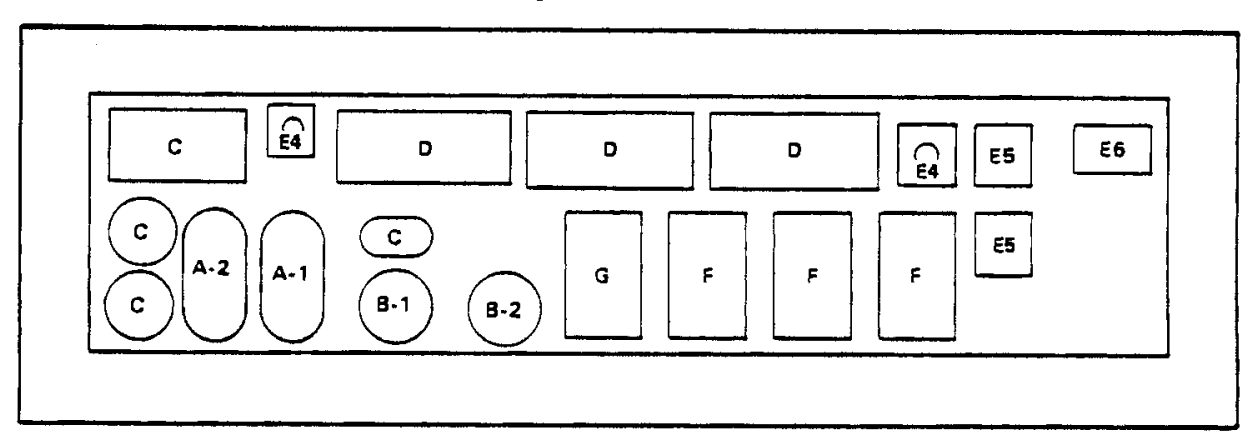

CHEMICAL PROCESS CELL

$$
2 m
$$

FIGURE 10.14. Conceptual Equipment Layout for the Vinyl Ester Styrene Process 
will have to be adapted from other technologies or be developed. The equipment used for inline blending, such as the extruder in the bitumen process or the pellet-making process demonstrated at PNL, is an example of technology that may be adapted to a continuous process. Other processes such as feed preconcentration, feed makeup, and waste packaging are demonstrated technology.

The system should be remotely operable and maintainable. In Radwaste systems the system is maintained manually, but this is not feasible for this process in the CPC.

Services and cell requirements for process operation and maintenance will need to be identified based on the equipment concepts selected for use. But most services would be similar to those for other in-cell chemical processes.

This vinyl ester-styrene process offers the advantage that little, if any effluents are generated. Thus, effluent-treatment systems, as required for other processes, are not needed, such as process off-gas treatment and condensate cleanup. There will be facility and process decontamination solutions that must be treated, and this process, as described here, can concentrate and solidify these solutions.

The two, existing, bridge cranes are used in the cell for installation of equipment and for handling waste canisters. The cranes are moved to an adjacent shielded area for decontamination and repair. A time and motion study should be conducted to determine if these two cranes have adequate capacity to handle the high canister-production rate in this process.

Master-slave manipulators and oil-filled lead glass shielding windows are required at locations where semi-remote operation and maintenance is required. Manipulators are not required for frequent and routine operations; however, they are needed for some nonroutine maintenance and equipment adjustment of the casting and curing equipment.

\subsection{CALCINE PROCESS}

Calcine is the general name for unconsolidated powder or granules made in a single-step process of evaporation and partial decomposition of HLLW nitrates and hydroxides. Calcine, at one time, was considered acceptable as a final, solid waste form. Presently it is considered as an intermediate form in the production of final waste forms. Calcine normally serves as a precursor to glass.

Calcine is produced by heating the waste slurry and chemical additives, if required, to an elevated temperature. Water is evaporated and metal nitrates, nitrites and hydroxides are partially decomposed to oxides. Organic material present is volatilized or pyrolyzed. The dispersion potential of calcine as airborne particulates or when exposed to leaching is high. However, dispersion characteristics can be substantially improved by agglomeration techniques or additives. Calcination technology for high-level wastes was developed at PNL (spray calcination), at INEL (fluid-bed calcination), and at ORNL (in-pot calcination). This basic waste-form process is simple, inexpensive, safe, and produces few environmental consequences. 


\subsubsection{Waste Form Properties}

Calcine is a fine particulate waste form, amorphous in structure, and composed of metallic oxides, nitrates and hydroxides, and various chemical salts. Chemical salts include metallic sulphates, phosphates, and carbonates that do not decompose or volatilize upon calcination. Calcine has a variable nitrate content depending on the feed composition, the calcination process, and the calcination temperature.

Acidic and alkaline waste calcines containing low-sodium concentrations (less than 5 wt\%) have been extensively characterized; however, only limited characterization of high-sodium calcines has been done.

The reference calcine composition resulting from solidification of blended alkaline Purex and acidic Thorex WNYNSC waste is summarized in Table 10.18. This composition assumes that only half of the sodium nitrate/nitrite is converted to sodium oxide and that all other metallic nitrates are converted to the oxide form. This composition is expected when operating the

TABLE 10.18. Projected Composition of Calcine from Blended Alkaline Purex and Acidic Thorex WNYNSC Wastes

\begin{tabular}{|c|c|}
\hline Compound & Weight, $\mathrm{kg}$ \\
\hline $\mathrm{Na}_{2} \mathrm{SO}_{4}$ & $8.9 \times 10^{4}$ \\
\hline $\mathrm{NaNO}_{3} / \mathrm{NO}_{2}$ & $5.6 \times 10^{5}$ \\
\hline $\mathrm{Na}_{2} \mathrm{O}$ & $2.2 \times 10^{5}$ \\
\hline $\mathrm{NaCl}$ & 500 \\
\hline $\mathrm{Fe}_{2} \mathrm{O}_{3}$ & $5.93 \times 10^{4}$ \\
\hline$P_{2} O_{5}$ & $1.4 \times 10^{4}$ \\
\hline $\mathrm{Cr}_{2} \mathrm{O}_{3}$ & 5180 \\
\hline NiO & 2530 \\
\hline $\mathrm{Al}_{2} \mathrm{O}_{3}$ & 1490 \\
\hline $\mathrm{AlF}_{3}$ & 1570 \\
\hline $\mathrm{RE}_{2} \mathrm{O}_{3}(\mathrm{a})$ & 1380 \\
\hline $\mathrm{FP}\left(\mathrm{SO}_{4}\right)(\mathrm{b})$ & 1240 \\
\hline $\mathrm{FP}_{2} \mathrm{O}_{4}(\mathrm{~b})$ & 1380 \\
\hline $\mathrm{FP}_{2} \mathrm{O}_{3}(\mathrm{~b})$ & 430 \\
\hline $\mathrm{MOO}_{3}$ & 1380 \\
\hline $\mathrm{MnO}_{2}$ & 2200 \\
\hline $\mathrm{PuO}_{2}$ & 35 \\
\hline $\mathrm{U}_{3} \mathrm{O}_{8}$ & 5980 \\
\hline Act. Oxide ${ }^{(c)}$ & 20 \\
\hline $\mathrm{ThO}_{2}$ & $1.17 \times 104$ \\
\hline TOTAL & $9.8 \times 10^{5} \mathrm{~kg}$ \\
\hline
\end{tabular}

(a) Rare earth oxide.

(b) Fission-product sulphate and oxides.

(c) Actinide oxide. 
calciner at a temperature of approximately $300^{\circ} \mathrm{C}$, which is required to prevent melting of the calcine product within the calciner. The estimated melting point of the calcine product is $310^{\circ} \mathrm{C}$ to $350^{\circ} \mathrm{C}$. Complete decomposition of sodium nitrate to the oxide form occurs at $380^{\circ} \mathrm{C}$, and complete decomposition of sodium nitrite to the oxide form occurs at $320^{\circ} \mathrm{C}$. Therefore, oniy partial nitrate decomposition can be achieved. All other metaliic nitrates will be converted to the oxide form. However, many of the metallic species will be fed to the calciner as hydroxide precipitates and will be discharged from the calciner as hydroxides.

Silica or other additives such as iron and aluminum nitrate can be added to the alkaline feed blend before calcination. These additives will allow the calciner to operate at higher temperatures $\left(650\right.$ to $800^{\circ} \mathrm{C}$ ) permitting greater nitrate/nitrite decomposition. The following reaction is postulated to occur when calcining a blend of sodium nitrate and silica. The melting point of the sodium-metasilicate product formed is $1088^{\circ} \mathrm{C}$.

$$
2 \mathrm{NaNO}_{3}+\mathrm{SiO}_{2}+\mathrm{H}_{2} \mathrm{O} \longrightarrow \mathrm{Na}_{2} \mathrm{SiO}_{3}+\mathrm{NO}+\mathrm{NO}_{2}+\mathrm{H}_{2} \mathrm{O}+\mathrm{O}_{2}
$$

This processing approach, however, substantially increases the quantity of calcine produced.

Calcine particle size distributions are shown in Figure 10.15 (Bonner, Blair and Romero 1976) for low-sodium acidic-type waste and Figure 10.16 for alkaline low-sodium waste (Larson 1980). While $65 \%$ of the total number of particles for acidic waste are in the diameter range of 1 to $5 \mu \mathrm{m}$, these particles account for only $15 \%$ of the mass. Only $17 \%$ of the total particles are 6 to $20 \mu \mathrm{m}$ in dia, but they account for $75 \%$ of the mass. The large acidic-waste particles (over $1 \mathrm{~mm}$ in dia) were analyzed and found to have the same composition as the rest of the calcine, except for higher water and nitrate contents. For alkaline waste slurry (Larson 1980), $88 \%$ of the total particles are less than $11 \mu \mathrm{m}$, but account for only $2.8 \%$ of mass. Since the alkaline waste is a slurry rather than a solution, the larger particles in the calcine represent the larger particles in the slurry. These large particles do not have the same composition as the smaller calciner particles produced from water-soluble compounds.

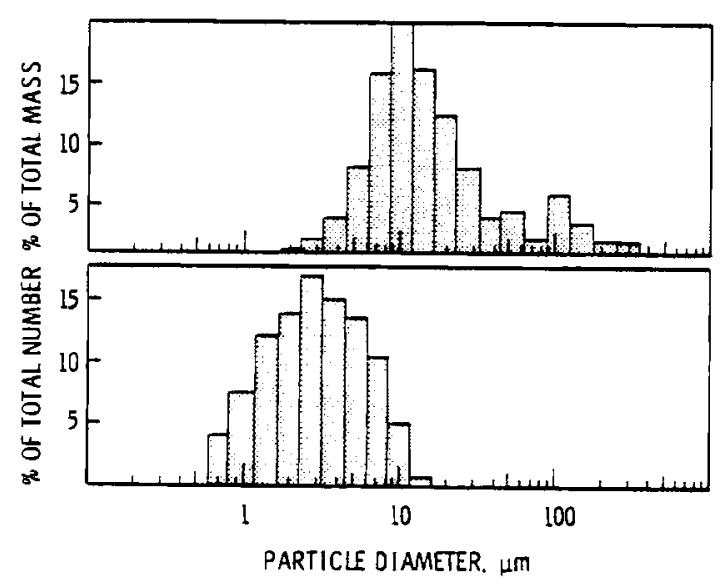

FIGURE 10.15. Acid-Waste Particle-Size Distribution 

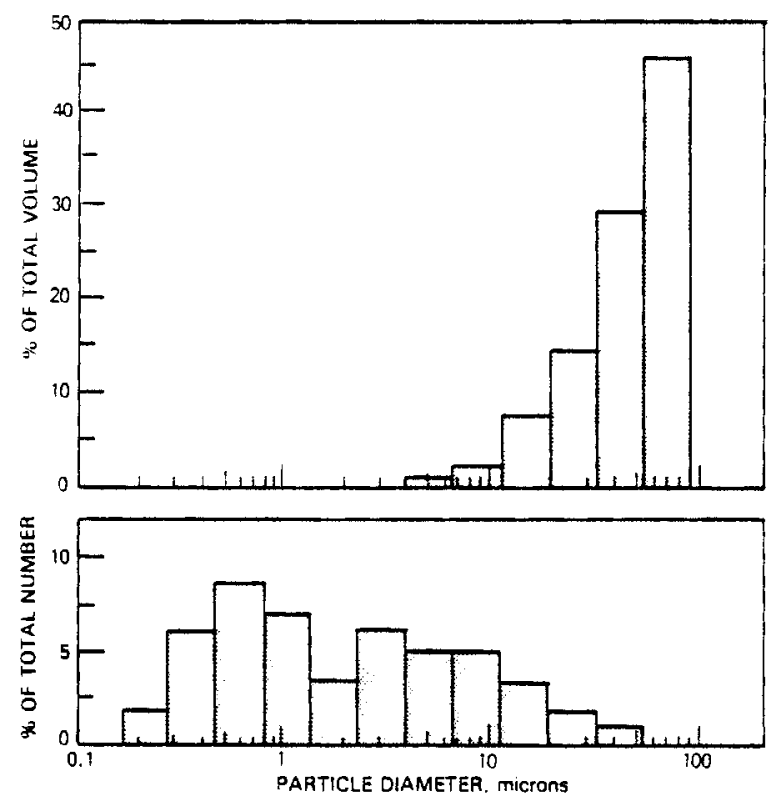

FIGURE 10.16. Defense Waste-Calcine Particle-Size Distribution

Typical calcine properties are presented in Table 10.19. The calcine properties are a function of waste composition and of calciner operating parameters. The calcine moisture content is normally less than $1 \%$ (not including water of hydration) but can be as high as $4 \%$ without significantly decreasing the calcine's ability to flow. Residual nitrate content from acidic wastes is a strong function of the alkali metal content of the waste and the calcination temperature. Most nonalkali metal nitrates are converted to oxides.

The calcine particles appear to be amorphous. The active surface area of the calcine powder is 10 to $20 \mathrm{~m}^{2} / \mathrm{g}$, which accounts, in part, for the high calcine reactivity.

Experience with the calcine shows that: it is floodable, it dusts, it is hygroscopic, it is difficult to feed at a constant rate with volumetric feeders, and it has a high surface activity. Calcines make a good feed-stock material for pressing, sintering and melting process because they are very active (Ross and Dakan 1974). Calcine has also been successfully agglomerated in a disc pelletizer at PNL (Blair 1975). Cursory studies with high-sodium synthetic WNYNSC calcine have shown it to be highly hygroscopic, i.e., it will become damp when sitting in air.

Some common properties of calcine that affect process design and other considerations include thermal conductivity, leachability, and volatiles' content. The thermal conductivity of calcine is generally two to three times lower than that of consolidated products. Thus, because of the high, heat generation in HLLW, the storage of calcine requires small-diameter bins or special heat-removal features.

The volatiles' content of calcine consists mainly of residual nitrates. Volatiles in the calcine produced in the waste Calcination Facility (INEL) were released through vents in the calcine storage containers. The calcine canisters must be sealed, however, for transportation to the storage site. During the development of the pot-calcination process ORNL, a processing 
TABLE 10.19. Properties of Simulated HLLW Spray Calcines

\begin{tabular}{|c|c|c|c|c|}
\hline Characteristic and Units & $P W-4 b$ & $P W-6$ & $P W-7 a$ & Defense \\
\hline Aerated bulk density, $\mathrm{g} / \mathrm{cm}^{3}$ & 0.85 & 0.41 & 0.69 to 0.92 & 0.95 \\
\hline Working bulk density, $\mathrm{g} / \mathrm{cm}^{3}$ & 0.97 & 0.48 & 0.87 to 1.04 & 1.03 \\
\hline Packed bulk density, $\mathrm{g} / \mathrm{cm}^{3}$ & 1.24 & 0.61 & 1.15 to 1.33 & 1.27 \\
\hline Compressibility, $\%$ & 32 & 33 & 31 to 40 & 25 \\
\hline Angle of repose, degrees & 42 & 39 & 42 to 43 & 27 \\
\hline Particle Density, $\mathrm{g} / \mathrm{cm}^{3}$ & 4.4 & 3.8 & 5.1 & Variable $e^{(a)}$ \\
\hline Surface Area, $\mathrm{m}^{2} / \mathrm{g}$ & 20 & 11 & 14 & $\cdots$ \\
\hline Nitrate Content, wt\% & 1 & 19 to 42 & 2 to 22 & $\cdots$ \\
\hline Moisture Content, wt\% & 1 & 1 & 1 to 4 & 1 to 3 \\
\hline pH of Equilibrium Aqueous Slurry & 4.5 & 5.0 & -- & 7.2 \\
\hline
\end{tabular}

(a) The calcine particle density is variable (about $4.3 \mathrm{~g} / \mathrm{cm}^{3}$ average) because particles from simulated defense waste slurries remain as separate and distinct compounds, i.e., the calcine is composed of $\mathrm{MnO}_{2}$ particles, NiO particles, zeolite particles, particles containing water-soluble compounds, etc.

(b) Adapted from Bonner, Blair and Romero 1976; Larson, 1980.

temperature of $900^{\circ} \mathrm{C}$ was found to achieve complete nitrate decomposition and thus to assure that sealed canisters of calcine would not pressurize. Such treatment of the WNYNSC calcine would first result in melting the calcine followed by solidification into a monolith. This monolith may be somewhat difficult to dissolve and remove from the canister, especially if silica is added.

Fluid-bed calcination was developed at INEL during 1952-1959. A demonstration plant-scale facility for solidifying aluminum nitrate wastes was constructed and radioactive operations were begun in 1963 (Buckham and McBride 1973; Cooper, Black, and Amberson 1965; Bailey, Legler, and Petrie 1966; Lakey and Wheeler 1972). The product from fluid-bed calcination is a mixture of granular, bed material and powdery solids removed from the off-gas system in the primary cyclone. Most nuclear applications of fluid-bed calcination have involved heat supplied through internal combustion of an organic material such as kerosene.

Approximately $25 \%$ of the bulk material from a typical calcine is readily leachable. Some materials, such as cerium oxide, are quite insoluble (Mendel and McElroy 1972). Mercury is not retained; sulfate can be largely retained; and alkali metals such as sodium can be largely retained in calcine by making the proper chemical feed adjustments (Clark et al. 1966).

Definitive leachability measurements are difficult to make on unconsolidated calcine, but some data have been reported. For the calcine in storage at the INEL, $60 \%$ of the ${ }^{137} \mathrm{CS}$ and $40 \%$ of the ${ }^{90} \mathrm{Sr}$ are removed after $2,000 \mathrm{~h}$ of continuous leaching by water at $25^{\circ} \mathrm{C}$ (U.S. ERDA 1976b). Mendel and MCElroy (1972) reported that 20 to $25 \%$ of the constituents in typical commercial calcines dissolve readily in a $25^{\circ} \mathrm{C}$ leaching test. Fission-product leachabilities of Eurochemic oxide calcines have been measured at $10^{-1} \mathrm{~g} / \mathrm{cm}^{2} / \mathrm{d}$, at $25^{\circ} \mathrm{C}$, in a standard IAEA leach test (van Geel, Eschrich, and Detilleux 1976). Hence, it can be inferred that all of a 
particular constituent of concern can be leached in $25 \mathrm{~min}$ from a typical $100-\mathrm{cm}^{2} / \mathrm{g}$ powder. Leachabilities of the modified aluminum-phosphate granular, Eurochemic calcines are $10^{-4} \mathrm{~g} / \mathrm{cm}^{2} / \mathrm{d}$ (van Geel, Eschrich, and Detilleux 1976).

\subsubsection{Process System Description and Material Balance}

A number of processes have been extensively developed for calcination of HLLW. These processes include spray calcination at PNL, fluid-bed calcination at INEL, pot-calcination at PNL and ORNL, the rotary kiln in France, and other calcination processes developed in Europe. Some of these processes have been developed for calcining wastes similar to the WNYNSC waste blend containing high concentrations of sodium, sulfate and nitrate. The reference calcination process selected for the process flowsheet is the spray calciner. The spray calciner process has been developed on several production scales and has been demonstrated with radioactive waste. There is limited solidification experience, however, with high-sodium wastes using the spray calciner process. The flowsheet presented is conceptual and requires additional development to reliably solidify the high-sodium waste.

The process, flow diagram for the calcination process is shown in figure 10.17. Two spray calciners will be needed to meet the requirements of the waste solidification process. The complete solidification system consists of: receiving and blending tanks for blended alkaline waste, two spray calciners, two canister lid-welding/decontamination stations, recycle and secondary evaporation processes, and calciner off-gas treatment processes.

8 lended alkaline Purex and acidic Thorex wastes are transferred from the waste tank farm to a waste receiving tank located inside the CPC. The waste is sampled and, if necessary, adjustments are made. The adjusted alkaline waste is then transferred to one of two spray calciner feed tanks. Alkaline waste is pumped from the spray calciner feed tank to a spray nozzle located on top of the spray calciner. The alkaline waste is atomized by air in the spray noz$z$ le into droplets of 70 to $100 \mu \mathrm{m}$ size. The droplets fall and are partially decomposed to

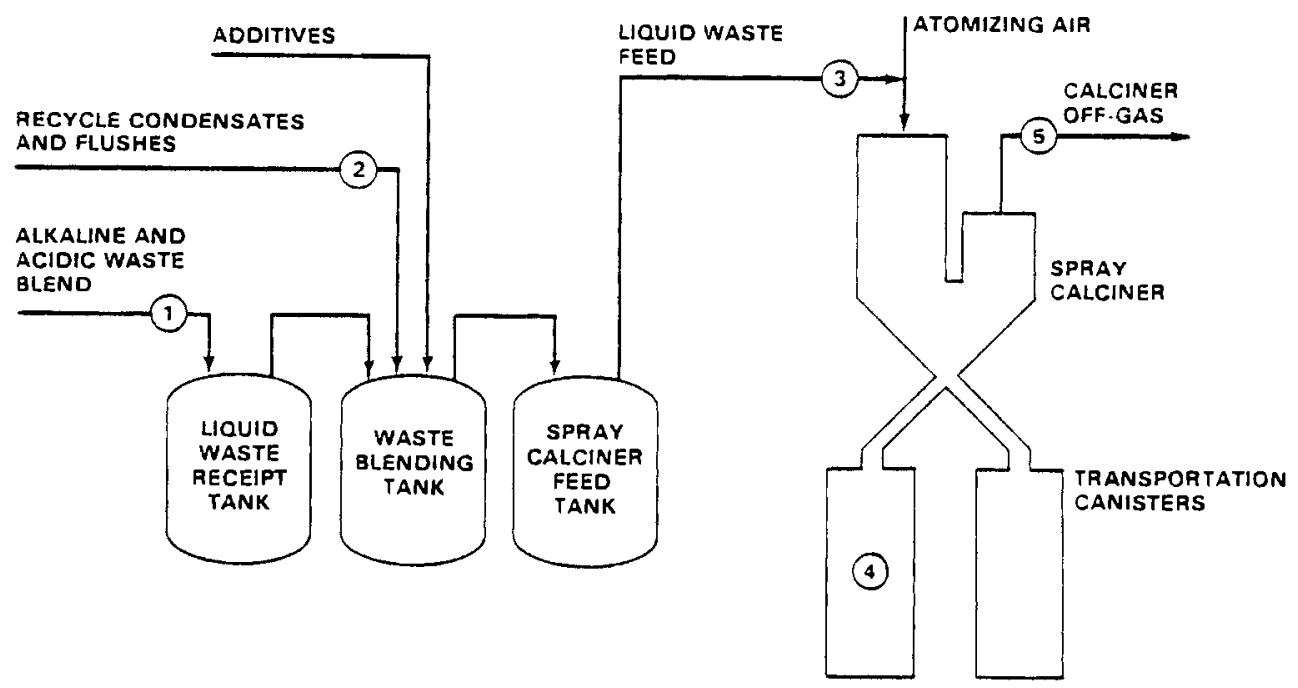

FIGURE 10.17. WNYNSC HLW Calcination Process Flow Diagram 
metallic oxides as they fall through the heated-wall spray calciner furnace. The operating temperature of the spray calciner furnace is about $350^{\circ} \mathrm{C}$. The calcine product formed will be at a nominal temperature of $200^{\circ} \mathrm{C}$ to $300^{\circ} \mathrm{C}$. Ory calcine falls from the calciner into one of two product-receiving canisters. The canister is vibrated during filling to assist in densifying the calcine product and to allow 20 to $30 \mathrm{wt \%}$ more calcine to be placed in the canister. When one canister is filled, the calcine mixture is diverted to the adjacent canister, and the canister-filling process is continued.

Filled canisters are decoupled from the calciner and transferred to the canister lid-weld stations. A lid is placed on the canister; the canister is seal welded; the weld is examined; and the canister is visually inspected for integrity. The canister is then transferred to the canister decontamination station before being sent to an interim storage facility. Eventually it is shipped to a final-processing site.

Off-gas effiuents from the calcination process consist of water vapor, $\mathrm{NO}_{x}$ from nitrate decomposition, potentially volatile fission products and waste atomizing air, which may entrain some dust. The gaseous effluent is decontaminated through successive steps of scrubbing, filtration, condensation and sorption processes. The effluent system for the calciner process treats the gaseous effluents from both spray caiciners. This system is conceptually the same as that for the reference, terminal waste-solidification process described in Appendix A. The effluent system will need to be sized larger, however to accommodate the additional atomizing air and in-leakage when operating the two spray calciners.

A simplified schematic showing how the calcine would be removed from the storage containers at the terminal-waste processing sites is shown in Figure 10.18. The canister is removed from the shipping cask at the terminal processing site, inspected, and then decontaminated if necessary. The seal weld is mechanically removed from the lid. The canister contents are

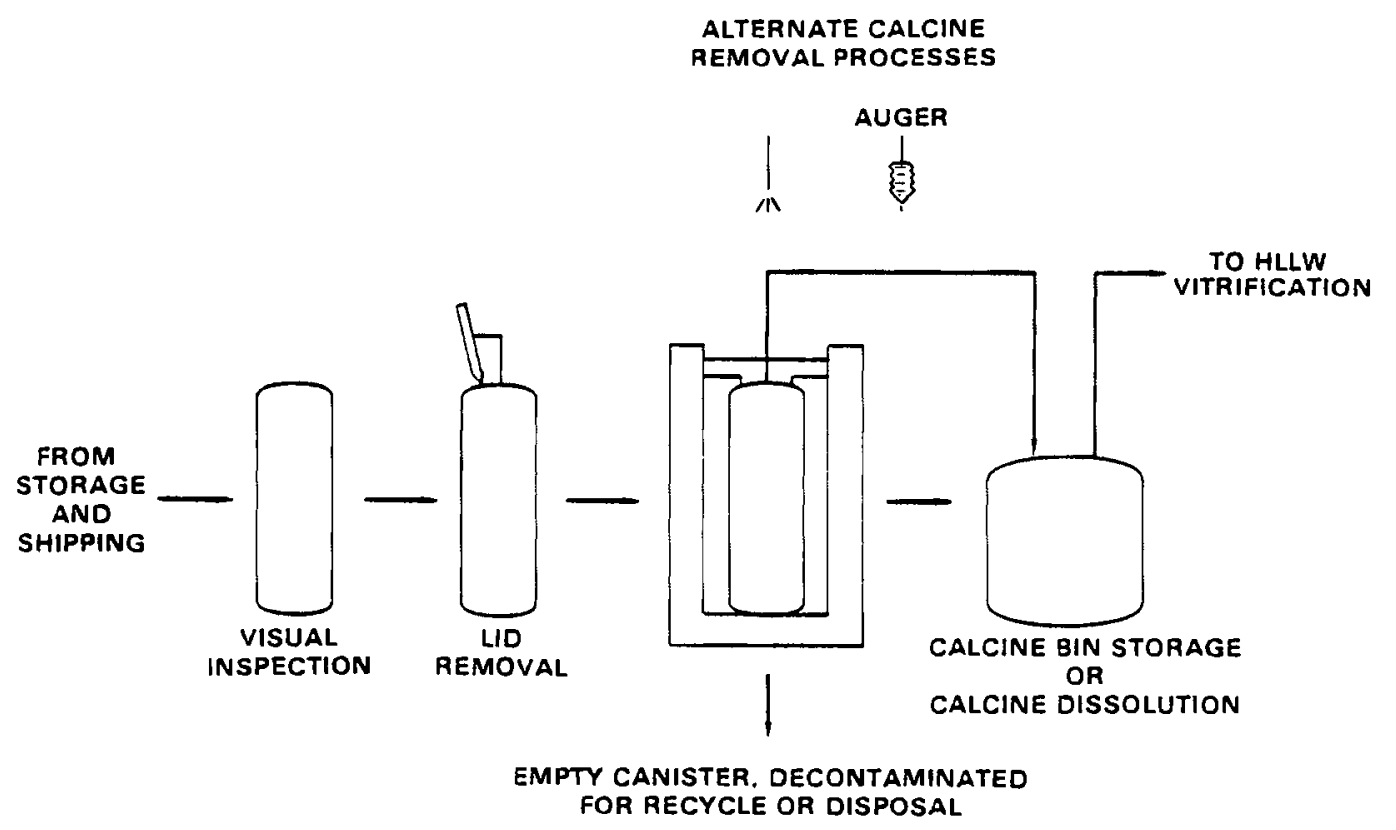

FIGURE 10.18. WNYNSC HLW Calcine Removal from Canister Process Flow Diagram 
vacuum transferred (dry or as a slurry) to a receptacle where they can be slurried or fed directly to the final solidification process. There has been little development related to calcine characteristics during storage or calcine removal from containers. If the calcine consolidates into a rigid structure during storage the removal can may become complicated. Mechanical (auger) and/or chemical dissolution could be needed to assist in the removal of the calcine from the canister. The removed calcine should be compatible with anticipated defensewaste solidification processes and other plant wastes for incorporation into glass. The canister may then be decontaminated, if appropriate, for reuse or disposal.

The material balance for the calcination process is summarized in Table 10.20. The material balance summarizes the combined flows from both calcination processes. The overall summary for the calcination process is given in Table 10.21. The calcine canister-production rate is approximately one every seven hours based on a three-year solidification campaign with a plant-efficiency factor of 0.60 . The surface temperature of the canisters is estimated to be $52^{\circ} \mathrm{C}$ if the ambient air temperature is $50^{\circ} \mathrm{C}$. The dose rate at the canister surface is estimated to be $145 \mathrm{R} / \mathrm{hr}$.

\subsubsection{Status of Technology}

Calcination and the associated process technology for high-level waste solidification is a mature technology that has been extensively developed and applied in the United States and other countries as shown in Table 10.22 .

TABLE 10.20. Process Condition and Material Balance Data for Solidification of Combined Alkaline and Acidic Waste in a Calcine Waste Form

\begin{tabular}{|c|c|c|c|c|c|}
\hline Stream Number (a) & 1 & 2 & 3 & 4 & 5 \\
\hline Description & $\begin{array}{c}\text { Alkaline } \\
\text { Waste } \\
\text { Blend } \\
\end{array}$ & $\begin{array}{c}\text { Recycle } \\
\text { and Flushes }\end{array}$ & $\begin{array}{l}\text { Calciner } \\
\text { Feed } \\
\end{array}$ & Calcine & $\begin{array}{l}\text { Calciner } \\
\text { Off Gas } \\
\end{array}$ \\
\hline \multicolumn{6}{|l|}{ Flow, $\mathrm{kg} / \mathrm{hr}$} \\
\hline Salt & 78.5 & - & 78.5 & -- & \\
\hline Solids & 6.3 & -- & 6.3 & -- & \\
\hline Calcine & - & -- & - & 62.1 & 0.06 \\
\hline water & 150 & 25 & 175 & 1 & 174 \\
\hline Air & & & & & 84 \\
\hline $\mathrm{NO}_{\mathrm{X}}$ & & & & & $>35$ \\
\hline $\mathrm{SO}_{2}$ & & & & & Negligible \\
\hline $\mathrm{F}_{1} \mathrm{Cl}$ & & & & & Trace \\
\hline Total & 234.8 & 25 & 259.8 & 63.1 & $>293$ \\
\hline Temperature, ${ }^{\circ} \mathrm{C}$ & Ambient & Ambient & 50 & 350 & $\sim 250$ \\
\hline Density, $\mathrm{g} / \mathrm{cm}^{3}$ & 1.57 & 1.0 & 1.4 & 0.6 & \\
\hline Flow, L/h & 150 & 25 & 175 & 105 & \\
\hline Activity, Ci/L & 14.4 & Negligible & 12.3 & 20.6 & $(0.02 \mathrm{Ci})$ \\
\hline Heat, w/L & 0.041 & 0 & 0.035 & 0.07 & \\
\hline
\end{tabular}

(a) Stream number refers to streams shown on Figure 10.17 . 
TABLE 10.21. Calcine Waste Form Process Summary Solidification of Combined Alkaline Purex and Acidic Thorex Wastes

\begin{tabular}{lc}
\multicolumn{1}{c}{ Process Characteristics } & Calcine waste Form \\
\hline Calcine production rate, $\mathrm{kg} / \mathrm{h}$ & 62.1 \\
Number of calcine canisters & 2292 \\
Activity per canister, Ci & $1.5 \times 10^{4}$ \\
Specific gravity of calcine waste form & 0.6 \\
Decay heat per canister, W & 42 \\
Dose rate at canister surface, R/h & 145 \\
Processing campaign length, d & 657
\end{tabular}

TABLE 10.22. Calcine as a Precursor for Glass and Composites (NAS 1979)

\begin{tabular}{|c|c|c|}
\hline Product & Process & Site \\
\hline Borosilicate Glass & $\begin{array}{l}\text { Rotary-kiln calcination } \\
\text { Giass Production (Metallic melter) }\end{array}$ & $\begin{array}{l}\text { Marcoule (van Geel and } \\
\text { Eschrich 1975) }\end{array}$ \\
\hline Borosilicate Glass & $\begin{array}{l}\text { Spray calcination } \\
\text { Glass production (in-can melting) }\end{array}$ & $\begin{array}{l}\text { Pacific Northwest Laboratory } \\
\text { (U.S. ERDA 1976a, Larson and } \\
\text { Bonner 1976) }\end{array}$ \\
\hline Borosilicate Glass & $\begin{array}{l}\text { Spray calcination } \\
\text { Glass production (metallic melter) }\end{array}$ & $\begin{array}{l}\text { Karlsruhe (Blasewitz et al. } \\
1973 \text { ) }\end{array}$ \\
\hline Borosilicate Glass & $\begin{array}{l}\text { Pot calcination } \\
\text { Glass production (In-can melting) }\end{array}$ & Windscale (Clelland 1973) \\
\hline $\begin{array}{l}\text { Phosphate Glass } \\
\text { (beads in netal } \\
\text { matrix) }\end{array}$ & $\begin{array}{l}\text { Fluidized-bed calcination(a) } \\
\text { Glass production (Metallic melter } \\
\text { Metal matrix production (casting) }\end{array}$ & Mol (Clelland et al. 1976) \\
\hline $\begin{array}{l}\text { Calcine/Glass } \\
\text { Composite }\end{array}$ & $\begin{array}{l}\text { Press and fire blocks of calcine- } \\
\text { glass mix }\end{array}$ & $\begin{array}{l}\text { Idaho National Engineering } \\
\text { Laboratory } \\
\text { (Berreth et al. 1975) }\end{array}$ \\
\hline $\begin{array}{l}\text { Calcine/Ceramic } \\
\text { Composite }\end{array}$ & $\begin{array}{l}\text { Hot press calcine/crystalline } \\
\text { ceramic mix }\end{array}$ & $\begin{array}{l}\text { Pennsylvania State } \\
\text { University (McCarthy and } \\
\text { Davidson 1976) }\end{array}$ \\
\hline $\begin{array}{l}\text { Calcine/Metal } \\
\text { Composite }\end{array}$ & $\begin{array}{l}\text { Granulate or pelletize calcine, } \\
\text { cast in metal matrix }\end{array}$ & $\begin{array}{l}\text { Mol (van Geel and Eschrich } \\
1975 \text {; Clelland et al. 1976) } \\
\text { Idaho National Engineering } \\
\text { Laboratory (Clelland et al. } \\
\text { 1976) }\end{array}$ \\
\hline
\end{tabular}

(a) Also uses direct feed of slurry into melter as an alternative to calcining.

For more than $15 \mathrm{yr}$, DOE has routinely been solidifying wastes from the U.S. Navy's nuclear-powered ships and research reactors. Some 2,000 tonnes of calcine, one of the largest quantities of solidified high-ievel wastes in existence, are now contained in underground storage bins at Idaho Falis, Idaho. The Eurochemic inventory in Mol, Belgium is approximately 40 tonnes of aluminum-rich calcines.

For almost two decades laboratories around the world have been exploring processes that would either convert calcine into a vitreous solid or isolate and protect the calcine in other 
inert matrices. Table 10.22 summarizes some of the typical processes and products that include the making of calcine as an intermediate step.

A1l current demonstration plants for glass making and many of the research programs use a calcine step. The INEL programs have demonstrated the viability of a full-scale hot-cell process for fluid-bed calcination. The French effort at Marcoule, the German work at Karlsruhe, and the hot-pilot operations at Hanford between 1966. and 1979 show that calcining can be done effectively on a laboratory and pilot-plant scale. In these cases handling of the powdered calcine is minimized, since it is fed directly into the furnace for glass melting. At INEL, the powder is pneumatically transferred directly to the storage tanks. This process demonstrates that very fine high-level-waste powders can be handled safely. At Eurochemic the granulated calcine is normally converted to glass, but it has also been directly incorporated into a lead matrix. Table 10.23 summarizes the status of current work on calcine.

There is little experience with the calcination of high-sodium nitrate waste. High-sodium nitrate wastes have a tendency to dry to salts and to fuse or melt in equipment operated at much over $300^{\circ} \mathrm{C}$. This tendency can cause equipment pluggage, scaling, and can reduce process capacity. Also, a high-nitrate calcine is produced, which could cause container pressurization from gases generated from radiolytic decomposition. Pacific Northwest Laboratory has had experience (Bonner, 8lair and Romero 1976; Holton et al.

TABLE 10.23. Status of Research and Development on Calcine(a)

\begin{tabular}{|c|c|c|c|c|c|}
\hline Site and Process & $\begin{array}{l}\text { Lab-Scale } \\
\text { Research }\end{array}$ & $\frac{\text { Pilot }}{\text { Cold }}$ & Hot & $\begin{array}{l}\text { Routine } \\
\text { Production }\end{array}$ & Storage \\
\hline \multicolumn{6}{|c|}{$\begin{array}{l}\text { Idaho National Engineering Laboratory } \\
\text { Fluidized Bed }\end{array}$} \\
\hline Defense high-level waste & $x$ & $x$ & $x$ & $x$ & $x$ \\
\hline Commercial high-level waste & $x$ & $x$ & & & \\
\hline \multicolumn{6}{|l|}{ Pacific Northwest Laboratory } \\
\hline Spray Calcination & $x$ & $x$ & $x$ & & \\
\hline \multicolumn{6}{|l|}{ Pacific Northwest Laboratory } \\
\hline Fluidized Bed & $x$ & $x$ & & & \\
\hline \multicolumn{6}{|l|}{ Marcoule } \\
\hline Rotary Kiln & $x$ & $x$ & $x$ & $x$ & $x$ \\
\hline \multicolumn{6}{|l|}{ Windscale } \\
\hline Pot Calcination & $x$ & $x$ & & & \\
\hline \multicolumn{6}{|l|}{ Karlsruhe } \\
\hline Spray Calcination & $x$ & $x$ & & & \\
\hline \multicolumn{6}{|l|}{ Eurochemic } \\
\hline Stirred Bed & $x$ & $x$ & & & \\
\hline \multicolumn{6}{|l|}{ Eurochemic } \\
\hline LOTES & $x$ & $x$ & & & \\
\hline
\end{tabular}

(a) National Academy of Sciences 1979. 
1980) with calcining high-sodium wastes, and some techniques such as temperature control and waste-feed additives have been successfully used to cope with the problems of high-sodium waste. Additional studies need to be done with specific WNYNSC waste compositions to verify that process techniques generically developed are applicable to this waste.

Studies have not been done with the WNYNSC waste to determine physical properties, thermal/ radiation stability, the tendency to agglomerate during storage, and the impact on the properties of the final waste form using WNYNSC calcine. These properites must be determined to facilitate process feasibility studies and to identify possible safety hazards.

The process to remove calcine from a canister will be largely dependent on the calcine properties at the time of removal. Preliminary conceptual studies have been done at PNL to remove calcine from a canister. However, developmental studies are required to confirm the proposed approaches and the feasibility of each.

\subsubsection{Safety Considerations}

The calcination process is a simple process that has low potential for consequential accidents and damage to the environment (Larson 1980; Barnes and Bendixen 1977; Southern Science Applications, Inc. 1978).

The spray calciner process has been developed and demonstrated for over $20 \mathrm{yr}$ at PNL. Tonnes of nonradioactive calcine and radioactive calcine have been produced for large canisters of waste borosilicate glass. In the $20 \mathrm{yr}$ development and demonstration experience there have been no significant accidents that have resulted in substantial damage. The spray calcination process has undergone specific and generic safety assessments, which conclude that the process can be operated safely in a radionuclide processing facility.

The spray calciner process normally operates at temperatures up to $800^{\circ} \mathrm{C}$, produces a dispersible powder product, and generates $\mathrm{NO}_{x}$ and some volatile radionuclides in the process off-gas. However, review of these potential dispersion sources indicates that any potential hazards associated with these process/product characteristics are safely handled with routine or backup process systems and multiple containment.

The most significant process hazard potential would be an explosion in the process equipment caused by igniting an accumulation of vaporized organic material or hydrogen. In such an accident there would be significant dispersion of calcine. Review of safety assessments has indicated that the consequences of such an event are unlikely to result in personnel injury or significant radionuclide release, since the process system is contained in a safety Class I facility. The process is designed to prevent these events, and, if the events did occur, it is doubtful that there would be a sufficient energy release to breach the primary equipmentcontainment systems.

The only process-related environmental impact is through the release of effluents and the discarding of some wastes for controlled disposal. Routine effluent releases from this process will cause no significant impact on the environment and no significant radiation exposure to the population. 
The calcination process may present a higher risk of damage to the environment when compared to the other interim waste form processes considered, since more $\mathrm{NO}_{x}$, volatile ruthenium, iodine, and waste condensate are generated. Higher off-gas volumes must be treated. After the calcine is produced, the most serious safety concerns are the pressurization of sealed canisters due to radiolysis and the possible buildup of explosive gases in the canister, which must be safely vented before the calcine can be removed for final processing.

\subsubsection{Facility Implementation}

Facility and equipment requirements are similar to those described in Section 8 for the vitrification flowsheet without the in-can melter and the frit-feed system. A layout of the equipment is shown in Figure 10.19. The principal process equipment is located in the CPC.

The major equipment needed for the calcination flowsheet is similar to that needed to implement the vitrification flowsheet (Section 8.0). The equipment needed includes that in Vitrification System, except for the in-can melters and frit-feeder, the process off-gas system, and the recycle and secondary evaporation system.

A. HLLW RECEIVING TANKS

B. WASTE FEED BLENDING TANK

E1. CALCINER FEED TANK

E2. SPRAY CALCINER

E4. CANISTER LID-WELD STATION
E5. CANISTER DECONTAMINATION

E6. CANISTER TRANSPORT CART

F. RECYCLE AND SECONDARY EVAPORATION

G. OFF-GAS TREATMENT SYSTEM

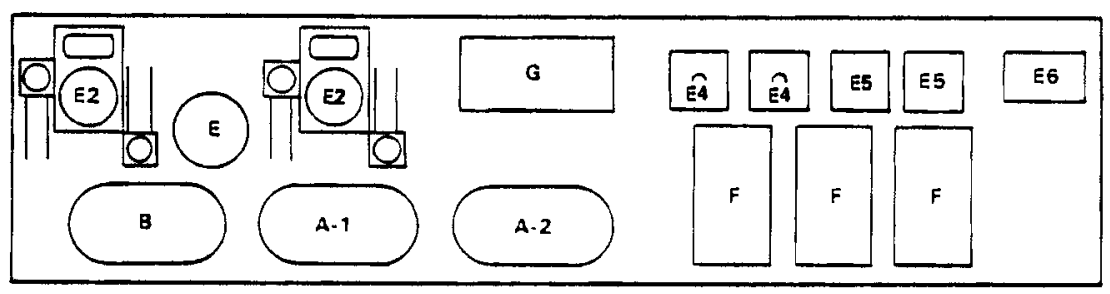

CHEMICAL PROCESS CELL

FIGURE 10.19. Conceptual Equipment Layout for the Calcine Process 


\subsection{REFERENCES}

Bailey, E. J., B. M. Legler, and J. C. Petrie. 1966. "Fluidized Bed Calcination of New Types of High-Level Wastes." In Proceedings of the Symposium on the Solidification and Long-Term Storage of Highly Radioactive Wastes, Richland, Washington, February 14-18, 1966, ed. W. H. Regan, CONF-660208, U.S. Atomic Energy Comm ission, Washington, O.C.

Barnes, R. G., and R. B. Bendixsen. 1977. Waste Solidification Accident Analysis Information. NEDG-21601, General Electric Company, San Jose, California.

Barney, G. S. 1976. "Fixation of Radioactive Waste by Hydrothermal Reactions with Clay," in High-Level Radioactive Waste Management, ed. M. H. Campbe11, Advances in Chemistry Series 153, Amer ican Chemical Soc iety, Washington, D.C.

Barney, G. S., and L. E. Browne11. June 7, 1977. "Process for Converting Sodium NitrateContaining Plastic Liquid Radioactive Wastes to Solid Insoluble Products, "U.S. Patent $4,028,265$.

Barney, G. S. 1975. Immobilization of Aqueous Radioactive Cesium Wastes by Conversion to Aluminosilicate Minerals. ARH-SA-218, At Tantic Richfield Hanford Comp any, Richland, Washington (Available from Rockwe 11 Hanford Operations, Richland, Washington).

Barney, G. S. 1974. Fixation of Radioactive Waste by Hydrothermal Reaction with Clays. ARH-SA-174, At lantic Richfield Hanford Company, Richland, Washington (Available from Rockwe 11 Hanford Operations, Richland, Washington).

Beite 1, G. A. 1976. Sodium Nitrate Combustion Limit Tests. ARH-LD-123, At lantic Richfield Hanford Company, Richland, Washington (Available from Rockwell Hanford Operations, Richland, Washington).

Berreth, J. R., et al. 1975. "Post Treatment of High Level Nuclear Fuel Wastes." Paper presented at the American Ceramic Society Symposium, Washington, D.C.

Blair, H. T. 1979. In-Can Melting Process and Equipment Develooment from 1974 to 1978. PNL-2925, P acific Northwest Laboratory, Richland, Washington.

Blair, H. T. 1975. "Solids Processing." Quarterly Progress Report, Research and Development Activities, Waste Fixation Program, October through December 1974. BNWL-1893, Pacific Northwest Laboratory, Richland, Washington.

Blasewitz, A. G., et al. 1973. "The High-Level Waste Solidification Program" In Management of Radioactive Wastes from Fuel Reprocessing. Proceedings of a Symposium organized jointTy by the OECD Nuclear Energy Agency and the International Atomic Energy Agency, Paris, November 17-December 1, 1972, International Atomic Energy Agency, Vienna, Austria.

Bloom, H. I., et al. 1953. Transactions of the Faraday Society 49:1458-65.

Bonner, W. F., H. T. Blair, and L. S. Romero. 1976. Spray Solidification of Nuclear Waste. BNWL-2059, Pac ific Northwest Laboratory, Richland, Washington.

Braden, D. E., et al. 1971. Safety Analys is Report - Waste Encapsulation and Storage Facilities. ARH-1986, Atlantic Richfield Hanford Co., Richland, Washington (Available from Rockwell Hanford Operations, Richland, Washington).

Breon, S. R., et al. 1980. Gamma Irradiation of Nitrate-Based Salts. ANL/FPP/TM-129, Argonne National Laboratory, Argonne, Illino is.

Buckham, J. A., and J. A. McBride. 1973. "Pilot-Plant Studies of the Fluidized-Bed Waste Calcination Process." In Proceedings of the Symposium on Treatment and Storage of High-Level Radioactive Wastes Held by the International Atomic Energy Agency in Vienna, 8-12 Oc tober 1962, International Atomic Energy Agency, Vienna. 
Buckingham, J. S. 1967. Waste Management Technical Manual. ISO-100, Isochem Inc., Richland, Washington.

Buelt, J. L., and C. C. Chapman. 1979. Slurry Feeding of Nuc lear Waste to an Electric Glass Melter. PNL-SA-7571, Pac ific Northwest Laboratory, Richland, Washington.

Buelt, J. L., and C. C. Chapman. 1978. Liquid-Fed Ceramic Melter: A General Description Report. PNL-2735, Pac ific Northwest Laboratory, Richland, Washington.

Campbe11, M. H., and M. J. Kupfer, eds. 1974. Atlantic Richfield Hanford Company Quarterly Report, Waste Management and Transportation Technology Deve lopment, July 1974 through September 1974. ARH-ST-110 A, At lantic Richfield Hanford Company, Richiand, Washington (Available from Rockwe 11 Hanford Operations, Richland, Washington).

Chiotti, P., ed. 1969. Nuclear Metallurgy, Vol. 15: Symposium on Reprocessing of Nuclear Fue1s. CONF-690801, U.S. Atomic Energy Commission, washington, D.C.

Clark, W. E., et al. 1966. Development of Processes for Solidification of High Level Radioactive Waste: Sumary for Pot Calcination and Rising Level Potglass Processes, ORIL-TM-1584, Oak Ridge National Laboratory, Oak Ridge, Tennessee.

Clelland, D. W., et al. 1976. "A Review of European High-Level Waste Solidification Technology." Proceedings of the International Symposium on the Management of Wastes from the LWR Fuel Cycle. Denver, Colorado, July 11-16, 1976. Sponsored by U.S. EROA. CONF-76-0701, National Technical Information Service, Springfield, Virginia.

Clelland, D. W. 1973. "High Level Radioactive Waste Management in the United Kingdom." In Management of Radioactive Wastes from Fuel Reprocessing. Proceedings of a Symposium Organized Jointly by the OECD Nuclear Energy Agency and the International Atomic Energy Agency, Paris, November 27-December 1, 1972, International Atomic Energy Agency, Vienna, Austria.

Colombo, P., and R. N. Neilson,.Jr. 1979. Properties of Radioactive Wastes and Waste Containers--First Topical Report. BNL-NUREG-50957, Brookhaven National Laboratory, Upton, New York. (ATso NUREG/CR-0619, U.S. Nuclear Regulatory Commission, Washington, D.C.)

Cooper, E. D., D. E. Black, and C. B. Amberson. 1975. "A Performance Comparison of Pilot and Plant Scale Fluidized Bed Calciners," Chem. Engr. Prog., vol. 61, no. 7, pp. 89-96, July 1965.

Delegard, C. H., and G. S. Barney. 1975. Fixation of Radioactive Waste by Reaction with Clays: Progress Report. ARH-ST-124, At lantic Richfield Hanford Company, Richland, Washington (Avaitable from Rockwell Hanford Operations, Richland, Washington).

Dierks, R. D., and W. F. Bonner. 1975. The Performance of a Wiped-Film Evaporator with Simulated High-Level Waste Siurries. BNWL-SA-5454, Pacific Northwest Laboratory, Richland, Washington.

Dow Chemical Company. 1978. The Dow System for Solidification of Low-Level Radioactive Waste from Nuclear Power Plants. DNS-RSS-001-NP-A, The Dow Chemical Company, Midland, Michigan.

DuPont Hitec. Heat Transfer Sait, E. I. du Pont De Nemours \& Co., Inc., Wilmington, Delaware.

Filter, H. E. 1978a. The Dow Solidification System--State of the Art. The Dow Chemical Company, Midland, Michigan.

Filter, H. E. 1978b. The Dow System for Solidification of Low-Level Radioactive Wastes from Nuclear Power Plants. The Dow Chemical Company, Midland, Michigan.

Filter, H. E. and K. Roberson. 1977. The Dow System for Solidification of Low-Level Radioactive Wastes from Nuclear Power Piants. The Dow Chemical Comb any, Midland, Michigan.

Filter, H. E. 1976. Vinyl Ester Solidification of Low-Level Radioactive Waste. 8-600-366-79, The Dow Chemical Company, Midland, Michigan. 
Fox, R. D., ed. 1975. Atlantic Richfield Hanford Company Semi-Annual Report BB Process Deve lopment May 1, $197 \overline{4}$ through October 31, 1974. ARH-ST-118 B, Atlant ic Richfield Hanford Company, Richland, Washington (Available from Rockwell Hanford Operations, Richland, Washington).

Godbee, H. W. 1973. Use of Evaporation for the Treatment of Liquids in the Nuclear Industry. ORNL-4790, Oak Ridge National Laboratory, Oak Ridge, Tennessee.

Goodlett, C. B. 1979. "Wiped-Film Evaporators for Evaporating Alkaline Light Water Reactor Radioactive Wastes." Nuclear Technology 43:259-267.

Goodlett, C. B. 1978a. Wiped-Film Evaporators for Evaporating Alkaline LWR Radioactive Wastes. DP-MS-77-100, Savannah River Laboratory, Aiken, South Carolina.

Goodlett, C. B. 1978b. Concentration of Radioactive Wastes. DP-1135, Savannah River Laboratory, Aiken, South Carolina.

Goodlett, C. B. 1976. "Concentration of Aqueous Radioactive Waste with Wiped-Film Evaporators." Radioactive Wastes from the Nuclear Fuel Cycle. AIChE Symp. Series 72, 154, 111, Anerican Institute of Chemical Engineers, New York, New York.

Goodlett, C. B. 1975. Concentration of Aqueous Radioactive Waste with Wiped-Film Evaporation. DP-MS-75-17, Savannah River Laboratory, Aiken, South Carolina. (Also presented at AIChE 68 th Annual Meeting, Los Angeles, November 16-20).

Hennig, G., R. Lees, and M. S. Matheson. 1953. "The Decomposition of Nitrate Crystals by Ionizing Radiations." J. Chem Phys 21:4, p. 664-668.665.

Holton, L. K., et al. 1980. "Alternatives for Vitrification of Existing Commercial High-Level Waste by Spray Calcination/In-Can Melting." Presented at ANS Topical Meeting, Waste Management 1980, March 10-14, Tuscon, Arizona.

Johnson, E. R., and J. Forten. 1961. Disc. Faraday Soceity 31:238-246.

Kirkman, M. J., and W. L. Godfrey. 1969. Treatment of Liquid Wastes by Evaporation to Salt Cakes. ARH-SA-25, Atlantic Richfield Hanford Company, Richland, Washington (Available from Rockwe 11 Hanford Operations, Richland, Washington).

Lakey, L. T., and B. R. Wheeler. 1972. "Solidification of High-Level Radioactive Waste at the ICPP." OECD-IAEA Symposium on the Management of Radioactive Wastes from Fuel Reprocessing, $P$ ar is, France, November 27-December 1, 1972, IAEA, Vienna, Austria.

Larson, D. E. 1980. Spray Calciner/In-Can Melter High-Level Waste Solidification Technical Manua 1. PNL-3495, Pacific Northwest Laboratory, Richiand, Washington.

Larson, D. E. and W. F. Bonner. 1976. High-Level Waste Vitrification by Spray Calcination/ In-Can Melting. BNWL-2092, Pacific Northwest Laboratory, Richland, Washington.

Long, J. T. 1967. Engineering for Nuclear Fuel Reprocessing. Gordon and Breach Science Publishers, Inc., New York, New York.

McCarthy, G. J. and M. T. Davidson. 1976. "A Ceramic-Waste Composite Prepared by Hot Pressing." Bulletin of the American Ceramic Society, 55:190.

McKenzie, D. E., et al. 1975. Disposal of Transuranic Solid Waste Using Atomics International Molten Salt Combustion Process. AI-ERDA-13151, Rockwell International Atomics International Division, Canoga Park, California.

Mende 1, J. E., and J. L. McElroy. 1972. Waste Solidification Program Volume 10, Evaluation of Solidified Waste Products. BNWL-1666, Pac ific Northwest Laboratory, Richland, Washington.

National Academy of Sciences. 1979. Solidification of High-Level Radioactive Wastes. NUREG/CR-0895, National Academy of sciences, Washington, D.C. 
Oak Ridge National Laboratory. 1978. Western New York Nuclear Service Center Study-Companion Report. TID-28905-2, U.S. Department of Energy, Washington, D.C.

Petrie, J. C., et al. 1975. Processing of Radioactive Waste Solutions in a Vacuum EvaporatorCrystallizer. ARH-SA-240, AtTantic Richfield Hanford Company, Richland, Washington (Available from Rockwell Hanford Operations, Richland, Washington).

Ross, W. A., and R. B. Dakan. 1974. "Glass Sintering." Quarterly Progress Report, Research and Development Activities, Waste Fixation Program, July through September 1974. BNWL-1871, Pac ific Northwest Laboratory, Richland, Washington.

Sax, N. I. 1979. Dangerous Properties of Industrial Materials. 5th ed., Van Nostrand Rhe inhold Comp any, New York, New York.

Schulz, W. W, et a1. 1975. Glass Forms for Immobilization of Hanford Wastes. ARH-SA-210, At lantic Richfield Hanford Company, Richland, Washington (Available from Rockwell Hanford Operations, Richland, Washington).

Southern Science Applications, Inc. 1978. Safety Analys is of High-Level Waste Solidification Processes. SSA-112, Southern Science Applications, Inc., Dunedin, Florida.

U. S. Energy Research and Development Administration. 1976a. "Advanced Nuclear Reactors: An Introduction." ERDA-76-107, National Technical Information Service, Springfield, Virginia.

van Geel, J. N. C., H. Eschrich, and E. J. Detilleux. 1976. "Conditioning High Level Radioactive Wastes." Chemical Engineering Progress: 49-51.

van Gee1, J. N. C., and H. Eschrich. 1975. "New Developments on the Solidification of High Level Radioactive Wastes at Eurochemic." Transactions of the American Nuclear Society, $20: 671$.

Weast, R. C. 1973. Handbook of Chemistry and Physics. CRC Press, Cleveland, Ohio.

Wheeiwright, E. J., et al. 1979. Technical Summary, Nuclear Waste Vitrification Project, PNL-3038, Pacific Northwest Laboratory, Richland, Washington. 


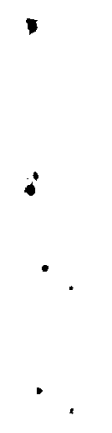




\subsection{PROCESS ALTERNATIVES ASSESSMENT}

The objective of this study was to assess various waste treatment options for solidifying the WNYNSC high-level liquid wastes. These options are shown in Table 11.1.

TABLE 11.1. Waste Treatment and Waste Form Processes Being Evaluated

$\begin{array}{ll}\frac{\text { Waste Treatment Approach }}{\text { Salt/Sludge Separation Process }} & \frac{\text { Waste Form Process }}{\text { Borosilicate Glass }} \\ \text { Low-Alkali Glass } \\ \text { Marbles-in-Lead Matrix } \\ \text { Crystalline Ceramic } \\ \text { Combined Waste Treatment Process } & \text { Borosilicate Glass } \\ & \text { Low-Alkali Glass } \\ & \text { Marbles-in-Lead Matrix } \\ & \text { Fused-Salt } \\ & \text { Calcine } \\ \text { Vinyl Ester-Styrene } \\ \text { Silicate/Salt Matrix }\end{array}$

\subsection{IDENTIFICATION OF EVALUATORY CHARACTERISTICS}

The following characteristics were identified to provide a framework for evaluating the various waste treatment options:

1. The ability of the process approach to satisfy requirements set in the study bases.

2. The relative technical merits of the process, and

3. The relative costs associated with each waste solidification approach.

With the exception of the relative process cost, each characteristic must be measured in a largely subjective manner. These characteristics are assessed in the following sections.

\subsection{ASSESSMENT OF ABILITY TO SATISFY STUDY BASES}

The study bases (Section 5) require that:

1. The waste solidification process must be sufficiently developed such that a waste form can be selected in 1984 and process operations started in 1987.

2. The solidification campaign length is three years.

3. The overall plant efficiency factor is 0.60 .

4. The high-level waste treatment and solidification process is to be implemented within the existing main process building at the WNYNSC.

To satisfy the schedular constraints set in the study bases, the particular processes being considered must be well-engineered at the present time. Specific process 
characteristics such as safety, equipment requirements, and process operating characteristics must also be fairly well understood.

All process approaches considered in this study except the crystalline-ceramic waste form process were judged to sat isfy the requirements of the study bases. The crystalline-ceramic process was judged to not be sufficiently developed such that an operating process could be implemented at WNYNSC facility by 1987. At present, the crystalline-ceramic process is at a conceptual laboratory-scale stage of development. Extensive equipment development and verification testing will be required before an actual crystalline-ceramic plant system can be operated. The process conceptualized is highly mechanical; therefore, the process reliability was considered to be low. The nine-year solidification campaign envisioned for this process reflects the expected low reliability. Implementation of the crystalline-ceramic process was also judged to be impractical within the existing WNYNSC facilities, and another processing cell would be required.

The crystalline-ceramic process can be considered an option for solidification of the WNYNSC wastes if it is decided: 1) to delay the waste solidification processing until a future date, and 2) to construct a new facility for housing the solidification process.

\subsection{TECHNICAL ASSESSMENT OF THE PROCESS ALTERNATIVES}

The present study draws support from earlier comparative rating studies (Ross, Rusin, and MCE Iroy 1979; Stone, Goforth, and Smith, 1980; E. R. Johnson Associates 1980; DOE 1980) in establishing an appropriate method for a technical comparison of the processes.

Six technical assessment categories, each comprised of subcategories was selected to assess and compare the waste treatment/waste form process a]ternatives. These rating categories are surmarized below:

1. Processing characteristics

- Process complexities

- Process control

- Process logistics

- Maintenance requirements

- Feasibility for production use

- Quality control

2. Waste form properties

- Sensitivity to feed variations

- Waste form stability (radiation, thermal, environmental, etc.)

- Waste volume

- Leach resistance

3. Status of technology

- State of development of waste form

- State of process development

- State of equipment development 
4. Safety considerations

- Transportation safety of waste form

- Dispersive driving forces in process

- Chemical toxicity of reagents

- Personnel exposures

- Secondary wastes generated from process

5. Facility implementation

- Feasibility of process to fit in existing facilities

- Modifications and upgrading required to process building to implement process

- Service requirements of process

6. Final waste form process compatibility, for inter im waste form process only

- Process complexity to prepare interim waste form for processing at DOE site

- Effect on terminal waste form volume.

A detailed description of the technical rating is found in Appendix 0 .

Each of the rating categories is assigned a weight based on what the authors judged its relative importance to be in the technical assessment. The weights for each rating category are surmarized in Table 11.2. These weighting factors emphasize process characteristics, availability of technology, and facility implementation. These factors are most important in judging the processes because they reflect those processes which can most easily meet the schedular constraints set for the WNYNSC waste solidification project. The weighting factor for safety considerations is relatively low because it is inherent in the design of the processes that they will be engineered to be safe, and no significant environmental consequences will result from process operations.

The following procedure is used to apply the technical rating methodology: 1) the waste treatment/waste form process under consideration is characterized for each rating subcategory; 2) a subcategory rating is assigned based upon a scale of one to ten; 3) the subcategory ratings are totaled and then weighted, corresponding to the category rating. Category ratings are then totaled to given an overall technical rating for the process alternative.

TABLE 11.2. Weighting Factors for Ranking Categories

\begin{tabular}{|c|c|c|}
\hline \multirow[b]{2}{*}{ Ranking Category } & \multicolumn{2}{|c|}{$\begin{array}{l}\text { Weighting Factors, } \\
\text { Total Points Possible }\end{array}$} \\
\hline & $\begin{array}{l}\text { Terminal waste } \\
\text { Form Processes }\end{array}$ & $\begin{array}{l}\text { Inter im waste } \\
\text { Form Processes }\end{array}$ \\
\hline Process characteristics & 25 & 20 \\
\hline Waste-form properties & 20 & 10 \\
\hline Status of technology & 20 & 20 \\
\hline Safety considerations & 10 & 10 \\
\hline Facility implementation & 25 & 20 \\
\hline Final waste form process compatibility & Not Applicable & 20 \\
\hline TOTAL & 100 & 100 \\
\hline
\end{tabular}


Results of the technical rating for the processes producing a terminal high-level-waste form are summarized in Table 11.3, and for the processes producing an interim waste form in Table 11.4. Details of the subcategory ratings are summarized in Appendix D. The terminal waste form processes and the interim waste form processes are not compared with each other in this technical assessment.

The overall technical ratings indicate that: in general there is no significant technical preference between the salt/sludge separation approach and the combined waste treatment approach for the terminal waste form processes. The order of technical preference for waste form processes for both the salt/sludge separation and the combined approaches is: borosilicate glass, low-alkali glass, marbles-in-lead matrix, and crystalline ceramic. The order of technical preference for the interim waste form processes is: calcine, fused salt, silicate/salt matrix, and vinyl ester-styrene.

TABLE 11.3. Sumary of Technical Comparison Ratings for Terminal Waste Form Processes

\begin{tabular}{|c|c|c|c|c|c|c|}
\hline \multirow[b]{2}{*}{ Process Alternatives } & \multicolumn{5}{|c|}{ Ratings } & \multirow[b]{2}{*}{ Total Rating } \\
\hline & $\begin{array}{c}\text { Process } \\
\text { Characteristics } \\
(25)(a) \\
\end{array}$ & $\begin{array}{l}\text { Waste Form } \\
\text { Properties } \\
(20) \\
\end{array}$ & $\begin{array}{l}\text { Status of } \\
\text { Technology } \\
\text { (20) } \\
\end{array}$ & $\begin{array}{l}\text { Safety } \\
\text { (10) }\end{array}$ & $\begin{array}{c}\text { facility } \\
\text { Implementation } \\
\text { (25) } \\
\end{array}$ & \\
\hline \multicolumn{7}{|l|}{$\begin{array}{l}\text { Salt/Sludge separation } \\
\text { waste treatment approach }\end{array}$} \\
\hline Borosilicate glass & 14.6 & 14.5 & 18 & 5.2 & 13.3 & 66.6 \\
\hline Low-Alkali glass & 14.6 & 13 & 10 & 6.2 & 13.3 & 57.1 \\
\hline Marbles-in-Lead matrix & 12.9 & 11 & 8.7 & 6.2 & 10 & 48.8 \\
\hline Crystalline ceramic & 5.8 & 16.5 & 4.7 & 5.4 & 3.3 & 35.7 \\
\hline \multicolumn{7}{|l|}{$\begin{array}{l}\text { Combined waste treatment } \\
\text { approach }\end{array}$} \\
\hline Borosilicate glass & 13.3 & 10 & 12.7 & 5.8 & 11.3 & 53.1 \\
\hline Low-Alkali glass & 11.7 & 10 & 10 & 5.3 & 11.3 & 48.8 \\
\hline Marbies-in-Lead matrix & 11.7 & 9 & 10 & 5.8 & 10 & 46.5 \\
\hline
\end{tabular}

(a) Numbers in parentheses represent the maximum possible rating for each category.

TABLE 11.4. Summary of Technical Comparison Ratings for Interim Waste Form Processes

\begin{tabular}{|c|c|c|c|c|c|c|c|}
\hline \multirow[b]{2}{*}{ Process Alternatives } & \multicolumn{6}{|c|}{ Ratings } & \multirow{3}{*}{ Total Rating } \\
\hline & $\begin{array}{c}\text { Process } \\
\text { Characteristics } \\
\frac{(201(\mathrm{a})}{}\end{array}$ & $\begin{array}{l}\text { Waste Form } \\
\text { Properties } \\
\quad(10) \\
\end{array}$ & $\begin{array}{l}\text { Status of } \\
\text { Technology } \\
\quad(20) \\
\end{array}$ & $\begin{array}{l}\text { Safety } \\
! 10 ! \\
\end{array}$ & $\begin{array}{c}\text { Facility } \\
\text { Implementation } \\
(20) \\
\end{array}$ & $\begin{array}{c}\text { Final } \\
\text { Waste Form } \\
\text { Comoatibility } \\
(20) \\
\end{array}$ & \\
\hline \multicolumn{7}{|l|}{$\begin{array}{l}\text { Combined waste } \\
\text { treatment approach }\end{array}$} & \\
\hline Fused-Salt & 14.7 & 5 & 13.3 & 7.2 & 10 & 20 & 70.2 \\
\hline silicate/salt matrix & 11 & 5.3 & 3.7 & 7.2 & 11.3 & 10 & 53.5 \\
\hline Vinyl ester-styrene & 12 & 5.2 & 10 & 6.2 & 11.3 & 6 & 49.8 \\
\hline Calcine & 15 & 4 & 20 & 7.2 & 12.7 & 20 & 78.9 \\
\hline
\end{tabular}

\footnotetext{
(a) Jumbers in parentheses represent the maximum possible rating for each categnry.
} 


\subsubsection{Processing Character istics}

The processing characteristics rating category is composed of six sub-categories that reflect: 1) the degree of processing complexity, 2) the process control requirements necessary to regulate the intermediate waste streams to assure a high integrity waste form, 3) the ease of sequencing the process operations, 4) the difficulty of maintaining the plant at at least $60 \%$ operational availability, 5) the feasibility of plant application of the process approach, and 6 ) the ease with which the final. product integrity can be controlled based on information developed from the intermediate waste process streams. These sub-categories reflect the difficulty in achieving a reliable plant-scale process system.

The salt/sludge separation approach is considered complex because of the high number of batch processes required (centrifugation, settling, filtration, and ion exchange). Process recycle of off-specification process streams is considered a normal part of this approach. The process logistics or sequencing are important especially where many batch operations are involved. For instance, borosilicate glass canister-production rates are approximately one every 66 hours. Canister-handling operations, process-system maintenance and operation of the batch processes, must be sequenced so that process conflicts are avoided and operating manpower is used efficiently. Most operations in the salt/sludge separation approach have been demonstrated either in a production facility or in radioactive development testing. Based on this experience there is a high confidence level for production operations of the salt/siudge process.

Quality control may be difficult for some waste form processes. For instance, glass waste form product integrity can be controlled by sampling and analys is of the HLLW feed stream. However the crystalline-ceramic waste form is not considered sufficiently developed so that the product quality can be controlled by sampling and analysis of the waste, feed streams alone. Actual sampling of the crystalline-ceramic waste form product will be necessary.

With regard to processing characteristics, the waste form processes in the salt/sludge separation approach were rated in the following order: borosilicate glass, low-alkali glass, marbles-in-lead, and crystalline ceramic. The marbles-in-lead process was considered more difficult to maintain remotely, and the feasibility of reliable plant operation was considered lower. The crystalline-ceramic process was given the lowest overall rating in all subcategory characteristics, based primarily upon its conceptual stage of development. Laboratory processes used to prepare the crystalline-ceramic waste form were used to develop the plant-scale flowsheet. The required unit processes for production of the crystalline-ceramic waste form are complex and not considered easily adaptable to remote plant-scale applications.

The combined waste treatment process may require as many as three joule-heated-melter solidification processes to meet the required production rate. This requirement is based upon the present state of development of the joule-heated melter for radioactive application. Each melter is simple; however, replication of the equipment complicates the overall process. Additional melter development can reduce the number of melters required. Much added complexity is related to the mechanical operations of additional canister handling and processing. To minimize canister handiing rates and consequently process complexity, the campaign length can be increased. The glass processes are considered easy to control. Glass properties within the 
joule-heated melter can be controlled by sampling, analysis and chemical adjustments to HLLW feed. Feed flow to the melters and glass production rates can be governed by controlling the feed rates to the system. It is felt that steam surges with in the joule-heated melter producing a variable glass pouring rate can be prevented, thereby allowing the consistent glass pouring rate required for glass-marble production.

The process logistics for the combined waste processing approach are dependent on the amount of time required for canister processing and the associated process maintenance requirements. A canister is produced every $10.4 \mathrm{~h}$ for the combined borosilicate glass process, every $7 \mathrm{~h}$ for the combined low-alkali glass process, and every $4.4 \mathrm{~h}$ for the combined marbles-in-lead matrix process. Moving these canisters between the operations of canister changeout, canister lid welding, canister inspection, canister decontamination and canister transportation to the onsite high-level waste storage facility requires heavy use of the two overhead cranes servicing the CPC and EDR cells. A much higher use of overhead cranes and more crane maintenance will be required for the combined process approach than for the salt/sludge separation approach.

In terms of overall process characteristics the combined borosilicate glass waste form process is rated higher than the low-alkali or marbles-in-lead process. The borosilicate glass process operates at a lower temperature $\left(1150\right.$ to $\left.1250^{\circ} \mathrm{C}\right)$ than the low-alkali glass process $\left(1350\right.$ to $\left.1450^{\circ} \mathrm{C}\right)$; therefore, the joule-heated-melter equipment lifetime is expected to be higher. Long-term reliability of the marble-making equipment is uncertain. Therefore the marble-making process was rated low.

The interim waste form processes range in complexity from simple (fused-salt process and calcine process) to moderately complex processes (silicate/salt matrix process and vinyl ester-styrene processes). The fused-salt and calcine processes involve simple waste blending and evaporation processes. The required waste solidification production rates require that multiple solidification processes be used, which again complicates the overall process. The silicate/salt matrix and the vinyl ester-styrene process require feed blending, feed adjustment, addition of binding agents, and pellet formation operations, complicating process operations.

Process logistics for the interim waste form processes will be difficult to maintain because of the high, production rate of canisters from each of the processes. The canister production rates are one canister every $15.8 \mathrm{~h}$ for the fused-salt process, one can ister every $3.4 \mathrm{~h}$ for the silicate/salt matrix, one canister every $3.3 \mathrm{~h}$ for the vinyl ester-styrene process, and one canister every $6.9 \mathrm{~h}$ for the calcine process. The high, canister production rates combined with the multiple solidification systems will make the overall process difficult to maintain, and require that all the movements with the existing overhead cranes be carefully planned. The fused-salt process is judged the simplest overall process to implement with in the facilities, and, with additional development work, this process can be further simplified.

All four inter im waste form processes are judged to be acceptable for remote operations provided the processing period is increased from 3-years. In terms of overall process feasibility the interim waste form processes were rated in the following order: calcine, fusedsait, silicate/sajt matrix, and vinyl ester-styrene. 


\subsubsection{Waste Form Properties}

The rating category for waste form characteristics is composed of four sub-categories: 1) sensitivity of waste form quality to feed variations, 2) long-term waste form integrity, 3) high-level-waste volume, and 4) leach resistance of the waste form.

The waste composition resulting from the salt/sludge separation approach will be composed primarily of iron, chromium, nickel and aluminum, nitrates and hydroxides. The feed blend to the solidification process will vary primarily in the concentrations of these elements, as well as the fission products. Controlling the terminal waste form products will involve sampling, analysis, and adjustments to this feed blend. The additional elements needed in the glass waste forms will be added in the glass-former mixture in relatively large amounts, which permits external control of the product quality. The highly loaded and sensitive crystallineceramic waste form may be much more sensitive to variability in waste composition and may require accurate analyses and chemical adjustments.

The waste composition in the combined waste process approach can vary significantly due to the difficulty of homogenizing the alkaline sludge and soluble salts. The waste form processes must therefore be capable of solidifying wastes with varying chemical compositions. The glass processes can easily be adjusted to widely varying feed composition; however, the waste loading or the waste form integrity may be reduced to satisfy this requirement.

With regard to long-term product integrity the glass processes were rated equally. The ceramic waste form was judged somewhat superior. There are large differences in the volume of waste forms produced from each process, which account for most of the differences in the overall rating. The waste form volumes, expressed as the number of canisters for each of the process approaches, are summarized below.

\begin{tabular}{|c|c|}
\hline Salt/Siudge Separation Approach & $\begin{array}{c}\text { Number of } \\
\text { High-Level-Waste } \\
\text { Canisters } \\
(.6 \mathrm{~m} \text { by } 3.0 \mathrm{~m}) \\
\end{array}$ \\
\hline Borosilicate glass process & 240 \\
\hline Low-Alkali glass process & 377 \\
\hline Marbles-in-Lead process & 682 \\
\hline Crystalline-ceramic process & 121 \\
\hline \multicolumn{2}{|l|}{ Combined Waste Approach } \\
\hline Borosilicate glass process & 1500 \\
\hline Low-Alkali glass process & 2572 \\
\hline Marbles-in-Lead process & 3596 \\
\hline \multicolumn{2}{|l|}{ Inter im Waste Form Approach } \\
\hline Fused-salt process & 944 \\
\hline Silicate/Salt matrix process & 4691 \\
\hline Vinyl ester-styrene process & 4708 \\
\hline Calcine process & 2292 \\
\hline
\end{tabular}


With regard to leach resistance, the ceramic waste form is superior to the low-alkali glass waste form, which is superior to the borosilicate glass waste form. The interim waste forms differ markedly in the leach resistance of each waste form. The silicate/salt matrix and the vinyl ester-styrene forms are considerably more leach resistant than the fused-salt or the calcine interim waste forms.

\subsubsection{Status of Technology}

The category for status of technolgoy is composed of three sub-categories. These are: state of development of the waste form, state of development of the process, and state of development of the processing equipment.

The borosilicate glass waste form is the most highly developed and characterized terminal waste form available for high-level waste. The low-alkali, marbles-in-lead, and crystallineceramic waste forms have been prepared on a laboratory-scale and are partially characterized. Some pilot-scale production of the marbles-in-lead process has occurred.

The process equipment for the salt/sludge separation approach has been used on a production scale at Hanford's B-Plant. The process is complex, however, design and operating standards have been set for remote operations of the required equipment pieces. Certain operations in the salt/sludge separation approach such as ion-exchange will require development because of the differences in the waste characteristics at the WNYNSC and those treated at B-Plant where the technology was developed.

The spray calciner/in-can melter system used to produce the borosilicate glass waste form in the salt/sludge separation approach is essentially ready for plant application. The process has been demonstrated in radioactive pilot-plant testing, and full-scale nonradioactive testing. A high confidence level exists for production operations of the SC/ICM. Some specific development work at the site may be required however. The liquid-fed joule-heated-melter glass process is presently the center of active development engineering at PNL (where it was conceived) and at SRL. It is anticipated that this process can be ready for plant application by 1987. Before development is completed, however, radioactive pilot-plant development testing will be required.

The combined waste is characterized by high sodium, nitrate, nitrite, and sulphate concentrations. Solidifying actual high-level waste with these characteristics has not been attempted. Therefore, the state of development for the combined waste approach is rated lower. However, it is felt that this process approach can be developed with in specified time constraints.

The interim waste form processes vary significantly in overall status of development. The calcine process is ready for plant application at the WNYNSC. The vinyl ester-styrene and silicate/salt processes will require considerable development effort.

\subsubsection{Safety Considerations}

The processes considered are assumed to be engineered safely, and only the significant differences between the process approaches were considered. The safety category is composed of 
five sub-categories: 1) transportation safety of the waste form, 2) dispersive driving forces within the process, 3) chemical hazards of added reagents to the process, 4) personnel exposures, and 5) secondary process wastes.

Accidents and consequent radionuclide release from hypothetical dispersive forces are more likely in the salt/sludge separation approach due to increased processing steps. The cesium ion-exchange resin could become nitrated, react exothermically and cause an explosion. Several of the salt/sludge separation processes involve pumping fluids at elevated pressures. Leakage of liquid waste due to transfer-line rupture is possible. The crystalline-ceramic process involving temperatures of $1300^{\circ} \mathrm{C}$ and pressures of $15,000 \mathrm{psi}$ presents a missile-generating potential.

The anticipated personnel exposures of the combined-waste processing approach are considered greater than the salt/sludge separation approach. The primary reason is the greater volume of high-level-waste canisters produced and handled. Nitrates generated during solidification in the combined waste approach will be catalytically reduced with ammonia. The large ammonia requirements present the potential for personnel accidents involving armonia gas. In addition, volatile $\mathrm{SO}_{3}$ representing a chemical hazard must be recovered from the process off gas.

The interim-waste processes were rated equally with regard to safety. The vinyl esterstyrene and silicate/salt processes are considered to be less dispersible, more stable forms in transportation accidents compared to calcine or fused salt, and therefore are rated higher in this regard. The higher volume of the silicate/salt and vinyl ester-styrene waste forms, however, increases workers' exposures because there is more maintenance of canister-transfer equipment and more high-level-waste canisters to be transported. Consequently, these two processes received a lower rating in terms of personnel exposure.

\subsubsection{Facility Implementation}

Subcategories of facility implementation are: the ability of the process to fit into existing facilities, the modifications required to the facility to implement the process, and the service requirements for the process.

A11 process alternatives considered in this report were judged capable of implementation within the existing facilities except the crystalline-ceramic process. In general, the simpler the process, the easier it is to implement.

The salt/sludge separation processes are considered easier to implement within the facilities than the combined waste processes because they require a lower rate for solidifying highlevel waste and therefore, smaller equipment. The difficulty of implementing the salt/sludge separation processes increases with an increase in waste form unit operations; from borosilicate glass to low-alkali glass, to the marbles-in-lead process and to the crystalline-ceramic process.

The interim waste processes that are the easiest to implement within the existing facilities are also the simplest. The ease with which the processes can be implemented with in the facilities decreases from the calcine process to the fused-salt processes, to the vinyl esterstyrene process, and to the silicate/salt process. 


\subsubsection{Compatibility of the Interim Waste Form Processes with the Final waste Form}

The interim waste form is assumed to be stored for a short period of time and then converted to a terminal waste form at a DOE site. The waste treatment process for conversion to a terminal waste form is also assumed to be similar to the salt/sludge separation process described in this report. The rating category for this compatibility is composed of two subcategories: process complexity for reconstitution of the interim waste form into a form that can be easily solidified, and the effect of the terminal waste form on the volume of the terminal waste form.

The calcine and fused-salt interim waste forms achieve superior ratings based on the two subcriteria discussed above. It is envisioned that these two waste forms could be adequately reconstituted with water and processed with defense wastes at the terminal-waste solidification facility. The salts from these inter im waste forms would be easily separated and processed in the defense-waste salt-processing system. The silicate/salt matrix waste form would be reconstituted, perhaps with nitric acid to aid dissolution, and processed with the defense wastes. Some increase in waste form volume is anticipated here because of the presence of additives in the waste form. The vinyl ester-styrene waste form may involve some complex processing steps. oxidation of the carbon in the pellets would likely be required before the waste could be incorporated into a final waste form. For these reasons the vinyl ester-styrene waste form was rated low with regards to final waste form compatibility.

\subsection{PROCESS ALTERNATIVES COST ASSESSMENT}

A preliminary cost estimate (Burns and Roe, 1981) was prepared to assess the relative economic benefits of various options for solidifying and disposing the HLW wastes at WNYNSC and for decormissioning the existing facilities. The cost estimate was originally made for the Draft Environmental Impact Statement being prepared by ANL. The bases and scope of the cost estimate are somewhat different than those used in the present technical study. However, the cost study and conclusions are relevant for a general economic comparison of the process alternatives considered.

Three basic options, were considered in both the present study and the Burns and Roe study: 1) salt/sludge separation waste treatment prior to high-level-waste solidification for final disposal (the reference case); 2) solidification of the combined high-level alkaline Purex and acidic Thorex wastes for final disposal; and 3) conversion of the combined HLLW to an interim form for eventual off-site processing for final disposal. In the Burns and Roe Study, borosilicate-glass was considered as the only final waste form. Fused salt was considered as the only interim waste form.

The bases used to make the cost estimates were:

Option 1: Solidification of HLLW by the salt/sludge separation process approach. Before vitrification the inert salts are separated from the radioactive and transuranic constituents in the HLLW. After vitrification, the solidified HLL'W and transuranic wastes are eventually removed to a Federal repository for permanent disposal, all low-level waste generated during 
the solidification operation is removed and transported for off-site burial at a commercial burial site and the structures used during solidification, including the HLLW storage tanks, are decontaminated, dismantled and removed.

Option 2: Solidification of combined alkaline Purex and acidic Thorex wastes. The HLLW solution is not treated to separate inert salts, but is vitrified together with the inert salts. Solidified HLLW and Transuranic wastes are removed for permanent disposal at a Federal repository and low-level waste is buried at a commercial facility off-site. All HLLW process facilities are decontaminated, dismantled and removed.

Option 3: Inter im waste form processing - combined waste solidification. The stored HLLW is dewatered and melted. The fused-salt product is transported to a UOE site. The fused salt will be processed at the DOE site where it will be converted to a vitrified form in a facility that will be constructed to treat HLLW stored at the DOE site. The vitrified salt will be eventually removed for permanent disposal at a Federal Repository. The facility for producing the interim waste form is decontaminated, dismantled, and the low-level waste is buried at a comercial off-site facility.

The program cost for each of the three solidification options is sumarized in Tables 11.5, 11.6 and 11.7. Cost elements considered in the estimate are indicated in these tables. The estimates also included the costs of all the activities that will be required to accomplish the goals of each option considered. These activities range from initial planning, to the burial of all wastes, as well as to the decomissioning of selected facility structures that were previously contaminated or which become contaminated during the solidification program. The remaining research and development costs were not included, however. These estimates are made in terms of mid-1980 dollars.

In a number of the program activities, such as construction of a structure for interim storage of the vitrified high-level waste, the cost estimate is based on designs developed by Burns and Roe in other studies done for the DOE. For other activities, the cost estimate is based on figures developed by others, such as Rockwell Hanford, for the removal of HLLW from the storage tanks. In those instances where previous estimates were not available, costs were developed using engineering judgement. Rough quantities of materials were determined and major items of equipment identified. From this information conceptual estimates were developed for each particular activity.

Construction craft labor rates included in the direct-cost portion of the estimates were developed specificaliy for the West valley, New York area. These rates included fringe benefits.

Material costs were taken from various estimating publications such as: R. S. Means, Richardson Engineering Services, and the National Price Service. The cost for special items of material and equipment were solicited from vendor sources who have familiarity and experience with the products involved.

Labor manhours were developed for each task using the above publications and established industry-wide standards as a bases. 

TABLE 11.5. Cost Surmary Salt/Sludge Separation Process, Solidification in a Borosilicate

\section{Description of Activity}

Planning and preparing decomissioning activities

Construct LLWTF, (b) building and equipment

Decontamination activities

Process $L L W^{(C)}$ resulting from decontanination effort

Modify existing facilities to process $\mathrm{HLW}^{(d)}$

Interim storage of solidified HLW

Capital cost of solidification process equipment

Removal of HLW from underground tanks and transfer to HLW solidification equipment

HLW processing - operational costs

Transfer of solidified HLW to interim storage

Maintain interim storage facility (for about 15 years)

Post operational decontamination

Process LLW generated during HLW processing

Decontamination of storage tanks

Process $L L W$ generated during final decontamination

Disposal of LLW
Total

Mid-1980

Dollars

2, 530,000

$26,403,000$

$22,480,000$

2,009,000

$2,814,000$

$5,400,000$

$15,500,000$

$16,000,000$

$16,861,000$

447,000

$4,140,000$

$9,223,000$

4,005,000

$12,354,000$

$2,009,000$

Disposal of LhH

\begin{tabular}{|c|c|c|c|c|}
\hline & Packaging & Transportation & Disposal & \\
\hline ) Non-Transuranic LLW & $2,980,000$ & $19,392,000$ & $2,545,000$ & $24,917,000$ \\
\hline Transuranic LLW & 766,000 & $2,830,000$ & $7,579,000$ & $11,175,000$ \\
\hline
\end{tabular}

HLW Disposal

$\frac{\text { Packaging }}{5,475,000} \quad \frac{\text { Transportation }}{2,092,000} \quad \frac{\text { Disposal }}{36,076,000}$

$39,643,000$

Decontamination LLWT facility

$1,742,000$

Interim care for facility

$N / A$

Entombment: filling areas that contain activity with concrete

$\mathrm{N} / \mathrm{A}$

Demolition and restoration activity

$7,182,000$

Solidification of the interim waste at a DOE site

$\mathrm{N} / \mathrm{A}$

Engineering, design \& construction management $015 \%$

SUB-TOTAL $\quad \overline{226,843,000}$

Contingency $025 \%$

Contingency e $25 \%$

$34,026,000$

SUB-TOTAL $\quad 260,869,000$

$65,217,000$

TOTAL $\quad 326,086,000$

\footnotetext{
(a) These costs are considered preliminary and should not be used for a project cost estimate.

(b) Low-level-waste treatment facility.

(c) Low-level waste.

(d) High-level waste.
} 
TABLE 11.6. Cost Sumary, Combined Alkaline Purex and Acidic Thorex Waste Process, Solidification in a Borosilicate Glass(a)

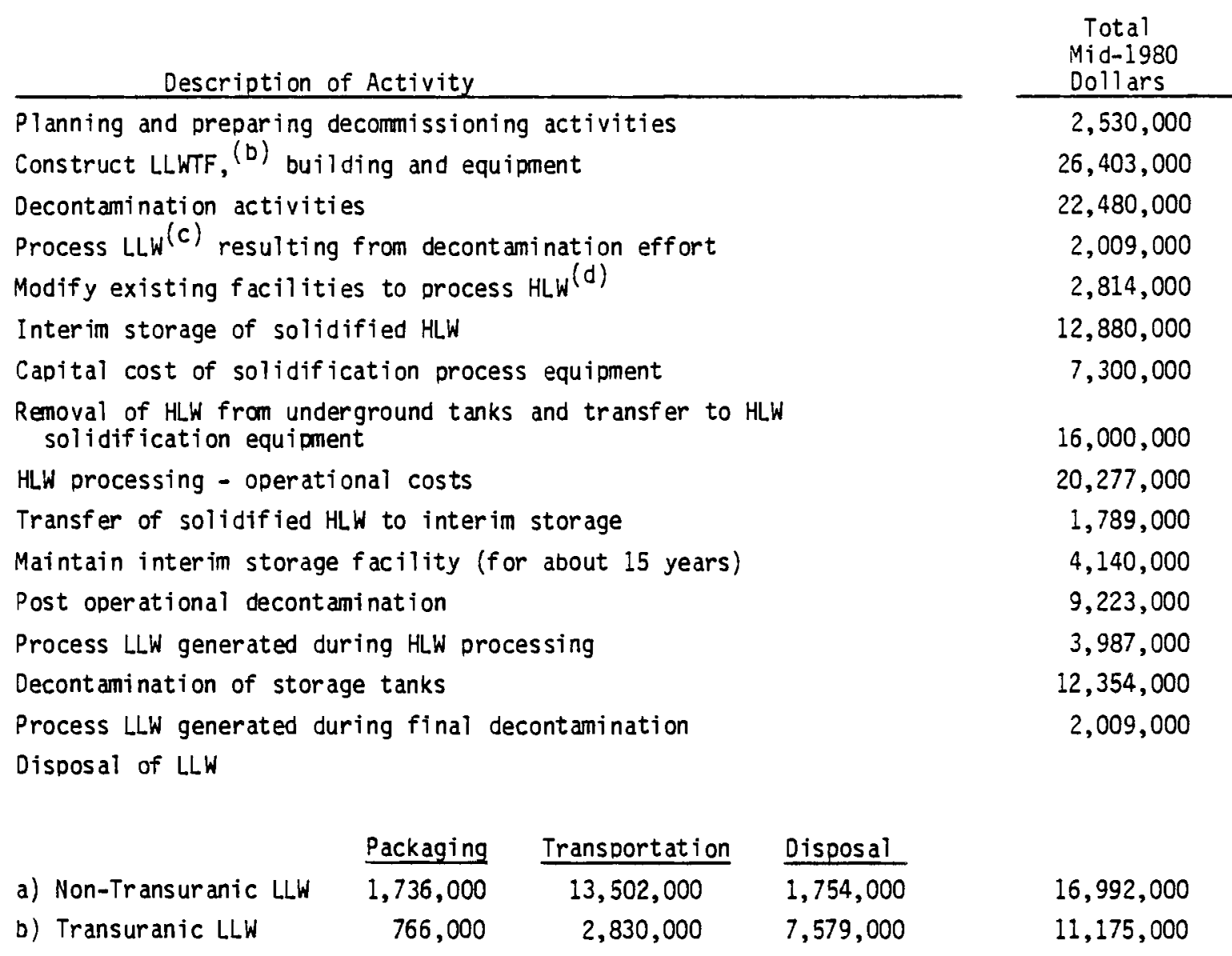

HLW Disposal

$$
\frac{\text { Packaging }}{21,900,000} \frac{\text { Transportation }}{8,366,000} \quad \frac{\text { Disposal }}{128,304,000} \quad 158,570,000
$$

Decontamination LLWT facility

Interim care for facility

$1,742,000$

N/A

Entombment: filling areas that contain activity with concrete

N/A

Demolition and restoration activity

$7,182,000$

Solidification of the interim waste at a DOE site

$\mathrm{N} / \mathrm{A}$

Engineering, design \& construction management $015 \%$

SUB-TOTAL $\quad \frac{N / A}{341,856,000}$

SUB-TOTAL
Contingency $0.25 \%$

$51,278,000$

Contingency of $25 \%$

$393,134,000$

$\underline{98,284,000}$

TOTAL

$\underline{491,418,000}$

(a) These costs are considered preliminary and should not be used for a project cost estimate.

(b) Low-level-waste treatment facility.

(c) Low-level waste.

(d) High-level waste. 
TABLE 11.7. Cost Summary, Combined Alkal ine Purex and Acidic Thorex Waste Process, Solidification as an Interim Fused-Salt Waste Form Before Off-Site Terminal Solidification(a)

\begin{tabular}{|c|c|c|c|}
\hline \multicolumn{3}{|c|}{ Description of Activity } & $\begin{array}{l}\text { Total } \\
\text { Mid-1980 } \\
\text { Dollars } \\
\end{array}$ \\
\hline \multicolumn{3}{|c|}{ Planning and preparing decommissioning activities } & $2,530,000$ \\
\hline \multicolumn{3}{|c|}{ Construct LLWTF, building and equipment } & $26,403,000$ \\
\hline \multicolumn{3}{|c|}{ Decontamination activities } & $22,480,000$ \\
\hline \multicolumn{3}{|c|}{ Process $L L W$ resulting from decontamination effort } & $2,000,000$ \\
\hline \multicolumn{3}{|c|}{ Modify existing facilities to process HLW } & $2,814,000$ \\
\hline \multicolumn{3}{|c|}{ Interim storage of solidified HLW } & $2,283,000$ \\
\hline \multicolumn{3}{|c|}{ Capital cost of solidification process equipment } & $1,700,000$ \\
\hline \multicolumn{3}{|c|}{$\begin{array}{l}\text { Removal of HLW fram underground tanks and transfer to HLW } \\
\text { solidification equipment }\end{array}$} & $15,000,000$ \\
\hline \multicolumn{3}{|c|}{$H L W$ processing - operational costs } & $16,225,000$ \\
\hline \multicolumn{3}{|c|}{ Transfer of solidified HLW to interim storage } & $1,087,000$ \\
\hline \multicolumn{3}{|c|}{ Maintain interim storage facility (for about 15 years) } & $N / A$ \\
\hline \multicolumn{3}{|c|}{ Post operational decontamination } & $9,223,000$ \\
\hline \multicolumn{3}{|c|}{ Process LLW generated during HLW processing } & $2,660,000$ \\
\hline \multicolumn{3}{|c|}{ Decontamination of Storage Tanks } & $12,354,000$ \\
\hline \multicolumn{3}{|c|}{$\begin{array}{l}\text { Process LLW generated during final decontamination } \\
\text { Disposal of LLW }\end{array}$} & $2,000,000$ \\
\hline & Transportation & Disposal & \\
\hline a) Non-Transuranic LLW & $10,806,000$ & $1,450,000$ & $13,825,000$ \\
\hline b) Transuranic LLW & $2,333,000$ & $6,291,000$ & $9,303,000$ \\
\hline
\end{tabular}

HLW Disposal

\begin{tabular}{|c|c|c|c|c|}
\hline & Packaging & Transportation & Disposal & \\
\hline To Savannah River & $14,600,000$ & $3,890,000$ & $-\cdots$ & $18,490,000$ \\
\hline To Federal Depository & -- & 592,000 & $32,076,000$ & $32,668,000$ \\
\hline \multicolumn{4}{|c|}{ Decontamination LLWT facility } & $1,742,000$ \\
\hline \multicolumn{4}{|c|}{ Interim care for facility } & N/A \\
\hline \multicolumn{4}{|c|}{ Entombment: filling areas that contain activity with concrete } & N/A \\
\hline \multicolumn{4}{|c|}{ Demolition and restoration activity } & $7,182,000$ \\
\hline \multicolumn{4}{|c|}{ Solidification of the interim waste at a DOE site } & $24,000,000$ \\
\hline & & & SUB-TOTAL & $225,969,000$ \\
\hline \multicolumn{4}{|c|}{ Engineering, Design \& Construction Management $@ 15 \%$} & $33,895,000$ \\
\hline & & & SUB-TOTAL & $259,864,000$ \\
\hline \multirow{2}{*}{\multicolumn{3}{|c|}{ Contingency $25 \%$}} & & $64,966,000$ \\
\hline & & & TOTAL & $\underline{324,830,000}$ \\
\hline
\end{tabular}

(a) These costs are considered preliminary and should not be used for a project cost estimate. 
Indirect costs were also included, such as:

1. field supervision;

2. quality assurance;

3. unemployment insurance, workman's compensation, social security and liability insurance;

4. field office trailers, telephone, water and electrical hook-ups;

5. minor construction equipment such as scaffolding, welding machines, small cranes, A-frames and trucks. Major construction equipment is included in the direct-cost portion of the estimate;

6. small tools and consumables;

7. contractor home office costs, including purchasing, estimating, administrative, bonds, permits and other costs;

8. general contractor mark-up on subcontracted work;

9. profit.

Included in the estimates is a contingency allowance of 25 percent, based on the conceptual nature of the design and the complexity and uncertainties of the component parts of the estimates.

Construction costs assumed that facility structures will be designed to withstand a seismic force of $0.1 \mathrm{~g}$. This is a design parameter that is applied to waste systems in nuclear power plants. It was also assumed that sufficient shielding is provided for operational activities such that personnel exposure for the operations will not exceed $0.1 \mathrm{mR} / \mathrm{hr}$. The estimate of manpower requirements in the operation of the facility takes into consideration that many activities require remote operations.

The total process option costs are summarized below. These costs are considered preliminary and should not be used as project cost estimates. They do however indicate the cost differences between the process alternatives.

Option

1. Salt/Sludge waste separation process--solidification in a borosilicate glass

2. Combined alkaline purex and acidic thorex wastes process--solidification in a borosilicate glass

3. Combined alkaline purex and acidic thorex waste process--solidification as an interim fused-salt form before off-site terminal solidification
Cost (\$ millions, mid-1980)

326

491

The cost of the salt/sludge separation approach producing a borosilicate glass waste form is substantially less than the cost associated with the combined waste processing approach. The principal factor governing this cost difference is the lower cost associated with high- 
level-waste packaging, transportation, and disposal of the much smaller volume of saltseparated high-level waste. This also assumes that the salt-cake produced from the salt/sludge separation process can be handled and disposed of inexpensively as low-level waste.

On the other hand, the cost of the salt/sludge separation process and conversion of the waste to a borosilicate glass is virtually the same as for the interim waste form fused-salt process. The economy of the inter im waste form process is based primarily on the inexpensive incremental cost of converting the interim waste form to a terminal form at an existing and operating facility and the low capital and operating costs of producing the interim form at WNYNSC.

The other terminal and interim waste form process options considered in the present PNL study were not considered in the Burns and Roe cost study. However, with in the accuracy of the cost estimates, it is anticipated that the capital and operating variations to produce these other terminal and interim forms are relatively insignificant when compared to the cost for packaging, storage, shipping and disposal of the high-level-waste canisters. The cost of processing salt separated from the high-level-waste is approximately $\$ 10 \mathrm{million}$. Hence, this cost factor is also relatively insignificant when comparing costs of the salt/sludge separation and combined-waste options. The differential costs for the various terminal waste form/process options, can therefore be calculated, on a cost per canister basis. These results are sumanarized in Table 11.8. Based on the Burns and Roe study, a cost of $\$ 130,000$ per canister is assumed for packaging, shipping and disposal. It is observed from Table 11.8 that borosilicate glass and low-alkali glass are the most cost-effective process approaches given the current assumptions. Since these processes are the simplest their relative capital costs are also expected to be lower.

For the interim waste forms it is difficult to compare the relative costs of the different options considered using the Burns and Roe study results. However, it is clear that the fused salt and calcination options would be less expensive than the salt/silicate matrix and organic binder options due to lower canister requirements and less process complexity.

\subsection{CONCLUSIONS}

The following conclusions were developed from the process alternatives assessment. These conclusions evolved from the three evaluatory attributes considered: conformance to projecttiming and implementation requirements, relative technical merit of the process alternatives, and the relative cost differences associated with the project.

- The salt/sludge separation approach for waste treatment is preferred over the combined-waste process approach when producing a terminal waste form. The bas is for this preference is the lower anticipated waste solidification project cost.

- The terminal waste form processes reviewed in this study are preferred in this order: borosilicate glass, low-alkali glass, marbles-in-lead matrix and crystalline ceramic. The reasons for this preference are the relative technical merits, and lower anticipated waste solidification project costs. 
TABLE 11.8. Relative Handling and Disposal Cost for High-Level-Waste Canisters from Process Options

\begin{tabular}{|c|c|c|c|c|}
\hline & Option & $\begin{array}{l}\text { Number of } \\
\text { Canisters } \\
\end{array}$ & $\begin{array}{l}\text { Canister Disposa) } \\
\text { Cost, } \$ \text { millions }(a) \\
\end{array}$ & $\begin{array}{c}\text { Differential } \\
\text { Cost, smillions }(c) \\
\end{array}$ \\
\hline A. & Salt separated & & & \\
\hline & $\begin{array}{l}\text { - Borosilicate glass } \\
\text { (Reference case) }\end{array}$ & 240 & 31 & 0 \\
\hline & - Low-Alkali Glass & 377 & 49 & 18 \\
\hline & - Marbles-in-lead & 682 & 87 & 56 \\
\hline & - Crystalline ceramic & $121(b)$ & $115^{(b)}$ & 84 \\
\hline B. & Total waste solidifica & & & \\
\hline & - Borosilicate glass & 1500 & 195 & $154(d)$ \\
\hline & - Low-Alkali glass & 2572 & 334 & $293(d)$ \\
\hline & - Marbles-in-lead & 3596 & 467 & $426(d)$ \\
\hline
\end{tabular}

(a) Packaging, transportation, and disposal cost per canister $=\$ 130,000$.

(b) This option requires construction of a new facility and a $10 \mathrm{yr}$ operating campaign to perform the processing, which is not included in any of the costs considered in this section. An order of magnitude estimate would be that the increased capital and operating facility incremental costs would be over $\$ 100$ million. This cost is included in the canister disposal cost and differential cost.

(c) Compared to salt-separated borosilicate glass (reference case).

(d) A $\$ 10$ million credit is made for reduced low-level waste disposal requirements.

- The crystalline-ceramic process was judged to not be available in 1987. This process also was judged to require additional facilities to be implemented at the WNYNSC.

- If the combined-waste process were to be used for conversion of the WNYNSC wastes to a terminal waste form, it is recommended that the process campaign length be increased from three years to improve process reliability.

- The salt/sludge separation approach, although preferred, will require development and verification testing before it is ready for plant application. Areas requiring development involve supernate/sludge separations and ion-exchange decontamination of the alkaline supernate. The salt/sludge process has potential for simplification of process and equipment requirements which would improve process reliability.

- Initial cost assessments indicate that the interim waste form processing approach for solidification of the WNYNSC wastes is cost competitive with the salt/sludge separation process. 
- The interim waste form processes considered in this study are preferred in this order: fused salt, calcine, silicate/salt matrix and vinyl ester-styrene. The basis for these ratings is primarily the relative technical merits and the lower cost associated with the lower volume processes.

- If an interim waste form process is to be used for solidification of the WNYNSC waste, it is recommended that the process campaign length be increased from three years. This will improve the overall process reliability by making the process easier to operate within existing WNYNSC facilities. 


\subsection{REFERENCES}

Burns and Roe Industrial Services Corporation. 1981 (January). Cost Estimates Supporting West Valley DEIS. DOE/NEW-44207-2, Burns and Roe Industrial Services Corporation, Paramus, New Jersey.

DOE. 1980. Evaluation and Review of Alternative Waste Forms for Immobilization of High-Level Radioactive Wastes, Report No. 2. DOE-TIC-11219, U.S. Department of Energy, Washington, D.C. (Prepared for DOE Alternative Waste Form Peer Review Panel).

E. R. Johnson Associates. 1980. Preliminary Evaluation of Alternative Waste Form Solidification Processes: Volume II Evaluation of Processes. JAI 80-160, E. R. Johnson Assocíates, Inc., Reston, Virginia.

Ross, W. A., J. M. Rusin, and J. L. MCElroy. 1979. "Processes for Production of Alternative Waste Forms." Presented at Waste Management Symposium 1979, Tuscon, Arizona.

Stone, J. A., S. T. Goforth, and P. K. Smith. 1979. Preliminary Evaluation of Alternative Forms for Immobilization of Savannah River Plant High-Level Wastes. DP-1545, E. I. OuPont deNemours and Co., Savannah River Laboratory, Aiken, South Carolina. 


.
$\cdot$
$\cdot$
.




\section{APPENDIX A}

FLOWSHEET AND MATERIAL BALANCE; SOLIDIFICATION OF THE SALT/SLUDGE SEPARATED ALKALINE WASTE 


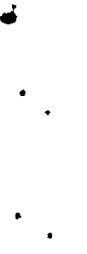




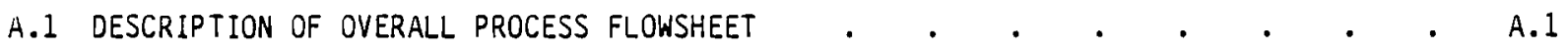

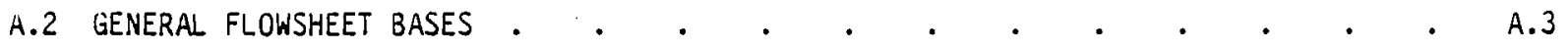

A.3 PROCESS AND FLOWSHEET DESCRIPTION DETAIL

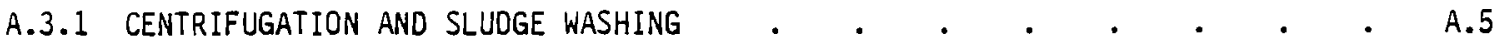

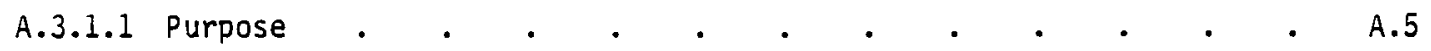

A.3.1.2 Process Description . . . . . . . . . . . . A.5

A.3.1.3 Process Flowsheet and Material Balance Bases . . . . . A.7

A.3.1.4 State of Process Development . . . . . . . . . . A.7

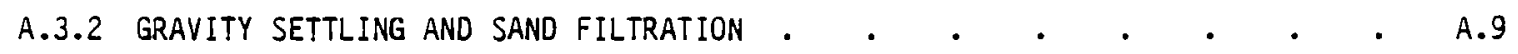

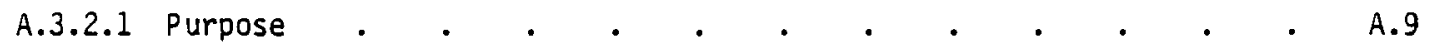

A.3.2.2 Process Description . . . . . . . . . . . . A.9

A.3.2.3 Process Flowsheet and Material Balance Bases . . . . . A.9

A.3.2.4 Status of Technology . . . . . . . . . . . A.12

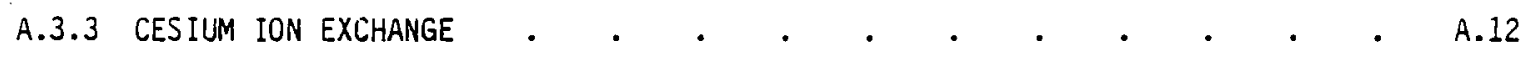

A.3.3.1 Purpose . . . . . . . . . . . . . . A.12

A.3.3.2 Process Description . . . . . . . . . . . . A.12

A.3.3.3 Process Flowsheet and Material Balance Bases . . . . . A.14

A.3.3.4 Status of Technology . . . . . . . . . . . A.14

A.3.4 CESIUM ELUTRIANT RECOVERY AND CESIUM ZEOLITE FIXATION • • • . • . A.16

A.3.4.1 Purpose . . . . . . . . . . . . A.16

A.3.4.2 Process Description . . . . . . . . . . A.16

A.3.4.3 Process Flowsheet and Material Balance Bases . . . . . A.17

A.3.4.4 Status of Technology. . . . . . . . . . . . A.17

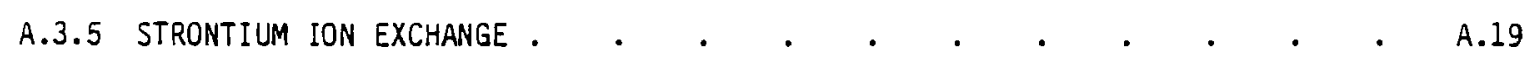

A.3.5.1 Purpose . . . . . . . . . . . . . . A.19

A.3.5.2 Process Description . . . . . . . . . . . . . A.19

A.3.5.3 Process Flowsheet and Material Balance Bases . . . . . A.20

A.3.5.4 Status of Technology . . . . . . . . . . . . A.22

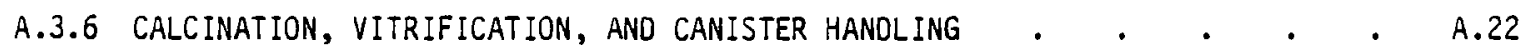

A.3.6.1 Purpose . . . . . . . . . . . . . . A.22 
A.3.6.2 Process Description . . . . . . . . . . . A.22

A.3.6.3 Process Flowsheet and Material Balance Bases . . . . . A.24

A.3.6.4 Status of Technology . . . . . . . . . . . A.27

A.3.7 RECYCLE AND SECONDARY EVAPORATION . . . . . . . . . . . . A.27

A.3.7.1 Purpose . . . . . . . . . . . . A.27

A.3.7.2 Process Description . . . . . . . . . . A.28

A.3.7.3 Process Flowsheet and Material Balance Bases . . . . . A.28

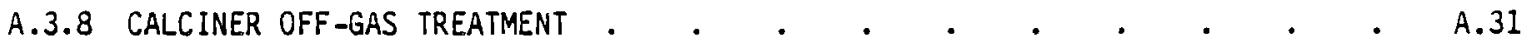

A.3.8.1 Purpose . . . . . . . . . . . . A.31

A.3.8.2 Process Description . . . . . . . . . . . . A.31

A.3.8.3 Process Flowsheet and Material Balance Bases . . . . . A.31

A.3.8.4 Status of Technology . . . . . . . . . . . . A.34

A.3.9 SOLIDIFICATION OF DECONTAMINATED SUPERNATE . . . . . . . . . . A.34

A.3.9.1 Purpose . . . . . . . . . . . . . . . A.34

A.3.9.2 Process Description . . . . . . . . . . A.35

A.3.9.3 Process Flowsheet and Material Balance Bases . . . . . A.37

A.3.9.4 Status of Technology . . . . . . . . . . . . . A.37

A.4 REFERENCES . . . . . . . . . . . . . . . . . . . . . A.39 


\section{FIGURES}

A.1 Simplified Process Flowsheet for the Salt/Sludge Separation Process

Solidification of the Alkaline Purex Waste.

A.2 Process Flowsheet (FS-1) Sludge/Supernate Centrifugation

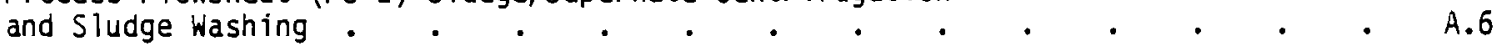

A.3 Process Flowsheet (FS-2) Gravity Settling and Sand Filtration . . • . . A.10

A.4 Process Flowsheet (FS-3) Cesium Ion Exchange . . . . . . . . . . . A.13

A.5 Flowsheet (FS-4) Cesium Elutriant Recovery and Cesium Fixation on Zeolite $\quad$. A.16

A.6 Process Flowsheet (FS-5) Strontium Ion Exchange $\quad$. . . . . . . . A.20

A.7 Process Flowsheet (FS-6) for the Calcination/Vitrification Process $\quad$ - $\quad$ - A.23

A.8 Process Flowsheet (FS-7) for Recycle and Secondary Evaporation . . . . . A.29

A.9 Process Flowsheet (FS-8) for Calciner Off-Gas Treatment . . . . . . . A.32

\section{TABLES}

A.1 Material Balance for Sludge/Supernate Separation and Sludge Washing . . . A.8

A.2 Material Balance for Gravity Settling and Sand Filtration . . . . . . $\quad$. A.11

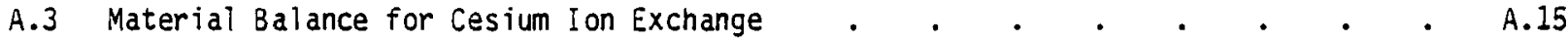

A.4 Material Balance for Cesium Eluate Concentration and Cesium Zeolite Fixation . A.18

A.5 Material Balance for Strontium Ion Exchange . . . . . . . . . . . . . A.21

A.6 Material Balance for Spray Calcination and Vitrification of

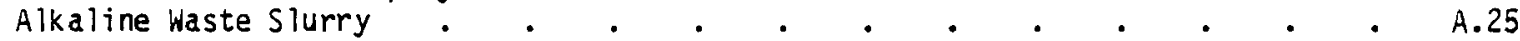

A.7 Estimated Chemical Composition of Salt/Sludge Separated Alkaline Waste 8lend . A.26

A.8 Representative Glass Former Mixture for Vitrification of Alkaline-Waste

A.9 Waste Form Process Summary for Solidifying Alkaline Purex Waste . . . . $\quad$. A.28

A.10 Material Balance for Recycle and Secondary Evaporation . . . . . . . A.30

A.11 Material Balance for Calciner Off-Gas Treatment $\quad$. . . . . . . . . . A.33

A.12 Estimated Salt-Cake Composition--Salt Sludge Separation Process . . . . . A.35

A.13 Calculated Isotopic Composition of Low-Level Salt Cake from the Salt/Sludge A.36
Separation Process

A.14 Material Balance for Solidification of Decontaminated Supernate . • . $\quad$ - A.38 

. 
Presented in this appendix are the process flowsheets, process bases, assumptions, and chemical and radiochemical material balances for solidification of the salt/sludge separated alkaline waste. Borosilicate glass formed by the SC/ICM process is the terminal waste form incorporated into this process flowsheet and material balance.

\section{A.1 DESCRIPTION OF OVERALL PROCESS FLOWSHEET}

A simplified process flowsheet for separation and decontamination of the alkaline waste supernate from the alkaline waste sludge is shown in Figure A.1. This simplified flowsheet is divided into eight separate unit processes whose purpose is to prepare and treat the highlevel-waste and low-level-waste side streams.

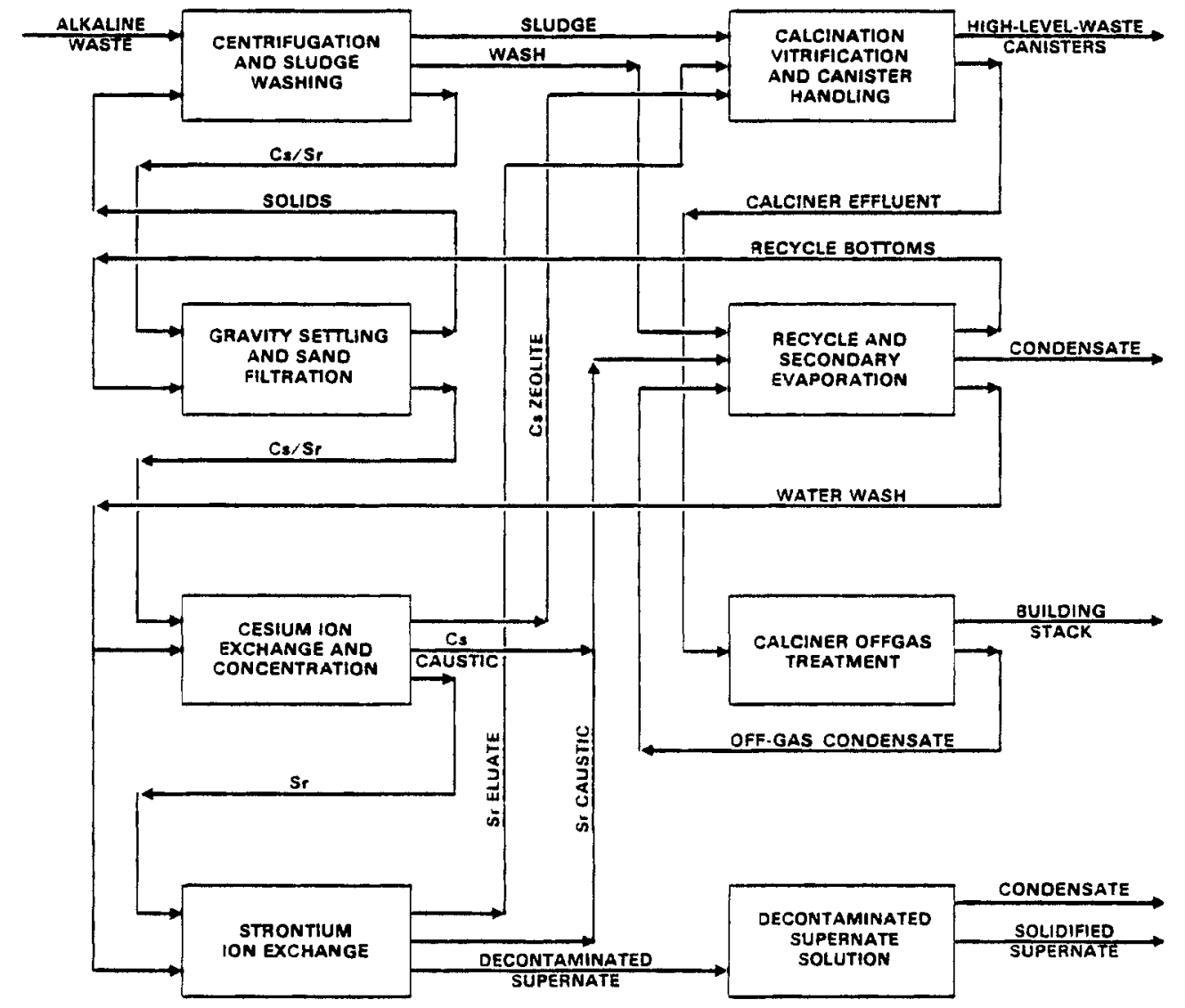

FIGURE A.1. Simplified Process Flowsheet for the Salt/Sludge Separation Process. Solidification of the Alkaline Purex Waste. 
Homogenized alkaline waste is transferred from the waste tank farm to the centrifugation process module. Here the bulk of the sludge is separated from the supernate by centrifugation. Centrate from the centrifuge is transferred to the gravity-settling and sand-filtration process module. Sludge solids discharged from the centrifuge bowl are washed with water in three steps.

Each wash step includes a water wash of the solids from the centrifuge, agitation of the sludge/water mixture and separation of the homogenized slurry by centrifugation. The purpose of the sludge-washing process is to remove soluble salts such as sodium nitrate and sulphate from the alkaline sludge. Washing the sludge results in a smaller volume of vitrified product formed by minimizing the sodium in the alkaline sludge. Washed sludge is transferred to the spray calciner feed-makeup tank. Wash centrate is transferred to the recycle evaporation process module.

Centrate from sludge/supernate separation is transferred to a gravity settler. Solids are removed in the gravity settler further clarifying the supernate. Solids collected in the gravity settler are recycled to the centrifuge feed tank. Supernate from the gravity settlers is passed through two sand $f i l t e r s$, which remove essentially all remaining suspended solids. Clarification of the supernate to less than 1 part-per-million is necessary to: 1) prevent passage of solids radioactivity through ion-exchange columns, and 2) prevent pluggage of the ion-exchange columns with solid material.

Filtrate from the sand filter is passed through two sets of ion-exchange columns. The

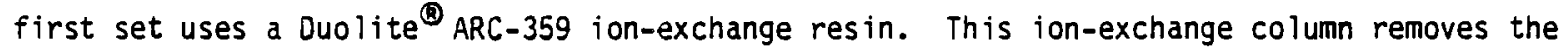
cesium activity and most of the actinide activity from the alkaline supernate. The second set of ion-exchange columns uses a Chelex ${ }^{\mathbb{P}}-100$ ion-exchange resin. This ion-exchange column is used to remove the strontium activity and the remaining actinide activity from the alkaline supernate. A backup ion-exchange column is also included to remove any residual actinide activity. The resin for this backup-exchange column has not been identified at this time.

Both the Duolite and Chelex ion-exchange columns are eluted of activity and regenerated. The cesium eluate is passed to a cesium concentrator where ammonia and carbon dioxide elution agents are recovered. The cesium concentrator bottoms are passed through a zeolite bed to strip cesium from the sodium carbonate solution. The stripped sodium carbonate is fed to the gravity settler. The cesium loaded zeolite is transferred to the spray calciner feed tank. Strontium eluate from washing the strontium ion-exchange columns is transferred directiy to the spray calciner feed tank.

Decontaminated supernate solution from the ion-exchange columns is dewatered in a twostage process. First, water from the supernate solution is removed in an evaporator. Second, bottoms from the evaporator are fed to a wiped-film evaporator. Salt cake from the wiped-film evaporator is packaged in 55-gal steel drums. Condensate is further processed through the lowlevel-waste treatment facility.

(8) Duolite ARC-359, Registered Trademark, Diamond Shamrock, Inc.

(A) Chelex-100, Registered Trademark, Bio-Rod Laboratories. 
Spray calciner feed is comprised of washed sludge, cesium loaded zeolite, strontium eluate and miscellaneous solids such as spent sand filters. This material is dried, and simultaneously converted to oxides in the spray calciner. This calcine solid is mixed with glass forming chemicals and melted to form a borosilicate glass using the in-can melter process. Canisters of high-level vitreous waste having an overall dimension of $0.60 \mathrm{~m}(2 \mathrm{ft})$ in diameter by $3.04 \mathrm{~m}(10 \mathrm{ft})$ in height are produced in this melter.

Process effluents from the calcination/vitrification process include air, water, -itrates, and volatile fission products. Activity from the vitrification process is removed in the calciner off-gas treatment system, which includes the unit processes of scrubbing, condensation. filtration and sorption. Process scrub liquids are recycled to the evaporation module.

The evaporation process consists of two evaporators operated in a series. Bottoms from the first evaporator, called the recycle evaporator, are recycled to the gravity settler; overheads are sent to the second evaporator. Bottoms from the second evaporation step are combined with miscellaneous waste streams and provide feed to the recycle evaporator. Overheads from the second evaporator are condensed and sent to the low-level-waste treatment facility.

\section{A.2 GENERAL FLOWSHEET BASES}

General bases used in development of the flowsheet are presented in this section. These bases are derived from the overall project schedule requiring a three-year high-level-waste solidification campaign, regulations, and process feasibility.

1. The alkaline waste is assumed to be completely homogenized before transfer to the CPC Cell. The volume of the alkaline waste is $2.12 \times 10^{6} \mathrm{~L}$. Transfer-line flush solutions composed of $1.89 \times 10^{5} \mathrm{~L}$ of water are added to the alkaline waste in transfer-line rinses.

2. The flowsheet flows are based on an instantaneous sludge/slurry feedrate of $170 \mathrm{~L} / \mathrm{h}$. This rate will insure vitrification of the entire contents of Tank 802 and Tank 8D4 in a three-year period, assuming a $60 \%$ onstream factor for the plant.

3. The flowsheet is based on proven technology wherever possible.

4. Spent ion-exchange resins from the cesium and strontium ion-exchange columns are considered low-level waste and are disposed of with other solid, processing cell-waste material. The backup, actinide ion-exchange resin has not been identified. It is assumed that this resin would be incorporated into the glass production; however, no material flows are quantified.

5. The alkaline supernate-decontamination process is designed to reduce cesium, strontium and actinide activity in the supernate to levels as low as reasonably achievable.

6. Decontaminated supernate solution will be converted to a salt cake containing 20 to $25 \%$ residual water.

7. Glass canisters are $0.60 \mathrm{~m}(2 \mathrm{ft})$ in diameter by $3.04 \mathrm{~m}(10 \mathrm{ft})$ high. The volume of vitrified waste in the canister is $712 \mathrm{~L}$. A fill height of $2.5 \mathrm{~m}(8.5 \mathrm{ft})$ is assumed. 
8. The separated alkaline Purex waste blend has a waste loading in the borosilicate glass matrix of $25 \mathrm{wt}$.

9. The radionuclide material balance for this preliminary flowsheet is based on a simple mode1. Those radionuclides originally in the insoluble sludge are assumed to remain homogeneously dispersed with sludge during separation and contacting operations. Those radionuclides originally associated with the supernate solution are assumed to remain with the supernate solution except during sorption processes.

10. Effluents from the process consist of:

- glass canisters,

- decontaminated salt cake in 55-gal drums,

- noncondensable gases released to the stack,

- decontaminated process water,

- spent ion-exchange resins.

11. Functional criteria on equipment pieces is specified where required. Flows are estimated based on these functional criteria and data extrapolated from previously demonstrated techno logy.

12. The radionuclide and chemical inventory of the wastes stored in Tank 802 and Tank 804 is based on information provided in Section 4.0 of this report.

13. The SC/ICM process is the reference vitrification process for this flowsheet.

14. Separate treatment of the Tank 802 alkaline waste and Tank 804 acidic Thorex waste is assumed. The flowsheets and material balances provided in this report refer to treatment of the alkaline Purex waste only. A much simplified flowsheet will result for vitrification of the Thorex waste, using the same process equipment, discussed in Appendix 3 .

15. Dilution of process streams due to jet transfers is not included within the material balance.

\section{A.3 PROCESS AND FLOWSHEET DESCRIPTION DETAIL}

The process operations for the salt separation flowsheet are further described in this section. The following information is provided for each unit process operation: the purpose, the description, the flow diagram, the assumptions used for material balance, the chemical and radiochemical material balance, and the status of technology.

The process flowsheets for solidification of the salt separated alkaline waste were developed from proven waste-management technology. Extensive application of data developed during treatment of high-level waste stored at Hanford, SRL and PNL has been used to define this flowsheet. It is assumed that process data developed at these DOE sites may be extrapolated to management of the WNYNSC alkaline wastes. 


\section{A.3.1 CENTRIFUGATION AND SLUOGE WASHING}

\section{A.3.1.1 Purpose}

The overall purpose of the centrifugation process is to separate greater than 95 wt\% of the solids from the original homogenized sludge/supernate mixture. Washing the centrifuge sludge is done to remove essentially all of the sodium nitrate and sulphate from the alkaline waste sludge. Washing these species from the sludge reduces the quantity of vitreous product produced.

\section{A.3.1.2 Process Description}

Shown in Figure A.2 is the flowsheet for the sludge/supernate centrifugation and sludgewashing process. Homogenized alkaline-waste sludge/slurry is transferred to the feed holding tanks from the tank farm. The sludge/slurry is mixed in the feed holding tanks with skim from the primary centrifuge, gravity-settler bottoms, and sand-filter backflush. The resulting centrifuge feed mixture is sampled before being sent to the primary centrifuge. These samples can be analyzed for solids and used to determine the centrifuge cycle time and feed rate.

The sludge/slurry mixture is fed first to the primary centrifuge where approximately $90 \mathrm{wt} \%$ of the solids are removed. Centrate is passed through a second centrifuge where approximately $50 \%$ of the remaining solids are removed. Skim liquor from each centrifuge is recycled to each respective feed tank. The cake from the primary and secondary centrifuges is mechanically discharged from each centrifuge, respectively, and combined with centrifuge wash water in the sludge slurry tank. Centrate from the secondary centrifuge is transferred to the gravity settler.

Sludge washing requires the use of the primary centrifuge. Additional wash water is added to the sludge-slurry mixture in the sludge-slurry tank to adjust the soluble salt to water ratio. This mixture is agitated then fed to the centrifuge. Wash centrate and skim are trans ferred to the recycle-evaporator feed tank. No solids are assumed to be in the cake skim. The cake is mechanically discharged into the sludge-slurry tank. A water spray is used to further remove solids from the centrifuge. The water volume is adjusted and the wash step is repeated, for a total of three wash steps. Approximately $85 \mathrm{wt} \%$ of the sodium, nitrate and sulphate are removed during each wash step. Specifications given on the washed sludge for sodium, nitrate, and sulphate are $>5 \mathrm{wt \%} \mathrm{Na}^{+},>10 \mathrm{wt}^{+} \mathrm{NO}_{3}^{-}$and $>3{\mathrm{wt \%} \mathrm{SO}_{4}}^{--2}$ on a dry weight basis.

Reducing the sodium concentration to the specified level minimizes the quantity of vitreous product formed. Reducing the nitrate level in the sludge should reduce the volatility of principle radionuclides such as Ruthenium-106. The sulphate level in the sludge is reduced to prevent sodium sulphate phase separation in the vitreous product. Sulphate has a solubility in borosilicate glass of less than 1 wt\%. Concentrations greater than 1 wt\% sulphate ion in the glass can lead to the formation of a water-soluble sodium sulphate in which other alkali elements such as cesium would tend to concentrate. 


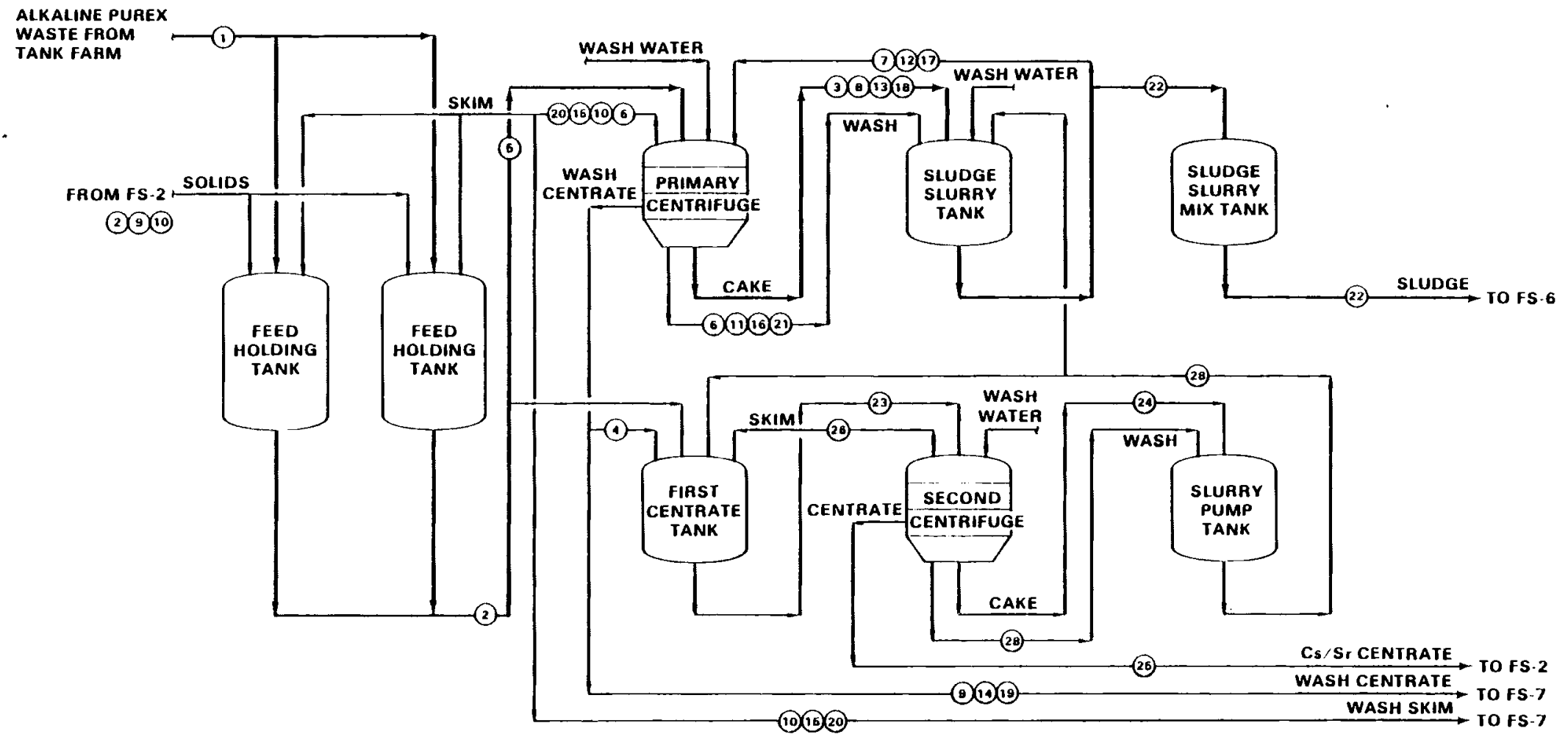

FIGURE A.2. Process Flowsheet (FS-1) Sludge/Supernate Centrifugation and Sludge Washing 


\section{A.3.1.3 Process Flowsheet and Material Balance Bases}

The bases for the material balance for sludge/supernate separation and siudge washing are presented below. The material balance for sludge/supernate centrifugation and sludge washing are sumnarized in Table A.1.

Centrifugation process bases are:

- The feed rate of homogeneous alkaline waste to the process is $170 \mathrm{~L} / \mathrm{h}$. This includes rinse water from waste transfers and tank flushes.

- Decontamination factors of 10 and 2 are assumed for insoluble solids across the primary and secondary centrifuges during initial separation, respectively.

- The time cycle of the primary centrifuge is two hours; the secondary centrifuge time cycle is eight hours.

- Material balance for centrifuge operation assumes continuous rather than semibatch operation.

- The ratio of salt to water is the same in the centrifuge feed and centrifuge cake. The bases of the sludge washing process are:

- Eight-five weight percent of the soluble salts in the centrifuge feed are removed during each wash.

- Water is added to the sludge-slurry mixture to keep the weight percent of solids in the feed at 6 to $8 \mathrm{wt \%}$. The volume of the centrifuge feed is identical in each batch wash.

- Recovery of solids during centrifugation is $97 \%$.

\section{A.3.1.4 State of Process Development}

Centrifugal separation of sludge-slurry mixtures similar to those proposed in this flowsheet have been performed in small, 1300-G vertical soild-bowl centrifuges with actual and simulated sludge slurries (Stone 1976). Results of these tests were similar for actual and simulated sludge slurries. In both series of tests, cumulative sludge recovery in two series centrifuges ranged from $90 \%$ to $99 \mathrm{wt \%}$. The use of polyelectrolyte flocculants was shown to aid in separation in some cases; however, in general, good separation could be achieved without the use of these agents.

Large-scaie tests using a 48-inch batch-basket centrifuge have been performed (Landon 1980, Okeson 1980). Based on these large-scale tests solid recoveries of 98 wt\% can be achieved. The test results have also indicated that the product specification on sodium, nitrate, and sulphate can be achieved.

The majority of remote, radioactive, plant experience with centrifuges has occurred at B-Plant located at Hanford. There have been several technical reports that describe the specific centrifuge applications (Larson and Smith 1969; Buckingham 1967). Average centrifuge life in radioactive operations for solid-bowl centrifuges was found to be five months. 
TABLE A.1. Material Balance for Sludge/Supernate Separation and Sludge Washing

\begin{tabular}{|c|c|c|c|c|c|c|c|c|c|c|c|c|}
\hline \multirow{2}{*}{$\frac{\text { Operation }}{\text { Stream No. }}$} & \multicolumn{6}{|c|}{ Primary Centrifuge Operation } & \multirow{2}{*}{\multicolumn{6}{|c|}{ First Wash Cycle }} \\
\hline & 1 & 2 & 3 & $=\frac{1}{4}$ & 5 & 6 & 7 & 8 & & & & \\
\hline Description & $\begin{array}{l}\text { Neutralized } \\
\text { Waste From } \\
\text { Iank } 8 D-2 \\
\end{array}$ & $\begin{array}{c}\text { Feed to } \\
\text { Pr imary } \\
\text { Centr if uge }\end{array}$ & $\begin{array}{l}\text { Solids from } \\
\text { Primary } \\
\text { Centrifuge }\end{array}$ & $\begin{array}{c}\text { Primary } \\
\text { Centrifuge } \\
\text { Centrate }\end{array}$ & $\begin{array}{c}\text { Primary } \\
\text { Centr if uge } \\
\text { Sk in } \\
\end{array}$ & $\begin{array}{l}\text { Primary } \\
\text { Centr if uge } \\
\text { Wash Water }\end{array}$ & $\begin{array}{c}\text { 1st Cycle } \\
\text { Solids } \\
\text { Recycle } \\
\end{array}$ & $\begin{array}{l}\text { Solids } \\
\text { Recycle }\end{array}$ & $\begin{array}{l}\text { Tst Wash } \\
\text { Cycle } \\
\text { Centrate }\end{array}$ & $\begin{array}{c}\text { Tst Wash } \\
\text { Cycle } \\
\text { Sk im } \\
\end{array}$ & $\begin{array}{c}\text { 15t Cycle } \\
\text { Wash } \\
\text { Water } \\
\end{array}$ & $\begin{array}{l}\text { 2nd Cycle } \\
\text { Solids } \\
\text { Recycle }\end{array}$ \\
\hline $\mathrm{Flow}, \mathrm{kg} / \mathrm{h}$ & & & & & & & & & & & & \\
\hline Salt & 83.84 & 96.96 & 9.41 & 84.73 & 2.82 & -- & 17.88 & 2.68 & 15.00 & -- & $\cdots$ & 2.68 \\
\hline Solid & 6.91 & 8.147 & 7.118 & 0.791 & 0.237 & -- & 7.514 & 7.28 & 0.225 & -- & -- & 7.28 \\
\hline $\mathrm{H}_{2} \mathrm{O}$ & 172.8 & 210.9 & 20.5 & 184.3 & 6.14 & 84.4 & 182.64 & 10.03 & 167.1 & 5.54 & 85.0 & 95.0 \\
\hline TOTAL & 163.5 & 316.01 & 37.02 & 269.8 & 9.20 & 84.4 & 208.03 & 19.99 & 182.3 & 5.54 & 85.0 & 104.98 \\
\hline Temp, ${ }^{\circ} \mathrm{C}$ & 35 & 35 & 35 & 35 & 35 & 35 & 35 & 35 & 35 & 35 & 35 & 35 \\
\hline Density, $\mathrm{g} / \mathrm{cm}^{3}$ & 1.55 & 1.50 & 1.80 & 1.47 & 1.5 & 1.0 & 1.13 & 2.0 & 1.019 & 1.0 & 1.0 & 1.10 \\
\hline Flow, L/h & 170.0 & 211.0 & 21.0 & 184.0 & 6.1 & 84.4 & 182.6 & 10.0 & 167.0 & 5.54 & 85.0 & 95.0 \\
\hline Activity, $C i / L$ & 12.69 & 11.98 & 54.2 & 7.15 & 12.0 & - & 7.21 & 107.0 & 1.46 & -- & -- & 11.24 \\
\hline Heat, W/L & 0.037 & 0.035 & 0.19 & 0.018 & 0.036 & -- & 0.002 & 0.37 & 0.004 & -- & -- & 0.04 \\
\hline
\end{tabular}

\begin{tabular}{|c|c|c|c|c|c|c|c|c|c|c|c|c|c|c|c|c|}
\hline \multirow{2}{*}{$\begin{array}{l}\text { Operation } \\
\text { stream No. }\end{array}$} & \multicolumn{5}{|c|}{ Second Wash Cycle } & \multicolumn{4}{|c|}{ Ihird Wash Cycle } & \multicolumn{7}{|c|}{ Secondary Centr ifuge Operation } \\
\hline & 13 & 14 & 15 & 16 & 17 & 18 & 19 & 20 & 21 & -22 & 23 & 24 & -25 & 26 & $2 T$ & $28-$ \\
\hline Description & $\begin{array}{l}\text { Solids } \\
\text { Re- } \\
\text { Cycle }\end{array}$ & $\begin{array}{c}2 \text { nd } \\
\text { Wash } \\
\text { Cycle } \\
\text { Centrate } \\
\end{array}$ & $\begin{array}{l}\text { 2nd } \\
\text { Wash } \\
\text { cycle } \\
\text { Skim } \\
\end{array}$ & $\begin{array}{l}\text { 2nd } \\
\text { Cycle } \\
\text { Wash } \\
\text { Water } \\
\end{array}$ & $\begin{array}{l}\text { 3rd } \\
\text { Cycle } \\
\text { Solids } \\
\text { Recycle }\end{array}$ & $\begin{array}{c}\text { Solids } \\
\text { Re- } \\
\text { Cycle }\end{array}$ & $\begin{array}{l}\text { 3rd Wash } \\
\text { Cycle } \\
\text { Centrate }\end{array}$ & $\begin{array}{l}\text { 3rd } \\
\text { Cycle } \\
\text { Wash } \\
\text { Skin } \\
\end{array}$ & $\begin{array}{l}\text { 3rd } \\
\text { Cycle } \\
\text { Wash } \\
\text { Water }\end{array}$ & $\begin{array}{l}\text { Sludge- } \\
\text { Slurry } \\
\text { to Spray } \\
\text { Calciner }\end{array}$ & $\begin{array}{l}\text { Feed to } \\
\text { Second- } \\
\text { ary Cen- } \\
\text { trifuge. }\end{array}$ & $\begin{array}{l}\text { from Sec- } \\
\text { ondary } \\
\text { Centri } \\
\text { fuge }\end{array}$ & $\begin{array}{l}\text { Sec and- } \\
\text { ary Cen- } \\
\text { trifuge } \\
\text { Centrate }\end{array}$ & $\begin{array}{l}\text { Second- } \\
\text { ary Cen- } \\
\text { trate } \\
\text { Sk jn }\end{array}$ & $\begin{array}{l}\text { Centri- } \\
\text { fuge Sec- } \\
\text { dary Wash } \\
\text { Water }\end{array}$ & $\begin{array}{l}\text { ary Cen } \\
\text { trifuge } \\
\text { Solids } \\
\text { Recycle } \\
\end{array}$ \\
\hline Flow, $\mathrm{kg} / \mathrm{h}$ & & & & & & & & & & & & & & & & \\
\hline Salt & 402 & 2.28 & -- & -- & 0.402 & 0.06 & 0.342 & -- & -- & -- & 97.27 & 8.47 & 76.26 & 2.54 & -- & 8.47 \\
\hline Solid & 7.06 & 0.22 & -- & -- & 7.06 & 6.91 & 0.150 & + & - & 6.91 & 0.814 & 0.395 & 0.395 & 0.024 & -- & 0.395 \\
\hline $\mathrm{H}_{2} \mathrm{O}$ & 7.54 & 84.26 & 3.2 & 86.8 & 94.36 & 6.91 & 84.62 & 2.83 & 39.1 & 39.1 & 189.8 & 1.84 & 182.47 & 5.53 & 75.9 & 77.74 \\
\hline TOTAL & 15.0 & 86.76 & 3.2 & 86.8 & 101.8 & 13.88 & 85.11 & 2.83 & 39.1 & 46.07 & 277.9 & 10.70 & 259.13 & 8.09 & 75.9 & 86.61 \\
\hline Temp, ${ }^{\circ} \mathrm{c}$ & 35 & 35 & 35 & 35 & 35 & 35 & 35 & 35 & 35 & 35 & 35 & 35 & 35 & 35 & 35 & 35 \\
\hline $\begin{array}{l}\text { Den- } \\
\text { sity, } g / \mathrm{cm}^{3}\end{array}$ & 2.0 & 1.02 & 1.0 & 1.1 & 1.07 & 2.0 & 1.0 & 1.0 & 1.0 & 1.18 & 1.46 & 5.8 & 1.42 & 1.46 & 1.0 & 1.11 \\
\hline Flow, L/h & 7.5 & 84.0 & 3.2 & 86.8 & 94.4 & 6.9 & 84.6 & 182.6 & 2.83 & 39.1 & 190.0 & 1.8 & 182.5 & 5.53 & 75.9 & 77.7 \\
\hline $\begin{array}{l}\text { Activity, } \\
\mathrm{Ci} / \mathrm{L}\end{array}$ & 133.0 & 0.76 & - & - & 10.6 & 141.7 & 0.31 & & -- & 25.01 & 7.08 & 95.7 & 2.47 & 7.1 & -- & 2.27 \\
\hline Heat, W/L & 0.48 & 0.002 & -- & -- & 0.038 & 0.51 & 0.001 & -- & -- & 0.09 & 0.02 & 0.27 & 0.016 & 0.018 & -- & 0.006 \\
\hline
\end{tabular}




\section{A.3.2 GRAVITY SETTLING AND SAND FILTRATION}

\section{A.3.2.1 Purpose}

The purpose of the gravity settling and sand filtration process steps is to remove essentially all of the remaining solids from the centrifuge centrate. Removal of suspended solids is necessary to prevent the passage of radioactive solids through the ion-exchange columns (largely insoluble Sr-90) and prevent the pluggage of the ion-exchange columns with the larger suspended solids.

\section{A.3.2.2 Process Description}

The flowsheet for the gravity settling and sand filtration process is shown in Figure A.3. Centrate from the centrifuge separation process is blended with recycle-evaporator bottoms and sodium carbonate solution from the cesium zeolite-fixation step. These three process streams form the feed material to the gravity settler.

Blended feed is transferred to one of two gravity settlers operated in parallel. An agglomeration agent is added and the resulting solution agitated vigorously then gently. The agglomeration agent serves to coagulate the colloidal particles into heavier, faster settling masses. The mixture is heated to $90^{\circ} \mathrm{C}$ and held at this temperature for 10 to $15 \mathrm{~min}$. Agitation of the solution is then discontinued, the solution allowed to cool, and the agglomerated colloidal particulates allowed to settle. The clarified top layer representing the majority of the feed volume is decanted and transferred to the supernate hold tank. The bottom settled sludge layer is left for resettling with additional feed batches. Several feed batches are received, solids are settled and the supernate decanted before the settled sludge is transferred to the centrifuge sludge-slurry feed tank. The gravity settler removes approximately 98 wt\% of the solids from the feed.

Decanted supernate from the gravity settler is cooled to less than $25^{\circ} \mathrm{C}$, and a polyelectrolyte is added. The supernate is then pumped through two sand anthracite filters and collected in the filtrate hold tank. Solids removal in the first sand filter is 90\%. Additional polyelectrolyte is added to the supernate before the mixture is pumped through the polish sand filter. Solids removal in the polish sand filter is $80 \%$.

Both the sand filter and polish sand filters are back flushed daily to remove suspended solids. Backflush solution is transferred to the centrifuge feed-holding tank. Monthiy the sand filters are fluidized with air and caustic and transferred to the spray calciner feedmakeup tank.

\section{A.3.2.3 Process Flowsheet and Material Balance Bases}

The material balance for gravity settling and sand filtration is sumarized in Table A.2. The bases of the material balance for the gravity settling and sand filtration processes are sumnarized below:

- Recovery of solids in the gravity settler is $98 \mathrm{wt} \%$.

- An 8 wt\% starch solution, which serves as an agglomeration agent, is added to the gravity settler feed. One liter starch solution is added to $8000 \mathrm{~L}$ feed to aid in settling. 


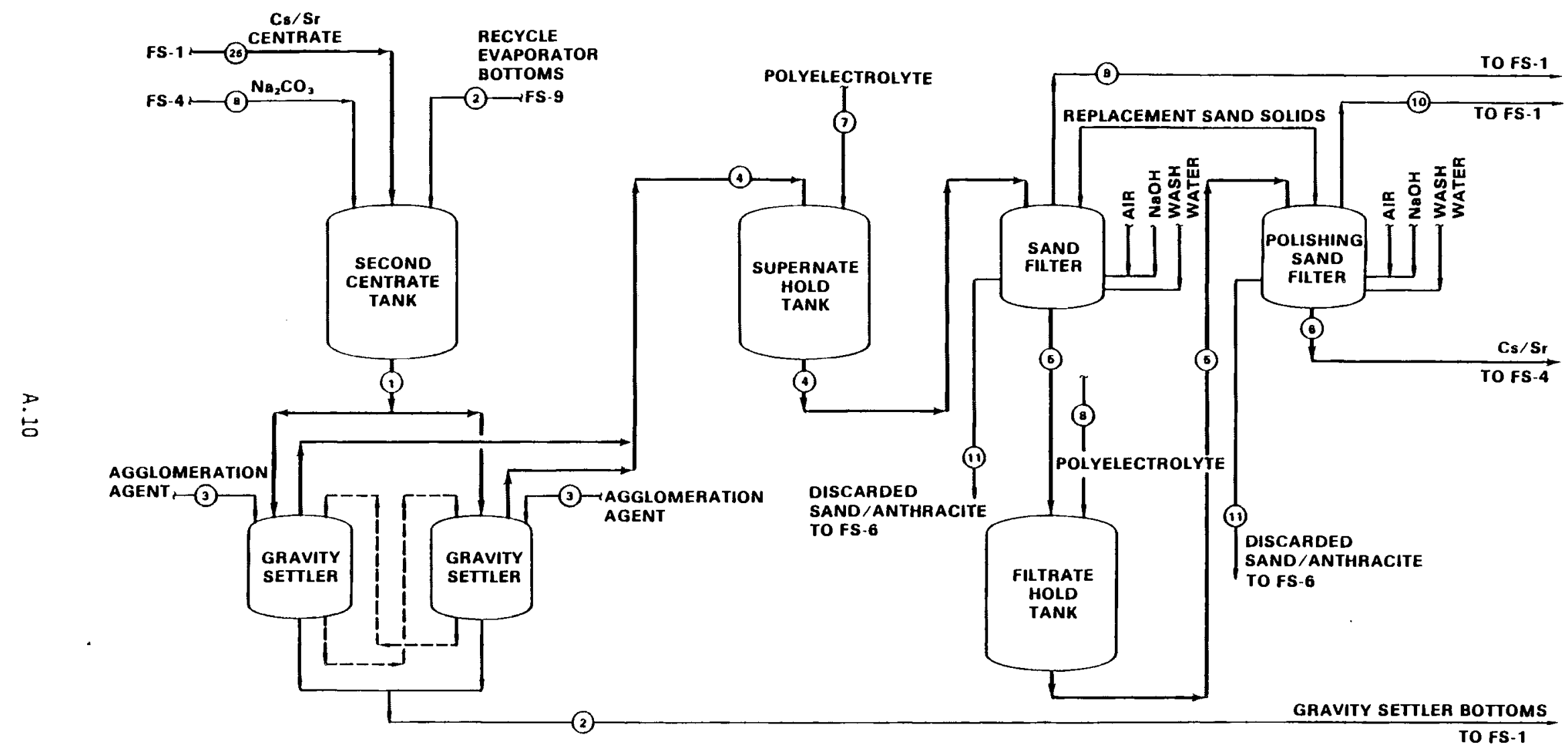

FIGURE A.3. Process Flowsheet (FS-2) Gravity Settling and Sand Filtration 
TABLE A.2. Material Balance for Gravity Settling and Sand Filtration

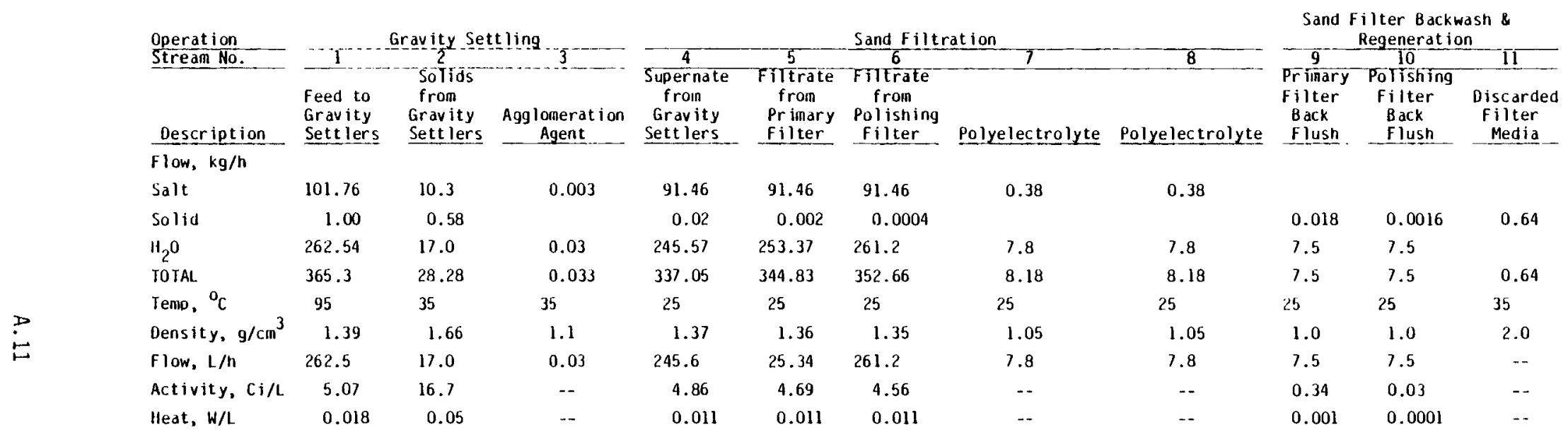


- Recovery of solids in the primary sand filter is $90 \mathrm{wt} \%$, and recovery of solids in the polish sand filter is 80 wt\%.

- Both the primary sand filter and the polish sand filter are backflushed with $180 \mathrm{~L}$ of process water daily to remove suspended solids.

- Spent sand-anthracite filters are fluidized with air and caustic and transferred to the spray calciner feed monthly.

- Polyelectrolyte solutions are added to the sand filter, feed solutions to aid in filtration.

\section{A.3.2.4 Status of Technology}

Large-scale gravity-settling studies have been performed at the TNX Facility, SRL (Landon 1980). In these studies, both high and intermediate alkaline concentration flowsheets were tested. The supernates tested were in the nominal compositional range expected for the WNYNSC flowsheet. Results of these large-scale tests (6000 L gravity settler) have showed less than $25 \mathrm{ppm}$ sludge remains with the decanted supernate at $35-45^{\circ} \mathrm{C}$. Settling rates of 50 to $65 \mathrm{~cm} / \mathrm{h}$ (20 to $25 \mathrm{in.} / \mathrm{h}$ ) were demonstrated. The tests have also shown that recycling the sludge several times in the gravity settler improves performance. The increased sludge loading produces a scavenging effect on the small particulate that is most difficult to settle.

Sand-filter studies have been performed in a radioactive environment with actual clarified supernate at the SRL (Stone 1976). In these tests centrate feeds containing 500 to $2000 \mathrm{ppm}$ of suspended matter were clarified to less than $100 \mathrm{ppm}$ of suspended matter.

Bench-scale and large-scale experiments have also been performed in nonradioactive environments. The bench-scale tests produced a filtrate containing less than $1 \mathrm{ppm}$ of suspended matter using synthetic supernates. The large-scale tests, conducted in a $44 \mathrm{~cm}\left(17.25-\mathrm{in}_{\text {. }}\right)$ in dia column also produced a supernate containing less than 1 ppm when two filters were operated in series.

\section{A.3.3 CESIUM ION EXCHANGE}

\section{A.3.3.1 Purpose}

The purpose of the cesium ion-exchange process is to remove essentially all of the cesium, plutonium, and other actinides from the clarified supernate by ion-exchange using a Duolite ARC-359 resin.

\section{A.3.3.2 Process Description}

The flowsheet for the cesium ion-exchange process is shown in Figure A.4. Filtrate from the polish sand filter is pumped downflow through two ion-exchange columns in series containing Duolite ${ }^{\circledR}$ ARC-359 ion exchanger resin. Cesium, plutonium and other actinides are removed from the filtrate by ion-exchange processes. The column effluent is transferred to the strontium ion-exchange feed tank. The loading step is followed by a water-rinse downflow.

Cesium and plutonium on the ion-exchange column are eluted countercurrently to the loading step using a $2 \mathrm{M} \mathrm{NH}_{4} \mathrm{OH}-2 \mathrm{M}\left(\mathrm{NH}_{4}\right)_{2} \mathrm{CO}_{3}$ solution followed by a water rinse. Eluate and water-rinse 


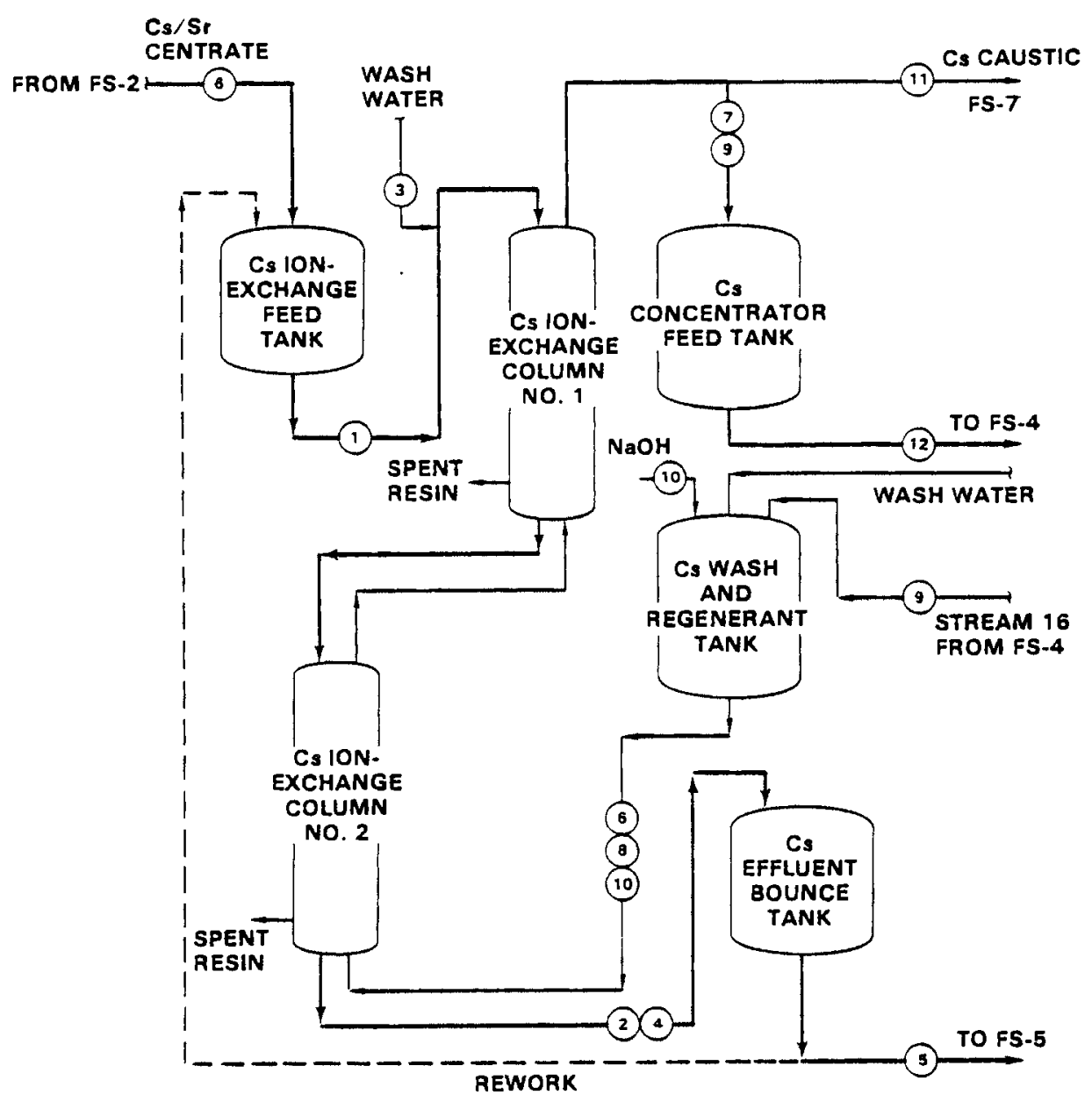

FIGURE A.4. Process Flowsheet (FS-3) Cesium Ion Exchange

effiuents pass on to elutriant recovery and cesium-concentration processes. The ion-exchange columns are then regenerated upflow using $2 \mathrm{M} \mathrm{NaOH}$. Excess caustic is transferred to the recycle-evaporator feed tank.

Duolite ${ }^{\circledR}$ ARC-359 resin is a strong-acid cation exchanger selective to cesium at high $\mathrm{pH}$. Decontamination factors of $10^{5}$ for cesium in actual clarified waste supernate, and 300 for plutonium have been demonstrated (Wiley and wallace 1975). A nominal decontamination factor of $10^{4}$ for cesium and 300 for plutonium is assumed for material balance purposes.

I On-exchange equipment will consist of two columns in series. A GE(Li) garma detector placed between the columns will continuously monitor Cs-137 in the first column effluent. The second column effiuent can also be monitored; however, background radiation may cause too much noise. The effluent will be sampled and analyzed before transfer to the strontium ion-exchange process. Off-specification effluent will be reworked.

Variations in the activity level and chemical characteristics of the column feed will exist. To compensate for these variations, the feed volume and cycle length can be adjusted to maintain the overall desired decontamination factors. 


\section{A.3.3.3 Process Flowsheet and Material Balance Bases}

The bases used for development of the flowsheet and material balance for cesium ion exchange are sumarized below. The material balance is sumarized in Table A.3. The system consists of two ion-exchange columns in series packed with Duolite ARC-359 resin. Materiai balance bases are:

- the assumed resin stoichiometry is:

$$
\begin{array}{ll}
\text { Column loading: } & \mathrm{RNa}^{+}+\mathrm{Cs}^{+} \text {(aq.) }=\mathrm{RCs}+\mathrm{Na}^{+} \text {(aq.) } \\
\text { Elution: } & \mathrm{RCs}+\mathrm{NH}_{4}^{+}(\text {aq. })=\mathrm{RNH}_{4}+\mathrm{Cs}^{+} \text {(aq.) } \\
& \left.\mathrm{RNa}^{+} \mathrm{NH}_{4}^{+} \text {(aq. }\right)=\mathrm{RNH}_{4}+\mathrm{Na}^{+} \text {(aq.) } \\
\text { Regeneration: } & \left.\left.\left.\mathrm{RNH}_{4}+\mathrm{Na}^{+} \text {(aq. }\right)+\mathrm{OH}^{-} \text {(aq. }\right)=\mathrm{RNa}+\mathrm{NH}_{3} \text { (aq. }\right)+\mathrm{H}_{2} \mathrm{O}
\end{array}
$$

- Decontamination factors for cesium and plutonium are assumed $10^{4}$ and 300 , respectiveiy.

\begin{tabular}{|c|c|c|c|c|}
\hline Stream & $\begin{array}{c}\text { Time, } \\
h \\
\end{array}$ & $\begin{array}{c}\text { Column volumes, } \\
\text { vol/h }\end{array}$ & Direction & Stream \\
\hline Load & 20 & 1.4 & down & supernate \\
\hline 1st rinse & 3 & 1 & down & water \\
\hline Elution & 10 & 1 & up & $2 \mathrm{M} \mathrm{NH}_{4} \mathrm{OH} 2 \mathrm{M}\left(\mathrm{NH}_{4}\right) \mathrm{CO}_{3}$ \\
\hline 2nd rinse & 3 & 1 & up & water \\
\hline Regeneration & 5 & 1 & up & $2 \underline{\mathrm{M}} \mathrm{NaOH}$ \\
\hline Standby & $\frac{3}{44}$ & 1 & & \\
\hline
\end{tabular}

- Resin is replaced annually.

- Material balance rates are shown as total batch flows.

- The flowsheet was based on the following cycle times:

\section{A.3.3.4 Status of Technology}

Duolite ${ }^{(2)}$ ARC-359 resin has been used extensively at Hanford's B-Plant to remove approximately 95\% radiocesium from Purex and redox supernates (Larson 1972). Two processing campaigns were conducted: one in 1972 in which $1.4 \mathrm{M}$ gal of supernate was processed, and one in 1974 in which $1.7 \mathrm{M} \mathrm{gal}$ of supernate were processed.

Removal of Cs-137 from simulated and actual SRP supernates has been demonstrated in laboratory tests using Duolite ${ }^{\circledR}$ ARC-359 (Wiley 1976, Wiley and Wallace 1975). Results from these tests averaged $4 \times 10^{5}$ for Cs-137 and 300 for plutonium. Decontamination factors for cesium of $10^{4}$ were also demonstrated in supernates with sodium concentrations of $4.0 \underline{M}$ and 9 M. 
TABLE A.3. Material Balance for Cesium Ion Exchange

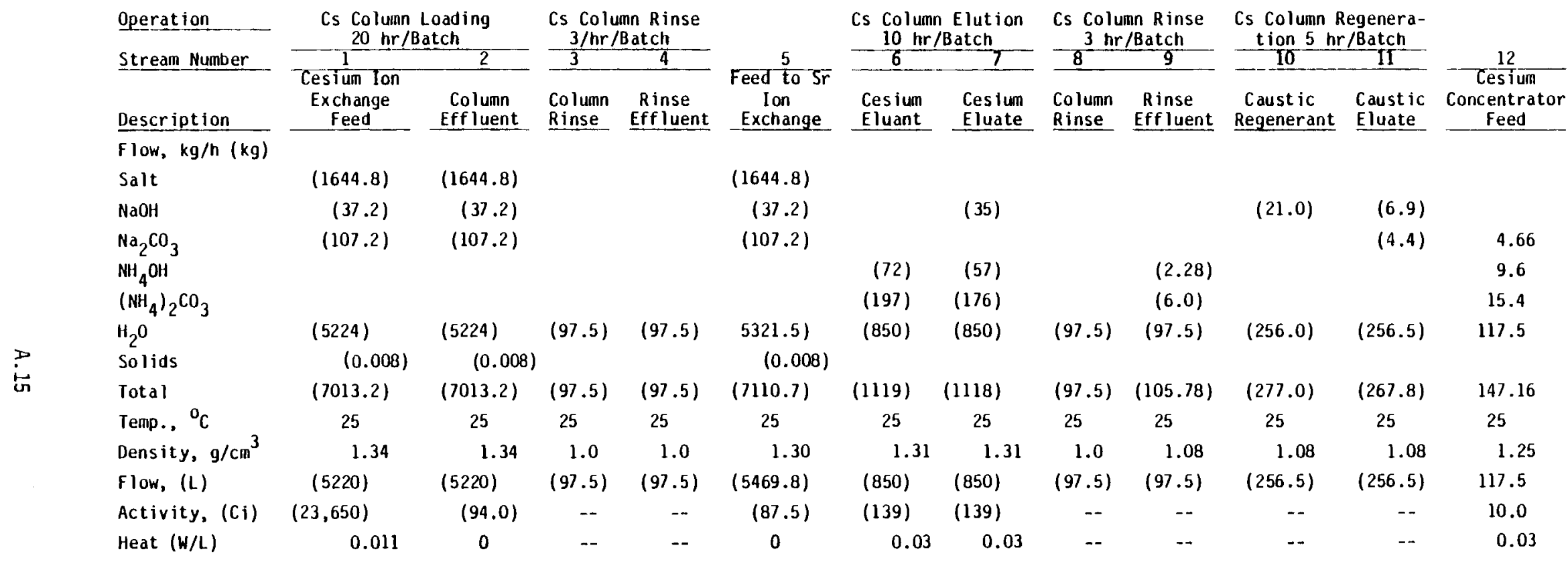




\section{A.3.4 CESIUM ELUTRIANT RECOVERY AND CESIUM ZEOLITE FIXATION}

\section{A.3.4.1 Purpose}

The purpose of the cesium eluate-concentration process is to concentrate the cesium elutriant and to strip and recover ammonia and carbon dioxide from the elutriant. Cesium is recovered from the sodium-rich concentrate by passage and absorption on a zeolite bed. This step reduces the quantity of sodium in the alkaline feed blend, thereby reducing the quantity of glass produced.

\section{A.3.4.2 Process Description}

Shown in Figure A.5 is the process flowsheet for the cesium-elutriant recovery, cesium concentration and cesium zeolite-fixation process. Cesium ion-exchange elutriant is fed to a concentrator/steam stripper. Ammonia and carbon dioxide are stripped from the elutriant in the concentrator tower. Carbon dioxide and ammonia are condensed with water as the overhead products are collected in an eluate makeup tank. Regeneration and additional preparation of the eluant solution is accomplished by adding ammonium hydroxide solution and bubbling in carbon dioxide gas through the solution. A water-scrub tower located over the eluant makeup tank removes volatile gases and returns them to the tank. Makeup water is added to the scrubber.

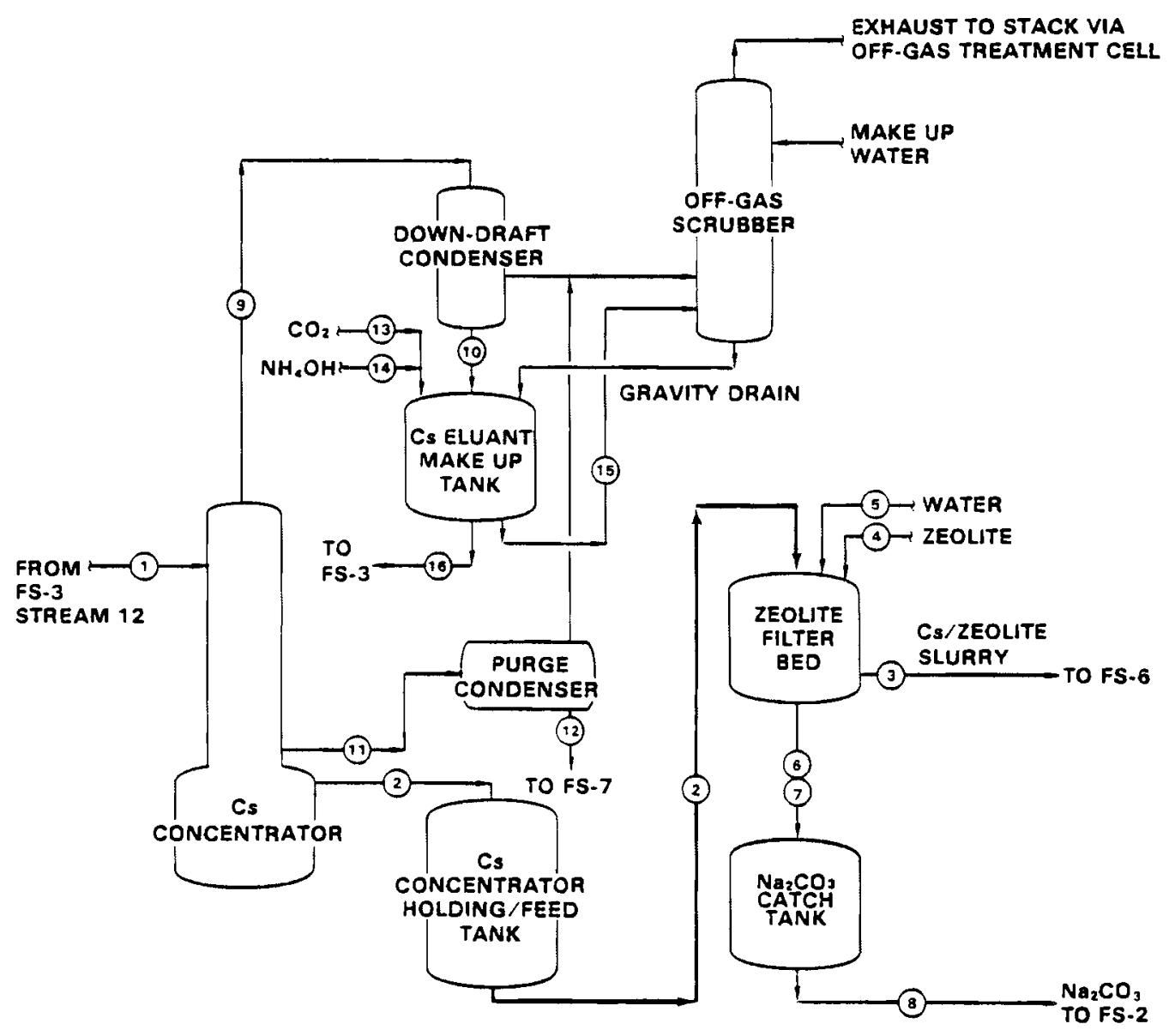

FIGURE A.5. Flowsheet (FS-4) Cesium Elutriant Recovery and Cesium Fixation on Zeolite 
Water added during rinsing of the ion-exchange columns is removed through a side stream in the steam stripper. The steam removed in the sidestream is condensed in the purge condenser and transferred to the recycle evaporator.

Cesium concentrator bottoms consist of a cesium enriched sodium carbonate solution. Direct addition of this high-sodium concentration solution to the spray calciner feed would increase the quantity of glass required to be produced. To alleviate this circumstance the concentrate solution is passed through a fixed zeolite bed that selectively absorbs the cesium from the sodium carbonate solution. After loading, the zeolite bed is rinsed with water to remove entrained sodium carbonate. The loaded zeolite bed is then fluidized with water and transferred to the spray calciner feed tank.

\section{A.3.4.3 Process Flowsheet and Material Balance Bases}

The material balance is presented in Table A.4. The bases used to develop the flowsheet and material balance for cesium elutriant recovery, cesium concentration and cesium zeolite fixation are summarized below:

- Cesium elutriant is concentrated to 2.5M $\mathrm{Na}_{2} \mathrm{CO}_{3}+\mathrm{Cs}_{2} \mathrm{CO}_{3}$ solution.

- $\mathrm{NH}_{4} \mathrm{OH}$ and $\left(\mathrm{NH}_{4}\right)_{2} \mathrm{CO}_{3}$ are decomposed and the $\mathrm{NaOH} / \mathrm{CsOH}$ in the eluate is converted to $\mathrm{Na}_{2} \mathrm{CO}_{3} / \mathrm{Cs}_{2} \mathrm{CO}_{3}$ in the steam stripper. The material balance assumes the following reactions;

$$
\begin{gathered}
\mathrm{NH}_{4} \mathrm{OH}(\mathrm{aq}) \rightarrow \mathrm{H}_{2} \mathrm{O}(\mathrm{L})+\mathrm{NH}_{3}(\mathrm{~g}) \\
\left(\mathrm{NH}_{4}\right)_{2} \mathrm{CO}_{3}(\mathrm{aq}) \rightarrow \mathrm{H}_{2} \mathrm{O}(\mathrm{L})+2 \mathrm{NH}_{3}(\mathrm{~g})+\mathrm{CO}_{2}(\mathrm{~g}) .
\end{gathered}
$$

- The scrubber bottoms contain $2 \mathrm{M}\left(\mathrm{NH}_{4}\right)_{2} \mathrm{CO}_{3}$.

- Essentially all (99.5\%) of the $\mathrm{NH}_{3}$ in the feed to the cesium concentrator is recovered.

- Steam stripper is assumed to operate at $100 \%$ efficiency.

- The zeolite bed is discharged weekly to the spray calciner feed tank.

- The cesium, decontamination factor in the zeolite bed is 100. Cesium not recovered is transferred with the sodium carbonate solution to the gravity-settler feed tank.

- Loaded zeolite beds are removed with a water slurry with a total volume six times the bed volume.

- The zeolite is loaded downflow only once.

\section{A.3.4.4 Status of Technology}

Experiments with the elutriant recovery/eluate-concentration system have been performed at Hanford (Richardson 1969). Two operating problems appeared: 1) foaming in the concentrator, and 2) $\left(\mathrm{NH}_{4}\right)_{2} \mathrm{CO}_{3}$ pluggage in the condenser. These problems were found to be eliminated through control of equipment operation and equipment design. 
TABLE A.4. Material Balance for Cesium Eluate Concentration and Cesium Zeolite Fixation

\begin{tabular}{|c|c|c|c|c|c|c|c|c|}
\hline$\frac{\text { Operation }}{\text { Stream No. }}$ & \multicolumn{3}{|c|}{$\begin{array}{c}\text { Cesium Concentration and } \\
\text { Zeolite Fixation }\end{array}$} & \multicolumn{5}{|c|}{ Zeolite Bed Renewal and Washing } \\
\hline $\begin{array}{l}\text { Stream No. } \\
\text { Description }\end{array}$ & $\begin{array}{c}\frac{1}{\text { Cesium }} \\
\text { Concentrator } \\
\text { Feed } \\
\end{array}$ & $\begin{array}{c}\text { Cesium } \\
\text { Concentrator } \\
\text { Bottom } \\
\end{array}$ & $\frac{3}{\begin{array}{c}\text { Cs/Zeolite } \\
\text { Slurry }\end{array}}$ & $\begin{array}{c}4 \\
\text { Fresh } \\
\text { Zeolite } \\
\end{array}$ & $\begin{array}{l}5 \\
\text { Zeolite } \\
\text { Flush } \\
\end{array}$ & $\begin{array}{c}6 \\
\begin{array}{c}\text { Zeolite } \\
\text { Bed } \\
\text { Rinse }\end{array} \\
\end{array}$ & $\begin{array}{l}7 \\
\mathrm{Na}_{2} \mathrm{CO}_{3} \\
\text { Eluate }\end{array}$ & $\begin{array}{c}8 \\
\text { Recycle } \\
\text { Na2 } \mathrm{CO}_{3} \\
\text { Solution } \\
\end{array}$ \\
\hline Flow, $\mathrm{kg} / \mathrm{hr}$ & & & & & & & & \\
\hline Salt & & & & & & & & \\
\hline $\mathrm{NaOH}$ & & & & & & & & \\
\hline $\mathrm{Na}_{2} \mathrm{CO}_{3}$ & 4.66 & 4.66 & & & & 2.33 & 2.33 & 4.66 \\
\hline $\mathrm{NH}_{4} \mathrm{OH}$ & 9.6 & -- & & & & & & \\
\hline$\left(\mathrm{NH}_{4}\right)_{2} \mathrm{CO}_{3}$ & 15.4 & -- & & & & & & \\
\hline $\mathrm{H}_{2} \mathrm{O}^{4}$ & 117.5 & 11.7 & 2.52 & 1.64 & 8.97 & 6.77 & 13.9 & 20.67 \\
\hline Zeolite & & & 0.33 & 0.33 & & & & \\
\hline $\mathrm{CO}_{2}$ & & & & & & & & \\
\hline Tota 1 & 147.16 & 16.36 & 2.85 & 1.97 & 8.97 & 9.10 & 16.23 & 25.33 \\
\hline Temp., ${ }^{\circ} \mathrm{C}$ & 25 & $102 / 25$ & 25 & 25 & 25 & 25 & 25 & 25 \\
\hline Density, $\mathrm{g} / \mathrm{cm}^{3}$ & 1.25 & 1.39 & 1.13 & 1.20 & 1.0 & 1.34 & 1.17 & 1.23 \\
\hline Flow, L/h & 117.5 & 11.7 & 2.52 & 1.64 & 8.97 & 6.77 & 13.9 & 20.6 \\
\hline Activity, $\mathrm{Ci} / \mathrm{L}$ & 10.0 & 100 & 465 & -- & - & -- & -- & $-\infty$ \\
\hline Heat, $W / L$ & 0.03 & 0.30 & 1.4 & -- & -- & -- & -- & -- \\
\hline
\end{tabular}

\begin{tabular}{|c|c|c|c|c|c|c|c|}
\hline Operation & & sium Eluate & Concentration & and Cesium & eolite & Fixation & \\
\hline Strean No. & 9 & 10 & 11 & 12 & 13 & 14 & 15 \\
\hline Description & $\begin{array}{l}\text { Cesium } \\
\text { Concentrator } \\
\text { Overheads } \\
\end{array}$ & $\begin{array}{l}\text { Overheads } \\
\text { Condensate }\end{array}$ & $\begin{array}{c}\text { Concentrator } \\
\text { Purge } \\
\end{array}$ & $\begin{array}{c}\text { Purge } \\
\text { Condensate }\end{array}$ & $\begin{array}{l}\text { Makeup } \\
\text { Gas } \\
\end{array}$ & $\begin{array}{l}\mathrm{NH}_{4} \mathrm{OH} \\
\text { Makeup }\end{array}$ & $\begin{array}{l}\text { Scrub } \\
\text { Water }\end{array}$ \\
\hline $\mathrm{Flow}, \mathrm{kg} / \mathrm{hr}$ & & & & & & & \\
\hline Salt & & & & & & & \\
\hline $\mathrm{NaOH}$ & & & & & & & \\
\hline $\mathrm{Na}_{2} \mathrm{CO}_{3}$ & & & & & & & \\
\hline $\mathrm{NH}_{4} \mathrm{OH}$ & 9.6 & 9.6 & & & & $2.6 \times 10^{-3}$ & \\
\hline$\left(\mathrm{NH}_{4}\right)_{2} \mathrm{CO}_{3}$ & 15.4 & 15.4 & & & & & \\
\hline $\begin{array}{l}\mathrm{H}_{2} \mathrm{O} \\
\text { Zeolite }\end{array}$ & 76.94 & 76.94 & 28.86 & 28.86 & & $1.8 \times 10^{-2}$ & 11.8 \\
\hline $\mathrm{CO}_{2}$ & & & & & 1.0 & & \\
\hline Total & 101.94 & 101.94 & 28.86 & 28.86 & 1.0 & 0.021 & 11.8 \\
\hline Temp., ${ }^{\circ} \mathrm{C}$ & 100 & 35 & 100 & 35 & 35 & 25 & 35 \\
\hline Density, $\mathrm{g} / \mathrm{cm}$ & -- & 1.32 & 1.0 & 1.0 & -- & 1.14 & 1.0 \\
\hline Flow, L/h & - & 77 & -- & 28.86 & -- & 0.018 & 11.8 \\
\hline Activity, Ci & - & -- & -- & - & -- & -- & - \\
\hline Heat, $W / L$ & -- & -- & -- & -- & -- & - & -- \\
\hline
\end{tabular}


Steam stripping the cesium elutriant in the packed concentrator tower effectively prevented foaming in the evaporator. This stripping operation removed $99 \%$ of the $\mathrm{NH}_{3}$ and $\mathrm{CO}_{2}$ from the liquid entering the evaporator, thereby preventing foaming. Down-draft condensation prevented pluggage in the condenser. Recoveries of $98 \%$ for ammonia and carbon dioxide were demonstrated in the condenser.

Cesium and sodium were first loaded on zeolite in fission-product separation processes at Hanford (Buckingham 1967; Carlstrom 1977). After loading, the cesium and sodium were eluted using a $\left(\mathrm{NH}_{4}\right)_{2} \mathrm{CO}_{3}-\mathrm{NH}_{4} \mathrm{OH}$ solution. This technique was used to reduce the $\mathrm{Na} / \mathrm{Cs}$ ratio before ion exchange to improve ion-exchange efficiencies.

Studies at SRL (Wiley 1976, Wiley and Wallace 1975) were also conducted using both tracerlevel synthetic cesium solutions and adjusted composition plant wastes. In these tests the feasibility of fixing cesium on zeolite was demonstrated adequately. Approximately 70 column volumes of concentrated column eluate is loaded on one column volume of zeolite before breakthrough. After the initial water wash, the cesium was not found to leach appreciably from the zeolite.

\section{A.3.5 STRONTIUM ION EXCHANGE}

\section{A.3.5.1 Purpose}

The purpose of strontium ion-exchange process is to remove strontium and actinide activity from the clarified supernate by a Chelex-100 ion exchanger. An additional ion-exchange column has also been added to remove any residual actinide activity that may be present in the clarified supernate.

\section{A.3.5.2 Process Description}

The flowsheet for the strontium ion-exchange process is shown in Figure A.6. Clarified supernate from the cesium ion-exchange process is pumped downflow through two ion exchange columns in series to remove strontium activity and residual actinide activity. The first column uses a Chelex-100 cation exchanger. Decontamination factors of $10^{3}$ have been reported for strontium removal in high pH supernates passed through this resin (Wiley 1976).

The second column is a cleanup column designed to remove any residual actinide activity from the waste supernate. This column has a nominal decontamination factor of 10 for actinide removal. At the time of this writing, the specific resin to be used in this column has not been identified.

Effluent from the strontium and actinide ion-exchange process is sampled and then transferred to the decontamination supernate-solidification process. Off-specification supernate that contains higher than desired fission-product and actinide-activity levels is recycled to the strontium ion-exchange feed tank.

The columns are backflushed upflow with water after loading. Strontium and other absorbed elements are eluted from the column, upflow using $1 \mathrm{MNNO}_{3}$. After elution, the column is regenerated using $2 \mathrm{M} \mathrm{NaOH}$. The first, column, water rinse and strontium elutriant solutions are transferred to the spray calciner feed tank. Excess caustic from the column regeneration is transferred to the recycle-evaporator feed tank. 


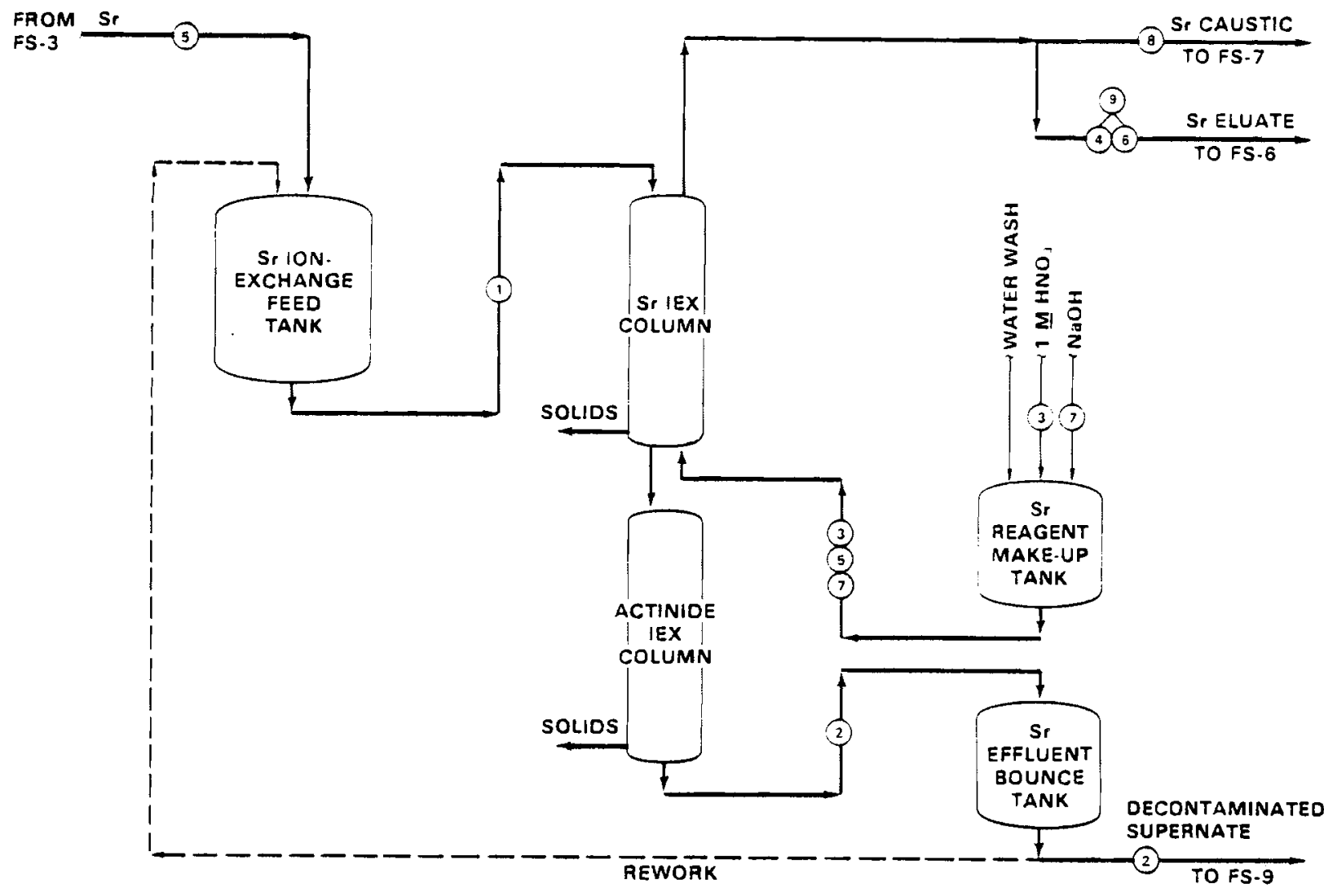

FIGURE A.6. Process Flowsheet (FS-5) Strontium Ion Exchange

The actinide ion-exchange column is envisioned to be an inorganic ion exchanger resistant to degradation in high $\mathrm{pH}$ solutions. This ion exchanger would not be regenerated but would be disposed of in the spray calciner feed or considered transuranic waste and disposed of appropriately.

\section{A.3.5.3 Process Flowsheet and Material Balance Bases}

The bases for the process flowsheet and material balance for strontium ion exchange are presented below. The material balance is summarized in Table A.5. The ion-exchange system consists of an exchanger packed with Chelex-100 resin having $50 \%$ voidage and no column freeboard and an exchanger packed with an unidentified ion-exchange resin. Material balance bases are:

- The decontamination factor for strontium is $10^{3}$.

- A nominal decontamination factor of 10 for actinide is assumed across both the Chelex-100 column and the backup ion exchanger.

- The assumed resin stoichiometry is:
- loading
$2 \mathrm{RNa}+\mathrm{Sr}^{+2}=\mathrm{R}_{2} \mathrm{SR}+2 \mathrm{NA}^{+}$
- elution
$\mathrm{R}_{2} \mathrm{Sr}+2 \mathrm{H}^{+}=2 \mathrm{RH}^{2}+\mathrm{Sr}^{+2}$, and
- regeneration $\mathrm{RH}+\mathrm{Na}^{+}+\mathrm{OH}^{-}=\mathrm{RNa}+\mathrm{H}_{2} \mathrm{O}$.

- The loading step is downflow through the resin bed; other steps are upflow. 
TABLE A.5. Material Balance for Strontium Ion Exchange

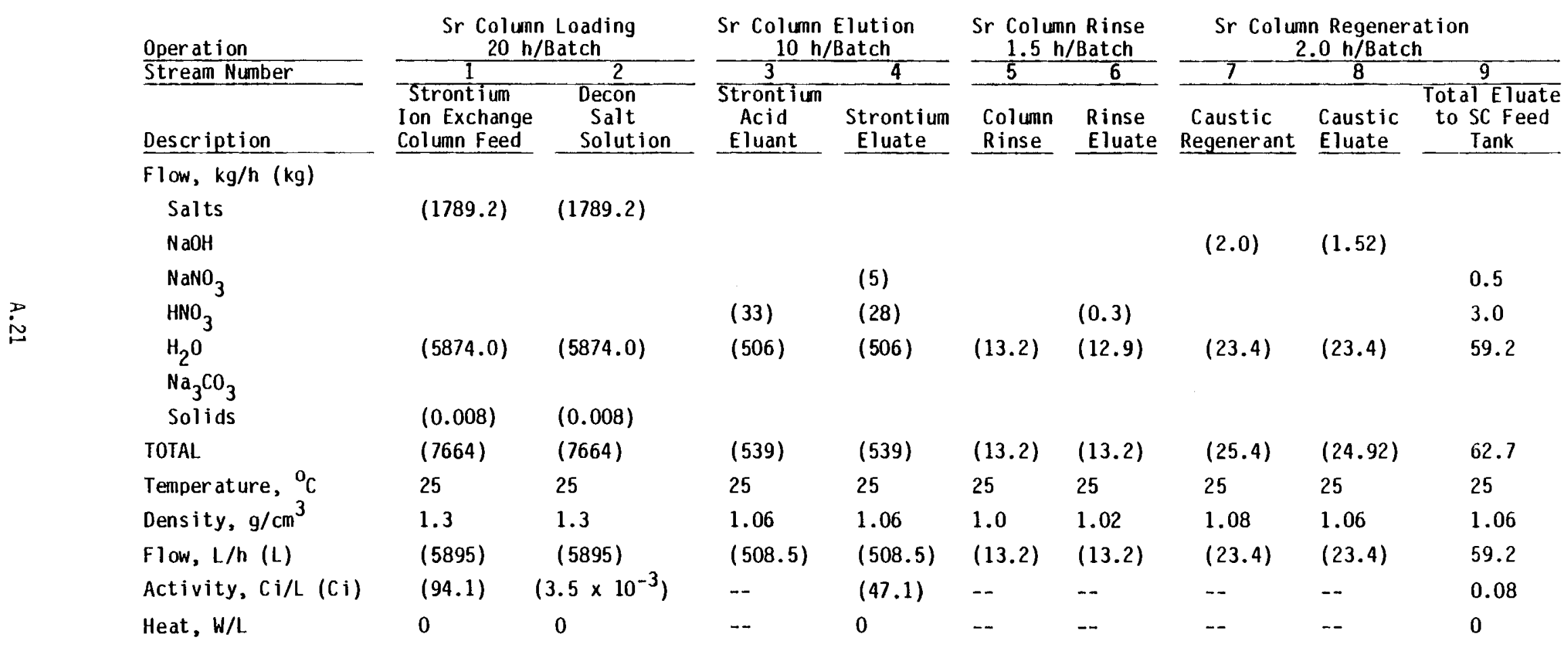


- Material balance rates are expressed as batch flows.

- The cycle steps are:

\begin{tabular}{|c|c|c|c|}
\hline Stream & $\begin{array}{c}\text { Time, } \\
\mathrm{h}\end{array}$ & $\begin{array}{c}\text { Column, } \\
\mathrm{Cv} / \mathrm{h}\end{array}$ & Stream \\
\hline Load & 20 & 2 & \\
\hline Elute & 10 & 1 & $1 \underline{M} \mathrm{HNO}_{3}$ \\
\hline Water Wash & 1.5 & 1 & \\
\hline Regeneration & 2 & 1 & $2 \underline{\mathrm{M}} \mathrm{NaOH}$ \\
\hline Standby & $\frac{6.5}{40}$ & & \\
\hline
\end{tabular}

\section{A.3.5.4 Status of Technology}

A limited amount of experience has been gained using Chelex-100 ion-exchange res in for strontium removal in high-caustic supernates. These tests have been limited to laboratoryscale scoping studies. Decontamination factors for strontium of $10^{3}$ have been demonstrated (Wiley 1976). Removal of plutonium and other actinides from the supernates will occur to some extent. However, no studies directed towards quantifying these decontamination factors have been performed.

The Chelex-100 resin is a small, beaded resin that packs closely. Feed flow through the column is characterized by a high-pressure drop. Smaller columns, such as those proposed for the WNYNSC flowsheet, should be easily operable.

\section{A.3.6 CALCINATION, VITRIFICATION, AND CANISTER HANOLING}

\section{A.3.6.1 Purpose}

The purpose of the calcination/vitrification process is to convert the alkaline highlevel-waste slurry resulting from waste processing into a borosilicate glass matrix. The glass product is produced and contained in a $0.6 \mathrm{~m}(2 \mathrm{ft})$ in diameter by $3.0 \mathrm{~m}(10 \mathrm{ft})$ - high stainless steel canister. Once filled the high-level-waste canister is cooled, sealed by welding on a lid, and the weld is leak checked, then the canister is visually inspected, decontaminated, removed from the process cell, and placed in an interim storage facility.

\section{A.3.6.2 Process Description}

A simplified process flowsheet for the calcination/vitrification process is shown in Figure A.7. The blended alkaline feed stream to be solidified is comprised of several waste treatment process streams. This blended feed mixture is comprised of sand filter solids, washed sludge slurry, zeolite loaded with cesium, acidic strontium eluate, and other solids from spent off-gas sorber beds comprised of silica gel and silver mordenite.

The blended feed mixture is transferred to one of two spray calciner feed tanks and sampled. The sample analyses provide information needed to select the optimum glass-former chemical mixture.

Alkaline high-level-waste blend is pumped to the spray calciner using a submerged cantilever pump. The liquid waste is atomized with air in a commercially available spray nozzle 


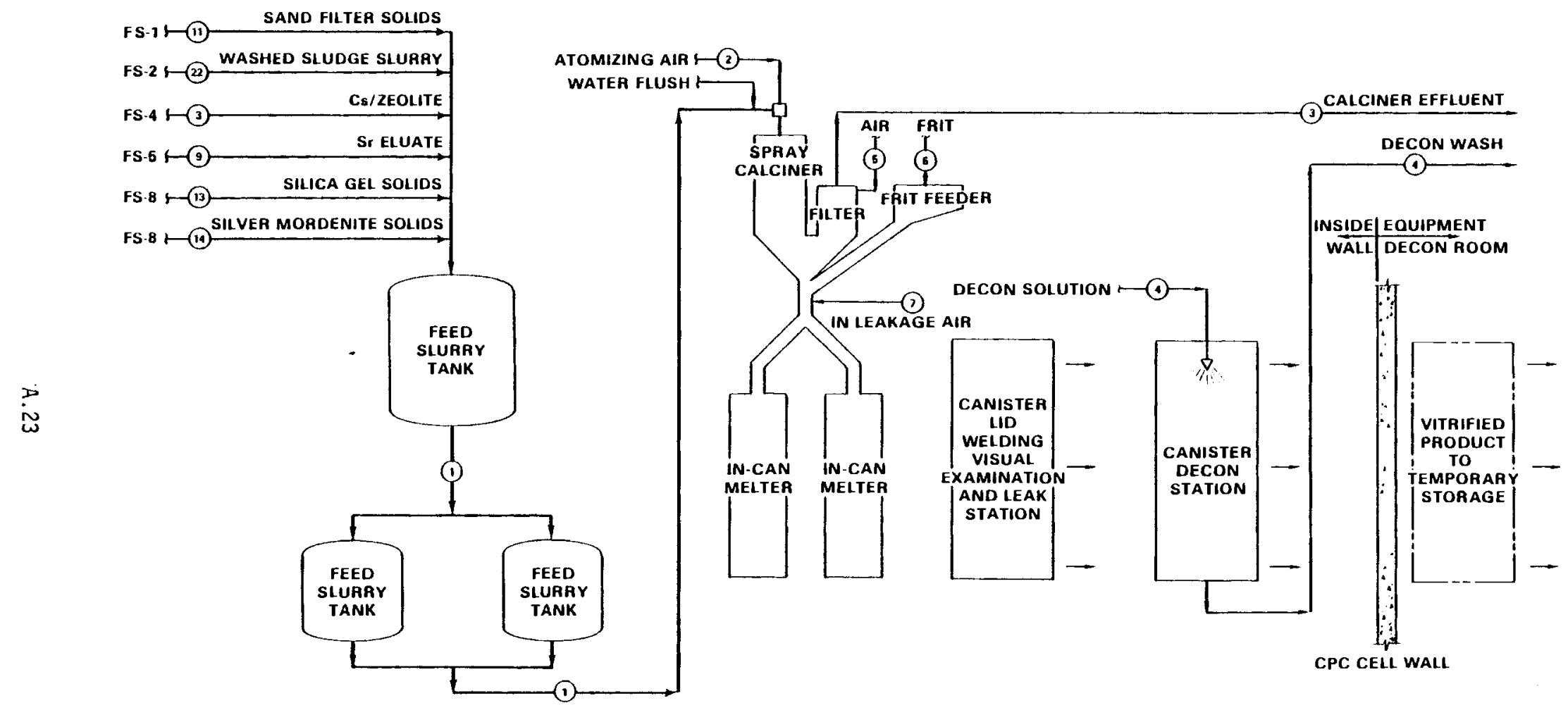

FIGURE A.7. Process Flowsheet (FS-6) for the Calcination/Vitrification Process 
into small droplets $(\sim 70 \mu \mathrm{m})$ that dry and are decomposed to metallic oxides, called calcine, as they fall through the heated wall spray calciner chamber. The temperature of the spraychamber furnace varies from $700^{\circ} \mathrm{C}$ to $900^{\circ} \mathrm{C}$ dependent upon waste characteristics. The calcine powder formed is mixed with the appropriate glass-former chemical mixture as it falls from the spray calciner into one of two canisters located inside the in-can melting furnaces. The calcine/glass former mixture is melted within the heated canisters at a temperature of approximately $1050^{\circ} \mathrm{C}$ to form a glass monolith. Once a canister is filled, the calcine/glass-former chemical mixture is diverted to the adjacent canister and the canister filling process continued.

The filled glass canisters undergo a fining process during which the melting of the calcine and glass-former mixture is completed at a temperature of approximately $1050^{\circ} \mathrm{C}$. A canister cooldown period is started at the completion of the fining period. The canister is decoupled from the calciner/in-can melter connecting section. The connecting section is pivoted aside. The canister is cooled to a temperature of approximately $700^{\circ} \mathrm{C}$. The tensile strength of the canister is sufficiently high at a temperature of $700^{\circ} \mathrm{C}$ so that removal of the canister from the in-can melting furnace is possible.

The hot canister is then transferred to a canister lid weld station and allowed to cool for at least a day. A twist lock lid, which has helium attached underneath, is placed on the canister and tightened. A remote arc-welding apparatus is placed on the twist lock lid and a weld, which seals the lid/canister interface, is completed. The canister lid is then heated, and helium sorbed on the sponge allowed to escape. A bell jar is placed on the top of the canister, and the seal weld is checked for helium leaks. A leaking weld is repaired by repeating the seal-weld process.

Sealed canisters are decontaminated using a steam spray. This spray removes canister spall and smearable contamination. The decontaminated canister is then placed upon a canistertransfer cart, which holds six canisters, and transferred from the CPC to the EDR. Here the canister is further decontaminated before transfer to an interim high-level-waste storage facility.

\section{A.3.6.3 Process Flowsheet and Material Balance Bases}

The bases that define the process flowsheet and material balance are summarized below. The material balance is sumarized in Table A.6.

The bases are:

- The atomizing air-flow rate is $0.48 \mathrm{~kg}$ of air per liter of feed.

- Filter-blowback air is estimated to be at a mass flow of $0.60 \mathrm{~kg} / \mathrm{h}$.

- All metallic nitrates and hydroxides are assumed to be converted to an oxide during calcination/vitrification operations.

- Operation of the calciner is continuous.

- The weight of stean used to decontaminate the canister is $20 \mathrm{~kg}$. 
TABLE A.6. Material Balance for Spray Calcination and Vitrification of Alkaline Waste Slurry

\begin{tabular}{|c|c|c|c|c|c|c|c|}
\hline \multirow{2}{*}{$\begin{array}{l}\text { Operation } \\
\text { Stream Number }\end{array}$} & \multicolumn{7}{|c|}{ Calcination/Vitrification } \\
\hline & 1 & 2 & 3 & 4 & 5 & 6 & 7 \\
\hline Description & $\begin{array}{l}\text { Calciner } \\
\text { Feed Slurry }\end{array}$ & $\begin{array}{l}\text { Atomizing } \\
\text { Air }\end{array}$ & $\begin{array}{l}\text { Calciner } \\
\text { Effluent }\end{array}$ & $\begin{array}{c}\text { Decont amination } \\
\text { Wash }\end{array}$ & $\begin{array}{l}\text { Filter Blow } \\
\text { Back Air }\end{array}$ & $\begin{array}{c}\text { Glass } \\
\text { Forming Frit }\end{array}$ & $\begin{array}{l}\text { In Leakage } \\
\text { Air }\end{array}$ \\
\hline \multicolumn{8}{|l|}{$\mathrm{Flow}, \mathrm{kg} / \mathrm{h}(\mathrm{kg})$} \\
\hline Salt & 3.56 & & & & & & \\
\hline Solids & 7.91 & & & & & 16.7 & \\
\hline $\mathrm{H}_{2} \mathrm{O}$ & 101.8 & & 101.8 & 1.0 & & & \\
\hline Air & & 49 & 71.5 & & 0.52 & & 22 \\
\hline $\mathrm{NO}_{2}$ & & & 2.34 & & & & \\
\hline TOTAL & 112.27 & 49 & 175.64 & 1.0 & 0.52 & 16.7 & 22 \\
\hline Temper at ure, ${ }^{0} \mathrm{C}$ & 35 & 35 & 300 & 25 & 35 & 35 & 60 \\
\hline Density, $\mathrm{g} / \mathrm{cm}^{3}$ & 1.1 & -- & -- & 1.0 & -- & 2.0 (bulk) & -- \\
\hline $\mathrm{Flow}, \mathrm{L} / \mathrm{h}$ & 100.8 & -- & -- & 1.0 & - & -- & -- \\
\hline Activity, Ci/L & 21.6 & - & $2.17 \mathrm{Ci}$ & -- & -- & -- & -- \\
\hline Heat, W/L & 0.08 & -- & -- & -- & - & -- & - \\
\hline
\end{tabular}


- The alkaline high-level-waste feed composition is summarized in Table A.7. This feed composition is an average composition based on continuous flow of all process feed streams.

TABLE A.7. Estimated Chemical Composition of Salt/Siudge Separated Alkaline Waste Blend

\begin{tabular}{|c|c|c|c|}
\hline Component & $\begin{array}{c}\text { Concentration, } \\
\mathrm{g} / \mathrm{L}\end{array}$ & Oxide & $\begin{array}{l}\text { Concentratio } \\
\text { equivalent of }\end{array}$ \\
\hline \multicolumn{4}{|l|}{ Solids } \\
\hline $\mathrm{Fe}(\mathrm{OH})_{3}$ & 33.9 & $\mathrm{Fe}_{2} \mathrm{O}_{3}$ & 25.3 \\
\hline $\mathrm{FePO}_{4}$ & 19.5 & $\mathrm{Fe}_{2} \mathrm{O}_{3}, \mathrm{P}_{2} \mathrm{O}_{5}$ & $10.3,9.2$ \\
\hline $\mathrm{Cr}(\mathrm{OH})_{3}$ & 2.6 & $\mathrm{Cr}_{2} \mathrm{O}_{3}$ & 2.0 \\
\hline $\mathrm{Ni}(\mathrm{OH})_{2}$ & 1.2 & $\mathrm{NiO}$ & 0.9 \\
\hline $\mathrm{Al}(\mathrm{OH})_{3}$ & 0.6 & $\mathrm{Al}_{2} \mathrm{O}_{3}$ & 0.4 \\
\hline $\mathrm{RE}(\mathrm{OH})_{3}$ & 1.1 & $\mathrm{RE}_{2} \mathrm{O}_{3}$ & 0.7 \\
\hline $\mathrm{FP}\left(\mathrm{SO}_{4}\right)$ & 0.9 & $\mathrm{FPSO}_{4}$ & 0.9 \\
\hline $\mathrm{FP}(\mathrm{OH})_{4}$ & 1.1 & $\mathrm{FP}_{2} \mathrm{O}_{4}$ & 0.9 \\
\hline $\mathrm{FP}_{2} \mathrm{O}_{3}$ & 0.1 & $\mathrm{FP}_{2} \mathrm{O}_{3}$ & 0.1 \\
\hline $\mathrm{Na}_{3} \mathrm{PO}_{4} \quad 1_{2} \mathrm{MoO}_{3}$ & 0.7 & $\mathrm{Na}_{3} \mathrm{O}, \mathrm{PO}_{4} \quad 12 \mathrm{MoO}_{3}$ & 0.7 \\
\hline $\mathrm{MnO}_{2}$ & 1.5 & $\mathrm{MnO}_{2}$ & 1.5 \\
\hline $\mathrm{PuO}_{2}$ & 0.02 & $\mathrm{PuO}_{2}$ & 0.02 \\
\hline $\mathrm{Na}_{2} \mathrm{U}_{2} \mathrm{O}_{7}$ & 4.6 & $\mathrm{Na}_{2} \mathrm{O}, \mathrm{U}_{3} \mathrm{O}_{8}$ & $0.5,4.1$ \\
\hline \multirow{2}{*}{$\begin{array}{l}\text { Act. Oxide } \\
\text { (a) Other Solids }\end{array}$} & 0.009 & Act. Oxide & 0.009 \\
\hline & 9.1 & -- & 9.1 \\
\hline TOTAL SOLIDS & & & 66.63 \\
\hline
\end{tabular}

Salts

$\begin{array}{llll}\mathrm{NaNO}_{3} / \mathrm{NO}_{2} & 5.4 & \mathrm{Na}_{2} \mathrm{O}, \mathrm{NO}_{x} & 2.16 \\ \mathrm{Na}_{2} \mathrm{SO}_{4} & 0.04 & \mathrm{Na}_{2} \mathrm{SO}_{4} & 0.05 \\ \mathrm{NaOH} & 0.008 & \mathrm{Na}_{2} \mathrm{O} & 0.006 \\ \mathrm{NaCL} & 0.0003 & \mathrm{NaCL}^{\mathrm{O}} & 0.0003 \\ \mathrm{FePO}_{4} & 0.006 & \mathrm{Fe}_{2} \mathrm{O}_{3}, \mathrm{P}_{2} \mathrm{O}_{3} & 0.006 \\ \mathrm{Cr}(\mathrm{OH})_{3} & 0.001 & \mathrm{Cr}_{2} \mathrm{O}_{3} & 0.0008 \\ \mathrm{Ni}(\mathrm{OH})_{2} & 0.0004 & \mathrm{NiO}_{3} & 0.0004 \\ \mathrm{AlF}_{3} & 0.0008 & \mathrm{AlF}_{3} & 0.0008 \\ \mathrm{Na}_{3} \mathrm{PO}_{4} 12 \mathrm{MOO}_{3} & 0.0003 & \mathrm{Na}_{3} \mathrm{PO}_{4} 12 \mathrm{MoO}_{3} & 0.0003 \\ \mathrm{TOTAL} \mathrm{SALT} & & & 2.225\end{array}$

Water

$102 \mathrm{~L} / \mathrm{h}$

(a) $0.06 \mathrm{Ag}$ Mordenite 3.24 Zeolite 0.19 Silica Gel $5.59 \mathrm{SiO}_{2}$ 
- The glass-former chemical mixture is summarized in Table A.8. This composition was estimated based upon the alkaline waste composition given in Table A.7.

- The waste-oxide loading in the vitreous product is $25 \mathrm{wt} \%$.

The waste form process summary for solidifying the alkaline Purex waste is summarized in Table A.9.

\section{A.3.6.4 Status of Technology}

The SC/ICM process is the most highly developed waste solidification process in the United States at this time. The generic process is essentially ready for plant application. Sitespecific development work may be required however to implement the process. The SC/ICM process involves many mechanical operations, which must be performed remotely on a routine basis in a production facility. Some of these process steps have not been done on a remote production scale; however, the specific details of these operations have been developed and demonstrated in a nonradioactive environment (Larson 1980).

\section{A.3.7 RECYCLE AND SECONDARY EVAPORATION}

\section{A.3.7.1 Purpose}

The purpose of the recycle and secondary evaporation process is to dewater process waste streams and to recycle essentially all of the radiochemical contamination to the solidification process. Decontaminated evaporator overheads are condensed and transferred to the low-levei waste treatment facility.

TABLE A.8. Representative Glass Former Mixture for Vitrification of Alkal ine-Waste Sludge Slurry, Based on Waste Composition Sumarized in Table A.7

\begin{tabular}{|c|c|}
\hline Component & Wt\% \\
\hline $\mathrm{SiO}_{2}$ & 49.3 \\
\hline $\mathrm{B}_{2} \mathrm{O}_{3}$ & 16.4 \\
\hline $\mathrm{Li}_{2} \mathrm{O}$ & 2.74 \\
\hline $\mathrm{Na}_{2} \mathrm{O}$ & 15.1 \\
\hline $\mathrm{K}_{2} \overline{0}$ & 1.4 \\
\hline CaO & 2.74 \\
\hline $\mathrm{TiO}_{2}$ & 4.1 \\
\hline $\mathrm{MgO}$ & 2.74 \\
\hline $\mathrm{BaO}$ & 2.74 \\
\hline $\mathrm{ZrO}_{2}$ & 2.74 \\
\hline
\end{tabular}


TABLE A.9. Waste Form Process Summary for Solidifying Alkaline Purex Waste

\begin{tabular}{ll}
\multicolumn{1}{c}{ Process Characteristics } & Alkaline Purex Waste \\
\hline Glass production rate, $\mathrm{kg} / \mathrm{h}$ & 24 \\
Number of high-level-waste canisters & 180 \\
Activity per canister, Ci & $1.7 \times 10^{5}$ \\
Decay heat per canister, W & 506 \\
Waste loading, wt\% & 25 \\
Processing campaign length, d & 597
\end{tabular}

\section{A.3.7.2 Process Description}

Figure A.8 is a simplified process flowsheet of the recycle and secondary evaporation process. This system is composed of a recycle-evaporator feed blend and holding tank, two thermosyphon evaporators equipped with downdraft condensers. A recycle-evaporator-bottoms hold tank, a recycle-water hold tank, and a condensate sample tank.

Feed to the recycle evaporator is composed of a blended mixture of several, process, waste streams. These process streams are composed of secondary-evaporator bottoms, liquids from the process-cell sumps, liquid waste from the analytical support cells, decontamination solutions, wash centrate from the sludge-washing module, caustic rinse solutions from the cesium and strontium ion-exchange system, and condensate purged from the cesium concentrator.

Bottoms from the recycle evaporator are collected in a hold tank. The recycle-evaporator bottoms product contains all salt and solids that entered in the evaporator feed. This bottoms product is periodically transferred to the gravity-settler feed tank. Overheads from the recycle evaporator compose the feed to the secondary evaporator. In the second evaporator essentially all of the remaining radioactive contamination is removed from the process condensates. The bottoms product is returned to the recycle evaporator. Overheads from the second evaporator are condensed and collected in a recycle water tank. To the extent possible, process condensates are recycled and used again in the process. Process condensates can be sampled in a hold tank. Condensate that is found to be below permissible contamination limits may be released to the low-level-waste treatment facility.

\section{A.3.7.3 Process Flowsheet and Material Balance Bases}

The bases used in developing the process flowsheet and material balance for the recycle and secondary evaporation process are summarized below. The material balance is presented in Table A.10.

These bases are:

- A decontamination factor of $10^{6}$ for radiochemical activity is assumed across each evaporator/condenser equipment pair.

- Bottoms product from the recycle evaporator is concentrated to 33 wt\% salt.

- An overheads to bottoms Split of 10 to 1 is assumed in the second evaporator. 


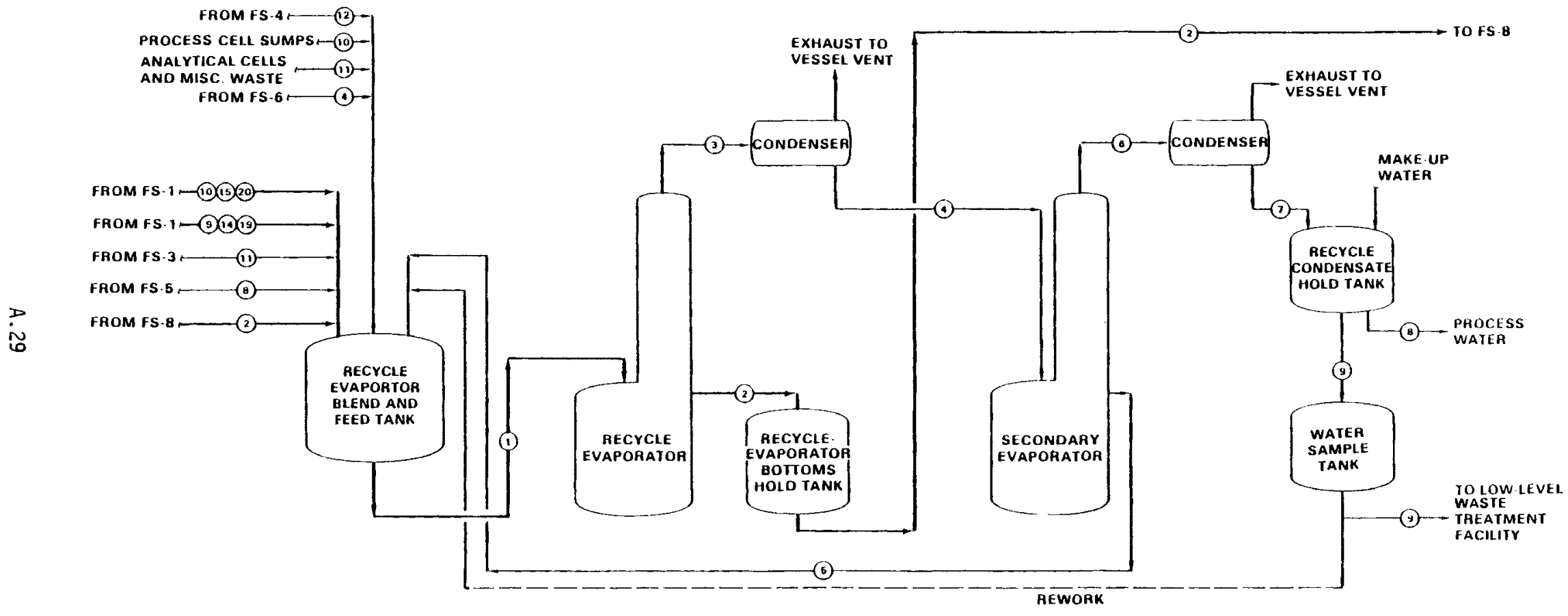

FIGURE A.8. Process Flowsheet (FS-7) for Recycle and Secondary Evaporation 
TABLE A.10. Material Balance for Recycle and Secondary Evaporation

\begin{tabular}{|c|c|c|c|c|c|c|c|c|c|c|c|}
\hline & \multicolumn{11}{|c|}{ Recycle Water Evaporation \& Clean-up } \\
\hline Stream Number & $\mathrm{T}$ & 2 & 3 & 4 & 5 & 6 & 7 & 8 & 9 & 10 & 11 \\
\hline Description & $\begin{array}{l}\text { Recycle } \\
\text { Evaporator } \\
\text { Feed } \\
\end{array}$ & $\begin{array}{c}\text { Recycle } \\
\text { Evaporator } \\
\text { Bot toms }\end{array}$ & $\begin{array}{l}\text { Recycle } \\
\text { Evaporator } \\
\text { Overheads }\end{array}$ & $\begin{array}{l}\text { Secondary } \\
\text { Evaporator } \\
\quad \text { Feed } \\
\end{array}$ & $\begin{array}{l}\text { Secondary } \\
\text { Evaporator } \\
\text { Bottoms }\end{array}$ & $\begin{array}{l}\text { Secondary } \\
\text { Evaporator } \\
\text { Overheads }\end{array}$ & $\begin{array}{c}\text { Condensate } \\
\text { from } \\
\text { Secondary } \\
\text { Conds. } \\
\end{array}$ & $\begin{array}{l}\text { Wash } \\
\text { Water }\end{array}$ & $\begin{array}{l}\text { Wash } \\
\text { Water }\end{array}$ & $\begin{array}{l}\text { Process } \\
\text { Cell } \\
\text { Sumps } \\
\end{array}$ & $\begin{array}{c}\text { Analytical } \\
\text { Cell \& Misc } \\
\text { Wastes }\end{array}$ \\
\hline Flow, $\mathrm{kg} / \mathrm{h}$ & & & & & & & & & & & \\
\hline Salt & 20.84 & 20.84 & & & & & & & & & \\
\hline Solid & 0.604 & 0.604 & & & & & & & & & \\
\hline $\mathrm{H}_{2} \mathrm{O}$ & 647.6 & 59.4 & 588.2 & 588.2 & 53.5 & 534.7 & 534.7 & 534.7 & & 25 & 25 \\
\hline TOTAL & 669.04 & 80.84 & 588.2 & 588.2 & 53.5 & 534.7 & 534.7 & 534.7 & & 25 & 25 \\
\hline Temp, ${ }^{\circ} \mathrm{C}$ & 35 & $100 / 60$ & 100 & 100 & 100 & 100 & 25 & 25 & 25 & 35 & 35 \\
\hline Density, $\mathrm{g} / \mathrm{cm}^{3}$ & 1.03 & 1.36 & - & 1.0 & 1.0 & -- & 1.0 & 1.0 & 1.0 & 1.0 & 1.0 \\
\hline Flow, L/h & 648 & 59.4 & $-\infty$ & 588.2 & 53.5 & -- & 534.7 & 534.7 & & 25 & 25 \\
\hline Activity, $\mathrm{Ci} / \mathrm{L}$ & 0.52 & 5.67 & -- & $1 \times 10^{-6}$ & $1 \times 10^{-6}$ & - & $1 \times 10^{-12}$ & $1 \times 10^{-12}$ & & - & - \\
\hline Heat, W/L & 0.001 & 0.10 & -- & 0 & 0 & -- & 0 & 0 & & - & -- \\
\hline
\end{tabular}




\section{A.3.8 CALCINER OFF-GAS TREATMENT}

\section{A.3.8.1 Purpose}

The purpose of the calciner off-gas treatment system is to remove radiochemical and chemical contaminants from the calciner effluent before release to the environment.

\section{A.3.8.2 Process Description}

A flow diagram of the calciner-effluent treatment system is shown in Figure A.9. Radiochemical and chemical contamination in the calciner effluent is removed by equipment that provides the unit process operations of wet scrubbing, particulate de-entrainment, condensation, sorption, filtration, and chemical destruction. The effluent treatment system is comprised of a venturi scrubber/cyclone, condenser, demister, packed sorption beds, heaters, filters, and an $\mathrm{NO}_{\mathrm{X}}$ destructor.

Off gases from the SC/ICM process consist primarily of water vapor, $\mathrm{NO}_{x}$ from nitrate decomposition, and possibly volatile forms of sulfur, chloride, and fluoride. Volatile radionuclides include cesium, strontium, antimony, ruthenium and iodine.

Initial decontamination of the calciner effluent is provided by the spray calciner filters. These filters remove particulates, allowing volatile chemical and radiochemical species to pass through. The venturi scrubber/cyclone unit provides further particulate decontamination and condensation of approximately $75 \%$ of the water vapor in the effluent. The venturi scrubber also provides a safety barrier should the calciner filters be breached.

The condenser and demister remove essentially all of the water vapor present in the gaseous effluent. The majority of the radiochemical decontamination also occurs in the condensation process.

Sorption processes remove volatile radionuclides, such as iodine in the silver mordenite bed and the ruthenium, cesium, and possibly antimony in the silica gel bed. The gas stream is heated by inline heaters to assure that no condensation occurs in the sorption beds and to improve efficiency of the sorption process. A deep-bed gas filter, which removes fine particulate, is located in the off-gas cleanup system immediately before exiting from the CPC.

The HEPA filters located in the off-gas cleanup cell provide additional removal capacity for fine particulate. These filters also serve as an additional safety factor for decontamination between the process cell and environment should an off-gas process-system accident occur.

$\mathrm{NO}_{\mathrm{x}}$ formed from decomposition of the metallic nitrates in the calcination process is not easily removed by normal scrubbing, filtration, or sorption processes. A chemical reactor is therefore used. This reactor operates by catalytically reacting ammonia and $\mathrm{NO}_{x}$ to form water and nitrogen. Sufficient $\mathrm{NO}_{\mathrm{x}}$ destruction is provided so that the effluent stream may be released to the environment through the building stack.

\section{A.3.8.3 Process Flowsheet and Material Balance Bases}

The bases for developing the process flowsheet and material balance for the calciner effluent treatment system are sumarized below. The material balance is summarized in Table A.11. 


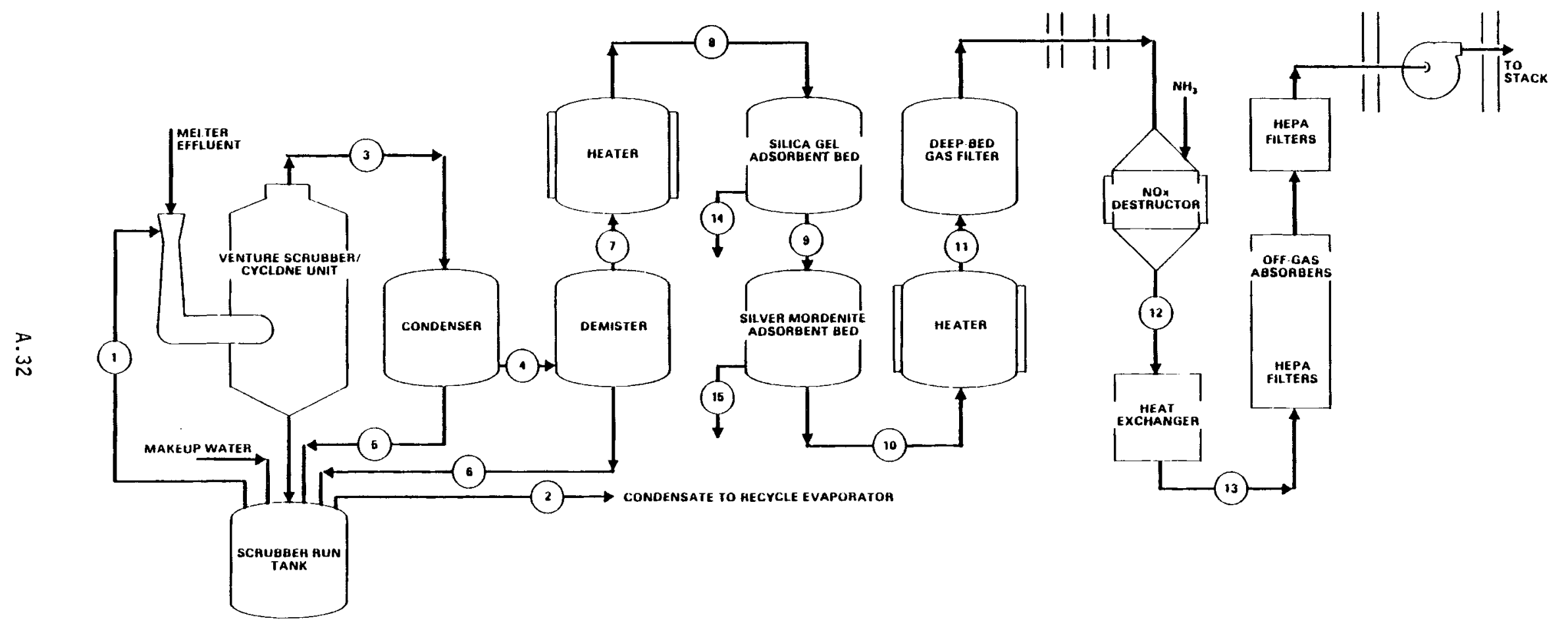

FIGURE A.9. Process Flowsheet (FS-8) for Calciner off-Gas Treatment 
TABLE A.11. Material Balance for Calciner Off-Gas Treatment

\begin{tabular}{|c|c|c|c|c|c|c|c|c|c|c|}
\hline \multirow{2}{*}{$\begin{array}{l}\text { Uperat ion } \\
\text { Stream Number }\end{array}$} & \multirow{2}{*}{\multicolumn{2}{|c|}{1}} & \multicolumn{7}{|c|}{ Off-Gas cleaning \& Decontamination } & \multirow[b]{3}{*}{$\begin{array}{c}10 \\
\begin{array}{c}\text { Off Gas } \\
\text { to } \\
\text { Heater }\end{array}\end{array}$} \\
\hline & & & 3 & 4 & 5 & 6 & 7 & 8 & 9 & \\
\hline Description & $\begin{array}{c}\text { Venturi } \\
\text { Scrub } \\
\text { Solution } \\
\end{array}$ & $\begin{array}{c}\text { Off-Gas } \\
\text { Condensate } \\
\text { to Recycle } \\
\text { Blend Iank } \\
\end{array}$ & $\begin{array}{l}\text { Cyclone } \\
\text { off Gas }\end{array}$ & $\begin{array}{c}\text { Off Gas } \\
\text { to } \\
\text { Demister }\end{array}$ & $\begin{array}{c}\text { Condensate } \\
\text { to } \\
\text { Scrub Iank } \\
\end{array}$ & $\begin{array}{c}\text { Condensate } \\
\text { to } \\
\text { Scrub Iank } \\
\end{array}$ & $\begin{array}{c}\text { Off Gas } \\
\text { to } \\
\text { Heater }\end{array}$ & $\begin{array}{c}\text { Off Gas } \\
\text { to } \\
\text { Silica } \\
\text { Gel Bed }\end{array}$ & $\begin{array}{l}\text { Off Gas to } \\
\text { Silver } \\
\text { Mordenite } \\
\text { Bed }\end{array}$ & \\
\hline \multicolumn{11}{|l|}{ flow, $\mathrm{kg} / \mathrm{h}$} \\
\hline $\mathrm{H}_{2} \mathrm{O}$ & 9606 & 101.8 & 25.4 & 3.0 & 22.4 & 3.0 & & & & \\
\hline Air & & & 71.5 & 71.5 & & & 71.5 & 71.5 & 71.5 & 71.5 \\
\hline $\begin{array}{l}\text { Nut } \\
\text { Solios }\end{array}$ & & & 2.34 & 2.34 & & & 2.34 & 2.34 & 2.34 & 2.34 \\
\hline TUTAL & 9600 & 101.8 & 99.24 & 76.84 & 22.4 & 3.0 & 73.84 & 73.84 & 73.84 & 73.84 \\
\hline Tempera ture, ${ }^{\circ} \mathrm{C}$ & 60 & 60 & 60 & 20 & 20 & 20 & 20 & 8 & 80 & 80 \\
\hline Density, $y / \mathrm{cm}^{3}$ & 1.0 & 1.0 & -- & -- & 1.0 & 1.0 & -- & - & -- & -- \\
\hline flow, L/n & 9606 & 101.8 & - & $\cdots$ & 22.4 & 3.0 & $\cdots$ & -- & -- & -- \\
\hline Activity, Ci/L (Ci) & $2.3 \times 10^{-4}$ & 0.021 & $\left(2.2 \times 10^{-2}\right)$ & $\left(2.2 \times 10^{-4}\right)$ & $2 \times 10^{-6}$ & $2 \times 10^{-6}$ & $\left(2.2 \times 10^{-4}\right)$ & $\left(2.2 \times 10^{-4}\right)$ & $\left(2.2 \times 10^{-6}\right)$ & $\left(2.2 \times 10^{-6}\right)$ \\
\hline Heat, $H / L$ & 0 & - & -- & -- & 0 & 0 & -- & - & -- & - \\
\hline
\end{tabular}

\begin{tabular}{|c|c|c|c|c|c|}
\hline \multirow{2}{*}{ Operation } & \multicolumn{5}{|c|}{ off-Gas Cleaning \& Decontanination } \\
\hline & II & 12 & 13 & 14 & 15 \\
\hline Description & $\begin{array}{l}\text { Off Gas } \\
\text { to } \\
\text { Deep Bed } \\
\text { Filter }\end{array}$ & $\begin{array}{l}\text { Uff Gas to } \\
\text { Condenser }\end{array}$ & $\begin{array}{r}\text { Off Gas to } \\
\text { Stack }\end{array}$ & $\begin{array}{l}\text { Silica } \\
\text { Gel to } \\
\text { Feed } \\
\text { Slurry } \\
\text { Hold Iank }\end{array}$ & $\begin{array}{l}\text { Silver } \\
\text { Mordenite } \\
\text { to Feed } \\
\text { Slurry } \\
\text { Hold Iank }\end{array}$ \\
\hline \multicolumn{6}{|l|}{ flow, $\mathrm{kg} / \mathrm{h}$} \\
\hline $\mathrm{H}_{2} \mathrm{O}$ & & 1.40 & 1.40 & & \\
\hline Air & 71.5 & 72.4 & 72.4 & & \\
\hline$N 0_{x}$ & 2.34 & 0.0234 & 0.0234 & & \\
\hline Solids & & & & 0.02 & 0.006 \\
\hline TUTAL & 73.84 & 73.8 & 73.8 & 0.02 & 0.006 \\
\hline Temperature, ${ }^{0} \mathrm{C}$ & 35 & 350 to 500 & 35 & 35 & 35 \\
\hline Density, $g / \mathrm{cm}^{3}$ & -- & -. & -. & 2 (bulk) & 2 (bulk) \\
\hline Flow, L/h & -- & -- & - & -- & - \\
\hline Activity, Ci/L & $\left(2.2 \times 10^{-6}\right)$ & $\left(2.2 \times 10^{-7}\right)$ & $\left(2.2 \times 10^{-7}\right)$ & - & -- \\
\hline Heat, $W / L$ & - & - & - & -- & -- \\
\hline
\end{tabular}


These bases are:

- All radionuclide contaminates are assumed to behave as a particulate.

- Seventy-five percent of the water vapor in the calciner off-gas is condensed in the venturi scrubber; the remaining water vapor in the off-gas is removed in the downdraft condenser and demister.

- The decontamination factor for radioactivity in the SC/ICM system is $10^{3}$.

- The decontamination factors for off-gas equipment pieces are summarized below:

\begin{tabular}{|c|c|c|}
\hline Component & $\frac{\text { Decontamination }}{\text { Particulate }}$ & $\frac{\text { Factor }(a)}{N 0}$ \\
\hline Venturi scrubber & $10^{2}$ & $\begin{aligned}-x \\
1\end{aligned}$ \\
\hline Cyclone & 1 & 1 \\
\hline Condenser & $10^{2}$ & 1 \\
\hline Demister & 1 & 1 \\
\hline Silica gel sorber & $10^{2}$ & 1 \\
\hline Ag Mordenite Bed & 1 & 1 \\
\hline Fiberglass filter (deep bed) & 10 & 1 \\
\hline $\mathrm{NO}_{\mathrm{x}}$ destructor & 1 & $10^{2}$ \\
\hline $\begin{array}{l}\text { Sintered filters } \\
\quad \text { (Calciner/Melter System) }\end{array}$ & $10^{3}$ & 1 \\
\hline
\end{tabular}

(a) Adopted from Christian and Pence 1977.

\section{A.3.8.4 Status of Technology}

A large amount of technical data has been developed on off-gas cleanup systems for waste solidification. The performance data for radioactive equipment for both the fluid-bed calciner and spray calciner off-gas treatment systems are applicable to the west valley spray calciner system assuming the waste characteristics to be similar. A thorough review of design considerations and effluent characteristics can be found in Christian et al. (1978), Christian and Pence (1977), Christian and Rhodes (1977), Hanson (1980), Rimshaw, Case and Tompkins (1980), and Thomas and Munger (1978).

\section{A.3.9 SOLIOIFICATION OF DECONTAMINATED SUPERNATE}

\section{A.3.9.1 Purpose}

The purpose of the decontaminated supernate, solidification process is to dewater and solidify the decontaminated supernate to form a salt cake containing 20 to 25 wt\% water. The salt-cake product is packaged in 55-gal drums for disposal at a low-level-waste burial ground. 


\section{A.3.9.2 Process Description}

Decontaminated alkaline supernate from the strontium ion-exchange process is dewatered in a two-stage evaporation process. Decontaminated-supernate solution is fed to a primary evaporator in which the water content of the salt solution is reduced from $77 \mathrm{wt} \%$ to $40 \mathrm{wt} \%$. The resulting concentrated supernate solution is then fed to a vertically mounted wiped-film evaporator. The wiped-film evaporator further dewaters the supernate solution until a product with 20 to $25 \mathrm{wt \%}$ water is produced. This salt-cake product is packaged and allowed to cool in 55-gal drums. Upon cooling, the concentrate forms a damp salt cake. These drums are transferred to a low-level-waste burial ground for disposal. The estimated composition of the salt cake is sumarized in Table A.12. The calculated isotopic activity of the salt cake is summarized in Table A.13.

TABLE A.12. Estimated Salt-Cake Composition--Salt/Sludge Separation Process

\begin{tabular}{lc}
\multicolumn{1}{c}{ Component } & $\begin{array}{c}\text { Quantity, } \\
\text { wt\% }\end{array}$ \\
$(\mathrm{Na}, \mathrm{K}) \mathrm{SO}_{4}{ }^{(\mathrm{a})}$ & 5.3 \\
$(\mathrm{Na}, \mathrm{K}) \mathrm{NO}_{3} / \mathrm{NO}_{2}(\mathrm{a})$ & 65.0 \\
$(\mathrm{Na}, \mathrm{K}) \mathrm{OH}^{(\mathrm{a})}$ & 2.7 \\
$(\mathrm{Na}, \mathrm{K}) \mathrm{Cl}^{(\mathrm{a})}$ & 0.03 \\
$\mathrm{FePO}_{4}$ & 0.07 \\
$\mathrm{Cr}(\mathrm{OH})_{3}$ & 0.1 \\
$\mathrm{Ni} \mathrm{OH}_{2}$ & 0.04 \\
$\mathrm{Na}_{2} \mathrm{CO}{ }_{3}{ }^{(\mathrm{b})}$ & 4.6 \\
$\mathrm{AlF}_{3}$ & 0.09 \\
$\mathrm{H}_{2} \mathrm{O}^{(\mathrm{C})}$ & 22.0
\end{tabular}

(a) Sodium to potassium ratio, 99 to 1 .

(b) Formed during cesium ion-exchange processes.

(c) Salt concentrated to 22 wt\% water. 
TABLE A.13. Calculated Isotopic Composition of Low-Level Salt Cake from the Salt/Sludge Separation Process

\begin{tabular}{|c|c|c|c|c|c|c|c|c|c|}
\hline & I sotope & Half-L ife & $\begin{array}{c}\text { Percent } \\
\text { Insoluble (a) } \\
\end{array}$ & $\begin{array}{l}\text { Actiyify in } \\
1987(b)(c i)\end{array}$ & $\begin{array}{c}\text { Activity } \\
\text { in Sludge, } \\
\mathrm{Ci} \\
\end{array}$ & $\begin{array}{c}\text { Activity in } \\
\text { Supernate, } \\
\mathrm{Ci} \\
\end{array}$ & $\begin{array}{l}\text { DF for }(d) \\
\text { Insoluble } \\
\text { I sotopes }\end{array}$ & $\begin{array}{l}\text { DF for (d) } \\
\text { Soluble } \\
\text { Isotopes } \\
\end{array}$ & $\begin{array}{c}\text { Activity jn } \\
\text { Salt Cake, (b) } \\
\text { nCi/gram }\end{array}$ \\
\hline & $\mathrm{Se}-79$ & $6.5 \times 10^{4} y$ & 0 & 50 & 0 & 50 & 1 & 1 & 30.4 \\
\hline & $\mathrm{Zr}-93$ & $1.5 \times 10^{6} y$ & 99.9 & 250 & 250 & 0.25 & $1.72 \times 10^{4}$ & 1 & 0.16 \\
\hline & $N b-93 m$ & $13.6 \mathrm{y}$ & 99.9 & 240 & 240 & 0.24 & $1.72 \times 10^{4}$ & 1 & 0.15 \\
\hline & Tc-99 & $2.13 \times 10^{5} \mathrm{y}$ & 0 & 1900 & 0 & 1900 & 1 & 1 & 1156.4 \\
\hline & $R u-106$ & $368 d$ & 99 & 110 & 108.9 & 1.1 & $1.72 \times 10^{4}$ & 1 & 0.67 \\
\hline & $\mathrm{Sb}-125$ & $2.71 \mathrm{y}$ & 99 & 6100 & 6039 & 61 & $1.72 \times 10^{4}$ & 1 & 37.3 \\
\hline & Cs-134 & $2.06 y$ & 0 & 21000 & 0 & 21000 & 1 & $10^{4}$ & 1.28 \\
\hline & Cs-137 & $30.2 y$ & 0 & $8.9 \times 10^{6}$ & 0 & $8.9 \times 10^{6}$ & 1 & $10^{4}$ & 542 \\
\hline & Pm-147 & $2.62 \mathrm{y}$ & 99.9 & 61000 & 60939 & 61 & $1.72 \times 10^{4}$ & 1 & 39.3 \\
\hline & $S m-151$ & $93 y$ & 99.9 & 200,000 & $1.99 \times 10^{5}$ & 200 & $1.72 \times 10^{4}$ & 1 & 128.8 \\
\hline & $E u-152$ & $13.4 \mathrm{y}$ & 99.9 & 1410 & 409 & 0.40 & $1.72 \times 10^{4}$ & 1 & 0.24 \\
\hline & $N p-239$ & $2.35 \mathrm{~d}$ & 99.9 & 220 & 219.8 & 0.22 & $1.72 \times 10^{4}$ & 1 & 0.08 \\
\hline & Pu-238 & $87.7 y$ & 99.9 & 1500 & 1500 & 1.5 & $1.72 \times 10^{4}$ & $3 \times 10^{3}$ & 0.053 \\
\hline & Pu-239 & $24,370 y$ & 99.9 & 1800 & 1800 & 1.8 & $1.72 \times 10^{4}$ & $3 \times 10^{3}$ & 0.063 \\
\hline & $P u-240$ & $6580 y$ & 99.9 & 970 & 969 & 0.97 & $1.72 \times 10^{4}$ & $3 \times 10^{3}$ & 0.034 \\
\hline & $P u-241$ & $13.2 \mathrm{y}$ & 99.9 & 70,000 & 69930 & 70 & $1.72 \times 10^{4}$ & $3 \times 10^{3}$ & 2.49 \\
\hline & $A m-241$ & $458 y$ & 99.9 & 20,000 & 19980 & 20 & $1.72 \times 10^{4}$ & $3 \times 10^{3}$ & 0.70 \\
\hline & $\mathrm{Cm}-244$ & $17.6 y$ & 99.9 & 8800 & 8791 & 8.8 & $1.72 \times 10^{4}$ & $3 \times 10^{3}$ & 0.31 \\
\hline & & & & & & & TOTAL ACTIV & ITY & $\begin{array}{c}2024.7 \mathrm{nCi} / \\
\text { gram salt cake }\end{array}$ \\
\hline
\end{tabular}

(a) Based on Table 3.7, TID-28905-2 (ORNL 1978)

(b) Total salt-cake weight $1.643 \times 10^{6} \mathrm{~kg}$

(c) Total actinide activity $3.65 \mathrm{nCi} / \mathrm{gram}$ salt cake Total fission-product activity $2021 \mathrm{nC} i / g r a m ~ s a l t ~ c a k e$

(d) DF = decontamination factor 
Condensate is collected from both the primary supernate evaporator and the wiped fiim evaporator. This condensate is sampled to determine activity levels. If required, the condensate is recycled to the primary evaporator feed tank located inside the CPC. Normally the condensate is transferred to the low-level-waste treatment system for further treatment before discharge to the environment.

\section{A.3.9.3 Process Flowsheet and Material Balance Bases}

The bases used to develop the flowsheet and material balance for solidification of the decontaminated supernate are summarized below. The material balance is summarized in Table A.14.

These bases are:

- Decontaminated supernate is evaporated to $60 \%$ water in the evaporator.

- Decontaminated supernate is evaporated to $22 \%$ in the wiped-film evaporator.

- A decontamination factor of $10^{6}$ is assumed in the primary evaporator and the wiped-film evaporator.

- Condensate is discharged to the low-level-waste treament facility for further treatment before discharge to the environment.

\section{A.3.9.4 Status of Technology}

Both the Hanford and SRL waste management programs have used evaporation and resultant crystalline-solidification techniques to reduce the volume of stored alkaline purex waste supernates. The solidification technology has been directed toward using bent-tube evaporators (Goodlet 1968). Wiped-film evaporators have been considered in the DOE high-level-waste solidification campaign for evaporating decontaminated salt cake (Goodlet 1975). Only limited experimental work has been reported to date to determine wiped-film performance characteristics. 
TABLE A.14. Material Balance for Solidification of Decontaminated Supernate

\begin{tabular}{|c|c|c|c|c|c|c|c|c|}
\hline Operation & & & Salt Dec & ontaminatior & \& Concentr & tion & & \\
\hline Steam Number & 1 & 2 & 3 & 4 & 5 & 6 & 7 & 8 \\
\hline Description & $\begin{array}{l}\text { Evaporator } \\
\text { Feed }\end{array}$ & $\begin{array}{l}\text { Concentrated } \\
\text { Salt Solution }\end{array}$ & $\begin{array}{l}\text { Wiped-Film } \\
\text { Evaporator } \\
\text { Product }\end{array}$ & $\begin{array}{l}\text { Evapor ator } \\
\text { Overheads }\end{array}$ & $\begin{array}{l}\text { Evaporator } \\
\text { Condensate }\end{array}$ & $\begin{array}{l}\text { Wiped-film } \\
\text { Evaporator } \\
\text { Overheads }\end{array}$ & $\begin{array}{c}\text { Overhead } \\
\text { Condensate }\end{array}$ & $\begin{array}{l}\text { Process } \\
\text { Condensate }\end{array}$ \\
\hline $\mathrm{Flow}, \mathrm{kg} / \mathrm{h}$ & & & & & & & & \\
\hline Salt & 89.46 & 89.5 & 89.5 & & & & & \\
\hline $\mathrm{H}_{2} \mathrm{O}$ & 293.7 & 134.2 & 25.2 & 159.5 & 159.5 & 109 & 109 & 268.5 \\
\hline Solids & 0.0004 & 0.0004 & 0.0004 & & & & & \\
\hline TOTAL & 383.16 & 223.7 & 114.7 & 159.5 & 159.5 & 109 & 109 & 268.5 \\
\hline Temperature, ${ }^{\circ} \mathrm{C}$ & 35 & 130 & 250 & 100 & 35 & 103 & 35 & 35 \\
\hline Density, $\mathrm{g} / \mathrm{cm}^{3}$ & 1.30 & 1.67 & 1.70 & -- & 1.0 & -- & 1.0 & 1.0 \\
\hline $\mathrm{Flow}, \mathrm{L} / \mathrm{h}$ & 294 & 134.2 & 67.5 & -- & 160 & -- & 109 & 268.5 \\
\hline Activity, Ci/L & $6 \times 10^{-7}$ & $1.3 \times 10^{-6}$ & 0.23 & -- & $1 \times 10^{-12}$ & - & $1 \times 10^{-12}$ & $1 \times 10^{-12}$ \\
\hline Heat, W/L & 0 & 0 & 0 & -- & 0 & -- & 0 & $\mathbf{0}$ \\
\hline
\end{tabular}




\section{A.4 REFERENCES}

Ames, L. L., and K. C. Kno11. 1962. Loading and Elution Characteristics of Some Natural and Synthetic Zeolites. HW-74609, General Electric Company, Hanf ord Atomic Products, Richland, Washington.

Atlantic Richfield Hanford Company. 1970. B Plant Recovery of Cesium from Purex Supernatant. ARH-1639, Atl antic Richfield Hanford Company, Richland, Washington. (Available from Rockwe 11 Hanf ord Operations, Richland, Washington.

Buckingham, J. C. 1967. Waste Management Technical Manual. ISO-100-DEL, Isochem, Inc., Richl and, Washington.

Buckingham, J. C. 1970. Laboratory Evaluation of Zeolite Material for Removing Radioactive Cesium from Alkaline Waste Solutions. USAEC Report ARH-SA 49, Atlantic Richfield Hanford Co., Richland, Washington.

Carlstrom, R. F. 1977. Ion-Exchange Flowsheet for Recovery of Cesium from Purex Sludge Supernate at B-Plant. U.S. ERDA Report, ARH-F-106, Atlantic Richfield Hanford Company, Richland, Washington. (Available from Rockwell Hanford Operations, Richland, Washington.)

Christian, J. D., and D. T. Pence. 1977. Critical Assessment of Methods for Treating Airborne Effluents from High-Level Waste Solidification Processes. PNL-2486, Pacif ic Northwest Laboratory, Richland, WA.

Christian, J. D., and D. W. Rhodes. 1977. Ruthenium Containment During Fluid-Bed Calcination of High-Level Waste from Commercial Nuclear Fuel Reprocessing Plants. ICP-1091, Idaho National Engineering Laboratory, Idaho falls, Idaho.

Christian, J. D., et al. 1978. Design of WFP Off-Gas Treatment System. SAI 78-899-LJ, Prepared for Pacific Northwest Laboratory, Richland, Washington

Dierks, R. D., et al. 1980. Investigation of Corrosion Experienced in a Spray Calciner/ Ceramic Meiter System. PNL-3406, Pacif ic Northwest Laboratory, Richland, WA.

Goodlett, C. B. 1968. Concentration of Radioactive Wastes. DP-1135, E. I. du Pont de Nemours \& Co., Inc., Savannah Kiver Laboratory, Aiken, South Carol ina.

Goodlet, C. B. 1975. Concentration of Aqueous Radioactive Waste with Wiped-Film Evaporators. CONF-751107-2, USERDA-TIC, Oak Ridge, Tennessee.

Hanson, M. S. 1980. Spray Calcination/In-Can Melting: Effluent Characterization and Treatment. PNL-3109, Pacif ic Northwest Laboratory, Richland, Washington.

Landon, L. F. 1980. Preliminary Technical Data Surmary No. 3 for the Defense Waste Processing Facility. OPSTO-77-13-2, Savannah River Laboratory, Aiken, South Carolina.

Larson, D. E., and P. W. Smith. 1969. Treatment of Hanford Nuclear Fuels Processing Wastes to Permit Long-Term Storage. ARH-SA-5I, Atlantic Richfield Hanford Company, Richland, Washington (Available from Rockwell Hanford Operations, Richland, Washington).

Larson, D. E. 1980. Spray Calciner/In-Can Melter High-Level Waste Solidification Technical Manual. PNL-3495, Pacific Northwest Laboratory, Richland, Washington.

MCElroy, J. L., et al. 1972. Waste Solidification Program Sunmary Report, Yol. II. BNWL-1667, Pacific Northwest Laboratory, Richland, Washington.

Okeson, J. K., et al. 1980. A Small-Scale Demonstration of High-Level Radioactive Waste Processing and Solidification Using Actua! SRP Waste. OP-MS-80-2, Savannah River Laboratory, Aiken, South Carolina. 
Pence, D. T., and T. R. Thomas. 1974. "NOx Abatement at Nuclear Processing Plants." Proceedings of the Second AEC Environmental Protection Conference, WASH-1332(74), U. S. Atomic Energy Comission, Washington, D.C.

Richardson, G. L. 1969. Evaporation of Cesium Ion Exchange Eluate and Recovery of Ammonium Carbonate; Pilot Plant Studies. BNWL-CC-2084, Pac ific Northwest Laboratory, Richland, Washington.

Rimshaw, S. J., R. N. Case and J. A. Tompkins. 1980. Volatility of Ruthenium-106, Technetium-99 and Iodine-129, and the Evolution of $\mathrm{Ni}$ trogen Oxide Compounds Ouring the Calcination of High-Level, Radioactive Nitric Acid Waste. ORNL-5562, Oak Ridge National Laboratory, Oak Ridge, Tennessee.

Stone, J. A. 1976. Separation of SRP Waste Sludge and Supernate. Report DP-1441, E. I. du Pont de Nemours \& Co., Inc., Savannah River Laboratory, Aiken, South Carolina.

Savannah River Laboratory 1977. Savannah River Laboratory Quarterly Report, Waste Management, Aoril-June 1977. DPST-77-125-2. E. I. du Pont de Nemours \& Co., Inc., Savannah River Laboratory, Aiken, South Carolina.

Thomas, T. R., and D. H. Munger. 1978. An Evaluation of NOx Abatement by $\mathrm{NH}_{3}$ over Hydrogen Mordenite for Nuciear Fuel Reprocessing Plants. ICP-1133, Idaho National Engineering Laboratory, Idaho Falls, Idaho.

Wheelwright, E. J. et al. 1979. Technical Summary Nuclear Waste Vitrification Project. PNL-3038, Pacific Northwest Laboratory, Richland, WA.

Wiley, J. R., and R. M. Wallace. 1975. Removal of Cesium from Savannah River Plant Waste Supernate. DP-1388, E. I. Du Pont de Nemours \& Co., Inc., Savannah River Laboratory, Aiken, South Carolina.

Wiley, J. R. 1976a. Decontamination of Savannah River Plant Waste Supernate. DP-1436, E. I. du Pont de Nemours \& Co., Inc., Savannah River Laboratory, Aiken, South Carolina.

Wiley, J. R. 1976b. A Study of Methods for Removing Strontium, Plutonium, and Ruthenium from Savannah River Plant Waste Supernate. OP-1408, E. I. du Pont de Nemours \& Co., Inc., Savannah River Laboratory, Aiken, South Carolina. 
APPENDIX B

FLOWSHEET AND MATERIAL BALANCE:

SOLIDIFICATION OF ACIDIC THOREX WASTE 
$\checkmark$ 


\section{CONTENTS}

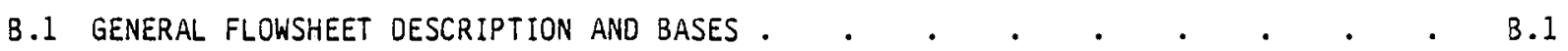

B.1.1 Calcination Vitrification and Canister Handling . . . . . . . . B.2

B.1.2 Calciner Gaseous Effluent Cleanup . . . . . . . . . . . . . B.4

B.1.3 Recycle and Secondary Evaporation . . . . . . . . . . B.5

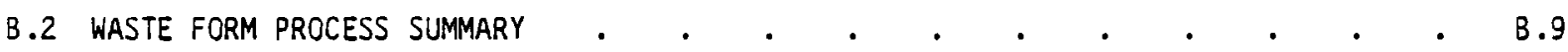

B.3 STATUS OF TECHNOLOGY

B.4 REFERENCES . . . . . . . . . . . . . . . . . . . . . . . . B.11 


\section{FIGURES}

B.1 Process Flowsheet (FS-1) for Calcination/Vitrification of Acidic Thorex Waste . B.3

B.2 Process Flowsheet (FS-2) for Calciner Gaseous Effluent Cleanup Equipment . $\quad$. 8.6

B.3 Process Flowsheet (FS-3) for Recycle and Secondary Evaporation . . . . . . B.8

TABLES

B.1 Estimated Chemical Composition of Acidic Thorex Waste and Equivalent Oxides $\quad$ B $\quad$ B.2

B.2 Material Balance for Spray Calcination and Vitrification of Acidic Thorex Waste . 8.4

B.3 Material Balance for Calciner Off-Gas Treatment . . . . . . . . . . . $\quad$. B.7

B.4 Material Balance for Recycle and Secondary Evaporation . . . . . . . B.8

B.5 Waste Form Process Surmary for Solidification of the Acidic Thorex
Waste in a Borosilicate Glass. . . . . . . . B.9 
APPENDIX B

FLOWSHEET AND MATERIAL BALANCE: SOLIDIFICATION OF ACIDIC THOREX WASTE

This appendix presents the process flowsheets, process assumptions, and chemical and radiochemical material balances for solidification of the acidic Thorex waste. The Thorex waste will be solidified in a separate campaign in the reference process, which will proceed solidification of the alkaline Purex waste. The reference waste form is borosilicate glass. The reference solidification process is the SC/ICM.

\section{B.1 GENERAL FLOWSHEET DESCRIPTION AND BASES}

Solidification of the acidic Thorex waste will be accomplished with the same process equipment used for solidification of the alkaline Purex waste blend. The unit process systems used from the salt/sludge separation process for solidification of the acidic Thorex wastes are:

1. calcination/vitrification and canister-handling equipment,

2. cleanup equipment for gaseous effluents from the vitrification process,

3. recycle and secondary evaporation equipment.

A detailed description of the process system may be found in Appendix $A$.

The acidic Thorex waste is periodically transferred from Tank 804 to a waste-receipt tank located inside the CPC. The waste will then be transferred to a feed-blend tank where the waste is combined with recycle process condensates. The waste is sampled and an analysis of the waste blend is performed. Analytical results are used to: 1) decide if any adjustments need to be made to the waste composition, and 2) to choose the appropriate glass-frit blend to be used in the vitrification process. In general, no adjustments will need to be made to the acidic Thorex waste prior to solidification.

The Thorex waste blend is then converted to a borosilicate glass using the SC/ICM process. The rate of glass production is 1 imited to approximately $80 \mathrm{~kg} / \mathrm{h}$ in the $0.6 \mathrm{~m}(2 \mathrm{ft})$ in dia reference in-can melter canister.

Gaseous effluents from the vitrification process are decontaminated in the vitrification effluent cleanup equipment. Process condensates are concentrated and decontaminated in the evaporation equipment. The concentrated activity from the evaporator is recycled to the feedblend tank. Decontaminated condensates are sampled and either recycled to the process or released to the low-level-waste treatment facility.

The bases used to define the overall process flowsheet and material balance are described below.

- The Thorex waste will be solidified in a 60 d campaign.

- The Thorex waste oxide loading in the final glass product is 15 wt\%. (10 wt\% thoria in the glass product.) 
- The waste composition is defined in Table B.1. The radiochemical activity level of the waste is based on estimates made for the year 1987. (See Section 4.0)

- All process operating parameters for the calciner effluent-treatment system and recycle and secondary evaporation are the same as those for solidification of the alkaline waste slurry (Appendix A).

Specific process bases and assumptions used to define the process flowsheets and material balances for each system are lisțed in the following sections.

\section{B.1.1 Calcination Vitrification and Canister Handling}

- The atomizing-air flow rate is $0.48 \mathrm{~kg}$ of air per 1 iter of feed.

- Filter blowback air is estimated to be $0.6 \mathrm{~kg} / \mathrm{h}$.

- All metallic nitrates are converted to an oxide during the vitrification process.

- Operation of the spray calciner is continuous.

- The weight of steam used to decontaminate each canister is $20 \mathrm{~kg}$.

- The waste oxide loading in the vitreous product is $15 \mathrm{wt \%}$.

- A simplified process flow sheet is shown in Figure B.1, the process material balance is sumarized in Table B.2.

TABLE B.1. Estimated Chemical Composition of Acidic Thorex Waste and Equivalent 0xides(a)

\begin{tabular}{|c|c|c|c|}
\hline Component & $\begin{array}{l}\text { Weight, } \\
\mathrm{kg}\end{array}$ & oxide & $\begin{array}{c}\text { Equivalent } 0 x i d e, \\
\text { Weight, } \mathrm{kg}\end{array}$ \\
\hline $\mathrm{Fe}$ & 2200 & $\mathrm{Fe}_{2} \mathrm{O}_{3}$ & 3143 \\
\hline $\mathrm{Cr}$ & 540 & $\mathrm{Cr}_{2} \mathrm{O}_{3}$ & 790 \\
\hline $\mathrm{Ni}$ & 320 & NiO & 407 \\
\hline$k$ & 150 & $\mathrm{k}_{2} \mathrm{O}$ & 180 \\
\hline Al & 460 & $\mathrm{Al}_{2} \mathrm{O}_{3}$ & 869 \\
\hline $\mathrm{Cl}$ & 63 & $\mathrm{NaCl}$ & 104.4 \\
\hline$S$ & 32 & $\mathrm{Na}_{2} \mathrm{SO}_{4}$ & 142 \\
\hline Mn & 32 & $\mathrm{MnO}_{2}$ & 50.6 \\
\hline$B$ & 18 & $\mathrm{~B}_{2} \mathrm{O}_{3}$ & 57.2 \\
\hline $\mathrm{Ca}$ & 6.8 & $\mathrm{CaO}$ & 9.5 \\
\hline $\mathrm{Na}$ & 310 & $\mathrm{Na}_{2} \mathrm{O}$ & 297 \\
\hline Th & 10,300 & $\mathrm{ThO}_{2}$ & 11,715 \\
\hline $\mathrm{HNO}_{3}$ & 46.7 & NOx & \\
\hline $\mathrm{NO}_{3}$ & 26,000 & NOX & \\
\hline & \multicolumn{2}{|c|}{ TOTAL } & 17,765 \\
\hline
\end{tabular}

(a) Estimated based on $\mathrm{NO}_{3}^{-}$complex of metal ions. 


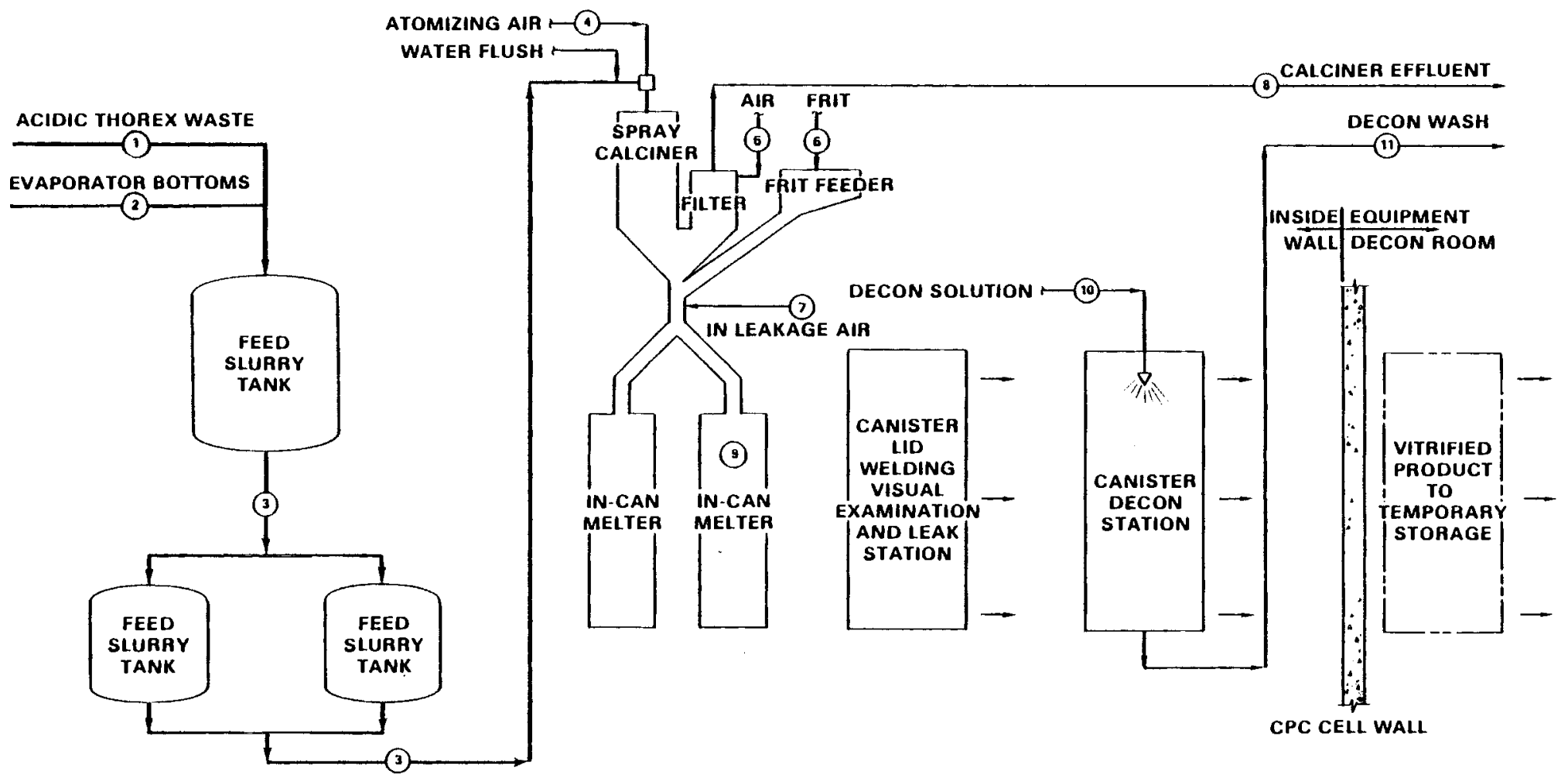

FIGURE B.1. Process Flowsheet (FS-1) for Calcination/Vitrification of Acidic Thorex Waste 
TABLE B.2. Material Balance for Spray Calcination and Vitrification of Acidic Thorex Waste

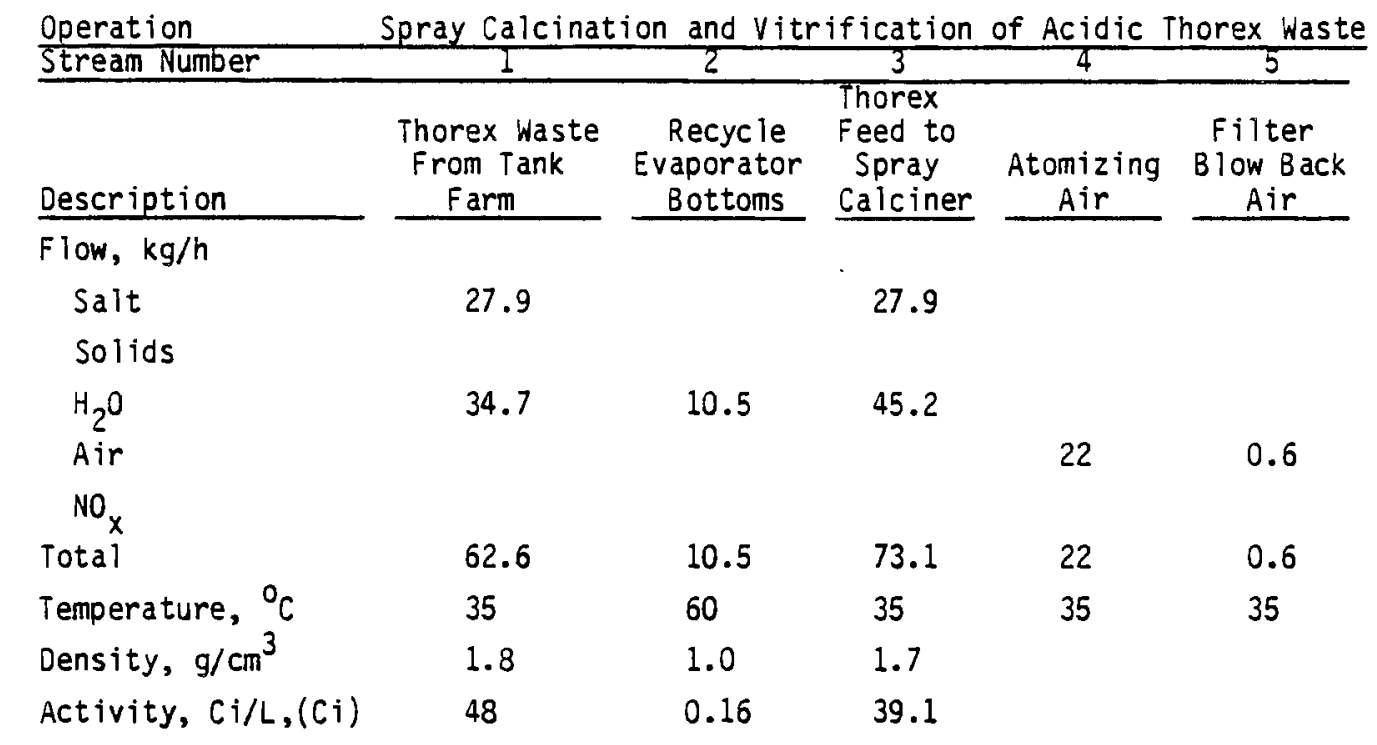

\begin{tabular}{|c|c|c|c|c|c|c|}
\hline \multirow{2}{*}{$\begin{array}{l}\text { Operation } \\
\text { Stream Number }\end{array}$} & \multicolumn{3}{|c|}{ Spray Calcination and } & \multicolumn{3}{|c|}{ Vitrification of Acidic Thorex Waste } \\
\hline & 6 & 7 & 8 & 9 & 10 & 11 \\
\hline Description & $\begin{array}{c}\text { Frit } \\
\text { Addition } \\
\end{array}$ & $\begin{array}{c}\text { In leakage } \\
\text { Air } \\
\end{array}$ & $\begin{array}{l}\text { Calciner } \\
\text { Off Gas }\end{array}$ & $\begin{array}{c}\text { Glass } \\
\text { Production } \\
\text { Rate } \\
\end{array}$ & $\begin{array}{c}\text { Canister } \\
\text { Decontamination } \\
\text { Spray } \\
\end{array}$ & $\begin{array}{l}\text { Canister- } \\
\text { Decontamination } \\
\text { Spray } \\
\end{array}$ \\
\hline \multicolumn{7}{|c|}{ 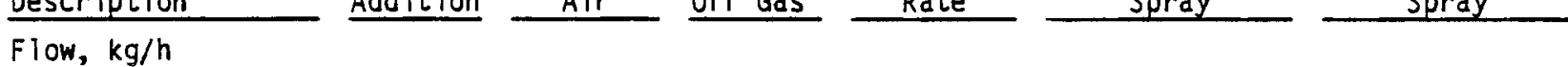 } \\
\hline Salt & & & & & & \\
\hline Solids & 68 & & & 81.3 & & \\
\hline $\mathrm{H}_{2} \mathrm{O}$ & & & 45.2 & & 0.8 & 0.8 \\
\hline Air & & 10 & 32.6 & & & \\
\hline $\mathrm{NO}_{\mathrm{x}}$ & & & 10.9 & & & \\
\hline Total & 68 & 10 & 88.7 & 81.3 & 0.8 & 0.8 \\
\hline Temperature, ${ }^{\circ} \mathrm{C}$ & 35 & & 300 & 1050 & 100 & 80 \\
\hline Density, $\mathrm{g} / \mathrm{cm}^{3}$ & & & & $2.8\left(35^{\circ} \mathrm{C}\right)$ & 1.0 & 1.0 \\
\hline Activity, $\mathrm{C} i / \mathrm{L},(\mathrm{Ci})$ & & & $(1.7)$ & 57.8 & Negligible & Negligible \\
\hline
\end{tabular}

\section{B.1.2 Calciner Gaseous Effivent Cleanup}

- Ali radionuclide contaminates are assumed to behave as particulate.

- Seventy-five percent of the water vapor in the calciner off-gas is condensed in the venturi scrubber; the remaining water vapor in the off-gas is removed in the downdraft condenser and demister.

- The decontamination factor for radioactivity in the SC/ICM is $10^{3}$.

- The following equipment-piece decontamination factors are assumed: 


\begin{tabular}{|c|c|c|}
\hline Component & $\frac{\text { Decontamination }}{\text { Particulate }}$ & $\frac{\text { Factors }(a)}{N^{N O} x}$ \\
\hline$\overline{\text { Venturi scrubber }}$ & $10^{2}$ & $\overline{1}^{x}$ \\
\hline Cyclone & 1 & 1 \\
\hline Condenser & $10^{2}$ & 1 \\
\hline Demister & 1 & 1 \\
\hline Silica gel sorber & $10^{2}$ & 1 \\
\hline Deep-Bed gas filter & 10 & 1 \\
\hline${ }^{N O}{ }_{x}$ destructor & 1 & $10^{2}$ \\
\hline $\begin{array}{l}\text { Sintered filters } \\
\text { (spray calciner) }\end{array}$ & $10^{3}$ & 1 \\
\hline
\end{tabular}

(a) Adopted from Christian and Pence, 1977.

- A simplified process flowsheet is shown in Figure B.2, the process material balance is summarized in Table B.3.

\section{B.1.3 Recycle and Secondary Evaporation}

- A decontamination factor of $10^{6}$ for radiochemical activity in the evaporator and condenser is assumed.

- An overheads to bottoms ratio of 10 to 1 is assumed in both the recycle and secondary evaporators.

- A simplified process flowsheet is shown in figure 8.3 , the process material balance is summarized in Table B.4. 


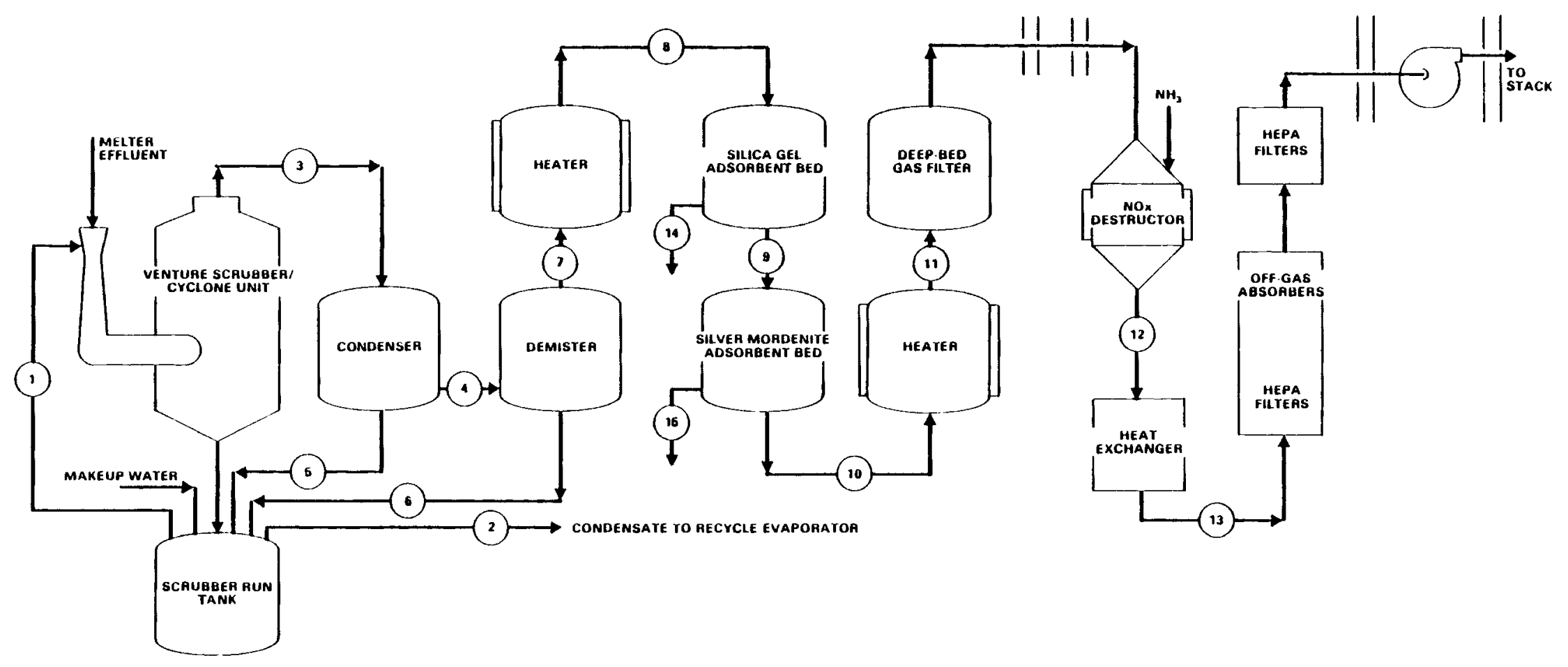

FIGURE B.2. Process Flowsheet (FS-2) for Calciner Gaseous Effluent Cleanup Equipment 
TABLE B.3. Material Balance for Calciner Off-Gas Treatment

\begin{tabular}{|c|c|c|c|c|c|c|}
\hline Operation & \multicolumn{6}{|c|}{ Spray Calciner Off-Gas Treatment } \\
\hline Stream Number & $I$ & 2 & 3 & 4 & 5 & 6 \\
\hline Description & $\begin{array}{l}\text { Venturi } \\
\text { Scrub } \\
\text { Solution }\end{array}$ & $\begin{array}{l}\text { Condensate } \\
\text { To Recycle } \\
\text { Evaporator }\end{array}$ & $\begin{array}{l}\text { Off Gas } \\
\text { from } \\
\text { Venturi } \\
\text { Cyclone }\end{array}$ & $\begin{array}{l}\text { Off Gas } \\
\text { From } \\
\text { Condenser }\end{array}$ & $\begin{array}{l}\text { Condensate } \\
\text { From } \\
\text { Condsenser }\end{array}$ & $\begin{array}{l}\text { Condensate } \\
\text { From } \\
\text { Demister }\end{array}$ \\
\hline \multicolumn{7}{|l|}{ Flow, $\mathrm{kg} / \mathrm{h}$} \\
\hline $\mathrm{H}_{2} \mathrm{O}$ & 9632 & 45.2 & 10.5 & 5.25 & 5.25 & 5.25 \\
\hline Air & & & 32.6 & 32.6 & & \\
\hline $\mathrm{NO}_{x}$ & & & 10.9 & 10.9 & & \\
\hline Totaî & 9632 & 45.2 & 54 & 48.8 & 5.25 & 5.25 \\
\hline Temperature, ${ }^{\circ} \mathrm{C}$ & 60 & 60 & 60 & 20 & 20 & 20 \\
\hline Density, $\mathrm{g} / \mathrm{cm}^{3}$ & 1.0 & 1.0 & 1.0 & & & \\
\hline Activity, $\mathrm{Ci}$ & $(1.7)$ & $(1.7)$ & $\left(1.7 \times 10^{-2}\right)$ & $\left(1.7 \times 10^{-4}\right)$ & $1.7 \times 10^{-4}$ & $1.7 \times 10^{-4}$ \\
\hline
\end{tabular}

\begin{tabular}{|c|c|c|c|c|}
\hline \multirow{2}{*}{$\begin{array}{l}\text { Operation } \\
\text { Stream Number }\end{array}$} & \multicolumn{4}{|c|}{ Spray Calciner off-Gas Treatment } \\
\hline & 7 & 8 & 9 & 10 \\
\hline Description & $\begin{array}{l}\text { Off Gas } \\
\text { From } \\
\text { Demister }\end{array}$ & $\begin{array}{l}\text { Off-Gas } \\
\text { to } \\
\text { Silica } \\
\text { Gel Bed }\end{array}$ & $\begin{array}{l}\text { Off Gas } \\
\text { to } \mathrm{Ag} \\
\text { Mordenite } \\
\text { Bed }\end{array}$ & $\begin{array}{l}\text { Off Gas } \\
\text { to } \\
\text { Heater }\end{array}$ \\
\hline \multicolumn{5}{|l|}{ Flow, kg/h } \\
\hline \multicolumn{5}{|l|}{$\mathrm{H}_{2} \mathrm{O}$} \\
\hline Air & 32.6 & 32.6 & 32.6 & 32.6 \\
\hline NO $x$ & 10.9 & 10.9 & 10.9 & 10.9 \\
\hline Totaî & 43.5 & 43.5 & 43.5 & 43.5 \\
\hline Temperature, ${ }^{\circ} \mathrm{C}$ & 20 & 80 & 80 & 35 \\
\hline \multicolumn{5}{|l|}{ Density, $\mathrm{g} / \mathrm{cm}^{3}$} \\
\hline Activity, $\mathrm{Ci}$ & $\left(1.7 \times 10^{-4}\right)$ & $\left(1.7 \times 10^{-4}\right)$ & $\left(1.7 \times 10^{-6}\right)$ & $\left(1.7 \times 10^{-6}\right)$ \\
\hline & Operation & Spray Calc & ciner off-Gas & Treatment \\
\hline & Stream Number & II & & \\
\hline & Description & $\begin{array}{l}\text { Off Gas to } \\
\text { NO } \\
\text { Destructor }\end{array}$ & $\begin{array}{l}\text { Off Gas } \\
\text { to } \\
\text { Heat } \\
\text { Exchanger }\end{array}$ & $\begin{array}{l}\text { Off Gas to } \\
\text { Atmosphere } \\
\text { Protection } \\
\text { System } \\
\end{array}$ \\
\hline & Flow, $\mathrm{kg} / \mathrm{h}$ & & & \\
\hline & $\mathrm{H}_{2} \mathrm{O}$ & & 6.5 & 6.5 \\
\hline & Air & 32.6 & 36.9 & 36.9 \\
\hline & No $x$ & 10.9 & 0.11 & 0.11 \\
\hline & Total & 43.5 & 43.5 & 43.5 \\
\hline & $\begin{array}{l}\text { Temperature, }{ }^{\circ} \mathrm{C} \\
\text { Density, } \mathrm{g} / \mathrm{cm}^{3}\end{array}$ & 200 & 300 to 500 & 35 \\
\hline & Activity, Ci & $\left(1.7 \times 10^{-7}\right.$ & $(1.7 \times 10$ & (1 \\
\hline
\end{tabular}




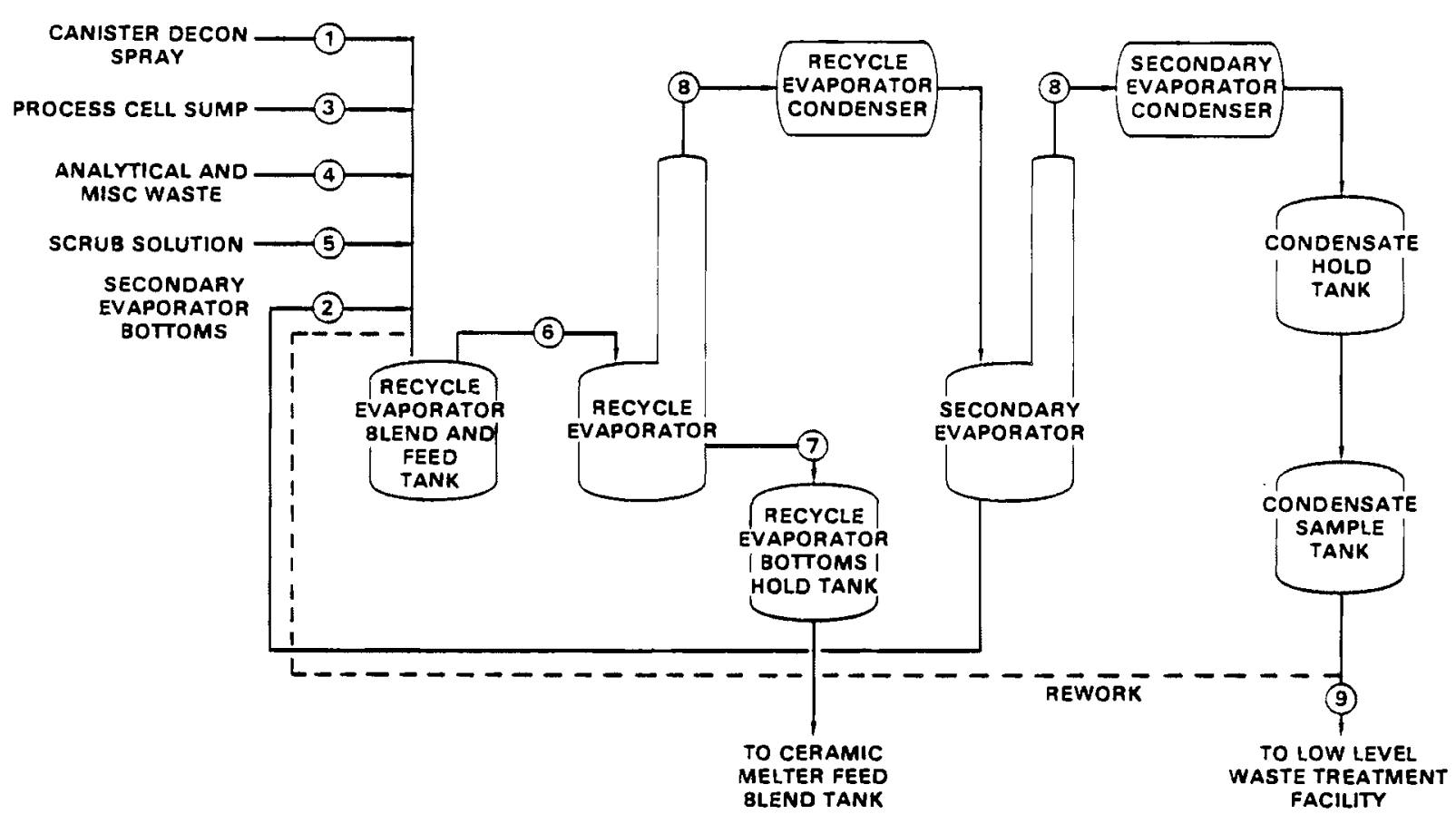

FIGURE B.3. Process Flowsheet (FS-3) for Recycle and Secondary Evaporation

TABLE B.4. Material Balance for Recycle and Secondary Evaporation

Operation

Recycle and Secondary Evaporation

\begin{tabular}{|c|c|c|c|c|c|}
\hline Stream Number & $\begin{array}{c}\text { Canister } \\
\text { Decontamination } \\
\text { Spray } \\
\end{array}$ & $\begin{array}{l}\text { Secondary } \\
\text { Evaporator } \\
\text { Bottoms } \\
\end{array}$ & $\begin{array}{c}3 \\
\text { Process } \\
\text { Cell } \\
\text { Sump } \\
\end{array}$ & $\begin{array}{l}4 \\
\text { Analytical and } \\
\text { Miscell laneous } \\
\text { Waste } \\
\end{array}$ & $\begin{array}{c}\frac{5}{\text { Off Gas }} \\
\text { Scrub } \\
\text { Solution }\end{array}$ \\
\hline \multicolumn{6}{|l|}{ Flow, $\mathrm{kg} / \mathrm{hr}$} \\
\hline $\mathrm{H}_{2} \mathrm{O}$ & 0.8 & 9.5 & 25 & 25 & 45.2 \\
\hline Total & 0.8 & 9.5 & 25 & 25 & 45.2 \\
\hline Temperature, ${ }^{\circ} \mathrm{C}$ & 80 & 100 & 35 & 35 & 60 \\
\hline Density, $\mathrm{g} / \mathrm{cm}^{3}$ & 1.0 & 1.0 & 1.0 & 1.0 & 1.0 \\
\hline Activity, Ci/L, (Ci) & Negligible & $\left(10^{-7}\right)$ & Negligible & Negligible & 0.037 \\
\hline
\end{tabular}

Operation

Recycle and Secondary Evaporation

\begin{tabular}{|c|c|c|c|c|c|}
\hline Stream Number & $\begin{array}{c}6 \\
\text { Feed to } \\
\text { Recycle } \\
\text { Evaporator } \\
\end{array}$ & $\begin{array}{c}7 \\
\text { Recycle } \\
\text { Evaporator } \\
\text { Bottoms } \\
\end{array}$ & $\begin{array}{c} \\
\text { Recycle } \\
\text { Evaporator } \\
\text { Overheads } \\
\end{array}$ & $\begin{array}{c} \\
\text { Secondary } \\
\text { Evaporator } \\
\text { Overheads } \\
\end{array}$ & $\begin{array}{c}0 \\
\text { Secondar } \\
\text { Evaporat } \\
\text { Condensa }\end{array}$ \\
\hline \multicolumn{6}{|l|}{ Flow, $\mathrm{kg} / \mathrm{hr}$} \\
\hline $\mathrm{H}_{2} \mathrm{O}$ & 105.5 & 10.5 & 95 & 85.5 & 85.5 \\
\hline Total & 105.5 & 10.5 & 95 & 85.5 & 85.5 \\
\hline Temperature, ${ }^{\circ} \mathrm{C}$ & 45 & 105 & 100 & 100 & 40 \\
\hline Density, $\mathrm{g} / \mathrm{cm}^{3}$ & 1.0 & 1.0 & 1.0 & 1.0 & 1.0 \\
\hline Activity, Ci/L, (Ci) & 0.016 & 0.16 & $\left(10^{-7}\right)$ & $\left(10^{-13}\right)$ & $\left(10^{-1}\right.$ \\
\hline
\end{tabular}




\section{B.2 WASTE FORM PROCESS SUMMARY}

The waste form process summary for solidification of the acidic Thorex waste in a borosilicate glass is given in Table B.5.

TABLE B.5. Waste Form Process Sumary for Solidification of the Acidic Thorex Waste in a Borosilicate Glass

Process Characteristics

Glass production rate, $\mathrm{kg} / \mathrm{h}$

Number of high-level-waste canisters

Activity per canister, $\mathrm{C} i$

Decay heat per canister, $W$

HLLW waste loading, wt\%

Processing campaign length, d
Acidic Thorex Waste

81.3

60

$4 \times 10^{4}$

112

15

60 


\section{B.3 STATUS OF TECHNOLOGY}

Thorium is recovered in the normal Thorex fuel cycle fuel-reprocessing flowsheet. Waste solidification development efforts have therefore been directed toward solidification of an acidic waste having a low thorium concentration. Nonradioactive development studies with these Thorex waste flowsheets have been conducted using the SC/ICM process. Cerium and other rare earth elements were used as a thorium substitute. The purpose of these tests however, was to evaluate chloride and fluoride corrosion on calciner and in-can melter construction materials (Hill 1978).

Thor ium was not recovered in the reprocessing of the Thorex fuel at the WNYNSC. The Thorex waste is therefore dominated by a high concentration of thorium, which presents unique problems in waste solidification. Thoria has a limited solubility in nuclear waste glasses. It is estimated that this solubility limit is comparable to other actinide elements. Walker and Riege (1979) indicate that actinide solubilities in high-alkaline borosilicate glasses range from 5 to 10\%. Glass development studies at PNL have shown that precipitation of cerium (an actinide substitute) and thorium from the borosilicate glass matrix will not significantly affect its chemical durability. However, there remain unanswered questions regarding the radiation stability of the waste form that could be degraded by the presence of the thoria crystals. For these reasons the Thorex waste loading is assumed to be $15 \mathrm{wt} \%$ (10\% Thoria) in the borosilicate glass matrix. 


\section{B.4 REFERENCES}

Christian, J. D., and D. T. Pence. 1977. Critical Assessment of Methods for Treating Airborne Effluents from High-Level Waste Solidification Processes. PNL-2486, Pacific Northwest Laboratory, Richland, Washington.

Hi11, O. F. 1978. AFCT/TFCT/ISFS Program Technical Progress Report, Apri1 1, 1978 - June 1978. PNL 2080-10, Pacific Northwest Laboratory, Richl and, Wasnington.

Walker, C. T., and U. Riege. 1979. "Compatibility of Actinides with HLW Borosilicate Glass: Solubility and Phase Formation." Published in Proceedings, Ceramics in Nuclear Waste Management, CONF -790420 , U.S. Department of Energy, Washington, D.C. 


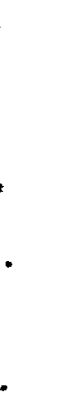


APPENDIX C

FLOWSHEET AND MATERIAL BALANCE SOLIDIFICATION OF COMBINED ALKALINE PUREX AND ACIDIC THOREX WASTE 


\section{CONTENTS}

C.1 DESCRIPTION OF OVERALL PROCESS FLOWSHEET

C.2 GENERAL FLOWSHEET BASES AND ASSUMPTIONS .

C.3 PROCESS AND FLOWSHEET DESCRIPTION . . . . . . . . . . . . . . . . . . c c.5

C.3.1 Blended Alkaline and Thorex Waste Vitrification . . . . . . . . c.5

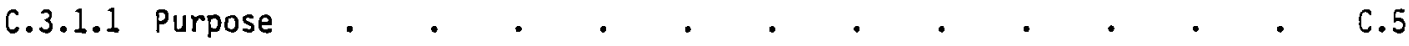

C.3.1.2 Process Description . . . . . . . . . . . . c.5

C.3.1.3 Process Flowsheet and Material Balance Bases . . . . . . C.7

C.3.2 Ceramic-Melter Effluent Cleanup . . . . . . . . . . . . . . C.7

C.3.2.1 Purpose . . . . . . . . . . . . . . . . . c.7

C.3.2.2 Process Description . . . . . . . . . . . . c.7

C.3.2.3 Process Flowsheet and Material Balance Bases . . . . . . C.10

C.3.3 Recycle and Secondary Evaporation . . . . . . . . . . c.10

C.3.3.1 Purpose . . . . . . . . . . . . . C.10

C.3.3.2 Process Description . . . . . . . . . . c.10

C.3.3.3 Process Flowsheet and Material Balance Bases . . . . . C.10

C.4 REFERENCES . . . . . . . . . . . . . . . . . . . . . . . . . . . . . . . . . 
C.1 Simplified Flow Diagram for Solidification of Combined Alkaline Purex

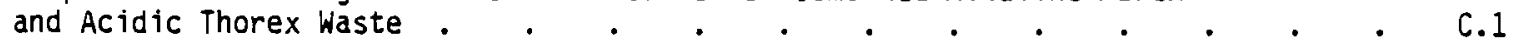

C.2 Process Flowsheet for Feed Blending, Vitrification and Canister Handing . . C.6

C.3 Process Flowsheet for Ceramic Melter Effluent Cleanup . . . . . . . . C.9

C.4 Process Flowsheet (FS-3) for Recycle and Secondary Evaporation . . . . $\quad$ C.12

TABLES

C.1 Estimated Blended Waste Composition, Alkaline Purex and Acidic Thorex Wastes . C.2

C.2 Anticipated Glass Former Mixture for Combined Alkaline and Thorex Waste $\quad$. C.4

C.3 Overall Process Sumary - Vitrification of Combined Alkaline Purex and

C.4 Material Balance for Vitrification of Combined Alkaline and Acidic Wastes . . C.8

C.5 Material Balance for Ceramic-Melter Effluent Cleanup . . . . . . . C.11

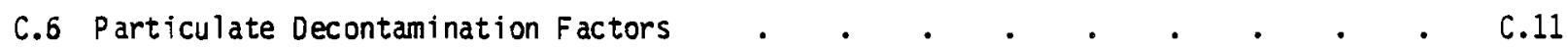

C.7 Material Balance for Recycle and Secondary Evaporation . . . . . . . . C.13 
FLOWSHEET AND MATERIAL BALANCE SOLIDIFICATION OF COMBINED ALKALINE PUREX AND ACIDIC THOREX WASTE

Presented in this appendix are the process flowsheets, process bases, assumptions, and chemical and radiochemical material balances for solidification of the combined alkaline Purex and acidic Thorex wastes. The reference high-level waste form is borosilicate glass. The reference waste form process is the liquid-fed ceramic melter.

\section{C.1 DESCRIPTION OF OVERALL PROCESS FLOWSHEET}

A simplified process flowsheet for solidification of the combined alkaline Purex and acidic Thorex waste is shown in Figure C.1. The alkaline waste and acidic Thorex wastes are blended in Tank 802. This blending process results in neutralization of the Thorex waste with possible precipitation of some metallic nitrates as hydroxides. Free hydroxide present in the alkaline waste is consumed by the hydronium ion in the Thorex waste and the metallic nitrates in the Thorex waste in the assumed order of thorium, iron, and aluminum. The homogenized alkaline waste is periodically transferred from the waste tank farm to a receipt tank located inside the chemical process cell. Water flushes following the waste transfers will dilute the waste blend. The chemical composition of the estimated waste blend is summarized in Table C.1.

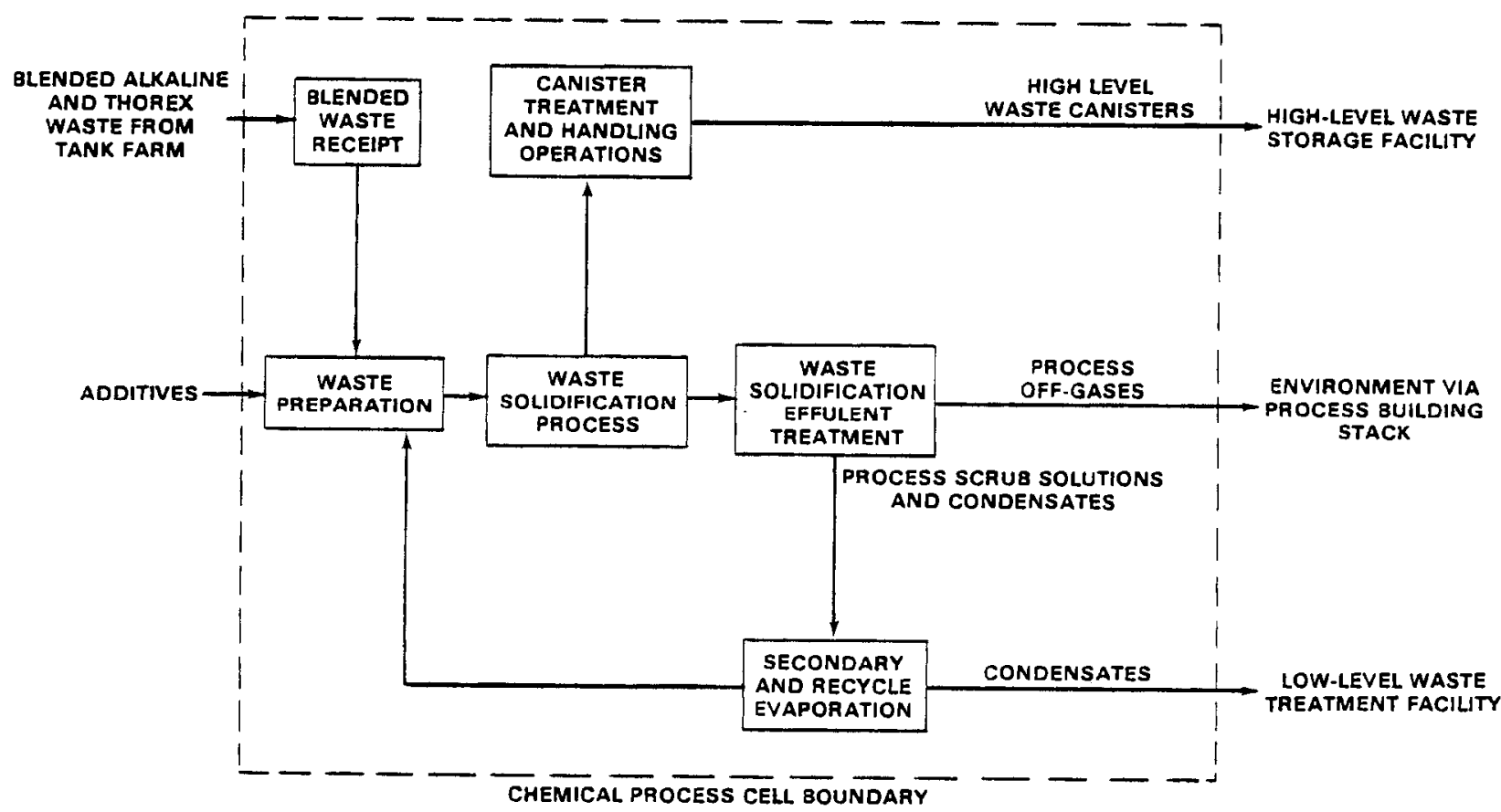

FIGURE C.1. Simplified Flow Diagram for Solidification of Combined Alkaline Purex and Acidic Thorex Waste 
TABLE C.1. Estimated Blended Waste Composition, Alkaline Purex and Acidic Thorex Wastes

\begin{tabular}{|c|c|c|c|}
\hline Component & $\begin{array}{c}\text { Concentration, } \\
\mathrm{g} / \mathrm{L}\end{array}$ & Oxide & $\begin{array}{c}\text { Equivalent Oxide } \\
\text { Concentration, } \\
\mathrm{g} / \mathrm{L}\end{array}$ \\
\hline$(\mathrm{Na}, \mathrm{K})_{2} \mathrm{SO}_{4}$ & 38.7 & $\mathrm{Na}_{2} \mathrm{SO}_{4}(\mathrm{a})$ & 38.7 \\
\hline$(\mathrm{Na}, \mathrm{K}) \mathrm{NO}_{3} / \mathrm{NO}_{2}$ & 487.6 & $\mathrm{Na}_{2} \mathrm{O}$ & 193.8 \\
\hline$(\mathrm{Na}, \mathrm{K}) \mathrm{Cl}$ & 0.22 & $\mathrm{NaCL}$ & 0.22 \\
\hline $\mathrm{Fe}(\mathrm{OH})_{3}{ }^{(d)}$ & 25.2 & $\mathrm{Fe}_{2} \mathrm{O}_{3}$ & 18.9 \\
\hline $\mathrm{FePO}_{4}$ & 12.9 & $\mathrm{Fe}_{2} \mathrm{O}_{3}, \mathrm{P}_{2} \mathrm{O}_{5}$ & 12.9 \\
\hline $\mathrm{Cr}(\mathrm{OH})_{3}$ & 2.6 & $\mathrm{Cr}_{2} \mathrm{O}_{3}$ & 1.9 \\
\hline $\mathrm{Cr}\left(\mathrm{NO}_{3}\right)_{3}$ & 1.1 & $\mathrm{Cr}_{2} \mathrm{O}_{3}$ & 0.34 \\
\hline $\mathrm{Ni}(\mathrm{OH})_{2}$ & 1.1 & NiO & 0.90 \\
\hline $\mathrm{Ni}\left(\mathrm{NO}_{3}\right)_{2}$ & 0.43 & NiO & 0.20 \\
\hline $\mathrm{A} 1(\mathrm{OH})_{3}{ }^{(\mathrm{d})}$ & 0.85 & $\mathrm{Al}_{2} \mathrm{O}_{3}$ & 0.55 \\
\hline $\mathrm{A} 1\left(\mathrm{NO}_{3}\right)_{3}$ & 0.41 & $\mathrm{Al}_{2} \mathrm{O}_{3}$ & 0.10 \\
\hline $\mathrm{AlF}_{3}$ & 0.68 & $\mathrm{~A} 1 F_{3}$ & 0.68 \\
\hline $\mathrm{RE}(\mathrm{OH})_{3}{ }^{(\mathrm{b})}$ & 0.70 & $\mathrm{RE}_{2} \mathrm{O}_{3}$ & 0.60 \\
\hline $\mathrm{FPSO}_{4}{ }^{(c)}$ & 0.54 & $\mathrm{FPSO}_{4}$ & 0.54 \\
\hline $\mathrm{FP}(\mathrm{OH})_{4}$ & 0.69 & $\mathrm{FP}_{2} \mathrm{O}_{4}$ & 0.60 \\
\hline $\mathrm{FP}_{2} \mathrm{O}_{3}$ & 0.19 & $\mathrm{FP}_{2} \mathrm{O}_{3}$ & 0.19 \\
\hline $\mathrm{Na}_{3} \mathrm{PO}_{4} \cdot 12 \mathrm{MOO}_{3}$ & 0.64 & $\mathrm{Na}_{3} \mathrm{PO}_{4} \quad 12 \mathrm{MoO}_{3}$ & 0.64 \\
\hline $\mathrm{MnO}_{2}$ & 0.96 & $\mathrm{MnO}_{2}$ & 0.96 \\
\hline $\mathrm{PuO}_{2}$ & 0.02 & $\mathrm{PuO}_{2}$ & 0.02 \\
\hline $\mathrm{Na}_{2} \mathrm{U}_{2} \mathrm{O}_{7}$ & 2.9 & $\mathrm{Na}_{2} \mathrm{O}, \mathrm{U}_{3} \mathrm{O}_{8}$ & $0.30,2.6$ \\
\hline Act. Oxide & 0.009 & Act. Oxide & 0.009 \\
\hline $\mathrm{Th}(\mathrm{OH})_{4}{ }^{(d)}$ & 5.8 & $\mathrm{ThO}_{2}$ & 5.1 \\
\hline \multicolumn{3}{|c|}{ TOTAL OXIDE EQUIVALENT } & $\begin{array}{c}280.7 \\
\text { gram oxide/1iter }\end{array}$ \\
\hline
\end{tabular}

\footnotetext{
(a) No sulfate decomposition assumed.

(b) Rare Earth Elements.

(c) Fission Product Elements

(d) Nitrates converted to hydroxides upon waste blending in order $\mathrm{Th}\left(\mathrm{NO}_{3}\right)_{3}, \mathrm{Fe}\left(\mathrm{NO}_{3}\right)_{3}, \mathrm{Al}\left(\mathrm{NO}_{3}\right)_{3}$.

(e) Volume of liquid waste plus rinse and process water, $2.3 \times 10^{6} \mathrm{~L}$.
} 
The alkaline waste blend in the feed receipt tank is combined with the recycle evaporator bottoms product, homogenized and sampled. Results from the sample analys is are used to select the optimum glass-former chemical mixture to be added to the waste blend and to assess the requirement for any other adjustments, such as dilution water to be added. The adjusted alkaline waste is transferred to one of three ceramic-melter feed tanks. The waste mixture is fed to the melter through an airlift where it is converted to a borosilicate glass. Glass flows from the melter into a receiving canister. After filling, the melter is tipped back and the glass flow stopped allowing the canister to be changed out.

Gaseous effluents from the vitrification system consist of water vapor, $\mathrm{NO}_{x}, \mathrm{SO}_{x}$ and potentially volatile fission product elements such as CS, TC, I and Sr. The water vapor is condensed along with the majority of the fission-product elements and recycled to the process. The $\mathrm{NO}_{\mathrm{x}}$ is chemically destroyed in a catalytic ammonia reactor. The $\mathrm{SO}_{\mathrm{x}}$ is not recovered in the reference process.

There is a large quantity of sulphate in the dried waste. Sulphate has a low solubility in borosilicate glass ( 1 to $2 \mathrm{wt} \%$ ). Sodium sulphate at concentrations in the borosilicate glass that exceed the solubility limit lead to the formation of a water soluble phase in which cesium and other alkali elements will concentrate. Two approaches are possible to prevent this situation. The first is to tailor the glass to accomodate the sodium sulphate by reducing the waste loading. The second approach is to add a strong reducing agent to the glass mixture that will volatilize the sulfate as sulfur dioxide. The second approach leads to high concentrations of sulfur dioxide in the effluent stream that must be removed by wet scrubbing and standard flue gas desulfurization techniques. The efficiency of these processes is at best $90 \%$. At these efficiencies assuming $90 \%$ of the sulfur dioxide volatilized the concentration of sulfur dioxide in the stack emissions (assuming a stack flow of 100,000 CFM) is too high to meet the National Air Quality Standard average annual release limit of $80 \mathrm{~g} / \mathrm{m}^{3}$ sulfur dioxide. The first approach will therefore be con- sidered for this waste treatment option.

\section{C.2 GENERAL FLOWSHEET BASES AND ASSUMPTIONS}

General bases used in development of the flowsheet and material balance for solidification of the alkaline Purex and acidic Thorex waste are presented in this section. These bases were derived from the overall project schedule requiring a three-year solidification campaign, existing environmental regulations, and process feasibility.

1. The alkaline Purex waste and acidic Thorex waste will be blended in Tank 802, the alkaline waste storage tank.

2. The volume of alkaline Purex waste blend is $2.12 \times 10^{6} \mathrm{~L}$ and the volume of acidic Thorex waste blend is $4.5 \times 10^{4} \mathrm{~L}$. Water is added to the blended waste in line flushes and in tank sluicing operations. The volume of water added during these operations is estimated to be $1.4 \times 10^{5} \mathrm{~L}$. The total waste volume to be treated is $2.3 \times 10^{6} \mathrm{~L}$. The waste composition of this blended mixture is given in Table C.1. 
3. The Plant efficiency factor is 0.60 for a three year period in which the high-level waste is solidified. This factor takes into account processing of the water added during line flushes and tank sluicing operations.

4. The flowrate of blended alkaline waste to the solidification facility is $150 \mathrm{~L} / \mathrm{h}$.

5. The composition of the glass formers added to the homogenized waste assuming an ideally blended waste is sumarized in Table C.2. The waste loading is 18.0 wt\% in the glass. The waste loading is limited by the high sodium content of the waste. The $\mathrm{Na}_{2} \mathrm{O}$ content of the waste glass is $14.4 \mathrm{wt} \%$. The sulfate loading in the glass is $1.8 \mathrm{wt} \%$ which is considered to be within its solubility limit.

6. Three liquid-fed ceramic melters are used in the solidification campaign. These melters are required based upon glass production rates demonstrated in simulated radioactive waste liquid feed ceramic melters. Each melter system has a liquid-waste feed system. All other process operations such as feed blending, canister handling and ceramic-melter effluent cleanup use common equipment. The material balance reflects the combined material flows for all three melters.

7. Ninety-nine weight percent of the $\mathrm{NO}_{x}$ evolved from vitrification operations is destroyed using an ammonia burner.

8. The silica-gel and Ag-mordenite sorber beds are discharged into the ceramic-melter feedmakeup tank once per year. The sorber bed material is incorporated into the vitreous product.

9. Process condensates are further decontaminated in the Low-Level Waste Treatment Facility before being discharged to the environment.

10. The flowsheet is presented as a simplified line diagram. Only major flow paths are indicated.

11. The flowsheet is based upon proven technology, wherever possible.

TABLE C.2. Anticipated Glass Former Mixture for Combined Alkaline and Thorex Waste

\begin{tabular}{lrr} 
Component & & wt\% \\
\cline { 1 - 1 } $\mathrm{SiO}_{2}$ & & 63.6 \\
$\mathrm{~B}_{2} \mathrm{O}_{3}$ & & 12.5 \\
$\mathrm{Li}_{2} \mathrm{O}$ & & 1.4 \\
$\mathrm{CaO}$ & 2.6 \\
$\mathrm{TiO}_{2}$ & 10.4 \\
$\mathrm{MgO}$ & 2.6 \\
$\mathrm{BaO}$ & 1.4 \\
$\mathrm{ZrO}_{2}$ & $\frac{5.5}{}$ \\
& & 100.00
\end{tabular}


12. Glass canisters are $2 \mathrm{ft}(.60 \mathrm{~m})$ in diameter with an overall height of $10 \mathrm{ft}(3.0 \mathrm{~m})$. The fill height of the canister is $8.5 \mathrm{ft}(2.55 \mathrm{~m})$. The volume of fill is $712 \mathrm{~L}$.

13. The radiochemical and chemical inventory of the wastes stored in Tank 802 and Tank 8D4 is based upon information provided in Section 4.0 .

14. Dilution of process streams due to jet transfers is not included within the material bal ance.

15. Material balance flow rates are based upon continuous operation.

\section{C.3 PROCESS AND FLOWSHEET OESCRIPTION}

The process operations for solidifying the combined alkaline and acidic Thorex waste are presented in this section. The following information is provided for each unit process operation. The status of development of the process has been discussed in other sections of the report and will not be repeated here (Sections 6,8 and 9, and Appendix $A$ ).

1. Unit process purpose

2. Description of unit process

3. Flow diagram of process

4. Assumptions used for material balance

5. Chemical and radiochemical material balance

\section{C.3.1 Blended Alkaline and Thorex Waste Vitrification}

\section{C.3.1.1 Purpose}

The purpose of the feed blending, waste vitrification, and canister-handling operations are to prepare the nuclear waste for solidification, to produce a vitreous waste form product contained within canisters, and to process the high-level waste form canister after filling operations.

\section{C.3.1.2 Process Description}

Shown in Figure $\mathrm{C.2}$ is the flowsheet for feed-blending operations, vitrification operations, and the canister-handling operations. The alkaline Purex and acidic Thorex wastes are blended in Tank 8D2, the alkaline Purex storage tank. Periodically this waste stream is transferred from Tank $8 \mathrm{D} 2$ to Tank $8 \mathrm{D} 4$, the Thorex waste tank, and then into the sludge-5lurry receipt tank located inside the Chemical Process Cell. A water flush of the transfer line flows all waste transfers. When required, the alkaline-sludge slurry having an assumed composition shown in Table C.I is transferred to the feed-blend tank. Here the alkaline waste is combined with recycle evaporator bottoms, glass-forming chemicals and any feed-adjustment chemicals or dilution water required to form a high-quality vitreous product.

Periodically blended waste is transferred to one of three ceramic-melter feed tanks. In these tanks the waste mixture is kept well mixed and continually recirculated through an airlift feed 5ystem. During normal operations the waste blend is continually fed to the jouleheated liquid-fed ceramic melter that converts the liquid waste blend into a vitreous product that overflows from the melter into the product-receiving canister. 


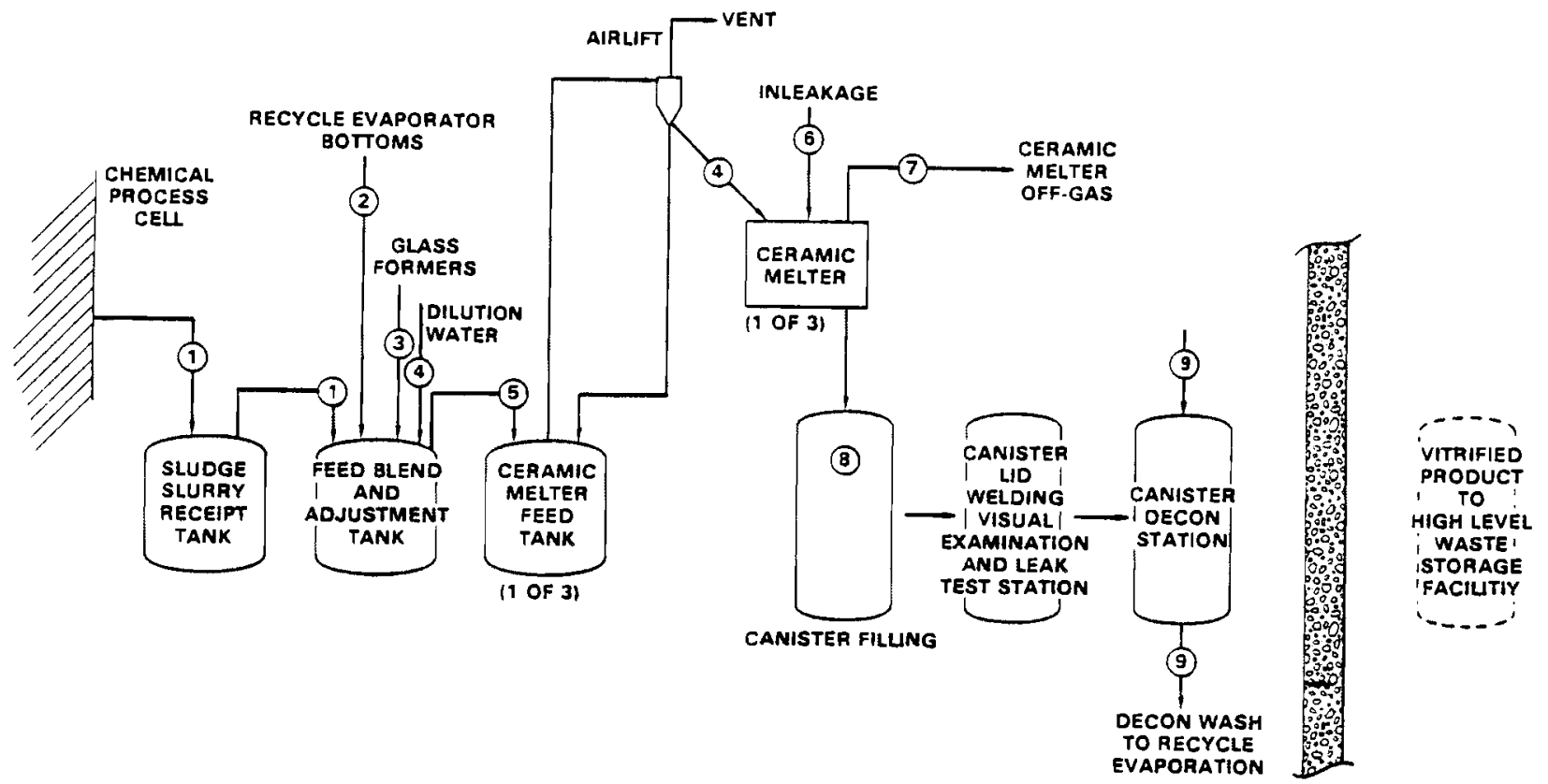

FIGURE C.2. Process Flowsheet for Feed Blending, Vitrification and Canister Handling (only one ceramic melter/feed system shown)

Once filled, the high-level waste canister is decoupled from the ceramic melter. This decoupling is accomplished by tilting the melter away from the canister, which discontinues the glass flow. Liquid waste is still fed to the melter; however, the molten glass that is formed is allowed to collect within the melter cavity. After decoupling, the canister is moved out from the melter on the canister hold cart. The canister is then transferred to the canister lid-welding station where a lid is welded on the canister, and leak testing is done. Visual inspection of the weld and the entire canister is done. The canister is finally transferred to a decontamination station where the bulk of smearable contamination is removed before being placed upon the transfer cart. The transfer cart is used for canister transfers between the Equipment Decontamination Room and the Chemical Process Cell. In the Equipment Decontamination Room the canister is further decontaminated before being transferred to interim storage at the High-Level Waste Storage Facility. The overall waste form process summary is shown in Table C.3.

TABLE C.3. Overall Process Sumary - Vitrification of Combined Alkaline Purex and Acidic Thorex waste

$\begin{array}{ll}\text { Glass Production Rate ( } 3 \text { melters), } \mathrm{kg} / \mathrm{h} & 190 \\ \text { No. of Canisters Produced } & 1500 \\ \text { Weight of Glass per Canister, } \mathrm{kg} & 1993 \\ \text { Activity in Each Canister, Ci } & 2.3 \times 10^{4} \\ \text { Heat Content of Each Canister, W } & 65\end{array}$




\section{C.3.1.3 Process Flowsheet and Material Balance Bases}

The bases for the material balance for the feed blending, vitrification, and canisterhandling operations are presented below. A simplified material balance for these process operations is summarized in Table C.4.

- Feedrate of alkaline waste blend to the sludge slurry receipt tank is $150 \mathrm{~L} / \mathrm{h}$.

- The alkaline waste blend is assumed to be homogeneous and to have the composition summarized in Table C.1.

- The glass-former mixture for the vitreous product, assuming a homogeneous feed, is surmarized in Table C.2.

- The waste loading in the vitreous product is $18 \mathrm{wt \%}$.

- The high-level waste canister has a fill capacity of $712 \mathrm{~L}$ and contains $1993 \mathrm{~kg}$ of glass with a density of $2.8 \mathrm{~g} / \mathrm{cm}^{3}$.

- A decontamination factor of 200 for radioactivity is assumed in the vitrification process.

- Steam spray for initial canister decontamination consumes $20 \mathrm{~kg}$ of steam per can ister.

\section{C.3.2 Ceramic-Melter Effluent Cleanup}

\section{C.3.2.1 Purpose}

The purpose of the ceramic-melter effluent-cleanup system is to decontaminate radiochemical and chemical effluents from the ceramic-melter off gas before the off gas is released to the atmosphere.

\section{C.3.2.2 Process Description}

Shown in Figure $\mathrm{C.} 3$ is the process flowsheet for the ceramic-melter off-gas treatment system. The ceramic-melter effluent treatment system is designed to decontaminate the ceramicmelter off gas through operations of condensation, scrubbing, absorption, and filtration. The melter effluent, which contains water vapor, $\mathrm{NO}_{x}$, and volatile fission products, is first passed through a venturi scrubber/jet scrubber, demister and down-draft condenser, which condenses and removes essentially all of the water vapor and radiochemical activity from the melter off gas. The wet-scrub solution containing the radioactive contaminates is fed to the recycle evaporator and eventually recycled to the melter feed-blend tank. It is assumed that the sulfate does not decompose or have appreciable volatility.

The off gas further passes through two dry-sorber beds that remove any volatile fission products from the gas stream. A deep-bed gas filter is used to prevent any potential particulate contamination in the off gas from leaving the chemical process cell. Heaters are located before the sorber beds and filter to improve sorbtion-bed efficiency and prevent condensation.

The off gas has essentially all water vapor and radiochemical activity removed before it leaves the process cell. $\mathrm{NO}_{\mathrm{X}}$ originating from nitrate decomposition is still present however, this $\mathrm{NO}_{x} \mathrm{NO}_{\mathrm{x}}=1 / 2\left(\mathrm{NO}+\mathrm{NO}_{2}\right)$ is chemically reduced to nitrogen with the use of amonia gas 
TABLE C.4. Material Balance for Vitrification of Combined Alkaline and Acidic Wastes

\begin{tabular}{|c|c|c|c|c|c|c|c|c|c|}
\hline \multicolumn{10}{|c|}{ if ication, $\mathrm{C}$ anister Handling } \\
\hline Stream Number & & 2 & 3 & 4 & 5 & 6 & 7 & 8 & 9 \\
\hline Description & $\begin{array}{l}\text { Blended } \\
\text { Waste } \\
\text { Receipt } \\
\end{array}$ & $\begin{array}{c}\text { Recycle } \\
\text { Evaporator } \\
\text { Bottoms } \\
\end{array}$ & $\begin{array}{l}\text { Glass- } \\
\text { Former } \\
\text { Solids }\end{array}$ & $\begin{array}{l}\text { Dilutjon } \\
\text { Water }(b)\end{array}$ & $\begin{array}{l}\text { STurry(a) } \\
\text { to Ceranjc } \\
\text { Melter } \\
\end{array}$ & $\begin{array}{c}\text { Inleakage (a) } \\
\text { Air } \\
\end{array}$ & $\begin{array}{c}\text { Ceramic(a) } \\
\text { Melter } \\
\text { Off Gas } \\
\end{array}$ & $\begin{array}{c}\text { Glass } \\
\text { Production (a) } \\
\text { Rate } \\
\end{array}$ & $\begin{array}{c}\text { Decont amination } \\
\text { Spray } \\
\end{array}$ \\
\hline \multicolumn{10}{|l|}{ Flow, $\mathrm{kg} / \mathrm{h}$} \\
\hline Salt & 78.5 & & & & 78.5 & & & & \\
\hline Solids & 6.27 & & 154 & & 160.3 & & & 190 & \\
\hline $\mathrm{H}_{2} \mathrm{O}$ & 150 & 47.6 & & 182.4 & 380 & & 380 & & 3.2 \\
\hline Air & & & & & & 60 & 60 & & \\
\hline${ }^{N} O_{x}$ & & & & & & & 34.3 & & \\
\hline Total & 234.7 & 47.6 & 154 & 182.4 & 464.8 & 60 & 474.3 & 190 & 3.2 \\
\hline Temper at ure, ${ }^{\circ} \mathrm{C}$ & 35 & 60 & 35 & 35 & 35 & 35 & 300 & 900 & \\
\hline Density, $\mathrm{g} / \mathrm{cm}^{3}$ & 1.56 & 1.0 & $3.0(\mathrm{bulk})$ & & 1.6 & & & $2.8\left(35^{\circ} \mathrm{C}\right)$ & 1.0 \\
\hline Flow, L/h & 150 & 47.6 & & 182.4 & 380 & & & 68 & \\
\hline Activity, Ci/L, (Ci) & 14.41 & 0.23 & & & 5.9 & & $(10.8)$ & 177 & \\
\hline Heat, W/L & 0.04 & 0 & & & 0.018 & & & 0.50 & \\
\hline
\end{tabular}

(a) Slurry to three ceramic melters.

(b) Water required to dilute feed to $500 \mathrm{~g}$ oxide solid equivalent/L. 


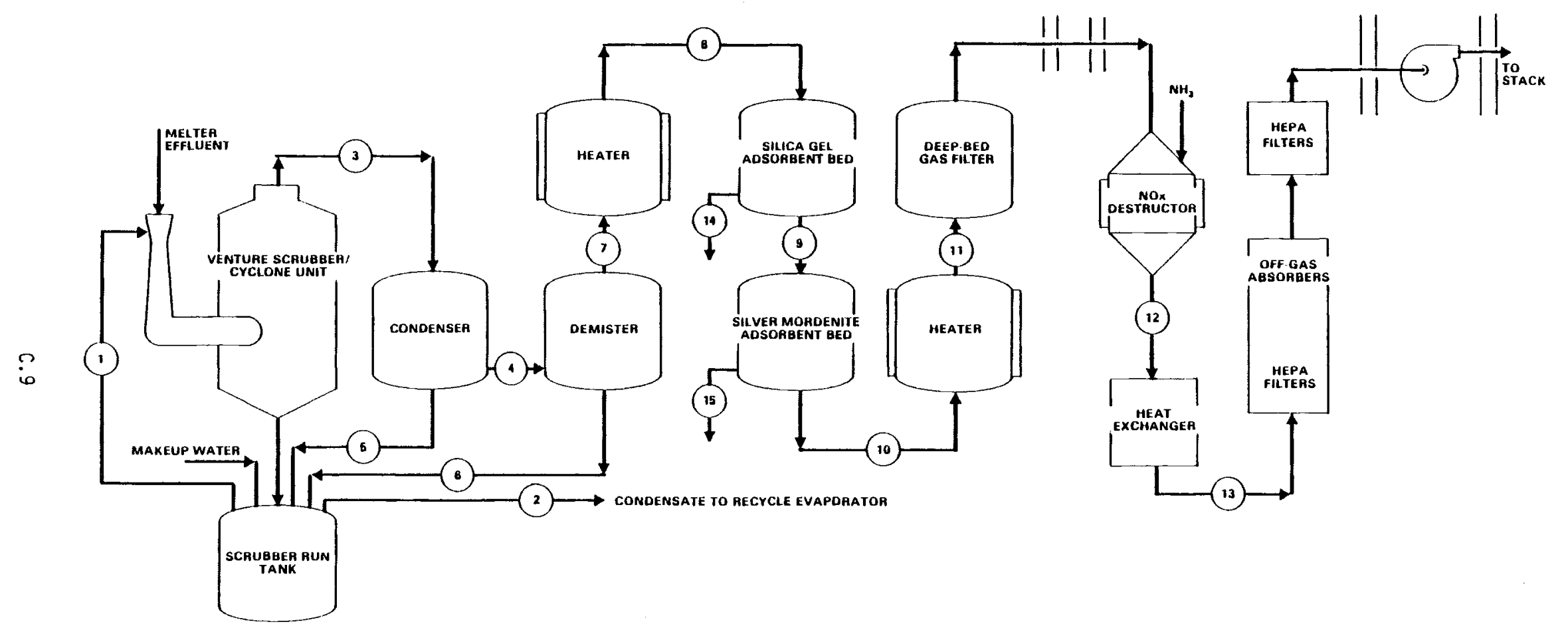

FIGURE C.3. Process Flowsheet for Ceramic-Melter Effluent Cleanup 
in a chemical reactor before being released to the environment. Additional filtration is anticipated for the off gas leaving the $\mathrm{NO}_{x}$ destructor before it is released to the building stack.

\section{C.3.2.3 Process Flowsheet and Material Balance Bases}

The bases for the material balance for the ceramic-melter effluent-cleanup system are presented below. A simplified material balance for these process operations is summarized in Table C.5

- $75 \mathrm{wt} \%$ of the water in the gaseous effluent is condensed in the venturi scrubber, the remaining water vapor is condensed and removed in the downdraft condenser and the demister.

- Radiochemical contaminates in the ceramic melter off gas are assumed to behave as particulate.

- Particulate decontamination factors for the process equipment pieces comprising the vitrification system are summarized in Table C. 6 .

- The dry sorber beds are annually discharged to the ceramic melter.

\section{C.3.3 Recycle and Secondary Evaporation}

\section{C.3.3.1 Purpose}

The purpose of the recycle and secondary evaporation process is to dewater and concentrate the radiochemical activity in the off gas scrub solution and various process waste streams.

\section{C.3.3.2 Process Description}

The process flowsheet for the recycle and secondary evaporation process is shown in Figure C.4. Feed to the recycle evaporator is comprised of canister-decontamination spray, liquid from the process-cell sump, analytical laboratory wastes, venturi scrub solution, and secondary evaporator bottoms. This blended feed mixture is fed in batches to the recycle evaporator. Overheads form the feed to the secondary evaporator; the bottoms product is recycled to the ceramic melter feed tank. The secondary evaporator provides final condensate decontamination before the condensate is sent to the Low Level Waste Treatment Facility. Off-spec secondaryevaporator condensate is sent to the recycle-evaporator feed-blend tank.

\section{C.3.3.3 Process Flowsheet and Material Balance Bases}

Bases for the material balance for the recycle and secondary-evaporation process are summarized below. A simplified material balance for these process operations is summarized in Table C.7.

- Liquid accumulation in the process-cell sump is assumed to be $25 \mathrm{~L} / \mathrm{h}$.

- Analytical and other wastes added to the process are assumed to be at a rate of $25 \mathrm{~L} / \mathrm{h}$. 
TABLE C.5. Material Balance for Ceramic-Melter Effluent Cleanup

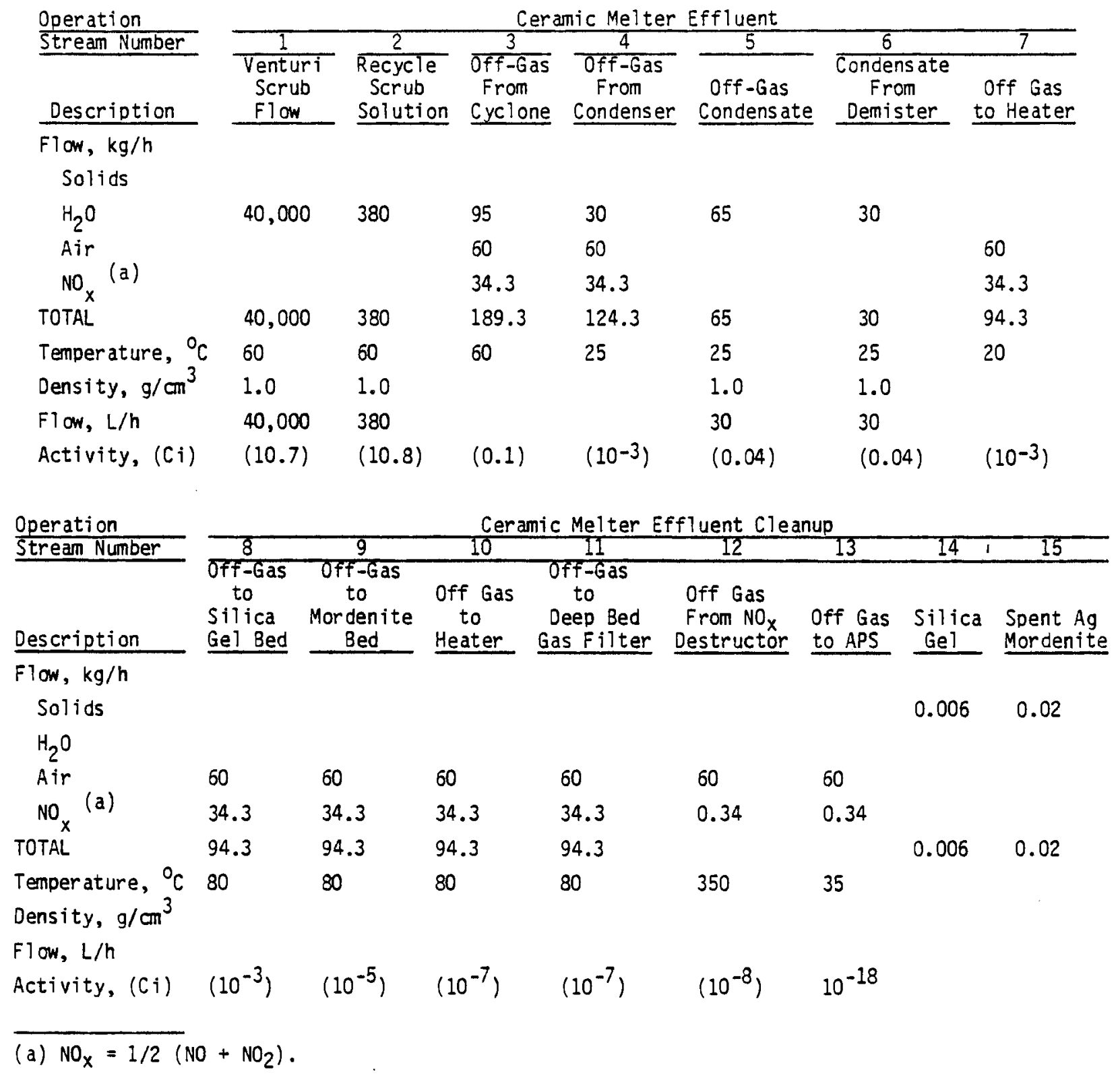

TABLE C.6. Particulate Decontamination Factors

\begin{tabular}{|c|c|}
\hline Equipment Piece & DF \\
\hline Ceramic Melter & 200 \\
\hline Venturi Scrubber/Cyclone & 100 \\
\hline Condenser & 100 \\
\hline Demister & 1 \\
\hline Fission Product Sorber Beds (2) & 100 \\
\hline $\mathrm{NO}_{x}$ Destructor & 1 \\
\hline Prefilter, Deep Bed Gas Filter & 10 \\
\hline
\end{tabular}




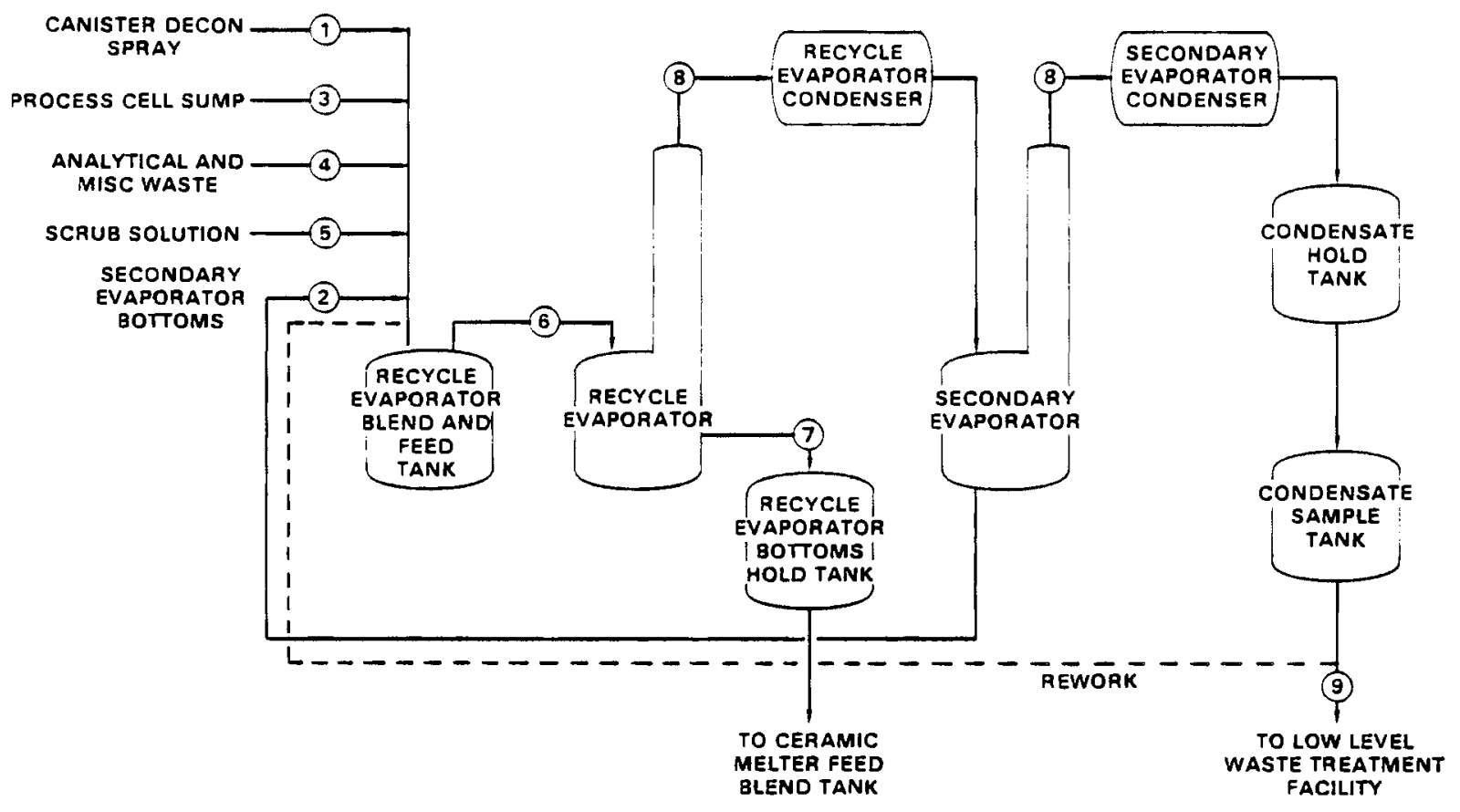

FIGURE C.4. Process Flowsheet (FS-3) for Recycle and Secondary Evaporation

- The decontamination factor provided for radioactivity in both the recycle and secondary evaporators and their reflux condensers is $10^{6}$.

- The split between overheads and bottoms product in both the recycle and secondary evaporator is assumed 9 to 1 . 
TABLE C.7. Material Balance for Recycle and Secondary Evaporation

\begin{tabular}{|c|c|c|c|c|c|c|c|c|c|c|c|}
\hline & & Operation & & & Recycle & and Secondary & rocess Lig & uid Evapora & ion & & \\
\hline & & Stream Number & 1 & 2 & $\frac{3}{3}$ & 4 & 5 & 6 & 7 & 8 & 9 \\
\hline & & Description & $\begin{array}{c}\text { Canister } \\
\text { Decontamination } \\
\text { Spray } \\
\end{array}$ & $\begin{array}{l}\text { Secondary } \\
\text { Evaporator } \\
\text { Bottoms } \\
\end{array}$ & $\begin{array}{c}\text { Process } \\
\text { Cell } \\
\text { Sumps } \\
\end{array}$ & $\begin{array}{c}\text { Analytical } \\
\text { and } \\
\text { Miscellaneous } \\
\text { Wastes } \\
\end{array}$ & $\begin{array}{l}\text { Scrub } \\
\text { Solution }\end{array}$ & $\begin{array}{l}\text { Feed to } \\
\text { Recycle } \\
\text { Evaporator }\end{array}$ & $\begin{array}{l}\text { Recycle } \\
\text { Evaporator } \\
\text { Bottoms } \\
\end{array}$ & $\begin{array}{l}\text { Recycle } \\
\text { Evaporator } \\
\text { Overheads }\end{array}$ & $\begin{array}{l}\text { Secondary } \\
\text { Evaporator } \\
\text { Overheads }\end{array}$ \\
\hline & & Flow, $\mathrm{kg} / \mathrm{h}$ & & & & & & & & & \\
\hline & & $\mathrm{H}_{2} \mathrm{O}$ & 3.2 & 42.8 & 25 & 25 & 380 & 476 & 47.6 & 428.4 & 385.6 \\
\hline & & TOTAL & 3.2 & 42.8 & 25 & 25 & 380 & 476 & 47.6 & 428.4 & 385.6 \\
\hline & & Temperature, ${ }^{\circ} \mathrm{C}$ & 35 & 90 & 35 & 35 & 60 & 35 & 60 & 100 & 100 \\
\hline & " & Density, $g / c c$ & 1.0 & 1.0 & 1.0 & 1.0 & 1.0 & 1.0 & 1.0 & 1.0 & 1.0 \\
\hline & & Flow, L/h & 3.2 & 42.8 & 25 & 25 & 380 & 476 & 47.6 & 428.4 & 385.6 \\
\hline & & Activity, $\mathrm{Ci} / \mathrm{L}$ & & 0.23 & & & 0.028 & 0.023 & 0.23 & $2 \times 10^{-4}$ & $2 \times 10^{-8}$ \\
\hline
\end{tabular}




\section{C.4 REFERENCES}

Buelt, J. L., and C. C. Chapman. 1979. Siurry Feeding of Nuclear Waste to an Electric Glass Melter. PNL-SA-7571, Pac if ic Northwest Laboratory, Richland, Washington.

Department of Energy. 1978. Western New York Nuclear Service Center Companion Report. TID28905-2, U. S. Department of Energy, Washington, D.C.

Godbee, H. W. 1973. Use of Evaporation for the Treatment of Liquids in the Nuclear Industry. ORNL-4790, Oak Ridge National Laboratory, Oak Ridge, Tennessee.

Holton, L. K., et al. 1980. "Alternatives for Vitrification of Existing Commercial High-Level Waste by Soray Caicination/In-Can Melting." Presented at ANS Topical Meeting, Waste Management 1980, March 10-14, Tucson, Arizona.

Radian Corporation. 1980. Investigation of High SO, Removal Design and Economics, Volume 1: Design. EPRI-CS-1439, Electric Power Research Institute, Palo Alto, California.

Rau, J. G. and D. C. Wooten. 1980. "Air Quality Impact Analysis." In Environmental Impact Analys is Handbook, Do. 3-22, MeGraw Hill Book Company, New York.

Tooley, F. V. 1974. The Handbook of Glass Manufacture. Vol. 1, p. 7, Books for Industry Inc., New York. 
APPENDIX D

TECHNICAL RANKING CRITERIA FOR WASTE TREATMENT AND WASTE FORM PROCESSES 


\section{CONTENTS}

o.1 RANKING CATEgORIES

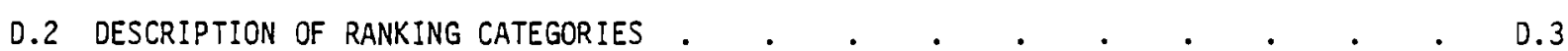

D.3 SUMMARY OF ALTERNATIVE PROCESS RANKINGS . . . . . . . . . . . . . . . D.11

D.4 REFERENCES . . . . . . . . . . . . . . . . . . . . . . . 0.16 
$\underline{T A B L E S}$

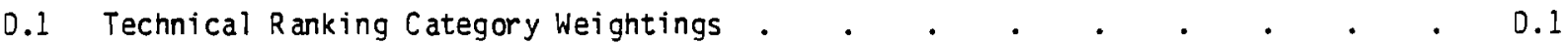

0.2 Ranking Categories and Subcategories for the Technical Ranking of the Process Alternatives...$\quad 0.2$

D.3 Technical Ranking of Salt/Sludge Separation Process with Alternative Waste Form Processes

0.4 Technical Ranking of Combined Waste Form Process with Alternative Waste Form Processes . . . . . . . . . . . . 0.13

0.5 Technical Ranking for Cambined Waste Process Approach with Interim Waste Form Processes 


\section{TECHNICAL RANK ING CRITERIA FOR WASTE TREATMENT AND WASTE FORM PROCESSES}

A technical ranking has been carried out on the alternative waste treatment and waste form processes considered for solidification of WNYNSC high-level nuclear wastes. A relatively simple rating structure has been used to quantify ranking judgments on the various processes in a manner which considers all alternatives on an equal basis. The format of the ranking system is such that other users of the study will be able to apply their own weightings to the various categories.

\subsection{RANKING CATEGORIES}

Several other comparative-ranking studies have been carried out for various high-level waste forms and associated processes (Ross et al. 1979, Stone et al. 1980, E. R. Johnson 1980). The present study uses the framework of these earlier studies in establishing an appropriate methodology for ranking.

There are five principal ranking categories for the waste treatment/terminal waste form process approaches, and six principal ranking categories for the interim waste form process approaches. The maximum weightings for each of these ranking categories is summarized in Table 0.1.

The maximum weighting of each of the ranking categories is reflective of the relative importance of each category to satisfy the bases of the study. The study bases require that the waste solidification process be operable at the plant in 1987, and that implementation of the waste solidification approaches into existing WNYNSC facilities be maximized. Processes that are simple, requiring a minimal development program, and which can be easily implemented into the existing WNYNSC facility are therefore most able to satisfy these requirements. Increased emphasis has therefore been placed on process characteristics, technology availability, facility implementation, and final waste form compatibility (for interim waste form processes on ly).

TABLE D.1. Technical Ranking Category Weightings

\begin{tabular}{|c|c|c|}
\hline Ranking Category & $\begin{array}{l}\text { Terminal Waste } \\
\text { Form Processes } \\
\text { (Maximum) }\end{array}$ & $\begin{array}{l}\text { Inter im Waste } \\
\text { Form Processes } \\
\text { (Maximum) } \\
\end{array}$ \\
\hline Process characteristics & 25 & 20 \\
\hline Waste form characteristics & 20 & 10 \\
\hline Technology availability & 20 & 20 \\
\hline Safety and environmental & 10 & 10 \\
\hline Facility implementation & 25 & 20 \\
\hline \multirow[t]{2}{*}{ Final waste form compatibility } & NA & 20 \\
\hline & 100 & 100 \\
\hline
\end{tabular}


The safety and environmental-ranking category has a relatively low ranking weight when compared to the other categories. This low ranking weight reflects the requirement that the processes be engineered safely. Only potential accidents that could impose a challenge to the engineered safety systems are considered.

Each of the ranking categories is comprised of subcategories. These categories and subcategories are sumarized in. Table 0.2. The subcategories are rated on a 1 to 10 scale and then normalized to give the total weight assigned to the ranking category. The principal ranking category weights, normalized to 100 , are then added to provide the relative technical ranking of the process alternatives considered.

TABLE 0.2. Ranking Categories and Subcategories for the Technical Ranking of the Process Alternatives

I. Process Characteristics

- Process Complexities

- Process Control

- Process Logistics

- Maintenance Requirements

- Feasibility for Production Use

- Quality Control

II. Waste Form Characteristics

- Sensitivity to Feed Variations

- Waste Form Stability (Radiation, Thermal, Environmental)

- Waste Volume

- Leach Resistance

III. State of Development for Process

- State of Development of Waste Form

- State of Process Development

- State of Equipment Development

IV. Safety Considerations

- Transportation Safety of Waste Form

- Dispersive Driving Forces in Process

- Chemical Toxicity of Reagents

- Personnel Exposures

- Secondary Wastes Generated From Process

V. Facility Implementation

- Feasibility of Process to Fit in Existing Facilities

- Modifications and Upgrading Required to Process Building to Implement Process

- Service Requirements of Process

VI. Final Waste Form Process Compatibility

- Process Complexity to Prepare Interim Waste Form for Processing at DOE Site

- Effect on Terminal Waste Form Volume 


\section{D.2 DESCRIPTION OF RANKING CATEGORIES}

\section{PROCESS CHARACTERISTICS}

\section{PROCESS COMPLEXITY}

10 Process is simple with few moving parts, all processing steps except canister changeout are continuous.

7 Process characterized by one of the following: many batch processes, high temperatures and high pressures, or many mechanical operations.

5 Process characterized by two of the following: many batch processes, high temperatures and pressures, or many mechanical operations.

3 Process characterized by three of the following: many batch processes, high temperatures, high pressures, or many mechanical operations (excluding canister changeout).

1 Process characterized by many batch operations. Process has batch operations at high temperatures and high pressures. Process has many mechanical operations (excluding canister changeout).

\section{PROCESS CONTROL}

10 Minimal process controls on material flows, composition, and processing parameters such as temperature and pressure required. Process can accommodate variation in operating parameters.

7 Major process control required. Process can accommodate some variations in operating parameters.

5 Complex process controls required. Accurate control and analyses of process system required.

3 Complex process controls required. Accurate control of high pressures, temperatures, and compositions required to assure quality product.

1 Complex control system required. Failure to achieve control variable can result in poor quality product. Failure of control system can result in severe equipment damage and potential safety concerns. 


\section{PROCESS LOGISTICS}

10 Unit processes within overall process can be easily sequenced to avoid conflict in material movements within the cell (via crane), conflicts in operating manoower, and replacement of failed process equipment such that the overall plant performance is not affected.

5 The unit processes can be sequenced to avoid conflicts in material movements, operating manpower. Replacement of failed equioment will lead to mismatch of process sequencing and affect the overall process performance.

1 The unit processes cannot be sequenced easily. Missed or delayed event in process sequence will affect overall plant performance leading to shutdown of one or more unit process systems.

\section{MAINTENANCE REQUIREMENTS}

10 Process equipment is simple with no rotating equipment pieces. All equipment pieces have a long service life.

7 Process equipment employs pumps, motors and other moving equipment which is easily and remotely replaceable.

5 Process equipment requires complex mechanical controls. Equipment replacement is frequent but $c$ an be easily and remotely replaceable.

3 Process equipment is mechanicaliy complex with a short service lifetime. Equipment requires frequent adjustment and/or lubrication. Equipment replacement may be difficult.

1 Equipment must be decontaminated and maintained in place. Equipment service lifetime is short.

\section{FEASIBILITY FOR PRODUCTION USE}

10 Process and equipment are relatively simple. Process can be adapted to full scale production use.

7 Process and equipment are relatively simple. Process includes one or more process steps in which reliability of long-term continuous operation is difficult.

5 Process and equipment are complex. Process includes many process steps in which the long-term reliability of the process is difficult. 
3 Process and equipment are complex. Process includes many production steps which are not practicabie for reliable production use.

1 Equipment not adaptable for production use.

\section{QUALITY CONTROL}

10 Process is simple, minimal quality control is required. Product quality can be controlled by sampling and adjustment of intermediate process waste streams.

7 Process is simple, significant amount of process stream quality control is required. Product quality can be controlled by regulation of process waste streams, additives, and process operating conditions.

5 Process is complex, significant quality control of process waste streams and additives required. Product quality can be controlled by careful adjustments to waste process streams (flow, composition, temperature).

3 Process is complex, significant control of intermediate waste streams and process variables in batch process steps required. Product quality can be predicted based on process parameters.

1 Product quality can be determined only by evaluation of final waste form product.

\section{TERMINAL WASTE FORM CHARACTERISTICS}

\section{SENSITIVITY TO FEED VARIATIONS}

10 Waste form capable of accepting substantial variations in feed composition and process conditions.

7 Waste form process capable of accepting minor variations of key chemical components in feed stream without degraded waste form integrity.

5 Waste form process requires careful control of all minor and major feed constituents to achieve high integrity waste form.

3 Waste form process requires strict control of feed composition and process variables to produce a high integrity waste form.

1 Waste form process not capable of producing a high integrity waste form if there are any deviations in the process conditions. 
HLW WASTE FORM STABILITY (RADIATION EFFECTS, CORROSION, HEAT INDUCED, CHEMICAL OR STRUCTURAL CHANGE)

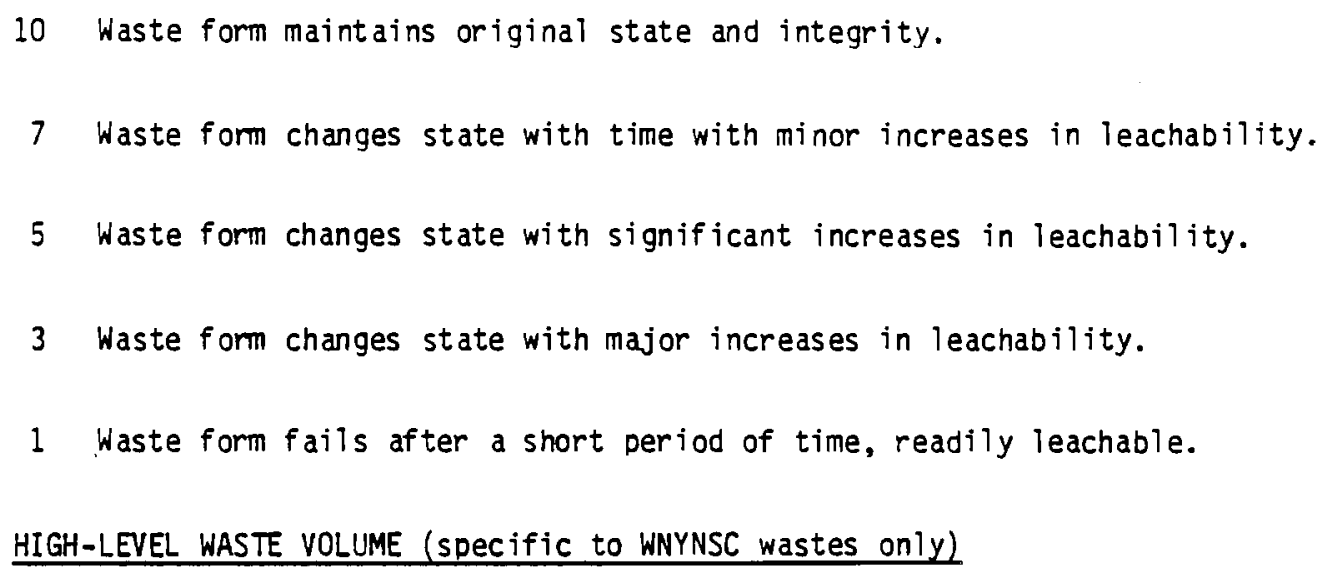

10 Leach resistance of waste form more than 100 times less than reference borosilicate glass.

7 Leach resistance of waste form 10 to 100 times less than reference borosilicate $g l a s s$.

5 Leach resistance of waste form approximately the same as borosilicate glass.

3 Leach resistance of waste form 10 to 100 times greater than borosilicate glass.

1 Leach resistance of waste form more than 100 time greater than borosilicate glass.

\section{STATE OF DEVELOPMENT}

STATE OF DEVELOPMENT OF WASTE FORM

10 Waste form orepared utilizing actual nuclear waste from waste form process. Waste form well characterized.

7 Waste form prepared utilizing simulated nuclear waste from pilot-scale or full-scale waste form process. Waste form well characterized. 
5 Waste form prepared by laboratory scale or pilot scale process utilizing simulated nuclear waste form process. Waste form partially characterized.

3 Laboratory samples of waste form prepared waste form partially characterized.

1 Conceptual process for waste form process defined. Waste form has not prepared on a laboratory scale.

STATE OF PROCESS DEVELOPMENT

10 Technology demonstrated and utilized in a production scale radiochemical operation.

7 Technology demonstrated utilizing pilot-scale equipment in both radioactive and nonradioactive environments.

5 Technology demonstrated with similar materials. No radioactive experience gained and only a limited amount of nonradioactive pilot plant experience gained.

3 Small-scale or pilot scale work on individual process operations completed.

1 Only limited laboratory development performed on process.

\section{STATE OF EQUIPMENT DEVELOPMENT}

10 Process equipment demonstrated in remote production operations. Either pilot-scale or full-scale operations.

7 Process equipment demonstrated in nonradioactive experimental work for extended periods of time. Equipment configurations similar to remote applications and similar size to production scale equipment.

5 Process equipment available from commercial manuf acturers, process equipment demonstrated in a nonradioactive environment, satisfactory performance achieved.

3 Equipment of standard commercial designs available and with modification will suit process. No experimental verification Derformed.

1 No experimental process equipment constructed to perform required process task.

\section{SAFETY CONSIDERATIONS}

\section{TRANSPORTATION SAFETY}

10 Waste form demonstrates superior properties in transportation accidents. The following parameters are considered important; fire resistance, thermal stability, strength, impact fracture resistance, dispersibility of waste form. 
7 Waste form demonstrates superior properties except some fracture of the waste occurs during impact.

5. Waste form or waste form matrix melts or degrades in excessive heat (Temperature $\left.\sim 700^{\circ} \mathrm{C}\right)$. Fracture of waste form occurs upon impact.

3 Waste form unstable at temperatures above $500^{\circ} \mathrm{C}$. Severe damage to waste form occurs upon impact.

1 Waste form unstable at temperatures above $500^{\circ} \mathrm{C}$. Severe fracture or dispersion of waste form possible if waste container breaks.

\section{DISPERSIVE DRIVING FORCES IN PROCESS}

10 Process operates at moderate temperatures and subatmospheric pressures.

7 Process operates with one process step at high temperatures $\left(>700^{\circ} \mathrm{C}\right)$ and subatmospheric pressures

5 Process operations include a step with a potential exothermic chemical reaction.

3 Process operates with one or more process steps at high temperatures $\left(>700^{\circ} \mathrm{C}\right)$ and high pressures.

1 Process operations include a step with the potential for thermal or chemical explosions, or pressure release.

\section{CHEMICAL TOXICITY OF REAGENTS}

10 No inherently hazardous materials required for process.

7 Materials of moderate toxic hazard utilized in process.

5 Materials of high-toxic hazard employed in process.

3 Materials of potential explosive hazard employed.

1 Materials of high toxicity or explosive hazard employed.

\section{PERSONNEL EXPOSURES}

10 No abnormal radiation exposures anticipated. Minimal exposure resulting from maintenance tasks and accidental releases only. Minimal HLW transfers to solidified waste storage involved. 
5 No unusual occurrence of radiation exposure anticipated. Moderate exposure resulting from accidental release or nonstandard maintenance. Frequent HLW transfers involved.

1 Maintenance requirements of process lead to higher than normal exposures.

\section{SECONDARY WASTES GENERATED FROM PROCESS}

10 Secondary wastes from process include:

a) process condensates approximately the same as original waste.

b) decont aminated off gases.

c) minimal failed and decontaminated equipment.

d) trash.

5 Secondary wastes from the process include:

a) process condensates at least twice the volume of original waste.

b) decontaminated off gases

c) A large quantity of failed and decontaminated equipment

d) trash

e) solidified low-level wastes (salt cake).

1 Secondary wastes from the process include:

a) process condensates at least 10 times greater than original waste volume

b) decontaminated off gases

c) a large quantity of failed and decontaminated equipment

d) a large quantity of trash

e) solidified low-level wastes (salt cake)

f) miscellaneous process streams containing organics, etc.

\section{FACILITY IMPLEMENTATION}

\section{FEASIBILITY OF PROCESS TO BE OPERABLE IN EXISTING FACILITIES}

10 All process equipment will fit in the existing facility. Adequate room provided for equipment maintenance, storage of failed equipment and lag storages of waste form products.

7 All process equipment will fit in the existing facilities. Adequate room provided for equipment maintenance. Only minimal storage of failed equipment and waste form products provided.

5 All process equipment will fit into existing facilities. No lag storage for failed equipment or waste form products available.

3 No all process equipment will fit into existing facilities unless process equipment simplifications occur. 
1 Process will not fit into existing facilities even with process simplifications. New facilities required to imolement process.

MOOIF ICATIONS TO PROCESS BUILDING REQUIRED FOR PROCESS IMPLEMENTATION

10 Minor modifications required to process building to implement process. Installation of service racks and control systems located in operating galleries.

5 Major modifications in primary cell contaiment required to implement process. Modification to cell structure, addition of windows, manipulators and service penetrations.

1 Major modifications required to main process cell and auxiliary process cell to implement process. Severe structural changes of processing cells required.

\section{SERVICE REQUIREMENTS OF PROCESSES}

10 Process equipment requires only a minimal amount of service facilities; (steam, cooling water, process water, air, instrument air, cranes and electric services: All which are available to the existing process cell).

7 Process equipment requires only slightly more service requirements than are presently available to the process cell. Additional service racks required in process cell.

5 Process equipment requires a large number of service requirements, beyond those currently available in the process cell.

3 Process equipment requires a $l$ arge number of service facilities plus additional services such as high-pressure hydraulics, high capacity cranes and a 1 arge quantity of electric power presently not available to the plant facility but can be implemented.

1 Process equipment requires a high density of services. Equipment cannot be implemented within existing facilities.

\section{FINAL WASTE FORM PROCESS COMPATIBILITY}

\section{PROCESS COMPLEXITY TO PREPARE INTERIM WASTE FORM FOR PROCESSING AT DOE SITE}

10 Interim waste form easily removed for transportation canister. Interim waste form reconstituted and blended into $p l$ ant process streams for waste processing. No complex treatment or processing of inter im waste form product required.

5 Inter im waste form easily removed from transportation canister. Several process steps required to the interim waste form process before it can be blended with the process streams at the waste solidification plant. 
1 Interim waste form cannot be easily solidified with other waste streams at the waste solidification facility. Separate processing for solidification of the interim waste may be required.

\section{EFFECT ON TERMINAL WASTE FORM VOLUME}

10 Interim waste form may be processed to produce; a terminal waste form which does not have volume greater than the volume if the waste had been solidified with the salt/sludge separation process approach at the WNYNSC.

5 Terminal waste form volume one to two times greater than the volume if the waste had been processed at the WNYNSC with salt/sludge separation process.

1 Substantial increase in terminal waste form volume from interim waste form compared to volume of HLW if waste processed by the salt/sludge separation process at the WNYNSC.

\section{D.3 SUMMARY OF ALTERNATIVE PROCESS RANKINGS}

A summary of the technical ratings of the process alternatives considered in this study is sumarized in the following tables. The subcategory normalized ratings are shown along with the total normalized ratings. 
TABLE 0.3. Technical Ranking of Salt/Sludge Separation Process with Alternative Waste Form Processes

I. Process Characteristics

Process Complexity

Process Logistics

Maintenance Requirements

Feasibility for Production

Quality Control

TOTAL

Normalized Total

Salt/Sludge Separation Approach Waste Form Process

\begin{tabular}{|c|c|c|c|}
\hline $\begin{array}{l}\text { Borosilicate } \\
\text { Glass } \\
\end{array}$ & $\begin{array}{l}\text { Low-Alkali } \\
\text { Glass } \\
\end{array}$ & $\begin{array}{l}\text { Process } \\
\text { Marbles-in- } \\
\text { Lead Matrix }\end{array}$ & $\begin{array}{l}\text { Crystalline } \\
\text { Ceramic } \\
\end{array}$ \\
\hline 3 & 3 & 3 & 1 \\
\hline 5 & 5 & 5 & 1 \\
\hline 10 & 10 & 10 & 5 \\
\hline 5 & 5 & 3 & 1 \\
\hline 7 & 7 & 5 & 3 \\
\hline 5 & 5 & 5 & 3 \\
\hline 35 & 35 & 31 & 14 \\
\hline 14.6 & 14.6 & 12.9 & 5.8 \\
\hline
\end{tabular}

II. Waste Form Characteristics

Sensitivity to Feed Variations

Waste Form Integrity (1 ong-term)

7

7

High-Level Waste Volume

Leach Resistance

TOTAL

Normalized Total

10

5

29

14.5

14.6

12.9

5.8

III. State of Development

Waste Form

Process

Equipment

TOTAL

Normalized Total

IV. Safety and Environmental

Transportation Safety

Dispersive Driving Forces

Chemical Toxicity of Reagents

Personnel Exposures

Secondary Process Wastes

TOTAL

Normalized Total

$\begin{array}{rrcl}10 & 3 & 3 & 3 \\ 7 & 5 & 5 & 1 \\ 10 & 7 & 5 & 3 \\ 27 & 15 & 13 & 7 \\ 18 & 10 & 8.7 & 4.7\end{array}$

V. Facility Implementation

Feasibility to fit into

Existing Facility

Modifications to Facility

Service Requirements

TOTAL

Normalized Total

7
5
7
7
5
31

6.2

\section{5}

7

3

10

7

7

10

$\begin{array}{ll}5 & 10 \\ 5 & 10\end{array}$

26

33

22

33

13

11

16.5 
TABLE 0.4. Technical Ranking of Combined Waste Form Processes with Alternative Was te Form Processes

I. Process Characteristics

Process Complexity

Process Control

Process Logistics

Maintenance Requi rements

Feasibility for Production

Quality Control

TOTAL

Normalized Total

\begin{tabular}{l} 
Combined Waste Process Approach \\
Waste Form Process \\
$\begin{array}{c}\text { Borosilicate Low-Alkali } \\
\text { Glass }\end{array}$ \\
\hline
\end{tabular}

II. Waste-Form Characteristics

Sensitivity to Feed Variations

Waste-Form Integrity (long-term)

High-Level Waste Volume

Leach Resistance

$\begin{array}{ccc}3 & 3 & 3 \\ 7 & 7 & 7 \\ 5 & 1 & 1 \\ 5 & 5 & 3 \\ 5 & 5 & 5 \\ 7 & 7 & 5 \\ 32 & 28 & 24 \\ 13.3 & 11.7 & 11.7\end{array}$

TOTAL

Normalized Total

13.3

3

7

1

3

5

11.7

III. State of Deve lopment

Waste Form

Process

Equipment

TOTAL

Normalized Total

$\begin{array}{rrr}7 & 5 & 5 \\ 7 & 7 & 7 \\ 1 & 1 & 1 \\ 5 & 7 & 5 \\ 20 & 20 & 18 \\ 10 & 10 & 9\end{array}$

IV. Safety and Environmental

Transportation Safety

Dispersive Driving Forces

Chemical Toxicity of Reagents

Personne 1 Exposures

Secondary Process Wastes

TOTAL

Normalized Total

7

5

7

19

12.7

5

7

1

5

18

9

Facility Implementation

Feasibility to fit in

Existing Facility

Modification to Facility

Service Requirements

TOTAL

$\begin{array}{rrr}7 & 7 & 7 \\ 7 & 7 & 7 \\ 5 & 5 & 5 \\ 5 & 5 & 5 \\ 5 & 5 & 5 \\ 29 & 29 & 29\end{array}$

5.8

5.8

5.8

Normalized Total

$\begin{array}{rlr}7 & 7 & 5 \\ 5 & 5 & 5 \\ 5 & 5 & 5 \\ 17 & 17 & 15 \\ 11.3 & 11.3 & 10\end{array}$

GRAND TOTAL

53.1

48.8

46.5 
TABLE D.5. Technical Ranking for Combined Waste Process Approach with Interim Waste Form Processes

I. Process Characteristics

Process Complexity

Process Control

Process Logistics

Maintenance Requirements

Feasibility for Production

Quality Control

TOTAL

Normalized Total

Combined Waste Process Approach
Interim Waste Form Processes

$\begin{array}{rrrr}7 & 5 & 5 & 10 \\ 10 & 7 & 5 & 10 \\ 5 & 1 & 1 & 1 \\ 5 & 3 & 5 & 7 \\ 7 & 7 & 7 & 7 \\ 10 & 10 & 10 & 10 \\ 44 & 33 & 33 & 45 \\ 14.7 & 11 & 11 & 15\end{array}$

15

10

10

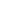

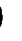

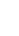

II. Waste-Form Characteristics

Sensitivity to Feed Variations

Waste Form Integrity

(long-term)

High-Level Waste Volume

Leach Resistance

TOTAL

Normalized Total

$\begin{array}{rccc}7 & 7 & 7 & 7 \\ 7 & 10 & 10 & 7 \\ 5 & 1 & 1 & 1 \\ 1 & 3 & 3 & 1 \\ 20 & 21 & 21 & 16 \\ 5 & 5.3 & 5.3 & 4\end{array}$

III. State of Development

Waste form

Process

Equipment

TOTAL

Normalized Total

5

5

10

20

13.3

7

1

1

16

IV. Safety and Environmental

Transportation Safety

Dispersive Driving Forces

Chemical Toxicity of Reagents

Personnel Exposures

Secondary Process Wastes

TOTAL

Normalized Total

$\begin{array}{cccc}1 & 5 & 5 & 1 \\ 10 & 10 & 10 & 10 \\ 10 & 10 & 5 & 10 \\ 5 & 1 & 1 & 5 \\ 10 & 10 & 10 & 10 \\ 36 & 36 & 31 & 36 \\ 7.2 & 7.2 & 6.2 & 7.2\end{array}$

v. Facility Implementation

Feasibility to $F$ it in

Existing Facility

Modifications to Facility

Service Requirements

TOTAL

Normalized Total

$\begin{array}{rc}7 & 7 \\ 3 & 5 \\ 5 & 5 \\ 15 & 17 \\ 10 & 11.3\end{array}$

$\begin{array}{crc}5 & 5 & 10 \\ 3 & 5 & 10 \\ 5 & 5 & 10 \\ 13 & 15 & 30 \\ 8.7 & 10 & 20\end{array}$

10

10

10

30

20

$\begin{array}{lll}11.3 & 11.3 & 12.7\end{array}$


TABLE 0.5. (Contd)

\begin{tabular}{l} 
Combined Waste Process Approach \\
Interim Waste Form Processes \\
\hline Fused Silicate/Salt Vinyl Ester- \\
Salt \\
\hline
\end{tabular}

VI. Final Waste Form Process

Compatibility

Process Complexity for

Reconstitution

$10 \quad 5$

Effect on Terminal HLW Volume

10

5

TOTAL

$20 \quad 10$

Normalized Total

20

10

10

53.4

49.8

70.2

.
78.9

10

10

20

20 


\section{REFERENCES - APPENDIX D}

E. R. Johnson Associates, Inc. 1980. Prel iminary Evaluation of Alternative Waste Form Solidification Processes, Volume iI: Evaluation of the Processes. PNL-3477, Pacific Northwest Laboratory, Richland, Washington.

Ross, W. A., J. M. Rusin, and J. L. McETroy. 1979. "Processes for Production of Alternative Waste Forms." Presented at Waste Management Symposium 1979, Tucson, Arizona.

Stone, J. H., S. T. Gorforth, Jr., and P. L. Smith. 1979. Preliminary Evaluation of Alternate Forms for Immobilization of Savannah River Plant High-Level Waste. OP-1545, E. I. du Pont De Nemours and Company, Aiken, South Carolina. 


\section{DISTRIBUTION}

No. of

Copies

OFFSITE

A. A. Churm

DOE Chicago Patent Group

9800 South Cass Avenue

Argonne, IL 60439

Don Bray

DOE Chicago Operations and Region Office

9800 South Cass Avenue

Argonne, IL 60439

S. A. Mann

DOE Chicago Operations and Region Office

9800 South Cass Avenue

Argonne, IL 60439

B. D. Shipp

DOE Chicago Operations and Region Office

9800 South Cass Avenue

Argonne, IL 60439

J. Neff

Department of Energy

Columbus Program Office

$505 \mathrm{King}$ Avenue

Columbus, OH 43201

2 J. P. Hamrick

DOE I daho Operations Office

550 2nd St.

Idaho Falls, ID 38401

2 T. K. DeBoer

New York State ERDA

Empire State Plaza

Albany, NY 12223

C. R. Cooley

DOE Nuclear Waste Management Programs

NEW, 8-107, HQ

Washington, OC 20545

G. H. Daly

DOE Nuclear Waste Management

Programs

NEW, B-107, HQ

Washington, DC 20545

J. E. Dieckhoner

DOE Nuclear Waste Management Programs

NEW, B-107, HQ

Washington, OC 20545
No. of

Copies

C. H. George

DOE Nuclear Waste Management Programs

NEW, B-107, HQ

Washington, DC 20545

C. A. Heath

DOE Nuclear Waste Management Programs

NEW, B-107, HQ

Washington, DC 20545

M. L. Lawrence

DOE Nuclear Waste Management Programs

NEW, 8-107, HQ

Washington, OC 20545

S. Meyers/R. Romatowski

DOE Nuclear Waste Management Programs

NEW, B-107, HQ

Washington, DC 20545

G. Oerte1

DOE Nuclear Waste Management Programs

NEW, B-107, HQ

Washington, DC 20545

A. F. Perge/R. Scott

DOE Nuclear Waste Management Programs

NEW, B-107, HQ

Washington, DC 20545

2 3. A. Turi

DOE Nuclear Waste Management Programs

NEW, B-107, HQ

Washington, DC 20545

R. W. Ramsey, Jr.

DOE Nuclear Waste Management Programs

NEW, B-107, HQ

Washington, DC 20545

D. L. Vieth

DOE Nuclear Waste Management Programs

NEW, B-107, HQ

Washington, DC 20545

R. D. Walton

DOE Nuclear Waste Management Programs

NEW, B-107, HQ

Washington, OC 20545 
No. of

Copies

S. H. Greenleigh

DOE Office of General Counse

$\mathrm{GC}-34$

Washington, DC 20545

L. Silverstrom

DOE Office of General Counsel

$\mathrm{GC}-32$

Washington, DC 20545

C. M. Borgstrom

DOE Office of NEPA Affairs

EV-121

Washington, DC 20545

S. G. Harbinson

DOE San Francisco Operations Office

1333 Broadway

Oak land, CA 94612

2 T. B. Hindman

DOE Savannah River Operations Office P. 0. Box A

Aiken, SC 29801

Los Alamos Scient if ic Laboratory

P. 0. Box 1663

Los Alamos NM 87544

3 C. J. Haughney

Division of Waste Management Nuclear Regulatory Commission

Washington, DC 20555

J. B. Martin

Division of Waste Management

Nuclear Regulatory Commission

Washington, DC 20555

R. $\varepsilon$. Cunningham

Office of Nuclear Safety Materials and Safeguards

Nuclear Regulatory Commission

Room 562

7915 Eastern Avenue

Silver Springs, MD 20910

27 DOE Technical Information Center

Charles Luner

Argonne National Laboratory

9700 South Cass Avenue

Argonne, IL 60439

M. J. Steindler

Argonne National Laboratory

9700 South Cass Avenue

Argonne, IL 60439
No. of

Copies

S. Vogler

Argonne National Laboratory

9700 South Cass Avenue

Argonne, IL 60439

2 N. E. Carter

Battelle Memorial Institute

Office of Nuclear Waste Isolation

505 King Avenue

Columbus, OH 43201

Beverly Rawles

Battelle Memorial Institute

Office of Nuclear Waste Isolation

505 King Avenue

Columbus, $\mathrm{OH} 43201$

2 J. L. Crandall

E. I. Du Pont de Nemours \& Co. Savannah River Laboratory

Aiken, SC 29801

A. S. Jennings

E. I. Du Pont de Nemours \& Co.

Savannah River Laboratory

Aiken, SC 29801

H. E. Filter

Dow Chemical Company

Lark in Laboratory

1691 N. Swede Road

Midland, MI 48640

G. B. Levin

EG \& G Idaho, Inc.

P.0. Box 1625

Idaho Falls, IO 83415

M. D. McCormack

$E G \& G$ Idaho, Inc.

P.0. Box 1625

Idaho Falls, ID 83415

R. Williams

Electric Power Research Institute

3412 Hillview Avenue

P.0. Box 10412

Palo Alto, CA 94304

Environmental Protection Agency

Technological Assessment

Division (AW-559)

Office of Radiation Programs

U.S. Environmental Protection Agency

Washington, DC 20460

Alfred Schneider

School of Nuclear Engineering Georgia Institute of Technology

At lanta, GA 30332 
No. of

Copies

12 P. Skinner

Law Department

Justice Building, Room 239

The Capitol

Albany, NY 12224

Vern Stephens

Los Alamos Technical Associates

P.0. Box 410

Los Alamos, NM 87544

J. P. Duckworth

Plant Manager

Nuclear Fuels Services, Inc.

P. 0. Box 124

West Valley, NY 14171

W. H. Lew is

Nuclear Fuel Services

6000 Executive Blvd.

Rockvil1, MD 20852

G. C. Allen

Sandia Laboratories

Albuquerque, NM 87185

2 D. E. Harrison

Westinghouse Electric Corp.

P.O. Box 355

Pittsburgh, PA 15230

2 J. K. Knabenschuh

Westinghouse Electric Corp.

P.0. BoX 355

Pittsburgh, PA 15230

Lloyd Michels

P. 0. Box 24821

San Jose, CA 95154
No. of

Copies

ONSITE

5 DOE Richland Operations Office
P. A. Craig
O. J. Elgert
H. E. Ransom
J. J. Schreiber
M. W. Shupe

4 Rockwell Hanford Operations
M. J. Kupfer
W. W. Schulz
R. E. Smith
D. D. Wodrich

Vitro Engineering Corporation

Gary Hughs

$34 \quad P$ ac if ic Northwest Laboratory

W. F. Bonner

J. R. Carrell

T. D. Chikalla

O. F. Hill

L. K. Holton (10)

D. E. Knowlton

L. T. Lakey

D. E. Larson

J. L. MCElroy

M. A. McKinney

R. E. Nightingale

M. E. 0lson

W. L. Partain

A. M. Platt

D. L. Prezbindowski (2)

D. H. Siemens

R. L. Treat

Technical Information (5)

Publishing Coordination $V_{i}(2)$ 
